Ewa Masłowska

\title{
Mediating the Otherworld in Polish Folklore
}

A Cognitive Linguistic Perspective

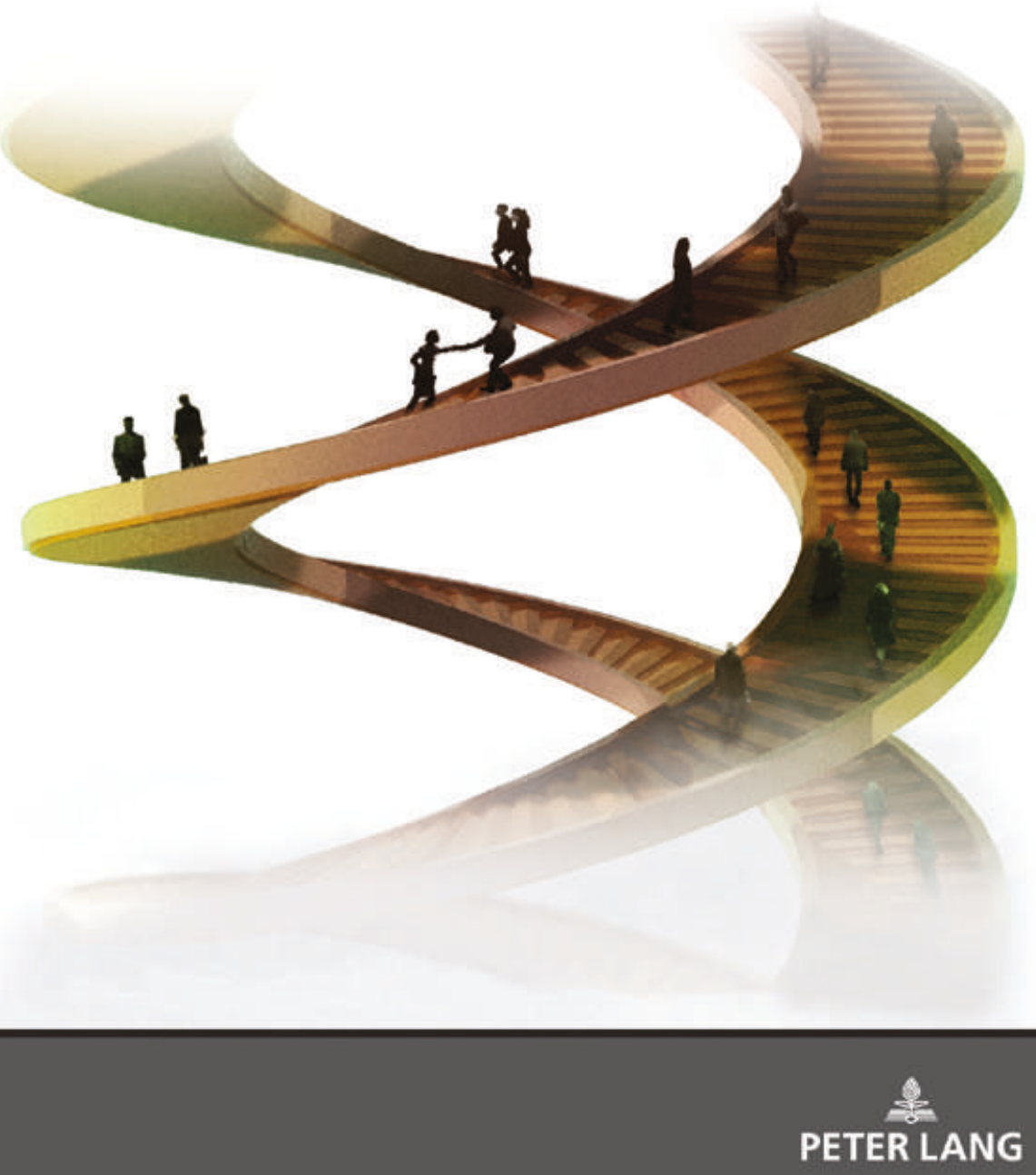


Ewa Masłowska

\section{Mediating the Otherworld in Polish Folklore A Cognitive Linguistic Perspective}

This book analyses the ways of conceptualising and interpreting the interaction between the physical and metaphysical worlds in Polish folklore. The linguistic and anthropological analysis offered in this study focuses primarily on myth, ritual and symbol as reflected in language (dialect lexis, phraseology, speech acts). Employing the methodology and analytical tools of cognitive linguistics (preconceptual image schemas, cognitive scene, profiling of concepts, development of cognitive paths), the author reconstructs the mental patterns at the heart of mythical thinking, linguistic actions and symbolic meanings which reflect universal conceptual schemas and may serve as models for intercultural studies.

\section{The Author}

Ewa Maslowska is Professor of Linguistics at the Institute of Slavic Studies, Polish Academy of Sciences in Warsaw. She specialises in cultural and cognitive linguistics; her main research interests include the linguistic worldview, especially spiritual culture, axiology, symbolism and linguistic memory. She studies Polish and Slavic folklore from both linguistic (dialect lexis, phraseology, paremiology) and extra-linguistic perspectives (folk texts, ethnological data). 
Mediating the Otherworld in Polish Folklore 


\section{POLISH STUDIES \\ TRANSDISCIPLINARY PERSPECTIVES}

Edited by Krzysztof Zajas / Jarosław Fazan

VOLUME 28 
Ewa Masłowska

\section{Mediating the Otherworld in Polish Folklore}

A Cognitive Linguistic Perspective

Translated by Maria Fengler and Piotr Styk

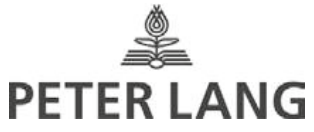




\section{Bibliographic Information published by the Deutsche Nationalbibliothek}

The Deutsche Nationalbibliothek lists this publication in the Deutsche Nationalbibliografie; detailed bibliographic data is available in the internet at http://dnb.d-nb.de.

\section{Library of Congress Cataloging-in-Publication Data}

A CIP catalog record for this book has been applied for at the Library of Congress.

This work was financed within the National Programme for the Development of the Humanities funded in 2017-2019 by the Minister of Science and Higher

Education of the Republic of Poland, project no. 21H 16005184.

\section{-1. national programime}

\section{(1) FOR THE DEVELOPMENT OF HUMANITIES}

Original edition: Ludowe stereotypy obcowania świata i zaświatów w języku i kulturze polskiej, 2nd revised edition, Warszawa: Wydawnictwo Agade Bis, 2016.

Printed by CPI books GmbH, Leck

Reviewed by Przemysław Łozowski · Proofreader: Penny Shefton Cover illustration: @ Krzysztof Kościuk

ISSN 2191-3293

ISBN 978-3-631-79512-5 (Print) · E-ISBN 978-3-631-79684-9 (E-PDF) E-ISBN 978-3-631-79685-6 (EPUB) · E-ISBN 978-3-631-79686-3 (MOBI) DOI 10.3726/b15926
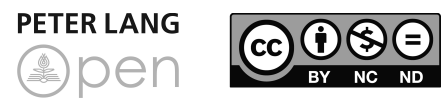

Open Access: This work is licensed under a Creative Commons Attribution Non Commercial No Derivatives 4.0 unported license. To view a copy of this license, visit https://creativecommons.org/licenses/by-nc-nd/4.0/

(c) Ewa Masłowska, 2020

Peter Lang - Berlin · Bern · Bruxelles · New York ·

Oxford $\cdot$ Warszawa $\cdot$ Wien

This publication has been peer reviewed.

www.peterlang.com 


\section{Contents}

Abbreviations

\section{Part 1 Conceptualisation of the interaction between the physical and metaphysical worlds: basic premises}

1 General characteristics of cognitive processes ............................... 29

1.1 The experiential myth: the starting point for cognitive analysis .......... 29

1.2 Preconceptual image schemas ................................................................ 30

1.2.1 The FORCE schema ..................................................................... 32

1.2.2 The CENTRE-PERIPHERY schema ……………………………... 37

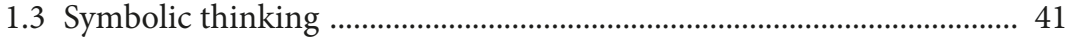

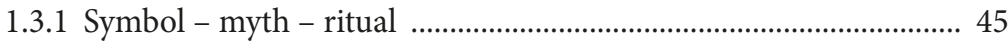

1.3.2 Prototypes of imaging the cosmic order:

the cosmic mountain and the tree of life ............................................ 48

2 Stereotype as a projection and interpretation of the world …... 55

2.1 The basis for creating stereotypes in folk culture ................................... 58

2.2 The individual and collective subject and the object of conceptualisation ........................................................ 59

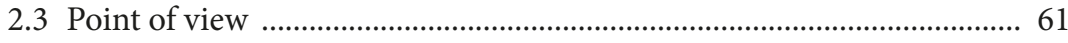

2.4 The opposition between the "own/familiar" (swój) and the "strange/alien" (obcy) perspectives ............................................. 63

2.4.1 The spatial concept ............................................................................ 63

2.4.2 Individual identity

based on the first-person bodily perspective .................................. 65

2.4.3 Identity based on group membership ............................................... 66 
2.4.4 Group identity in a cosmic perspective .......................................... 68

2.4.5 Emotional attitude and bipolar values: "own/familiar" $(s w o ́ j)=$ 'good' versus "strange/alien" $(o b c y)=$ 'bad' ...................... 68

2.4.6 The spatial and temporal factor .................................................. 69

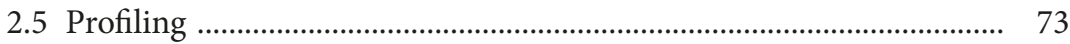

2.6 Elemental forces and lights in the sky as the basis of imaging natural and supernatural reality .............................................................. $\quad 76$

2.7 Preconceptual image schemas in the creation myth ............................ 77

\section{Part 2 Imaging the relations between the physical and metaphysical worlds: the four natural elements}

3 Water

3.1 The creation myth and the demiurgic properties of water .................. 81

3.2 The interaction of demonic forces in the act of creation ..................... 85

3.3 Water - the devil - "otherworlds" (zaświaty) .......................................... 88

3.4 The sanctity of water ................................................................................... 93

3.4.1 The miraculous power of water in scenes involving divine and holy figures ............................................................................. 94

3.4.2 The cleansing power of water in scenes of God's wrath ............... 101

3.5 The power of water in the interactions between man and the sacred ........ 105

3.5.1 The cult of water ....................................................................... 105

3.5.1.1 The stereotypical motif of a miraculous spring ............... 106

3.5.1.2 The system of norms regulating behaviour with respect to water ......................................................... 108

3.5.1.3 Sacrificial offerings ............................................................. 111

3.5.1.4 Lexical exponents of the cult of water ………………....... 113

3.5.2 Practices making use of the life-giving power of water ................ 114

3.5.3 Practices making use of the cleansing power of water .................. 124

3.5.4 Magical practices making use of the destructive power of water ...... 130

3.6 Water symbolism ................................................................................. 133 
4.1 The semantic memory of archetypal creation myths in profiling the relations between heaven and earth

4.2 Mother-earth and the archetypal model of the union between heaven and earth

4.3 The creation myth based on the concept of the cosmic egg 163

4.4 The agricultural version of the creation scene 168

4.5 Patterns of interaction in the act of creation and its ritual re-enactment ............................................................. 170

4.5.1 Interaction on the part of man ................................................... 170

4.5.2 Interaction on the part of demonic forces ................................. 175

4.6 Earth symbolism ..................................................................... 181

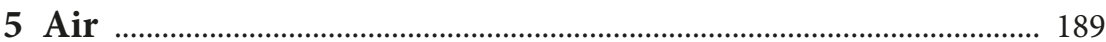

5.1 The creation myth: the breath of life ............................................... 189

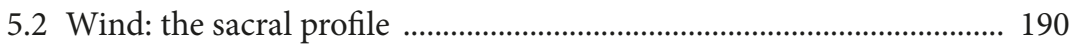

5.2.1 Wind in the relations between God and man ............................. 191

5.2.2 Wind in the relations between man and God .............................. 196

5.3 Wind: the demonic profile ................................................................ 202

5.3.1 Wind in the relations between the devil and man ....................... 205

5.3.2 Wind in the relations between man and demons ........................ 207

5.3.3 Souls in the power of evil forces: ghosts, spectres, witches .......... 212

5.4 Air symbolism ............................................................................. 223

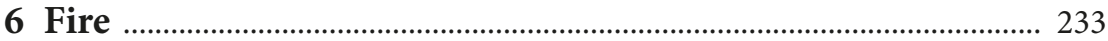

6.1 Archetypal profiles of the cult of fire .................................................. 233

6.2 The profiles of otherworldly fires ....................................................... 234

6.2.1 The creation myth and heavenly fire .......................................... 234

6.2.2 Thunderbolt fire ....................................................................... 237

6.2.3 Hell fire ......................................................................................... 247 
6.2.4 Purgatorial fire ............................................................................... 253

6.3 The profile of the home fire ...................................................................... 264

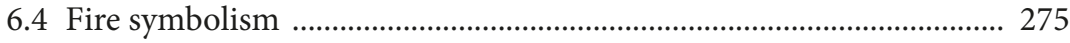

\section{Part 3 Imaging the relations between the physical and} metaphysical worlds: the sun and the moon

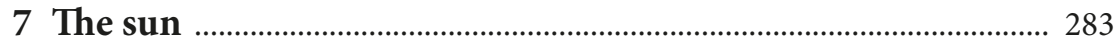

7.1 The creation myth and the life-giving profile of the sun ..................... 283

7.2 Sunrise and sunset: the temporal and spatial boundaries .................... 288

7.2.1 After sunset: the demonic time ...................................................... 292

7.2.2 Before sunrise: the magical time .................................................. 293

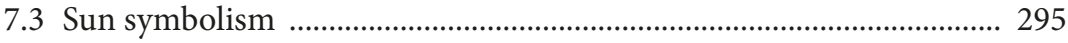

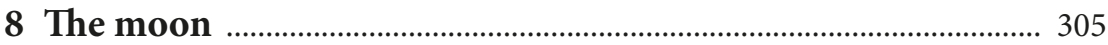

8.1 The creation myth: the sacral profile of the moon ………………….... 305

8.2 The influence of the moonlight on human beings ................................. 315

8.3 Moon symbolism ................................................................................. 323

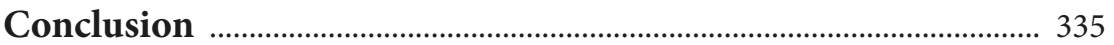

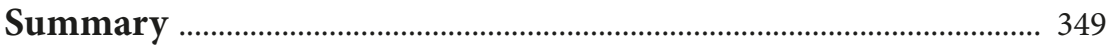

Bibliography .......................................................................................... 351

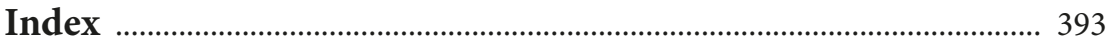




\section{Abbreviations}

DorSJP Stownik Języka Polskiego, ed. Witold Doroszewski, Warszawa: Wydawnictwo Naukowe PWN 1996.

DRB Douay-Rheims Bible, available at http://www.drbo.org/ (accessed 16 December 2018).

ESSJ Ėtimologicheskiŭ slovar' slavianskikh iazykov. Praslavianskiŭ leksicheskiǔ fond, 1974-2014, vol. 1-39, ed. Oleg N. Trubachëv, Moskva: Nauka, 1974; (Этимологический словарь славянских языков. Праславианский лексический фонд, вып. 1-39, ред. Олег Н. Трубачёв. Москва: Наука, 1974).

ESV The Bible, English Standard Version, available at https://www. biblegateway.com/ (accessed 16 December 2018).

K Kolberg Oskar, Dzieła wszystkie, vol. 1-, Warszawa, Kraków, 1961- (ongoing).

KarSGP Karłowicz Jan, Słownik gwar polskich, vol. 1-6, Kraków: Akademia Umiejętności, 1900-1911.

KJV The Bible, King James Version, available at https://www. kingjamesbibleonline.org/ (accessed 16 December 2018).

KLS Moszyński Kazimierz, Kultura ludowa Słowian, vol. 2, Kultura duchowa, part 1 and 2, Warszawa: Książka i Wiedza, 1967, 1968.

KopSS Kopaliński Władysław, Słownik symboli, Warszawa: Wiedza Powszechna, 1990.

Lubelskie Polska pieśń i muzyka ludowa. Lubelskie, vol. 4, part 1-4, ed. Jerzy Bartmiński, Lublin: Instytut Sztuki Polskiej Akademii Nauk, Uniwersytet Marii Curie-Skłodowskiej, Wydawnictwo Muzyczne Polihymnia, 2011.

MifyNM Mify narodov mira. Éntsiklopediia, vol. 1-2, ed. Sergieŭ A. Tokarev, Moskva: Sovetskaia Entsiklopediia, 1987-1988; (Мифы народов мира. Энциклопедия, т. 1-2, гл. ред. Сергей А. Токарев, Москва: Советская Энциклопедия, 1987-1988).

NKPP Nowa księga przysłów i wyrażeń przysłowiowych polskich, vol. 1-4, ed. Julian Krzyżanowski, Warszawa: Państwowy Instytut Wydawniczy, 1969-1978.

SE Słownik etnologiczny. Terminy ogólne, ed. Zofia Staszczak, Warszawa, Poznań: Państwowe Wydawnictwo Naukowe, 1987. 
SEKasz Boryś Wiesław, Popowska-Taborska Hanna, Słownik etymologiczny kaszubszczyzny, vol. 1-6, Warszawa: Instytut Slawistyki Polskiej Akademii Nauk, Slawistyczny Ośrodek Wydawniczy, 1994-2010.

SGP Słownik gwar polskich; Źródła and vol. 1, ed. Mieczysław Karaś, Jerzy Reichan; vol. 2-5, ed. Jerzy Reichan, Stanisław Urbańczyk; vol. 6, ed. Joanna Okoniowa, Jerzy Reichan; vol. 7-9, ed. Joanna Okoniowa, Jerzy Reichan, Barbara Grabka, Renata Kucharzyk; vol. 10, part 1, ed. Barbara Grabka, Renata Kucharzyk; Wrocław, 19771991, Kraków, 1992-2018.

SlavDrev Slavianskie drevnosti. Ėtnolingvisticheskiŭ slovar', vol. 1-4, ed. Nikita I. Tołstoŭ, Moskva: Mezhdunarodnye Otnosheniia, 1995-2009; (Славянские древности. Этнолингвистический словарь, т. 1-4, ред. Никита И. Толстой. Москва: Международные отношения, 1995-2009).

SLSJ Słownik ludowych stereotypów językowych. Zeszyt próbny, ed. Jerzy Bartmiński, Wrocław: Wydawnictwo Uniwersytetu Wrocławskiego, 1980.

SłSE Sławski Franciszek, 1952-1982, Słownik etymologiczny języka polskiego, vol. 1-5, Kraków: Towarzystwo Miłośników Języka Polskiego.

SPs Słownik prasłowiański, vol. 1-8, ed. Franciszek Sławski, Wrocław: Zakład Narodowy im. Ossolińskich, 1974-2001.

SSS Słownik starożytności słowiańskich, vol. 1-8; vol. 1-2, ed. Władysław Kowalenko, Gerard Labuda, Tadeusz Lehr-Spławiński; vol. 3, ed. Władysław Kowalenko, Gerard Labuda, Zdzisław Stieber; vol. 4-7, ed. Gerard Labuda, Zdzisław Stieber; vol. 8, ed. Antoni Gąsiorowski, Gerard Labuda, Andrzej Wędzki; Wrocław: Zakład Narodowy im. Ossolińskich, 1961-1996.

SSSL Słownik stereotypów i symboli ludowych, ed. Jerzy Bartmiński, vol. 1, Kosmos, part 1, Niebo, światła niebieskie, ogień, kamienie, 1996; part 2, Ziemia, woda, podziemie, 1999; part 3, Meteorologia, 2012; part 4, Świat, światto, metale, 2012; vol. 2, Rośliny, part 1, Zboża, 2017, Lublin: Wydawnictwo Uniwersytetu Marii CurieSkłodowskiej, 1996-2017.

Vasmer Fasmer Max (Vasmer Max), Ėtimologicheskil slovar' russkogo iazyka, vol. 1-4, trans. and suppl. Oleg N. Trubachëv, Moskva: Progress, 1986-1987; (Макс Фасмер, Этимологический словарь русского 
языка, т. 1-4, пер. и доп. Олег Н. Трубачёв. Москва: Прогресс, 1986-1987).

ZWAK Zbiór Wiadomości do Antropologii Krajowej, vol. 1-18, Kraków: Akademia Umiejętności, 1877-1895. 



\section{Introduction}

The present study focuses on folk stereotypes of interconnections between the physical and the metaphysical worlds in Polish language and culture. It takes as its point of departure relations between three concepts: lud (the folk), kultura ludowa (folk culture) and religijność ludowa (folk religiosity/folk religious practices). The terms have long stirred heated debate and controversy among scholars in a number of fields, including ethnology, anthropology, cultural sociology, folklore and religious studies. The discussion concerns not only the meaning of the concept "folk culture" and the scope of the terms "folk" and "folk religiosity" but, importantly, also their valuation. All three are closely interrelated and have an established position in Polish and European scholarship.

The concept lud (the folk) was in use in Poland already in the eighteenth century, ${ }^{1}$ mainly with reference to peasants and the rural population as opposed to privileged groups - nobility, aristocracy and burghers; from the early nineteenth century it also came to include the urban proletariat. Today, its relevance is often put into question owing to the processes of democratisation of society, which have eliminated estate distinctions.

The term kultura ludowa (folk culture), in turn, appeared in the nineteenth century with reference to peasant culture, which had emerged as part of national culture already in the feudal period and flourished particularly in the nineteenth century, when it attracted the interest of such eminent ethnographers as Oskar Kolberg ${ }^{2}$

1 The term lud appeared in official discourse during the debates on the Constitution of 3 May 1791, when it was used with reference to non-privileged social strata, particularly peasants. As put forward by the proponents of the Constitution, this group were to enjoy the protection of the state and access to schooling.

2 Oskar Kolberg (1814-1890) was a Polish ethnographer, folklorist and musicologist documenting folk culture. In the course of his field studies he collected an immense wealth of material from the area of the former Polish-Lithuanian Commonwealth (i.e. the area also including the territories of present-day Lithuania, Belarus and part of Ukraine) and some neighbouring regions, published in his lifetime in two series entitled Lud (The Folk, 33 volumes) and Obrazy etnograficzne (Ethnographic Pictures). The ongoing edition of his collected works currently includes eighty-six volumes (Dzieła wszystkie, re-issued collections and edited manuscripts). His unique collection is part of Polish and European cultural heritage and remains an invaluable source for the study of identity issues, nineteenth-century culture and the place of folk culture in a broader cultural framework of the day. 
and Kazimierz Moszyński. ${ }^{3}$ Although, like many of their followers, both Kolberg and Moszyński treated folk culture as an essentially peasant phenomenon, its nature is more complex and far from uniform. Native (ethnic) sources were not the only basis for the development of folk culture. As it evolved, it assimilated elements of the culture of higher social strata, which it adapted to rural reality; it also came to include features developed as a result of inter-ethnic contact [SE: 196]. The turn of the twentieth century, usually considered the heyday of Polish folk culture, also marked the beginning of its progressive decline [Burszta 1998: 168; SE: 197]. The causes of this process may be found both in the transformation of traditional rural communities after the Second World War and a general change of economic and political patterns, both in Poland and other European countries.

Thanks to the committed efforts of nineteenth- and early twentieth-century researchers who collected, systematised and documented all types of available sources, a record of oral folk culture of different ethnic groups in the historical area of the Polish-Lithuanian Commonwealth was preserved for future generations, becoming part of Polish, Ukrainian, Belarusian and Lithuanian national cultures. In its heyday, folk culture aroused great interest not only in scholarly but also artistic circles. This fascination certainly stemmed from the political situation at the time. Poland had lost independence at the end of the eighteenth century and did not regain it until 1918. Without their own state, people turned to national values and saw their cultivation as a key factor in the preservation of national identity. The fact that folk culture was viewed - particularly by Romantics - as unsullied by civilisation, and thus endowed with high moral and ethical values, contributed to its mythologisation.

Radical socio-economic changes after the Second World War in general, and mass-scale migration from rural areas to urban centres in particular, brought a levelling of cultural differences between the rural and urban population, resulting in a gradual decline or, as some scholars claim, the ultimate disintegration of folk culture as such [Burszta 1998: 168]. Post-war scholarly discourse has included voices questioning the very use of the term in modern ethnology since the discipline has steadily evolved towards a study of typology and structure of culture as well as the processual nature of changes that it undergoes. As a result, the definition of the term "folk culture" has been revised and its applicability in

3 Kazimierz Moszyński (1887-1959) was the author of a monumental study Kultura Ludowa Stowian (Folk Culture of the Slavs), vol. 1: Kultura Materialna (Material Culture), vol. 2: Kultura Duchowa (Spiritual Culture) [Moszyński 1967-1968, hereafter KLS]. 
the study of urban and rural mass culture has come under scrutiny. Based on the model of a cultural continuum, a new approach - which views the process and the dynamics of change in terms of a gradual decline of features recognised as typically folk ones - has made it possible to bridge the gap between folk culture before and after the great social transformation. " "Folk-type culture" (kultura typu ludowego), a new term proposed by Ludwik Stomma [Stomma: 1986], has been favourably received by specialists in folk studies (ethnologists, anthropologists, folklorists and sociologists alike). In general use, however, folk culture has remained associated with rural culture or even with folklore (notions which in Poland carry negative connotations). This undoubtedly has had an impact on its social perception, especially as the lines between urban and rural populations have become increasingly blurred, particularly among the younger generation.

The term religijność ludowa (folk religiosity/folk religious practices), in turn, appeared in Polish scholarly discourse in the twentieth century and is the most recent of the three terms considered here. The term initially carried negative connotations associated with the unorthodoxy of local forms of religious life in terms of the official doctrine of the Roman Catholic Church (theology and liturgy). Another factor at play here was that religious folklife or folk religion as it is known in European scholarship - often involved magical practices or rituals that did not adhere to established forms of contact with the sacred, and thus were viewed as shamefully marginal in a dynamically developing modern

4 The most important voices in the debate on the term kultura ludowa (folk culture) appeared in the journal Lud (The Folk) in 1991 (vol. 74). In reply to a survey undertaken in 1989, folk studies specialists presented their views on the semantic scope of the term and its application in ethnography, ethnology, folk studies and cultural anthropology in Poland and other countries. The principal question they considered was whether it could be applied in ethnography and ethnology in the future. As presented in Stownik Etnologiczny (An Ethnological Dictionary) [SE: 195-198], the history of the term folk culture and its evolution indicate that it has been approached from different perspectives at different historical periods, depending on the current state of research at that time, and hence its scope has been subject to continuous change. In fact, the debate proved inconclusive and the question has continued to be discussed in other journals and publications. I discuss its principal streams in my article "Kultura ludowa czy tradycyjna? Problemy z terminologią" (Folk culture or traditional culture? Problems with terminology) [Masłowska 2015].

5 According to Ludwik Stomma, such typical folk features which have evolved in rural communities in conditions of geographical, social and mental isolation include mythical thinking, sensualism and a type of religious sensitivity which is based on a profound belief in the divine order of the universe [Stomma 1986: 145-146]. 
society. However, in a new wave of research emerging in the 1970s in reaction to this negative approach, folk religion came to be seen as an expression of the natural human need and beliefs actually held by particular communities. The so-called vernacular perspective in religious studies shifted the focus of interest to the question of how people view, interpret and experience contact with the sacred [Yoder 1974; Primiano 1995; Bowman, Valk 2012]. Interpretation of religious practices, particularly of the persistence of ritual, was greatly enhanced by Pierre Bourdieu's concept of habitus, cultural "dispositions", set patterns of behaviour supported by a system of social commands and prohibitions passed on from generation to generation. Although dependence on a cultural code does not mean that individuals cannot make their own conscious choices or rely on their own experience, habitus seems to have an undeniable impact on their personal worldview, behaviour, actions and convictions [Bourdieu 1977: 72].

In Polish scholarly discourse, folk religiosity has been criticised as naïvely sensual, heterogeneous, prone to particularity [Czarnowski 1956; Ciupak 1973; Tomicki 1981; Olszewski 1996], and characterised by superficial devotion (pobożność) devoid of spiritual reflection. On the one hand, the concept of habitus can be used to justify the criticism of folk religiosity by its principal detractors. On the other, however, when a code, including a religious one, is perceived as a pattern of practice revealing how people function in the world, such criticism proves groundless. In this way, a change in perspective can point research in the right direction:

Criticism of inadequate knowledge among believers loses its force if we consider the following circumstances: modern European societies overestimate what is fully available to reason, verbalised and subject to individual, presumably rational control. Meanwhile, the essential element of any culture of paideia, any process of education, that is, socialisation, has been to inculcate "artificial" principles in such a way that they would become "instinctive" so that what is conventional would become, in a way, naturalised. The final product is supposed to be a particular habitus, an embodied social pattern, and a measure of success - its preferably unreflective reproduction. From this point of view, folk religiosity is a perfect example of unarticulated and verbally inarticulable "knowledge-how" (a concept proposed by Gilbert Ryle), "tacit knowledge" (Michael Polanyi), "practical consciousness" (Anthony Giddens), "cerebral" (habitual) memory (William James), as well as "incorporating practices" (Paul Connerton) and "ritual coherence" (Jan Assman): that is actions, gestures and verbal formulas whose meaning is determined by the fact of their automatic, routine and preferably collective re-enactment rather than pure reasoning subject to a continuous process of reflection. [Bukraba-Rylska 2016: 18]

A growing number of scholars have come to view folk religiosity as a factor shaping common imagination and sensitivity as well as a sense of security and 
identity [Dobrowolski 1961: 60; Tomicki 1981; Stomma 1986]. Consequently, the scope of scientific interest has been widened to include questions concerning how folk culture assimilated Christianity: which of the old pagan beliefs and rituals became part of Christian religious practices in rural communities, and which of them were adapted by the Roman Catholic Church as part of its liturgy. Researchers have become interested in processes of interpretatio christiana in the early period of Christianity in the Slavic world [Szyjewski 2003; JózefówCzerwińska 2017]. They have also turned their attention to the circulation of biblical and apocryphal motifs in folk culture, as well as to ways in which spiritual needs for contact with the sacred are manifested in rural communities [Zowczak 2000, 2015; Bukraba-Rylska 2008, 2016].

Today, anthropological and ethnological discourse adopts a broad research perspective. Consequently, the three terms considered here function as part of a holistic view of culture understood as a complex of meanings that underlie concepts, convictions and beliefs forming a commonly shared base of knowledge about the world and providing people with patterns of behaviour. This base of knowledge is central to the construction of a collective worldview, which in turn gives rise to norms of behaviour that rely on shared values. A cultural model of behaviour provides people with a sense of security and identity with the group and endows their actions with meaning, while at the same time leaving the individual with an alternative choice: he/she can follow the rules or, conversely, break them and face condemnation or exclusion from the community as a result [Piątkowski 1994: 125 ff; cf. Burszta 1998: 48-57; Szyjewski 2018: 33]. The research apparatus available in the holistic study of culture includes such operational concepts as myth, worldview and symbol, which capture the relationship between culture and tradition. Since mythical thinking along with its cognitive and perceptual potential are the basic frame of folk-type culture (which also includes features listed by Stomma: sensualism, ritualism and high religious sensitivity), this apparatus is an indispensable tool for the description and interpretation of meanings attributed to reality. The meanings in question arise from both traditionally transmitted patterns of understanding the world and their creative transformation, whereby old symbols are endowed with new meanings, as is apparent in magical and religious practices, rites and rituals [Stomma 1986: 147; Piątkowski 1994: 125-127; Szyjewski 2018: 42].

Adopting the ethnolinguistic approach, I take as my subject of study an entire complex of meanings in a broadly interpreted cultural context, a complex that has shaped the multi-dimensional reality of rural culture, preserved in both linguistic and non-verbal form. Apart from its communicative function, this code, shared by language users, is also characterised by accumulated creative energy 
which stimulates creative thinking and action within old structures. In my description I follow the established pattern of ethnolinguistic studies and use the term "folk culture" in the sense of "folk-type culture" proposed by Stomma; the radial structure of this category makes it possible to classify its members as central or peripheral in relation to the prototype, depending on the degree of their typicality. Given that the material studied here comes largely from the late nineteenth and the beginning of the twentieth century, it ranks high on the scale of typical features and thus can be viewed as central in terms of its position in the category "folk culture". The distance between today's exponents of folk culture and the vision of the world created by their ancestors is not evidence of the demise of this culture but of its evolution. Although some of cultural contents and behaviours have vanished, this does not necessarily mean a decline in its values, which are preserved in stereotypes and in a general cultural tendency for mythologisation [Robotycki 1998: 137]. In this way, attachment to the system of values and rules of behaviour encoded in the collective subconscious, which continue to guide people's actions, has a decisive influence on the longevity of myth and stereotype as part of the symbolic sphere of culture:

(...) the historical substratum never vanishes without trace. Its elements can play a different role than they used to, become components of different entities than before, or be altogether unrecognisable to those living today as relics of the past. This, however, does not change the fact that they continue to exist and they become functional in new ways, and that the rules of conduct they involve - grounded in the collective subconscious still guide people's actions. [Bukraba-Rylska 2008: 473]

Adopting the perspective of a cultural continuum enables me to use the term "folk culture" ahistorically, treating it as a mental phenomenon (pertaining to both thought and action) of a processual nature, subject to constant changes. Such an approach is in keeping with the term itself, which, depending on the current level of knowledge, has undergone continuous modification.

The aim of this study is to present the (rural) folk interpretation of the cosmic vision of the universe as a form of coexistence between the physical world and spheres identified as supernatural - inaccessible to sensory cognition or human control. The conceptualisation of mysterious powers that have an impact on human fate reveals a religious and mythical pattern of thought and imaging, as well as cultural codes of behaviour towards such forces. Ingrained in the collective imagination, mental patterns of interaction between natural and supernatural reality, in conjunction with their linguistic correlatives, create a network of semantic links in the minds of language users, making up a coherent image of the cosmos. The interrelated links of this chain of semantic correspondences rely 
on various patterns: opposition (e.g. day vs night, life vs death, heaven vs earth, water vs dry land), correlation (e.g. night turns into day, death is the beginning of eternal life) or analogy (the movement of the sun across the sky, the annual rhythm of nature - the cycle of human life). In the centre of thus understood linguistic image of the cosmos is the conceptualiser, who creates his/her subjective vision of the universe from an earthly point of view, adopting a wider or narrower perspective.

The present study analyses folk stereotypes of interaction between the physical and the metaphysical worlds. Belief in the existence of metaphysical forces of good and evil, whose actions can be beneficial or, conversely, detrimental to people, is reflected in such commonly used phrasemes as dopust Boży 'a disaster that happens by God's leave', wola Boska 'God's will', świat Boży 'God's world', łaska Boska 'God's grace' on the one hand, and diabli nadali 'the devils have brought it', czort wie 'the deuce knows', licho nie śpi 'the devil never sleeps', diabelskie sprawki 'the devil's doings' on the other. The concept of the sacred includes both divine and demonic forces, two phenomena of a highly abstract nature that are, in axiological terms, poles apart. Their interpretation, which relies on the conceptualiser's imagination along with all available means of perception, is grounded in magical thinking, a religious attitude and belief in supernatural phenomena. Since it is the conceptualiser who takes the central position in the universe, his/her vision is inevitably based on the immediate (physical) experience of actions performed by these forces. The most readily available way of imaging by analogy is personification: it endows deities with identity, makes it possible to establish contact with them and enables interpretation of their actions in the form of myth. The origin myth - a vision of primordial reality which continues to have an impact on the fate of people and their world - then serves as an archetype for the perception of the human place in the cosmic order, both in the pragmatic and spiritual sense.

Symbolic thinking, which involves representing mysteries of supernatural reality as images, makes it possible to combine the experience of the world available to sensory perception with a mystery of transcendence. Those images which acquire a conventional form turn into symbols. The symbolic imagination integrates disparate realities - physical and metaphysical. Since the use of symbol makes it possible to cross the boundaries of space and time, the conceptualiser can re-enact past events in the here and now. The highly abstract nature of symbol does not mean that it cannot be evoked as a representation of the physical reality of everyday life (bread, as a symbol of earth, is still food; an oak, symbolising the structure of the cosmos, is still a tree). Symbolic images are part 
of everyday reality and, at the same time, enable an insight into the metaphysical realm [Berger, Luckmann 1991: 121-123].

Interactions with the metaphysical world take place in a particular space and at a particular time, and are subject to conventionalised routines. Such patterns are determined by a system of commands and prohibitions grounded in a belief in the power of the sacred and in the possibility of getting access to it, or in the efficacy of practices aiming to protect people from the harmful impact of otherworldly reality. Although rites, rituals and magical practices certainly foster the development of stereotypical models of relations with the sphere of the sacred, the principal means of communication between the physical and the metaphysical worlds is language, which generates particular actions and their scenarios. In ritual practices, words function as "real transmitters of an energy coming from another world" [Kołakowski 1982: 166] - they are endowed with causal power, particularly in the case of magical formulas [Engelking 1991b: 84; 2017: 216-219, 222-233; Malinowski 1935: 52-53; Masłowska 2014, 2016a; Niebrzegowska-Bartmińska 2001; 2007: 187-194; Pisarkowa 1998: 154, 161], uttered in combination with gestures and appropriate objects - and their use is subject to strict rules which forbid any divergence from the set model [Bartmiński 2009b: 209-210; Niebrzegowska-Bartmińska 2001; Pisarkowa 1998: 153].

The scope of this study is limited to the process of communication between the physical and the supernatural worlds and its pragmatic considerations. The focus, then, is on patterns of linguistic behaviour in cultural context and the attendant processes of symbolisation, lexicalisation and grammaticalisation as part of the cognitive process.

Contact with the metaphysical world, and between the participants of events aimed at attracting supernatural forces, is based on oral communication. Event participants are bound by close social ties based on the category "own/familiar" (swój), a shared knowledge about the world, a religious attitude and familiarity with the methods of accessing the source of power. Consequently, communication occurs under the circumstances of immediate personal contact and involves particular rules of participation. This situation is conducive to the use of a restricted linguistic code, typical of communication within closed communities, whose members are familiar with the structure and sequence of the message and the roles they are supposed to perform according to their social position in the group [Bernstein 1965: 153-156]. In this way, cultural communicative community is conducive to the development and consolidation of stereotypical patterns of behaviour.

The communicative situation and the means of linguistic expression on which it relies have an impact on the type of culture and its way of thinking. This 
observation, proffered by such authors as Bronisław Malinowski, Jack Goody and Walter J. Ong [Godlewski 2003], has been gaining increasing recognition in scholarship [Bartmiński, Niebrzegowska-Bartmińska 2009: 80]. Oral communication underlies the mode of existence in the world, while participation in customs and rituals fosters the emergence of ready-made texts in the form of language formulas, based on the thought patterns of a particular community and on its general perception of the world in the linguistic, axiological and symbolic sense [Bartmiński, Niebrzegowska-Bartmińska 2009: 80]. The type of text and code and the situational context have a considerable influence on the course and type of communication. In view of the frequent use of a restricted linguistic code (lacking literal forms of expressing intentions, relying on limited vocabulary and a condensed form of utterance), non-verbal actions play a significant role in creating a stereotype of interaction between physical and metaphysical reality. The function of language is particularly apparent in the pragmatic power of words inducing collective action and shaping patterns of thought and behaviour as well as norms which enable social coexistence.

\section{Methodological principles}

Methodological and philosophical premises of cognitive grammar and tools developed by the proponents of this method of language study ${ }^{6}$ seem to be the

6 The principles of the cognitive approach were established by Ronald Langacker in his two-volume Foundations of Cognitive Grammar [Langacker 1987, 1991]; they were subject to modifications by the author himself and by his main followers: Mark Johnson, John R. Taylor and George Lakoff. The cognitive approach was met with considerable interest in scholarly circles and soon began to live its own life, sometimes, as argued, to the detriment of Lakoff's original proposal [Grzegorczykowa 1998: 10]. Cognitive grammar also became popular in Poland. Discussions concerning its theoretical and methodological principles were held at the seminars called Język a Kultura (Language and Culture), and their results were published in volume eight of the series [Nowakowska-Kempna 1992b]. Another volume was Langacker's Wykłady z gramatyki kognitywnej (Lectures in Cognitive Grammar), published following a discussion with the author held at a conference organised by the Maria Curie-Skłodowska University in Lublin [Langacker 1995]. A volume of studies edited by Henryk Kardela, in turn, presented the standpoints of various scholars from different research centres in Poland as well as their proposals for the development of cognitive grammar [Kardela (ed.) 1994]. Subsequent years have seen many publications concerning cognitive linguistics, including a number of articles which appeared in the journal Etnolingwistyka (Ethnolinguistics). 
most adequate for the presentation of different components which make up the semantic continuum between the spheres of extralinguistic reality, thought and language. Cognitive grammar relies on experiential realism as the principal factor shaping the conceptual system. Given the immediate connection between thinking and the body (in terms of a broadly interpreted sensory experience: movement, perception, social experience), thought is viewed as imaging, and metaphors - as the dominant aspect of language use. It is also assumed that thought - understood as operations performed on abstract symbols by means of the entire conceptual system - takes the form of Gestalten [Langacker 1987, 1991, 1995; Fife 1994: 14-16, 20-22, 43; Kardela 1998: 13-14]. Consequently, in this approach pragmatics and semantics are not separated, which means that cultural context, including activities and behaviours displaying a considerable degree of habituation, is an inherent component of meaning [Anusiewicz 1995; Bartmiński 1980b, 1988a, 2001, 2006a, 2006b, 2009a, 2009b; Bartmiński, Niebrzegowska 1998; Bartmiński, Niebrzegowska-Bartmińska 2004; Bartmiński, Tokarski 1993; Kalisz 1993, 1994b; Kardela 1992a, 1992b, 1994, 1998; Krzeszowski 1994, 1997, 1999; Tokarski 1998a, 1998b, 1990; Wierzbicka 1996, 1999].

Since customs and rituals involve particular actions and behaviour connected with convictions and beliefs, they can be regarded as a case of habituation. ${ }^{7}$ They are also closely related to the sphere of culture, which is grounded in the experiential base and provides the basis for constructing stereotypical images of contact with the sphere of the sacred, entrenched in particular ritual scenarios. This study presents the cognitive process of imaging and conceptualisation of the interaction between the natural and supernatural worlds on the basis of folk stereotypes in the following aspects:

(1) the experiential myth and the function of preconceptual image schemas,

(2) creation myths as symbolic models re-enacted in cognitive scenes of interaction between the natural and supernatural worlds,

(3) stereotypes based on the opposition between "one's own/familiar" (swój) and "strange/alien" (obcy),

(4) linguistic forms of conceptualisation.

7 In phenomenology and cognitive studies, habituation refers to gradually developed habitual response to particular stimuli, much in line with the saying "practice makes perfect". When a certain cognitive routine is relatively frequent or sufficiently intense to occur, it becomes entrenched/habituated. Although habituation and subsequent activation of a particular cognitive routine initially require a considerable mental effort, in the course of time its activation becomes increasingly easier, which makes it possible to perform particular actions more smoothly [Fife 1994: 14]. 
The material used here to illustrate and discuss the phenomenon of coexistence of physical and metaphysical reality consists of linguistic and cultural stereotypes and symbolic representations of the four natural elements: earth, fire, water and air. Assuming that their conceptualisation is based on the experiential myth, the phenomena under investigation are grounded in the physical experience of the world, stored in the experiential base in the form of preconceptual image schemas. Creation myths tell of primordial matter which gave rise to the cosmos and provide symbolic images of the scene of creation, found in different narratives around the globe. The sheer number of variants indicates the wide circulation of such stories and thus the preservation of the myth in collective memory. Different variants of cliché reproduction of the origin myth generate a cognitive pattern which defines the relations between the physical and the metaphysical worlds.

The four natural elements, which are available to sensory experience, symbolise the primordial matter that gave rise to the cosmos and life. In ancient cultures, natural forces represented supreme divinities; symbolic images of elements as instruments of the sacred power ruling the world are rooted in culture and can be found in different parts of the globe. The vitality of these symbols, adopted by successive religious systems, can be seen as an example of cliché reproduction, which underlies stereotype.

In many religions fire was associated with the sun, and the light it gave - with the shining sky. The sun and its night-time counterpart, the moon, in turn, were identified as the divine face. In view of their connection with the sacred, analogical representations of the sun and the moon in Polish folk culture are also included in this study.

The impact of the natural elements, the sun and the moon is part of a human primeval physical experience, stored in the experiential base as FORCE and COLOUR schemas, and, in more abstract senses, also LINK and CONTROL schemas. The ritual use of fire, water and earth, as well as numerous traces of the cult of the natural elements, the sun and the moon, indicate that they all have long been perceived as a medium linking physical and supernatural reality. Such a vision has provided the framework for the development of associations which make up a coherent linguistic and cultural vision of the cosmos.

The analysis of issues in the focus of this study was greatly facilitated thanks to an immensely rich collection of source material - Słownik stereotypów i symboli ludowych (A Dictionary of Folk Stereotypes and Symbols, hereafter SSSL), ${ }^{8}$

8 Stownik stereotypów i symboli ludowych (A Dictionary of Folk Stereotypes and 
conceived and edited by a team of ethnolinguists at the Maria Curie-Skłodowska University in Lublin, headed by Professor Jerzy Bartmiński. Based on cognitive definitions and a facet structure of entries, the dictionary presents its material in a particularly accessible manner; documentation of individual entries is classified according to genres, which makes it possible to identify differences in the description of particular images. Although the present study also takes into consideration material available elsewhere (dictionaries of local dialects, ethnographic and ethnolinguistic studies), it is mainly based on the SSSL dictionary.

The present English edition of the original Polish monograph is addressed to anthropologists, ethnologists, folklore scholars, linguists and specialists in cultural studies. However, an English-speaking reader should realise that while the translation attempts to find the closest English equivalents to render the content of the Polish original, there remain inevitable differences arising from the way each culture and language conceptualises the world. Names of demons, deriving from their dwelling places (wodniki 'water demons' or latawce 'flying demons') or the way such creatures torment people (dusiołki 'chokers', gnieciuchy 'crushers', topielniki, topielce, utopce 'drowning demons', lit. 'drowners'), are a case in point. They do not have English equivalents; neither is it possible to find a fully corresponding English word to render the Polish concept of the otherworld. The noun zaświaty, literally 'worlds beyond', is not only plural, indicating the multiplicity of such metaphysical worlds, but also formed by adding the prefix $z a$ - 'behind/beyond', which suggests a much larger space situated beyond the physical world. Furthermore, the multi-layered spatial conceptualisation is reflected in the grammatical opposition between the singular noun świat 'world' and the plural zaświaty 'worlds beyond', which also involves such oppositions as near vs far, own/familiar (swój) vs strange/alien (obcy), uniform vs heterogeneous. Consequently, to indicate the difference between the conceptualisation of the metaphysical world in English and Polish culture, the Polish word zaświaty is rendered as "otherworlds" in the present translation.

Examples of Polish proverbs and expressions, as well as quotations from folk tales, songs and poems, are provided in both the original (often dialectal) form and in English translation. This offers the opportunity of a comparative study of

Symbols), ed. J. Bartmiński, vol. 1 Kosmos (Cosmos), part 1, Niebo, światła niebieskie, ogień, kamienie (Sky/heaven, Celestial Lights, Fire, Stones), 1996; part 2, Ziemia, woda, podziemie (Earth, Water, Underground), 1999; part 3, Meteorologia (Meteorology), 2012; part 4, Swiat, światło, metale (The World, Light, Metals), 2012, Lublin: Wydawnictwo Uniwersytetu Marii Curie-Skłodowskiej. 
the Polish stereotype of the interaction between the physical and metaphysical worlds in both an intercultural and interlinguistic dimension. Such a comparison of Polish conceptualisations of the studied phenomena as reflected in cultural and linguistic forms with those existing in the reader's native language will reveal both similarities and differences between English-language and Polish culture. Publications which may provide a starting point for comparative research of representations of metaphysical reality and its influence on the human condition include encyclopedias offering analysis of supernatural worlds, elemental forces and heavenly bodies in cultures other than Slavic [Bane 2014; Lecouteux 2016]; monographs concerning images of the otherworld among Celts [Black (ed.) 2005; MacLeod 2018] and Anglo-Saxons [Pollington 2017]; as well as general [Sirhan 2014; Zankroff 2019], and more specific studies (for example on the element of water in Celtic [Avalon 2019] or Japanese culture [Smith 2019 [1908]]).

Valuable material supplementing the Polish folk image of the metaphysical world against Slavic background can be found in English editions of Polish and Slavic folk tales [e.g. Grand 2017; Naaké 2016; Tibbits 2018]. 



\section{Part 1 Conceptualisation of the interaction between the physical and metaphysical worlds: basic premises}





\section{General characteristics of cognitive processes}

\subsection{The experiential myth: the starting point for cognitive analysis}

Processes of conceptualisation are grounded in the experience of language users, gained through interaction with the external world. The cognitive process involves sensory, emotional and kinaesthetic experiences, which become subject to intellectual interpretation, leading to the formation of the experiential base. As such, then, the base constitutes an already developed structure of knowledge acquired as a result of repetitive cognitive events - psycho-physical experiences consolidated in the course of perception and interpretation of the world. So-called cognitive paths developed through habituation make it possible to reproduce analogical reasoning and join simple units into complex structures [Fife 1994: 14; Langacker 1995: 14-15]. Consequently, the creation of new forms is grounded in model schemas, i.e. features that have been abstracted from common, more basic structures.

The experiential base is built of domains, i.e. structures of human knowledge that shape specific concepts, with the so-called source domains as its most elementary constituents. The structure of source domains, which emerge directly from experience, may subsequently be employed in order to image more complex or abstract concepts. In this way, the experiential myth relies on a base, treated as an organised structure of concepts that we can understand by means of structural metaphors deriving from simpler base elements. This demonstrates how human beings comprehend a whole class on the basis of selected similar features [Kardela 1992a: 15-16].

According to cognitivists, scanning and profiling are elementary operations performed by a conceptualiser in relation to data gathered in the experiential base. Scanning involves comparing various domains in order to create a cognitive path linking selected areas. Profiling, in turn, is a creative process which involves the conceptualiser's point of view and an area he/she selects, where he/ she suppresses or foregrounds the chosen semantic features, making it possible to establish a new onomasiological path. This leads either to designation or to a metaphorical or metonymic extension, by means of which some concepts (usually more complex ones) come to be interpreted in terms of other, simpler concepts. The process of profiling is closely linked to imaging, which relies on familiar, conventional associations, while at the same time it entails a constant search for new connections. In this way, the conceptual system remains open 
to the discovery and naming of new phenomena, whose models are shaped on the basis of previous experiences and stereotypes, as well as conventionalised methods of categorisation and their typicality. Patterns that are most often reproduced within a certain category come to function as prototypes. The categorisation of objects, states and phenomena in terms of prototypes enables their extension, which ensures its open character and is a crucial feature in the semantic continuum of culture and language. Rules governing transfer from reality to language describe what is conceptualised and how this is done (rather than what it means) and what semantic components are used to create linguistic forms of expression [Nowakowska-Kempna 1992a: 125-156].

\subsection{Preconceptual image schemas}

Ways of imaging concepts are directly linked with the psycho-physical experiences of the outside world accumulated in the experiential base, i.e. the conventionalised routines of perception. Conceptualisation develops on the basis of so-called preconceptual schemas emerging from primal experiences such as: birth and the purely physical connection with the mother's womb through the umbilical cord (the LINK schema); a sense of balance, arising out of the need to maintain an upright position (the BALANCE schema); a sense of the integrity of the human body (the PART-WHOLE schema); experience of the impact of outside forces and the ability to exert force on outside objects (the FORCE schema); perception of space in relation to one's own body (the CENTRE-PERIPHERY schema); and, finally, the SCALE schema, involved in processes of axiologisation [Johnson 1990: 101-137; Krzeszowski 1994: 39-40].

In complex structures, such schemas may appear together in many different configurations, e.g. the LINK, PART-WHOLE and CENTRE-PERIPHERY schemas are combined in the concept of family (which involves a sense of bonding and safety built on the metaphors of the umbilical cord, the mother's womb and a shared space). When combined with the BALANCE and the VERTICAL UP-DOWN schemas, they serve to conceptualise the domain of family relations and other social bonds. Thus, hierarchical relations of a generational type, such as father-son, are construed according to the VERTICAL schema, while the HORIZONTAL schema structures bonds between peers, like mother-father, brother-sister, etc. This model of family relationships underlies the stereotype of the interaction between the physical and metaphysical worlds (God the Father, the Mother of God, man - God's child). 
As the concepts of good and evil are among the elementary components of the experiential base, preconceptual schemas have an inbuilt axiological scale of positive and negative value. The positive scale includes all phenomena connected with LINK, WHOLE, BALANCE and CENTRE, while disintegration (with the attendant consequences of severing the link, losing the central position and disturbing the balance) is placed at the opposite pole [Krzeszowski 1994: 35-36]. Since stereotypes of contact with the divine sphere include the WHOLE, LINK and BALANCE schemas, they are assigned a positive value. On the other hand, the structure of references to the demonic world involves fragmentation (the PART schema), disintegration (lack of LINK) and loss of BALANCE, which places them at the negative pole of the scale.

The experience of distinguishing between positive and negative beings and entities lies at the basis of processes of categorisation. As a result, concepts (sets as a whole), classes and categories on the one hand, and their particular representatives on the other, are all subject to valuation. This means that the value assigned to a given class of objects is not necessarily identical to the value of a specific item, especially that the value of a concept itself (a set or a category as a whole) is not always immediately apparent or consistent with the contextual (actual) emotional marking [Johnson 1990: 121-124; Krzeszowski 1999: 22-23].

The CENTRE-PERIPHERY and BALANCE (UP-DOWN) schemas introduce a horizontal (different distances from the "plus" and "minus" poles) and vertical (higher or lower position of entities and phenomena) hierarchy of values, respectively. Both scales are crucial in evaluating relations between the physical and metaphysical worlds. However, it is the UP-DOWN hierarchy of their relative location that plays the primary role, since it derives from the elementary model of perceiving and organising reality, i.e. the Great Chain of Being. This schema functions as an unconscious cultural model, and ascribes a position at a lower or higher level of the hierarchy to all material and spiritual beings. God - the highest Spiritual Being - occupies the top of the pyramid, with people, animals and plants taking progressively lower places, while inanimate matter is placed at the bottom. Every level entails a different kind of experience with its corresponding type of values. The level of spiritual beings is associated with religious experience and the attendant divine and holy values. The level of human experience involves spiritual life, while emotions and instincts correspond to the animal level and isomorphic animal values. Life and vital values, in turn, are connected with the plant level. Finally, sensory experience and values arise in the course of human interaction with inorganic entities, which are placed at the lowest position [Krzeszowski 1999: 34-35]. 


\subsubsection{The FORCE schema}

FORCE is the basic preconceptual schema present in all images of the interaction between the natural and supernatural worlds; the parameters of its generic structure reveal how the conceptualiser experiences the power of the sacred. The prototypical impact of FORCE relies on six elementary principles [Johnson 1990: 42-48; Libura 2000: 160]:

(1) The action of force is connected with potential interaction. In the relation: man - the sacred, the object of the action of supernatural forces may actively summon their power or, conversely, defend him/herself against them.

(2) Every force has its origin. For the purposes of the present study, we assume that force derives its power from the sacred.

(3) The action of force involves a certain path, taken by the object that is moved by its power. We assume here the use of the source-path-goal schema, e.g. out of God's will (source of power), a bolt of lightning (the tool of power) falling from the sky (path) strikes a tree inhabited by demons (goal).

(4) Every force has its unique power and intensity. While divine power is unrestricted and absolute, the actions of demonic forces are subject to their specific circumstances. A human being, who is at the receiving end of the impact of force, may come to experience it in varying degrees. One way of conceptualising power involves the image of a circle. The closer to the centre, the stronger the force's impact. This image is reflected in magical practices which aim to intensify force by means of walking around in a circle or drawing a circle, thereby delimiting the space where the force is in operation. Another type involves establishing linear borders, such as thresholds, fences, boundary ridges (miedze), or the line of the horizon corresponding to the perceptual capacities of human sight. This turns them, in practice, into symbolic boundaries marking out a safe territory protected by the power of the sacred. The intensity of a force's impact is thus also directly related to the CENTRE-PERIPHERY schema (see below).

(5) The experience of force is a result of interaction. In the interaction between the natural and supernatural worlds, divine actions initiate a chain of events, consisting of both demonic counteractions and the relevant actions of the human being, who responds to God's will while at the same time undertaking measures to protect him/herself from satanic designs. The experience of God's power will thus be enclosed within the triangle of divine-humansatanic interactions. 
(6) The experience of force has a causal structure. Hence its course may be described as a sequence of actions involving cause and effect.

The last two aspects are particularly important for the FORCE schema, as they presuppose that its operation is interpreted in terms of the events it causes. The causal structure of the experience of FORCE, construed as a series of sequences, corresponds to the model of a chain of energy, in which the participants of the events pass on energy from one to another. Consequently, in imaging the influence of supernatural forces on the physical world, it seems appropriate to conceptualise an event as the effect of the impact of a billiard ball [Kardela 1998: 80-81].

In the interactions between the sacred and earthly worlds, God manifests His power through acts of creation, revelation, blessing or punishment. By contrast, demonic forces engage in destructive actions, such as constant opposition to the Creator (which is the main principle of their activity), as well as attempts to possess human souls and deceive and harm human beings. Man's response, in turn, involves offering thanks for God's blessing, or praying for His grace or for the punishment to be averted, thus invoking God's power in protective magical practices against the vicissitudes of fate and the actions of evil forces. Man may also, conversely, cooperate with those forces.

Only God's power is unlimited, even if its manifestations may vary in intensity. The actions of evil forces, in turn, are dependent on more or less favourable circumstances. By contrast, human actions aimed at summoning power are attended by numerous practices which are meant to increase their efficacy, such as using sacramentals, praying for intercession to divine and holy persons, or performing magical actions in a specific time and place. Undoubtedly, then, we are dealing with a scenario which profiles archetypal roles: agent - instrument patient or theme [Langacker 2008: 260-264; Kardela 1998: 81]. Depending on the setting, the realisations of the FORCE schema may vary: they may involve different motivations, directions of action and paths leading to the goal.

The process of imaging a scene itself depends on the point of view of the subject, who may function as an active participant in the scene (for example by placing a blessed candle (gromnica lit. 'thunder candle'; the name derives from the word grom 'thunderbolt') in the window to protect his/her house from a thunderbolt), a participant and experiencer (e.g. a sick person subjected to magical practices meant to expel the disease), a chance recipient "drawn into" the scene (struck by lightning, afflicted by illness) or an observer (a witness to a miracle or a revelation). Each scene will involve a profiling of archetypal roles of varying discursive relevance, with the role of the agent (the initiator of the flow of force) as the most, and the role of the instrument or recipient - the least, 
prototypical. Furthermore, the scale of discursive relevance depends on both the place the conceptualiser occupies within the scene, and the degree to which he/she identifies him/herself with an abstract participant in an event [Kardela 1998: 82-84].

The experience of force may take different forms [Libura 2000: 176]:

- A singular, rapid stroke, e.g. natural disasters, lightning shock, the first bolt of thunder in spring which drives away evil forces from the ground, an outbreak of fire, hailstorm, harm inflicted by evil powers, casting an evil spell (rzucanie uroku), undoing an evil spell (odczynianie uroku), driving away demons, expelling a disease (zamawianie choroby, lit. 'speaking away a disease') and other magical practices meant to produce the desired event.

- Long-term, steady action, e.g. a blessing for the rest of their life conferred on the bride and groom during the wedding; protective practices employed at the laying of the foundations of a new house (zakładziny) in order to ensure safety, blessing and protection against evil forces for its inhabitants; cyclical actions connected with the rhythm of the day, nature, the sacred calendar: rites and attendant ritual activities. In all these cases, while the action itself is singular, the effects of its power are long-term.

- Periodic, intermittent actions (actions of evil forces against people and animals, e.g. nocturnal haunting by a mare (zmora)).

- Actions whose force diminishes with time (activities connected with the renewal of the tools of power, such as the blessing of water, renewing the power of fire, returning to the time of origins and restoring the world to its primal divine order; all these cases involve the interplay between the FORCE schema on the one hand, and the BALANCE and CONTROL schemas on the other).

The canonical model of experiencing the operation of force in terms of the SOURCE-PATH-GOAL schema is realised in the case of a primary experience of force, which is independent of human will. Taking into account potential interactions, the experience of force entails a number of possible event scenarios with a varying structure and axiology [Johnson 1990: 45-48; Libura 2000: 160-175].

(1) Compulsion, as an experience of force operating independently of, or contrary to, human will, assumes a negative value. When combined with the CONTROL schema, however, it may result in a more or less voluntary submission to the forces in question, such as social norms, customs, etc. In such cases we are dealing with inner compulsion, which may result either 
from one's choice (a sense and/or manifestation of membership in a group), or from some form of social pressure put on the individual. Depending on the conceptualiser's point of view, the value assigned to inner compulsion may be placed at varying distances from the extreme points of the axiological scale.

(2) Blockage, which takes place when a force encounters an obstacle, requires a change of direction. The blockage schema as such is assigned a negative value. However, depending on the actual course of events and the profile of archetypal roles, a radical change of value may occur: e.g. protective practices counteracting evil forces will assume a positive value.

(3) Counterforce leads to neutralisation as a result of a clash between two contrary forces of the same value. The effect of the forces' action is then zero. The undoing of spells (odczynianie uroków) or the Virgin Mary stopping the progress of a disease are cases in point.

(4) Diversion involves a change in the path of force on its way to the goal. Bringing a fire under control and directing it away from threatened areas or banishing disease into the wilderness, where it cannot harm people, may serve as examples. Since the CONTROL schema is also included in the scenario, the event may be evaluated in a positive way, but in each case its place on the axiological scale will depend on the conceptualiser's point of view.

(5) Removal of a restraint/an obstacle is a preventive action which prepares the path for the force to reach its goal smoothly. Assuming that the goal is achieved, the scene of the removal of the obstacle is evaluated positively, with the CONTROL and BALANCE schemas incorporated into the structure of the force's operation. Examples include activities which aim to facilitate a process such as giving a blessed candle (gromnica) to a dying person to light their way into the afterlife; providing the dead with a coin to pay for the passage across a river at the border between worlds; opening drawers and locks to help a woman give birth, etc.

(6) Enablement involves opening up possibilities of increasing or weakening the action of force; such scenarios are linked with circumstances that can impact the force's intensity (time, place, magical or blessed objects), inviting a medium to take part in the scene e.g. a dziad (a wandering beggar, singer, storyteller and mediator between the earthly and metaphysical worlds; lit. 'grandfather/forefather') or a znachor (folk healer), or invoking the intercession of divine and holy persons.

(7) Attraction-repulsion is mainly linked with the experience of the action of supernatural powers and involves arranging situations conducive to the working of sacred forces (e.g. ritual protective actions: fumigating, 
sprinkling with holy water, placing bunches of herbs or blessed garlands in the corners of a house or in barns to drive away evil powers).

The perceived operation of supernatural forces produces certain reactions and impacts on how such activities are motivated and evaluated. The involvement of the CONTROL and BALANCE schemas is a crucial factor which influences such evaluation. Both schemas are activated in the case of events caused by INNER COMPULSION. Inner compulsion creates obligation, which finds its linguistic manifestation in such verbal forms as powinienem 'I should', musze 'I must', mam zrobić $x$ 'I am to do x', corresponding to a sense of inner necessity [Libura 2000: 177-178]. Since inner compulsion is dictated by human will, it acquires a positive value. The experience of force also leads to the emergence of social norms, which influence collective behaviour and may become the basis for the development of a sense of obligation motivating the actions of an individual.

The impact of social norms can be manifested through different actions: blockage, counteraction or diversion, undertaken in response to superordinate situations in which a given action is obligatory, permitted or forbidden. As a participant, the conceptualiser adopts forms of action appropriate to the situation, and as an observer, he/she communicates the existence of norms which determine the course of events. The external impact of norms in the form of commands and prohibitions is expressed by means of such verbal forms as trzeba 'one needs to', godzi się 'it behoves', należy 'one ought to' and nie wolno 'it is forbidden to'. Combined with the FORCE schema, modal verbs such as trzeba 'one needs to', należy 'one ought to', musieć 'must/to have to', mieć + inf. 'to be to do', godzi sie 'it behoves', wypada 'it befits', wolno 'it is permitted' not only reveal beliefs, opinions and emotions concerning the operations of supernatural powers, but also reflect man's volitional and cognitive attitude. In this way, they build the basis of knowledge about the material and spiritual worlds.

The emergence of preconceptual structures of knowledge enhanced human cognitive abilities, based on experience and biological circumstances, and led to the development of highly abstract ways of reasoning. The application of metaphorical structures of preconceptual schemas in abstract thinking makes it possible to construe processes of interaction between the physical and the metaphysical worlds in terms of FORCE, combined with other image schemas. This principle is borne out by the development of modal lexemes, starting with force, through deontic modality, to epistemic modality [Libura 2000: 205211]. The illocutionary force of speech acts relying on the connection between modal predicates and the FORCE schema turns them into commands, requests, promises, warnings or threats, while their perlocutionary force produces the 
desired response of the addressee, who performs an action or changes his/her mental state [Libura 2000: 206-208].

In event scenarios where the power of the sacred is invoked (incantations expelling a disease (zamawianie choroby) in the name of Jesus or the Holy Mother, "appeasing" a fire in the name of the Holy Trinity, casting a curse), the perlocutionary force of the speech act is reinforced as the use of the holy name endows words with causal power. The disease is cured, the fire dies down, and the curse acts instantaneously and irrevocably. In communicative acts, variants of the FORCE schema are actualised in the form of physical actions, e.g. magical healing practices involving the performance of particular actions such as fumigating, burying in the ground, giving the sick a piece of clay from the bread stove to eat, etc. They also inform patterns of behaviour dictated by epistemic necessity (COMPULSION-BLOCKAGE, e.g. observing the prohibition against putting out a fire started by lightning or using wood from a tree felled by a thunderbolt for timber, etc.). From the onomasiological point of view, models of the FORCE schema contribute to the development of causative concepts as well as concepts connected with social, moral or ethical obligation [Libura 2000: 220-221]. They also underlie metaphorical extensions of lexemes, which acquire a symbolic significance in cultural-religious contexts.

The use of the FORCE schema in the construction of a scene involves locating its origin either in a primary figure (e.g. the Holy Mother who opens up the gates of heaven to purgatorial souls; a vampire (upiór) bringing death to the villagers) or in the background, if it is the agent who is the figure invoking supernatural powers (e.g. a mother conferring a blessing or casting a curse on her child; the purification of water by throwing St Agatha's salt into a well; striking cattle with traditional Easter palms (bunches of willow twigs) ${ }^{1}$ before the first pasturing in spring to protect the animals from evil forces lurking outside the safe space of the farmyard).

\subsubsection{The CENTRE-PERIPHERY schema}

The location of the source of force introduces a further schema which is inextricably related to the construal of a scene, namely CENTRE-PERIPHERY (C-P). The C-P schema determines the degree of the conceptualiser's empathy towards the object of perception - a supernatural force, which manifests itself

1 In Poland, Easter palms are bunches of willow twigs in bloom, or elaborate decorations of straw, dried grasses and flowers, and/or coloured paper and ribbons on a stick (translator's note). 
in its primal form as an external, hence alien $(o b c y)$, power. The sense of otherness (obcość) may, however, be alleviated by reducing the distance between the recipient and the source of force; in this way, the CENTRE-PERIPHERY schema also comes into play in concepts connected with identity (i.e. the category "own/ familiar" (swój) vs "strange/alien" (obcy)).

The CENTRE-PERIPHERY schema is grounded in the following experiences [Johnson 1990: 124-127; Libura 2000: 151-157]:

(1) The structure of the body, which also involves the operation of the BALANCE schema and specific schemas UP-DOWN, FRONT-BACK.

(2) The structure of space within sight; in stereotypes concerning the natural and supernatural worlds, this space is treated as own and familiar (swój), which finds its linguistic expression in lexemes suggesting physical connection by means of the sense of touch, e.g. w zasiegu wzroku 'within eyesight', gdzie wzrokiem siegnać 'as far as the sight reaches', ogarnać wzrokiem 'to encompass with eyesight'.

(3) The structure of a village and the structure of a house/home (dom); it is home, in particular, that is directly linked with the C-P schema both as man's immediate environment, considered to be own, safe space (in opposition to the space outside), and as a metaphorical reflection of the model of the world, parallel with the cosmic mountain and the world tree. Since the vertical, hierarchical order of a house is consonant with the structure of the human body as well as with the corresponding structure of the cosmos, the space of home is considered sacred (imitating God's model of the world) [Eliade 1959b: 42-44]. The sanctity of home is evinced by patterns of behaviour which the family and strangers are obliged to follow, as well as by numerous rites and rituals aimed at ensuring constant contact with the sacred [Benedyktowicz D., Benedyktowicz Z. 1992: 45-58; Bartmiński 1997: 22].

Agnieszka Libura distinguishes two types of the CENTRE-PERIPHERY schema [Libura 2000: 157]:

(1) $\mathrm{C}-\mathrm{P}_{1}$ includes patterns based on the experience of space as a whole, available to the senses from a given vantage point (expressed by such lexemes as szerokie horyzonty 'wide horizons', widnokrag 'the horizon' lit. 'the circle of what can be seen', ogarnąc spojrzeniem 'take in at a glance'). The $\mathrm{C}-\mathrm{P}_{1}$ schema combines specific schemas: BALANCE, UP-DOWN, FRONTBACK, as well as PART-WHOLE and FAR-NEAR. In the relations between the natural and supernatural worlds, the $\mathrm{C}-\mathrm{P}_{1}$ schema serves to delineate 
spaces belonging to the "intersphere" at the border between worlds (a mountaintop, a cave, "the seventh boundary ridge" (siódma miedza), a fork in the road, etc.). As it is usually a remote place, it may be considered alien (obcy), although the final evaluation - as usual - depends on the conceptualiser's point of view.

(2) The $\mathrm{C}-\mathrm{P}_{2}$ schema is present in spatial structures that can be taken in at a glance (e.g. a house, a field); it endows them with order and coherence, thus including them in the "own/familiar" category (swój). In the same way, things that are important or unimportant acquire their proper location in the scene: in the centre or on the periphery, respectively. Magical practices associated with delineating a safe or sacred space involve controlling it by a literal or symbolic enclosing, or marking the boundary (by walking or drawing a circle around it, raking ashes towards the middle, burying an umbilical cord under the threshold). The schema is also apparent in the structure of time, especially magical time, occurring at certain periods of the day or year. In moments of communion with the sacred, time is suspended, it ceases to flow; this is often associated with a change of state, a passage from the "familiar" to the "alien" sphere or vice versa.

Both schemas structure acts of perception and processes of abstract thinking, not necessarily revealed through language. In models of closed space, $\mathrm{C}-\mathrm{P}_{1}$ is combined with the specific schema of a container and the attendant schemas of opening, closing, being inside or outside [Johnson 1990: 126; Krzeszowski 1994: 36]. The open-closed space dichotomy is associated with such values as safety, restriction and identity as opposed to lack of safety, freedom and alterity. Their evaluation depends on the presence of other, more detailed schemas. The model of "being in" a container may play the main role in construing the concepts of safety and identity, building the "own/familiar" (swój) category, and, in most contexts, it is placed on the positive scale of values. The cognitive path in this case is established through means of connections with such domains as the body, family (the mother's womb, the umbilical cord), home (a cradle, a bed). Objects inside a container are less exposed to the impact of external forces ("there is no place like home" (wszędzie dobrze, ale w domu najlepiej); "as cosy as by God's stove" (dobrze, jak u Pana Boga za piecem)), but their capacity for movement tends to be restricted. Thus "being in" has a clearly positive value when the goal is protection, aimed at counteracting destructive forces.

By contrast, enclosing or boundedness perceived as an obstacle to creative powers or as a restriction to cognitive activities ceases to have a positive value, which in such cases is ascribed to the opening schema (summoning external 
forces, e.g. bringing down rain, opening windows and making a hole in the roof to facilitate the passage of a soul of the dead from the earth to heaven). Positively valued, the schema of "being outside" underlies the concepts of freedom and cognition, which, combined with the "alien" category, may lend it their positive emotional charge. The traditional obligation to give a hospitable reception to a dziad (wandering beggar-singer) and invite him to preside over important ritual ceremonies, especially those concerning contact with the metaphysical world (rites of passage) is a case in point. The custom may serve as an example of the openness of rural communities to the outside world, their admiration of freedom represented by the wanderer, and their need to satisfy a simple curiosity about the world: news, stories (often chanted) about heroes, great wars, crimes and punishments. The dziad's relations with the supernatural world sanctioned not only his artistic skills (singing, story-telling) but also his itinerant lifestyle, likened to the wandering of Jesus Christ (or God Himself) on the earth under the guise of a vagabond dziad [Masłowska 2016a: 470-477; Michajłowa 2010: 97; Grochowski 2003: 114; Zowczak 2000: 363-370].

The dominant role of visual over other sensory experiences in providing knowledge of the world not only prompts imaging the FORCE schema as a billiard ball, and the CENTRE-PERIPHERY schema as a circle, a ring or a broadly understood container, but is more generally reflected in the spatialisation of abstract phenomena. An extensive use of the CENTRE-PERIPHERY schema, an elementary component of the structure of space, derives from such spatial conceptualisations of non-spatial notions. In language, the presence of $\mathrm{C}-\mathrm{P}$ schemas is apparent in the semantic structure of words (e.g. zaświaty 'otherworlds' lit. 'worlds beyond'; for more about the concept of "otherworlds" see Chapter 2); in oppositions (e.g. świat $i$ zaświaty 'the [earthly] world and otherworlds', ten $i$ tamten świat 'this and the other world'); in structural metaphors used for classification purposes, such as X IS A CONTAINER [Lakoff, Johnson 1980: 61; Johnson 1990: 37-40]; and in metaphorical extensions, especially in vocabulary referring to the spiritual sphere, to God and to the relationship between the natural and supernatural worlds (e.g. dom ojca 'the Father's house' for heaven).

Preconceptual image schemas are characterised by a bipolar scale of values. Positive values, ascribed to the concept of being, involve such schemas as WHOLE, CENTRE, LINK, "being inside", GOAL, BALANCE, CONTROL. Schemas related to non-being constitute anti-values: PART (destruction), PERIPHERY, lack of LINK, "being outside", BACK, DOWN, LEFT, lack of BALANCE. It should also be borne in mind that source domains (preconceptual schemas) preserve their structure in abstract notions built on their basis [Krzeszowski 1994: 47]. 
The axiological ambivalence which attends the interpretation of phenomena manifests itself differently depending on a given situation, the assignment of roles and places in the scene as well as the hierarchical structure of preconceptual schemas and specific schemas constructing the event. Schemas which form the core of ethical concepts (e.g. BALANCE or CONTROL) motivate the generalised sense of concepts such as 'good', 'possessing proper or desired properties'. Movement along a path leading to a goal is also an important axiological factor. While, in most contexts, the goal as such is positively charged, the path may acquire an ambivalent valuation [Krzeszowski 1994: 39-41].

Onomasiological processes are performed within the framework of specific actions conditioned by the manner in which the energy chain has been activated, as well as the situation, location and time in which events take place. Even if preconceptual image schemas related to space are local or restricted to their area of operation, it is possible to develop a network of semantic interconnections thanks to the cognitive paths linking particular domains. This enables the creation of linguistic correlatives reflecting the traditionally established relations between human and supernatural reality in terms of deontic (ability, possibility, obligation, necessity) or epistemic modality (concerned with beliefs and convictions). ${ }^{2}$

\subsection{Symbolic thinking}

\begin{abstract}
He who marvels that a formal symbol can remain alive not only for millennia, but that it can spring to life again after an interruption of thousands of years, should remind himself that the power from the spiritual world, which forms one part of the symbol, is eternal. ${ }^{3}$
\end{abstract}

Walter Andrae

Symbolic thinking is an integral part of the cognitive experiential myth relying on human embodiment as the basis of images on which the whole conceptual system is built. The cognitive approach makes it possible to see the symbolic act as a phenomenon actualised in communication, parallel to other mental

2 Epistemic and deontic modality is understood here in the sense proposed by Danuta Rytel-Kuc [1982: 14].

3 From the Schlusswort (Conclusion) to Walter Andrae, Die ionische Saule, Bauform oder Symbol?, Berlin, 1933, translated by Ananda K. Coomaraswamy [Andrae 2007: 228] (translator's note). 
processes that serve to translate both the experiences of outside reality and inner feelings into language. In view of the elementary assumptions of the experiential myth - according to which embodiment creates a structured system in the mind, and all operations involving the base (scanning and profiling) are essentially a creative process - we must conclude that the same principles also inform symbolisation. Such premises, then, lead to the adoption of theories which treat symbolisation as a process that is governed by certain rules and capable of being organised into a system, in contrast to the methodological approaches which see the assignment of symbolic meanings as an uncontrollable phenomenon whose roots lie in the unconscious and in psychologically motivated behavioural reflex actions. $^{4}$

Although symbolic thinking relies on visual conceptualisation, metaphorisation - of linguistic and other kinds - prohibits an accidental choice of image. While the range of possibilities for combinations of domains in terms of analogical features or associations is relatively wide, they are far from being fully arbitrary and certainly cannot be considered accidental.

Like other mental operations, symbolic thinking depends on conscious and controlled activities of scanning and profiling the base material. The peculiarity of processes of symbolisation, however, derives from the fact that the choice of domains in the process of scanning focuses on the description of supernatural phenomena which defy rational analysis. Hence the preliminary selection is usually limited to the fundamental questions of being, the mystery of life and death, or the place of the human being in the universe. In other words, it concentrates on the relations between the natural and metaphysical worlds.

The imaging of such relations relies mainly on those entities of the external world that are universal to the human experience (such as water, fire, tree, stone or mountain). These form the base of archetypal symbolic images familiar to most peoples of the world and retain some most general shared meanings, even if their specific semantic content and social functions are determined by the local culture.

The next step in the process of symbolisation is the creation of cognitive paths between the concept that is to be represented by a symbol and an element from the base which is to become its image. Symbolic thinking follows established routines marked out by preconceptual image schemas, which are deeply

4 A critical survey of the two theoretical approaches to research on symbol can be found in such works as Tillich 1960: 75-98; Durand 1964: 19 ff; Eliade 1958: 448-456, 1991: 12-21. 
ingrained in the consciousness of language users. Although profiling is a creative process, it is not possible to create a symbol. Symbols are always formed on the basis of conventional associations by analogy with already existing patterns, which explains their serial character. The creative aspect of profiling involves the foregrounding of those similarities which, from the conceptualiser's point of view, will enrich the content of a linguistic sign with meanings that connect the supernatural and physical worlds and thus give it the character of a synthesis. It is only the dynamics of viewpoint ${ }^{5}$ that makes it possible to show the multiplicity of aspects involved in the phenomenon that a symbol is supposed to represent. This change of angle opens new perspectives, which reveal still further parallels between the natural and supernatural worlds, thus creating a multi-layered vision of the symbolised concept.

The two contradictory levels - of senses and ideas - contained in a symbol produce a tension, which determines the intensity of impact of a symbolic image representing an ineffable mystery. Such tension is especially visible in the religious symbol, which by definition refers to the last things, but never reduces the transcendent to the empirical [Tillich 1960: 77]. This is consistent with the original Greek meaning of the word symbolon, implying an inner unity of a physical phenomenon and suprasensible meaning, which is subsequently divided and then conjoined again [Gadamer 2004: 67].

Similarly to preconceptual schemas, the ambivalent content of a symbol is accompanied by axiological polarity and isomorphism. In keeping with its etymology (imago 'image', imitor 'imitation'), the symbolic imagination reproduces model patterns, combining them in ever newer configurations, thus constantly reinventing archetypal images and endowing them with fresh meanings. Symbols show everything that is subject to conceptualisation; in other words, they show the world in all its complexity [Eliade 1958: 450; Eliade 1991: 20; Lurker 1990: 21-22].

The link between archetypal images and the preconceptual schemas which provide their basis seems obvious. The symbol of the centre, which is present in all cultures, is the most representative example. The centre, i.e. the place where the axis of the world (axis mundi) connects the three cosmic spheres (the divine world - heaven, the earth and the underground world), relies on the CENTREPERIPHERY and VERTICAL schemas. The UP-DOWN schema organises the cultural model of the hierarchical structure of the universe in which the

5 For a discussion of the dynamics of the point of view, see Bartmiński, NiebrzegowskaBartmińska 2004a: 321-358. 
supernatural world, situated above (e.g. the sacred), may be represented by means of elements from earthly reality, located below, but not the other way round. For example, in accordance with the Great Chain of Being, a stone or the sun can become a symbol of the sacred. The symbolic function assigned to elements of sensory reality does not in any way impair their original meaning (a thunderbolt which symbolises the power of the sacred does not cease to be a physical phenomenon), but builds cognitive links that open them up to new associations. In this way, they come to be included in the network of semantic associations of the concepts that they symbolically represent.

While the symbolic imagination involves thinking through images, there are marked differences between an ordinary metaphor and symbol. Since the distinctive feature of symbolic thinking is the capacity to bind materialism with metaphysics, a symbol is always multi-layered and ambiguous. It enables the comprehension of a concept that otherwise cannot be known through the senses, but does not fully reveal its mystery. A symbol is a synthesis uniting opposites, which allows for a semantic and axiological ambivalence (e.g. fire and water may symbolise both creative and destructive powers).

The multi-layered nature of symbol is also apparent in the number of parallel images assigned to a particular concept, which co-exist in the consciousness of language users. The multiplicity of symbolic representations rendering the significance of one concept increases the impact of a symbol, which works on many levels of reality concurrently [Eliade 1958: 450-451; Cirlot 1971: xlix-liii], e.g. the forces of fertility are represented as an egg, sunbeams, the moon, water, fire, earth, wind, etc.

The longevity of archetypes is another feature that symbolic images rely on. As part of the experiential base, archetypal representations are ahistorical by nature, yet they are capable of adjusting to particular temporal and spatial circumstances. The universal character of an archetype means that it can appear independently in distant, unconnected cultures; this does not imply, however, that the meanings it acquires in particular places are identical [Eliade 1991: 34-35; Cirlot 1971: xxxv]. Analogy, which is the basis of symbolic thinking, plays an ordering and unifying role in the process. Establishing points of similitude between particular symbolic images makes it possible to capture the relationships that emerge between them, forming a sequence of parallel associations whose aim is to grasp a certain whole. The ordering and synthesising function manifests itself in connections established between the physical and the psychological, the material and the spiritual, the internal and the external, as well as similarities revealed between activities or processes (especially rituals), and correlations based on formal similitude [Cirlot 1971: xxxii-xxxiv]. Cognitive paths, established 
on the basis of the principle of parallelism, make it possible to profile a series of connections related through meaning or situation. Light that symbolises the sacred becomes part of a chain linking wisdom, knowledge, good, truth, justice and majesty, thus immediately pointing to their divine origin. In this way, light becomes not only an image of the sacred, but also a symbol of its attributes and, consequently, values (of wisdom, knowledge, truth, majesty) connecting heaven and earth. The necessary tension, characteristic of a living symbolic sign, is achieved thanks to the connection between the sensory experience of light, the sacred and a series of values most cherished by man, culminating in the property that integrates all the levels of the image: eternity.

\subsubsection{Symbol - myth - ritual}

In the world of symbolic connections, the transitory being of creation becomes a parable of the eternal being of God, even if God stands above such a parable. The analogy of being (analogia entis) makes it possible to see the invisible in what is visible. Nothing is too humble to represent and to glorify the sublime. ${ }^{6}$

\section{Manfred Lurker}

The essence of parallelism which lies at the basis of a symbolic image consists in the evocation of a higher, spiritual world whose existence is ingrained in the social consciousness in the form of myth, especially the cosmogonic myth. The creation myth, present in all cultures of the world, forms the basis of the archetypal religious attitude, which imbues human existence with a sense of participation in transcendent reality. Such a primordial religious attitude not only relies on the experience of God's presence to grant human actions the status of imitations of the actions of God, but it also involves the perception of physical objects as manifestations of the sacred [Eliade 1958: $448 \mathrm{ff}$ ].

In folk culture, the creation myth both constitutes the basis of the worldview and plays a modelling function in a number of spheres, especially those connected with beliefs and magic, folk morality and the value system [Tomicki 1976: 47]. The cognitive value of myth derives from the fact that its structure

6 "In einer Welt symbolischer Zusammenhänge erscheint das vergängliche Sein der Schöpfung als Gleichnis des ewigen Seins Gottes, wobei jedoch Gott über diesem Gleichnis steht. Die analogia entis läßt in dem Sichtbaren (visibilia) das Unsichtbare (invisibilia) erkennen. Kein Ding ist zu niedrig, als daß est nicht das Höchste bedeuten und zu seiner Verherrlichung dienen könnte" [Lurker 1990: 14] (translator's note). 
encompasses simultaneously the past, present and future [Tomicki 1976: 51]. Mythical thinking organises the human cosmos. In providing models and ideas, it satisfies the individual's inner need for a sense of identity and cultural belonging, and assigns a human being his/her place in the world and in the community in which he/she lives. Every society is bound by a system of myths and complexes of thought patterns (the basis of stereotypes) which lie at the root of human actions and dictate ways of behaviour. The interdependence between myth and culture lies in the fact that myth cannot exist outside the framework of a culturally determined social reality with its values. While the content of myth is often common to all humanity, it is always expressed in the categories of local culture. In this sense, the mythical past is actualised in the present and motivates future actions, providing them with a significance and a sense of purpose [Mróz 1976: 35-37].

The experience of myth acquires the form of symbol, and imitation of divine actions turns into ritual practice. Thus myth, ritual and symbol form an interrelated triad: the vitality of a symbol, whose content evokes a mythical event, is revealed in ritual and magical practices. Myth as such - as an archetypal experience of the sacred - is indestructible; it assumes still newer symbolic forms or manifests itself in ritual-like actions. Ritual repetition not only reactualises a symbol as such, but also incorporates its image into the stereotype of relations with supernatural reality [Eliade 1958: 455-456; Lurker 1990: 10].

The inclusion of the mythical element opens the symbol to transcendence, thus offering a sense of divine presence in its immediate surroundings. Identification with a mythical event makes it possible to evoke the time of origins, re-create the primordial order and submit oneself to cosmic rhythms (cyclic death and rebirth imposed by the progress of day and seasons). Every cyclic festival interrupts historical time, transferring the participants of the ritual into the sphere of mythical time, created and sanctified by divine beings in the course of their gesta - deeds that a given celebration is re-enacting. By suspending the flow of contemporary time, the ritual subsumes man into the sphere of eternity. In this way, holiday celebrations afford the opportunity to transfer periodically from the sphere of real time to the mythical present and experience a sense of actual participation in the sacred event [Eliade 1958: 32-33; 1959b: 68-70].

Ritual re-enactment of myth provides models for the way an individual should function in society, thus establishing norms of behaviour. According to the ethics of myth, man should be integrated into his community. Participation in a rite or submission to ritual actions create a situation conducive to transcending the boundaries of self and identifying oneself with a group. On the other hand, myth re-lived in ritual scenes of passage provides a model for individual development 
in liminal situations, when human existence is open to the mysteries of transcendence: the rituals of birth, marriage and death. The symbolism of rites of passage makes it possible to experience a sense of metaphysical unity with the supernatural world [Eliade 1958: 412; Campbell, Moyers 1988: 38-39, 227-228].

MOYERS: You say that mythology is the study of mankind's one great story. What is that one great story?

CAMPBELL: That we have come forth from the one ground of being as manifestations in the field of time. (...)

MOYERS: So the one great story is our search to find our place in the drama?

CAMPBELL: To be in accord with the grand symphony that this world is, to put the harmony of our own body in accord with that harmony. [Campbell, Moyers 1988: 64-65]

Myth, symbol and ritual are bound by mutual interdependence: myth lives in symbol, symbol feeds on myth and ritual applies them in practice. They share their relationship with the sacred, which ensures their eternal survival. Admittedly, some symbols may lose their relevance and become mere signs or allegorical images as a result of the decline of ritual and religious attitudes, caused by the development of civilisation and the attendant general tendency towards secularisation. However, symbols display a remarkable capacity for revival in new forms, even if language users cease to recognise their mythological content. The vitality of symbol and myth derives from the fact that they lie at the foundation of the human experience of the world; they belong to the experiential base of the conceptual system. In other words, archetypal images, having set in motion a web of semantic interrelations, have become its permanent and active elements, with unlimited potential for the creation of new configurations. In this way, symbol links the current state of knowledge of the world with the endlessly re-discovered mystery of eternity, and thus acquires a cosmic dimension [Campbell, Moyers 1988: 64-65; Eliade 1958: 125, 429-434, 451-456; Lurker 1990: 21-25].

Manfred Lurker writes: "Myths and symbols, which belong to the primordial layer of human historical and psychological development, are deeply grounded in such experience. The symbolic vision of the world reveals a higher (and deeper) meaning of individual existence, transcending its being as a physical phenomenon" [Lurker 1990: 11].7 In this way, symbol and myth unveil a higher (divine)

7 "In der Tiefe solcher Wirklichkeitserfahrung wurzeln Mythen und Symbole, die deshalb der Urschicht der historischen und psychischen Entwicklung des Menschen angehören. In symbolischer Weltschau erschließt sich die höhere (und zugleich tiefere) Bedeutung, die ein Einzelnes über sein Dasein als sinnliche Erscheinung hinaus besitzt" [Lurker 1990: 11] (translator's note). 
world and supernatural marvels, which "filter" into the world of everyday life. Through myths and symbols we learn about the metaphysical world as a transcendent reality, which is the basis of temporal and spatial reality.

Ingrained in the social consciousness through the ritual reiteration of behaviours, attitudes, valuations and through the mental processing of images, prototypes of symbolic representations form the basis of communication. Even if they are not necessarily reflected in lexis, they have penetrated into the connotational aspect of meaning, thus paving the way for the creation of serial symbolic representations which build the linguistic worldview common to both the sender and addressee.

\title{
1.3.2 Prototypes of imaging the cosmic order: the cosmic mountain and the tree of life
}

\begin{abstract}
All this (...) is ciphered in the cosmic rhythms; man need only decipher what the cosmos says in its many modes of being, and he will understand the mystery of life. But one thing seems clear beyond doubt: that the cosmos is a living organism, which renews itself periodically. The mystery of the inexhaustible appearance of life is bound up with the rhythmical renewal of the cosmos. This is why the cosmos was imagined in the form of a gigantic tree. ${ }^{8}$
\end{abstract}

Mircea Eliade

According to the creation myth, God gave shape and structure to primal chaos, thus turning it into the ordered cosmos. Since the direct experience of space is construed in terms of the CENTRE-PERIPHERY schema, in order to imagine the cosmos as a whole, the conceptualiser needs to establish a stable point which will function as the middle, the symbolic centre of the world. The image of divine order grounded in bodily anthropology further situates heaven and earth in a vertical arrangement, consistent with the UP-DOWN schema. The axis of the world, passing through the meeting point between heaven and earth, is imagined as a pole supporting the skies, a pillar, a mountain peak or a tree top, i.e. a series of cosmological images based on the prototypical schema of the centre: the holy place, where divine power is revealed [Eliade 1958: $28 \mathrm{ff}$ ]. The vantage point of the conceptualiser of the cosmos is thus located in the centre of the world, from which he/she re-enacts the divine model of creation, taking as the basis the

8 Mircea Eliade, The Sacred and the Profane [Eliade 1959b: 148]. 
position of his/her own body. In keeping with the vertical axiology of the Great Chain of Being, the upper level, above the head, is dedicated to God.

A mountain - whose top reaches the sky, the foot rests on the ground and the inside is enveloped in darkness - is the best reflection of mythical geography. The top of the cosmic mountain corresponds to the divine sphere, while the underground parts, the opposite of the peak, become the sphere of the demonic (the reverse of the sacred) [Eliade 1958: 274-275; Tomicka, Tomicki 1975: 73; Kowalski 1998: 141-142; Adamowski 1999d: 130-131]. Predictably, mountaintops are locations of religious experiences: places where the sacred is revealed, hence belief in the sanctity of mountains and the special power of their peaks. This is why sites of religious rituals and sanctuaries - monasteries, churches, chapels, crosses, figures of saints - are often located on mountaintops [Eliade 1958: 99-102; Kowalski 1998: 142; Adamowski 1999d: 55]. The very architecture of consecrated buildings reflects the image of a mountain, all the more to focus its power drawn from contact with the sky - the metaphysical world [Kowalski 1998: 142].

A mountaintop is a natural image for absolute, omniscient, perfect, unlimited being. Endowed with a spatial structure, the concept of the absolute, inaccessible to direct human cognition, becomes easier to approach. The cosmic mountain as a model of the universe combines all the positively valued schemas: CENTRE, WHOLE, LINK and BALANCE, supported by the vertical organisation. In this way, the mountain becomes a model schema (prototype) for other structures requiring hierarchical arrangement.

As a symbol of the cosmos, the cosmic mountain relies on the principle of physical similarity and on conventional axiology, while preserving its multilayered significance. Additionally, it is a complex image, which binds opposites (sky vs earth, heaven vs hell), and thus makes it possible to pass from one sphere to another. The location of evil forces inside the mountain is also consistent with the conventional identification of evil spirits with darkness. The symbol of the cosmic mountain has become a prototypical image for other cosmic models: the tree of life, a pole, a pillar, a ladder, which bind together the three spheres. Temples and houses also reflect the structure of the cosmic mountain. Both a temple and a home represent a sacred space: the centre of the world. Rituals performed during their construction (laying the cornerstone, blessing) repeat the act of creation, reactualising the mythical time of origins; by the same token, they create a sanctified space [Eliade 1958: 379-380; 1959a: 4-6; 1959b: 44-47].

The most widespread symbol, however, is the cosmic tree, situated in the middle of Paradise as the tree of life, and on Golgotha as a symbol of both death and resurrection. As a way of imaging the cosmic order, the tree of life relies 
on the same schema as the cosmic mountain, but includes other elements of the Great Chain of Being missing in the mountain image. The top of the tree corresponds to the mountain peak, i.e. the divine sphere; the trunk - to earthly reality, and the roots - to the underground demonic world [Eliade 1958: 269, 292; Tomicka, Tomicki 1975: 72-79; Marczewska 2002a: 47].

Additionally, however, the central location of the tree of life (in the middle of the world: in Paradise and on Golgotha) links the cosmic tree (representing the plant world) with the level of religious experience appropriate to the human sphere, while the cyclic death and rebirth of the tree represents not only the abstract category of time, but also evokes associations with vital values and experiences associated with the plant level, i.e. life and death. The beginning and end of human life are naturally connected with wood: from the wooden cradle to the (also wooden) coffin and cross on the grave [Marczewska 2002a: 91]. In this way, the symbol of the cosmic tree comes to include the concept of the path of life (droga zycia) from birth to death, as borne out by the etymology of the word drzewo 'tree', which includes the semantic root that denotes the road/way (the way of the soul to "otherworlds" (zaświaty)); cf. the Indo-European *der-u 'tree', *dor-u 'way'; Polish drzewo 'tree', droga 'road/way'; Old Icelandic trog 'trough'; Irish drochat 'bridge' [Ivanov, Toporov 1965: 166-167; Marczewska 2002a: 41].

Extended to include the journey of the souls to "otherworlds" after death, the symbolism of the tree as the path of life reveals its most archaic layer: the mediating function as a connection between heaven and earth (similarly to a mountain). The image of a tree as a way into the supernatural world generates a series of parallel images of souls climbing up a rocky mountain, a pole, a rope or a beanstalk towards the sky [Kowalski 1998: 145-146]; all of these ultimately derive from the mythical image of ascension into heaven [Eliade 1958: 102; Marczewska 1998: 131]. A cross on a grave, the custom of planting trees in cemeteries and the command to bury those who had died a tragic death under a tree in order to facilitate their passage into "otherworlds" are all practical applications of the symbol, thus testifying to its cultural vitality and rootedness [Marczewska 2002a: 59].

9 The symbolic connection between man and tree as an image of the human path of life is also evinced in the custom of planting a tree on the day a child is born (an oak for a boy, a lime for a girl). The correspondence between the sex and the tree is so deeply ingrained in folk tradition that it applies also after death. The bodies of the dead are placed in rough sawn wooden coffins, oak for men, lime for women, since in folk culture trees are also believed to be the abode of the souls of the dead [Marczewska 2002a: 90-91; Tolstoî 1995]. 
Thus, as a symbol of death, a tree is a synthesising conceptualisation which unites opposites and facilitates the passage from the sphere of life to death. This is particularly visible in rituals preparing the dead for the journey to "otherworlds". The custom of pouring away the water used for washing a dead body under an elder tree symbolically connects the dead with the lower sphere of the cosmos, thereby separating them from the world of the living. The command to put wood shavings from a coffin inside it as well as the tools used to make it also plays a protective function [Marczewska 2002a: 91]. Similarly, the custom of stopping the burial procession at a cross standing at a fork in the road is meant to both protect the living from the return of the dead and point the soul in the right direction on its onward journey. Such progress is further facilitated by hanging a linen towel on the cross, as a second, reinforcing, symbol of the path of life. The very location of memorials of Christ's Passion at crossroads has the symbolic function of separating the familiar from alien space that belongs to "otherworlds" and is ruled by alien, supernatural powers [Adamowski 1999d: 219; 2011: 181; Marczewska 2002a: 57].

The conceptualisation of life by means of the tree image paves the way for other metaphorical extensions, such as an identification of a girl with an apple tree (tree-life-fertility-girl), which recurs in texts of folklore [Marczewska 2002a: 79-80] as a contrasting symbol to that of a withered tree representing death; ${ }^{10}$ or a green branch as a textual equivalent of life and fertility. Green branches symbolising life, rebirth and fecundity are also used in rites and rituals; examples include a podłaźnik (the prototype of a Christmas tree hung from the ceiling), traditional Easter palms (bunches of willow twigs) with which boys whip girls on Easter Monday, a gaik (a small tree or bunch of green branches) carried around a village as part of spring celebrations and a rózga weselna held by the groom (a tip of an evergreen tree decorated by the bride with apples (a symbol of fertility), flowers and ribbons on the night before the wedding). In folk stories and Christmas carols, a golden tree represents dream and wealth [Marczewska 2002a: 43-45].

The connection between the cosmic tree and spiritual beings from the highest level of the Great Chain is manifested in beliefs and religious rituals in which a tree acquires holy properties through a direct or symbolic association with the sacred, e.g. the tree of the cross (it was traditionally believed that Christ's cross

10 As opposed to a healthy tree, the image of a withering or moulding tree (and rotting plants more generally) is the basis of the metaphorical opposition healthy vs ill [Masłowska 2004: 183-184]. 
was made from the Tree of Life, which grew in in the middle of Paradise [Eliade 1958: 292-294; Kowalski 1998: 97; Marczewska 2002a: 49-50, 89]), relics of the True Cross and, by extension, all crosses symbolising Christ's Passion (hence the names of wayside crosses: Boża męka 'God's Passion', męka Pańska 'Lord's Passion').

The link between the cosmic tree and the absolute is also apparent in motifs in folk Christmas carols and in paper cut-outs showing two birds perching on the top of a tree which symbolise the two creators of the world: the divine and the demonic sacred [Tomicka, Tomicki 1975: 74-80]. The image of two demiurges as birds and their symbolic position on the tree of life reflect the dualistic model of the world with the in-built polarity of the scale of values. The two opposing sides of the highest spiritual being represent good and evil - archetypal values inscribed in the experiential base as the elementary criterion of classification. The birds symbolising the sacred are yet another example of the possibilities of imaging abstract beings by means of entities that derive from lower levels of the Great Chain and are known from direct experience.

The metaphorical image of the cosmic order as a tree of life or a cosmic mountain thus turns out not only to be a reflection of the Great Chain of Being, but also a vivid example of the cognitive use of source domains to explain such complex phenomena as physical and spiritual beings. The images of the COSMOS AS A MOUNTAIN and the COSMOS AS A TREE are already symbolically charged. Linking the concrete and the ideal, they are imbued with a semantic depth that requires a wide background knowledge to unravel, relying as they do on a system in which the earthly world is part of the cosmic universe [Bartmiński 2009b: 211]. As a universal schema structuring reality, such imaging reveals the hierarchical interrelations of all the levels in the model in keeping with the principle according to which beings of a higher order display all the features of beings from a lower one (e.g. human beings have certain characteristics in common with animals) and consequently can be represented in their terms (e.g. an apple tree symbolising a girl, birds (representatives of the animal level) symbolising the sacred: the two demiurges). The principle, however, does not work in the opposite direction, since beings of a higher order have features which differ from beings from the lower orders in the model. Thus the Great Chain of Being turns out to be deeply embedded in the unconscious as an archetypal cultural model structuring our perception of reality [Krzeszowski 1999: 34].

The axiological value of the images of both the cosmic mountain and the tree of life displays an isomorphic correspondence with the preconceptual schemas that make up their structure (see the principles of axiological isomorphism [Krzeszowski 1999: 35]). Hence the cosmos is construed as a whole (the 
WHOLE-PART schema) which is hierarchically structured (the UP-DOWN schema) and formed by elements linked both vertically and horizontally (the LINK schema).

In keeping with the Invariance Principle [Krzeszowski 1999: 65], source domains, which function in our unconscious as preconceptual schemas organising the experiential base, retain their original structure when mapped onto target domains (e.g. in abstract notions). Consequently, imaging the universe as a mountain or a tree presupposes a holistic, vertically ordered structure whose axiological scale is also vertically oriented. In this way, the cosmic model based on the anatomy of the human body creates a prototype for an anthropocentric interpretative attitude. 



\section{Stereotype as a projection and interpretation of the world}

Eight decades of research on stereotype, involving representatives of various disciplines - from sociology, through psychology, philosophy, history, literary theory, ethnology, to linguistics - testify to the appeal of stereotype as a subject of investigation, as well as to its multifaceted nature. All these fields of study have made a valuable contribution to the understanding of the subject, revealing an array of issues involved in popular schematic thinking, previously deemed worthless and devoid of cognitive value. Sociology considers stereotype in the context of collective behaviour and the operation of social norms; psychology focuses on the phenomena of perception, categorisation, attitudes and beliefs, and literary history - on conventionalised forms of expression and stylistic devices. ${ }^{1}$

Linguistics, in turn, approaches the issue of stereotype in a number of different ways. Some scholars limit the question to conventionalised and reproductive word combinations [Kurkowska, Skorupka 1959: 158; Lewicki 1976: 23]; others are fascinated by the mental element involved [Bartmiński 1985, 1998b, 2007; Bartmiński, Panasiuk 1993; Chlebda 1998: 31]. Psycholinguists, in turn, are mainly concerned with the emotional dimension and value judgment of stereotype [Pisarek 1975; Pisarkowa 1976; Schaff 1981], while cognitivists tend to focus on its emotional, social and, above all (as proposed by Walter Lippmann and Hilary Putnam), ${ }^{2}$ cognitive function.

Cognitive linguistics approaches stereotype in very broad terms - as a specific mental construct realised in stable linguistic forms at the structural or lexical level, or only in cultural contexts. Treated as a tool which enables perception and cultural interpretation, stereotype acquires the status of a cognitive category that mediates two-way communication between individuals and their environment (message "to" and "from" the world) [Chlebda 1998: 34]. This approach, adopted particularly in cultural linguistics [Bartmiński 1985, 1988a, 1998b, 1993b; Anusiewicz 1995; Tołstaja 1998], attaches considerable importance to the cognitive value of mental stereotypes, both those which have a fixed linguistic

1 For more information about the history of the study of the phenomenon of stereotype, see Bartmiński, Panasiuk 1993; Bartmiński 1998a, 1998c; Chlebda 1998: 31.

2 Lippmann 1922; Putnam 1975. 
form and those which are communicated by means of other cultural signs. In the latter case, the presence of stereotypes manifests itself in language in the sphere of semantics, the communicative function and at the level of text interpretation [Bartmiński, Panasiuk 1993]. In this way, the cognitive stream has introduced a range of research concepts and tools revealing the value of stereotype in the study of language. ${ }^{3}$

In Poland, methodological issues (both theoretical and practical) involved in the study of linguistic and cultural stereotypes - including questions relating to study material and, consequently, its semantic content, as well as definition and function - were particularly addressed in the course of work on Stownik stereotypów i symboli ludowych (A Dictionary of Folk Stereotypes and Symbols, hereafter SSSL) ${ }^{4}$ [cf. Bartmiński 1980b, 1985, 1988c, 1994a, 1994b, 1998a; Bartmiński, Panasiuk 1993].

Following a broad definition proposed for the SSSL dictionary, according to which stereotype is "a subjectively determined image of an object, including both descriptive and evaluative features, which is a result of interpretation of reality within the framework of social cognitive models" [Bartmiński 1998c: 64], the present study analyses both linguistic and mental stereotypes approached in conjunction.

The analysis offered here aims to investigate the interaction of the cultural and linguistic codes by discussing the stereotype of interaction between the physical and metaphysical worlds from the perspective of the conceptualiser, including:

- the use of the experiential base, i.e. mental modes of imaging relations between the two spheres and the role and function of preconceptual image schemas in the structure of stereotype;

- the mode and process of perceiving this relationship (feelings and attitudes to the divine and the demonic sacred; the place, time and type of contact; particular actions undertaken in order to summon the power of the sacred; actions of supernatural forces affecting the subject: creating an event scenario establishing the archetypal roles of the participants);

3 The issues of stereotype in linguistic study are discussed in volume 12 of the series Język a kultura (Language and Culture), entitled Streotyp jako przedmiot lingwistyki. Teoria, metodologia, analizy empiryczne (Stereotype as an Object of Linguistic Description: Theory, Methodology, Empirical Studies) [Anusiewicz, Bartmiński 1998]. The volume is a collection of papers presented at an international conference held in 1994 as part of a series of seminars called Jezzyk a Kultura (Language and Culture).

4 SSSL 1.1 (1996); SSSL 1.2 (1999); SSSL 1.3 (2012). 
- the process of profiling stereotypes (scanning the base, using cognitive paths to connect different domains, supressing and foregrounding selected characteristics of created objects, axiologisation);

- the generation of prototype profiles - characterised by a distinct, typical structure, and hence most often reproduced - which form the basis of derived profiles, referring to peripheral, often borderline, properties.

In a particular culture, scripts of behaviour in relation to the sacred have a set form and structure. Closely connected with the mode of imaging and interpreting abstract concepts and relations with the supernatural, they establish norms and principles of conduct passed on from generation to generation in verbal and non-verbal form. The cognitive structure of stereotype reveals its symbolic, cultural and myth-making function, which can become apparent in language at a number of different levels, including:

- the internal form of a word revealing its semantic motivation (e.g. gromnica 'thunder candle', a blessed candle offering protection from thunderbolts; dusiolek 'mare', lit. 'choker' (< dusić 'to suffocate'));

- phraseological units (e.g. jak trwoga, to do Boga 'when in fear, God is dear'; diabet ogonem przykryt 'the devil has covered it with his tail', used when something has been misplaced and cannot be found);

- fixed lexical combinations (e.g. jak Bóg da 'God willing'; diabli nadali 'the devils have brought it', used to express annoyance about an unexpected nuisance);

- collections (co-occurrence of particular concepts and lexical units, e.g. poruszyć niebo i piekło 'to move heaven and hell'; wszystkie znaki na niebie $i$ na ziemi 'all signs in the heavens and on earth');

- the functioning of synonyms (synonymic chains with a different semantic dominant, e.g. czarownica 'witch', znachorka 'female healer', szeptunka 'female healer', lit. 'female whisperer', baba 'a wise (old) woman'), and euphemisms (e.g. on 'he', ten 'this one', czarny 'the black one', i.e. diabet 'the devil');

- the development of metaphorical meanings and symbolic functions of language units (words and word strings forming a chain of symbolic associations, e.g. ogien' 'fire' - życie 'life' - dom 'house/home' - rodzina 'family'; chleb 'bread' świat 'the world' - zycie 'life' - kobieta 'woman');

- extensive polysemy of words (the inclusion of words in association or opposition sequences by means of profiling);

- denomination (e.g. Jasna Góra 'The Bright Mountain' vs Czarna Góra 'The Black Mountain'; Bożyca 'God's Mountain' vs Czortyca 'The Devil's Mountain'; Czarcia Skała 'The Devil's Rock'; Diabelska Góra 'The Devil's Mountain'). 
Onomasiological processes stemming from stereotypical behaviours at the semantic and pragmatic level of language are approached here as panchronic phenomena (which occur both diachronically and synchronically) consisting in the stabilisation of certain semantic combinations (i.e. the emergence of phrasemes [Chlebda 1991]), resulting in the emergence of:

- principles of lexical connectivity (e.g. diabelskie sprawki 'the devil's doings', upiorne myśli 'nightmarish (lit. 'ghostly') thoughts', moc boża 'God's might', siła nieczysta 'evil force', lit. 'impure force');

- fixed metaphorical comparisons (e.g. czarny jak diabet' as black as the devil', biaty jak śmierć 'as white as death', czerwony jak upiór 'as red as a vampire');

- metaphorical or metonymic associations that make it possible to create expressions based on distant domains which do not share a common component at the core structure of their meaning (e.g. dusza 'the soul' and strach 'fear': mieć dusze na ramieniu 'to have one's soul on one's shoulder', i.e. 'to be very frightened'; twórczość 'creativity' and oddech 'breath': natchnienie 'inspiration'; Bóg 'God' and ogień 'fire': iskra Boża 'God's spark', ogień Boży 'God's fire');

- metaphorical extension (e.g. miłość 'love' - żywiot 'elemental force’: zapałać miłościa 'to become enflamed with love'; życie 'life' - ogień 'fire': życie się $w$ kimś tli, gaśnie 'life is smouldering in someone,' 'life is burning out');

- metaphorical image schemas (e.g. the container metaphor);

- metaphorical axiological models (e.g. 'up' is 'good', 'down' is 'bad') and their linguistic correlatives - phraseological units and lexical items stemming from cultural determinants (e.g. schytek $\dot{z} y c i a$ 'the decline of one's life', i.e. 'the close of one's life'; duchowy upadek 'spiritual fall'; wznosić prośby/modty do Boga 'to raise supplications/prayers to God').

\subsection{The basis for creating stereotypes in folk culture}

Stereotype plays an important role in ethnolinguistics since it provides a wealth of material reflecting the mode of perception and judgment of reality in the rural social environment, as well as attendant models of behaviour, all of which generate the folk cultural code. As demonstrated by research on folk culture, ${ }^{5}$ the

5 Research on folk culture in Poland has a long tradition going back to the nineteenth century; it has produced a wealth of study material in the form of descriptions of rituals, traditions, customs, rites, songs, folk literature and phrasebooks of local dialects. These materials were mostly published in ethnographic journals, including Wisła (The Vistula), Lud (The Folk), Literatura Ludowa (Folk Literature), Zbiór Wiadomości do 
conservatism of this social group and, consequently, its attachment to tradition and observance of customs, rites and rituals are particularly conducive to preserving archetypal patterns of spiritual culture based on the most ancient beliefs. This has also been confirmed by ethnolinguistics, as revealed in the course of work on Stownik stereotypów i symboli ludowych, particularly important from the point of view of linguistic anthropology. Studying stereotypes makes it possible not only to identify the remaining traces of archetypes in folk culture, but also to discover the roots of images (preconceptual schemas), attitudes and patterns of behaviour related to the sacred, and to investigate their evolution.

Although the development of a stereotype is a long and collective process, it is not without its subjective component. Indeed, the subject and the object of cognition are the essential elements involved. The relations between them are defined by the conceptualiser's point of view, which in turn determines the cognitive perspective. Dynamic relations between the subject's viewpoint and the observational perspective result in the emergence of stereotypical profiles [Bartmiński 1993a, 1993b; Bartmiński, Niebrzegowska 1998; Bartmiński, NiebrzegowskaBartmińska 2004a; Tokarski 1998c].

\subsection{The individual and collective subject and the object of conceptualisation}

Treating the image schemas of interaction between the physical and metaphysical worlds in folk culture as the basis of their conceptualisation, we assume that they are created by a collective subject, i.e. they stem from the experience and beliefs of rural communities. This, however, does not mean that the inherited and transmitted pattern is impersonal. Indeed, although it is a social group that is the construing and experiencing subject, the emerging image is a joint creation of its particular members: their personal involvement in tradition and rituals, their ritual actions, their observance of norms and restrictions, as well as their engagement in the process of communication and designation as such, confirm their membership of the community. In this way, they become co-creators of the cultural and linguistic image of a given fragment of reality.

It is assumed that the cognitive process begins with an act of seeing [Libura 2000; Tabakowska 2004; Tołstaja 2004: 178], which leads to interpretation and,

Antropologii Krajowej (A Collection of Studies for National Anthropology) and dictionaries of local dialects; they became a major source of all important monographic and lexicographic studies (cf. the list of sources in SSSL). 
eventually, categorisation of phenomena, resulting in the emergence of a structured, subjective mental image of the world. Although the preservation of this image in the social imagination does not necessarily involve lexicalisation, it remains an equally important conceptualisation component [Bartmiński, Panasiuk 1993: 337; Bartmiński 2006b: 81-82]. Interpretation of texts is made possible by cultural contexts arising as a result of particular beliefs, religious and magical practices, rituals, convictions and widely accepted assumptions, all of which shape emotional attitudes, communication strategies and patterns, and the value system, and in this way belong to the linguistic worldview (jezykowy obraz świata). ${ }^{6}$ Jerzy Bartmiński refers to all these elements as the 'co-linguistic context' (kontekst przyjęzykowy, also known as 'ad-linguistic context'):

The linguistic worldview draws on data entrenched in the linguistic system, as well as on characteristics revealed by language use and the beliefs and patterns of behaviour which form the 'co-linguistic context', relevant to the interpretation of linguistic texts.

[Bartmiński 2006a: 20]

Although the co-linguistic context is not always explicitly reflected in lexis or grammar, it is implicitly present in the role played by cognitive schemas in the processing of information [Quasthoff 1989] and in the realisation of the category "own/familiar" (swój) as a component of non-verbalised social knowledge about the world, common both to the sender and the addressee. Since this knowledge forms part of the conceptualiser's experiential base, it should be regarded as linguistically relevant [Muszyński 1988: 129-153].

The cognitive process shaped by culture-making factors is a long-term one by its very nature. Consequently, in order not to lose sight of the inter-generational contact in the creation and reproduction of images of the interpenetration of

6 Information about theoretical foundations of this concept (developed in the course of work on the SSSL dictionary) and about discussions concerning this issue held in a programme of seminars called Język a Kultura (Language and Culture) can be found in the series of conference proceedings published under the same title by Wrocław University, in the so-called "Red Series" (Czerwona seria) edited by the Institute of Polish Studies at the Maria Curie-Skłodowska University in Lublin (especially the volume Językowy Obraz Świata (The Linguistic Worldview), ed. Jerzy Bartmiński, Lublin 1990), and in a number of articles which appeared in the journal Etnolingwistyka (Ethnolinguistics). Jerzy Bartmiński’s Językowe podstawy obrazu świata (Linguistic Foundations of the Image of the World) sums up the long period of research devoted to the concept [Bartmiński 2006a]. The author also considers the linguistic worldview and stereotype in ethnolinguistic study in his other works published in Poland and abroad [Bartmiński 2005, 2007, 2009a, 2009b]. 
the sacred and the profane, this analysis considers (mainly ethnographic) material collected between the turn of the twentieth century and today. ${ }^{7}$ In view of the rapid pace of change in the modern world, one in which traditional rural communities have merged into national and global society, we need to be aware that the reconstructed context has become somewhat obsolete, as confirmed by field studies, recording such comments from respondents as "that's what it used to be like in the old days" (tak dawniej byto) and "that's what the old people say" (tak starzy mówia). This indicates that today's language users distance themselves from the originators of this old rural linguistic worldview [Bartmiński 1989, 2006a: 25-27; Kurek 2004b: 218-219] that existed in the late nineteenth and early twentieth centuries. However, the spiritual dimension of the relationship between the physical and metaphysical worlds would be entirely incomprehensible if the study material were to be limited to the present. Indeed, the experiential base, structured by preconceptual image schemas, is an element of a cultural-linguistic continuum. Passed on from generation to generation, it is not subject to verification but accepted as the status quo, as cultural heritage that determines our identity.

\subsection{Point of view}

The category of point of view includes three basic factors: objective (concerning the content of awareness, knowledge, experience and perception), formal (concerning the expression of time and space) and axiological (concerning the system of values) [Muszyński 2004; Tabakowska 2004; Bartmiński 1990: 111]. ${ }^{8}$

Representations of "this" and "the other" world, and patterns of their interaction, rest on a mythical thinking and a religious attitude to supernatural phenomena. Developing an image of these relations is a multi-stage and multidimensional process. The point of view is not a fixed category, as it changes

7 The analysis is mainly based on the material collected in Słownik stereotypów i symboli ludowych (SSSL) and ethnolinguistic studies occasioned by work on this dictionary, as well as on other ethnographic publications and studies of local dialects.

8 I adopt the terminology proposed by Zbysław Muszyński [Muszyński 2004]. Elżbieta Tabakowska uses the term 'determinants of the point of view' (wyznaczniki punktu widzenia), including the perspective of observation (subject - object), conceptualisation (time, space, object) and lexicalisation [Tabakowska 2004]. Jerzy Bartmiński, in turn, defines point of view as a subjective-cultural factor which determines the way an object is talked about, including such elements as its categorisation, the choice of the onomasiological base when creating its name, and the choice of features attributed to an object in particular utterances and preserved in the meaning [Bartmiński 1990: 111]. 
depending on the situation, emotional attitude and a number of culture-making factors [Bartmiński 1990: 111], including the acceptance of the existence of the sacred and its impact on human fate. A religious attitude to supernatural forces provides the conceptualiser with a particular perspective, which includes elements of visible and invisible reality that construct the scene of interaction, mainly time, space and participants - the agent and the object (the sacred and the human). The conceptualiser can view the scene from within (as a mediator, participant, an object of magical practices or an object of action or impact of the supernatural) or from outside (as an observer). Since the position of an outside observer presupposes distance, it provides the conceptualiser with an opportunity to form a more subjective judgment and interpretation of the event. When the conceptualiser is part of the scene and is exposed to the experience, his/her point of view merges with the outlook of the group. The ensuing image of reality is a product of the collective imagination, which makes it more objective and hence provides the basis of linguistic communication in a precisely determined subject area. In this way, the collective point of view of the "generalised observer" creates conditions for the lexicalisation and grammaticalisation of the message [Tabakowska 2004: 52-53].

The process of gaining an understanding of the sacred may be seen as a type of contact, which determines a specific nature of the relation between the subject and the object. As a result, the distance between them is naturally reduced, and in extreme cases the subject may even identify with the object. "Every process of coming to know something includes in one form or another a process of assimilation, a sort of inner unification of the knower with the known. This process differs according to the respective level of being on which the knowing subject and the known object exist" [Ratzinger 2007: 340]. Consequently, the initial relation between the subject and the object (i.e. the categories swój 'own/familiar' and $o b c y$ 'strange/alien') undergoes dynamic changes from a theophanic fear of the experience of the sacred (fear of God) to projections of typically familial bonds which assume the unity of God's and man's worlds (cf. "Our Father (...) Let Thy Kingdom come").

One example of such a projection of human perspective is the attribution of behaviour, reactions and even language typical of the rural social environment to the divine:

Jędrzej Wowro, a famous pre-war folk sculptor and storyteller, believed that the Holy Family and all the Apostles originally came from his home village of Gorzenia near Wadowice. In one of his stories, when the Angel appeared to Mary, he said "Praised be Jesus Christ", to which she replied: "Jesus and Mary! And what kind of bird is that?" 
Jędrzej Wowro, słynny przedwojenny rzeźbiarz ludowy i gawędziarz, wierzył, że cała Święta Rodzina i apostołowie pochodzili z jego wsi, Gorzenia pod Wadowicami. Opowiadał, że Maryi objawił się janioł i powiedział „Niech będzie pochwalony Jezus Chrystus”, na co Maryja odpowiedziała: „Ło Jezus, Maryja, a co to za ptok?”."

Depending on the actual course of the process of cognition of, and communion with, the sacred, the subject and the object come closer together or further apart. Culturally shaped patterns of contact with the metaphysical worlds enable the researcher to reconstruct the perception of the object and, consequently, the conceptualisation of the sacred in the social imagination. The changing point of view, in turn, casts light on the subject and on the mode of interpreting reality. The mode of communicating these relations, and the linguistic means involved in building such a vision, form the basis of the linguistic worldview.

\subsection{The opposition between the "own/familiar" (swój) and the "strange/alien" (obcy) perspectives}

\subsubsection{The spatial concept}

Relations between the world and "otherworlds" (zaświaty, lit. 'worlds beyond') are grounded in a pluralist conception assuming the existence of both natural and supernatural reality. When we speak about the existence of the world, we mean the natural world viewed from the perspective of the conceptualiser: both the immediate vicinity, usually perceived as "one's own/familiar" (swój) world, and the distant world, perceived as "strange/alien" $(o b c y)$. The perception of space in terms of the CENTRE-PERIPHERY schema makes it possible to distinguish two basic spheres: the world experienced by the conceptualiser in a broader perspective which can be seen all around as far as the horizon $\left(\mathrm{C}-\mathrm{P}_{1}\right)$, and the immediate surroundings that can be taken in at a glance, often simply the scene of an event $\left(\mathrm{C}-\mathrm{P}_{2}\right)$.

The space beyond the scene is generally construed as strange, distant lands, amorphous areas without structure. Described as dangerous, they are often regarded as the dwelling place of demons, which makes them resemble "otherworlds". In folk culture, inaccessible places, particularly those dark and wet where the worlds above and under ground meet (gorges, potholes, caves, caverns), and places that can be seen along the line where the sky seems to meet the earth (mountaintops, the farthest boundary ridges (miedze, sing. miedza) in

9 This quotation comes from an interview conducted by Robert Mazurek with Ryszard Montusiewicz, a former Polish Radio correspondent in Israel [Mazurek 2009]. 
the fields, forks in the road) are considered "interspheric" as they are the locus of particularly intense contact between the natural and supernatural worlds [Adamowski 1999d: 219; 2011: 181]. Focusing on the sphere which is inaccessible to sight removes the conceptualiser from the scene and makes him/her assume the position of an observer. This, in turn, stretches the limits of his/her ability to interpret the world imposed by sensual perception. Cognition relying on imagination, which makes it possible to project immediate (sensual) experience onto unfamiliar or abstract domains, opens up broader perspectives of conceptualising remote space and "otherworlds". In this way, the imaging of "otherworlds" becomes based on a direct projection of the structure of the familiar world (the house, the farm, the field, the valley), or involves projecting it as opposite e.g. the image of hell as space overtaken by the element of fire (smażyć się w piekle 'to burn in hell', lit. 'to fry in hell'); or the realm of death as an empty and silent area beyond the reach of any sounds (gdzie kogut niedopieje, pies niedoszczeka 'beyond the cock's crow and the dog's bark').

The dividing line between "this" and "the other" world is difficult to determine. On the one hand, areas that are distant in space or unknown to the subject (za siódma góra, za siódma rzekq 'beyond the seventh mountain and the seventh river'; za siódma miedza 'beyond the seventh boundary ridge'; za lasami 'beyond the forests'; $z a$ morzami 'beyond the seas', etc.) usually refer to unreal worlds. On the other hand, even the immediate human environment is exposed to interference from the demonic world. Consequently, connotations of the concept "world" (świat) evoke two types of content. Firstly, content directly associated with the subject which in terms of time and space locates him/her in the here and now, stressing an in-group membership or identity (mój/swój świat, 'my/my own world'). Secondly, by adopting a broad perspective, they also evoke content which includes the entire spatio-temporal reality that is visible to the subject, or that is part of his/her knowledge (caly świat 'the entire/whole world', koniec świata 'the end of the world', od początku świata 'since the beginning of the world').

In the Polish language, the multidimensional nature of the metaphysical world is apparent in the very word that describes it: zaświaty, 'otherworlds', lit. 'the worlds beyond', is a derivative of światy 'worlds', the plural form of the noun świat 'the world', which assumes their multiplicity, or at least diversity. The onomasiological structure of both spheres suggests their formal interdependence and presupposes a conception of their coexistence in the all-embracing cosmic perspective.

It only seems natural that the opposition between what is "own/familiar" and "strange/alien" has become a perspective for imaging the relations between the 
sphere of the sacred and earthly worlds. This representation is by no means limited to spatial relations, as the conceptualiser's focus (the core of the category of "own/familiar") also includes personified images of divine and demonic figures construed in relation (or in opposition) to human figures from his/her own family and social environment (Bóg Ojciec 'God the Father', Matka Boska 'The Mother of God'; but: ciotka 'an aunt' or baba 'a wise (old) woman' to mean 'a witch').

"The other" world is also the dwelling place of the dead who used to belong to "our own", "familiar" sphere in their lifetime. Codes of behaviour towards those who passed away reveal an ambivalent attitude. On the one hand, rituals of exclusion from the world of the living and practices preventing the return of the dead suggest their categorisation as "strangers" (obcy). On the other hand, however, the customs and rituals of making contact with the ancestors indicate that they are still treated as "ours" (swoi).

Christian saints are another case in point. Although they belong to "the other" world by virtue of their connection with God, believers call on them for help in solving everyday problems (e.g. St Apollonia is invoked against toothache, and St Anthony finds lost objects), which means they are treated as "ours" (swoi). It follows that the concept "own/familiar" can be understood in two different ways: someone who is a member of our own group, or someone/something that belongs to the subject [Moroz 2007: 144-150]. The "possessive" understanding of saints or holy figures is evidenced by the subject's relation to his/her patron saint (personal guardian) and by traditional appellations of the Virgin Mary derived from the names of places where her miracles were performed and images of her (paintings or sculptures) are kept (Matka Boska Swarzewska, Ostrobramska, Czestochowska, lit. 'God's Mother of Swarzewo', etc. (Our Lady of Swarzewo, Ostra Brama, Częstochowa). The fact that holy figures belong in the category of "ours" is also confirmed by stories from the lives of saints, who are often attributed typically human weaknesses (e.g. St Peter's denial presented as a lie).

\subsubsection{Individual identity based on the first-person bodily perspective}

An act of seeing, which makes it possible to delineate "one's own/familiar" (swój) sphere, is conditioned by the perspective of the conceptualiser's own body. As a result, space considered "one's own/familiar" is determined by means of sight and touch [Libura 2000: $116 \mathrm{ff}$ ], often in conjunction with each other: it is a space that is $w$ zasięgu wzroku 'within eyesight', dajaca się objąćlogarnać wzrokiem 'possible to be seen' (lit. 'possible to embrace/encompass with eyesight'), ogarnać gdzie/ jak okiem siegnaćc 'as far as the eye can reach'. This perspective is also apparent 
in the division of the world into widzialny 'visible', i.e. 'real', and niewidzialny 'invisible', i.e. 'unreal', since it is inaccessible to sight. Consequently, only what the conceptualiser can touch or see is perceived as real, and what is inaccessible to sight or tangible experience - as non-existent or, at best, "strange/alien". The bodily aspect of what is considered "one's own/familiar" is confirmed by the oppositions front vs back and right vs left and by the attendant valuation of space [Ivanov, Toporov 1965; Stomma 1986; Tolstoil 1995]. Our sense of individual identity is also grounded in a bodily perspective, as can be seen in the relationship between the pronouns ja 'I' and swój 'one's own': the individual 'I' creates swój świat 'my own world'; ze swego punktu widzenia 'from my own point of view'; acting wedtug własnego widzimisię 'according to my own whim' (lit. 'according to my own it-looks-to-me'). Another component of the category "one's own/familiar" is a sense of possession [Tolstaia 2008: 31], expressed by the use of the pronouns swój 'one's own' and mój 'my/mine' with reference to different dimensions: spatial (mój/swój świat 'my/my own/familiar world'; moje/ swoje miejsce na ziemi 'my/my own place on earth'); temporal (w swoim czasie 'at my own time', $w$ swoim tempie 'at my own pace') and existential (umrzeć swojg śmiercia 'to die one's own death', kierować swoim życiem 'to be in charge of one's own life').

\subsubsection{Identity based on group membership}

A sense of collective identity is a complex phenomenon conditioned by social, cultural and linguistic factors. ${ }^{10}$ The transition from "I" to "we" is a primal experience inscribed in the experiential base in the form of the LINK and WHOLE schemas.

The perspective which extends beyond the subject's own body expands his/ her "own/familiar" (swój) sphere from the individual to the social dimension [Tolstaia 2008], with the "I" remaining in the centre of the category, as expressed in such words as środowisko 'milieu', krag 'circle', otoczenie 'surroundings'. The identification of the individual and collective subject is reflected in the image of a circle expanding its range depending on a change in perspective [Libura 2000;

10 Different aspects of the opposition between "own/familiar" and "strange/alien" are discussed in volumes 19 and 20 of the journal Etnolingwistyka (Ethnolinguistics), including papers presented at the conference: Swój - obcy (inny) w jezzykach i kulturach słowiańskich Problem tożsamości grupowej w Europie (The opposition between 'us' and 'strangers' ('others') in Slavic languages and cultures: Issues of collective identity in Europe). 
Tolstaia 2008]. The first level of identification is a small circle including the immediate social milieu (otoczenie 'surroundings', an image of a circle): krag rodzinny 'a family circle', kragg przyjaciót, znajomych 'a circle of friends, acquaintances'. It is worth noting that marking out a ritual circle or walking around in a circle when performing a ritual has a magic dimension as it designates a safe space: a space which is "my/our own" (swój).

The concept of family ties is one of the determinants of social bonds, which create a network of connections whereby "our own" people are "we/ us" (swój = my; rodzina 'family', ród 'kin', braterstwo 'brotherhood', pobratymcy 'kinsmen', naród 'nation'). Other determinants of this category, which also find their linguistic expression, are blood ties (cf. krewni 'relatives', lit. 'related by blood'; pokrewieństwo 'kinship', lit. 'blood relationship') and territorial community, both immediate (sasiedzi 'neighbours', etym. lit. 'sitting together in the same place,' 'settled in the same place') and wider, based on regional identity (krajanie 'countrymen'; ziomkowie 'landsmen').

People outside these designated circles are perceived as strangers. Importantly, a sense of belonging to "one's own/familiar" sphere is shaped by the co-linguistic context: the performance of rites and rituals, observance of moral norms and restrictions, involvement in religious and magical practices invoking the power of the sacred are essential, constitutive elements of a common cultural code determining patterns of behaviour, thought and communication, which form the basis of stereotype. All of those elements build a common pool of knowledge about reality and a common worldview held by both the individual and collective subject. In this way, the category "own/familiar" acquires yet another dimension, based on shared stereotypes and values.

While shared knowledge is another component of the category "own/familiar", lack of knowledge is a constitutive element of the sphere of "strange/alien". Mystery surrounding the demonic world, one associated with death, endows it with the status of a dangerous, threatening realm which the conceptualiser considers alien. This requires protective behaviours preventing contact and constructing barriers that ensure distance.

By contrast, attitude to the divine sacred is markedly different. The need to gain an understanding of God, to approach and commune with the divine, results in attempts to include the sacred in the category of "one's own/familiar" in spite of the distance between them. Indeed, a social bond between followers of the same religion is one of the strongest factors of cultural identity.

The desire for knowledge of the forbidden sphere of the sacred (both the divine and the demonic) is realised through festive scenes (carnival, carol singing and mumming). On such occasions, parody and humour, sometimes 
accompanied by vulgar language or obscenity that amount to a ritual breach of established norms, become a means of experiencing unity with a "world inside out" [Bakhtin 1984: 15-17, 153].

The inclusive "we", which integrates and consolidates a group, is based on the collective experience of reality shared by a closed social circle formed on the basis of LINK, WHOLE and CONTROL schemas.

\subsubsection{Group identity in a cosmic perspective}

In a cosmic perspective, it is possible to make a distinction between the earthly sphere, perceived as "people's own", in contrast to the unearthly one, which is alien to the conceptualiser and belongs to the sacred. The sense of belonging to "one's own" world finds its expression in the oppositional use of the relative pronouns ten 'this' and tamten 'that' with reference to the noun świat 'world'. However, even if the unearthly sphere is categorised as "alien", a religious attitude towards the sacred permits situations where the knowing subject (the human) strives to identify with the divine, breaking the separating barrier in the process.

In the linguistic worldview, the divine and the demonic sacred are generally treated in conjunction, although this does not mean that they are identified as one and the same, as revealed in the contextual co-occurrence of niebo 'heaven' and piekło 'hell' [Bartmiński, Niebrzegowska 1999; SSSL 1.1: 86], anioł 'angel' and diabet 'devil', Bóg 'God' and szatan 'Satan' (some scholars see this as a reflection of a dualist conception of the world [Benedyktowicz D., Benedyktowicz Z. 1992; Brzozowska-Krajka 1994; Tomicka, Tomicki 1975]). Consequently, this connection will be preserved in the reconstruction of the stereotype.

\subsubsection{Emotional attitude and bipolar values: "own/familiar" $($ swój $)$ = 'good' versus "strange/alien" $(o b c y)=$ 'bad'}

Another element of the cognitive process is the emotional attitude of the conceptualiser. Stereotypical patterns of behaviour are mainly based on a clearcut bipolar scale of values "good" versus "bad" [Bartmiński, Niebrzegowska 1999: 189; Krzeszowski 1994: 35-47]. This kind of valuation makes it possible for the conceptualiser to identify him/herself, to some extent, with the divine sacred. By contrast, the demonic world, located at the opposite end of the scale, is relegated to the category "alien". Although we can also encounter strategies designed to create a human image of a demon, the goal of such an operation is entirely different than in the case of the divine sacred. Indeed, the aim is not to familiarise a demon or make it closer to the world of people but, quite on the contrary, to ridicule it by connotative depreciation, which deprives it of its power 
and is tantamount to an act of annihilation. The conceptualiser's emotional attitude towards the supernatural is expressed in the valuation of space along the vertical axis (up-down), related to the location of the forces of good and evil: the heavenly sphere of the divine, and the underground realm of evil spirits, with the "familiar" sphere extending between them. This endows what is "up" with a positive, and what is "down" - with a negative value. Again, the valuation of space is grounded in the conceptualiser's bodily perspective determined by his/ her upright position [Lakoff, Johnson 1980; Krzeszowski 1994].

Not only spatial, but also visual experience comes to be associated with the dichotomous valuation of the divine and demonic spheres. Thus the opposition between jasny 'bright/light' and ciemny 'dark' becomes part of the chain dobry 'good' - swój 'own/familiar' - jasny 'bright/light' - boski 'divine', as opposed to zły 'bad' - obcy 'strange/alien' - ciemny 'dark' - diabelski 'devilish'. While the association between jasność 'light' and the sphere of the divine endows it with a positive valuation related to life, ciemność 'darkness' is characterised by negative connotations with death. Importantly, the words jasność and ciemność are the only items in the sequence that have acquired symbolic significance owing to their fixed contextual association with the sacred, e.g. Pan jasności 'the Lord of light', i.e. 'God', blask chwaty 'brightness of glory', światto wiary 'the light of faith', promieniować świętościa 'radiate with holiness'; piekielne ciemności 'the darkness of hell', władca ciemności 'the master of darkness', czarny 'the black one', i.e. 'the devil'.

The opposition between jasność 'light' and ciemność 'darkness' (grounded in the experience of light during the day and its absence at night) is a prototype of a number of derivatives. e.g. mądrość (jasność) 'wisdom (brightness)' vs głupota (ciemnota) 'stupidity (ignorance, lit. darkness)'; dobro 'good' vs zło 'evil', prawda 'truth' vs kłamstwo 'lie'. The dichotomy between day and night, in turn, provides the basis for a connotational differentiation between opposite pairs, enabling further, more abstract imaging, such as dzień 'day' and noc 'night' for życie 'life' and śmierć 'death', respectively [Brozowska-Krajka 1994].

\subsubsection{The spatial and temporal factor}

In Polish tradition, the location of the supernatural world is known as niebo 'heaven/the sky' and piekło 'hell. The authors of “Językowy obraz polskiego nieba i piekła" (The Linguistic Image of Heaven and Hell in Polish) [Bartmiński, Niebrzegowska 1999] observe the semantic affinity of both terms with the Greek Hades and the biblical Sheol, referring to 'the dwelling place of the souls of the dead', as well as with the Hebrew tradition of Gehenna 'the place of punishment 
of the damned. The concept of punishment for sins in the otherworld was adopted and developed in Christian, particularly Roman Catholic, tradition, which introduced the division into a space for those deserving salvation and for those doomed to eternal damnation and punishment.

However, the semantic content of the words niebo 'heaven/the sky' and piekło 'hell' in different periods of the development of the Polish language indicates the presence of both conceptualisations [Bartmiński, Niebrzegowska 1999: 196]. The medieval terms piekło and pkiet 'hell' meant both otchłań 'abyss', podziemie 'underground, 'the dwelling place of the souls of the dead', and 'the place of punishment for the doomed'. Niebo 'heaven', in turn, referred to the universe, including also the earthly sphere. The seventeenth and eighteenth centuries saw a clear differentiation between piekło as 'the dwelling place of Satan and damned souls' and niebo as 'the realm of God and saved souls', based on ethical premises.

From the nineteenth century onwards, this polarisation gradually subsided, as evidenced by sequential combinations of the two elements (zaklinać się na niebo i piekło 'swear by heaven and hell', poruszyć niebo i piekło 'move heaven and hell'). This development may have stemmed from the textual activation of semantic components common to both of them, i.e. 'supernatural force' (moc Boża 'God's might', potęgi piekiet 'the powers of hell') and 'eternity' (wieczne potepienie 'eternal damnation', na wieki wieków 'for ever and ever', lit. 'for ages of ages', odwieczny, wiekuisty Bóg 'the eternal, everlasting God'). This co-occurrence suggests that both spheres should be approached in conjunction as zaświaty 'otherworlds' [Bartmiński, Niebrzegowska 1999: 196-197], which, however, does not mean that language users have become oblivious to the distinction between the divine and the evil spheres, or that this distinction has lost its significance.

God's abode and the dwelling place of Satan are located at opposite ends of the vertical axis, niebo 'heaven' - up in the sky, and piekło 'hell' - down underground. Developed in Old Polish literature (under the influence of medieval European patterns) and promulgated in popular devotional publications used by the clergy and preachers, this image dominated also in the seventeenth and eighteenth centuries and continued in folk tradition for much longer [Sokolski 1990: 109$119,244]$. In language, the opposition between "up" and "down" corresponds to the evaluation good-bad, as reflected in the stereotypical location of heaven and hell.

However, it should be noted that the sphere of the afterlife has not always been so clearly defined. The pre-Christian Slavic equivalent of the otherworld, the Old Church Slavonic adt, referred to 'the land of the dead', analogical to Hades and Sheol. In the absence of the concept of 'the place of eternal punishment' (after their death, wicked people became demons wandering the world), proto-Slavic 
had no word to denote it [Moszyński 1999: 11; Bartmiński, Niebrzegowska 1999: 197].

Apart from the stereotypical images of niebo 'heaven' and piekło 'hell', Polish folk culture also preserves the archaic topography of the demonic world, usually locating it in places far from people’s dwellings. "Otherworlds" (zaświaty), then, lie on the peripheries of space, in the skies, on an island or beyond the sea [Bartmiński, Niebrzegowska 1999: 196]. In Slavic culture, Christian concepts are superimposed on pagan ones, which makes it impossible to draw clear-cut borders between the two spheres. Thus the realm of the demonic sacred also includes the earth, with oppositions up vs down, near vs far and light vs dark serving as the dividing criteria.

The location of "otherworlds" becomes problematic considering the border between life and death. Since it was believed that the souls of the damned, the wicked or those unbaptised existed in some sort of demonic state, crossing the threshold of death did not entirely divorce them from the earthly realm. Although they reach a different dimension, they remain suspended between heaven and earth in locations associated both with the underworld and the world above ground. Damned souls dwell at the bottom of lakes and rivers (as utopce 'drowning demons', lit. 'drowners'), in caves (home to evil forces and sleeping spirits of dead warriors), or wander on marshes and swamps as błędne ogniki 'will-o'-the-wisps' (lit. 'wandering lights'). The souls of unbaptised children and those who did not "die their own death" (i.e. were killed or committed suicide) are driven by the wind up in the air, dwell in (especially hail) clouds or assume the form of a bird [KLS 1967: 480]. Souls of those sinners who did harm to others and died unforgiven keep wandering the earth until their families have made up for the evil they have done and secure forgiveness by prayers and offerings.

The realm of death is imagined as an earthly wilderness, a remote area uninhabited by any living creatures, located beyond the horizon and natural borders (forests, mountains, rivers and seas), or found in areas associated particularly with the numbers seven and nine. Za siódma/dziewiata rzeka/góra 'beyond the seventh/ninth river/mountain' there is inny, drugi świat 'another, different world' (fairy-tale, magical, demonic or divine), accessible only to the select few by means of magical formulas and spells [Adamowski 1999d: 16-28; NiebrzegowskaBartmińska 2007: 181-183, 278-280].

Both European and non-European tradition has established certain models for passage into domains beyond earthly existence. Such an entry into the realm of death was made possible by archaic initiation rituals, particularly those transforming young people into full members of the group. Rites of passage were preserved in the oral tradition of ancient societies in the form of myths which, 
although different from one another, include some common elements such as the symbolic death and rebirth of the protagonist or tests of endurance he has to undergo. Recurrent patterns of initiation found in myths and magical tales include an image of the journey to the otherworld. The mythical hero's contact with spirits, and the tests through which he is put, reveal the mystery of the afterlife and shape the image of the otherworld inhabited by demons and monsters. Although its geographical location is by no means precise, it is not a coincidence that Europeans associated it with Ireland, the westernmost part of the continent. The westward journey of souls to the otherworld is a recurrent motif in different mythologies, and Irish Celts themselves located their otherworld on the islands of the western ocean [Sokolski 1990: 51-52].

For the most part, spatial imagery of "otherworlds", both horizontal and vertical, was grounded in visual experience: the "alien" world was located at the far edge of what could be seen, above ground and beyond the horizon. Consequently, borderline areas (e.g. forks in the road), points where the sky meets the earth (e.g. mountains, the horizon) and where the underground world meets what is above ground (e.g. caves, potholes), as well as mixed terrain such as marshes and swamps (half-way between earth and water), were considered "interspheric" [Adamowski 1999d: 16-28]. Another important factor is the presence of light as a pre-condition for seeing, which explains the westerly location of the realm of death.

While the border between "this" and "that" world is both invisible and impenetrable to the living, supernatural forces and the spirits of the dead can cross it in both directions. Consequently, the supposedly safe sphere conceptualised as "one's own/familiar" is, in effect, constantly at risk and can only be protected by God's might. In folk beliefs, although demonic creatures have their own dwellings and places they frequent, they lie in wait for people almost anywhere and are particularly dangerous at certain periods of time. This is especially the case in moments of transformation, of transition from one state to another, which involve the crossing of the physical and symbolic border between life and death: the border between day and night, between different seasons and phases of the moon, and between different stages of people's lives: birth, wedding and death [Brzozowska-Krajka 1994: 34].

It follows that time is another important factor shaping the stereotype of relations between the world and "otherworlds". Conceptualisation of the opposition between a safe time ("one's own/familiar") and a time when people are particularly vulnerable relies on the COLOUR schema, light vs darkness and the attendant (in)ability to see, hence, perceive, which also brings into focus the CONTROL schema. Light, semantically related to the divine, connotes a safe 
time (in prototypical terms: day), while darkness implies the time of demons (night). Symbolic meanings of light as an attribute of the sun and of God are the first element in a chain of associations with life, good, knowledge, wisdom and faith, which have their opposite counterparts connected with darkness (świetlana postać lit. 'a bright character', i.e. 'a noble and honourable person' vs ciemny typ lit. 'a dark type', typ spod ciemnej gwiazdy lit. 'a type from under a dark star', i.e. 'a shady character, an evil and dangerous person'; jasne jak słońce lit. 'as clear as the sun', i.e. 'easy to understand, obvious'; oświecenie 'enlightenment', i.e. 'knowledge' vs ciemnota 'darkness', i.e. 'ignorance'; światło wiary 'the light of faith' vs mrok pogaństwa 'the darkness of paganism').

The most important temporal factor setting apart the natural and supernatural worlds is the opposition between eternity and temporality. At the point of transition from one reality to another and the attendant change of one's state, earthly time as it were stops, particularly in the case of crossing over from the sphere of life (the temporal) to death (the eternal). At this point, all events occur outside time and the return of the living to the normal rhythm of temporal reality requires special ritual acts.

\subsection{Profiling}

For the purposes of this study, the interpretation of patterns of human interaction with "otherworlds" (zaświaty) will involve a reconstruction of events involving such contact with a particular focus on the conceptualiser: his/her motivation, system of values, the circumstances of contact (time, place, participants and their roles), the course of the event, the factors which have an impact on whether contact is successful, the modes of imaging the unknown reality, and the linguistic means that enable communication. Such analysis will reveal different profiles of the phenomenon under discussion, which are not synonymous with different meanings. Rather, they indicate how contact with the supernatural sphere is conceptualised under different circumstances.

Cognitive analysis makes use of the concept of profiling ${ }^{11}$ in order to provide a reasonably faithful reconstruction of the principles organising the semantic

11 The concept of profiling, introduced by Ronald Langacker, a founding father of cognitive linguistics, met with great interest and provided inspiration to other scholars, which led to modifications in his original proposal. The considerable potential for the use of profiling in semantic analysis was discussed at a conference held as part of the series of seminars called Jezzyk a kultura (Language and Culture); there is also a volume of conference proceedings entitled Profilowanie w języku i w tekście (Profiling 
content of particular schemas and to determine the frame of their meaning and interpretative formula [Bartmiński 1993a: 8-11; Tolstoî 1995]. Although particular profiles can include content that is ambivalent, this does not mean they are inconsistent, but reveals different conditions under which they were created. Each profile has its own characteristics which operate across a range of different subcategories (time, place, particular conditions, required behaviour). ${ }^{12}$ Profiling is grounded in the conceptualiser's knowledge of the world and his/her system of values, and concerns different prototypical situations. As replicated structures, these situations, in turn, provide the basis for creating a stereotype [Bartmiński 1993a: 13-15; Bartmiński, Niebrzegowska 1998: 220].

The stereotype of interaction between the physical and metaphysical spheres can be approached from the perspective of the dynamics of point of view. ${ }^{13}$ Such multidimensional analysis focuses on a number of factors, including the conceptualiser's linguistic performance, his/her knowledge of the world, rationality, motivation, reactions to supernatural phenomena, modes of making contact with the sacred and of constructing a vision of the supernatural world from the position of an interpreter and organiser of the scene [Bartmiński, Niebrzegowska 1998: 213 ff; Tokarski 1991: 137].

What plays a particularly important role in creating a stereotype is the experiential base preserved in the conceptualiser's cultural code in general, and in a number of its component codes in particular: the verbal code, the behavioural code (e.g. prohibitions concerning behaviour towards the sun), the mythologicalideological code (e.g. personification of the sun) and the symbolic code (e.g. a symbolic association of light and the sun with the sacred). Actualised in particular profiles, all these elements make up a coherent anthropological model of the creative attitude towards the mystery of the sacred held by an average member of the rural community [Bartmiński, Niebrzegowska 1998: 212-213].

Profiling a stereotype involves adopting a particular point of view, and thus a broader or narrower perspective, which determines the construction of the scene in terms of the conceptualiser's experience of the events. The trajectory of contact between the natural and supernatural worlds runs in two directions: from

in Language and Text), published by the Maria Curie-Skłodowska University in Lublin [Bartmiński, Tokarski 1998].

12 I adopt an expanded concept of profiling proposed by Jerzy Bartmiński [Bartmiński 1993a, 1993b; Bartmiński, Niebrzegowska 1998; Bartmiński, NiebrzegowskaBartmińska 2004a].

13 For more information about the category of point of view in language, text and discourse, see Bartmiński, Niebrzegowska-Bartmińska 2004b. 
the former to the latter and vice versa. While the conceptualiser is the same in both cases, his/her role and field of observation vary.

In the case of contact initiated by the sacred, the divine or demonic power is the agent, and the conceptualiser can either play the double role of the object of action of the supernatural and its observer, or remain outside the scene, taking the role of an observer only. Typical divine actions include blessings (with the act of creation as prototype), miracles, curses and acts of punishment. Demonic forces, in turn, focus on contesting God's will on the one hand and doing harm to people and trying to possess their souls on the other.

When the trajectory is reversed, and contact is initiated by human beings, the conceptualiser assumes the archetypal role of the agent: he/she turns (directly or indirectly) to the divine sacred (God, the divine persons and saints) with a request, supplication or thanksgiving. In the case of prayers involving supplications or spells, the aim is to reach God as the source of power. An analogical pattern (with the devil as the source of power) operates when witches or wizards turn to demonic forces. In both cases the sacred (divine or demonic) remains in the background of the scene as the agent proper, whose power is summoned by the agent-mediator.

If the point of view of the conceptualiser, who is the recipient of power, is located in the centre of the scene, the event is interpreted as familiar, and the ensuing image is more generalised, which makes it closer to the prototype. Regardless of the role (agent, instrument or object), participation in the event creates a sense of belonging to the group. The role of an outside observer, by contrast, places the conceptualiser in the background of the event, thus affording him/her a broader perspective. Consequently, he/she may, but does not have to, identify with the participants of the scene. As a result, the conceptualiser can construe the event either as "one of us" or as "a stranger", which makes the interpretation more subjective, producing derivatives of prototype profiles in the process.

It follows that the construction of the scene of a speech event plays a major role in profiling. While a specific event of this kind results in a specific utterance, it is those cases of language use that display features of a social convention that are more interesting from the point of view of stereotype [Bartmiński, Niebrzegowska 1998: 217]. In "our own" group, oral communication tends to rely on the use of a restricted code, in which the verbal content of the message can be reduced to a minimum when the context makes it evident to the participants [Bernstein 1965: 153]. However, regardless of the degree of conventionalisation, the nature of speech communication is such that the interlocutors are not impersonal: the utterance has both a particular author and addressee, and 
is constructed in anticipation of a response. In spite of its stereotypical character, then, the words that are used are always somebody's. In this way, dialogue involves joint action which co-creates reality [Bakhtin 1986: 94-95].

\subsection{Elemental forces and lights in the sky as the basis of imaging natural and supernatural reality}

The experience of the power of elemental forces beyond human control is stored in the experiential base as the FORCE and LACK OF CONTROL schemas. Vivid images of the unharnessed power of water, fire, air and earth provided the basis for the symbolic association between the force that controls them and the sacred. The power manifested by elemental forces can be considered prototypical in the construction of images of interaction between the natural and supernatural worlds. Scenes in which the conceptualiser is subject to their force represent the impact of the (divine or demonic) sacred. The difference lies in the pattern of action of these forces and in the way they are experienced.

Manifestations of divine power are invariably construed in terms of the SOURCE-PATH-GOAL schema. In this case, the source of power is inexhaustible and the goal is achieved regardless of the circumstances. Energy coming from the divine source has life-giving power, even if the intermediate stage involves a disaster, since the ultimate goal is to restore the divine order which ensures further existence. The image of this restored order relies on the CONTROL, WHOLE and BALANCE schemas.

The pattern of action of demonic forces is a mirror image of the divine, which explains the ambivalent conceptualisation of fire, earth, wind and water in the folk worldview: heavenly fire vs the fire of hell; the healing water of life vs murky, dangerous waters inhabited by demons; earth as a giver of life vs the underground hiding the demonic world; wind as God's life-giving breath vs the destructive power of evil wind (wichry wojny 'the winds of war', morowe powietrze 'the plague', lit. 'pestilential/death air', zawirowania społeczne, polityczne 'social/ political turbulence'), a whirlwind as the devil or a damned soul.

In the case of human interaction with elemental forces, the structure of the FORCE schema is somewhat different and involves the use of the ATTRACTION and REPULSION models. In response to the experience of the sacred embodied in the forces of nature, the subject may perform magical practices aiming either to prevent a natural disaster (e.g. a fire, a hailstorm, gale-force wind), or to summon the elemental power (e.g. reawakening the fertility of the earth, bringing life-giving rain, wishing fair winds, blessing fire). Practices of summoning the power of the sacred include imitating God's actions by means of the symbolic use 
of the same tools: water (blessing with holy water), fire (the ritual of lighting the fire, the use of embers in ritual practices), earth (using soil in healing and magical practices), air (breathing on the objects of magical practices).

It is also worth noting that the operation of the FORCE schema in magical practices requires particular actions in order to intensify the power of the tools that are used since the natural forces which are being summoned do not have the same potential as the inexhaustible source from which they spring. Consequently, summoning the supernatural needs to be performed under favourable circumstances, at a particular time and by a knowledgeable medium. The pattern of the FORCE schema is rather complex, as can be seen in such practices as the periodical blessing of water, fire and earth, calling God's name, praying to patron saints, using sacramentals, performing ritual holiday practices in a specific space devoted to this purpose. Indeed, the path from the source of power to the goal is not simple: it requires removing barriers and overcoming obstacles, or finding another way. Reaching the goal depends on access to the ultimate source of power, which is the sacred itself.

\subsection{Preconceptual image schemas in the creation myth}

The folk image of the creation of the world is the basis for the archetype of relations between God and man. Scenes of creation rely mainly on the FORCE schema used in conjunction with the BALANCE and CONTROL schemas. The Creator, the source of power, is the archetype of the agent, while pre-cosmic chaos, transformed into a structured world, becomes the prototype of the object. Although the act of creation involves all the elements constituting the cosmos, the conceptualiser's point of view imposes an earthly perspective of interpretation, which becomes the central point of reference.

While different variants of the creation myth involve different realisations of the FORCE schema, they all share the element of COMPULSION since the object submitted to creative power is not consciously involved in the act of creation, and the action of FORCE does not depend on human will. Thus in such scenes the conceptualiser assumes the role of an observer who remains in the background as an interpreter of the event, or becomes its involuntary participant "drawn into" the scene and subjected to the creative power of God. He/she takes up the archetypal role of the agent only when he/she experiences FORCE and begins to interact. At this stage, he/she acts according to INNER or OUTER COMPULSION, either voluntarily accepting, or reluctantly conforming to, social norms or an established system of values and models of behaviour. In both cases, this is an act of his/her own will. 

Part 2 Imaging the relations between the physical and metaphysical worlds: the four natural elements 



\section{Water}

\subsection{The creation myth and the demiurgic properties of water}

Devoid of a fixed form, yet capable of giving shape to all material things, water is the most mysterious substance encountered in the human experience. Although cosmogonic myths often present it as the prima materia, both its origin and the nature of its relationship with the supernatural world are far from unequivocal. Christian doctrine claims that God created heaven and earth before He made water, and thus sees Him as the Lord of the universe who rules over this element. Hence, even though Judeo-Christian religion adopted the idea of dividing the waters into those above and below the firmament from Babylonians, it nevertheless regards God as the creator of the overall order of things [Léon-Dufour 1995: 644-645]. By contrast, pre-Christian mythology conceptualised water as a primeval and perennial substance preceding the appearance of the cosmos. There are also discrepancies concerning the emergence of the earth and the matter from which it arose, as well as the problem of the demiurge (creator) as such. In some myths the earth hatched from the cosmic egg, floating on the waters of the pre-ocean; ${ }^{1}$ according to a Babylonian legend, heaven and earth were made from the body of Tiamat (primordial water), while in other stories it is mud or a stone brought up from the bottom of the primal ocean that is transformed into the earth by divine hands [MifyNM 1987: 240; Kowalski 1998: 609]. Another discrepancy concerns the question of whether the Creator should be seen as the sole demiurge. Pre-Christian religions assume the perennial existence of the forces of good and evil, and ascribe an equal role to both of them in the act of creation

1 The motif of the cosmic egg, present in numerous myths from Europe, Asia, Africa, China, India and so on, is variously interpreted in different cultures. For more, see MifyNM 1988: 681. For a reconstruction of the myth of the cosmic egg in Slavic culture based on the imagery in Russian fairy tales, which include the most archaic and widespread motif of the link between the cosmic egg and water (the ocean), see Toporov 1967: 81-99. The vitality of the myth of the cosmic egg in Slavic culture, particularly visible in vegetation rituals and funeral rites, points to its semantic association with the symbolism of renewal and rebirth. According to some scholars, the myth of the egg as a germ of life is the basis of Slavic cosmogony [Kowalik 2004: 121-126; Mianecki 2010: 136-169]. 
[Tomicki 1976: $50 \mathrm{ff}$ ]. ${ }^{2}$ Christianity, by contrast, acknowledges God as the sole Creator [Léon-Dufour 1995: 644-645].

Even though Polish folk stories about the creation of the world are based in the main on the biblical account, they contain vestiges of pre-Christian beliefs, common to Slavic and Indo-European folklore. Christian tradition preserves the Old Testament image of the Spirit of God who moved upon the face of the waters (Genesis 1:2), i.e. God as the lord and master of the waters that He created. Slavic mythology, by contrast, shows the world before the creation of the earth as a dark space filled with water, a primeval substance preceding all existence [MajerBaranowska 1995: 116-117; Mianecki 2010: 38; MifyNM 1987: 240; SlavDrev 1995: 386; Tomicki 1978: 82]:

(1) In the beginning, that is a very long time ago, there was nothing in the world, save only water.

(2) Before the creation of the world, there was nothing; there was neither heaven with its light, nor earth, nor animals, nor fish, nor man. There was only water, the breadth and depth of which no-one knows. And darkness enveloped the water.

(1) Na początku, tj. bardzo dawno, nie było niczego na świecie, tylko same wody. [Tomicki, 1978: 82, Mit 38]

(2) Przed stworzeniem świata nie było nic, nie było ani nieba $\mathrm{z}$ jego światłościami, ani ziemi, ani zwierząt, ani ryb, ani człowieka, a była tylko woda, rozmiarów i głębi której nikt nie zna. Wodę otaczała ciemność. [Tomicki, 1978: 82, Mit 79]

In keeping with the typical structure of mythological narratives, the fragments quoted above offer a description of chaos, to be followed by successive sequences

2 For a discussion of the idea of religious dualism (divine and diabolic), visible in the beliefs underlying the conceptualisation of water, see Majer-Baranowska 1995: 115128. Ryszard Tomicki presents a wide-ranging analysis of the structure of Slavic cosmogonic myths which suggest belief in the primal existence of waters filling the cosmic space before the act of creation and may be seen as evidence of a dualist cosmogony (see the unpublished doctoral thesis Kosmogonia dualistyczna w Europie i Azji w XIX$X X$ wieku. Studium etnolingwistyczne (Dualist Cosmogony in Europe and Asia in the Nineteenth and Twentieth Centuries) [Tomicki 1978]). I would like to thank Professor Jerzy Bartmiński for allowing me access to the typescript held in the library of the Institute of Polish Philology at the Maria Curie-Skłodowska University in Lublin. Myth numbers quoted after Tomicki. Some sections of the dissertation were published in the journal Etnografia Polska (Polish Ethnography) [Tomicki 1976, 1980]. By contrast, Adrian Mianecki does not subscribe to the idea of dualism, proposing instead the concept of the cosmic egg as the primal origin myth in Slavic culture of the pre-Christian period. This is borne out by the presence of the egg as an attribute in numerous rituals and magical and religious practices [Mianecki 2010: 136-169]. 
recounting the creation of the cosmos [Toporov 1967: 92]. In the subsequent scenes, the omnipresent and perennial waters become the object of demiurgic actions, leading to the emergence of the future order of the world. Folk cosmogonic accounts preserve the motif of water's existence before the creation of the earth; nevertheless, in every version it is God who is seen as the creator and master of the waters, even if the devil also makes a frequent appearance in such scenes. ${ }^{3}$ In the so-called Cracow myth (mit krakowski), water is said to have been singled out by the Creator as the most important of the elements, and assigned a special role [Tomicki 1978: 74, Mit 10; SSSL 1.1: 227]:

Thou shalt be the best-respected one: nothing can live without thee, thou hast to carry the heaviest burden, for it is on thee that I will found the earth. Water, retreat; earth, arise from the void!

Ty będziesz najzacniejszą - bez ciebie nic żyć nie może, największe ciężary dźwigać musisz, bo ja na tobie ufunduję ziemię. Wodo opadnij, ziemio powstań z nicości!

The conceptualisation of water presented in the scene of Mit 10 (Myth 10) relies on the FORCE schema, in which the Creator - as the source of power - plays the role of the agent, while water (and earth) is the object (goal) of his actions. By the power of His word, God commands the water to recede and the earth to emerge onto the surface, thus establishing a cosmic order in keeping with the UP-DOWN model. In the act of creation, the FORCE schema proceeds according to the SOURCE-PATH-GOAL model, without encountering any obstacles on the way.

God's next act with respect to water is to imbue it with divine energy, thanks to which it acquires demiurgic powers. In this way, the FORCE schema becomes an integral part of the concept of water, as is reflected in the structural metaphor

3 The motif of the presence of the devil in scenes of creation is found in folk versions of the cosmogonic myth in Slavic cultures. According to Ryszard Tomicki, this gives grounds for adopting a dualist conception of the creation of the world. Dualist cosmogonic myths are known in many European and non-European cultures which were not subject to strong Christian influence. Analogies in the structure of the myth, and their wide geographical extent, suggest the primacy of the dualist conception, with the Christian interpretation superimposed at a later stage. Cosmogonies from Poland preserve relatively few examples of dualist ideas, which are far more often found in East Slavic areas; there are also traces of such beliefs among South Slavs. A general overview of accounts of the origin myth from East and South Slavic areas suggests that they form a system with a clear dualist structure, which constituted the foundation of the conceptualisation of the world [Tomicki 1976: $50 \mathrm{ff}$ ]. 
WATER IS POWER. This is evident in beliefs concerning qualities attributed to water and its use in magical and healing practices (see below).

According to the biblical account, the creation of the earth led to a division of the waters into those below and above the firmament, thus harnessing the primeval chaos. In folk narratives, the myth is presented in the following way:

- "The Lord God separated water from the earth and drove it into brooks" (Pan Bóg wode odłacył od ziemi i zagnoł jom w potoki) [SSSL 1.2: 158];

- "God (...) took six parts of water and gathered it in one place; and seas, rivers and lakes were made of this water" (Bóg (...) sześć części wody zebrał w jedne miejsce i z tyj wody powstały morza, rzeki, jeziora) [SSSL 1.2: 228];

- "[The Creator took some water to heaven]: seven parts [of water] stayed on the earth, but two parts he took up with him [and clouds and rain arose from this water]" ([Część wody Stwórca zabrał jednak ze soba do nieba]: siedem części zóstało na ziemi, a jedne część, a dwie części zabrat dó góry, wode z sobo, [a z nich powstaly chmury i deszcz]) [SSSL 1.2: 228].

In the scene of the earth and water emerging from chaos, the conceptualiser does not limit the role of God - the agent - to that of the demiurge, but presupposes His constant control of the world. By assigning appropriate space to each element, God introduces cosmic order. The division of the waters into heavenly and earthly ones means that God wields power over the earth after the act of creation is completed, as is consistent with the conceptualiser's religious attitude. ${ }^{4}$ This is demonstrated in the scene where God takes some parts of the water up to heaven in order to be able to send blessing (in the form of rain) or punishment (flood) to the earth. In both cases, water is a tool in the hands of the Lord and serves to maintain order on earth. Life-giving rain, the waters of a flood or a drought, all come from heaven as a manifestation of God's power, as related in the myth of the Deluge [Majer-Baranowska 1995: 119]:

[The Angel says:] For water will come by the will of God, and flood the earth so that it will be saved for the good who come afterwards. (...) for forty days there were downpours and torrential rains. Once again, water rose up towards the thresholds of heaven.

4 The conceptualiser's belief that God commands the waters is grounded in the biblical account of the separation of the waters into the upper (heavenly) and the lower (earthly and underground) realm. The motif of "living" (heavenly) and "dead" water, which underpins the notion of water as both a life-giving and destructive element, can also be found in the mythologies of numerous peoples [MifyNM 1987: 240]. 
[Anioł mówi:] Z woli albowiem bożéj przyjdzie woda, zatopi ziemię, ażeby na późniéj dobremu została. (...) przyszły przez 40 dni dészcze i ulwy straszne. Woda powtórnie wzniosła się pod progi nieba.

In this scene, the CONTROL and BALANCE schemas as well as the VERTICAL schema (concerning the hierarchical order of the world according to the UPDOWN model) are combined with the FORCE schema. In this way the division of the waters into upper and lower ones becomes the basis of the opposition between heavenly and earthly water. This opposition can be seen not only in acts of divine punishment (flood, drought) or benediction (life-giving rain), but also in the connection of earthly waters with death and the world of demons [MifyNM 1987: 240; SlavDrev 1995: 386].

\subsection{The interaction of demonic forces in the act of creation}

As discussed above, the biblical image of the Spirit of God moving on the face of a dark expanse of water draws on the myth of a boundless primordial ocean, upon which the Creator founded the earth (cf. the passages from myths quoted above). According to accounts from eastern Poland, when earth and water were still mixed together in a state of chaos, God cast the devil down from the heights of heaven into the depths of the waters [SSSL 1.2: 227]:

(...) in the beginning, when there was neither earth nor water, and all was mixed together like sourdough, the evil spirit that had been cast down from the heavenly height had no foothold in the other world and asked God for the earth that he would be able to walk on. So the Lord God divided the earth beneath and the water above. And God commanded the evil spirit to dive into the water to take a lump of earth and bring it up to the water's surface and then there will be earth, "only as you take it, take it in God's name (...)". From this tiny bit [of sand] God created the earth.

(...) na początku, kiedy nie było ani ziemi, ani wody, a tylko wszystko były pomieszane jak rozczyna chleba, zły duch strącony z wysokości niebieskiej, nie miał oparcia na tamtym świecie i prosił Boga, żeby była ziemia, po której mógłby chodzić. Więc Pan Bóg oddzielił ziemię na spód, a wodę na wierzch. I kazał Bóg złemu duchowi pójść w wodę po ziemię, aby wziął w garść ziemi i wyniósł na wierzch wody, to będzie ziemia, „tylko jak będziesz brał, to bierz w imię Boże (...)”. Z tej odrobiny [piasku] stworzył Bóg ziemię.

The passage quoted above clearly states that the earth was created at God's command out of the void. However, the belief that it is created from grains of sand brought up from the bottom of the primal ocean preserves elements of the notion of water as amorphous primeval matter which gives origin to all forms that come up to the surface. 
Equally puzzling is the amorphousness of Satan, who emerges out of the water in front of the Creator in the form of foam or mud, ${ }^{5}$ which would point to both his aquatic origin and perennial existence [Tomicki 1976: 56; 1978: 84, Mit 2]:

Before the creation of the world there was nothing, only heaven and sea. God sailed on the sea in a boat and he came across an enormous mass of thick foam in which dwelled the devil. "Who are you?" asked God. "Let me into your boat and I will tell you," said the devil. "Come on then," said God, whereupon He heard: "I am the fiend," answered the one coming aboard. They sailed on in silence.

Przed stworzeniem świata nie było nic, tylko niebo a morze. Bóg pływał po morzu w łódce i napotkał ogromną i gęstą pianę, w tej pianie mieszkał diabeł. Kto żeś ty? - zapytał Bóg. Weź mnie do siebie, do łódki, to ci powiem - odpowiedział czart. No chodź rzekł Bóg, a zaraz potem usłyszał: Ja jestem czart - odpowiedź wchodzącego. Milcząco płynęli.

For the conceptualiser, the scene of casting the devil down to the bottom of the ocean becomes the basis for construing him as a counterforce to God: treacherous, dangerous and unpredictable, capable of taking all manner of shape.

In folk versions of the creation myth collected in Polish-speaking areas, the Creator is always presented as an absolute power (the origin of FORCE), and His word (an instrument of FORCE) sets out the path towards the goal with immediate effect. In such scenes God plays the archetypal role of the agent, while water, depending on the scenario, takes on different functions: background, instrument, matter or object of his actions. Satan, in turn, appears in the scene as a being subordinate to the Creator, but striving to have an impact on the course of events. ${ }^{6}$ Hence his malevolent attempts to change God's plans

5 In the Ukrainian version of the myth, God found Satanael in the mud: "When God found Satanael in the mud, He said unto him: 'Be an angel' and gave him two wings, and ordered him to fly. But he could not, so he received two more wings and a sword. And on the second day God created heaven, and on the third he told Satanael to bring Him a small lump of earth from the sea" (Gdy Bóg znalazł Satanaela w szlamie, rzekł do niego: „Bądź aniołem” i dał mu dwa skrzydła i nakazał latać. Ale on nie mógt i otrzymat jeszcze dwa skrzydła i miecz. A w drugim dniu stworzył Bóg niebo, $w$ trzecim polecit Satanaelowi przynieść z morza kawałeczek ziemi) [Tomicki 1976: 56].

6 Adrian Mianecki offers a different interpretation of the relations between God and Satan, presenting the Devil as the second demiurge, playing an even greater role in the act of creation than God. In Mianecki's view, the world is created as a result of the reaction of hitherto passive God to the creative action of the Devil, who is credited with establishing the central point in space and thus introducing spatial differentiation [Mianecki 2010: 69-72]. 
proceed according to the INTERACTION schema. Since Satan cannot surpass God's power, the divine goal is achieved in all the scenes. However, the harmful results of these devilish machinations leave their mark, as in scenes of the creation of man [SSSL 1.2: 158]:

[Afterwards, God created people from clay and water], and from mud and from water He created all manner of living creatures, animals and reptiles.

[Następnie z gliny i z wody Bóg stworzył ludzi], z mułu i z wody - żywioły, czyli wszystkie stworzenia, ji źwierze, ji gady.

The role of the devil is also visible in the most developed version of the story, preserved in the sixteenth-century apocryphal myth (Mit 2 [Myth 2]):

After He created paradise in the east, the Lord decided to create the first man, Adam, and He made his body from seven elements: flesh from earth, bones from stone, blood from the sea, eyes from the sun, thoughts from clouds, breath from the wind, warmth from fire. And the Lord went to heaven, to His father, to bring a soul for Adam. Satan did not know what to do, so he pricked Adam's body with his fingers. Returning to His work, the Lord saw that the body was pierced through and said "Devil, how did you dare to do such a thing?" And the Devil replied: "Lord, when man feels that he is sick, he will remember you". The Lord hid Adam's wounds inside his body and thence comes all sickness. Satan it was who caused it; so that whoever feels pain, sighs "Oh, oh, Lord have mercy". The Lord animated Adam and gave him power over all the fowls and wild beasts and domestic animals in paradise.

Po stworzeniu raju na wschodzie, postanowił Pan stworzyć pierwszego człowieka Adama i zrobił jego ciało z siedmiu składników: ciało z ziemi, kości z kamienia, krew z morza, oczy ze słońca, myśli z obłoków, oddech $\mathrm{z}$ wiatru, ciepło z ognia. I poszedł Pan do nieba, do swego ojca, by przynieść duszę dla Adama. Szatan nie wiedział, co zrobić, więc pokłuł palcami ciało Adamowe. Pan wrócił do swego dzieła i spostrzegł, że jego ciało jest pokłute i powiedział: „Diable, jak ważyłeś się to zrobić?” A diabeł odparł: „Panie, gdy człowiek poczuje, że będzie chory, to będzie pamiętał o tobie”. Pan schował rany Adama do wewnątrz i stamtąd pochodzą choroby. Szatan sprawił, że kto poczuje ból, wydaje westchnienie: „Oh, oh, Panie, zlituj się”. Pan ożywił Adama i dał mu w raju władzę nad wszystkimi ptakami, oraz dzikimi zwierzętami i domowymi.

In this scene, water - together with earth, air, fire and the sun - functions as matter from which God creates the human being according to the model of the cosmic man [Tomicki 1978: 125].

The motif of the devil's interference in the act of the creation of man appears in numerous versions of myths and legends:

(1) God made man from a clod of clay, and breathed on him and the man moved, came to life. The devil saw it all; so he chose a moment when the man was asleep and breathed 
on him - and thus the evil spirit came to dwell in man and man acquired an inclination towards evil.

(2) Right after the creation, man was very beautiful; but the devil spat all over his body out of envy. And God took all the devil's spittle and put it inside the human body.

(1) Zlepił Bóg z gliny człowieka, tchnął nań i człowiek zaruszał się, ożył. Diabeł widział to wszystko; wybrał chwilę, gdy człowiek spał, tchnął nań - i osiedlił się w człowieku zły duch i człowiek otrzymał skłonność do złego. [Tomicki 1978: 125, Mit 64]

(2) Człowiek zaraz po stworzeniu był bardzo piękny, dyabeł z zazdrości opluł go na całym ciele. Bóg te wszystkie plwociny schował do wnętrza człowieka. [Tomicki 1978: 125, Mit 28]

All the versions clearly demonstrate the devil's hatred of man and the destructive character of all his demonic actions. The view that all sickness and evil in the world are the devil's doing is deeply rooted in folk beliefs, and finds expression in folk medicine and practices of undoing evil charms (odczynianie uroków) ${ }^{7}$ (e.g. spitting three times, lexicalised in the idioms wypluj to słowo lit. 'spit out this word' (i.e. take it back) or $t f u, t f u, n a$ psa urok! 'spit, spit, let the curse fall upon a dog!'). Although the FORCE schema works according to the SOURCE-PATHGOAL model, the devil's treacherous machinations interfere with the final act of breathing the soul into the human body. As a result, divine power has to overcome an obstacle which appears on the path of the FORCE, thus introducing the REMOVAL OF RESTRAINT schema.

\subsection{Water - the devil - “otherworlds" (zaświaty)}

The presence of the evil spirit in scenes of creation introduces an ambivalence into the conceptualisation of water. Consequently, it is credited with antithetical

7 "The most commonly known are incantations offering protection from evil charms (urok) and their accompanying gestures, usually spitting. Further examples include protective formulas (formuly zażegnywań) used in situations other than evil charms. For instance, to prevent the misfortune predicted by a crow crying over a man, one should spit three times in its direction, shouting 'Spit on you! Your mother shrieked, and so do you!' (A tfy! Darła się twoja matka, drzesz się i ty!)" [Engelking 1991b: 81]. Saliva, as an impure substance, is used in contagious magic, where it may act as a substitute onto which disease, as an example, is transferred. On the other hand, in ancient mythologies saliva was the substance from which gods created the world. The symbolic meaning of saliva is thus ambivalent, which is why it may be used in very different practices: to drive away evil spirits, to heal, or, conversely, to cause harm to someone's health [Kowalski 1998: 457-459]. 
properties and assigned opposite values on the axiological scale. On the one hand, as created solely by God, water bears the mark of being sacred and, in the Christian view, is connected with both the earthly and the eternal life. On the other hand, through the mythical link with evil powers, water acquires an utterly different character, evoking associations with hidden forces, alien and dangerous worlds and annihilation. Thus the motif of casting the devil down to the bottom of the ocean, as well as the division of the waters into those below and above the firmament during the act of establishing cosmic order, become the basis for the creation of a demonic image of water. By suppressing water's sacred features, such images foreground instead associations with evil powers and their corresponding type of axiology [SlavDrev 1995 : 386]. The devil and his helpers are connected with water in many origin myths: the devil emerges from the waters in front of the Creator in the form of foam or a bubble, God finds him in mud, the devil's helpers are made from a stone brought up from the bottom of the sea, while the angels who are cast out of heaven fall down like drops of rain [Tomicki 1976: 64-65]:

The Prince of darkness was falling from heaven, and nine hosts of angels from the left-hand side with him, who from then on, by the will of God the Father, turned into dark spirits, that is devils (...). For nine days, nine hours, nine quarters of an hour and nine seconds fell the choirs of angels thrown down from heaven and the Prince of darkness with them, like the lightest shower of rain. Since the earth, floating on the sea waters, lay on their way to the place that they were to reach, a lot of devilish raindrops fell down on the ground and arose in all manner of places, and even got inside the garden of Paradise. This was when ugly reptiles appeared in Paradise next to innocent creatures; snakes that had not been seen there before.

Leciał książę ciemności z nieba, z nim 9 zastępów aniołów od lewicy, którzy się odtąd z woli Boga Ojca stali ciemnymi duchami, czyli diabłami (...). Przez 9 nocy, 9 godzin, 9 kwadransy, 9 minut i 9 sekund spadały chóry strąconych aniołów, wraz z księciem ciemności w postaci najdrobniejszego deszczu. Ponieważ ziemia pływająca wśród wód morskich była na drodze do miejsca gdzie dolecieć mieli, przeto dużo kropel diabelskiego deszczu spadło na ziemię i powstało wszędy gęsto po różnych miejscach, nawet dostało się do Rajskiego ogrodu. Wówczas to w Raju pojawiły się oprócz czystych istot brzyćkie gady, węże dotąd niewidziane.

Such a point of view opens a broader perspective, triggering the development of connotations which stem from fear of the demonic world. This is visible in textual oppositions juxtaposing water, dangerous and alien by nature, with the familiar earth (land), such as water vs land: "Both on land and at sea, only trouble, my Gregory" (I na lądzie i na morzu - Wszędzie bieda, mój Grzegorzu) [SSSL 1.2: 397]; wet vs dry: "who praises the sea sits on dry land" (ten chwôli 
morze, co sedzy na suchym) [SSSL 1.2: 384]; ground vs underground: "to stand firmly on the ground" - "to sink underground" (stać mocno na ziemi - zapaść się pod ziemię); shallow vs deep: "to have ground under one's feet" - "to reach the bottom, to sink to the bottom" (mieć grunt pod nogami - siegnać dna, spaść na samo dno); near vs far: "own/familiar" - "overseas" (swojski-zamorski), the earthly world vs "otherworlds" (zaświaty).

In myths of creation, water appears to be the perennial abode of the fiend. The folk imagination has created images of an underwater kingdom of demonic beings, dwelling in "palaces (...) from glass and ice, transparent crystal" [Pełka 1987: 84]. The demonic inhabitants live at the bottom and do not leave their homes during the day. Their activities take place at night, especially at midnight, and cease at sunrise. The majority of names of underwater beings derive from the verb topic 'to drown' (e.g. topiec, topich, topień, topnik, topik, topek, topielec, topieluch, topczyk, utopiec, utopek, utoplec and their female equivalents: topielica, topielczyna), which points to their origin. In folk accounts, the rebellious angels cast down by God into the abyss of underground waters became topielce-diably 'drowner fiends'; they drown human beings, turning the souls of their victims into demons and thus increasing the hosts of the damned. Topielce lie in wait to drag people into water and drown them. As the rulers of all underground waters, topielce can drown their victims in any amount of water: in a pond or a river, as well as a puddle or a bucket [Mianecki 2010: 116].

Another group includes water devils called wirniki or wirusy, whose names derive from the word wir 'whirlpool', since, according to folk beliefs, they make whirlpools in order to draw in, and drown, human beings [Dźwigoł 2004: 162163]. Demonic abodes are located in isolated and dangerous places, such as whirlpools, underwater hollows, or confluences of rivers [Pełka 1987: 84]. The underwater world becomes a model for otherworldly space, which is imagined to be wet, cold, dark and dangerous. Evoking negative emotions, the image of the immeasurable expanse of primordial waters motivates the location of alien space beyond the sea (in keeping with the opposition near vs far): "And so he went far, far away, beyond the deep blue sea" (I pojechat hen daleko, za to morze sine) [SSSL 1.2: 417] and its association with death: "When the sun sets, first it sinks into the sea, and then it travels through the sea into the other world" (Gdy słonko zajdzie, to się naprzód zanurza w morzu, potym morzem idzie na drugi świat) [SSSL 1.2: 416]. Overseas lands are also described as "a foreign land where people fall asleep" (obca kraina, $w$ której ludzie zapadaja $w$ sen) [SSSL 1.2: 393].

In fairy tales and orphan songs (pieśni sieroce), the faraway, foreign land is usually situated "beyond the seven seas" (za siedmioma morzami) or "beyond 
the seven rivers" (za siedmioma rzekami). ${ }^{8}$ In cure spells (zamówienie), sickness is banished "beyond the sea" (za morze) (especially black or red sea) or "beyond the seventh river" (za siódmą rzekę), i.e. into "otherworlds" (zaświaty), e.g. "Sickness! Go beyond the red sea! You'll be fine there" (Boleśnico! Idź za czerwone morze! Tam ci będzie dobrze!) [SSSL 1.2: 397].

In the folk imagination, vast stretches of water: seas and rivers serve as images of the border between the earthly world and "otherworlds" (zaświaty), the sphere of death: "At the edges of the Earth there are great rivers which enclose the world" (Na krawędziach Ziemi sa rzeki wielkie, co zamykaja świat) [KLS 1967: 603]. The souls of the dead must cross this border between life and death [Kowalski 1998: 611; Niebrzegowska 1999d: 12; MifyNM 1987: 240; SlavDrev 1995: 386] before they come across the next obstacle: a narrow bridge over-spanning a river of fire which divides "otherworlds" into different spheres: paradise, purgatory and hell:

(...) its waters, black as soot, burn with a fire of many colours. Above this wide river hangs a tiny bridge, as narrow as a baulk, so that it is difficult to stand firmly even on one foot. On both sides of the bridge, fiends stand in water up to their waist (...) they push off whoever dares step onto the bridge.

(...) jéj wody jak sadze czarne, płoną ognisto w różnych kolorach. Na rzece téj szerokiéj, zawieszony mosteczek tak wąski jak belka, że nawet jedną nogą nie stanie na nim dobrze. $\mathrm{Z}$ obu stron mostu djabli zanurzeni po pas w wodzie (...) spychają natychmiast, ktoby tylko na most wniść się odważył. [SSSL 1.2: 347-348]

Death and infectious disease, often personified as an old woman sitting at the water's edge, also come from beyond a river (from the other world). Whoever carries the woman across to the other side will bring a plague upon people [SSSL 1.2: 329].

Heaven, hell, "the other world" (tamten świat) - the sphere of death - are often located beyond the sea or river (the symbolic border of the world). Their image, together with the inbuilt SCALE of positive and negative values, is created by means of the CENTRE-PERIPHERY schema in both the horizontal and vertical dimension. For instance, the image of the abode of Satan at the bottom of the sea, deriving from mythical accounts of the fight between God and Fiend, relies on the UP-DOWN schema [Tomicki 1978: 103, Mit 31]:

8 For more about the symbolic meanings of numerical concepts in describing distance, see Niebrzegowska-Bartmińska 2007: 332-349. 
[When, after their failed attempt to drown God, the devil and his helpers], tired, fell asleep, God and angels cast them into water and went to heaven.

[Kiedy po nieudanej próbie zatopienia Boga diabeł ze swymi pomocnikami] zasnął tym zmęczony, Bóg z aniołami zrzucił ich do wody i poszedł do nieba.

The vitality of this myth is evidenced in the following tale, which combines the plot of the fiend's attempt to drown God with the motif of the differentiation of primal waters. According to a folk account of the devil's treacherous tricks during the creation of the earth, all the waters of the world converged and the fiend, running to hide from God's wrath, chose to live in them, thus becoming their ruler [Mianecki 2010: 117]:

And then This One, may he perish forever, began to pierce with his fingers the flat patch (palanyczka) [the germ of the earth] that God stood on, so that water would come onto the surface through the holes and flood over the Lord God and so He would drown. But this did not help because water would not come out onto the surface. And This One, may he perish forever, when he saw that water did not seep through those little holes, he began to make ever bigger holes, and in the end he tore large pieces out of this patch of earth: still water would not seep onto the surface and drown God, for such was God's will. Then saw the Son of Perdition that he would not drown the Lord God, so he tried yet another way and he began to pour water with his hands from the holes onto the Lord God, but still water would not flow underneath God; each time the Son of Perdition spilt it on the surface, it trickled down some furrow into another hole and dripped back into the sea. Then the Lord God, having slept well, woke up, and This One, may he perish, took fright lest God would punish him - shout at him or beat him - so he took to his heels and he ran and ran as fast as he could, but he looked back to see if the Lord God did not catch up with him. And at that moment he came across one of the holes he had made himself, a great big one, and he sank under water and he still stays there. The Lord God did not repair the holes made by This One, may he perish, but left them as they were; the small ones are springs and wells, the bigger ones are ponds, and the biggest are lakes. The flat patch is the earth, the same one where we live; and it lies on water, on the sea, and it is surrounded by water, by the sea. (...) The water that the Son of Perdition had poured under God and which had trickled down furrows into other holes - made streams and rivers; and the pieces that the Son of Perdition tore out and scattered around: these are mountains.

Wtedy ten - bodajby sczezł - wziął i podziurawił palcami pod Bogiem palanyczkę [zaczątek ziemi], żeby przez te dziureczki woda na palanyczkę wystąpiła, i tak, żeby Pana Boga zalało, żeby się utopił. Ale i to nie pomagało, bo woda nie chciała na placek wypływać. A Ten - bodajby sczezł - jak ujrzał, ż woda przez te małe dziurki nie występuje, zaczął, to zaczął coraz większe dziury robić, w końcu wielkie kawały tej palanyczki wydzierał: wszystko jedno woda nie chciała występować na ten placek 
i Boga utopić, bo to Pan Bóg tak dał. Zobaczył sczezun, że i tak Pana Boga nie utopi, to wziął się jeszcze na inny sposób i zaczął rękami wody z tych dziur na Pana Boga polewać, ale jeszcze woda ni szła pod Boga; co ją sczezun na placek lujnie, to ona pocieknie rowkiem gdzie do innej dziurki, i ścieknie z powrotem w morze. Za ten czas Pan Bóg się przespał i przebudził, a Ten - bodajby sczezł - zląkł się, żeby go Pan Bóg nie ukarał - niby nie skrzyczał, albo nie bił za to - zerwał i w nogi - uciekał, uciekał, ile miał siły, ale obejrzał się w biegu, czy go Pan Bóg nie dogania. Natrafił wtedy na jedną taką, co ją sam zrobił, wielką dziurę i poszedł pod wodę i do teraz tam siedzi! Tych dziur, co Ten - bodajby sczezł - porobił, Pan Bóg nie reperował, ale już tak pozostawały; te, co małe - to źródła i krynice; większe to stawy; a największe to jeziora. Ta palanyczka to ziemia, ta właśnie, co my na niej jesteśmy; ona stoi na wodzie, na morzu, a wokół niej także woda - morze. (...) Ta woda, co ją sczezun lał pod Boga i która rowkami ściekła do innych dziur - to potoki i rzeki; a te kawały, co sczezun z tej palanyczki powydzierał i po niej porozrzucał - to góry. [K, vol. 31, Pokucie]

The motif of the fight between God and Satan is related to the story of Lucifer, bound to a gigantic post in the middle of hell as punishment for his attempt to imprison God. The post indicates the opposite end of where God's abode, located in the centre, lies. Thus the devil is always situated below both heaven and the earth inhabited by people, which entails a negative valuation of areas located down below [Mianecki 2010: 116; Tomicki 1976: 65].

Since the earth is imagined as a flat patch floating on the surface of the sea, the sphere of underground waters becomes a prototypical location of hell. However, it is only dark, standing, shallow groundwaters that belong to the devil's domain. Darkness and lack of movement evoke connotations with death. Hence the negative value ascribed to standing and shallow groundwater, which is reflected in the adjectives that call it "dead" (martwa) or "old" (stara) as opposed to running water described as "living" ( $\dot{z} y w a)$, "young" (młoda) and "clean" (czysta) [MajerBaranowska 1995: 119].

\subsection{The sanctity of water}

The presence of water as an object or tool in the hands of God testifies to its special role in the act of creation. The Creator assigned it the status of the most important element, upon which all life on earth would depend. This means that water was not only imbued with divine energy, but also acquired a demiurgic function; hence its supernatural causal power (life-giving, healing and cleansing) and the highest axiological value [Léon-Dufour 1995: 644-647; MifNM 1987: 240; SlavDrev 1995: 386]. 
Thus the notion of the sanctity of water rests on a belief that it is directly associated with God. This image of water derives both from experience (there is no life without water, water washes off dirt) and mythical-religious belief in the cosmic order established by the supernatural power of God: “The Lord God created fire, water and earth" (Pan Bóg stworzył łogień, wode i ziemie) [MajerBaranowska 1995: 118, recorded near Krasiczyn]. The concept of life-giving water governed by God or holy figures is thus grounded in a religious point of view. The mythical grain of sand brought up from the bottom of the primordial ocean becomes the germ of the earth, which, by God's power, grows into an expanse of land. According to a Ukrainian myth, the seeds of trees planted in Paradise, like the sand, also come from the primeval sea [Tomicki 1978: 90, Mit 40].

\subsubsection{The miraculous power of water in scenes involving divine and holy figures}

Scenes which demonstrate water's miraculous power deriving from divine or holy figures recur in the oral tradition, passed down from generation to generation: rites, religious legends and ritual celebrations, often accompanied by singing. Lyrics such as carols or Lenten songs, which evoke the sacred events from the time of origins, play a significant role in creating the linguistic image of water in relation to the sacred.

Re-enactment of Christ's birth during traditional visits by carol singers and mummers (koledowanie) ${ }^{9}$ creates a situation in which the conceptualiser and participants are drawn into the scene, and the importance of the event transfers them to the centre of the world and the mythical time of origins. The texts of carols, repeated from year to year, contain the scenario of the miraculous event, which often features a water spring as an important element of the background [SSSL 1.2: 271; Niebrzegowska-Bartmińska 2007: 202]:

9 The custom of kolędowanie is practised around Christmas and New Year, and involves rounds of visits by groups of young people, often dressed up in costumes and masks, singing carols, presenting folk plays and wishing happiness, health and prosperity to their neighbours (translator's note). 
A w ty wodzisi źródłowy Maryjá się myła A umywszy się Maryjá na brzeg wystąpiła

A wystąpiwsy Maryjá, Syna porodziła

A porodziwsy Syna Maryjá, w kąpiołkę włozyła

A i w kąpiołkę włożyła, pięknie okąpała

A i z kąpiołki wyjęna, w pieluski zawiła.
And Mary washed in spring water

And having washed, Mary came out onto the bank

And having come out, Mary brought forth her Son

And having brought forth her Son, Mary

put Him in the bath

And in the bath she put Him and she bathed Him well

And she took Him out of the bath and swaddled Him.

The mythical spring water acquires supernatural properties through the very act of contact with the sacred. Its presence in the scene of God's revelation (the birth of the Son of God) further bestows the power of divine blessing on it, making it sacred itself. Hence belief in the miraculous healing and cleansing powers of spring water, which in Christian culture acquires the symbolic meaning of the water of eternal life, identified with Christ and the Holy Spirit [Forstner 1986: 71]. ${ }^{10}$

Carols also mention the miracle of water turning into wine on Christmas Eve, accompanied by other extraordinary events [SSSL 1.2: 336]:

Na ziemi wesele,

że Bóg żyje w ciele.

Wszystko się zmieniło,

jak nigdy nie było;

wino rzeką ciecze,

ciepło, jakby w lecie.

Lwami drzewo wożą,

niedźwiedziami orzą,

zając z chartem siedzą,

$\mathrm{z}$ jednéj misy jedzą.
Joy on the earth,

for God lives in the flesh.

Everything is changed,

as it has never been;

there's a river of wine,

it's warm like summertime.

Lions draw cartfuls of wood, bears pull a plough, the hare and the greyhound share the same bowl.

10 "Christ himself evokes the joyful custom of drawing water during Sukkot (...): 'If any man thirst, let him come unto me, and drink. He that believeth on me, as the scripture hath said, out of his belly shall flow rivers of living water. (But this spake he of the Spirit, which they that believe on him should receive)' (KJV John 7:37-39)" [Forstner 1986: 71]. 
Other feasts of the Catholic calendar, such as the feast of St John the Evangelist [SSSL 1.2: 351] or the Epiphany [SSSL 1.2: 159], also feature the miracle of water turned into wine. We are thus witnessing a repetition of the motif across a range of genres, such as religious legends, which is obvious evidence of its habituation. ${ }^{11}$

The atmosphere of wonder is further developed in other scenes from Christmas carols, in which water comes of its own accord to help Mary wash the child and clean His swaddling cloths. The genre includes many variants of the motif: water comes from a river, lake, or sea, depending on the setting [SSSL 1.2: 194]:

A pod Jeruzalem

Najświętsza Panna Syna porodziła, nie miała go w czém umywać sama i(éj) wodiczka z morza przypłynęła. variant:

Rzyczką woda popłynęła

i Dziecinę mi omyła.
Not far from Jerusalem the Blessed Virgin brought forth her Son, she had nothing to wash him with water of itself came to her from the sea.

variant:

Down the river water flowed and it washed my Child.

According to another carol, water stopped flowing while Mary was washing Jesus: "Still stood the water at Bethlehem, where the Blessed Virgin bathed her Son" (Przy Betlejem cicha woda stojała, Gdzie Panna Najświętsza syna swego kapała) [SSSL 1.2: 194]. Other events in Christ's life: the baptism, crucifixion and resurrection are also accompanied by wondrous acts of water: for example, water in the River Jordan stopped flowing when St John was baptising Jesus. This scene is recalled in the invocations of cure spells (zamowy, sing. zamowa): "Stand still, blood, stand still, like water in a lake, as when St John baptised the Lord Jesus in the Jordan. Amen" (Stoń krewicko, stoń, jak woda w jeziorze, kiedy pana Jezusa święty Jan chrzcit w Jordanie. Amen) [SSSL 1.2: 193].

In Lent songs where scenes of Christ's Passion are re-enacted, all the waters take part in the ritual mourning of the elements after Jesus' death [SSSL 1.2: 195; Majer-Baranowska 1988: 109]:

11 For an extensive discussion of this motif in texts of folklore, see NiebrzegowskaBartmińska 2007: 65-74. 
Płaczci pótoki, płaczci niezmierzony rzeki i źródła, płaczci niezbrodzone. Płaczcie, umar Pan, który wasze wody stworzył i źródłam naznaczył przechody. (...) płaczcie pod wodą niepojęte dziwy, umarł Pan a wasz Stworzyciel prawdziwy.
Cry, streams, cry, you measureless rivers and springs, cry, you ones unforded. Cry, for the Lord is dead who created your waters and caused the springs to know their place.

(...)

cry, oh you unfathomed wonders of the deep, for your true Lord and Creator is dead. ${ }^{12}$

During the annual performance of such songs, the conceptualiser and participants of the ritual celebrations summon water (and all other elements) to join the lament, thus uniting with all the cosmos, which is drawn into the scene of the Lord's death. Thanks to this adopted point of view, the conceptualiser becomes the organiser of the scene, and is located at the centre of the events. The dramatic aspect of Christ's death is further increased by a belief that "all flowing water" (wszelka woda ciekąca) turns into blood during Maundy Thursday night, thus acquiring miraculous properties: it cures diseases and ensures prosperity for people and their farms [SSSL 1.2: 159].

Water also plays an active part in all acts of revelation, re-enacted and celebrated during major Christian feasts: at Christmas, Easter, St John the Baptist, Epiphany. In such scenes waters pay homage to the Creator, Jesus and Mary. The very act of interaction with divine and holy figures endows water with miraculous properties, while the re-enactment of the time of origins enables the conceptualiser to gain access to the very source of power. Hence in practices used to expel disease, folk healers (znachorzy, sing. znachor) invoked the miraculous stopping of the waters of the Jordan at Christ's baptism [SSSL 1.2: 193]:

Still stood the water when the sweet Mother of God bathed the Son. So let this ulcer stand still; variant: Still stood the water in the sea (...) Let the adder lie still, O May moon, draw out the poison.

Cicha woda stojała, Gdy matuchniczka Boża Syna kąpała. Niechże i ten wrzód cicho stanie; variant: Cicho woda w morzu stojała (...) Niechże żywieja [żmija] cicho lega, księżyczka maju [księżyc majowy], wydawa jadu.

12 The translators would like to thank Jean Ward for her help in translating this passage. 
The incorporation of a fragment of a Christmas carol into a formula of a magic spell is not only evidence of how deeply ingrained the text is in the social consciousness, but also how it may be endowed with a new communicative function. The imitated model, transferred into another genre, confirms certain traditional preconceptions about water while also transposing the event into another context. Thus we are dealing with a conventional, stereotypical motif which plays a modelling function [Niebrzegowska-Bartmińska 2007: 65-75].

The motif of a healing bath (kapiótka) mentioned in the carol about Mary washing the Child is repeated in apocryphal tales and religious songs about the miraculous curing of the sick child of the thief with whom the Virgin Mary found refuge during the flight to Egypt:

(1) The Mother of God says: "I will lead him [the thief's son] out [cure him], but you need to bring me different water". (...) The Mother of God first put her little son into water and bathed him, and then she told the thief's wife to put her son into the water. When the thief's wife bathed him, out he sprang from the water, he who had all been broken before. Oh, how he leapt out of the water and jumped around the room.

(2) And the water that Mary had used for a bath became fragrant like a costly balm. The thief's wife did wisely, she poured it into a jar and preserved it buried in the ground.

(1) Matka Boska mówi: „to ja go [syna zbójowego] wyprowadzę ['wyleczę’] ale mi trzeba innéj wody przynieść". (...) Matka Boska wprzódy włożyła swego synaszka i okąpała, a potém kazała zbójowéj, żeby swego znów włożyła w tę wodę. Jak go zbójowa okąpała, a on hujt! z wody, co był wpiérw połamany. Jak chulnął z téj wody, skacze po izbie. [SSSL 1.2: 234]

(2) A ta woda, którego Maryja obmyła, jakoby drogi balsam wonnością się stała. Wtedy żona łotrowa mądrze postąpiła, do dzbana ją wylała, w ziemię zachowała. [SSSL 1.2: 223]

The motif of a healing bath also recurs in prayers, where its function is to wash away sins: "May [the angels after death] lead me to this sweet water, where the Lord Jesus was baptised, and was loved"; "I long for this sweet baptismal water, visited by the Lord Jesus"; "I want to come to this water in which Mary bathed her Son" (Niech mnie doprowadzo [aniołowie, po śmierci] do tyj wodeńki, Gdzie Pana Jezusa chrzcono, Miłowano (...); Chce tyj wódyńki uochrzconej, Od Pana Jezusa nawidzonej (...); Chce ty łódki ['wódki'] dojść, Co Maryja swego syna umywała) [SSSL 1.2: 192].

The healing bath, originating in the actions of the Virgin Mary herself according to apocryphal tales, becomes the model for healing and magical practices (cleansing ablutions). Consequently, invoking the Blessed Virgin or Jesus as the first doctors is a staple part of the narrative in a large number of cure spell formulas [Niebrzegowska 2007: 156]. 
In turn, a popular Marian song about the miraculous healing spring which the Mother of God "made flow for the suffering" (dla cierpiacych wylała) on the site of her apparition in Lourdes has become the model for numerous variants as well as legends about analogical events in Poland [SSSL 1.2: 272, 282; Adamowski 1996: 247-248]:

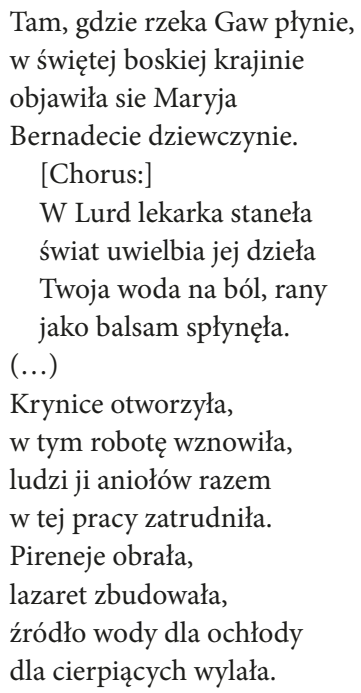

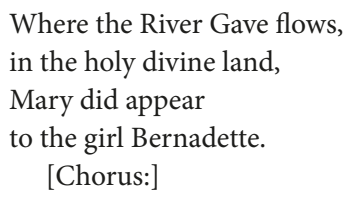

Variants of this motif mention miraculous apparitions of the Virgin Mary either as an image impressed in a tree or as a sacred picture which had been hidden and was recovered by chance [SSSL 1.2: 268, 273]. The site of the apparition is further blessed by the appearance of a spring with supernatural properties: restoring health, life, youth and energy:

- "At the foot of the tree where the Mother of God appeared, water began to flow. A servant from the manor dug a hole on this spot and serfs working in the fields drank from this spring. Many people were healed" ( $U$ stóp drzewa, na którym Matka Boska sie objawiła, wypłyneła woda. Jakiś dworzanin wykopat $w$ tym miejscu dołek $i$ z tego źródełka pili wode dworzanie pracujący $w$ polu. Ludzie doznawali uzdrowień) [SSSL 1.2: 273];

- "where the Mother of God appeared, three streams sprang from the ground which are still there today and (...) heal" (na miejscu, ka była Matka Boska, trzy źródła wytrysty, co som do dziś i (...) leczom) [SSSL 1.2: 274]; 
- in Poczajów a spring flows "from the foot of the Blessed Virgin Mary" (ze stopy Najświętszej Panny Marii) [SSSL 1.2: 274].

Saints, too, were able to miraculously draw water out of a rock, usually by striking it with a staff, thus repeating Moses' archetypal gesture [SSSL 1.2: 274]:

- "St Salomea passed by the town of Skała ['rock'] and here she thrust with her walking stick and here water sprang out" (Świętá Salomeja przechodziŭa do Skaŭy i tutáj lazécko źgnęŭa i tu woda wytrysŭa);

- St Adalbert "struck a stone lying in a field with his staff and water sprang out" ([święty Wojciech] uderzył laska $w$ kamień, znajdujący się $w$ polu $i$ wytrysnęła woda).

Also other actions of holy figures could draw water out from the ground [SSSL 1.2: 274]:

- "St Hedwig made a hole in the sand with her heel and then water sprang out" (św. Jadwiga zrobiła pieta zagłębienie w piasku i wtedy wytrysło źródło);

- Piotr Skarga, "having thrust a spade into the ground" in the name of God, "brought forth a spring," which was later called Sigismund's Well (Piotr Skarga w imię Boże „zapuściwszy rydel w ziemię, dobyt źródło”, nazwane później Zygmuntowa Studzienka);

- "a spring of bitter water" burst out from under a stone on which "St Kinga sat crying bitterly” („źródełko gorzkawej wody” wytrysło spod kamienia, na którym "gorzko zapłakała św. Kinga");

- "at the foot of a mountain called Biedzina, a spring burst forth to refresh St Jan Kanty, who prayed and suffered much here" (pod góra, zwana Biedzina, wytrysło źródło, aby pokrzepić św. Jana Kantego, który się tu modlit i biedzit).

The operation of the FORCE schema here involves a chain of actions transferring divine energy: first to the Virgin Mary and saints (St Adalbert, St Hedwig, St Salomea, St Kinga) and through their mediation, to spring water.

According to religious legends, saints directly associated with water: St John the Baptist and St John of Nepomuk, the latter a Czech martyr drowned for his faith in the River Vltava, also wielded power over water. Consequently, figures of St John the Baptist or, in the south of Poland, of St John of Nepomuk, were erected on river banks to protect the inhabitants from floods [SSSL 1.2: 332]. In this case, the experientially grounded use of the FORCE schema relied on the model of COUNTERFORCES (the destructive power of water and the protective power of the saint) balancing each other out. 
In folk beliefs, God reveals His power and grace through the miracle of water turning into wine (on Christmas Day) and into blood (on Good Friday). The power of God was also revealed during the martyrdom of St Dorothy at the hands of Herod ${ }^{13}$ [SSSL 1.2: 224]:

I kazał król wody zimny nawozić,

i świętą Dorotę umrozić.

A woda [z woli bożej] tak uczyniła, co się letnią stanęła.

( $Z$ nieba skry gorące leciały, święty Dorocie wodę grzały).

variant:

Z nieba gwiazdki padały, wódkę jej zagrzewały.
And the king commanded that cold water be brought

to freeze St Dorothy.

But the water [by the will of God] became lukewarm.

(Hot sparks poured from the sky to heat up the water for St Dorothy).

variant:

Stars fell down from heaven, warming the water for her.

\subsubsection{The cleansing power of water in scenes of God's wrath}

God's power over water and earth is also revealed through deluges and floods sent down to the sinful world as punishment [Léon-Dufour 1995: 645-646]:

In heaven there is water, there are stones, there is hail and there is fire. All this God keeps for His needs. When punishment is needed, they are used to destroy evil on earth.

Na niebiosach jest woda, jest kamieni, jest grad, jest ogień. To Bóg trzyma dla swoich potrzeb. Jakaś kara, jakaś co, to to musi zostać i zniszczyć to na ziemi. [SSSL 1.2: 228]

In scenes of disaster, water becomes a tool of punishment in the hand of God, who shows His wrath by means of the destructive power of torrential rain or flood, submerging places overcome by evil. The participants of events, as the object of God's punishment, are drawn into the scene, while the conceptualiser plays the role of an observer relating the course of the action.

The biblical Deluge, an archetype of a natural disaster, is preserved in collective memory in numerous:

13 The folk version of St Dorothy's martyrdom identifies Emperor Diocletian, known for his bloody persecution of Christianity, with King Herod (translator's note). 
- riddles, e.g. "What was the great water that once fell, which reads the same backwards and forwards <Potop 'Deluge'>” (Co to bëła za viélgô woda, co rôz sę zdarzëła, co napisónô i wprzódk i wspak jednako sę czëto? - <Potop>) [SSSL 1.2: 421];

- legends, e.g. "The Lord God punished those people who were sinful by sending the Deluge and they perished by the Deluge throughout the world. One Noah remained alive" (Pan Bóg potopem nakarał ludzi, którzy zgrzeszyli i pótopem wszystki w całéj kuli ziemskiej wyginęli. Tylko jeden pozostał Noj) [SSSL 1.2: 421];

- popular religious songs, which were often part of the wandering beggars' (dziad) repertoire, for example [SSSL 1.2: 421]:

Noe z potopu świata uwolniony,

Lot z sodomskiego ognia wywieziony,

Mojżesz i Jonasz w morzu nie zginęli,

bo Ciebie mieli (v. czcili).

Bo Bóg wybranych w nieszczęściu ratuje, tysiące giną, jednego salwuje, gdy sprawiedliwy u Boga w estymie, nigdy nie zginie.
From the deluge of the world Noah was saved, from the fire of Sodom Lot was carried away, Moses and Jonah did not perish in the sea, because they had [variant: worshipped] Thee.

For God in misfortune saves the chosen, when thousands are lost, He rescues one, if the righteous one by God is cherished, he will never perish.

The moralising songs of wandering beggars warned of God's wrath ("May there be peace and love throughout the nation,/ Then God will not punish us with another deluge" (Niechże w narodzie zgoda, miłość będzie,/ To nas Bóg karat potopem nie będzie) [SSSL 1.2: 421]), evoking terrifying images of e.g. a disastrous rain [SSSL 1.2: 342]:

\footnotetext{
Niebo się zagniewało, deszcz leje strugami, The heavens are irate, the rain keeps pouring down,

Woda $\mathrm{z}$ łożysk powstaje, co się dzieje $\mathrm{z}$ nami. Water leaves riverbeds, what will become of us,

Niesie domy i ludzi dunajcowa fala, The waves of the Dunajec carry away people and houses,

Padła ofiarą wody niejedna rodzina. Many is the family who fell victim to the waters.

Inne rzeki co robią: wszystko zalewają, Other rivers also flood everything around,

Ludzie w strasznej rozpaczy na dach uciekają. People in great despair onto rooftops climb.
}

Song lyrics also provided examples of a miraculous rescue of those who prayed to the Lord to avert punishment [SSSL 1.2: 342]: 


\begin{abstract}
A rodzina Kusiołów cudu tu doznała, Woda z rzek wystąpiła, cały dom zalała. Straszna fala przychodzi, bierze swą ofiarę. - O Jezu, z nieba Boże, oddal od nas karę! Przenajświętsza Panienka cud tu uczyniła, Trzy ściany poszły z wodą, a jedna została. I piec był im obroną: na nim zamieszkali I Najświętszej Panience za to dziękowali.
\end{abstract}

\begin{abstract}
The Kusioł family, a miracle true they saw, The rivers overflowed, their house was flooded all, A fearful wave comes, claims its victim whole. - O Jesu, God from heaven, your punishment withdraw! The Blessed Virgin Mary a wonder here she wrought, Three walls did water take, yet left one on the spot. The stove was all their rescue: on it they stayed and thence, To the Most Blessed Virgin they offered all their thanks. ${ }^{14}$
\end{abstract}

The motif of the biblical Flood and the prospect of impending divine punishment are also evoked in stories about drowned churches, villages and towns [SSSL 1.2: 165], as well as inns and mines [SSSL 1.2: 234]. Since the motif is widespread in a number of different genres, it may be regarded as a stereotypical commonplace. Depending on the variant of the story, divine wrath falls on sinners (for failing to keep fast, dealings with the devil or murder) or traitors of the nation [SSSL 1.2: 234]:

- "[on Good Friday carters were drinking and singing in an inn. Suddenly a great clap of thunder was heard] and only a [bottomless] pit full of black water remained on the site of the inn. The pit has never since dried" ([w Wielki Piątek woźnice pili i śpiewali $w$ karczmie; nagle rozległ się straszny grzmot] $w$ miejscu karczmy pozostał tylko czarna wodą zalany dół [bezdenny]. Dót ten jeszcze nigdy nie wyschnąt);

- "[St Jan Kanty cast a curse on sinners.] The curse resulted in the withdrawal of God's blessing. Ores hid deep underground, the silver-giving mountains were flooded with water which will not recede until the descendants of the sinners propitiate God's wrath" ([Św. Jan Kanty rzucił klątwę na grzeszników.] Za klątwa poszło niebłogosławieństwo Boże. Uciekły kruszce w głą ziemi, a srebrnodajne góry zalała woda i nie ustapi $z$ nich dopóki potomkowie grzeszników nie przebłagaja gniewu Bożego);

- "The owners of the silver mines in Bytom (...) drowned the parish priest and his vicar. They were punished for it because water flooded their mines" (Wtaściciele kopalń srebra w Bytomiu (...) utopili proboszcza oraz jego wikarego. Spotkała ich za to kara, ponieważ woda zalała kopalnie);

14 The translators would like to thank Jean Ward for her help in translating this passage. 
- "When the old miner commended the young ones to the devil, all became wet; a hole sprang in the wall and water poured out that could not be stopped" (Gdy stary górnik oddał młodych w opiekę diabłu, zrobiło się mokro; wyleciała $w$ ścianie dziura i poptynęła woda, której nie udało się zatamować);

- "When the Palatine of Kujawy, Grzmisław, betrayed his country, opening the gates to the Swedish invaders [in the 1650s], a storm arose on Lake Gopło; water swelled and, crashing against the walls of his castle, engulfed him and all his people" (Gdy wojewoda kujawski Grzmisław zdradził kraj, otwierajac bramy szwedzkiemu najeźdźcy, powstała burza na Gople; woda się wzdęła, a uderzajac o mury jego zamku, pochłonęła go ze wszystkiemi).

In flood scenes, the FORCE schema operates according to the model of OUTER COMPULSION, over which the conceptualiser has no control. Other schemas involved in scenarios of cataclysms are those of DESTRUCTION (PART-WHOLE) as well as CONTROL and BALANCE. The prototypical DESTRUCTION schema is assigned a negative value. However, since in such scenarios God is the agent and the aim of the action is to mete out justice and restore order to the earth, the axiological scale is adjusted so that the event acquires a positive value. ${ }^{15}$ The BALANCE and CONTROL schemas come into play in stories in which lakes or springs appear on the sites of submerged churches, inns or cities [SSSL 1.2: 267].

Such beliefs confirm the vitality of water symbolism deriving from the cosmogonic myth in which God imbues water with His life-giving power. Water reveals its cleansing properties and capacity to destroy evil, thanks to which the site of $\sin$ is transformed into a spring or a lake. In this way punishment turns into grace, a gift of water.

Genre holds a great importance in the treatment of a stereotypical commonplace motif [Niebrzegowska-Bartmińska 2007: 65-74] since it determines both the development of the context and the illocutionary force of the message. Religious legends based on the biblical Deluge - an event as distant in time as the creation of the world - mainly have a cautionary function. Religious songs (especially those from the repertoire of wandering beggars), besides issuing a threat or warning, also include commands (to pray, to appeal to God's mercy in extremity, to observe God's commands to love). In turn, when the same motif is used in stories recalling local events preserved in collective memory, it serves not only to warn, but also to condemn the most flagrant examples of iniquity.

15 For a discussion of positively evaluated destruction schemas, see Masłowska 2012b. 


\subsection{The power of water in the interactions between man and the sacred}

\subsubsection{The cult of water}

The religious attitude towards revelations of God's power is manifested in numerous forms of the cult surrounding sacred water. ${ }^{16}$ The most conspicuous examples involve the worship of the Virgin Mary and saints whose influence drew forth healing springs from the rock or the ground. To commemorate such events, springs were often given the names of their patrons, e.g. Mary's Well (Studnia Marii), God's Passion (Boża Męka), St Peter's Spring (Źródło św. Piotra) (in Biadolin), St Anne's (near Brzesko), St Adalbert's (in Modlnica), St Hedwig’s (near Włoszkowice), St Francis' (near Łysica), St Roch's (in Krasnobród), Kadłubek's Spring, St Wincenty's Hill (Źródło kadłubkowe, Stok św. Wincentego) (near Opatów) [SSSL 1.2: 268]. In addition, figures of saints, crosses, shrines and sometimes even churches were erected next to such springs as votive offerings for a miraculous recovery. In order to emphasise their importance, some springs were encased within the walls of a chapel so that the water flowed out next to the altar itself. Chapels built on stilts above springs are known as "chapels on water" (kaplice na wodzie, e.g. in Krasnobród). Such places, regarded as holy, still attract numerous pilgrims; Holy Masses and devotions are held there, especially on the feast of the patron saint and at Easter time, when the Stations of the Cross are celebrated, the water is blessed, etc.

The sacred character of spring water derives from the fact that its source is located in "otherworlds" (zaświaty). In this way, a spring becomes a holy place - the CENTRE - open to interaction with the sacred [Kowalski 1998: 640]. Holy springs are thus usually located in high places and surrounded by trees (mainly oaks, limes, pines or firs) as water issuing from under a tree is believed to have particularly strong powers, especially when the tree in question is a lime $e^{17}$ [SSSL 1.2: 269]. The location of a tree at a spring reinforces

16 In Slavic culture there are numerous traces of the archaic cult of water, which, under the influence of Christianity, turned into the cult of divine and holy figures (mainly the Virgin Mary, St John the Baptist, St John of Nepomuk, St Nicholas) [SSSL 1.2: 154; Łowmiański 1986: 130, $136 \mathrm{ff}$; Gieysztor 1986: $168 \mathrm{ff]}$. The cult of water, widespread in the pre-Christian period, had a religious dimension since water was treated as a hierophany of the sky divinity [Eliade 1958: 93].

17 In folk culture, the lime tree is associated with Our Lady [Tomicka, Tomicki 1975: 89]. This may be connected both with the perceived female character of the tree and the 
its symbolic significance as a cosmic centre. In this way, the lime tree comes to play a double role here: it is the local axis mundi, connecting the underground, earthly and heavenly worlds, while at the same time protecting the holy spring from defilement.

\subsubsection{The stereotypical motif of a miraculous spring}

For the conceptualiser, water springing out of the ground, and thus directly from the other world, is pure, undefiled and as such is endowed with miraculous, supernatural properties. Numerous variants of local stories and legends feature the motif of a miraculous healing as a result of drinking, or bathing in, water from a holy spring. In fairy tales, such water not only heals, but also brings back to life, restores lost limbs, enhances beauty, e.g.:

The princess [whose evil father had had her hands cut off] went [following the advice of an old beggar, i.e. Jesus $]^{18}$ and saw a pure spring that had never been seen in the garden before. The old man said: "Bend down and put your right arm into this water." The princess did as she was told and she had her right hand again. The old man bade her put in the left arm. No sooner had the princess touched the water, she had her left hand back, too.

Królowa [której zły ojciec obciął ręce] poszła [za radą żebrzącego dziadka, czyli Jezusa] i widziała przed sobą źródło przeczyste, którego przedtem w ogrodzie nie było. Staruszek rzekł: - Schyl się i zanurz w tej wodzie prawe ramię twoje. Królewna uczyniła tak i miała prawą rękę. Staruszek kazał zmaczać lewe ramię. Ledwo się królowa wody dotknęła, miała lewą rękę. [SSSL 1.2: 273]

Belief in the supernatural properties of spring water corresponds with the motif of miraculous "living water" (woda $\dot{z} y w a$ ), extensively developed in folk tales. Plots of this kind often additionally introduce the figure of a guardian of the water, usually such as a monstrous reptile (snake, adder, dragon) or a frog, or a wild animal: fox, bear, wolf, leopard, lion [SSSL 1.2: 238]. A reptile (especially a snake or dragon) has symbolic associations with water, while a fox and bear are archaic lunar symbols, whose presence is prompted by the close connection between water and the moon [Eliade 1958: 170].

fact that in numerous folk accounts the figure of the Virgin Mary appeared on a lime. The epiphanic properties of the lime derive from the underground world, where life comes from and where death takes us. The location of holy springs under lime trees is certainly not accidental and is confirmed in many folk texts [Kowalski 1998: 285].

18 According to folk beliefs, Christ often disguises himself as a wandering dziad (beggar and storyteller) [cf. Michajłowa 2010: 97; Grochowski 2003: 114]. 
The motif of miraculous water from a spring (krynica), mountainside (stok) or a well (studnia) appears in a variety of genres (legends, local stories, folk tales, prayer-like salutations), which points to its stereotypical character. As in each genre the conceptualiser's point of view is different, the same basic image is shown from a number of different perspectives. In legends and local stories, the conceptualiser assumes a position inside the scene, identifying him/herself with the participants of the miraculous event, who interpret the healing as a result of God's grace (bestowed through the mediation of the Virgin Mary or saints). By contrast, the folk tale convention places the conceptualiser outside the scene as an observer who recounts the events and ascribes the miraculous effect of the "living water" to its magical properties.

In folk culture spring water, due to its purity, is sometimes called "the Virgin Mary's sister", or "the holiest", as it cleanses and sanctifies. Its power to wash away sins is invoked in prayers [SSSL 1.2: 192]:

(1) Niech będzie pochwalona przenajświętsza (1) Praise be to the most blessed water, wodecka,

Która obmywała krzacki, pniacki, kaminie. which has washed bushes, trees, stones.

Obmyj i to moje stworzynie! Wash me clean, too, creature that I am!

variant:

Bądź pozdrowiona wodziczko, variant:

Panny Maryi siostrzyczko,

Hail to thee, dearest water, Blessed Mary's sister,

Czyścisz góry i korzynie, You cleanse mountains and roots,

Obmyj i mnie grzeszne stworzynie! Wash clean my sinful self, creature that I am!

(2) Pure, transparent water, which washes roots and rocks (...).

(3) Crystal clear water, you wash all roots, wash me, too.

(2) Wodziczko czysto, przeźroczysto, Co obmywasz kamienie, korzenie (...).

(3) Wodo kryształowa, obmywasz wszelkie korzenie, obmyj i mnie.

It seems that the image of pure water, "Blessed Mary's sister", which washes away human sins, may derive from the archetype of the "bathwater" described above or the water used by St John during Christ's baptism. This is evinced in prayers that sinful souls address to spring water [SSSL 1.2: 192]:

Żebyśmy mogli ty wodyńki dostać,

Co Pana Jezusa krzcili,

Tobyśmy sie w ni pomyli,

Wszystkich grzychów byśmy sie pozbyli.

(...)

Kiebyśmy mogli się ty wody napić.
If we could get this dearest water That the Lord Jesus was baptised in, Then we would wash in it, And get rid of all our sins.

(...)

If only we could of this water drink. 
Such forms of address directed to water are found in many similar variants collected across Poland, which suggests that the motif is deeply ingrained in the awareness of language users. A salutation combined with a prayer of propitiation increases the level of illocutionary force. Addressing water directly as if it were a living being endowed with special powers, coupled with the prayer-like character of the entreaty, evidence the veneration of, and belief in, the sanctity of water [Majer-Baranowska 1991].

\subsubsection{The system of norms regulating behaviour with respect to water}

Since the cult of water demands that springs (and wells) should be kept clean, it is accompanied by numerous rules prohibiting the defilement of water, and commands to observe certain norms of behaviour as a sign of respect [SSSL 1.2: 168-169]. The conceptualiser assumes a position within the scene and becomes subject to the FORCE of OUTER COMPULSION, which requires him/her to observe the rules established by the social group he/she belongs to as flouting them may bring negative consequences for the conceptualiser or the whole community.

In a place which is open to contact with the sacred, it is forbidden to do anything that would cause defilement, and thus deprive the spring of its miraculous properties. Consequently, those who are in a transitional state, subject to influences coming from the otherworld, and hence exposed to the actions of impure forces, are forbidden to use "living water" [Wasilewski 1989: 110; Kowalski 1998: 641]:

- menstruating women must not visit springs so as not to incur the risk of grave illness or even death;

- people in mourning must not visit springs;

- one must not take part in rites of passage (baptism, weddings, funerals) after visiting a spring.

Wells had to undergo ritual cleansing on strictly prescribed occasions [SSSL 1.2: 168]:

- on the eve of St John's feast, water must be drawn out from the well to make room for new water to flow in, for St John baptised water and so it must be clean (in the Poznan region this is done at Pentecost);

- holy water must be poured into the well on Easter Saturday;

- on St Agatha's feast, one should/ought to (trzeba/należy) throw St Agatha's salt and a slice of blessed bread, or stones brought from holy places, into water so that "water does not go off" (woda się nie psuje). 
The use of sacramentals and the choice of occasion are meant to increase the power of water, in keeping with the INTENSIFICATION OF FORCE schema. A command structure trzeba/należy (one should/ought to), the linguistic correlative of the FORCE schema, is employed to indicate specific actions involving the use of particular attributes in order to achieve the desired goal. To restore sanctity to water, it is necessary to invoke the aid of the sacred (through the use of blessed objects and the performance of prescribed actions on specified feast days).

The system of norms forbidding unworthy acts with regard to water evinces the connection between the cult of water and the cult of divine and holy figures. Thus disrespect shown to the life-giving element is tantamount to offence against the Virgin Mary or Jesus Christ [SSSL 1.2: 168]:

- it is forbidden to spit into water, "because water is used for baptism", "because it's spitting in the face of the Mother of God" (bo woda się chrzci; bo pluje się Matce Boskiej w twarz);

- it is forbidden to urinate into water, "to piss" (sikać), "because it's a sin, for our Lord Jesus was baptised with water from a river" (bo to grzech, gdyż pan Jezus woda z rzeki był ochrzczony).

The prohibition is reinforced by a threat of punishment (loss of life or deprivation of water) for any defilement of water. In Kashubia, there is a saying "who spits into water will drown" (chto plwie na woda, ten sa utopi), and in the Przemyśl region it is believed that shooting into a well may cause it to go dry [SSSL 1.2: 168-169].

No one can be refused water since it is a gift from God: "What the Lord God has given to man freely as a gift, belongs to everybody" (co Pan Bóg dat człowiekowi bez jego udziału, należy do wszystkich). A folk saying states: "If someone forbids the use of water from their well, it will become smelly or even dry out" (Jeszle chto zabrániá wódę ze stédnie, téj wóna zasmierdnie abo czésto weschnie); or he will be punished after death: "Who begrudges other people water during his life, will have plenty of it in his coffin after death" (Ten, co załuje ludziom wody za zyciá, bedzie ji miát petno po śmierci $w$ trumnie) [SSSL 1.2: 166]. Eternal thirst is a punishment meted out to those who break the basic command of mercy "to give water to the thirsty" [SSSL 1.2: 174], and religious songs warn about such fate by recalling the figures of well-known sinners who suffer in hell for refusing water to the thirsty [SSSL 1.2: 224]: 
(1) [tazarz prosi bogacza:]

Zmiłuj się, wyślij wody,

Kropelkę dla ochłody,

Widząc rany i wrzody.

Język ledwo przerzecze,

$Z$ wierzchu, wewnątrz ból piecze

(...)

[bogacz do Łazarza:]

(...) leżysz o głodzie,

Ni o chlebie, ni wodzie,

Nie liczże się w mym rodzie.

(2) [Bogacz widzi swoje wieczne męki:] Proszy Łazarza, żeby przyniós wody

na spalóny jénzyk, coby mnioł gody.

(3) Prosi syn ojca o kropelkę wody:

„Ochłódź, ochłódź! mój języcek drogi”.

[Ojciec:]

Choćbym ci spuścił i całe morze, Juz tobie, synu, w piekle nie pomoze.

(4) Po małej chwili dał Bóg takie gody, że syn ojca prosił o kropelkę wody.
(1) [Lazarus asks the rich man:]

Have mercy on me,

Send some water to me,

See the sores and wounds on me.

My tongue can hardly speak,

For pain without and in

(...)

[the rich man to Lazarus:]

(...) hungry you lie here,

Nor bread nor water near,

To my house you are not dear. ${ }^{19}$

(2) [The rich man sees his eternal punishment:] He begs Lazarus to bring water for his burning

tongue,

so it could sing a joyous song.

(3) Son asks father for a drop of water:

"Cool me, my poor tongue, cool me."

[Father:]

Even if I drained the whole wide sea,

In hell, my son, 'twould bring no help to thee. ${ }^{20}$

(4) After a short while God sent such fortune, that a son begged father for a drop of water.

In songs of wandering beggars ( $d z i a d)$, the motif of punishment through deprivation of water presages the end of the world or the rule of the Antichrist [SSSL 1.2: 224]:

Choroby straszne zapanują,

Powietrze i wodę zatrują,

Wnet mrok na ziemie spłynie wieczny

I zbliży się sąd ostateczny.
Diseases foul will reign,

Will air and water taint,

Eternal dark will come upon the earth

And Doomsday will draw nigh. ${ }^{21}$

19 The translators would like to thank Jean Ward for her help in translating this passage.

20 The translators would like to thank Jean Ward for her help in translating this passage.

21 The translators would like to thank Jean Ward for her help in translating this passage. 
Similarly:

Na ziemi [antychryst] będzie panować,

Każe sobie pieczętować,

Wierni dla naszej wygody,

Nie dostaną kropli wody.
[Antichrist] on the earth will reign,

All will homage have to pay,

The faithful for our pleasure,

Will not get a drop of water.

The curse formula is another type of text which features the motif of deprivation of water: "May you lack even a drop of water!" (Ażeby ci kropli wody zabrakło!) [SSSL 1.2: 174]. The performative force of the malediction is believed to bring death or suffering upon the cursed one.

In folk tales, the good man, who gave water to the thirsty (an angel, saint, bird, apple tree) is amply rewarded [SSSL 1.2: 174], while the wicked one, who refused to give water, is severely punished [SSSL 1.2: 231].

Another stereotypical motif which extends the range of meanings associated with the sanctity of water is that of lack of water as a form of punishment. The motif, recurring in many genres and textual variants, is connected with folk morality, based on belief in divine justice, which rewards the good and punishes the wicked. Thus water - as an instrument in God's hand - carries out His decrees (see the motif of drowning as divine punishment described above). Likewise, water is invoked as a tool of justice in oaths [SSSL 1.2: 191]:

If I am not telling the truth, then may not fire, nor water, nor earth, nor hell, nor heaven accept me after my death.

Jeśli nie mówię prawdy, niech mnie nie przyjmie po śmierci ani ogień, ani woda, ani ziemia, ani piekło, ani niebo.

Examples of punishment meted out by water include refusing to accept sinful souls after death; washing up a dead body to reveal a crime; throwing out a maiden's garland belonging to a girl who does not deserve it; punishing incest [SSSL 1.2: 163]; demanding a human sacrifice in return for the salvation of a drowned person [SSSL 1.2: 164]. Scenes in which water punishes sins place it in the centre of events as the agent, while the real source of power - God - remains in the background. The victims become the object of the action of FORCE, while the conceptualiser is located outside the scene as an observer and commentator of events.

\subsubsection{Sacrificial offerings}

The cult of water also involves ritual sacrificial offerings, common among Slavic peoples [KLS 1967: 511; SlavDrev 1995: 386]. While the tradition dates back to pagan times, the sacrificial practices observed in Poland are heavily influenced 
by Christianity. The custom of offering sacramentals - blessed bread, St Agatha's salt (salt blessed on St Agatha's day), candles or holy pictures as sacrifices - was intended to propitiate the elemental force or win its favour. The gift of a loaf of bread (feeding the element) was supposed to protect one from drowning, while throwing St Agatha's salt and a slice of bread into a well was to purify and consecrate the water in it. The time of ritual practices was not accidental, either [SSSL 1.2: 169]:

- holy pictures should be thrown into water on every Good Friday "so that there are fewer victims" (aby tyle ofiar nie było);

- bread and candles should be thrown into water on Good Friday;

- a slice of bread and blessed salt should be thrown down the well on St Agatha's feast;

- a silver grosz 'penny' should be thrown into a newly dug well. ${ }^{22}$

Rituals of propitiation (not involving sacrificial offerings) also include the custom of carrying around palms on Palm Sunday "so that water does not take away soil from the fields" (żeby woda nie zabierała ziemi z pól), observed in the mountains in the south of Poland [SSSL 1.2: 163].

The command to make offerings to water in a traditionally prescribed form is expressed by means of directive speech acts, in which the modal verbs trzeba/ należy 'ought to/should', coupled with the illocutionary force of the command and/or persuasion, act as the linguistic correlative of FORCE. The FORCE schema also applies to the protective aspect of sacrifices (to prevent drowning or loss of crops), based on the model of COUNTERFORCES (the power of sacramentals against the power of water) which neutralise each other. The perlocutionary force of the command functions in terms of the OUTER COMPULSION (offering sacrifice as a result of the pressure of the social group) and the REPULSION schemas (as regards water's destructive power).

By contrast, in desiderative acts - e.g. one ought to/should (trzeba/należy) throw a grosz coin or St Agatha's salt into a bath/well so that water should be clean, hard and healthy, or so that it should be sanctified - the INNER COMPULSION variant of the FORCE schema is in operation. The illocutionary

22 Silver coins were also thrown into the bath of a newborn or sickly child and into the tub in which people washed on Christmas Eve, so that those who bathed in it should acquire the qualities of the coin: purity, resilience, strength and health [SSSL 1.2: 177]. Such rituals are an example of imitative magic. A silver coin thrown into a well could combine their sacrificial and magical functions: to make water pure and hard [SlavDrev 1995: 387]. 
force of a wish is based on the ATTRACTION schema in order that the power of the coin/St Agatha's salt should pass into the water. The INTENSIFICATION OF FORCE is realised through temporal factors: offering sacrifices or performing rituals of propitiation on holy feasts (Palm Sunday, Good Friday), which are believed to have a special power. In the case of salt, which possesses apotropaic as well as preserving and purifying properties [Łeńska-Bąk 2002: 87-89], the INTENSIFICATION OF FORCE was achieved by its additional blessing and application on the appropriate occasion. ${ }^{23}$ Such a fusing of means designed to protect, or to induce the desired change, is evidence of a weakening belief in the primal magic power of water or salt in their own right. The magical outlook is overlaid with a Christian awareness, moulding an attitude which combines the two points of view. In scenes of sacrificial offerings, the participants in the ceremony, with whom the conceptualiser identifies, play the role of the agent, water is the object of magical practices, while the sacred is the addressee proper.

\subsubsection{Lexical exponents of the cult of water}

Lexical exponents of the cult of water include mainly names of water springs, coined after the names of their holy patrons. Stereotypical motifs, featuring in a number of different variants across a range of folk genres, also play an important communicative function, since through their very popularity they become fixed in the connotational layer of concepts represented by the image of water. Thus popularised and ingrained in collective memory, they function as minimal contexts: ${ }^{24}$ sentences expressing conventional beliefs about water as regards its characteristics (e.g. water from a spring has miraculous properties); actions (e.g. waters mourn the death of Christ); the processes it undergoes; the time of events and dependence on other circumstances (on Christmas Day water turns into wine; on Good Friday - into blood). In turn, directive speech acts such as commands, prohibitions, warnings and threats

23 Katarzyna Łeńska-Bąk discusses the symbolism and apotropaic properties of salt as well as its use in rituals and magical practices [Łeńska-Bąk 2002].

24 Jerzy Bartmiński, the author of the concept of minimal context (also called a stereotypical motif), defines it as "a statement which communicates a stereotypical opinion about an object, understandable without the knowledge of other opinions" [Bartmiński 1980b: 28]. A brief description of the uses of minimal context and stereotypical motifs can be found in Stownik stereotypów i symboli ludowych (SSSL) [cf. NiebrzegowskaBartmińska 2007: 65-70]. 
are translated into specific scenarios for (usually ritual) actions. Together with oaths sworn on water, maledictions and prayer-like salutations, they create a canon of culturally connoted common knowledge, used in recurring communicative situations indicating the cult of water. Due to their widespread use, they are an integral component in the semantics of water as an optional element, relevant from the cultural point of view. Jerzy Bartmiński aptly captures the status of a motif:

To fill a connotational schema with specific lexical items is to move from the sphere of abstract models of combining words to the sphere of meaning, the thematic sphere. This process takes place against a background worldview, a certain pool of knowledge of the addresser and addressee, the adopted point of view and perspective, as well as the intended goal of communication. [Bartmiński 2001: 65]

Thus communication takes place in traditionally determined situational and temporal contexts, which condition the type of discourse. In ritual practices, i.e. in magical discourse, the context is limited and does not require any verbal engagement of the participants other than a repetition of formulas. The context is limited also in scenes such as oaths or curses, which invoke the sanctity of water within discourse of a pragmatic type, devoid of a magical function, even if such a function is evoked contextually and its performative power is activated (an oath confirms the validity of an event; a curse works and brings about particular consequences).

\subsubsection{Practices making use of the life-giving power of water}

The proverb "Father wind, mother water" (Wiatr ojciec, a woda matka) is perhaps the most succinct formulation of a belief in water's life-giving power. Such beliefs derive from the cosmogonic myth of the male sky divinity fertilising mother earth with rain [Eliade 1958: 191-192; MifyNM 1987: 240] and its Slavic variants quoted above, as well as the biblical account and folk tales featuring "living water".

The belief in the sacredness of water is accompanied by practices aiming to make use of its power. In this way, the experience of water's life-giving properties becomes a means of entering into interaction with the sacred, and practices involving the use of water are magical and ceremonial in nature.

Practices which re-enact gestures of divine and holy figures have the most solemn character. These include ceremonies of baptism, the blessing of water and blessing by means of water. The re-enactment invokes the first act of creation, endowing water with an original life-giving power. The ceremony is thus construed in terms of the ATTRACTION OF FORCE schema. 
The christening ceremony evokes the archetypal scene of St John baptising Christ in the River Jordan, and draws on the demiurgic powers of water bestowed on the element during the act of creation. Thus repetition of the scenario is imbued with multi-layered symbolism (see Chapter 3.6 below). The cleansing and life-giving power of water not only washes away original sin but also allows access to the sacred both during this life and after death. This is the motivation behind the traditional prohibition forbidding the bathing of a newly baptised child so that water does not wash away the sacrament [SSSL 1.2: 176]:

- a child must not be bathed, or have his/her head washed or water poured on him/her for three days after baptism, "for the sacredness would be washed off the child" ( $g d y \dot{z} z$ téj dzieciny zmyłyby się świętości).

The ritual itself requires the presence of a consecrated officiant, sacramentals and a sanctified place of ceremony, i.e. a church, and the scenario determines the roles of the participants in all particulars. The conceptualiser usually plays the role of a participant in the event, while the priest conferring the sacrament becomes the agent. When the newborn's life is in danger, however, emergency baptism with water that has not been blessed (chrzest $z$ wody) should be performed at home [SSSL 1.2: 176]:

- when a newborn child is sick or weak, he/she ought to be baptised immediately after birth.

The command to confer baptism also applies to the souls of the dead who did not receive the sacrament in their earthly life. In such situations, the conceptualiser assumes a position inside the scene and takes the role of the agent, acting under the circumstances of EXTERNAL COMPULSION exerted by a commonly accepted belief that the soul of an unbaptised child cannot cross the border between worlds and will wander around asking for baptism until the wish is granted. Traditional commands dictate not only the actions to be taken, but also the verbal formulas that must be pronounced in such situations [SSSL 1.2: 176]:

One should then take water and baptise the child, saying: "If you're a maid, your name's Kate, if you're a man, your name's John", or christen them Adam and Eve because it is not certain what sex the deceased was.

Należy wtedy wziąć wodę i to dziecko ochrzcić, mówiąc: Jeśliś panna - to ci Anna, jeśliś pán, to ci Ján, albo dać na imię Adam i Ewa, bo nie wiadomo, jakiego rodzaju (płci) był nieboszczyk.

While in the scenes described above the person performing baptism is the agent, it is the sacred, whose hidden presence is revealed through the life-giving and sanctifying power of water, which is the real author of the event. 
The annual ritual of the blessing of water, which is held in church on Easter Saturday, also re-enacts the scene of Christ's baptism in the Jordan. There are regional variations regarding this ceremony: in Warmia it is performed on Good Friday, in Kashubia on Pentecost, while in other regions it may also be celebrated during Epiphany (when chalk and water are blessed) or St Agatha's feast, including the blessing of bread, salt and water [SSSL 1.2: 169].

The importance of the event commemorated by the feast (Christ's death and resurrection, Epiphany, the descent of the Holy Spirit) further reinforces the power acquired by water blessed on that day (the INTENSIFICATION schema).

The blessing of waters ritual is also connected with belief in the presence of demonic forces in water which pose a threat not only to people but to the very life of the world. ${ }^{25}$ Hence periodical divine intervention is necessary to destroy evil and bring back water's life-giving and cleansing power (see Chapter 3.6 below). In this way, the annual celebrations of feasts commemorating the events of Christ's life on earth serve to restore the world to the state of original purity as at the time of the creation.

The feast of St John is commonly regarded as celebrating water's baptism, which deprives demons of their power, and thus makes the waters of lakes and rivers safe for human beings. Hence the injunction against bathing after the winter season until St John's day. The illocutionary force expressed by the modal verb nie wolno 'it is forbidden' is thus reinforced by a belief in the danger implicit in the breach of what is prohibited. In this situation, the religious context (the blessing of water) is transferred into magical discourse, operating with the language of commands and prohibitions in order to prescribe safe patterns of behaviour [SSSL 1.2: 169]:

- until St John baptises water in rivers, it is forbidden to bathe in them.

The date when bathing becomes safe may also coincide with feasts during which water is blessed, such as Pentecost or Corpus Christi, as conveyed in such proverbs as [SSSL 1.2: 169]:

- "Whitsunday, dive you may" (Święty Duch, w wodę/do wody buch);

- "On Corpus Christi leap into the water confidently" (Na Boże Ciało skacz do wody śmiało).

25 According to ancient beliefs, also found in Slavic folk culture, dragons (identified with the devil) were capable of ingesting enormous amounts of water, which could lead to a disastrous drought threatening life on earth [Tomicki 1978: 112-116]. 
Protective measures against evil spirits included blessing water by making the sign of the cross before bathing or drinking water in the open air. The commands to sanctify water deploy the INNER COMPULSION variant of the FORCE schema (through the causal power of a warning) and the REMOVAL OF RESTRAINT schema. The performative force of the warnings, prohibitions and permissions is reflected in the fact that they are observed, since taking precautions is in the interest of the addressee, as illustrated in the following examples [SSSL 1.2: 169]:

- before one gets into water, one should bless it with the sign of the cross to rid it of evil power;

- when one drinks water outside, one should bless it with the sign of the cross while it is still in the vessel, and then pour a bit onto the ground so that one does not swallow a devil with it.

Both the presence of evil spirits in water, and the danger to which a human is exposed in the event of contact with a demon, introduce an important opposition between pure and polluted (turbid, dirty), or sanctified and unsanctified water. Magical practices aimed at benefitting from water's life-giving powers in order to secure happiness, health, prosperity and fertility require the use of spring water, perceived as originally pure, undefiled (in folk tales it is "living water"). Ritual actions involve drinking, as well as dousing, sprinkling or immersing people or objects in water [Kowalski 2002: 96-97; SlavDrev 1995: 387].

The ritual drinking of water takes place at important points in an individual's life, especially at moments of initiation, when its transformative powers are called upon. "After the wedding ceremony the best man drinks a toast of water to the bride's good health, and she douses him with water" (po ślubie drużba przypija wode do panny młodej, żeby zdrowa byta, a ona chlusta woda na niego) [SSSL 1.2: 175]. The drinking of water is supposed to bestow water's power on the bride, whilst splashing the best man is to grant him prosperity. In love songs, the motif of a girl drinking water implies the loss of virginity (transformation into a woman), and in wooing scenes a youth persuades a girl to drink water "from under the maple tree" (spod jawora), which would mean consent to the sexual act. A youth who drinks clear spring water, in turn, wants to marry a pretty girl (śwarne dziewczę), or a good (grzeczna), pure girl [SSSL 1.2: 175]. The motif also recurs in folk tales, where partaking of "living water" restores youth, health and strength.

Magical practices also involve the ceremonial act of dousing people, animals and objects with water. In such cases, direct contact with water, under strictly prescribed circumstances, makes it possible to partake of its life-giving power, enhancing fertility, vitality, and, what follows, bringing about an abundant harvest, wealth and happiness. 
The ritual pouring of water over a plough before the first ploughing of the year is meant to increase the fecundity of the earth. The re-enactment of the archetypal act of the father sky fertilising mother earth by pouring copious rain over her actualises the ATTRACTING FORCE schema in order to summon the power of the original demiurgic act. Pouring water over the ploughman "so that he doesn't fall asleep at work" (zeby nie spat przy robocie), or the sower "to make sure the grain does not lack moisture" (aby ziarnu nie zabrakło wilgoci) [Niewiadomski 1999: 129; SSSL 1.2: 179] derives from the same mythical tradition. In turn, the action of pouring water over harvest workers and the harvest garland (wieniec dożynkowy), as well as the custom of boys pouring water over female harvesters and splashing the face of the woman carrying the harvest garland, are meant to confer blessing on the fruit of the earth and the work of human hands [Niewiadomski 1999: 126-132].

The agricultural scenario also included the custom of pouring water over farm animals and the cowherd, especially when the cattle were driven out to pasture for the first time after winter. The sanctifying power of water was meant to protect them from demons, while its life-giving properties were to ensure good growth, fertility and abundance, and to increase the amount of milk produced by cows. This is reflected in the performative force of commands and warnings [SSSL 1.2: 179]:

- the cowherd and cattle should have water poured over them on the first day of being sent to the pastures to protect them from evil forces;

- water should be poured over cows to make them produce a lot of milk;

- water should be poured over newly bought cattle or pigs, so that they keep well.

The aim of throwing or pouring water over people, animals and objects is to make use of both its fertilising and sanctifying power [Niewiadomski 1999: 128-129]. The connotations of the notion of fertility are expanded to include meanings associated with multiplying and abundance, thus creating a semantic node which links fertility with wealth, prosperity and happiness. In wedding rituals, this was the function played by the pouring of water over the newly-weds and wedding guests [Niewiadomski 1999: 130]. The manner in which ritual actions were performed was determined by traditional commands observed both by the newly-weds and their guests, in keeping with the model of OUTER COMPULSION (compliance with conventional behaviour). The force of such commands is expressed through the modal verbs należy 'one ought to', powinien 'one should', pertaining to the actions of the agent [SSSL 1.2: 178]: 
- the groom should give a glass of water to the bride, and she should sprinkle water into his eyes;

- the wife should splash her husband with water so that he is good to her;

- the bride and groom should splash a handful of water into the eyes of the person who is giving it to them;

- the best man should drink a toast of water to the bride, and she should splash his face with this water [SSSL 1.2: 175].

The dousing with water in farming and wedding rituals involves the conceptualiser in the scene. Like other participants, he/she is in the centre of events and complies with the traditional commands, thus conceiving the scene from the "own/familiar" (swój) point of view (participation in the ritual based on beliefs shared by the wedding guests).

Similarly, the custom of Easter dyngus (dousing people with water on Easter Monday) combines the life-giving/fertilising and protective functions. "Wet dyngus" was often accompanied by playful whipping with a bundle of bound birch twigs. The conjunction of the power of water and green twigs (called "the wands of life") is an example of the INTENSIFICATION OF FORCE. Sanctioned by tradition, the Easter pouring of water was to ensure prosperity and health, warding off diseases throughout the entire year. Tradition demanded that farm animals be doused with water, too: horses so they "do not sweat" (żeby sie nie pocity), and cows - so that "they milk well and they are not bothered by insects" (żeby się dobrze doity, żeby im robactwo i muchy nie dokuczały) [Niewiadomski 1999: 127; SSSL 1.2: 179-180]. The custom is reflected in the lexical system, as evidenced by its numerous dialect names created on the basis of the verb lac 'pour': oblej, lejek, lejos, lejus, oblewanka, polewaczki, leja, dzień świętego Lejal Lejka/Lela, as well as compound nouns with the word dyngus: śmigus-dyngus, mokry dyngus 'wet dyngus', dyngus smagany 'whipped dyngus' [SSSL 1.2: 179].

Ablutions and baths taken on special occasions were also held to have magic powers. In this case, too, the system of obligations and commands regulated the use of the miraculous, life-giving power of water, specifying both the time most conducive to magical practices and the manner of their performance.

Eastertide - as a holy time, endued with a miraculous power of regeneration - provides a perfect setting for magical practices imitating this model, thus allowing access to the power of the sacred, particularly strong and freely dispensed in this period. The ATTRACTION and INTENSIFICATION OF FORCE schemas are at work here.

The custom of immersing girls in troughs or barrels during Eastertide, now discontinued, was another example of a magical practice relying on the 
enhanced powers of water. In the Lublin region, the ritual seating of unmarried girls in a trough (krypa) near a well, "so that a girl may get well soaked in water, she is seated with her bottom in cold water like a hen" (aby się wychlastata panna - tyłkiem się sadzo w zimna woda jak kwoke) [SSSL 1.2: 182], also draws on fertility magic.

Immersion practices also include boiling and scalding, with the temperature acting as a factor reinforcing the healing power of water. Upon immersion, the synergy of FORCES was believed to cause an instantaneous transformation, which was called on in curative practices: e.g. immersing a sick child in hot water was supposed to restore it to health [SSSL 1.2: 183]. The motif of immersing/ boiling in water, leading to a miraculous metamorphosis, often appears in folk tales and stories where e.g. Jesus heals a princess, the devil rejuvenates a man, a princess turned into a frog recovers her human shape, or a young man becomes uncommonly handsome after a bath in scalding water. Boiling water can also kill the devil [SSSL 1.2: 232]:

(1) Then the Lord Jesus and St Peter together took the princess and put her into the cauldron, into boiling water. And so the princess boiled in the cauldron. [Afterwards Jesus ordered the bones to be taken out], (...) covered the bones up and they both prayed with St Peter (...). And the princess rises, healthy.

(2) The frog says: my dear (...) boil the water in this [cauldron] (...); the water boiled, (...) take me and put me into the water [then the frog turns into a beautiful maiden].

(3) The lord (...) had water boiled and put him [the cobbler's son] into the bath (...). When he had bathed in the water, he became a very beautiful young master.

(4) [The devil hid in a groat cutter (stępa)]; (...) [the servant] brought water to the boil and she poured it into the groat cutter. And he began to wail terribly - this devil in the groat cutter. And he boiled in this water and he was well cooked (...); [the man and woman of the house looked in] and he - this devil - was already dead (...). She simply killed him (...).

(1) Tak te królewnę Panjezus wziąn ze świętym Piotrem i wsadzili ja do tego kotła, do ty gorący wody. I gotowała się ta królewna w tym kotle [Kazał Pan Jezus wyjął kości z kotła] (...) przykrył te kości i modlili się oba ze świętym Pietrem (...). I królewna wstaje już zdrowa.

(2) Ta żaba powiéda: mój kochany (...) zawrej tę wodę w nim [kociołku] (...); woda zawrała (...) weź mnie, włóż mnie w te wodę [wtedy zmieniła się w piękną pannę].

(3) Pan (...) dał wodę zagotować, i do kąpiele go [syna szewca] dał (...). Jak się w téj wodzie wykąpał, bardzo był piękny Panic ś niego.

(4) [Diabeł schował się w stępie]; (...) [służąca] zagotowała kipioncy wody ji nalała tam $\mathrm{w}$ te stempe. I un zaczoł strasznie piszczyć - ten diabeł w tyj stempie. Gotował się w tyj wodzie. No ji zgotował się (...); [gospodarze zaglądają] a ten - diabeł - już nie żyje (...). No straciła go (...). 
The custom of ritual baths - to be undertaken during the transition period between winter and spring in order to ensure health, prosperity and good looks throughout the whole forthcoming year - derives from the combined belief in water's life-giving and cleansing power. Traditional recommendations indicated the most propitious circumstances for this, such as the feast, the time of day, and other factors conducive to the efficacy of sympathetic magic. Christmas, the Holy Week, Easter, the Feasts of the Holy Trinity and of St John were considered to be particularly favourable, especially if the water used for the bath (or ablution) was drawn before sunrise [SSSL 1.2: 177]:

- to secure health and prosperity for oneself throughout the year, one should bathe in running water (a river or a stream) on Christmas Eve;

- to reinforce the power of water drawn from the well on Christmas Eve, one should add silver or gold coins, or iron objects, to be "as clean as a coin, like a coin healthy, rich throughout the year" (czystymi jak pieniadz, być jak ten pieniadz zdrowy, być bogatym przez caly rok);

- on Palm Sunday young people should wash before sunrise to be beautiful;

- on Maundy Thursday or Good Friday one should wash with water drawn before sunrise, or wash in running water, to secure health, and young girls should do this to secure beauty. Water must be drawn in silence so that it guards from diseases of the skin and eyes;

- on Good Friday all farm animals should be washed so that they breed well and cattle do not go lame; also weighted covers on sauerkraut should be washed so that it does not go off during the period of scarcity in early spring (przednówek);

- on Easter Saturday all household members should wash themselves before sunrise to secure health, as evidenced by the proverb "Who does not wash himself on Holy Saturday, will not live long" (Chto w Wielga Sobote sę nie (u)mëje, ten długo nie pożëje);

- to prevent the appearance of lichen or ulcers on the face, one should wash in the water left after the boiling of blessed eggs;

- to enhance beauty one should wash before sunrise on the feast of the Holy Trinity;

- on the feast of St John one should wash before sunrise to prevent ulcers, scabies and other skin diseases;

- whoever sees the first swallow in spring should immediately wash their face in cold water to prevent freckles, to be "as lively and cheerful as these birds" (rzeźwy $i$ wesoly jak te ptaki), or should wipe water into their eyes to prevent them from hurting. 
As follows from the customs listed above, water acquires its purifying and life-giving properties on strictly determined occasions: during the most important Christian feasts, which suggests that it draws its power from the same source, namely, the sacred. Periods when running waters become dangerous indicate that they are also governed by demonic forces. Hence the command to draw water before sunrise to eradicate germs and diseases before they are animated by sunbeams. It is also fear of evil forces inhabiting running waters that dictates the command to remain silent while drawing water from such sources. This is in marked contrast to spring water, which is seen as untouched, pure and sacred. As such, it is free from any demonic influence and does not have ambivalent properties.

The motif of a healing bath which appears in various genres of folk texts and in illocutionary communicative acts can be regarded as a stereotype, all the more so that it confirms the transformative powers of water known from other practices and myths.

A ritual sprinkling also enables access to water's life-giving powers. In myth, God blessed the earth after the creation by sprinkling, and thereby sanctifying it, with water. A re-enactment of God's gestures is always a solemn occasion performed at important moments in life. Such a repetition of the gesture of blessing is based on the FORCE schema, and is meant to ATTRACT God's power and grace [Niewiadomski 1999: 126-129].

In wedding scenes, sprinkling with water had a double function: to bring happiness and prosperity for the bride, groom and wedding guests and to protect them from evil forces, particularly active during all rites of passage. For this reason, the protective power of water was augmented by throwing salt on the road that the wedding procession was to take from the house to the church, as well as providing the bride and groom with a piece of blessed bread and a pinch of salt, which they placed directly on their breast (on the naked flesh) [Łeńska-Bąk 2002: 110]. The actual scenario of events varied from region to region according to local beliefs determining particular attitudes and patterns of behaviour [SSSL 1.2: 180]:

(1) the bride, groom and wedding guests were sprinkled with water on departure for the church in order to ensure fertility for the couple and prosperity for all; they were showered with salt and grain for the same purpose (ŁeńskaBąk 2002: 111);

(2) the newly-weds were sprinkled with cold water after the wedding ceremony;

(3) the sprinkling of the newly-weds was repeated three times to banish, and protect from, evil spirits. "Before the departure for the church, the mother 
comes out with bread and salt, she puts the bread in front of the horses, sprinkles the bride and groom with salt to protect them from evil charm; the father sprinkles them with holy water for the same purpose" [Biegeleisen 1929b: 157 in Łeńska-Bąk 2002: 110];

(4) the bride and groom were sprinkled with water as they were walking on white cloth which "they spread from the threshold nearly to the gate; they took a plate full of water, a palm or a sprinkling brush and sprinkled everybody with water" (ścielili ód proga prawie dó bramy, brali w talerz wody i brali palme albo kropidło $i$ wszystkich tych tam kropili);

(5) the smith sprinkled the wedding guests, which was meant to bring prosperity;

(6) the bride sprinkled the household and its members, the farm buildings and wedding guests.

While all the scenarios share the same ritual action, its purpose and manner relies on a different use of the FORCE schema.

Examples (1) and (2) directly re-enact the divine gesture, whose power is meant to bring grace upon all the participants in the event according to the SOURCE-PATH-GOAL schema.

Example (3) additionally introduces the numerical concept and an element of apotropaic magic, i.e. salt, thus INTENSIFYING the FORCE. A triple repetition of an action in magical practices ensures their efficacy, connected with the symbolism of the number three [Niebrzegowska 2007: 340] and has the markings of a stereotype. Similarly, salt, which, like water, symbolises life, both enhances the procreative powers and protects from bewitchment and evil spirits [Łeńska-Bąk 2002: 116].

Example (4) has a complex structure. The gesture of blessing focuses on the bride and groom walking down a white linen cloth symbolising the path of life (cf. Chapter 8.3 below). Thus the power of the blessing is experienced not only on this single occasion, but is meant to accompany the newly-weds throughout their life.

Example (5) also involves INTENSIFICATION OF FORCE, but relies on different principles. The smith, whose job requires great physical strength, assumes the role of the sacred at the moment of sprinkling the wedding guests with water. This is, again, a case of sympathetic magic in which the power of water, increased through the re-enactment of the divine gesture and the smith's physical strength, is bestowed upon the wedding guests.

In example (6), the divine gesture of blessing is repeated by the bride, who takes charge of a new household. Sprinkling water over the house, its inhabitants and the whole farm re-enacts the scene of blessing the earth after the creation, 
thus conferring God's grace upon them, while the bride herself assumes her role of the mistress of the house. Unlike the other scenarios in which the bride was the object of the actions, in this scene she performs the function of the agent acting in God's name. Consequently, the model of the ATTRACTION of divine power applies in this case.

The natural desire to receive the gift of wealth, prosperity and happiness means that compliance with the requirements of the ritual is motivated by INNER COMPULSION. The sprinkling of water over the newly-weds and wedding guests before their departure for the church cleanses them and wards off evil spirits, bringing God's blessing upon all the participants in the scene. Thus involvement in the act of initiation ushers them all into a new reality, which they enter in a state of grace thanks to the cleansing and life-giving power of water.

\subsubsection{Practices making use of the cleansing power of water}

Since the Creator singled out the element of water, imbuing it with His power and making it responsible for maintaining life on earth, water serves to cleanse and sanctify the world. The archetypal act of cleansing the earth from sin is the biblical Deluge, recurring cyclically wherever divine law is broken and iniquity comes to rule [Léon-Dufour 1995: 645-646]. Similarly, baptism cleanses man of original sin. At all stages of life, from the cradle to the grave, humans undergo purifying ablutions, with the profile of the action being different in each case.

The first ritual bath given a newborn was meant to free the baby from the remaining traces of its otherworldly origin: a different order prevailing in the world of the spirits. The newborn, seen as coming from the other world, brought potential danger of the intervention of evil forces, which could intrude into the domain of the home at the time of the infant's birth, threatening particularly the baby and the mother. This is why the ritual first bathing of the child had a protective function and was performed by the midwife: baba/babka 'old woman/ grandmother' [SGP 1981: 204], known in Kashubia as 3ecynna baba, dobrå baba 'good old woman', and in Kociewie as dobra pani 'good lady' [Treder 1989: 160]. It is thus the good midwife, traditionally required to be unrelated to the family, who plays the archetypal role of the agent in the scene introducing the newborn into the world. Given the fact that baba/babka means both the oldest woman in the family and a witch/healer (znachorka) [SGP 1981: 204], her role as a mediator between the real and the supernatural worlds seems highly apposite. A midwife combines two ambivalent values: "own/familiar" (swój) and "strange/alien" $(o b c y)$. On the one hand, she represents a grandmother (babka), an ancestor connecting the generations of the family, while on the other she is a stranger, adept 
at magic and versed in secret knowledge [Masłowska 2007a: 99]. The scenario of the first bath is governed by a set of rules whose force is expressed by means of the modal verbs należy/trzeba 'ought to/should':

- only untreated, i.e. not boiled, water may be used to bathe a newborn child [Kowalski 1998: 614];

- water should first be blessed with the sign of the cross to cleanse it of evil powers before it is used to bathe a child [SSSL 1.2: 176];

- holy water should be added to the first bath;

- herbs blessed on the Octave of Corpus Christi or on the Feast of the Assumption (Matka Boska Zielna 'Our Lady of the Herbs') should be added to the bath;

- salt ought to be added to the newborn's bath so that "the baby is not charmed" (nie było oczarowane) [Łeńska-Bąk 2002: 94];

- coins should be added to the bath "so that the child is always in the money" (aby [pieniadze] się dziecka trzymaty);

- camomile, soap or an egg should be added to bathwater (the egg should then be eaten by the father);

- milk should be added to the bath "so that the child has a clear complexion" (żeby dzieci miały ładna cerę);

- a few ears of rye should be added to a girl's bath so that her hair grows beautiful and thick, as well as honey, mint and great burnet so that she is lovely and smells sweet.

The first time a newborn was bathed was thus a rite of passage from otherworldly order to the order of the human community and as such was regulated by strict rules. Since it involved initiation, the ritual demanded the use of appropriate props to evoke the time of origins. Untreated, untouched water, similar to the materia prima, functioned as a medium between the physical and the metaphysical worlds [Kowalski 1998: 614]. Furthermore, cleansing the child in this way of all the traces of its otherworldly existence had a protective and transformative function. The addition of salt, as a factor of change, facilitating a safe transition from the world of nature to culture [Łeńska-Bąk 2002: 95] ${ }^{26}$ also played a purifying and initiating role. Other ingredients added to the bath (eggs, soap, honey, ears of rye, camomile and other sweet-smelling herbs) and

26 As children were believed to be particularly prone to attacks from demons until they reached puberty, salt was sewn into their garments to make sure they survived (aby się dochowało) [Łeńska-Bąk 2002: 96]. 
the manner of its performance strengthened the power of the ritual through the use of sympathetic magic. The application of sacramentals, in turn, coupled with blessing the water with the sign of the cross, turned the bath into a religious rite, including the participants - the midwife and the baby - in the sphere of the sacred. In this way, the scene combines three interdependent models of the FORCE schema: COUNTERACTION (the purifying power of water and salt), INTENSIFICATION (the use of sacramentals) and ATTRACTION (sympathetic magic).

In addition, the strength of the illocutionary and perlocutionary force of rules specifying the type of water to be (or not to be) used should be taken into account. Their impact depends on whether the command is formulated as a threat, warning or advice [SSSL 1.2: 176]:

- the child should be bathed in cold water drawn from a well to ensure popularity with girls in the case of boys, and with boys in the case of girls;

- water from a well must not be used so that the child does not have sweaty feet in later life (boby potem dziecku ciekła noga);

- the child should be bathed in warm, but not boiled water, to ensure people do not treat it badly (warlić się 'boil with anger at someone');

- rainwater must not be used for the first bath, "because the child will swallow all kinds of disease" (bo choroby wszelkie będzie w siebie wciagało);

- a child not washed after delivery "will have bad breath all their life" (będzie [mu] cuchnąć z gęby przez całe życie).

Adherence to the prescribed rules of behaviour was motivated by INNER COMPULSION dictated by concern for the child's good and belief in their validity. The ambivalent instructions with respect to the role of raw water suggest that traditional customs requiring the use of objects associated with otherworldly reality have lost currency. This does not mean that the borders between the natural and supernatural worlds have become blurred; however, it seems that the idea of evoking the time of origins has lost its original meaning.

The place where the water used to wash the newborn was poured out was also of prime importance in magical practices, since the spot chosen was believed to influence the behaviour and future character of the child. As water was supposed to have both beneficial and destructive properties, the ability to deal with it appropriately determined whether its power would benefit the person, or turn against him/her. The choice of place to pour out the water used in this first bath was specified by a system of recommendations, warnings and prohibitions stemming from a concern for the safety of the child and the household. Water that ensured the prosperity of the house (e.g. water blessed by a ritual) was supposed 
to be kept within the bounds of the farm (within "own" (swój) space). By contrast, water used as protection against demons, evil charms, or for washing a sick person had to be disposed of by being poured away as far from the house as possible [SSSL 1.2: 166-167]:

- in order to banish evil charms, bathwater used to wash a newborn should/ ought to (trzeba/należy) be poured away where three fences converge;

- or under the fence of another post-partum mother;

- if the baby is a girl, water from her first bath should be poured out under the fence, i.e. in a place where other people do not tread, otherwise she would be untidy;

- bathwater should be poured out onto the road, so that the child is lucky;

- until baptism, bathwater should be poured out in isolated places;

- bathwater should be poured onto the hands of the baby's father;

- bathwater should be poured out onto animals or under their trough so that the baby is quiet until baptism;

- water used to bathe a girl should be poured out in the cowshed while that used for a boy - in the stable, but in places where the animals do not tread so that the child does not cry;

- water should be poured out onto grass so that the baby does not cry; under an apple tree bearing sweet fruit so that the baby has a sweet life; after baptism it should be poured out onto grass so that it grows well;

- water must not be poured out onto the dung heap "because children will be brats" (bo dzieci będą gnojki; gnojek lit. 'one like dung').

Pouring water out within the bounds of the farmyard: in the garden, under the fence, in the cowshed, is consistent with rules forbidding the disposal of "own" water lest this causes loss of happiness and prosperity of the house (similarly to the prohibition against taking fire or rubbish out of the house). The FORCE schema, underlying a belief in the cleansing power of water, is combined with the CENTRE schema, thus creating one's own, safe space. The atmosphere of safety is also created by the obligation to pour out the water used to wash a newborn onto the hands of the father.

In turn, the choice of a secluded place, where no one goes (under the fence, under a trough in a stable or barn, in the garden), is a mark of protective behaviour, aimed at warding off evil forces which the conceptualiser deems particularly dangerous to the unbaptised child. It is also an example of sympathetic magic since the tranquillity of the place is supposedly passed onto the baby, ensuring that it does not stir evil spirits with its cries. Tradition also dictated such protective practices as the custom of keeping a burning candle by the baby's 
bed until baptism, or placing a bowl of water next to it to allow the fire to purify itself in it to preserve its power. In such cases, the power of fire and water to purge or cleanse was cumulative, in keeping with the INTENSIFICATION OF FORCE schema.

The belief in the magical character of the place where water from the first bath was poured out and its influence on the future fate of the child is also evidenced in traditional precepts advising the choice of an apple tree bearing sweet fruit, or the road. Given that both the tree (of life) and the road are powerful ancient symbols of fate, such a choice seems hardly accidental.

Marriage is the next turning point in life that is accompanied by practices invoking the mediating and purifying properties of water. The wedding ritual includes a number of scenes which indicate a belief in the life-giving and cleansing power of water, protecting the newly-weds from evil forces that could jeopardise the sanctity of their union. Apart from sprinkling, dousing and washing with water, the rite of passage involves the custom of pouring water in the newly-weds' room after their return from the church or after oczepiny (the ritual taking off of the maiden garland and replacing it with the wife's bonnet). Depending on the region, the scenario was performed according to local traditions specifying the assignment of roles, the time and manner of magical actions [SSSL 1.2: 166]:

- the choraży (master of ceremonies) pours water around the room to ensure prosperity for the wedding guests and newly-weds and to welcome them into a new reality (see the command to pour out water within "own" space);

- the newly-weds are to pour water behind them over their heads after returning from the church;

- at the beginning of the wedding reception, the best man should spill out water, breaking the vessel in which it has been brought, after which the wedding guests should cry "He has spilled the black soup!" (Rozlat czerninę! (traditionally, black soup was served to an unwanted suitor and meant rejection)).

When water is spilled by the wedding guests (the best man, master of ceremonies), the magical practice is intended to bring water that ensures happiness into the house, hence the rules forbidding the pouring of it outside the boundaries of "own" space. In turn, the gesture with which the newly-weds pour water behind their backs signifies that they have passed from a pre-marital into the marital state. In this instance, the ATTRACTION OF FORCE schema is used, as the supernatural power of water is summoned to act as a medium that enables the transformation of the youth and maid into husband and wife. 
By contrast, a ritual bath of the newly-weds and wedding guests called taplanie 'splashing around' that took place on the second day of the wedding, after the bedding ceremony, played a cleansing and apotropaic function [SSSL 1.2: 176].

The last rite of passage which involves cleansing ablutions is connected with the moment of death. Whereas the first bath of a newborn child is meant to wash off the traces of its otherworldly provenance, washing the body of the dead cleanses him/her of the attachment to earthly life. Since death, like birth, opens earthly reality up to contact with the supernatural world, exposing the participants in the ritual to the dangerous activity of evil forces, the power of water is called on to wash away sins and protect the dead from the threat of demons lying in wait for their souls. A belief that the soul of the dead, too, must wash in water to ensure a peaceful afterlife is accompanied by conventional commands and prohibitions concerning the use of water in funeral rites [SSSL 1.2: 177]:

- on the day before the funeral, a bowl of water and a towel should be placed by the dead body;

- the dead body should be washed in water boiled with herbs blessed on the Feast of the Assumption (Matka Boska Zielna 'Our Lady of the Herbs');

- after washing the body, it should be dressed in "death garments" (śmiertelne szaty, garments to clothe the deceased);

- to cleanse the way before the funeral procession, after the body has been taken out of the house, one should dip one's hand in water and sprinkle the mourners with drops of water three times.

Water used to wash a dead body belongs to the sphere of death; hence the disposal of "dead man's water" (trupia woda) is governed by a strictly observed canon of commands, prohibitions and warnings. Since it represents a COUNTERFORCE to life, it should be removed from the "own" space as fast as possible [SSSL 1.2: 166-167]:

- after washing a dead body, the water should be poured out in the most inaccessible places: where no one goes, neither people nor animals, and where nothing grows;

- after washing the body of a dead child, the water should be poured away behind the people carrying the coffin for the funeral;

- after washing a dead body, the water should be poured out onto the wheels of the cart carrying the coffin [Sychta 1972: 83];

- one should make sure that one does not pour the water used to wash a dead body onto one's shadow because it will bring misfortune; 
- on returning from the funeral, one should wash one's face to cleanse oneself of evil forces;

- one must not use the water that was in the house while the dead person was still in it (because the soul of the dead has washed in it).

In the ritual cleansing of the dead body, water's purifying function served primarily to wash off all traces of life and thus prepare the dead for their passage to "otherworlds" (zaświaty). After washing the dead body, the water was regarded as contaminated by death. Consequently, it had to be removed from the domain of "own" space immediately, as it acquired particularly strong destructive properties. It could also be used for magical purposes. Water also protected the body from evil spirits, hence the addition of blessed herbs to strengthen its power. The habit of cleansing the road taken by a funeral procession also protected both the dead and the mourners from evil forces which were believed to be particularly active at all moments of passage, when otherworldly reality intrudes into the earthly one. As an additional precaution, salt was sprinkled on the road in order to ward off demons [Łeńska-Bąk 2002: 120].

Only those taking part in the wedding ritual are able to act motivated by INNER COMPULSION, willingly choosing to comply with social norms. By contrast, in scenes of arrival in, and departure from, this world, the protagonist (the newborn/the dead) is drawn into the scene and subjected to customary procedures, with the person administering the rites playing the role of the agent. Thus the protagonist becomes the object, and the FORCE at play is motivated by OUTER COMPULSION. In all the cases water is the tool of the sacred, which is present in the background of the scene.

\subsubsection{Magical practices making use of the destructive power of water}

Magical practices which make use of the destructive power of water invite the world of death into the scenario. When water that has been used to wash a dead body is thrown onto a house it brings death upon its inhabitants, and pouring it over animals causes disease. The destructive power of such water may also be used for protective purposes: dousing sheep will ward off disease, and watering the wheat field will guard it against sparrows, which might peck out the grain [SSSL 1.2: 180].

The ambivalent function of "dead man's water" suggests that it is the purpose - i.e. the words pronounced with a good or bad intention - that determines the consequences of its use. It may be surmised that magical actions were accompanied by performative speech acts, capable of either causing illness or death, or effectively protecting against them. Water as such often assumes opposite 
axiological values depending on the intention and consequences of its actions, in keeping with the SCALE schema, which ascribes an axiological charge to the PART-WHOLE schema. Prototypically, destruction (the PART schema) is ascribed a negative value, as is the case with harmful magical practices. On the other hand, preventive actions, summoning the supernatural destructive FORCE (which water acquires through direct contact with a dead body) in order to protect health and life, are positively charged, since they serve to preserve integrity (the WHOLE schema) and life.

Magical practices aiming at destruction are performed according to strictly prescribed rules and are often accompanied by verbal formulas known to the initiated. A magical procedure carried out by a female healer (znachorka) - a mediator between the earthly and supernatural worlds - to deprive a woman of her fertility is a case in point [SSSL 1.2: 178]:

- to make it impossible for a woman to have more children, the spellcaster "the knowing one" (znająca) - must wash her feet, uttering a magical formula, and pour the water out onto the foundations of the house.

In this scene, the agent - "the knowing one" (znajaca) - gains access to the destructive power of water by means of the spell formula (zamówienie) she utters while pouring out water after washing the woman's feet. Hence the agent's actions should be analysed in terms of the INTENSIFICATION OF FORCE schema. The scenario involves the introduction of a stranger, who assumes the role of the agent, while the woman undergoing the magical procedure to remove fertility becomes the object. Water, which seemingly plays the role of the instrument, is in fact the driving force of the scene. The fact that dirty water is poured out onto the foundations of the house is of great significance as it is the place of contact with mother-earth, and thus with fertility. When dirty water used to wash the woman's feet is poured out onto the foundations, such contact is broken, implementing the BLOCKAGE schema. Hence the scene is built on the basis of destructive schemas: the broken LINK and the BLOCKAGE of life-giving powers, which entails a negative axiological charge.

The use of the destructive properties of water in order to regain lost love involves a different scenario. Given that love is connected with life, the destructive action acquires a positive value [SSSL 1.2: 178]:

- to regain someone's love, a girl must wash in the water "that falls backwards from a waterwheel” (co wspak splywa z koła mlyńskiego).

The annihilating power of water obliterates the fact of rejection by the beloved and creates a new reality according to the girl's wish. In this case, the COUNTERFORCE 
schema is activated, as the power of water is able to turn back time. Secret knowledge is conveyed in the form of advice, with the illocutionary force of imperative (the use of the modal verb musieć 'must', the most explicit verbal correlative of the FORCE schema). This entails behaviour motivated by INNER COMPULSION as it is in the girl's interests to comply with traditional customs.

Water's destructive powers may also be employed in protective practices, in which ablutions serve to avert evil charms or prevent disease [SSSL 1.2: 178]:

- to ward off an evil spell (urok) coming from evil eyes, one ought to wash all the locks in the house and then use the water to wash one's head;

- to protect a child from consumption, the mother must wash her hands after cleaning the house.

Water has a different function here than in ritual drenching to ensure prosperity since the scenario allows for the intervention of forces from the alien world. In the case of washing people and objects to ward off evil charms, protective actions focus on two centres of "own" space: the home (washing the locks) and the head of the agent. Protecting the human body and the home from the evil eye relies on a complex combination of preconceptual schemas: CENTRE, LINK and COUNTERFORCE (water's neutralising power). Practices offering protection from tuberculosis also fall into that category.

Water's destructive properties can be ambivalent, since they may coexist with the cleansing function, usually when water is used for healing or protective purposes (to eradicate disease or deprive demons of their power).

Healing practices involving ablutions designed to destroy illness also include detailed instructions concerning the disposal of water contaminated by disease. In contrast to the command to pour out "beneficial" water within "own" (swój) space: in the house or the farmyard, "sick" water (like "dead man's water") should be disposed of as far as possible from the house, in "alien" (obcy) space [SSSL 1.2: 166-167]:

- after bathing a sick child, the bathwater should be poured out on the road, in front of travellers so that they take away the sickness;

- after bathing a sick child, the bathwater should be poured onto someone else's dogs so that they "take the sickness away from home" ([ażeby] choróbstwo $z$ domu wyniosty);

- when a child falls ill with consumption, water should be poured onto a dung pile;

- bathwater should be poured out on the crossroads before sunrise so that "the dawn should take away tears from the child" ([aby] zorze zabraty od dziecka placznice); 
- after bathing a sick child, the bathwater should be poured out into a river/ stream so that the water takes the sickness away;

- after bathing a child, the bathwater should be poured out where three fences come together so that evil charms go away.

"Alien" (obcy) space, where the contaminated water should be poured away (thereby taking evil charms or sickness with it), is delineated by means of symbolic borders: forks in the road, places where three fences come together, rivers or streams. Given the fact that these are "interspheric" places inhabited by evil spirits, disease is effectively sent into their abodes in order to annihilate them. In this case water plays a mediatory role, transferring illness from a child (a sick person) to an alien space ruled by demonic forces. Such customs bear a similarity to magical practices designed to drive away disease from the human body into an alien space, peripheral places located far away ("where the road forks", "beyond the seventh mountain", "beyond the seventh river" (na rozstajne drogi, za siódma górę, za siódma rzekę)), deep below ("a hundred ells underground" ( $n$ a sto tokci $w$ ziemię)), high above ("up to the sun", "up to the clouds" (pod słońce, pod obłoki)), or places that are empty ("onto dry roots, rocks", "where a horse cannot leap" (na suche korzenie, kamienie, gdzie kon nie doskoczy)), wet ("to the sea" (do morza)), dead ("where no living creature can survive" (gdzie nie postoi zadne żywe stworzenie)) or silent ("beyond the cock's crow and the dog's bark" (gdzie kogut nie dopieje, pies nie doszczeka)) [Niebrzegowska-Bartmińska 2007: 169, 181-183].

\subsection{Water symbolism}

As the materia prima, which is the origin of all forms of life, water is the basis of existential representations of man's place in the cosmos, the manner of existence in earthly and otherworldly reality, the relation with the sacred, the beginning and end of the world [MifyNM 1987: 240; SlavDrev 1995: 386].

Experience prompts the image of water as a driving force of life. The concept of water's creative energy relies on the FORCE schema combined with other schemas: the PART-WHOLE schema serves to represent the possibility of disintegration and appearance of new forms after emergence from water, while the CONTROL schema structures images of action aiming to achieve a certain goal.

The creation myth in which the cosmos emerges from the primal ocean by the power of God's word, while water acquires life-giving properties, becomes the basis for symbolic presentations of water as the origin of all processes of becoming. Owing to the bipolarity of symbol, every act of "becoming" is presented 
as a link in the chain of being, of birth and death, in all its complexity. In this way, complex symbolic images come to illustrate eternal being, based on the cyclic rhythm of death and rebirth. ${ }^{27}$ The multi-layered meaning of the symbol is revealed in the way it functions in acts of communication. Ritual contexts provide the basis for the development of connotations stemming from religious beliefs and magical practices, including symbolically represented concepts in the web of semantic links with other elements of the lexical system.

The symbolic imagination presents the rich semantic content associated with water through a series of images and scenes whose meaning is profiled according to the circumstances in which the creative power of water is revealed, its purpose, and the manner in which it is summoned. In folk culture, such imaging is grounded in two basic types of conceptualisation: the functional (concerning the uses of water) and the partitive profiles (water perceived from the ontological point of view as a part of the structure of the world, either as a particular source: a river, lake, spring, sea, or as a constitutive element of the cosmos, besides earth, the sun and the moon) [Majer-Baranowska 1993: 277-291]. In such cases, the imagery of water's creative potential relies on a specific FORCE model, accompanied by other relevant preconceptual image schemas.

Preserved in folk legends, the mythical picture of the earth as a flat round patch floating upon the waters provides the archetype for the symbolism associated with the mythical origins of the world [SSSL 1.2:390]:

The earth floats upon the sea like a pancake, a thin circle, a hemisphere, a giant island, but in comparison to the sea it is as small as a clump of grass. This is how people know that the earth floats upon the sea's waters: wherever you dig a well, everywhere you will find water, and there are bottomless sea holes on the earth.

Po morzach pływa ziemia jako placek, cienki krąg, półkula, wielka wyspa, ale w porównaniu z morzem jest taka malutka, jak kępka trawy. Że ziemia pływa po wodach morskich, stąd ludzie wiedzą: bo gdzie bądź wybić studnię, wszędy woda się najdzie, ponadto na ziemi są morskie oka bezdenne.

27 While a symbol typically unites opposite meanings, this feature seems particularly consistent with Thomas and Znaniecki's concept of dualism in the folk worldview. Such dualism, according to Thomas and Znaniecki, acknowledges the existence of two opposing orders, and involves loyalty both to life and to death and decay [Thomas, Znaniecki 1918]. Ryszard Tomicki also posits a dualist conception of the world created and ruled by two demiurges: God and Satan. On the other hand, Mircea Eliade discusses this question in terms of the cosmic cycle of life, death and rebirth. 
The waters of the primeval ocean provide the image of the beginning of the world, based on a partitive profile, in which they form a constitutive part of the universe: the primal matter filling the cosmos, made and ruled by the Creator (the agent).

Symbolism connected with the origins is apparent in ritual scenes of religious celebrations, especially Christmas ones, which place a particular emphasis on the role of water and its power to restore sanctity to the world. Both the celebration of the feast itself and the customs accompanying preparations for it enable the experience of the sacred.

Traditional visits by carol singers and mummers (kolędowanie), involving a re-enactment of the scene of the Nativity in popular texts, consolidate the motif of water's active participation in the wondrous event. The image of a river, lake, or sea, which willingly offered its waters to wash the baby Jesus, becomes the cultural model for the washing of a newborn child. By analogy with God made man, the ceremony of the first bath turns the newcomer from "otherworlds" (zaświaty) into an earthly being.

Practices connected with Christmas celebrations such as cleansing the house, the farm buildings and all belongings with spring water [SSSL 1.2: 294], or the ritual bath of all members of the household, are meant to ensure a re-integration with the sacred. As such, they illustrate the symbolic passage from real time to the mythical time of origins, when God sent his Son to earth.

The motif of the Virgin Mary bathing herself and her Son in spring water recurs in Christmas carols [SSSL 1.2: 290], suggesting that the image of a spring as a symbol of sacred origins is deeply ingrained in folk culture. A popular folk carol featuring the primeval mythical symbols of both a spring and a green lime tree (which functions as the tree of life and the axis of the cosmos) may more clearly illustrate the point. The location of the spring and the lime tree at the scene of Christ's birth creates a symbolic image of the centre of the world, where the work of redemption begins [Niebrzegowska-Bartmińska, 2007: 203]:

Z tamtej strony jeziora stoi lipka zielona, hej, hej kolęda, lipeńka zielona.

A tam pod tą lipeńką wodeńka zdrojowa, hej, hej kolęda, wodeńka zdrojowa.

I w tej tam wodeńce Maryja się myła, hej, hej kolęda, Maryja się myła. A jak się umyła, Syna porodziła, hej, hej kolęda, Syna porodziła.
Beyond the lake, a lime tree green, let's sing a carol, a lime tree green. And under the lime tree a water spring, let's sing a carol, a water spring. And Mary bathed in the water there, let's sing a carol, bathed in the water there. And having bathed, her Son she did bear, let's sing a carol, her Son she did bear. 
In this carol, the symbolic image of origins is formed on the basis of both profiles: partitive (water as part of the cosmos as well as a particular water source) and functional (bath, ritual cleansing, ablutions). The symbolic image of origins is thus associated with such notions as the creation, the world, mother, child, birth, sanctity and blessing.

Both the image of water springing from the centre of the earth and the act of Mary bathing in it, which precedes the Nativity, suggest natural associations with the mother's womb, where life begins, thus evoking fertility symbolism. Since the fertility aspect is foregrounded, all other properties of water that are not consistent with the scheme of creating new life need to be suppressed. As a result, without losing its multi-layered nature, the symbol acquires an unequivocally positive value.

The wedding custom which usually follows oczepiny (the taking off of the maiden garland from the bride's head and replacing it with the bonnet worn by wives) is perhaps the most vivid example of the activation of symbolic content in ritual behaviour. The bride is seated on the groom's lap while water is poured under their stool [SSSL 1.2: 166].

Less obvious are numerous magical practices such as pouring water over, or bathing, the newly-weds during the wedding celebrations. Apart from fertility magic, such customs involve multi-layered meanings, which develop by analogy into a chain of associations. The very concept of fertility, in the communicative context of wishing someone well, paves the way for the establishment of cognitive paths between the concept of vitality connected with water and such notions as wealth, prosperity, abundance and good harvest. Since wellwishing presupposes mutuality, its power comes to include the wedding guests, thus allowing yet other possibilities of making new symbolic connections and associations of the water image. As wish-making is highly conventionalised, and all the participants in discourse are perfectly familiar with the context, communication is limited to symbolic gestures of a performative nature (sprinkling with salt or grain, pouring with water). Customs involving the use of words appear later on during the wedding feast, and take the form of short dialogic songs exchanged by the wedding guests [Łeńska-Bąk 2002: 111].

The custom requiring the bride to bring water home also derives from fertility magic and is to ensure prosperity for the household [SSSL 1.2: 165]. Bringing water home meant that the bride took on the role of a future mother and provider of food for the family (the bride poured water into a kneading trough). The symbolic meaning of this scene evokes the mythical model of mother-earth, thus including the archetypal image of life-giving water (prototypically a spring) in a 
chain of symbolic associations that links the womb, earth, mother, home, bread, happiness and prosperity.

Spring customs involving the pouring of water on girls or immersing them in water (in troughs, barrels, ponds, rivers and lakes) are also strictly connected with fertility symbolism.

Apart from the wedding traditions of dousing or sprinkling with water, the fertility profile also involves household rituals such as pouring water on animals and plants in order to ensure abundant crops, or magical practices aiming to bring rain in the time of drought [SSSL 1.2: 282]. In this way, the image of rain comes to be included in the fertility profile and linked to a chain of notions: female fertility, good crops, health, prosperity and abundance. The fertilising symbolism of rain is apparent in traditional wedding songs performed by girls during the ritual of rozpleciny, the undoing of the bride's plait, which serves as a prelude to the climax of the wedding day: the sexual intercourse between the newly married couple.

The motif of rain or dew plays the same symbolic role in folk love poetry [Majer-Baranowska 1986: 30-31]:

$\begin{array}{ll}\text { Sumi descyk po lescynie, } & \text { Rustling rain on hazel trees, } \\ \text { Twój wianecek marnie ginie. } & \text { Your maiden garland perishes. } \\ (\ldots) & (\ldots) \\ \text { Oj cięzy-ć mnie z tym wianeckiem } & \text { Oh, my garland's heavier by far } \\ \text { niźli tobie z dzieciąteckiem. } & \text { Than the child upon your arm. }\end{array}$

The use of rainwater as a symbolic image of fertility is also grounded in the cosmogonic myth about the impregnation of mother-earth by father-sky through life-bringing rain [Majer-Baranowska 1986: 31]. In general, the power and longevity of a symbol depend precisely on the fact that its meaning may be represented by means of various images, as long as they are connected by a shared semantic node. This is provided by a conceptualisation of the mysterious creative power of the sacred which is grounded in sensory experience. The content of the symbol is revealed in communicative acts in the context of ritual actions. The symbolic representation of the experience of the life-giving potential of water relies on the ATTRACTING POWER schema (by reproducing mythical scenes) and the LINK schema (making contact with the sacred). As a result, God's blessing is secured. The symbolic images of fertility build the partitive (spring, rain) or functional profiles in which the agent makes use of water's magical properties (pouring water over people and objects, pouring water out, sprinkling, carrying water). 
Ritual actions involving immersion, in turn, represent the symbolism of regeneration through water, the restoration to the former state. According to Mircea Eliade, "Immersion in water symbolises a return to the pre-formal, a total regeneration, a new birth, for immersion means a dissolution of forms, a reintegration into the formlessness of pre-existence; and emerging from the water is a repetition of the act of creation in which form was first expressed" [Eliade 1958: 188].

The profiling of symbolic representations of regeneration relies on the foregrounding of water's ambivalent properties: the dissolving and creative ones. Their antithetical axiological value determines the impact of the image, which unites the notions of life and death.

The rite of baptism is a canonical example of a symbolic regeneration through water. The repetition of the archetypal scenario of Christ's baptism in the Jordan signifies a symbolic death and a second birth in a new form. In Kashubia, in the north of Poland, when the godparents take the child to church, they predict the change that is about to happen: "We are taking a heathen and we will bring back a Christian” (pogóna b’erzemë, a chrzesc(ë)jóna przëniesemë). When they bring the child back home, they utter a formula which confirms the transformation and the inclusion of the newly baptised into the community: "We have taken a heathen and brought back a Christian" (pogóna më wzęlë, a chrzesc(ë)jóna przënieslë) [Treder 1989: 162].

The initiation ritual comprises elements of a symbolic death and birth. The scene of immersion represents a symbolic return to the mother's womb, while emerging from water figures another birth. A symbolic re-enactment of birth is also found in other magical practices, especially healing ones, as in drawing the sick through an underground tunnel or a hole in a decaying tree [Marczewska 2002a: 125], or in fairy tales, where the victims of human wrath (a princess, a child) are set adrift on the sea (usually in transparent vessels) and, miraculously saved, begin a new life in a better, new world [SSSL 1.2: 384].

The multi-layered symbolic meaning of baptism not only involves the acceptance of the child into the sphere of the familiar (swój), but also points to its sacred character. The child is cut off from the sin of the original parents and thus included in the sphere of the sacred, which ensures the immortal life of the soul after the death of the body. In Christian symbolism, the image of immersion in water synthetically captures the mystery of death and resurrection [Eliade 1958: 196-197]. Additionally, Christ's baptism in the Jordan is interpreted as a symbolic re-enactment of the Spirit of God ruling the waters in Genesis. By His immersion in water, Christ overcomes the power of Satan and restores the 
sanctity of water. The link created between the mythical scene of Christ's descent into hell and the binding of Satan in chains on the one hand, and the scene of His descent to the bottom of the River Jordan (which becomes a symbolic equivalent of the primal ocean: the devil's abode) on the other, collapses the two events into an image of God's victory over Satan. The meaning of the symbol is reactualised in the annual ritual of blessing the waters on the feast of St John the Baptist. The semantic layer of the ritual suggests a constant presence of demonic powers, threatening life and the stability of the world. The ritual thus plays a protective function. This re-enactment of the scene of baptism is meant to summon God's power which will release water from the influence of evil forces. Such beliefs are also evinced in the prohibition against bathing in lakes or rivers before St John's feast.

The multi-layered nature of the symbolism of baptism is also apparent in the number of cognitive paths linking water both with existential notions pertaining to human bodily experiences such as birth, life and death, and metaphysical ones: resurrection, sin, redemption, immortality, God and Satan.

Scenes of deluge can also be linked to the symbolism of regeneration. A cyclic flooding of the sinful earth bears similarities to baptism both in terms of imagery and its significance. In both cases, the aim of submersion is to create a new reality, free from sin. However, although the parallel is clear, each scene relies on a different model of the FORCE's action. In the case of flood, a destructive FORCE is sent straight from the source of power (God) and is directed against sinful cities, villages, inns or churches, which are not themselves transformed after submersion. Nevertheless, regeneration takes place: the destructive FORCE annihilates a site of sin, restoring original order (the use of the PART-WHOLE schema), which is illustrated by the appearance of primordial water: a spring or a lake. In this way, the scene of a flood is a re-enactment of the creation of the world by the Maker himself (the use of the CONTROL schema). Ritual actions which evoke flood symbolism include magical practices for driving away rain, such as pouring water behind the fence so that rain will bypass the house and go somewhere else [SSSL 1.2: 166]. Here the action of FORCE is conceptualised in terms of REPULSION. The same model is used in prayers begging God to stop or avert rain or floods.

Flood imagery expands the web of water's semantic connections so as to add the concepts of guilt, punishment and annihilation to an already existing network of meanings.

By contrast, the folk customs of drowning "the bear", marzanna (a straw doll impersonating winter) or Judas (see below) [SSSL 1.2: 181] represent a slightly different type of transformation, even though they, too, draw on the symbolism 
of regeneration. Drowning "the bear" and marzanna belong to those rituals concerned with driving away winter and summoning spring. Like baptism and the Flood, they represent the cyclic renewal of the world, the difference being that spring ceremonies aim to renew the powers of nature, while the Flood and baptism concern the regeneration of the spirit.

The ritual drowning of winter, represented as a straw effigy called śmierciucha 'death', finishes with a triumphant procession, parading a doll decorated with ribbons and green branches, personifying spring. In this way, spring celebrations enact the perpetual victory of life over death and are naturally associated with the feast of the Resurrection. Hence the figure of Judas-sin, a straw snowman, appears in spring rituals alongside the straw effigy representing winter-death. Both symbolic personifications were usually drowned before Easter; depending on the region, the śmierciucha was drowned either on mid-Lent Sunday, or, alternatively, on White Sunday (Biała Niedziela), the first Sunday after Easter. Judas, in turn, was traditionally drowned on Easter Saturday [SSSL 1.2: 183].

Easter Monday celebrations, in turn, featured "drowning the bear" (topienie niedźwiedzia), i.e. immersing a boy wrapped up in fur and pea stalks in water [SSSL 1.2: 183]. While, from the point of view of the intention and manner of performance, drowning the bear seems to be a magical practice akin to that of drowning the marzanna (a straw effigy personifying winter), its symbolism is essentially different. As an archaic lunar symbol, the bear is an image of the cosmic rhythm. Like the disappearance and reappearance of the moon, the bear's awakening after its winter hibernation ${ }^{28}$ symbolises the cycles of cosmic death and rebirth. Christian tradition adapted the symbol in the Easter celebrations of the Resurrection, even though the ritual itself, magical by nature, is not part of religious discourse. Drowning the bear demonstrates the connection between water and moon symbolism as regards the renewal of nature, and is meant to cause spring to come. Archaic symbols like this are stored in the experiential base, thus providing a basis for the depiction and conceptualisation of the world. As such, they never perish entirely. Language users need not be fully aware of the symbol's semantic content, especially its archaic meanings, just as they do not have to know the etymology of the vocabulary they use in order to be able to use it to communicate.

Semantic ambivalence is visible in all water symbols, which synthetically capture both the moment of the beginning and the end. Death symbolism takes

28 The bear is known as a lunar symbol in many archaic cultures, cf. Eliade 1958: 157, 175. 
the end of earthly reality as its perspective. For instance, songs of wandering beggars (pieśni dziadowskie) predict that the world will end in a final deluge [SSSL 1.2: 408]:

Gdy z Antychrystem człek się zbrata, Nastąpi wkrótce koniec świata

(...)

Morze wystąpi z swoich brzegów,

Wśród wielkich mrozów, zwałów śniegu,

Lud będzie ginąć tak jak muchy.
When man makes friends with Antichrist, The end of the world has sure come nigh (...)

The sea will overflow its bounds, There'll be great frost and huge snow mounds, Folk will die like flies. ${ }^{29}$

Unlike the biblical Deluge, caused by torrential rain, scenes depicting the end of the world involve images of the sea submerging the earth. Thus the end of the world is imagined in terms parallel to the time before the creation of the world, i.e. the primordial ocean. Death symbols also rely on images of a space beyond the sea (especially a red or black sea), where "the other world" is located. The setting sun, too, sinks into the sea and travels to the other world [SSSL 1.2: 416].

The world of death also comprises rivers, which function both as borders of earthly reality and elements of otherworldly landscape, separating heaven from hell and purgatory [Niebrzegowska 1999d: 12-13]. In addition, this purgatorial landscape features a bottomless fiery lake [SSSL 1.2: 317]. The connection between lakes and death can also be seen in folk stories about lakes appearing in the places destroyed as a result of God's wrath.

Death symbolism also involves images of evil spirits, dwelling in all waters except for springs: rivers, streams, lakes and the sea, as evinced by numerous names of water demons [Dźwigoł 2004: 162-176], folk beliefs and protective magical practices (see Chapter 3.3 above). The connection between water and demonic forces derives from the biblical tradition, where the stormy waters of chaos "lift[ing] up their waves with a wild swoosh and uproar almost to the throne of God have become a symbol of powers hostile to Him" [Athanasius Miller, quoted after Forstner 1986: 69; cf. also Psalm 93:3 ff and 46:3]. ${ }^{30}$ In folk cosmogonic myths, the fiend is also located in the waters: he emerges in front of the Lord from out of the ocean's waves, accompanies Him in the act of creation and is then cast to the bottom. Furthermore, in ancient cosmogonies all forms of being originate in water and eventually return to it [Forstner 1986: 70]. This

29 The translators would like to thank Jean Ward for her help in translating this passage.

30 Athanasius Miller, Die Symbolik des Wassers in der Osterliturgie, Benediktinische Monatsschrift 17 (1935), p. 146. 
provides a firm foundation for folk beliefs that souls of the drowned haunt the waters as malicious demons lying in wait for human life.

Water symbolism profiled by its destructive powers combines opposites: images of death and regeneration (submerging, annihilation, penance). The mystery of death is rendered through images of the depths of water inhabited by demons, distant lands beyond the sea where "otherworlds" are located, fiery bottomless lakes, and rivers flowing at the border between the earthly and supernatural worlds that must be crossed by souls of the dead. On the other hand, such images as baptism, the defeat of winter and the summoning of spring evoke opposite meanings.

The next link in the wide spectrum of water semantics is the symbolism of grace, strictly associated with the symbolism of regeneration and fertility, but profiled from a slightly different point of view. The significance of the symbol originates in the first gesture of blessing performed by God, sprinkling the earth with water. Ritual re-enactments of the divine gesture bring grace upon the participants of an event or on the blessed object. The imagery of blessing is connected with the functional profile, as evinced in the symbolism of sprinkling with water. For instance, the bride sprinkling the household with holy water secures prosperity, happiness and health for herself and the family. The farmer who blesses the grain or the ground during the first ploughing of the year is assured of a bountiful harvest. The ceremonial blessing of a new house, or blessing the whole household on Christmas Eve, have a similar function.

The symbolism of grace is also represented by means of the imagery of holy springs, brought forth from the depths of the earth by the Virgin Mary or saints. Since their untainted water preserves the creative power of primal waters, the sick receive the grace of recovery from their illness. In folk tales, "living water" ( $\dot{z} y w a$ woda) restores life, lost limbs, or the human shape to the wretches transformed into an animal or a monster by magical powers. In Christian symbolism, spring water, also called the water of life (woda $\dot{z} y c i a$ ), represents divine grace and eternal life [Forstner 1986: 72-73]. This is conveyed in such metaphors as krynica łask 'the fountainhead of grace', źródło łask 'the source/spring of grace'. As a symbolic image - which by nature combines opposites - a spring may also be endowed with negative meanings. The sanctity of a spring does not preclude the danger incurred in approaching an epiphanic site leading straight into "otherworlds", thus exposing the human being to contact with another order of reality, alien to the earthly one. Fear of direct interaction with the sacred is manifested through normative discourse, regulating appropriate behaviour in places regarded as holy. For example, it was forbidden to build a house above a spring (or a place where water seeped from 
the ground), since such a building would be a profanation of the sacred site and, as such, would be prone to lightning. By contrast, churches and shrines were often erected around a spring. Also the use of sacred spring water was guarded by taboos. The otherworldly nature of springs did not permit any contact with human biological functions (e.g. women in impure states: during menstruation, pregnancy or puerperium were forbidden to use them) or impurity coming from the other world (the taint of death, which meant that it was forbidden to approach a spring after a funeral, and after childbirth (until the churching)). Casual use of spring water for everyday use and drawing water with dirty vessels was also prohibited lest the spring became contaminated or lost its miraculous properties [Kowalski 2002: 96].

The gesture of sprinkling, representing grace, generates semantic links with the notions of health, happiness, wealth, good crops, woman, farmer, sanctity, love, God, while the drinking of spring water is associated with health and life, both in the physical and metaphysical sense. The symbolic representation of grace allows a glimpse into the mysterious link between earthly existence and eternity. The discrepancy between those concepts is visible in the ambivalent value ascribed to health (body vs spirit), happiness (earthly vs heavenly), wealth (material vs spiritual) and life (earthly vs eternal). These interconnections are construed in terms of the FORCE (ATTRACTION) and LINK schemas.

A spring is a prototypical image of grace constructed on the basis of the partitive profile, while the sprinkling with water in a gesture of blessing, as well as drinking water, rely on the functional profile. The symbolic profile of grace is also built around such qualitative characteristics as: the presence of the agent (God in the archetypal version, a woman or a farmer in situations modelled on the archetype), object (e.g. earth, newly-weds, wedding guests, a field, grain, a farm, a house), its attributes (the healing or magical powers), and its uses (sprinkling, drinking, cleansing).

The symbolism of grace is directly connected with the symbolism of potential, implying possibility, which also makes use of the imagery of the ocean, the sea, rivers or springs. The partitive profile (pertaining to sources of water) provides a range of possibilities by which to present the unlimited creative potential of water, epitomised in the archetypal image of the emergence of the world out of the primeval ocean. In this scene, the symbolism of potential overlaps with the image of the beginning. The multi-layered nature of the symbolism of potential, especially in relation to mythical origins, leads to the acceptance of the notion of God's plan for the future of the world. Consequently, water acquires such attributes as prophesying powers and knowledge of the future, used in magical practices of fortune-telling [SSSL 1.2: 354]. 
For example, a girl looking at the surface of water (a river or lake) may see the face of her future husband; similarly, the ritual of floating garlands on St John's night serves to predict the likelihood of marriage. Practices of throwing various objects into, or taking them out of, water also serve to foretell the future (for instance, drawing out a lump of iron means that the future husband is going to be a smith, while a coin suggests he will be rich), provided they take place on certain occasions conducive to fortune-telling (Christmas Eve, New Year's Eve, St John's night, St Andrew's feast) [SSSL 1.2: 184]. Likewise, prophecies of wars and natural disasters are made on the basis of observation of water sources, especially rivers. Fortune-telling and prophesying reactualise symbolic meanings related to prophetic capacities of water (river, lake, pond, sea). Water ordeals, in turn, testing the innocence of people suspected of witchcraft, as well as the practice of swearing oaths on water, suggest that it also serves as the guardian of truth [SSSL 1.2: 191]. In this way, the symbolism of potential provides a link between the meanings of water and the semantics of such concepts as prophecy, truth and knowledge.

The structure of a symbolic representation (a scene) is built on the basis of such elements of the partitive profile as: the agent (a person telling the fortune, swearing an oath, or putting someone through a water ordeal) who treats water as an oracle (thus water becomes the object of the agent's actions and interpretations) and makes use of its prophetic powers (attributes) on occasions when such powers can manifest themselves.

Rooted in myth, the semantic memory of a symbol includes existential meanings, related to the connection of the world of physical objects and the world of ideas. The reactualisation of the meanings of symbolic images in acts of communication enables a constant development of semantic relations with other elements of the lexical system, depending on the type of discourse in which a given context is placed. The choice of words included in the semantic network of particular water symbols suggests which fragments of reality come within the perspective determined by the adopted point of view. An overview of the concepts which come within the compass of all symbolic images of water both reveals the relations between the particular profiles of the symbol and positions the notion of water within the lexical and semantic system. Groups of concepts recurring across particular symbols create interpenetrating spheres, arising as a result of the adoption of similar points of view during the profiling process. On the other hand, lack of shared lexical and semantic links suggests that a different perspective has been adopted, thus extending the network of water's symbolic representations to include new meanings. 
The semantic connection between the symbolism of fertility and grace is established by references to blessing, abundance, prosperity, good crops, welfare; the symbolism of origins is linked with the symbolism of grace by such concepts as miracle, God, sanctity, and with the symbolism of fertility - by the notions of birth, mother and blessing. The symbolism of renewal also generates a link with the notion of birth, as well as baptism, flood, resurrection, redemption and death, which distinguish the semantics of this profile. The concepts of sin, annihilation, guilt and punishment are linked with the symbolism of death, enriched by associations with the end of the world, penance, "otherworlds", hell, purgatory, Satan and demons. The symbolism of grace, potential and origins are all connected with the mythical scene of the creation of the earth but they take differing points of view, building a network of interrelated meanings. Although all other images could be treated as representations of potential, the extensive network of meanings that has developed around them suggests that this profile should be restricted to existential concepts, such as truth, knowledge and prophecy, current in fortune-telling practices.

Symbolic imagery relying on the partitive profile of water (as both an element of the cosmos and particular earthly reservoir) serves to show the impact of supernatural (divine and demonic) powers on human life and fate. Springs of clear water issuing from the depths of the earth represent the power of God's blessing, as reflected in such metaphors as "the spring/fountainhead of grace" (źródło/krynica łask). Rivers, lakes, seas and rain waters are used as images of divine providence: wielding control over the world, keeping it alive and maintaining order. On the other hand, since water is Satan's primal abode, they also serve as images of his power. In the cosmic dimension, water imagery represents divine authority over the universe.

Water symbolism based on the functional profile reflects the relations between man and the sacred. Actions involving the use of water and the manner of their performance show how human beings attempt to gain access to the sacred in order to deploy its miraculous life-giving (or destructive) powers or to protect themselves from demonic forces. 



\section{Earth}

\subsection{The semantic memory of archetypal creation myths in profiling the relations between heaven and earth}

Different versions of folk cosmogonic myths feature the image of the allencompassing primeval ocean and the Spirit of God that moved upon the waters. The state prior to the act of creation is conceived as an ocean in an overwhelming darkness, with heaven, God's abode, above it. Some versions include Satan in the depths of the waters. His relations with God are not straightforward and, to some extent, diverge from the biblical tradition. These images distinguish the upper and lower domains of cosmic space (according to the UP-DOWN schema): while God is always presented above the waters (moving upon them, walking on the surface, or sailing a boat), the devil either emerges from, or is thrown into, their depths [Tomicki 1978: 86].

The semantic memory of cosmogonic myths has been preserved in folk tradition in the form of mythical stories, riddles, proverbs and carols; it can also be traced in customs, rituals and magical practices governed by a set of rules prescribing the course of their performance. It is grounded in the experiential base of the conceptualiser: a peasant farmer who remains in close contact with the earth, and whose fate depends upon it. This is apparent in conceptualising the Creator as a farmer sowing grains of sand that become the earth; in the motif of ploughing with a golden plough (found in traditional rural New Year folk carols) and in certain rituals, particularly the first ploughing and sowing of the year, which include divine actions, gesta deorum, in their structure [Niewiadomski 1986: 59-662; 1987: 21-23; 1992: 69-70; 1999: 47-104].

Another agricultural motif is the fertility of the earth, visible in vestiges of pre-Christian cosmogonic myths in which the earth was hatched from the cosmic egg (as discussed further below) or father-sky fertilised mother-earth with life-giving rain or a bolt of lightning [Eliade 1958: 239-260].

The agricultural perspective of profiling the relations between heaven and earth manifests itself also in the fundamental idea that, as God's creation, the earth is sacred ("God created heaven and earth" (Bóg stworzyt/postanowit niebo $i$ ziemie) [SSSL 1.2: 24, 31]). The superimposition of the biblical story of the creation onto elements of pre-Christian beliefs resulted in the emergence of a multi-layered image of the cosmos, with the earth (the conceptualiser's vantage point) invariably remaining at the centre of scenes presenting relations between the sacred and the profane. This is the case regardless of whether the archetypal 
role of the agent is performed by supernatural forces or by a human who ritually re-enacts the divine act of creation. Folk tradition includes different variations of the cosmogonic myth resting on religious foundations (both Christian and pagan). An analysis of their elements will make it possible to discuss relations between the natural and supernatural worlds in terms of preconceptual image schemas.

\subsection{Mother-earth and the archetypal model of the union between heaven and earth}

The mythical concept of marriage between heaven and earth is unknown in the biblical tradition, according to which the world was created by the word of God. However, as in the case of pre-Christian supreme divinities of the sky and lightning (e.g. Perun/Perkun), ${ }^{1}$ God's power is also associated with thunder (this also pertains to such holy figures as the prophet Elijah and Archangel Michael).

In the mythical pre-Christian vision of the world, the principal actors, heaven and earth, are personified as a couple, while the creation is interpreted as a symbolic procreative act between the masculine and feminine elements. In this scenario, the combination of the FORCE schema and the LINK, PART-WHOLE and BALANCE schemas produces a consistent image of cosmic harmony based on the domain of family relations (the vertical relationship between father-sky and mother-earth).

The creation scene is conceptualised as a manifestation of demiurgic power over the elements of earth and fire (in some myths: earth and air), with the archetypal division of functions as follows: the Creator as the agent located in the centre of the scene; the earth as the object of his action; fire (in the form of lightning) as an instrument, and the conceptualiser in the background as an observer (or, more likely, an interpreter) of the event.

Although this form of the creation myth is not attested in Polish folk culture, certain contexts in which the words ziemia 'earth' and niebo 'the sky/heaven' appear in conjunction, as collocations, point to their union: "on earth and in heaven", i.e. 'everywhere' (na ziemi i na niebie); "God will create a new heaven and a new earth in the other world" (nowe niebo i nowa ziemię stworzy Bóg na

1 For the etymological connection between the name of this divinity (Perun/Perkun) and the word piorun 'lighning', see Brückner 1957: 414; Gieysztor 1986: 45-46; Ivanov, Toporov 1974: 3-34; Łowmiański 1986: 99-109; SPs 1974: 134. 
tamtym świecie) [SSSL 1.2:20]. Folk riddles, in turn, clearly indicate the marriage between heaven and earth [SSSL 1.2: 28]:

- "A father that doesn't charge but shoots and a mother that has no gob but eats": heaven and earth (Ojciec strzela nie nabija, matka zjada, gęby nie $m a$ );

- "A mother low down, a father high up, a blind daughter and a mad son": earth, heaven, night, wind (Matka nisko, ojciec wysoko, córka ślepa, syn szalony).

Such riddles reactualise the archetypal cosmic act whereby father-sky impregnates mother-earth with a bolt of lightning. The contexts in which the archaic myth is re-enacted expand the scope of meaning of the lexemes niebo 'the sky/heaven' and ziemia 'earth' and endow them with a symbolic function, as can be seen in the metaphorical association of ploughing the field with the sexual act [SSSL 1.2: 28]:

- "A bed creaks, a woman squeaks; a man drives, a woman sighs": a ploughman and earth (Łóżko trzeszczy, pani wrzeszczy, pan popycha, pani wzdycha).

Similar examples can be found in folk love lyrics, where the sexual act is sometimes euphemistically presented as ploughing [Niewiadomski 1988: 33; 1999: 11-19; Wężowicz-Ziółkowska 1991: 149-150]:

Na piecu orał, żyto siał, ona płakała, on się śmiał.

Oj nie płacz, nie płacz, kobito, dobra to rola na żyto.
He ploughed on the stove ${ }^{2}$ and sowed rye, she cried and he smiled with delight.

O woman, don't you, don't cry, this is good soil for rye.

The procreative model of the union between heaven and earth provides the semantic node linking a number of scenes which show the engendering function of rain and lightning. Such scenes rest on a belief in the interpenetration of cosmic spheres, resulting in the emergence of cosmic-human image schemas: heaven - rain - man, and earth - womb - woman [Niewiadomski 1999: 29]. These gave rise to a number of commands, prohibitions and warnings whose perlocutionary force imposed particular patterns of behaviour.

2 In some regions, peasants slept on stove tops, especially in winter (translator's note). 
For example, a belief in the power of the first thunderclap of spring, which restores the fertility of the earth, entails prohibitions against ploughing the "pregnant earth", beginning work in the fields or even lying on the ground before it strikes [SSSL 1.2: 23]:

- "during Advent, the earth is asleep and it (ona 'she') gets sick if you plough it" ( $w$ adwenta ziemia spi i je chorô, kiej sę ję orze) [Niewiadomski 1999: 262; Treder 1989: 246];

- "it's a sin to hit the ground in spring; the earth is pregnant, she gives birth to rye, flowers and all kinds of grass" (na wiosne grzech bić ziemię; jest brzemienna na wiosnę, wypuszcza płód żyto, kwiaty, wszelka trawa) [KLS 1967: 510; Gieysztor 1986: 154];

- before the Annunciation (25 March) "it's forbidden to plough or to hammer in fence posts (you can't put up fences at all), or even swing on logs lying across tree trunks because when they fall their ends hit the ground" (nie wolno ani ziemi orać, ani wbijać w nia kołki, grodzac płoty (w ogóle nie wolno grodzić), ani nawet huśtać się na kłodach położonych w poprzek pnia, ponieważ końce ich przy spadaniu uderzaja o ziemię) [KLS 1967: 510];

- "you can't lie on the ground before the first thunder; there's still a sickness in the earth; the earth hasn't shaken it off yet" (bo jak grzmotu ni ma jeszcze, to na ziemi nie można się jeszcze położyć. O to choroba jest. Na ziemi, ziemia jeszcze nie otrzęsła się) [SSSL 1.2: 49].

The myth of heaven-sent rain impregnating the earth can also be traced in the wedding ritual of the undoing of the bride's plait (rozpleciny) when she is seated on a rain stone (kamień deszczowy) in order to ensure her fertility [MajerBaranowska 1986: 34]:

Moja Marysia siadła na białym kamieniu,

Rozpuściła włosy po białym ramieniu

(...)

A po białym kamieniu

Drobny deszcz pada, kochana,

Drobny deszcz pada, kochana,

Drobny deszcz pada.

A juźci tyn młody pun

Na kónia siada,

Na kónia siada.
My sweet Mary has sat on a white stone,

She's let her hair fall loose over her white shoulder

(...)

And on this white stone

A thin drizzle is falling, my love,

A thin drizzle is falling, my love,

A thin drizzle is falling.

And now the groom

Mounts his horse,

Mounts his horse. 
The fertilising power of rain stones was attributed to their meteoric origin: ${ }^{3}$ like rain, they fell from heaven [Majer-Baranowska 1986: 34]:

Dajze Boze descu powolnego,

Niechze mu sie nie spiesy,

Niechze mu sie nie spiesy.

A niechze sie ta dziewcyna nasa

Dzis w wianecku uciesy,

Dziś w wianecku uciesy.
God, send a gentle rain, May it not hasten away, May it not hasten away. May this girl of ours Be happy dressed in her garland today, Be happy dressed in her garland today.

Cognitive events in which the wedding participants: the bride, groom and bridesmaids re-enact the scene of the cosmic marriage of heaven and earth stem from a belief in the fertilising function of rain and the mediating power of stone [Brzozowska 2009: 63-65]. The conceptualiser is involved in the scenario, which means that he/she represents the point of view common to other participants. Owing to his/her identification with the group and to the ritual nature of the event, the scenario is viewed as "familiar" (swój).

Based on the ATTRACTION schema, the experience of the power of the sacred involves a sense of proximity to the divine. It is achieved through the ritual re-enactment of the act of creation by means of conscious actions (the act of undoing of the bride's plait as a symbolic gesture of opening up to the sacred), ${ }^{4}$ which are performed according to prescriptive guidelines taking the form of such presupposed speech acts as:

- during the undoing of the plait the bride should/ought to (trzeba/należy) be seated on a rain stone to ensure her fertility.

The marriage of heaven and earth functions as an unconscious archetype which provides the basis for further profiling of the earth as a symbol of the feminine element and, further on, a life-giving and nourishing mother.

3 Belief in the fertilising power of rain stones is found in a number of different cultures, cf. Eliade 1958: 226. In folk culture, sitting on a rain stone was a symbolic sexual act resulting in a change of status: a maid became a woman; the passage quoted below includes an anticipation of losing the maiden garland. For more on the function of the rain stone in Polish culture, see Brzozowska 2009: 63-65; Masłowska 2017: 204-206.

4 All acts of contact with the sphere of the sacred, particularly in the rites of passage, typically involve magical gestures of untying or opening [Stomma 1976: $101 \mathrm{ff}$ ]. 
Both the idea of the sacred marriage between heaven and earth and the biblical belief in God's act of creation endow the earth with a sacred status (święta ziemia 'the sacred earth'). This entails a number of commands and prohibitions as regards the respect it is due. Such actions as hitting the ground, spitting on it or swearing, which could be considered offensive to the earth, are disapproved of and strictly forbidden [KLS 1967: 510, 514; SSSL 1.2: 23; Treder 1989: 21]. Adherence to these rules relies on the OUTER COMPULSION schema, whereby socially accepted norms of behaviour are expressed through speech acts as formulas of prohibition, warning or threat. Failure to comply with a prohibition carries the risk of punishment being inflicted not only on the culprit, but also the entire community as the offended earth can refuse to bear crops, or strong winds may arise, causing damage:

- it is forbidden to hit the ground; the earth will not accept the dead body of the culprit and will throw it out of the grave, or stir the wind: "don't hit the sacred earth or it won't accept you" (nie bij świętej ziemi, bo cię nie przyjmie) [KLS 1967: 510; Treder 1989: 21]; "the earth gets angry and quakes when someone pokes a stick in front of him, whether for fun or out of ignorance, it must hurt so no reasonable person would do such a thing" (gniewa się ziemia i trzessie, kiedy ktoś przez zbytki lub nieświadomoś przed soba popycha, boli ja to widać, żaden więc rozsadny człowiek tego nie robi) [SSSL 1.2: 52]; "One must not hit the ground or else the wind will come straight away" (Ziemi nie wolno bić, bo zaraz będzie wiatr) [SSSL 1.2: 48];

- it is forbidden to spit on the ground: "Also, when spitting on the ground in anger, one needs to watch out so as not to offend the earth" (Także przy gniewnym spluwaniu na ziemię $w$ chwilach uniesienia trzeba uważać, by jej nie obrazić); in this case, one needs to apologise immediately by saying "It's not upon you, sacred earth" (Nie na ciebie, święta ziemio) [SSSL 1.2: 53];

- it is forbidden to curse in the presence of the earth: "In the old days, mothers warned their children not to swear or else the earth under their feet would become eggshell-thin" (Drzewiej matka nakazywała dziecku, coby nie kleno, bo sie ziemia pod niem tako cienka bedzie robieła, jak skorupka na jojku) [SSSL 1.2: 48].

The INNER COMPULSION schema - acting according to one's own beliefs and system of values - is apparent in acts of reverence for the earth, particularly in the archaic gesture of kissing the ground (when leaving one's family home or returning to one's homeland, or in a gesture of atonement, thanksgiving or entreaty) [SSSL 1.2: 23-24; Bartmiński 2009b: 149-156], which is probably 
related to touching the ground when making a vow. ${ }^{5}$ Bowing to the ground (kłonienie się) and touching it with one's hand to confirm the truth of one's words is another archaic gesture deriving from the cult of the earth [Engelking 2017: 110-111]. A further example is the custom of kissing a loaf of bread before cutting it: a combination of reverence for the earth and thanksgiving for its fruit. The symbolic meaning of the gesture stems from the creation myth according to which God formed the earth out of dough, like bread, and made it the bearer and nourisher of all life. The custom of showing respect for the earth by giving it a solemn kiss demonstrates the existence of socially accepted conventions of behaviour and principles of marking particular occasions as extraordinary. Accordingly, one needs to/it behoves one to/one should (trzeba/godzi się/należy) kiss the ground [Bartmiński 2009b: 149-156; SSSL 1.2: 23-24]:

- when returning home from a long journey,

- when leaving the family home,

- in a gesture of thanksgiving for a return to health, and for nourishment,

- when asking the earth for crops,

- in a gesture of atonement on arrival at a holy site.

Gestures manifesting one's sense of belonging to a native land or family home mark the setting as one's own (swój). Such signs of recognition of the sanctity of the earth and of attachment to it confirm a personal relationship with the earth mother and nourisher, to whom one owes one's own life and health [Masłowska 2012a: 134-135]. By kissing the earth as a pilgrim, in turn, one treats it as an ethical entity able to absolve one of one's sins. ${ }^{6}$

The mythical image of the world born of the union of heaven and earth displays prototypical features, as evinced by mental representations which faithfully re-enact the original. The image of the cosmos as a whole is based on the pattern of family relations, the ultimate model of the category "one's own/familiar" (swój). The earth, portrayed as mother, is accordingly treated as a sentient being,

5 Aleksander Brückner suggests an etymological connection between the Proto-Slavic

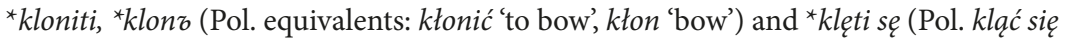
'to pledge oneself/to vow'); the forms ${ }^{*} k l ı n q-k l e ̨ k n e ̨ t i$ (Pol. klęczeć 'to kneel') would be analogical to ${ }^{*} z v o n q$ - ${ }^{*} z v e ̨ k n a ̨ t i$ (Pol. dźwięczeć 'to sound') - ${ }^{*} z v o n z$ (Pol. dzwon 'bell'). His proposal is supported by analogy with the Latin in-clinō $m \bar{e}$ 'I bow/bend down' [Brückner 1957: 194].

6 A pilgrim's kiss bears a semiotic affinity to the East Slavic peasant custom of confessing sins to the earth (the motif of pokaianie zemle, Rus. 'confession to the earth', described by Nikita Tolstoŭ, to which I refer after Jerzy Bartmiński [Bartmiński 2009b: 154]). 
endowed with human properties: the earth "breathes" (oddycha), "talks" (mówi), "smiles" (uśmiecha się), "moans" (jęczy), "lulls to sleep" (kołysze), "gives birth" (rodzi) and "nourishes" (karmi) [SSSL 1.2: 22]; it can also be addressed directly in communication. This leads to the expansion of the lexical connectivity of this profile of the earth, actualised particularly in folk literature: tales, stories, legends and poetry [Bartmiński 2009b: 151-153].

The archetypal cosmogonic myth of the union of heaven and earth on the one hand, and the sacred status of the earth as God's creation on the other, shaped a distinctive image of mother-earth in the folk consciousness. This image was projected onto the conceptualisation of the profile of Our Lady (commonly referred to in Polish as Matka Boska, the Mother of God) as a patron of crops:? her motherly protection over women in labour and newly-weds formed the basis of cognitive paths leading to fertility and a bountiful harvest, thus establishing a direct connection between mother-earth and the Virgin Mary.

In folk culture, Marian feast days came to be correlated with the agricultural cycle, their names reflecting the involvement of Our Lady in the rhythm of natural life [Bartmiński 2009b: 193-194; Niewiadomski 1992: 63; 1999: 61]: the Feast of the Purification of the Blessed Virgin Mary (2 February) is known as Our Lady of the Thunder Candle (Matka Boska Gromniczna, reflecting a belief that she protects the fields from thunder); the Feast of the Annunciation (25 March) - as Our Lady of the Streams, of the Opening or of the Warming (Matka Boska Strumienna, Roztworna, or Zagrzewna, reflecting a belief that she revives the frozen waters in streams, "opens" (roztwiera) the earth for the seed, and awakens the sleeping earth); the Feast of the Visitation (2 July) - as Our Lady of the Flowers, or of the Berries (Matka Boska Kwietna or Jagodna); the Feast of the Assumption (15 August) - as Our Lady of the Herbs (Matka Boska Zielna, the day of blessing herbs and crops); the Feast of the Nativity of the Blessed Virgin Mary (8 November) - as Our Lady of the Sowing (Matka Boska Siewna, marking the period of sowing winter corn). Folk names of Marian feast days are also to be found in proverbs, e.g. "If the day of Our Lady of the Thunder Candle is bright, the autumn will bring good crops" (Gromniczna pogodna, będzie jesien dorodna); "On the feast of Our Lady of the Streams brooks begin to thaw" (Na Strumienna strumienie puszczaja); "When the sky on the feast day of Our Lady of the Sowing

$7 \quad$ A religious attitude to mother-earth is a general cultural phenomenon, as evidenced by the cult of ancient female divinities, including the Egyptian Isis, the Hindu Prithivi, the Greek Demeter and the Roman Ceres [Forstner 1986: 82-83; Bartmiński 2009b: 201; Niewiadomski 1992: 63-64]. 
is blue, heather will be in lovely bloom" (Gdy na Siewna jest błękitnie, wtedy pięknie wrzos zakwitnie) [Bartmiński 2009b: 193-194, examples after NKPP].

The semantic link between the Virgin Mary and the earth is also apparent in a number of plant names, particularly herbs believed to have healing powers. This initiates a network of further connections between the profile of the Virgin Mary as a patron of good crops (an equivalent of mother-earth) and that of a healer. The cognitive path linking these two profiles connects the healing powers attributed to the earth and its fruit (herbs), and those attributed to Mary. The names of medicinal herbs associated with the Virgin Mary include such examples as: drzewko Panny Maryi 'Virgin Mary's wood' (southernwood, Artemisia abrotanum, Pol. bot. bylica boże drzewko 'bylica god's wood'); miatka Matki Boskiej 'Mother of God's little mint' (also known as włoska mięta 'Italian mint', mentha saracenica and mentha Mariae; costmary or bible leaf, Tanacetum balsamita, Pol. bot. wrotycz balsamiczny); ziele Panny Marii 'Virgin Mary's herb' (also known as sempervivum and buphthalmus; St John's wort, Hypericum perforatum, Pol. bot. dziurawiec zwyczajny); ${ }^{8}$ there is also maryjanek, used for the name majeranek 'marjoram'; the form maryjanek (which includes 'Maryja', a traditional Polish form of the name 'Mary', referring to the Blessed Virgin) is attributed to naïve etymology and to analogy with other herbs whose various names were associated with that of Mary's [Brzozowska 2009: 20].' The image of the Virgin Mary expelling disease or healing the sick appears in legends ${ }^{10}$ and cure spells (zamowy, sing. zamowa). The healing power of the earth, in turn, is apparent in magical practices involving as follows: burying in the ground, applying an earth poultice, wrapping in mud and rubbing with earth [SSSL 1.2: 49]:

- "people said that when someone suffered (...) from ischias [sciatica], (...) he/ she was buried in yellow soil" (mówili, że jak kto chory był (...) na isjasz, (...) że go zakopywali do źótty ziemi);

8 Jerzy Bartmiński [Bartmiński 2009b: 202] lists twelve examples of such plant names going back to the Middle Ages, which he provides after Józef Kopeć [Kopeć 1997: 114]. They are informed by mythological references, certain aspects of religious cult (reference to appearance, attributes, glory), or practical aspects of healing practices; cf. also Niebrzegowska-Bartmińska 2010.

9 Małgorzata Brzozowska observes that reinterpretation of names can be attributed not only to naïve etymology, but also to strong associations with rituals.

10 Cf. particularly legends concerning the life of the Virgin Mary bringing up baby Jesus (e.g. the miraculous healing of a thief's child as thanksgiving for the shelter that felon had offered them during their flight from King Herod's soldiers) [Zowczak 2000: 276-283]. 
- a person struck by lightning "was buried in the ground in an upright position so that he/she could breathe, but the rest of the body was buried in the ground" ([człowieka porażonego piorunem] zakopywano do ziemi. W stojacej pozycji, jakżeby mu tutaj zostawić do oddychania, a tak całego zakopywali do ziemi);

- "you use a poultice made from earth, (...) you use a pad soaked in vinegar (...) [and it soothes] inflamed skin, (...) reduces fever" (okłada się ziemio (...) z octem robi się okłady (...) takie zaczerwienienia, (...) goraczka, bo to wyciaga);

- "if someone's legs were sick, they wrapped them in yellow clay mixed with water (...); they wrapped people's legs and arms in clay mixed with vinegar. Whatever part of the body was sick, such earth had a healing power and helped" (chore nogi miat, woda i glina żótta, uwijali (...) ta glina $z$ octem $i$ ówijali nogi ludziom, ręce. Tam jaka część ciała miał chore, że to miała moc ta ziemia, że pomagała).

Speech acts prescribing the course of magical practices - addressed to the participants of the event in the form of commands or advice using the form trzeba 'need to' - were thought to be more effective if they included an invocation of the power of the sacred by the intercession of the Holy Virgin, for example: "By God's power, by the Dear Mother's power and with the help of all saints" (Boża moca, miłej Matuchny moca, wszystkich świętych pomoca) [Niebrzegowska-Bartmińska 2007: 112; Bartmiński 2009b: 202-203].

The motif of the Virgin Mary healing a sick person or ridding someone of a disease is also an element of the narrative structure of cure spells (zamówienie, lit. 'speaking away' an illness). The mythical cognitive events they evoke, with Mary as the agent and an illness as the object of her actions, sanctify the practice. In this way, the healer, who is in the centre of the scene, re-enacts the sacred model and, as a result, gains access to the power of the sacred. An illness is overcome "with the help from the Mother of God" (z Matki Boskiej dopomoca) and sent away to a distant place "beyond the mountains, beyond the forests, to the ends of the world" (za góry, za lasy, na krańce świata), or one that is empty and barren: "where people don't go, where ploughs don't plough, where there isn't anyone" (gdzie ludzie nie chodza, pługi nie orza, gdzie nikogo nie ma). This often involves the use of a numerical concept strengthening the magical formula: a repetition of healing procedures three or nine times [Niebrzegowska-Bartmińska 2007: 180-182], or reciting a countdown that makes the disease vanish, e.g. "So, St Anthony's fire [erysipelas, Pol. róża, lit. 'rose'], you've got nine flames! It's not nine, not eight [and so 
on]" (Oj, Różo różo, masz ty dziewięć wierzchołków! Nie dziewięć, nie osiem...) [Niebrzegowska-Bartmińska 2007: 347-349].

The model of mythical scenes of healing presents situations in which the Virgin Mary orders the disease to turn back (as in (1) below), performs healing practices (2), or cures it (3):

(1) As the Mother of God and the Lord Jesus were making their way through the woods, they met pain (bolec). "Where are you going?" the Holy Virgin asked. "I'm on my way to this man called [name] and so into his eye; I'll make it burn and give him pain until it goes blind." "No, you won't do that," said the Mother of God "because I forbid you by the Power of the Holy Virgin and Jesus Christ: off you go into the sea!"

(2) As the Mother of God was walking along a green path, she met the Lord Jesus himself. "Where are you going, Mother of God?" he asked. "I'm on my way to this Christian man called [name] to expel (zamówić) St Anthony’s fire [erysipelas] with my five fingers and my whole hand so that it won't give him pangs of pain or make him shake and bleed."

(3) As the Most Blessed Virgin and the Lord Jesus were walking along a road, they met sciatica (strzelec-postrzelec lit. 'hunter-shooter'). "Where are you going?" "I'm on my way to this Christian man called Stach (Peter, etc.) and then into his leg (arm, etc.); I'll give him aches and pains in his bones and suck his blood." "Don't go there. We've been there already and done a good thing."

(1) Szła Matka Boska z Panem Jezusem przez las, spotkała w drodze bolec. „Gdzie ty idziesz bolcu?” zagadnęła Panienka święta. „O! Ja idę do tego człowieka N.N., w oko, będę je ognić i męczyć, aż zaślepnie!” „O, ty tego nie uczynisz - rzeknie Matka Boża - bo ja ci zakazuję Mocą Panny Świętej i Pana Jezusa: Idź bolec do morza!" [NiebrzegowskaBartmińska 2007: 177, 178]

(2) Szła Matka Boska ścieżką zieloną i spotkał ją sam Pan Jezus. „Dokąd idziesz Matko Boża?” "Idę do tego chrzczonego - tu wymienia się imię chorej osoby - zamówić różę pięciu palcy a szóstą dłonią, aby go nie rwała, nie trzęsła, krwi nie przelewała." [Niebrzegowska-Bartmińska 2007: 176]

(3) Szła Najświętsza Panienka z panem Jezusem drogą, napadła [spotkała] strzelcapostrzelca [uosobienie postrzału]. „Kaj ty idziesz strzelcu-postrzelcu?” „Dy ja idę do tego człowieka chrzczonego, mianowanego Stachem (Pietrem, itp.), w nogę (w rękę itp.) i będę mu kości łupać, krew ssać.” „Nie chodźże ta(m) strzelcu-postrzelcu, bo my już tam byli i dobrze sprawili." [Niebrzegowska-Bartmińska 2007: 157]

Mythical events ritually re-enacted by the healer and the speech acts that he/she performs rely on three different patterns of the FORCE schema: BLOCKAGE (the Virgin Mary does not allow the disease near the victim by ordering it to turn back), REMOVAL OF AN OBSTACLE (she cures the illness), and COUNTERFORCE (she performs healing practices herself).

The healer relies on a ready-made model of practices and textual patterns. The magical actions he/she performs are a ritual re-enactment of the acts of divine 
and holy figures, which means that "it reactualises the mythical time of origins, both the origin of the world and the origin of [diseases] and their treatment" [Eliade 1959b: 81]. Consequently, the participants of such healing practices are profoundly convinced of their effectiveness. Such spells conclude with a prayer, usually Hail Mary repeated several times, which further demonstrates the belief in the power of the intercession of the Holy Virgin. In this way, magical healing practices that she is believed to perform create another cognitive path linking her to the profile of mother-earth.

In the cult of the earth, the image of the mother and her function as the one who raises and cares for a child is also apparent in scenes where the earth is treated as a guardian and protector of moral order. The earth is called on as a witness when swearing an oath or making a vow, while in curses and malediction formulas it plays the role of both judge and punisher. The causal power of words in such formulas as "Open up, earth!", "Let the earth swallow you!", "Let the earth refuse to support you!", "Let the earth open up under you!" (Rozstap sie ziemio; Niech cię ziemia pochłonie; Niech cię ziemia nie nosi; Niech się ziemia pod toba zapadnie) [SSSL 1.2: 22; cf. Engelking 2017: 216-217] is supposed to annihilate the culprit, make him/her vanish from the face of the earth. Although the speaker addresses the earth, in fact he/she turns to God, the ultimate power, who makes judgments and metes out punishment (such as sinking into the ground or the earth opening up beneath one). Curse formulas of the type niech cie ziemia... 'let the earth...' are synonymous with the original bodaj cie... 'may you...' (a lexicalised form of bog daj, lit. 'God grant', imperative) since they both function as "operators for enchanting a power" [Engelking 2017: 216], with God Himself as their executor.

This entails the use of two types of communicative acts with a similar illocutionary force. In the first case, the speaker uses the imperative (e.g. "Open up, earth!" Rozstap się ziemio!) so as to address directly the earth as the agent of justice, expected not only to judge but also to execute punishment. In the second one, the message is addressed to the wrongdoer him/herself (e.g. "Let the earth swallow you!" Niech cię ziemia pochtonie!). In both cases, however, the perlocutionary force of the curse formula is identified as an act of God's will; the message is implicitly addressed to God Himself: "God, grant/allow that (some specified) harm comes to X".

Oral tales often feature the motif of people, their property and belongings sinking into the ground as a result of a curse or as God's punishment for their wicked deeds [SSSL 1.2: 44-45]: 
- [when a shepherd was refused his lord's permission to go to Sunday Mass and ordered to work instead, he cursed:] "'May all this sink [into the ground]!' And the town and the manor immediately sank beneath the ground. On the surface, a forest grew where they had once been" (Bodajeś się zapadło! - $i$ natychmiast miasto i dwór się zapadty w ziemię. Na tém miejscu wyróst na powierzchni las);

- "the mill, which had turned into the devil's place, sank underground with a mighty crash" (mlyn, ze to jus but diabelski, zapod się pod ziemie z wielgim trzaskiem);

- "on Easter Sunday afternoon, a priest carrying the Blessed Sacrament to a sick person walked by the inn where [a sinner blasphemed against God]; there was a sudden earthquake which made the whole town [of Kosi Targ in the Nowy Targ Valley] sink beneath the ground, together with all the people and their belongings" ( $w$ wielkq niedziele po południu szedł ksiądz z najświętszym sakramentem do chorego koło karczmy, a w téj [bezbożnik bluźnił Bogu], powstało trzęsienie ziemi, wskutek którego całe sie miasto [Kosi Targ w Dolinie Nowotarskiej] zapadło wraz z mieszkańcami i calym ich dobytkiem).

Although such scenarios display various differences, they all rely on a common belief that sinking into the ground is a punishment for evil deeds committed by wicked people. Some scenes include the person who makes the curse as the agent at the centre: he/she uses the power of the word (in the form of a fixed formula) as an instrument that instantly produces the desired effect. In the background, however, there is God as the actual source of power and the earth as the executor of God's judgment. In folk beliefs, then, the one who curses is a mediator [Engelking 2017: 142-143], whose function is to guard and protect God's law. In turn, scenes in which the earth - carrying out God's punishment - swallows the wrongdoer and the place where they committed their deeds, feature God at the centre as the source of power that makes it all happen. In both cases, the earth functions as an instrument in the hands of the supreme sacred force.

The status of the earth as an ethical authority is apparent in a number of examples in which it executes God's punishment: the earth annihilates a perjurer, refuses to accept the body of a villain or a vampire, refuses to "support" (nosić) a sinner, shakes and trembles (six fathoms deep) when a child killer makes her confession [SSSL 1.2: 20]. The profile of the earth as a guardian and protector of moral order overshadows the physical properties foregrounded in the profile of mother-earth (fertility, the ability to feed).

The profiling of the earth in terms of the opposition between "one's own/ familiar" (swój) and "strange/alien" (obcy) results in a distinction between the 
sacred earth and the land that does not belong to anyone (amorphous and open to interference by evil forces). This distinction is conveyed in the prohibition against burying suicides, villains and those who "did not die their own death" in consecrated ground (graveyards or cemeteries). Instead, they are supposed to be buried wherever their life came to a tragic end, often by the roadside or in a forest [SSSL 1.2: 20]. In this case, the operation of the FORCE schema involves a willing acceptance of the system of commands and prohibitions embodied in such formulas as:

- it is forbidden to bury suicides and villains in consecrated ground;

- those who did not "die their own death" need to be buried where they died.

The profile of the earth as "alien" also includes its interior. Owing to its darkness and depth (similar to that of the waters), it is associated with the demonic sacred and with death as such. Images of wicked people and evil places sinking underground introduce the opposition between the surface of the earth, viewed as God's world created for the living, and the earth's interior, seen as "otherworlds" (zaświaty). In this case, "otherworlds" are understood in a narrow sense, as a dwelling place of evil forces (devils, demons and the people they have stolen), identified with hell, the place of punishment for the wicked who had been swallowed up by the earth, or with the grave, where human bodies wait for the Last Judgment.

Scenes of the earth opening up are based on mythical images of evil spirits being thrown into the abyss of hell: "Hell was said to be located in that hemisphere of the earth where devils, the rebel angels, had fallen for forty days and nights, until they called God's name and stayed there" (Twierdzono, że piekło jest na jednej pótkuli ziemi, gdzie diabły, zbątowane anioły, leciały 40 dni i nocy, asz wezwały imienia boskiego i tam się ostały) [SSSL 1.2: 46].

The profile of the earth's interior in general, and of caves and caverns in particular, is based on the oppositions up vs down, light vs darkness, familiar vs strange and open vs closed, which endow it with an air of menace and mystery. The folk imagination associates such places with hidden treasures guarded by underground evil spirits (mamon 'evil spirit guarding buried treasures'; skarbnik 'mine spirit', lit. 'treasurer'), snakes, mythical dragons, or the Slavic evil demon called licho [SSSL 1.2: 146; Adamowski 1999d: 133]. Linguistic correlatives of this image include modal expressions of prohibition (nie wolno 'it's forbidden to', nie należy 'one shouldn't'), as can be observed in the case of the prohibition against entering caves, particularly common in the mountain regions of southern Poland [SSSL 1.2: 143]: 
- one should not enter caves with long corridors, as there are unknown forces at work there;

- one should not enter a cave where a snake has gone into hiding.

The negative image of the earth's interior is also reflected in magical practices performed to banish what is evil and dangerous into the underground depths. This is apparent not only in curses and malediction formulas (e.g. "Open up, earth!", "Let the earth swallow you!" Rozstap sie ziemio!, Niech cię ziemia pochłonie!) but also in cure spells, spells against vampires, directive speech acts (e.g. a command to bury men suspected of being vampires face down to prevent them from walking the earth) and the practice of "burying the disease" [SSSL 1.2: 30$]$ :

- "Pain, go as deep down into the ground as the sun is high up in the sky" (Idź bólu w ziemię głęboko, jak na niebie słońce wysoko);

- [addressing keratitis (łuszczka):] "If you belong to the moon, off you go to the moon! If you belong to... [the enumeration includes six more items and concludes with:] If you belong to the earth, off you go into the ground! Not by my own power, but with the help of the Lord Jesus and His Holy Mother" (Jeśliś księżycowa, idź do księżyca! Jeśliś... (...) Jeśliś ziemska, idź do ziemi! Nie moja moca - Pana Jezusa dopomoca i Matki Najświętszej dopomoca);

- "Hot and cold paskudnik [a disease in horses and cattle, lit. 'a nasty sort of creature'], you got into my beast's nostrils, and from its nostrils into its horns, and from its horns into its eyes, and from its eyes may you now vanish a hundred ells underground" (Paskudniku zimny, goracy, wlazłeś memu bydlęciu w nozdrza, a z nozdrzów do rogów, z rogów do oców, a $z$ oców, abyś się przepádt na sto łokci $w$ ziemię);

- "Walk underground and don’t scare anyone!" (Chodź ziemią, a nie strasz nikogo!), a formula uttered when burying a male vampire (strzygoń);

- "A vampire (strzygoń) has to be buried face down so that he will walk deep into the ground" (Strzygonia trzeba pochować twarza do ziemi, by upiór wszedt w głą ziemi);

- "Burying the disease involves burying the sick person's hair, an item of his/her clothing or belongings and, most often, his/her urine; as they rot, so does the disease" (Zakopywanie choroby zasadza się na zakopywaniu w ziemi włosów, rzeczy lub szmaty jakiej chorego, a najczęściej moczu jego; w miare jak one gnija, gnije i choroba).

Caves, caverns and potholes are liminal places on the border between different worlds and, as such, are profiled as "strange/alien". On the other hand, they can 
also acquire positive connotations - they offer shelter and are identified as sites of apparitions of holy figures (particularly the Virgin Mary). As a place of seclusion, however, they are profiled as "strange/alien". Folk legends mention knights and armies sleeping in their depths, and saints taking refuge or doing penance in rocky shelters [SSSL 1.2: 138, 139, 142, 143; Adamowski 1999d: 131-136]. In view of the popularity of such motifs in oral literature, these connotations form an axiologically charged stereotype of relations between the real and supernatural worlds. Underground locations which offer shelter to holy figures and sleeping armies are perceived as sacred and, consequently, are ascribed a positive value on the axiological scale.

The image of the earth's interior (caverns and caves) as a safe place is grounded in the primal experience of the safety of the mother's womb, consolidated as the LINK schema. Thus the axiological charge of the LINK schema prevails over both the UPDOWN and CENTRE-PERIPHERY schemas. It should be noticed, however, that in the case of the latter, it only depends on the conceptualiser's point of view as to whether the cave providing the shelter will be considered the centre (for the person hiding within) or a place of seclusion (for an outside observer).

The profiles of the earth based on the structural metaphor EARTH IS A MOTHER emerged as a result of focusing the conceptualiser's attention on particular features of the mother and the functions she performs in the family: the child-bearer, nurturer, carer, guardian and protector of moral order. The polysemy of this metaphor and its function of linking the human world with the universe endow it with symbolic meaning, related mainly to the earth's life-giving power. An important element of this profile is that the earth as mother is attributed the maximum positive axiological value, which entails an obligation to honour and respect it.

The prototypical nature of the family-based model of the cosmos, particularly the distinctive image of mother-earth and her union with heaven/the sky, had an impact on imaging other natural elements, weather phenomena and celestial bodies. In a pattern analogical to that of the earth, they acquired a sacred status and became personified. In the folk imagination, fire, wind, water, the sun, the moon and the stars - like the earth - have a human form and are treated as conscious living beings with feelings and emotions [Tomicki 1981: 31; Bartmiński 2009b: 135-137, 208], who eat, drink and live in their cottages. For example, fire is presented as "a guest in a red coat" (gość w czerwonym płaszczu) ${ }^{11}$ who "devours" (pożera) and "digests" (trawi) [Szadura 1998: 330]; the sun - as a farmer

11 This is an example of the euphemistic use of the word gość 'visitor' with reference to a potentially dangerous phenomenon (e.g. fire). As believed, any disastrous effects of its 
who "eats raw honey with a large wooden spoon" (miód przaśny jada kopyścią) [Niebrzegowska 1986: 38]; the wind - as "a dark-complexioned man in a patched sheepskin coat" (mężczyzna czarny lub smagławy w połatanym kożuchu). Winds, like people, sleep and consume food and drink; they have their homes "in inaccessible rocks and cliffs or in dense forests" (po niedostępnych urwiskach i skałach lub w lasach gęstych) [Bączkowska 1986: 56].

Other atmospheric phenomena, in a more or less anthropomorphised form, take a peripheral place in the structure of the living cosmos, in which the prototypical images HEAVEN AS A FATHER and EARTH AS A MOTHER (based on the more general metaphor COSMOS IS A FAMILY) occupy a central position. These, in turn, become a model for further conceptual derivatives, such as personified representations of the sun, fire, wind and water. Since the image of mother-earth is closest to the conceptualiser's perspective, and thus the most vivid, it is the one most often replicated. It also becomes a semantic node for the development of cognitive paths leading to other cognitive events, showing scenes of creation and the ensuing relations between the physical and metaphysical worlds.

\subsection{The creation myth based on the concept of the cosmic egg}

According to another pre-Christian cosmogonic myth, the earth hatched from the cosmic egg. Remnants of this archetype can be found in many different cultures around the globe, including Slavic culture [Eliade 1958: 413-416; Kowalski 1998: 172; MifyNM 1988: 681; Niewiadomski 1989: 65-66; 1999: 139 ff; Toporov 1967: 81-82]; they have also been recorded in Poland: "The earth was created out of a huge egg which lay on a sky-high tree" (Ziemia została stworzona $z$ wielkiego jaja, które leżało na niebotycznym drzewie) [SSSL 1.2: 27, 28]. This brief quotation combines two images: the cosmic egg and the tree of life. In this case, the connection is based on the profile of the earth as life-bearing mother, with the life-giving power as a shared semantic node. Owing to its role in the act of creation, the earth is believed to have demiurgic powers. This, in turn, warrants numerous agricultural rituals aiming to stimulate its fertility by combining the life-giving power of the egg and earth [Niewiadomski 1989: 61; 1999: $142 \mathrm{ff}$; Kowalski 1998: 174].

unexpected occurrence can be prevented by observing appropriate rules of conduct in order to make such a "visitor" leave; cf. Chapter 6.2.2 below. For more on taboo in Polish dialects, see Krawczyk-Tyrpa 2001a, 2001b, 2001c. 
Scenes in which the vital powers of the earth are quickened by means of the magical properties of the egg are mostly connected with the rituals of the first ploughing of the year. The role of the agent is performed by a couple (as in the original act of creation, involving the female and male elements) - the farmer, who begins ploughing, and his wife, who throws a raw egg into the first furrow. In another variant of the ritual scenario, the farmer eats an egg he is given by his wife before he starts work [KLS 1967: 513; Niewiadomski 1989: 61-62; 1999: 145-146]. In this case, it is the farmer who is in the centre of the scene: he eats the egg to absorb its power, which he then passes on to the earth. ${ }^{12}$

In folk culture, ploughing symbolically represents a procreative act. In this context, the first driving of the ploughshare into the ground becomes a repetition of the act of creation; the addition of an egg as an instrument of power is supposed to make the act more effective. The scene under consideration is a complex derivative of several prototypical images: the act of the fecundation of the earth by the sky, the cosmic egg (a symbol of the beginning, condensed vital energy and rebirth) and the farmer as the demiurge (see further below).

In this case, the FORCE schema operates according to the patterns of ATTRACTION and INTENSIFICATION, which involves such directive formulas as:

- one needs to throw an egg into the first furrow so that the soil will be more fertile;

- the man of the house has to eat an egg before he starts the first ploughing of the year so that the earth will bear more crops.

Rituals aiming to stimulate the fertility of the earth by feeding it (e.g. throwing an egg into the first furrow or eating an egg before the first ploughing of the year) are connected with the profile of mother-earth who devours her own offspring. This motif appears in a legend according to which the earth complained to Jesus that

(...) people benefited so much from her crops that she had no food for herself (...). And the Lord Jesus said to her: "You will give birth to people and you will devour them; you will eat what you give birth to because it is yours." Ever since, people have been her

12 Analogical use of the egg in agricultural rituals which survived into modern times has been recorded among Swedish, German and Estonian peasants. Similar customs are practised by the Cheremisses and the Votyaks, who throw eggs up in the air before they start sowing the land. In other cultures, eggs were buried in the ground or eaten before ploughing or sowing [Eliade 1958: 415-416]. 
property, which is why each and every one of us has to be buried in the ground after death so that we will return to where we came from.

(...) ludzie tyle korzyści czerpią z jej płodów, a ona sama nie ma się czym pożywić (...). A Pan Jezus powiedział jej tak: „Ty będziesz ludzi rodziła i będziesz ich pożerała, co sama urodzisz, to sama zjesz, bo to twoje”. Odtąd ludzie stali się jej własnością, dlatego każdy z nas musi po śmierci do ziemi wrócić i w niej być pochowanym. [SSSL 1.2: 40]

The motif of the earth devouring the bodies of those who have passed away can also be found in a number of funeral hymns and speeches: "You return to earth that has been your mother,/ She has fed you so far, now you'll be devoured" (Powracasz w ziemie, co twa matka była,/ Teraz cie strawi, niedawno żywiła) [SSSL 1.2: 35]. The reproduction of this fixed pattern resulted in its lexicalisation, as can be seen in some commonly used phrases: oddać ciało ziemi ('to commit/return one's body to the ground', i.e. 'to bury'), być już trawionym przez ziemię 'to be digested by the earth', i.e. 'to be dead', gryźć ziemię 'to bite the ground, i.e. 'to be dead').

In view of the symbolic connection between the earth, with its life-giving power, and the egg, with the life it carries within, the magical practice of combining their energy aims to intensify their potential. This is also visible in Easter customs, such as decorating Easter eggs (pisanki, sing. pisanka), exchanging them as gifts between young men and girls, adding Easter eggshells to seed corn, throwing them into the freshly ploughed earth, scattering them over the field, in the vegetable garden and under fruit trees [Niewiadomski 1989: 69; 1999: 141146; Kowalski 1998: 174]. The same ATTRACTION OF FORCE schema is at work here, motivating actions that are consciously performed according to such directive/persuasive formulas as:

- at Easter, you should make a gift of an Easter egg to the lass/lad you choose;

- one should/needs to add Easter eggshells to seed corn so that the crops will be better;

- one should/needs to scatter Easter eggshells over the field/vegetable garden/ under fruit trees so that they will bear more crops.

The fact that traditional techniques of decorating Easter eggs make use of selected colours symbolising vital energy (red - prototypically associated with blood, yellow - with the sun and God, and green - with the rebirth of vegetation) demonstrates a profound belief in their effectiveness [Niewiadomski 1989: 63] ${ }^{13}$

13 The custom of decorating eggs is a very old one and has been recorded in a number of different cultures around the world. As part of springtime celebrations, painting eggs in symbolic colours and patterns was a magical practice whose aim was to stimulate 
The illocutionary force of this belief is embodied in speech acts which recommend using particular colours:

- Easter eggs should be decorated using green, red or yellow.

Reference to the basic domain of COLOUR forms a cognitive path between the egg (particularly its yolk) and the sun, ${ }^{14}$ which is also credited with a fertilising power. This connection recurs in folk texts, where the image of hot sunbeams burning a young woman suggests a procreative act, particularly if it appears in conjunction with dew, rain or water [Majer-Baranowska 1986: 35]:

(1) Słońce siada, rosa pada po drobnej leszczynie

Kochaj-ze mnie a nie zdradzaj, kochaj dworzaninie.

(2) Czego ty dziewczyno pod jaworem stoisz?

Czy cię słońce piecze, czy się deszczu boisz? Słońce mnie nie piecze, deszczu się nie boję

Czekam na Jasieńka, pod jaworem stoję.
(1) The sun is setting, the dew is falling on the hazel tree

Do love me, my swain, and be true to me.
(2) Why are you standing under a maple tree, girl? Are you too hot in the sun or afraid of the rain? No, I'm not too hot in the sun or afraid of the rain, I'm waiting for my own dear Johnny under a maple tree.

The symbolic meanings of the above texts preserve traces of two cosmogonic myths: the fecundating power of sunbeams is analogous to that of a bolt of lightning during the act of creation, while the motif of rain recalls the original fertilisation of the earth by a shower from the sky.

The link between the egg and cosmogonic energy is also apparent in magical healing practices which involve rolling an egg over the sick person's body with a view to restoring his/her vital forces [KLS 1967: 280; Niewiadomski 1989: 69; Kowalski 1998: 177]. These are analogical to curative practices which draw on the powers of earth, such as pulling a sick person through a tunnel dug in the ground, burying him/her in the ground for some time, applying an earth poultice

the vital powers of the earth after winter and to summon spring. Decorative patterns in the shape of the sun, green tree branches and flowers evoke cosmogonic meanings. In Christian culture, they are interpreted as symbols of resurrection, with the colour red symbolising the blood of Christ [Kowalski 1998: 178].

14 The egg is also an archaic solar symbol [SSSL 1.1: 122]; since the cosmic egg was described as golden, it also acquired other solar qualities [Kowalski 1998:173]. 
and rubbing with earth [SSSL 1.2: 25]. Direct physical contact between the egg and the patient's body involves a kind of exchange: the egg absorbs the disease and transfers its own vital powers to the patient. The apotropaic qualities of the egg are attributed both to its shape (a sphere) and to its prototypical function as a container (the shell), hiding compressed life-giving energy [Kowalski 1998: 177; Niewiadomski 1999: 149].

Although in this case we also encounter directive/persuasive formulas, they are usually applied by the healer, who performs a magical action and assumes the archetypal role of the agent; the sick person, in turn, is the object, and the egg an instrument of FORCE. The perlocutionary force of consequent speech acts is revealed in scenes of magical practices performed according to a ritual scenario framed by directive/persuasive formulas:

- an egg should be rolled over the sick person's body so that it absorbs the disease;

- a person who is sick should be pulled through a tunnel dug in the ground;

- a person who is sick should be buried in the ground (for a specified amount of time), and he/she will be cured thanks to the healing power of earth;

- an egg rolled over the sick person's body gives him/her its vital energy.

Both the egg and earth take their power directly from the source - the sacred, present in the background of the scene. The ritual scenario re-enacts the scene of creation, in which the earth received its power from God. Pulling a sick person through an underground tunnel reactualises the act of birth: he/she is symbolically reborn. Creating a new reality is only possible thanks to summoning the inexhaustible power of God. However, unlike in the original act of creation (when the Creator was the agent himself and the event was a single and immediate act), the operation of FORCE in a ritual performed by a mediator (a healer) involves a much longer scenario, as it requires additional actions to summon the power of the sacred (the ATTRACTION and INTENSIFICATION schemas).

Rolling an egg over the sick person's body evokes the myth of the cosmic egg, hence also the scene of the origin of the world. Divine energy, the source of power, is symbolically enclosed in the egg, which functions as the principal attribute in the hands of the main actor of the ritual scene. Traces of this myth can also be seen in funeral rituals and in the custom of placing an egg in the coffin in expectation of the afterlife and the resurrection on Doomsday. The process of profiling focuses on certain particular qualities of the egg and the earth which - apart from their life-giving energy and power of fertility - highlight the continuous natural cycle of death and rebirth. The above scenarios of 
ritual practices related to fertility, birth and death suggest that the energy that is being transmitted not only stimulates the fecundity of the earth and fertility of the woman, or heals the sick, but also has the power to transfer the soul into the afterlife [Niewiadomski 1989: 69; 1999: 148-149; Kowalski 1998: 174].

Remnants of the myth of the cosmic egg, apparent in beliefs and rituals presented above, provided a common platform for the development of cognitive paths connecting the symbolic meanings of the earth, the egg and the sun with the domains of life and death. In the creation myth, the metaphysical states of being and non-being are construed on the basis of immediate experience and observation of new life hatching from an egg, which naturally comes to be associated with the idea of fertility, the cycle of life and vitality. A further process of scanning the experiential base results in the inclusion of other domains (colour, shape, temperature and atmospheric phenomena). This leads to the development of a network of connections based on the concept of the prototypical union between the male and the female elements, linking the egg and the earth with the sun, rain and lightning.

\subsection{The agricultural version of the creation scene}

Magical practices performed at the first ploughing of the year evoke the farmyard version of the scene of creation (known from the so-called Cracow myth, mit krakowski), in which God, who is the source of power, performs the archetypal role of the sower and creates the earth out of a grain of sand that He throws into water (onto the back of a whale). This version shares the SOURCE-PATH-GOAL schema common to all images of the act of creation:

God took his sprinkling brush, drove the waters apart and sprinkled drops from heaven to the right and the left (...). He ordered the water to sink to the bottom of the sea, picked up two whales, laid them across each other and threw a tiny grain of sand on top of them. The earth grew on their backs like dough (...). When the earth He created had grown so much that it reached the threshold of heaven, the God of light said unto her: "Thou earthly world, the souls' stairway to heaven thou shalt be; I will give thee light, I will give thee heat from the sun so that thou bearest life and thou nourishest what thou givest birth to".

Bóg wziął kropidło, rozegnał wodę i kropił z nieba na prawo i lewo (...). Nakazał wodzie, by opadła na dno morza, wydobył dwa wieloryby, złożył na krzyż, na nie rzucił kruszynę piasku. Ziemia rosła na ich grzbietach jak ciasto (...). Kiedy ziemia stworzona dorosła pod próg nieba, Bóg światła rzekł do niej: „Ziemio, świecie ziemski, ty będziesz 
dla duchów schodami do nieba, oświecę cię światłem, ogrzeję słońcem, żebyś rodziła i żywiła, co urodzisz". [Mit krakowski (The Cracow Myth), K vol. 7: 4; Benedyktowicz D.,

Benedyktowicz Z. 1992: 34]

The process of construing the scene of creation relies on knowledge stored in the experiential base, which includes everyday experience (as in the image of sowing, or of rising dough which becomes the earth), personifications (God as a farmer, the earth as a life-bearing and nurturing mother), religious beliefs based on the biblical tradition (the breaking of darkness, the separation of land and waters, the creation of the sun as the source of light and heat) and gestures of sanctification (sprinkling with water).

The profiling of the scene, archetypal roles and the conceptualiser's point of view are consistent with the canonical model of a primary experience of FORCE independent of human will. God the Father is the agent located in the centre of the scene, a grain of sand is the instrument, and the result is the creation of the earth, which is immediately assigned the role of a life-giving and nourishing mother and the mediating function of "the souls' stairway to heaven". The human being is in the background as the recipient of the act of creation, expected to follow God's will: his/her task will be to journey from the earth to heaven in order to reunite with the Father. The conceptualiser is an observer positioned outside the scene; he/she transmits knowledge of the creation, which is based on religious beliefs that he/she shares with the addressee. Although the experience of FORCE involves COMPULSION (an experience of force operating independently of human will), a contextual interpretation of this image reveals that God's action should be treated as an act of grace (the gift of life on earth) and a promise of immortality (the journey of souls to heaven). The conceptualiser's point of view displays a high degree of identification with the image, as evidenced both by construing the Creator as a farmer-sower who blesses his land and farm with his sprinkling brush, and by the positive axiological value of the message.

Apart from the source of power and the mode of its experience by the object, the FORCE schema implies interaction of varying intensity and types of impact. The creation of the world is construed here as a completed process, performed in a specified, relatively short period of time rather than an instant. While the source of power is inexhaustible, the time and intensity of its impact can vary. The roles ascribed to the sun (to provide heat and light) and the earth (to bear and nourish life) make them permanent recipients and transmitters of the inexhaustible power of God. 


\subsection{Patterns of interaction in the act of creation and its ritual re-enactment}

\subsubsection{Interaction on the part of man}

Human response to God's act of creation mainly involves its re-enactment in agricultural rites and in rituals performed when laying the foundations of a new house (zakładziny). Such prototypical patterns of behaviour include sprinkling a newly built house with holy water [Benedyktowicz D., Benedyktowicz Z. 1992: 45, 57] and reproducing the cosmic beginning in the ritual of the first sowing of the year [Niewiadomski 1998: 59; 1999: 47-53]: the work is started before dawn (evoking the darkness before the creation) and performed in silence and solitude (the sower cannot be seen and has to be alone, as God was). Rituals of the first ploughing and sowing require that work must be done very carefully since leaving out patches of land unsown would bring death upon the farmer or his family, as can be seen in the expression "to sow [one's own] grave" (usôc [sobie] grób) [Sychta 1967: 363; 1972: 6; Treder 1989: 21].

Other examples of imitating the act of creation include sowing ash in order to ensure good crops [Szadura 1995: 89] and the ritual of baking bread, which evokes the idea of the earth emerging from rising dough. Making the sign of the cross on the loaf before putting it into the oven, and before cutting it, endow baking with the status of a holy ritual; the gestures signify making contact with the sacred to receive blessing, and draw God's creative power upon the fruit of human work [Treder 1989: 179]. The same function is apparent in making the sign of the cross before the first ploughing and sowing of the year, as well as in sowing grain in a cross-like pattern (walking both along and across the field) [Niewiadomski 1999: 110, 137; Treder 1989: 181].

The ritual scenarios presented above display the pattern of ATTRACTING divine power. In this model, the person performing the role of the Creator (the farmer blessing a new house with a sprinkling brush, the sower, the woman baking bread) takes over the centre of the scene, and the source of FORCE (God) is moved into the background. Since the agent is only a mediator transmitting God's power, the impact of force diminishes and needs to be intensified by performing certain actions, such as evoking the circumstances of the act of creation and using magical gestures and tools (e.g. adding ash, Easter eggshells, or catkins from traditional Easter palms (bunches of willow twigs) ${ }^{15}$ to seed corn; feeding the earth by burying eggs in the fields saying "Eat, earth, and make cereals

15 See Chapter 1, note 1. 
grow well" (Jedz ziemio i spraw, by zboża dobrze rosty) [Niewiadomski 1989: 67; 1999: 146]; making the sign of the cross before sowing).

In one such example, a woman baking bread jumps saying "Bread, rise as high as the sun in the sky" (Rośnij chlebie jak stonko na niebie) [SSSL 1.1: 127], a formula aimed at intensifying the power of the leavening process. The spell itself evokes the creation myth in which the earth was moulded out of dough, like bread, and repeats God's words to give the leaven the energy to make the dough rise as high as the sky. In this way, the woman ritually re-enacts the act of creation and strengthens it by an additional imitative action (jumping). The metonymic connection between the sky and the sun on the one hand, and common properties shared by the sun and bread, based on similarity (such as their shape, colour and the high temperature required for baking) on the other, open up new possibilities of creating a chain of links between the earth, the sun, bread, the stove and the woman as the principal actor of the scene [Kubiak I., Kubiak K. 1981: 16, 27]. Magical formulas which explicitly associate bread (and the process of baking) with the sun uttered by women putting bread into the oven can serve as an example of direct lexical connections between bread and the sky and the sun (and thus God) [Treder 1989: 17]:

- "Bread, come out high, like the sun in the sky" (Zdarzë sę chleba, jak stuńce $z$ nieba);

- "Bread, bake well and high, like the sun in the sky" (Upiecz sie chlebie, jak słońce na niebie);

- "Bread, rise as high as the sun in the sky" (Rośnij ty chlebie, jak słońce na niebie);

- "May bread come out good and brown as if baked by the sun" (Niech się chléb darzy, jak słónuszko skwarzy).

The pattern of attracting divine FORCE is grounded in the conceptualiser's religious attitude and results from INNER COMPULSION. This model is illustrated by the observance of rules stemming from a sense of importance of the moment and from respect for work on the land, and for bread as a gift of God. Examples include: the command to remain silent while sowing; the prohibition against beginning sowing if the sower has met someone on his way to the field; the obligation to carefully sow the whole field since leaving empty patches would bring death upon the sower or his family [Niewiadomski 1999: 249-253, 264]:

- one should remain silent while sowing;

- you must not begin sowing if you have met someone on your way to the field; 
- the whole field needs to be sown carefully so that there are no empty patches left, as this would bring death upon the man of the house or his family;

- one needs to fast before the first sowing of the year and begin the task on an empty stomach.

By contrast, the prohibition against turning a loaf of bread upside down reflects a conviction that the same would happen to the order of the world [Benedyktowicz D., Benedyktowicz Z. 1992: 63; Kowalski 2000: 85; Kubiak I., Kubiak K. 1981: 117; Niewiadomski 1999: 160; Simonides 1991: 180]. It is a canonical example of OUTER COMPULSION stemming from a social belief in catastrophic consequences of infringing the system of values embodied in the symbol of bread, as phrased in the following warning:

- one must not turn a loaf of bread upside down or else the same will happen to the world.

The image of the earth as a path to heaven for souls is reflected in death rituals. Laying the dead body on white sand, placing the dying on the ground to make their death easier, or throwing a lump of earth on the coffin actualise the mediating function of the earth, which, according to the above version of the myth, God conferred on it in the act of creation. Such ritual actions follow the model of OUTER COMPULSION, based on adherence to the binding norms of behaviour. The funeral ritual endows the ceremony with symbolic meaning: the body is returned to mother-earth. The custom of placing a loaf of bread in the coffin evokes the image of the earth as sourdough (and hence bread) and its function as "the souls' stairway to heaven". A symbol of life, bread - like an egg - placed in the coffin has a similar function: it provides food for the soul and enables passage to eternity [Kowalski 2000: 148-149], particularly if it has been baked in the shape of a ladder to make it easier for the soul to reach heaven [Kubiak I., Kubiak K. 1981: 92].

A loaf of bread is placed at the head of the deceased so that they will not be hungry on their long journey, and another one in their right hand, so that they can appease Cerberus, who is tied at the entrance gate to paradise; they also place two coins, for the passage across the river, in their left hand (...). [Biegeleisen 1930: 182]

In turn, the symbolic custom of throwing grains of corn on the coffin (or placing them inside) is a variant of imitative sowing. This tradition evokes rites of passage representing the journey through life and death. Since the grain dies in order to come back to life again, it is a sign of transformation. Providing the deceased with grain "for the journey to eternity" in his/her coffin confirms its 
symbolic meaning and transformative function, analogical to that of the egg and of bread [Niewiadomski 1999: 179-181].

The custom of eating "funeral bread" (żałobny/żałosny chleb, lit. 'mournful bread' [Gloger 1978: 234]; in Kashubia: pustonocny chleb, lit. 'empty-night bread' [Treder 1989: 177]) by mourners attending an "empty night" (pusta noc, the night before the funeral) or a funeral meal is a gesture of bidding farewell to the deceased. As sacrificial food, funeral bread had the mediating function of connecting the world of the living with the souls of the ancestors. Specially-made bread was given to beggars invited to the feast so that they would pray for the soul of the deceased and make his/her passage to "otherworlds" (zaświaty) easier. This was supposed to protect the family against the soul returning home, as well as to ensure the well-being of the dead person in "the other world". Similar practices were performed on All Souls' Day [Kowalski 2000: 154; Kubiak I., Kubiak K. 1981: 92]:

(...) in memory of the dead, small loaves of special ritual bread baked before All Souls' Day were given to beggars to pray for the souls. [Biegeleisen 1930: 261]

The metonymic connection between mother-earth on the one hand, and bread and house/home (dom) on the other, led to the development of fixed cognitive paths between them. At a funeral, carpenters who had made the coffin received thanks for "building a house" (postawienie domu) and a gift of the bread that lay on the lid during the ceremony. The ritual was performed according to a strictly observed scenario: addressing the mourners, the carpenters said "Forgive us" (Przebaczcie nam), and heard "We forgive you" (Przebaczamy wam) in reply; then they received their gift and their pay. Likewise, when someone died it was a custom to say euphemistically that he/she "has built him/herself a house" (postawit sobie chatupe); coffins were sometimes referred to as "new little houses" (nowe domki) [Kubiak I., Kubiak K. 1981: 92]. Also, the knell of church bells was interpreted as an onomatopoeic call home, e.g. "Home, go home" (Dodóm, poj dodóm), "The bells will soon call me home" (Zwonë mie ju wnet dodóm zawołaja), a phrase expressing a premonition of death [Krawczyk-Tyrpa 2001b: 81]. Funeral hymns, too, include references to the house/home as an equivalent of the grave: ${ }^{16}$

16 Quotations from funeral hymns come from materials published by Jan Adamowski, Jadwiga Doda and Halina Mickiewicz [Adamowski, Doda, Mickiewicz 1998: 253-318]. 
Ostatni raz żałobny ton

w pożegnaniu w rozstaniu dzwon, w trumnie na cmentarz prowadzi on, w krainę ciszy, gdzie wieczny dom.
The last mournful tone

The toll of parting and farewell As the coffin goes to the graveyard

Into the land of silence, the eternal home.

from "Ostatni dzwon" (The last toll of the

bell), a funeral hymn

The hymn deploys two profiles of death of the locational type, developed by euphemism based on the concept of home. Both of them present death as moving into a new house, which is imagined either as heaven or, alternatively, as a cold, dark grave. ${ }^{17}$

The semantic connection between the earth and death, in turn, can be seen in a number of lexemes based on the verb grzebać 'to bury': pogrzeb 'burial', i.e. 'ceremonial placing of a dead body in the earth', grób 'grave', grabarz 'gravedigger'; cf. also St. Pol. expressives: iść do piachu 'to go into the sand', iść do ziemi 'to go into the earth', znaleźć się kilka metrów pod ziemia 'to go a few metres underground, i.e. 'to die'; chylić się ku ziemi 'to bend to the ground', i.e. 'to age, to approach death'; Kashubian: cało chce $w$ ziemie 'the body wants to go into the ground', i.e. 'a dead body should be buried as soon as possible' [Sychta 1967: 113], komus je juz czas do zemi 'it's time for someone to go into the ground', i.e. 'time to die' [Treder 1989: 178].

The funeral rite closes earthly existence: the body is solemnly returned to mother-earth, where it will wait until the Last Judgment to be resurrected, while the liberated soul makes its journey to "otherworlds" (zaświaty):

Pogrzebiemy ciało w grobie,

niechaj odpoczywa sobie,

albowiem z ziemi stworzone

w ziemię będzie obrócone.

Alibo się w proch obróci,

znowu mu Bóg życie wróci,

ciało nasze skazitelne

zmartwychwstanie nieśmiertelne.
We'll bury the body in the grave

Let it have its rest,

For of earth was it first made

And so will turn to dust.

Though to dust it will turn

God will bring it back to life.

Our tainted body

Will rise eternal.

from "Pogrzebiemy ciało w grobie" (We'll

bury the body in the grave), a funeral

hymn

17 For the motif of death in the context of taboo, see Engelking 1984; Krawczyk-Tyrpa 2001b: 73-86. 


\subsubsection{Interaction on the part of demonic forces}

Construed in terms of the SOURCE-PATH-GOAL schema, the mythical image of creation also includes the concept of Satan's involvement as the opposite demiurgic power. The folk image of the devil accompanying God in the act of creation confirms the belief in the perennial existence of good and evil. This motif is present in a mythical story from central Poland in which God orders the devil to bring some sand from the bottom of the sea so that He can create the earth [Tomicka, Tomicki 1975: 24]: ${ }^{18}$

"Dive to the bottom of the sea and bring me a handful of earth saying that you do it in my name; bring it and I will create the earth out of it." The devil dived and grabbed some sand in his hands saying "I take you in my own name". When he surfaced, he did not have a single grain left. He dived again and said "I take you in His name". When he returned, he had some sand under his claws left. God took it and sprinkled it over the water, and the sand turned into the earth, but it was only big enough for the two of them to lie down comfortably. Lie down they did then: God in the east, and the devil in the west. When the devil thought that God had fallen asleep, he began to push Him so that He would fall off and drown in the sea. But it was all in vain: wherever God was, the earth grew underneath, and so it kept growing further and further to the east. Having seen this, the devil pushed Him west, and then south and north, which made the earth grow in different directions. When God woke up, He went to heaven. When the devil followed suit, God waved His hand and, amidst bolts of thunder and flashes of lightning, the devil was thrown into the abyss.

Zejdź na dół w morze i przynieś mi ziemi garść, mówiąc, że niesiesz w moim imieniu, przynieś, uczynię $\mathrm{z}$ tego piasku ziemię. Djabeł poszedł, nabrał piasku w garście mówiąc - Biorę cię w imieniu Mojem. Gdy wyszedł na wierzch, nie zostało ani ziarnka piasku. Poszedł drugi raz mówiąc - Biorę cię w imieniu Jego. Gdy wrócił zostało mu trochę piasku za pazurami. Bóg wziął ten piasek, posypał na wodę i stała się z niego ziemia, ale tylko tak duża, aby mogli się obaj wygodnie położyć. Położyli się tedy, Bóg ku wschodowi, djabeł ku zachodowi. Gdy djabłu się zdawało, że Bóg usnął, zaczął go spychać, aby wpadł do morza i aby utonął i zginął. Ale nadaremnie, ziemi pod Bogiem przybywało i rozszerzała się daleko ku wschodowi. Widząc to czart jął pomykać ku zachodowi, dalej ku południowi i północy a przez to ziemia rozszerzyła się w rożne strony. Bóg obudziwszy się wstał i poszedł na niebiosy. Czart pobiegł za nim, wtedy Bóg skinął - pioruny zaczęły uderzać, błyskawice zabłysły i djabeł strącony został w przepaść. [Mit 3]

18 Similar versions of this motif are known among different Slavic peoples, particularly the East Slavs; some studies (especially Tomicki 1976) view this as evidence of attributing the act of creation to two demiurgic powers. 
According to the SOURCE-PATH-GOAL pattern of the FORCE schema, God, who performs the archetypal role of the agent, is both the source and wielder of power. He causes a grain of sand brought by the devil from the bottom of the sea to grow into an island, thus establishing the central point of the cosmos. God and the devil lie down to have a rest: God in the east, and the devil in the west. As a result, the island acquires a horizontal structure with the attendant bipolar axiology. The dichotomy between east and west reflects the opposition between God and Satan, and hence good and evil, and pertains to both the geographical directions and times of the day: ${ }^{19}$ God performs the act of creation at sunrise, and the devil begins his machinations at sunset. This temporal opposition also involves the contrast between light (associated with God) and darkness (associated with the devil). Throwing the devil into the depths of the waters introduces the vertical opposition between UP and DOWN [Tomicki 1976: 58, 59]. ${ }^{20}$ In this way, the SCALE schema is inscribed into the spatio-temporal structure, assigning, respectively, positive and negative values to it.

One attribute of God's power is that it can be transferred to those who act on His behalf as He pleases. This means that the scenario also incorporates the CONTROL schema since God is presented not only as the Creator but also the master of the universe: water and earth obey His orders and refuse to give Satan even a grain of sand. In addition, God is shown as the lord of thunder and the victor over the devil, whom He throws into the depths of the ocean when $\mathrm{He}$ discovers his trick.

The conceptualisation of Satan as sea foam, in turn, stems from archaic cosmogonic myths according to which the primordial ocean was the source of all potential forms of being (hence the amorphous nature of Satan). On the other hand, it also draws on the biblical tradition, where Satan was created by God. Traces of the archaic version seem to confirm the belief in the perennial existence of both God and Satan, while the subordination of Satan to God as well as his devious actions against the Creator are consistent with the biblical image of Satan as the eternal antagonist of God.

19 The dichotomy between east and west is also the case in the Ukrainian version of the myth, according to which God having discovered Satan's trick and cursed him "flew higher to the east, and Satan flew lower to the west" (poleciał wyżej na wschód słońca, a szatan dołem na zachód) [Tomicki 1976: 59].

20 According to Ryszard Tomicki, the association of God with the east and the devil with the west confirms the concept of two demiurges as the basis for structuring the world. 
The fact that the devil's actions, which are contrary to God's will, are unsuccessful reflects a folk belief that the natural elements are conscious beings that obey the Creator: Satan is not able to bring sand from the bottom of the sea when he does this in his own name, and his attempt to drown God brings the opposite result: the earth underneath God keeps growing, which makes it extend further in all directions. In this scene, Satan is presented as a treacherous adversary of God, though not of the same rank. Acting as COUNTERFORCE, he is overcome and thrown into the abyss.

As presented in different versions of apocryphal myths, the pattern of the devil's interactions with God involves attempts to copy the act of creation, which fail due to lack of access to the source of creative power. Mythical stories include a recurrent motif of the devil trying to create his own earth out of a few grains of sand that he brings from the depths in the name of God and hides under his claws or in his mouth [Zowczak 2000: 66]:

The Lord God told him [the devil] to bring some sand from [the bottom of] the sea (...). "Bring me some sand so I will create the earth (...)." And the devil brought some sand under his nails and in his mouth and gave it to the Lord God. And God said: "I bless you, let there be earth". And the devil's ugly mug felt as if it was being torn apart, and his nails, too; he coughed up and spat a lot. And that's how we have marshes and swamps today; they are the devil's land, as they say.

Pan Bóg mu [diabłu] kazał przynieść piasku z morza (...). Przynieś tego piasku, to będę stwarzał ziemię (...). A ten diabeł nabrał tego piasku za paznokcie i w usta i dał Panu Bogu. A Pan Bóg: Błogosławię, niech się stanie ziemia. A jemu pysk rozdzierało, paznokcie, on tak pluł, charkał. I to jest teraz gdzie te bagna są, trzęsawiska, to mówią, że to diabelska ziemia. [Mit 64]

As can be seen, while dry land was created by God, marshes and swamps came into being accidentally out of the devil's spittle when he coughed up the sand he had stolen. Although both God and Satan are present at the scene, it is God who is the archetypal creator. The clumsy attempts of the devil make him the alter ego of the Lord, responsible for the ambivalence in the ideal world created by God.

While God "sows" the earth, Satan "sows" stones which turn into mountains and huge rocks [Gieysztor 1986: 78; KLS 1967: 516; Kopaliński 2006: 456; Mazurkiewicz 1986: 52; Treder 1989: 21]. This belief is reflected in the names of glacial erratics, geological formations known as "the devil's stones/rocks/ boulders" (diabelskie kamienie; cf. also dialectical djôbli kam, purtków kam 'the devil's stone'; tego purtk $w$ loce zgubit 'the devil dropped this one when he was flying', talking about a boulder [Sychta 1970: 230]). Satan is also linked with 
stone in more recent beliefs and legends about the origin of particular peaks and mountain ranges in general [after Adamowski 1999d: 56]:

The mountain near Cracow was built by devils on the orders of Twardowski (...), and the mountain in Sławęczyn, in turn, was Devil Boruta’s doing; when he heard the cock crowing, he lost his grip on a boulder that he wanted to drop on the church in Tum (...). Mountains as such came into being when Lucifer sowed the dust (which, as ordered by God, he had brought from the bottom of the sea) with his left hand.

Górę pod Krakowem usypali diabli na rozkaz Twardowskiego (...), natomiast do powstania góry w Sławęczynie przyczynił się Boruta, któremu w momencie, gdy zapiał kogut, upadł jeden $\mathrm{z}$ kamieni przenoszonych na kościół w Tumie (...). Ponadto góry powstały w wyniku posiania ziemi lewą ręką przez Lucypera (wydobytej z dna morza na rozkaz Boga).

In a different version of the myth, the devil, sent to dive into the depths of the waters, brings up with him not only sand but also a stone. God and the devil strike it and create their respective helpers [after Tomicka, Tomicki 1975: 57-58]:

God breaks it [the stone] and creates angels by hitting one half with a hammer - "pure spirits" fly out of the stone. By doing the same, Satanil creates devils from the other half.

Bóg przełamuje go i uderzając $\mathrm{w}$ jedną połowę młotem powoduje powstanie aniołów - $\mathrm{z}$ kamienia wylatują „duchy czyste”. W ten sam sposób Satanił tworzy z drugiej połowy kamienia diabły.

The pre-Christian image of warring divinities representing good and evil can be traced in the etymology of the names Bożyca 'God's Mountain' and Czortyca 'The Devil's Mountain'. Legend has it that "God [fighting with the devil] was stronger, so there are more rocks thrown onto Czortyca [The Devil's Mountain]" (Bóg [walczacy z diabłem] miał więcej siły, więc narzucanych kamieni na Czortycy jest więcej) [Mazurkiewicz 1986: 55].

Rocks, then, are seen as weapons used in the fight between God and Satan. Meteoric stones, in turn - whether round in shape (kamienie piorunowe 'thunderstones'), or arrow-headed (strzatki piorunowe 'thunder arrows'), thrown by St Elijah or Archangel Michael - were believed to kill the devils hiding on earth [Brzozowska 2009: 59]. Although the stone/rock as God's weapon against evil is known in Christian culture [Forstner 1986: 125-130], and meteorites were commonly associated with the power of the sacred [Eliade 1958: 226-229], it should be observed that in Slavic culture the connection between stone and the devil is much stronger. This is confirmed both by calling boulders "devil's stones" (often, as believed, bearing marks of the devil's claws), and by the fact that complex names for "thunder-stones" in which one of the elements is associated with the sacred more often point to the devil (diabli/czarci palec/paznokieć 'the devil's 
finger/nail', etc.) than God (paluszek Pana Jezusa/Matki Boskiej 'the Lord Jesus'/ Mother of God's little finger'; palec Boży 'God's finger') [Brzozowska 2009: 57].

Linguistic evidence for the belief that the world was created by two antagonistic forces can be traced not only in the contrasting names of hills or mountains. It is also apparent in the ambivalent nature of such places, which were considered "interspheric" and thus subject to the operation of the forces of the divine and the demonic sacred. Hence, Jasna Góra, Święta Góra, Bożyca ('Bright Mountain, 'Holy Mountain', 'God's Mountain') on the one hand, and Eysa Góra, Czortyca ('Bold Mountain', 'The Devil's Mountain') on the other. While the former are identified as holy sites, the latter are perceived as the sites of witches' covens attended by devils. ${ }^{21}$

Although these oppositions between place names may seem to suggest a certain parallelism in the perception of divine and evil forces, their unequal status, validated by religious beliefs, is reflected in how the devil is commonly depicted: his bodily form is always defective (he has a limp) and displays animal features (he has horns, hoofs, a tail and is covered in fur) [Tomicka, Tomicki 1975: 36]. Coupled with his association with darkness, all this adds up to a highly depreciative image. The principles of lexical connectivity create the image of God as wszechmocny 'almighty', lit. 'all-powerful', nieskończony 'infinite', wszechobecny 'omnipresent', wszechwiedzacy 'all-knowing'; none of these adjectives collocates with diabet 'the devil' or Szatan 'Satan'. Also, while the result of the creation is referred to as dzieło boskie 'God's work', boskie stworzenie 'God's creation', świat boży 'God's world', the effect of the impact of demonic forces is known as diabelskie sprawki 'the devil's doings', szatańskie sztuczki 'Satan's tricks', pomiot diabelski 'the devil's brood'. Although in some contexts such collocations as moc diabelska/szatańska 'the devil's/Satan's power' are possible, they do not refer to the scene of creation, nor do they appear in opposition to a manifestation of God's power. Rather, they only refer to the relations between demonic forces and people.

Indeed, Satan's power appears meagre in comparison with God's might (cf. "as scared as the devil of holy water” (boi się jak diabet święconej wody)). This view, particularly visible in more recent beliefs, is also apparent in various versions

21 Associations of stone with the divine and the demonic sacred endowed it with ambivalent cultural meaning. The locations of some sacred stones were treated as the centre of the world [Eliade 1959b: 25-26]. Some sacred stones served as altars [Eliade 1958: 25, 452; KopSS 1990; Gieysztor 1986:170-172], and some were identified as gates to other worlds: heaven or hell [after Brzozowska 2009: 45]. 
of the cosmogonic myth, even if some scholars (especially Ryszard Tomicki [Tomicki 1978]) tend to see the divine and satanic powers as equal. However, the conceptualisation of the devil as an amorphous and powerless figure in Polish folk culture does not support this view. In the passage quoted above, the devil's plan to push God off the island not only fails, but also backfires on him (the earth keeps growing underneath God like dough) [Niewiadomski 1986: 59]. The devil's impotence is also visible in the scene in which the grains of sand he has hidden in his mouth start growing and then tear his "ugly mug" apart when God says "Let there be earth". Likewise, in a legend about the origin of mountains, the devil wants to create his own earth and persuades a duck to steal a lump of earth from God. However, the duck drops it when it is attacked by a hawk, and the lump falls on the ground creating mountains as a result [Adamowski 1999d: 56].

In oral texts about the creation which are clearly Christian in origin, Satan's participation is generally depicted as failed counteraction to God's actions. In a pattern consistent with the REMOVAL OF OBSTACLE schema, God's infinite power appears in its full glory in opposition to the force of the devil. Nevertheless, the figure of Satan is present in almost all the scenes in which God acts as the creator. Sometimes he performs the role of active subject, as in the case of his failed attempts to copy God's gestures (e.g. when God sows the earth, he sows stones). Importantly, whatever his role, he always remains in the background and is never on a par with God.

It is only in absolute terms of good and evil that the two forces - God, associated with life, and the devil, connected with death - appear as equal antagonists. This is evident in mythical accounts about the perennial existence of the Lord of light and the Spirit of darkness [Tomicki 1978: 74]:

First there was heaven, where the God of light had been king for centuries. Beneath, on his left, there was also the dark prince, who was subordinate to the God of light. The God of light first created water (...). The God of light took his sprinkling brush, made the sign of the cross over the water and sprinkled drops from heaven to his right and left. The falling drops (...) turned into archangels (...). Those angels who were on the right followed the God of light, and those on the left - the dark prince, who ruled the shadows of the night, and they later turned into devils (...).

Najpierw było niebo, w niem Bóg światłości panował od wieków. Był tam i książę ciemny, niżej po lewej jego stronie, który podlegał Bogu światła. Bóg światła stworzył najprzód wodę (...). Bóg światła wziął kropidło, przeżegnał wodę i kropił z nieba na prawo i lewo. Ze spadających kropli (...) urodziły się archanioły (...). Ci anieli, którzy byli z prawej strony, stanęli za Bogiem światła, ci co z lewej należeli do księcia ciemności, mającego w swej władzy cienie nocy, i stali się diabłami potem (...). 
In this account, the status of the devil is clearly regarded as inferior; this is further underlined by the oppositions light vs darkness, right vs left, up vs down, which are immediately assigned opposite values (plus vs minus) on the axiological scale. However, the nature of the spirits is accidental as it depends on which side the drops of water are sprinkled; this indicates that the folk imagination perceives the bipolar distinction between good and evil as perennial. The concept of God as the embodiment of good and might is construed in terms of the FORCE and SCALE schemas (with the maximum positive value), as well as the CONTROL schema. The physical shape of the human body and the faculty of sight determine a perspective which relies on the COLOUR, VERTICAL and HORIZONTAL AXIS schemas. The ones which carry positive values LIGHT, RIGHT, UP - are attributed to God. By contrast, the opposite features, representing negative schemas - DARKNESS (night), LEFT, DOWN - are assigned to the devil. This indicates a clear division of power: the dark prince is the lord of the night and evil spirits. Consequently, in the folk imagination the earth's interior is seen as the land of damned souls, a dangerous realm and the abode of the devil.

\subsection{Earth symbolism}

Earth symbolism derives primarily from the idea of the sacred union of the sky/heaven and earth. The image of their relations relies on the memory of the cosmogonic myth according to which the earth was impregnated by the sky, and on the experiential model of a human married couple. ${ }^{22}$ Since the conceptualiser's vantage point is located on the earth, it is the earthly perspective that will always determine the modelling of the relations between the sacred and the profane.

The perception of earth as a symbol of fertility is grounded in the mythical image of the world's origin as a sexual act. The symbolic pattern resting on the chain linking heaven/the sky, earth, rain and lightning is reactivated in wedding customs, particularly in the rituals of the undoing of the bride's plait (rozpleciny) and putting on the wife's bonnet (oczepiny). The seating of the bride on a rain

22 According to Mircea Eliade, "it is probable that [the] sacred marriage between heaven and earth was the primeval model both of the fertility of the land and of human marriage" [Eliade 1958: 257]. I only subscribe to his proposal concerning fertility. 
stone and the accompanying songs include the motif of fertilising rain. In this example, the experience of FORCE is construed in terms of the ATTRACTION schema, the expected result being the transmission of the power of fertility to the bride. Rain and stone acquire a symbolic meaning by their contextual association with the sacred and its life-giving power. The chain is extended to include two more elements: stone and woman, with fertility bestowed by heaven upon earth as the semantic node that they all share.

The motif of the first ploughing with a golden plough, which features in a New Year rural carol, is an example of fertility symbolism based on the agricultural myth of creation. In the carol, the wish for abundant crops is presented as a miraculous scene in which God (in the person of Jesus Christ), accompanied by the Virgin Mary and saints, descends from heaven to plough the farmer's field and restore the earth's fertility after its winter sleep [Niewiadomski 1999: 54-77]:

A wyńdze do nas Panie gospodarzu hej nam hej, hej nam hej!

A my co wiemy, o ci opowiemy

hej nam hej, hej nam hej!

Bo na twoi roli zoty puzek stoi,

A przi tym puzku śtery konie w cuzku,

A za tym puzkiem sam Paniezus chodzi,

A święty Scepan kuoniki Mu vodzi.

Naświetsa Panienka śniadanko Im nosi, swego Synaca zeby jad prosi.

Dej ze tu Boze dwojakie zboze,

Miedziano słome, a złote zboze,

A bedą tu zeńcy, sami mlodzieńcy,

Bedą zniwiarecki, same panienecki,

A bedą tu snopy, jako siana kopy.

Pojado tu fury, jak o niebie chmury.

Panie gospodarzu nie wychodź do pola

Da bo pobłądzis miedzy kopeckami.

Da jko miesiącek miedzy gwiazdeckami.
Come out to meet us, our host, hey, sing a song, hey, sing a song! And we'll tell you all we know. hey, sing a song, hey, sing a song! There's a golden plough in your field And four horses in their harness; The Lord Jesus himself is walking behind it And Saint Stephen is leading His horses. The Most Blessed Virgin has brought them food And She's asking her Son to have some.

May God give you crops twofold:

Copper straw and golden corn.

And there'll be reapers, all of them young lads, There'll be reaper girls, all of them young maids; And there'll be sheaves like haystacks, There'll be carts like clouds in the sky. Don't go out into your field, our host, Or you'll be lost among the stacks Like the moon among the stars.

The sacred nature of the symbol is evoked by the image of an extraordinary communion between the physical and metaphysical worlds, which restores the blessed time of origins and quickens the fertility of the earth. The participants of the event, the host and carol singers, experience the sacred, God incarnated, and gain access to grace. The golden plough as an attribute of divinity endows the event with the air of a miracle, and the performed work acquires a religious 
dimension. The text of the carol conjures up the agricultural version of the creation myth in which God sends to the earth gold tools so that people can cultivate it and make it fertile [Mazurkiewicz 1989: 21; Niewiadomski 1992: 68-69]:

When the earth was still empty and people had already been driven out of paradise, four gold tools fell from heaven: a plough, a yoke, an axe and a jug. At first, the handful of people who lived on the earth were afraid to pick them up as they did not know what they were for. The youngest son of the earth took them, learned how to use them and, as the wisest, was soon elected king.

Kiedy ziemia była jeszcze pustą, a ludzie już z raju wypędzeni zostali, z nieba spadły cztery złote narzędzia: pług, jarzmo, siekiera i dzban. Zrazu garstka ludzi jaka była na świecie, lękała się podnieść przedmioty, których nie znała użytku. Najmłodszy z synów ziemi podjął je i wkrótce nauczywszy się nimi pracować, jako najmędrszy wybrany został królem. [Mazurkiewicz 1989: 21]

The myth in which God sows the earth constitutes a parallel with the image of ploughing with a golden plough [Mazurkiewicz 1989: 21; Niewiadomski 1992: 68-69] and is re-enacted in the rituals of the first ploughing and sowing of the year (see above). The lexical complex of symbolic references to the earth's fertility is expanded to include the plough and ploughing (often used as a euphemistic reference to sexual intercourse in folk love lyrics, see above), as well as crops and harvest.

The symbolic image of mother-earth rests on their analogical functions: giving birth, nourishing and protecting life. As in the case of most symbolic images, this parallel goes back to ancient traditions, including the myth of Mother Goddess and the death and resurrection of her son, the god of vegetation [Niewiadomski 1992: 63]. As such, it motivates the link between myth and fertility rites, subject to the cyclical rhythm of death and regeneration of nature. Found in many different cultures, the myth was also part of Mediterranean civilisation, from which it was adopted in early Christian tradition. A female divinity connected with the cycle of death and rebirth of plant life (Gaia, Demeter, Isis, Kore) provided a prototype for the agricultural profile of Our Lady, the patron of good crops [Niewiadomski 1992: 64]. The holiness of the Virgin Mary and the veneration she is due thus came to be connected with the cult of the earth and the obligation to show it respect. Importantly, the concept of the sanctity of the earth also stems from a fundamental belief in its divine origin ("The Lord God created the earth" (Pan Bóg ustanowił ziemię)).

Filial reverence for the earth is apparent in such symbolic customs as kissing the ground or taking a lump of soil when leaving one's homeland and placing 
it in the coffin if one is buried away from home [SSSL 1.2: 25]. The need to be buried in the soil of one's homeland reflects mythical autochthonism, a sense of belonging to one's own land, which is one's home and place on earth. This attitude is found in many cultures in different historical periods [Eliade 1958: 253]. ${ }^{23}$

An intimate attitude towards mother-earth is also evidenced by such customs as the laying of women in labour, newborn children, the sick and the dying on the ground [SSSL 1.2: 53]. These practices are found in many different cultures, both in Europe and around the world [Eliade 1958: 247-248]. They indicate the archaic nature of the symbolic image of earth as mother, construed on the basis of the LINK schema. The bearer of all life, the earth accompanies all living creatures from their birth to death.

The symbolic image of the earth as a loaf of bread originates from the cosmogonic myth in which God created the earth and made it the bearer of all life, which will return to it after death. The connection between the earth and bread is metonymic in nature: the product of earth's crops comes to represent the earth itself. The relationship is also based on the similarity of shape and, most of all, function. Both bread and the earth are associated with life, while bearing crops is connected with the cosmic rhythm. The symbolic image is a complex representation of cosmic order in which the earth (and hence bread) functions as a link with heaven, thus becoming imbued with sacredness. The earth, and bread as its symbol, are mediators between man and the sacred, thus providing a link between earthly and otherworldly life. As such, they combine the opposite meanings of life and death. The connection with death, however, does not entail decay but a transformation into another form of being. Hence the images of bread and the earth are based on the LINK and WHOLE schemas, and are invariably ascribed positive value in terms of the SCALE schema.

The memory of the origin myth, involving the symbolic function of the earth and bread, is reactualised in ritual actions, performed particularly in rites of passage (such as baptism, wedding, death rites) and at other important moments in life (such as a return to one's homeland or family home after a long period of absence).

The custom of welcoming guests with bread and salt, which includes bestowing a solemn kiss on a loaf of bread as a gift of heaven, is a symbolic gesture of

23 This is confirmed by burial inscriptions of the Roman Empire expressing the joy of being buried in one's homeland, or the sorrow of not having this consolation [Eliade 1958: 253-254]. 
acceptance into the community, signifying a readiness to share bread, and the recognition of them as fellow countrymen (regardless of whether the guest is a stranger or a person returning home).

At the wedding, the welcoming of the bride and groom with bread and salt is a sign of accepting them into their respective new families, and recognising them as a married couple. The custom is also part of the ritual blessing of the couple by their parents, who make a gift of bread as a sign of their fate (dola/los), dependent on the earth and its fruit. The sacred dimension of the symbol of bread is apparent in a belief that the actual agent of the blessing is God, while the parents are only mediators of His grace. The blessing formula is usually uttered by the mother, which - in view of her symbolic connection with the earth, life-bearer and nourisher - additionally stresses the significance of the ritual. Although the formula is not fixed, the mother always summons the power of the sacred and speaks on behalf of God: "As God blesses you, I bless you as well" (Jak Pan Bóg błogosławi, to i ja błogosławię) [Engelking 2017: 279].

The custom of making a gift of bread (or sharing it) in rites of passage reveals close associations of bread with the earth and with life. The ritual of giving a loaf of bread to a post-partum woman, her newly born child and the midwife is the first event in the cycle linking human life with bread as a symbol of the earth. It is a gift of welcome, a sign of including the baby in the "own" (swój), earthly sphere. This rite of inclusion involves both the mother and the child since both of them were subject to the influence of the "alien" (obcy) world and its otherworldly rules. Bread, then, functions as a medium between the physical and metaphysical worlds. In turn, the custom of preparing a sacrificial loaf of bread for the Virgin Mary (eaten together by the woman and her family) stems from a belief in her protection of women in labour. Such a communion with a holy person who belongs to supernatural reality is also a symbolic gesture showing an openness for contact with the guardian spirits of the ancestors with a view to ensuring their protection over the baby in its future life [Kubiak I., Kubiak K. 1981: 58-59]. This "communion of bread", which connects the world of the living with that of the dead, begins at birth and is repeated in all ceremonies marking important stages in life, such as weddings and funerals, as well as during annual Christmas and Easter celebrations. The symbolic meaning of the ritual of sharing bread makes it possible to combine the oppositions: life and death. As a symbol of the earth, bread also joins the upper and lower sphere of the cosmos.

A gift of bread from godparents to a newly baptised baby is also a sign of welcome on earth and a wish for a happy life, abundant in the fruit of the earth [Engelking 2017: 277]: 
[After baptism the godparents and guests] go to the house but before entering they stand with the baby by the window and ask from outside: "Is this a good child?" Then they hear a reply from the cottage: "Good, good" and the oldest person inside takes a few loaves of bread and a measure of salt, places the bread and salt onto the baby's pillow and invites everyone inside. ${ }^{24}$

The sharing of traditional wedding bread (kołacz/korowaj) ${ }^{25}$ among wedding guests is believed to ensure God's blessing, fertility and prosperity for the newlyweds [Bączkowska 1988: 79]. The custom of eating funeral bread, in turn, is both a sign of community with the family of the deceased (sharing their fate) and a solemn send-off from the world of the living. A loaf of bread placed in the coffin symbolises the closure of the cycle of earthly existence and marks the passage to eternal life.

Grounded in myth, the metaphor THE EARTH IS BREAD connects heaven and earth, providing a metaphorical stairway to heaven. A symbol of the earth, bread nourishes in earthly life, but through its associations with the sacred ${ }^{26}$ it also becomes food for souls, enabling their transformation and passage into eternal life.

The contexts discussed above include bread in a chain of interconnected concepts of earth, life, death, woman, home/house, fate, offering a range of possibilities of lexical connectivity, thus generating further metaphorical and symbolic meanings.

The symbol of the cosmic egg ${ }^{27}$ grounded in the mythical image of the earth hatching from an egg, is firmly based on direct experience. Since an egg contains a seed of life, it provides a link with the life-giving properties of the earth. In this way, the egg, like bread, combines the semantics of earthly and eternal life. Their connection with heaven is motivated by their resemblance in terms of colour (the yellow of an egg yolk, the golden shine of the crust of a well-baked loaf of bread), shape and life-giving and purifying properties. These meanings are

24 Translated by Anna Gutowska (translator's note).

25 In eastern Poland, traditional wedding bread is known as korowaj (cf. Belarusian karavă, Ukr. korovă̌, Rus. karavă), in other regions - as kołacz.

26 I restrict my analysis to bread as a symbol of earth as a natural element, and do not discuss the religious symbolism of bread as the body of Christ.

27 The archaic motif of the cosmic egg is found in many cultures in different parts of the world, including India, Iran, China, Africa, Australia and Polynesia [Eliade 1958: 413414]. For its reconstruction in Slavic culture, see Toporov 1967: 81-99. Traces of this myth are also found in a Polish folk tale from the Dobrzyń region [Biegeleisen 1929b: 176-177, in Niewiadomski 1989: 66]. 
actualised in rituals, with symbolism of life particularly visible in agricultural rites and magical healing practices (see above).

The link with the divine world, in turn, is reflected in the rituals of sharing an egg during Easter breakfast, and sharing bread (opłatek 'wafer') at Christmas Eve supper (wigilia). In symbolic terms, sharing food and exchanging wishes consolidates the bond between the participants of the meal and the divine world, which endows their good words with causal power [Kowalski 1998: 179; Niewiadomski 1999: $152 \mathrm{ff]}$.

The ritual use of the egg "is founded on the symbol embodied in the egg, which bears not so much upon birth as upon a rebirth modelled on the creation of the world" [Eliade 1958: 414]. The transformative properties of the egg are apparent in rituals which involve making contact with "otherworlds" (zaświaty). One such example is the custom of throwing Easter eggshells into a river (a symbolic border between the worlds of the living and the dead), so that they are carried to the land of the departed [Niebrzegowska 1999d: 12]. An important element here is both the period when the ritual is performed (the feast of the Resurrection of Christ, also symbolically represented by an egg), characterised by intense contact between heaven and earth, and the use of shells from blessed and symbolically decorated Easter eggs (see above). The custom of sending Easter eggshells to "the other world" is a means of maintaining the link between the lands of the living and the dead. Symbolising the triumph of life over death, Easter eggs demonstrate belief in eternal life. The command to decorate them is thus meant to ensure continuity of life, while its breach would entail the annihilation of human existence [Niewiadomski 1992: 66].

A ritual Easter game called "kiss of the dead" (pocatunek zmartych) has a similar significance. The game, whose function was to release both the male and female life force, took place on the third day of the feast. After Mass, people would go to the cemetery to bury Easter eggs in the graves of deceased members of their families in order to release their souls from the devil's power and enable their passage to heaven. The next stage of the ritual involved young people forming a magic circle, dancing and chasing one another over the graves. The girl who got caught had to pass on "the kiss of the dead" to all participants [Niewiadomski 1999: 145]. The kiss was supposed to have come from beyond the grave and thus was a peculiar way of making contact with the other world. Dancing in the cemetery and the exchange of kisses between boys and girls were intended to release energy that would intensify the power of the eggs buried in the graves. Placing an egg in a grave would entail a re-enactment of the scene of the creation of the earth, and thus summon the primal power of the original act of creation in order to enable the transformation of souls and their passage to eternal life. 
The tradition of placing an egg in the coffin or directly in the hands of the dead, ${ }^{28}$ putting a loaf of bread into, or scattering grain on, the coffin performed a similar function. The FORCE activated by the re-enactment of the archetypal model operates here according to the SOURCE-PATH-GOAL schema.

As a symbol of the fertility of the earth, the egg combines the opposites, life and death, in a synthesis of the cosmic rhythm, involving the cycle of death and regeneration in the natural world, and the corresponding passage of the human soul from earthly to eternal life. This is illustrated by the custom of hanging empty eggshells on a gaiczek - a small green tree carried around a village as a sign of the return of spring, the cyclically recurring regeneration of nature in accordance with the cosmic rhythm. The symbolism of the egg thus contains, in a condensed form, the myth of periodic creation [Eliade 1958: 412-415; Niewiadomski 1999: 91].

Deriving from myths and reactualised in rituals and ceremonies, symbolic images build a complex structure integrating different spheres: heaven/the sky, earth, the sun and water. Particular images grounded in a symbolic complex (earth, woman, mother, bread, egg, farmer, ploughman) make up a coherent whole focused around the cycle of birth, death and regeneration, with the latter entailing transformation into another form of being in another, supernatural, reality. Participation in a ritual allows the human to transcend the border between the physical and metaphysical worlds and to enter into the sphere of the sacred [Eliade 1958: 31-33]. In this way, the dichotomy between the sacred and profane is momentarily obliterated. In the symbolic scenery, human participants in the ritual become integrated with the anthropocosmos, of which the earth is a constituent part.

28 An archaic custom, well preserved in many cultures. The figures of Dionysus found in Boeotian graves always hold an egg as a sign of the return to life [Eliade 1958: 415]. 


\section{Air}

\subsection{The creation myth: the breath of life}

According to the Bible, during the creation of the world "the Spirit of God was hovering over the face of the waters" (ESV Genesis 1:2), and man was brought to life by divine breath: "And the Lord God formed man of the dust of the ground, and breathed into his nostrils the breath of life" (KJV Genesis 2:7). In further biblical accounts, the presence of the Holy Spirit is manifested as a gust of wind; likewise, violent, rock-shattering winds herald the coming of the Lord: "And, behold, the Lord passed by, and a great and strong wind rent the mountains, and brake in pieces the rocks before the Lord" (KJV 1 Kings 19:11); "At his sight shall the mountains be shaken, and at his will the south wind shall blow" (DRB Ecclesiasticus 43:17).

It is on the basis of such images that wind - non-material energy identified with divine breath - came to represent the mystery of the invisible sacred and manifestations of its power. There is an etymological relationship between the Proto-Slavic ${ }^{*} d u c h s$ 'spirit' (deriving from the Indo-European ${ }^{*} d h o u-s$-, with the same structure, but the apophony of the root vowel as the Proto-Slavic ${ }^{\star} d z c h$, Polish dech 'breath', and, without the suffix $-s$, the Proto-Slavic ${ }^{\star} d u t i, d u j a$, Polish duć 'blow') and oddech 'breath', dusza 'soul' and duć 'to blow', and, by the same token, with wind and air. Data from the Lithuanian language show evidence of an analogical development (Lithuanian dialectal daũsos 'spirit, breath'); the semantic similarity between the Greek theós 'God' and Gothic dius 'wild animal', and the Latin animal and anima 'soul' might also point to a distant relationship with God [SłSE 1953: 176]. Folk lexis in dialectal Polish confirms the same direction of semantic development. The meaning of the lexeme duch 'spirit' in Polish dialects [SGP 2005: 424-426] is recorded as referring to both a physical and mental condition. Thus, in the former sense, duch denotes oddech 'breath', a sign of life as in e.g. jak mu dat w piersi, to a $\dot{z}$ duch zajęto 'when he got struck in the chest, it took his spirit (breath)' and leżeć bez duchu 'lie without spirit (breath)'; in the latter, it may mean consciousness, a particular psychological state as in e.g. pokrzepić się na duchu 'to lift the spirits', or the human soul (duch $z$ ciała wychodzi 'the spirit leaves the body'). Duch can also signify an immaterial being, phantom or apparition (wloz jak duch 'he came in like a ghost'). In fixed collocations with the adjectives święty 'holy', boży 'God's', dobry 'good', zky 'evil', czarny 'black', it means God, angel, devil and demon, respectively. The following examples illustrate its various guises: e.g. Duch Święty 'Holy Spirit, the 
third person of the Holy Trinity', dobry duch 'good spirit', Boży duch 'angel' (lit. 'God's spirit'), or $z \nmid y$, czarny, niedobry duch, meaning 'evil, black spirit', i.e. 'devil', but also 'whirlwind'.

For many cultures around the world, the experience of invisible FORCE manifested in a gust of wind was evidence of the power of the sacred. Violent gales inspired terror and were perceived as a sign of divine wrath or as a malicious act of demonic power [Kowalski 1998: 586]. In the human experience, air, breath and wind were both symptoms of life and harbingers of death, and thus represented supernatural forces. As a result, they became the basis for depicting abstract concepts - Bóg 'God', immaterial spirit, dusza 'soul', immaterial form of man's existence, and duch 'ghost', immaterial apparition of a dead person. The cognitive paths between these notions turn air and wind into intermediaries between the earthly, material world and the immaterial world of spirit.

\subsection{Wind: the sacral profile}

One of the folk versions of the creation myth envisages two agents in the scene of "breathing the breath of life into man's nostrils": God and the devil. Their roles are not equal, as the devil repeats God's actions, but both figures wield their own power [Tomicki 1978: 125, mit 64]:

God made man from a clod of clay, and breathed on him and the man moved, came to life. The devil saw it all; so he chose a moment when the man was asleep and breathed on him - and thus the evil spirit came to dwell in man and man received the inclination to evil.

Zlepił Bóg z gliny człowieka, tchnął nań i człowiek zaruszał się, ożył. Diabeł widział to wszystko; wybrał chwilę, gdy człowiek spał, tchnął nań - i osiedlił się w człowieku duch zły i człowiek otrzymał skłonność do złego.

While the power of God's breath gives life, the FORCE of the devil's exhalation blows evil into the human soul. Even though the myth was recorded in Eastern Slavic rather than Polish-speaking areas, it is nevertheless characteristic of the folk conceptualisation of the world, which relies on oppositions. In such a conceptualisation, good and evil, perceived as perennial counterforces, form the basis of all axiological processes. This is evinced in a passage from the Cracow myth (mit krakowski), in which the God of light and the Prince of darkness appear in the same scene as perennial forces representing good and evil [Tomicki 1978: 74]:

First there was heaven, where the God of light had been king for centuries. Beneath, on his left, there was also the dark prince, who was subordinate to the God of light. 
Najpierw było niebo, w niem Bóg światłości panował od wieków. Był tam i książę ciemny, niżej po lewej jego stronie, który podlegał Bogu światła.

The belief that it was the fiend who planted the inclination to evil in man is further confirmed by set phrases denoting possession by the devil, which contain the lexeme duch 'spirit' (e.g. mieć nieczystego ducha lit. 'to have an impure spirit', i.e. to be possessed, od złego ducha dręczony lit. 'tormented by the evil spirit' [SGP 2004: 427]). It can also be seen in practices of expelling the evil spirit from the body [SGP 2004: 426]:

- "even if one had an evil spirit [i.e. was possessed], this liver and this heart [cut from the innards of a fish] put on hot coals and made to smoke will make it run away" (ta wontrobe i te syrce [wyjęta z ciała wyłowionej ryby], choćby kto nat ducha necystego, to weźnie na rospalone wengle i zakadzi i uciece); ${ }^{1}$

- "and when they wanted to expel disease and the evil spirit which disturbed the human body, there was a prayer to be said by the bedside of the sick" (a jak mieli wypendzać chorobę i niedobrego ducha, który przeskadzał w czele ludzkiem, to do wypendzania była taka modlitwa nad chorem).

The connection between the sacred and the movement of air, apparent in the etymological link between the spirit and the action of breathing and blowing, is reflected in the folk image of wind. Based on the FORCE schema, it represents both divine power and demonic forces.

\subsubsection{Wind in the relations between God and man}

As God's life-giving spirit, wind is presented as a reviving gust, a protective spirit, accompanying human beings at all stages of their lives: from the cradle to the grave. Acts performed by God during the creation of man became a prototype for further representations in which "breath" (and, by the same token, a refreshing breeze) appears as a creative, life-giving and generative force [K, vol. 47: 4]:

Asked by his servants, the God of light, heavenly Father, took a grain of earth from Paradise, and when it grew and softened in His hands, He made from it the first man; and blowing the spirit into him, He made him different from the angels. And God called this first man Jadam [Adam].

1 The quotation alludes to the folk version of the biblical story from the Book of Tobias, in which the angel instructs young Tobias how to expel an evil spirit from the human body permanently: "If thou put a little piece of its [the fish's] heart upon coals, the smoke thereof driveth away all kind of devils, either from man or from woman, so that they come no more to them" [DRB, Tobias 6:5-7:5]. 
Bóg światła, Ojciec niebieski na prośbę sług swoich, wziął kruszynę ziemi Rajskiej i gdy ta mu w rękach rosła, miękczała, ulepił z niej pierwszego człowieka a natchnąwszy go duchem, uczynił odmiennym od tego, czym byli anieli. Tego pierwszego człowieka nazwał Bóg Jadamem.

The notion of wind as a manifestation of life-giving force (cf. powietrze 'air', duch 'spirit/ghost', tchnienie 'breath', powiew 'gust') is visible in beliefs and convictions preserved in communicative acts.

The divine act of "breathing", in the sense of bringing to life, is re-enacted by healers, who repeat the model set by the Creator (blowing) to summon His power in the course of their magical practices. These gestures are often accompanied by incantations (zamówienie), i.e. speech acts whose perlocutionary force is intended to cause a specific change: bring back to life, expel disease, or prevent misfortune [Zowczak 2000: 297]:

The Lord Jesus blew, the whole world over He blew.

And so I will blow, the whole world over I'll blow. Puff, puff!

Pan Jezus dmuchnął, cały świat rozdmuchnął

I ja chuchnę, cały świat rozdmuchnę! Chu, chu!

Although the healer re-enacts the archetypal role of the Creator, who remains in the background of the scene, it is in fact the Creator Himself who is the agent proper. The spellcaster (zamawiajacy) performs an act of healing (reviving) by invoking the perceived SOURCE of power: God Himself and the FORCE of His breath. The use of the ATTRACTION OF FORCE schema allows the mediator (the healer) to enter the sphere of the sacred and recreate the energy accompanying the creation of man. In this way, the synergy of gesture and conventionalised text produces a performative communicative act.

The prototype of the motif of wind that blows by God's will, bringing the dead back to life, can be found in the Bible: "Thus saith the Lord God; Come from the four winds, O breath, and breathe upon these slain, that they may live" [KJV, Ezekiel 37:9]. The belief that wind has a reviving power is also reflected in folk tales, which frequently feature the motif of God-driven wind restoring the dead protagonist to life (as in the story about a boy torn into pieces by a dragon [Bączkowska 1986: 56]).

Agrarian culture identifies life-giving powers with fecundating properties. According to such beliefs, the generative power of the wind which blows during the wedding is passed on to the bride. A gust of wind during the ceremony of rozpleciny (the undoing of the bride's plait, a symbol of maidenhood) causes the bride to lose her maiden garland (i.e. her maidenhead). Wind is present in the scene "when a brother unplaits the sister's hair" (gdy bratek siostrzyczkę rozplituje), 
and during the oczepiny (the ceremony of putting on a wife's bonnet) it "undoes the bride's ribbons" (rozwija wstążeczki panny młodej) [Bączkowska 1986: 56]. Though invisible, it assumes the archetypal role of the agent (impregnating the girl), while other participants, "drawn into the scene", become recipients of its life-giving energy (the bride directly, the wedding guests indirectly), as joint protagonists of the ritual wedding scene.

The divine power of wind initiating a change of a state is displayed also in scenes of death, especially unexpected death, in which wind, as a witness of the events - a murder or suicide - blows throughout the day and night until the funeral (cf. the saying "it's windy as if someone hanged himself" (wieje, jakby sie kto powiesit)) [Bączkowska 1986: 57]. In such cases, the role of the wind is relegated to the background of the scene. However, in scenes depicting the ultimate transformation, when the dying exhales his/her last breath, wind becomes the instrument of divine power, releasing the soul from the body. A gust of wind blowing at the moment of death is sometimes also identified with the soul leaving the body, thus becoming the main figure in the scene: "This strong wind, which begins to blow at the moment of death, or after the death of a suicide, sorcerer, etc., is the soul-breath leaving the body" [KLS 1967: 480].

The presence of wind accompanying man from the cradle to the grave is not limited to pivotal moments of his/her life. The rural worldview, combined with a religious attitude, assumes that God is the just ruler of the world, rewarding good and punishing evil. From this perspective, wind appears as an instrument of blessing, fertilising fields, bringing life-giving rain to farmers and aiding sailors and fishermen. For Kashubians from the coastal region of northern Poland, ${ }^{2}$ a favourable wind is "a shepherd of fish" (pastérz rib) or "the king of winds" (król wiatrów). Wind bringing rain from the south $(z u d a)$ is unfavourable from the fishermen's point of view, hence its names "fishermen's misfortune" (rëbackô biéda), "pissed-on aunt/witch" (cotka oszczónô), "stinking aunt/witch" (smierdzacô cotka). The fishermen also say "a hungry bitch is barking" (głodnô sëka łaje) about southern wind, and attribute bad weather to the influence of strangers, mainly of a different faith (and thus favoured by the devil): "the Swedish wind is blowing" (szwéda dmuchô), "evil is coming from the Swedes" (od Szwedów jidze złe; the Swedish are believed to keep winds in huge sacks, and the strength of the wind depends on how many sacks they open [Sychta 1973: 122]), "the weather is so bad today (lit. 'it's wolf's weather'), it must be a Jewish feast" (Żëdë muszą dzys jakié swięto miec, że takô wilczô pogoda je). Kashubians also

2 Examples from various sources quoted after Treder 1989: 38-40. 
treat strong wind as a sign of God's wrath: "heaven is angry" (niebo se gorzi) [Treder 1989: 40].

The expressive charge attached to the names of winds determines their axiological value. The names of unfavourable winds usually consist of a number of components, indicating their effects ("the fishermen's misfortune") or the fact that they belong to an alien world, be it supernatural (ciotka 'aunt' may mean a witch, and $z \nmid y$ 'evil' is a euphemism for the devil), foreign (Swedes, Jews) or animal ("bitch" (suka)). Such names also include a derogatory component ("stinking"/"pissed-on" aunt/witch; "hungry", "barking bitch"). By contrast, the names of favourable winds are associated with concepts that have positive connotations and as such are charged positively: "the king", "the shepherd of fish" (król, pasterz owiec).

In rural culture, torrential rains and hailstorms are treated as a punishment for sins and unworthy conduct: "The Lord God punishes people by sending hail" (Pan Bóg karze i spusco grady); Kashubian "God’s whip strikes" (boži batug seče) [SSSL 1.3: 275]. The wind that brings hail clouds thus acts as an instrument in the hand of God, through which He shows His wrath. In this case, the FORCE schema operates according to the SOURCE-PATH-GOAL pattern, manifesting God's absolute power.

The effects of hail, as well as the specific types of hailstone, are reflected in rich lexical material. According to Aleksander Brückner, the very name grad 'hail' is a proto-word deriving from the Indo-European ${ }^{*}$ ghrōud-os (Lithuanian gruodas 'frozen lumps of earth'; 'frozen icecap on snow' [SłSE 1954: 336]). The effects of a hailstorm include gradowisko 'a field destroyed by hailstones', gradowizna, gradowina 'fruit or grain battered by hailstones'; Kashubian gradovče 'straw or grain battered by hail'. Depending on size, hailstones are called gradzina, gradzinka (a diminutive form), or krupa/kruka lit. 'groats'. The names recorded for small hailstones also include krupy niebieskie 'groats from the sky/heaven', and jad 'poison' in Kashubia (related to the meaning of jad as 'anger, wrath'). In proverbs, a hailstorm is called "the worst whip for a field" (najstraszliwszy bicz pola) and "iron rain" (deszcz żelazny) in Kashubia [SSSL 1.3: 273]. According to warnings contained in songs of wandering beggars (pieśni dziadowskie) and in orally transmitted prophecies, a special type of hail, accompanied by fire, will fall on the earth on Doomsday. It will be stone hail (grad kamienny): "It is written that stone and fire hail will fall from the sky/heaven, and fire will fall" (Jest napisane, że będzie grad kamiennyj i $z$ ognia padał $z$ nieba, $i$ ogień będzie padat) [SSSL 1.3: 286].

Both the number and meaning of those names indicate the seriousness of the phenomenon as well as fear aroused by the size of damage that it causes. In 
folk belief, some areas are particularly prone to hailstorms. These include fields belonging to godless and sinful people, and abodes of impure souls: burial places of miscarried (porońcy) or unbaptised babies, buried in ditches or at field borders by unmarried mothers [Pełka 1987: 61]:

There was a place in the village where willows grew. Those willows were constantly struck by lightning. It was said that unmarried women buried their children there and that's why lighting kept striking that place.

We wsi było takie miejsce, gdzie rosły wierzby. W te wierzby stale waliły pioruny. Opowiadano, że tam panny zakopywały swoje dzieci i dlatego pioruny biły $\mathrm{w}$ to miejsce.

While damage caused by a hailstorm is irreversible, the intercession of the saints may still work a miracle. In the legend of St Jack, the saint's prayer causes the damaged ears of corn to rise and grow again [SSSL 1.3: 285]. Thus St Jack plays the role of a mediator, with God as the only wielder of power capable of reversing the effects of the hailstorm sent as punishment. Folk culture developed a whole system of norms and patterns of conduct aimed at preventing punishment or propitiating God's wrath (see Chapter 5.2.2 below). In addition, a different set of countermeasures and protective practices was employed against damage produced by hail caused by demonic forces (see Chapter 5.3.2 below).

God's wrath could also be manifested by a visitation of "pestilential/death air" (morowe powietrze). Diseases caused by "bad air" (złe powietrze) include mornica 'deathly disease' (< Proto-Slavic moriti 'die'), pottuka 'disease that spreads (lit. knocks) around', pošedło < ${ }^{\star} p o$-šbd-lo literally 'going round' (the name deriving from the way the disease spread through an area: "poszédto is going round now" ( poszědło chodzi terá po lědzach)). In Kashubia, cholera, kolera 'cholera' was imagined as a woman wrapped in a shawl, visiting cottages, or as a shawl itself falling on a village. In Wielkopolska and Kujawy, in western and central Poland, it was represented as a red-striped sheet, and it was said that "whoever is touched by the shadow of this cloud passing by, will die" (kogokolwiek ta chmura w przechodzie cieniem swym dotknie, ten umrze) [Dźwigoł 2004: 37-38]. The phenomenon of a spreading epidemic lent itself readily to personification [Popowska-Taborska 1999], especially since the representation of death as a woman was already well established in Slavic culture. Morana (< Proto-Slavic ${ }^{*}$ mor 'causing death'), one of the names of death, is associated with marzanna (also recorded as morena, morana, marena), a personification of death and winter in Slavic mythology [Dźwigoł 2004: 33]. "Death air" causes trętwiet 'numbness/paralysis', as well as morowi wrzód 'deathly ulcer'. It is also said of a sick person affected by "bad air" that "wind has jostled him" (wiatr go tracit); in Kashubia they say that "wind 
turns him round" (wiodro go kracy), i.e. he is sick; divine punishment itself is called "God's bad wind" (bożé niewiodro) [Treder 1989: 50].

Since it was forbidden to utter names of diseases for fear of bringing them about, the direct mention of cholera was clearly prohibited: "do not summon cholera" (nie wywotuj cholery). Consequently, it was euphemistically referred to as słabość 'weakness' (a hypernym meaning 'illness') or bieda 'misery' ("people fell ill with 'misery'; because you couldn't speak about cholera at all, it's such a dreadful disease. [They went down] with cholera, and we called it misery" (ludźe na bida xorowali. Bo o xolerze to nii mozno było fcale muvić,

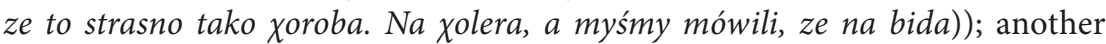
name was śpiączka 'sleeping illness' (in a metonymic sense, where a symptom of the disease functions as its name). There were also euphemisms for hypernyms: zaraza 'contagion', povjetrze 'air', złe powietrze 'bad air', powietrze zaraźliwe 'contagious air', choroba straszliwa 'dreadful disease'. Some of these names, including those denoting specific epidemic diseases, refer to the fatal outcome of the disease e.g. mor, przymorek 'death', often in the form of an extended periphrasis morowe povjetrze 'deathly air', czôrnô smjerc 'black death'. Owing to the causal power ascribed to the name, cholera does not feature in folk dialects as a swear word, which it is in standard Polish. There are also folk names for cholera associated with a demon, which derive from the ProtoSlavic *chyra 'illness' (< Proto-Slavic ${ }^{\star} \chi y$ rati 'to be ill'): hera, chira, Kashubian xëra [Dźwigoł 2004: 38-39].

\subsubsection{Wind in the relations between man and God}

When God allows an unfavourable wind to arise, man may undertake specific actions or comply with certain prescribed ways of conduct intended to permit entry into the sphere of the sacred. The purpose of establishing such contact is to acquire access to the source of power, i.e. the Creator Himself, either directly, or through the mediation of divine (Jesus, the Holy Spirit) and holy persons (the Virgin Mary and saints regarded as patrons of agriculture). A re-enactment of divine gestures makes it possible to break the barrier between physical and metaphysical reality. In such cases, the pattern of the action of FORCE depends on the manner in which people attempt to secure access to God's power so that winds that it rules should bring a sufficient amount of rain and drive away hail clouds and storms. Since summoning the supernatural is attended by fear of its unlimited power, all actions in this instance are surrounded by protective taboos. Consequently, it is necessary to adhere strictly to prescribed advice, commands, warnings and prohibitions. 
This is evidenced in scenes summoning a cooling breeze, especially on hot days during harvest. A group of people (harvesters) usually takes the role of the subject, calling out together "The thin one, the thin one!" (Chudy, chudy!) to bring the wind [KLS 1967: 485]. Employing the magic power of words, the group re-enacts the divine acts performed during the creation (God's "let there be" calling the world into existence ex nihilo). In this scene, which relies on the ATTRACTION OF FORCE schema, God, hidden in the background, performs the archetypal role of the agent, who is to send the wind in response to the harvesters' entreaty. However, the cooling breeze had to be given a euphemistic name in order to mislead hostile demons dwelling in winds, who might be accidentally attracted by these calls. Thus the additional BLOCKAGE schema also operates in the scene, with the euphemism and the illocutionary force of the warning as its linguistic correlative:

- one should ask for the wind by calling "the thin one, the thin one" (chudy, $c h u d y$ ) so as not to wake up evil spirits.

In order to secure abundant crops, a number of protective practices are employed against the effects of hail, storms and torrential rains. Such practices involve the sanctification of a protected space, especially by rich and varied rituals of individual and collective blessing of the fields. The custom of groups walking round the fields goes back to the fifteenth century and is still observed in many parts of the country [Adamowski 1999d: 221].

Drawing magic circles was an archaic method of concentrating FORCE, based on the CENTRE and CONTROL schemas. The rituals of delineating concentric sacred space were subject to strict rules as they re-enacted the mythical model of the creation of the world. According to mythical accounts, God first created the earth as a small island, barely big enough to offer Him a foothold, thus establishing the central point of the cosmos [Tomicki 1976: 58, 59]. By sanctifying his land, the farmer assumes the role of the Creator-Master of the House. In this way, entering the sphere of the sacred, he acquires access to the source of power. As a result of his fear of God and his religious attitude, he experiences the FORCE of the sacred as INNER COMPULSION, even if he follows ritually prescribed commands:

- in order to ensure lasting protection of a field against hailstorms, a pair of twins should plough along the borders of the field or the village with a pair of twin oxen: "Farms or villages on the borders of which young twin brothers have driven a plough, pulled by two oxen that are also twins, are completely free from hail, and not a hailstone will fall in these areas world without 
end" (Oborane po granicach pola gospodarstwa lub wsi (...) przez dwóch młodzieńców braci bliźniaków i para wołów, które by też były bliźniakami, sa zupetnie wolne od gradu, a nawet $w$ takie okolice jak świat światem już grad padać nie będzie) [Pełka 1987: 58]; the custom, recorded in the nineteenth century, has been preserved in a proverb "Who has his field ploughed by twins, God will not send him hailstones" (Kto pole w bliźniaki orze, nie dasz mu gradu Boże) [SSSL 1.3: 280]; ${ }^{3}$

- on Easter Sunday, after the morning Mass, a procession should carry a cross around the field ("processions went to the four boundary markers, where prayers were offered: from storms, from hail, from lightning, from all gales protect us our Lord" (odbywano procesje na cztery kopce i tam głoszono prośbę: od burzów, od gradów, od piorunów i wszelkiej nawałnicy zachowaj nas Panie)) [SSSL 1.3: 281];

- on Easter Sunday fields should be ridden around on horseback, and during the procession "a litany should be said asking for God's blessing for a plentiful harvest: 'Merciful God, from all evil, from hunger, from the plague, fire and war, from lightning and hail, from contempt for Your gifts and blessings protect us our Lord" (Litanię o błogosławieństwo Boże dla urodzajów pól: Miłosierny Boże od wszego złego, od głodu, od moru, ognia i wojny, od piorunów i gradu, od zniewagi darów i dobrodziejstw Twoich - zachowaj nas, Panie) [SSSL 1.3: 284];

- on the eve of St John's feast, young people should walk around the fields carrying torches and singing; belief in the efficacy of such practices is evinced by the proverb "Where voices can be heard, no hailstones pound down" (Gdzie się głosy rozlegajum, tam ci grady nie bijajum) [SSSL 1.3: 282].

Another method of sanctifying space through recourse to God's word was the commonly practised custom of burying passages copied from the gospels at field boundaries. Such rituals, which also rely on the concept of a magic circle, are similarly governed by a system of rules determining the time and manner of their performance [SSSL 1.3: 282]:

- the first chapter of each of the four Corpus Christi gospel readings should be copied on a separate sheet of paper and buried in the four corners of the village (or in a nearby lake);

- on the last day in the Octave of Corpus Christi a procession carrying a cross should go around boundary markers (kopce graniczne), stop at each of them

3 This custom also concerns protection against thunder (see Chapter 6.2.2 below for more information on lightning fire). 
to pray, and bury sheets of paper with passages copied from the gospels that have been placed by the altar throughout the whole octave;

- on the feast of Corpus Christi, sheets of paper with passages copied from the gospel should be woven into garlands that should be blessed and left in the church for the whole octave, and subsequently buried at the border of the field or village.

While the use of the gospel to sanctify space demonstrates deep faith in the power of divine word, the ritual also provides for additional elements reinforcing its efficacy. The choice of holiday time is of prime importance, as it immediately introduces the participants in the ceremony into the sphere of the sacred. Furthermore, the feast of Corpus Christi as such evokes the power of the event that it celebrates, i.e. the Incarnation of the Word, hence the gospels acquire a particularly strong causal force at that time so that what is heavenly could be performed on earth. Burying passages copied from the gospel at the border of the village symbolically represents bringing the Kingdom of Heaven into a particular village on earth. By consecrating the place through the living, incarnated word of God, the ritual reactualises the myth, thus ensuring that the participants in the ceremony and all the villagers enjoy the blessing and protection from evil spirits this offers, and are shielded from committing unworthy acts against the Lord (cf. above the litany asking for good crops: "from contempt for Your gifts and blessings, protect us our Lord"). In this way, the ATTRACTION OF FORCE is further INTENSIFIED to achieve the desired effect.

The cumulative model of attracting FORCE in order to sanctify "own" space is also employed in practices of burying crosses made of blackthorn twigs, blessed in church on Good Friday or Holy Saturday [Adamowski 1999d: 220, 222]. Both the time of Christ's Passion and a re-enactment of its details, e.g. the use of the crown of thorns, reinforce the power of the cross itself. In this case, FORCE is construed as operating according to the same patterns as in the practice of burying passages from the gospel.

The fields, the village and the farm itself could also be sanctified through the use of objects blessed during Easter celebrations, such as Easter palms (bunches of willow twigs or decorations on a stick $)^{4}$ or crosses made from their stems, placed behind the holy pictures in a home, stuck into the soil in the field or laid in the corn. Bones from the meat blessed before Easter and logs from the fire consecrated on Holy Saturday were buried for protective and sanctifying purposes; such logs were also used to make crosses [SSSL 1.3:281]. The power of

4 See Chapter 1, note 1. 
salvation invoked through such practices was to restore order on earth, destroy evil (protect from devilish forces), and assuage God's anger so that He would not punish people with gale-force wind or hail. Consecrated objects sanctifed the space they were placed in, thus making it an "own" space not only for humans but for God, too. Protective practices of this kind followed the general directive schema. The sanctifying rituals listed below were required in order to protect fields and farms from hail and storm-bringing winds arising by God's leave:

- processions celebrated on the feast of Corpus Christi, including burying passages of holy words taken from the divine texts of the four gospels;

- placing Easter palms, crosses made from blackthorn, logs blessed on Holy Saturday, or stems of Easter palms in the fields and at home;

- burying the bones from the meat blessed at Easter.

Other methods of warding off dark forces, which did not involve sanctification, included supplications for a plentiful harvest or protection of the crops and were addressed to God through the intercession of the saints. The FORCE schema underlies the illocutionary power of the entreaty: "By your intercession, St Lawrence, may God send all lightning, thunder, flashes, gales and hail into the wilderness, we all beg of you" (Niech za Twa prośba, Wawrzyńcze, pioruny, grzmoty, błyskania Bóg na puste strony i nawałnice z gradami odnosi, każdy cię prosi) [SSSL 1.3: 401].

Formulas for undoing spells (zamówienie), in turn, belong to the category of verbal rituals aiming to reverse what has been done, and are thus capable of changing the existing reality [Engelking 1991b: 82]. The person who casts a spell to undo a storm already in progress does this on behalf of divine and holy persons, who have the power to harness the elements. Thus the spellcaster plays the role of a mediator; speaking to the storm, he/she invokes the actual source of power [SSSL 1.3: 283]:

Against hail, to make it pass away (...) When a storm has already arisen, one ought to take three beads and say: storm, you arise by God's power, with the help of all saints, by God's leave. The sweet Virgin Mary, St Mary Magdalene, St Anne and the Son of God Himself ask of you that you shall go to desolate forests, desolate mountains, desolate lands, where you will not harm anyone. In the name of the Father and the Son and the Holy Spirit.

od gradu, aby przeminął (...) Gdy już burza powstanie, tedy trzeba wziąć trzy koraliki i mówić: burzo wstajesz Bożą mocą, wszystkich świętych pomocą, z Boskiego dopuszczenia. Zamawia Ciebie miła Panna Maryja, święta Maryja Magdalena, święta Anna i sam Syn Boży, iżby szła w puste lasy, w puste góry, w puste dziedziny, gdzieby nikomu nic nie szkodziło. W imię Ojca i Syna i Ducha Świętego. 
In this spell, analogically to the creation scene in which God bids Satan to bring a lump of earth from the bottom of the sea in His divine name, the holy names become the SOURCE OF FORCE. A hailstorm - like a disease is banished to the remote, desolate wilderness. The power of the names of holy persons is illustrated by the fact that the Feast of the Purification of the Blessed Virgin Mary (2 February) came to be called Matka Boska Gromniczna (Our Lady of the Thunder Candle). The protective function of words can also be seen in the name gromnica 'thunder candle', blessed in Roman Catholic churches on 2 February, and put in windows during storms and gales "to avert thunder". The name, deriving from the Proto-Slavic * gromons 'thunder-like, horrifying', was recorded in Old Polish from the fourteenth century onwards; it also appears in Polish and Slavic dialects: e.g. Polish dialectal gromnice (formed from the adjective gromny 'thundery' by the addition of the suffix -ica), Czech hromice, Ukrainian hrimnýtsia, hromnýtsia [SłSE 1955: 349].

Rituals practised for protection against storm introduce a clear division of space in terms of "own/familiar" (swój) and "strange/alien" (obcy). The resulting oppositions are based on the CENTRE-PERIPHERY schema: near vs far, cultivated vs wild, sacred vs amorphous.

Similarly, practices preventing the spread of an epidemic involved a separation of the space yet unaffected by "bad air" from the sphere of contagion. In this case, a cross or a row of crosses arranged in a line played a protective function, thus activating the BLOCKAGE model of the FORCE schema. A cross, as a sign of God, was supposed to stop the noxious air from overcoming the village. Additionally, the symbolism of the cross - a sign of the Passion for the redemption of human sins - was to avert God's punishment and ward off the disaster. Fear of a deadly disease also prompted the use of other means in order to cumulate FORCE, which were implemented according to strictly determined patterns of conduct. These are prescribed by emphatically imperative communicative acts such as [Adamowski 1999d: 219]:

- a cross should be erected within one night and men from the village must take part in the task;

- women must weave a white linen towel within one night; the towel should be buried under the erected cross;

- an epidemic should be driven away "by encircling the borders of the village with a thread spun within one night [along the line formed by the crosses standing there]" (przez otoczenie granic wsi nicia sprzędziona w ciagu jednej nocy [wzdłuż linii znajdujacych się tam krzyży]). 
This combination of a number of different methods of protecting oneself draws on different patterns of the FORCE schema: ATTRACTION, INTENSIFICATION and BLOCKAGE. The command to finish work within one night (the cross, thread and cloth), in turn, is consistent with the principles of imitative magic. Uninterrupted work creates an impermeable barrier, strengthened by the use of one thread. The burying of the cloth, a symbol of a road, is meant to interrupt the progress of the disease and direct it deep into the ground.

\subsection{Wind: the demonic profile}

In myths of creation, the Spirit of God is depicted hovering above the waters, which suggests the perennial existence of air filling the space between heaven and the waters, with the Creator as the only inhabitant and master of the sky. After the creation of the earth, the conceptualisation of this boundless airy space changes since it becomes a medium between heaven and earth. In addition, it is further subdivided into layers: the highest, heaven, the abode of God, angels, saints and saved souls; and lower ones, closer to the earth and covered with clouds, which the folk imagination peopled with demons, thus endowing them with an otherworldly quality [KLS 1967: 480]:

Suddenly the air and the clouds were swarming with the miscarried, the unbaptised, with the souls of children who had died suffocated by their mothers sleeping in the same bed, or poisoned by them, or otherwise killed; with the drowned, the hanged, and all kinds of suicides, with people who had died a sudden death or were simply buried badly (...). Many of those souls - as they are almost one with the wind - support and drive the clouds.

The voices of such souls can be heard in the wind howling in the fields or wailing in the stove. In Silesia it is said on such occasions that the souls of the "impure dead" are asking their living relatives for help. Wind is also whipped up when the peace of a soul is disturbed. If the soul has hidden in a broom or the rubbish collected while cleaning the house after the removal of the dead body, it will fly away in alarm when the rubbish is burnt, causing a sudden gust of wind [Kowalski 1998: 587].

In its demonic aspect, wind is conceived in folk culture as a movement of air produced by dark forces and devils lurking in wait for the souls of sinners and of those who have died an unnatural death: suicides or murder victims. Their souls, suspended between heaven and earth, dwell in clouds or wind before they are cleansed of their sins: 
- "all around the world wanders the soul of a man who goes neither to heaven nor to hell" (wędruje po świecie dusza takiego człowieka, który nie idzie ani do nieba, ani do piekła [SGP 2004: 494];

- "the soul would gladly to heaven go, but it hasn't got what it needs so" (rôda bë dëszëczka do nieba, ale nie mô co jé potrzeba);

- "the soul would be glad to go to paradise, but sins will not let it rise" (rada bë dësza do raju, ale grzéchë nie daja) [Treder 1989: 125].

In folk belief, the fiend turns stray souls into demons if their families do not make amends to those wronged or perform the necessary rites according to established patterns, or if the living fail to fulfil the requests of the suffering souls. According to social norms, it is the family that is obliged to pray for the souls of dead relatives; one should also pray for the so-called "empty souls" (dusze puste), i.e. the souls of those who have no one to say a prayer for their redemption [SGP 2004: 494]:

- “one says a prayer for souls" (i za dusami śe zmóvi påćórek);

- one should submit the names of the dead to be commemorated during the prayers said for the dead around All Saints' Day (1 November) (wypominki lit. 'naming') (na wepomink'i dajo za duse zmarłe); “On All Souls' Day farmers (...) gave out bread to the poor in the church graveyard on condition that those poor should pray for the souls of the dead whose names were indicated to them (...) and for 'empty souls'” ( $W$ dzień Zaduszny gospodarze (...) chléb na cmentarzu kościelnym rozdawali ubogim z warunkiem, aby ciż ubodzy odmawiali pacierze za dusze wskazanych im po nazwisku lub imieniu zmarlych (...) - za dusze puste).

Air demons also include the souls of unbaptised children, called duchomówcy lit. 'soul-speakers' or powietrznice 'airy spirits', which take the form of either small white owls or pigeons, or big black birds, and haunt people, asking for baptism [Pełka 1987: 50, 61]:

When an airy spirit (powietrznica) is flying around, it squeaks, it laments. If one is not in mortal sin, one should ask: Who are you? Let all spirits praise the Lord God. I baptise you in the name of the Father and the Son and the Holy Spirit. If you are a maid, may your name be Kate, if you are a lad, may your name be Thad. After these words have been said, the airy spirit goes quiet.

Jak ta powietrznica leci, to piszczy, lamentuje. Jak kto nie ma ciężkich grzechów, to pyta się: Kto ty jesteś? Wszelki duch Pana Boga chwali. Ja cię chrzczę w imię Ojca i Syna i Ducha Świętego. Jakżeś panna, niech ci będzie Anna, a jakżeś młodzieniec, niech ci będzie Wawrzyniec. Po wymówieniu tych słów powietrznica cichnie. 
If such souls are not baptised within seven years, they will be turned into demons who live in the clouds and, together with wind, do harm to people, bringing storms and hail [Pełka 1987: 61]:

Old people used to say that clouds carry around spirits called "soul-speakers" (duchomówcy). Such spirits arose from the souls of children who died before they were baptised.

Starzy ludzie opowiadali, że chmury przenoszą duchy nazywane duchomówcami. Duchy te brały się z dusz dzieci zmarłych przed chrztem.

Lexical evidence for the belief that souls do their penance in the wind is provided by the Kashubian name "wild hunt" (dzëkô jachta), referring to a demonic gale which blows over a forest, carrying a host of the souls of poachers led by a wild master hunter (Sychta 1967: 268). Their presence is heralded by a noise that accompanies the wind, in which can be heard the barking of dogs, the firing of guns, whistling and trumpet calls. The belief in the "wild hunt", also called "devilish" (diabelskô) or "German" (mniemieckô), is related to Germanic traditions [Kowalski 1998: 587]; it is found on the western outskirts of Slavic culture and in Lausitz (Łużyce), where it is called "night hunt" (nocny hajnik) [Treder 1989: 40]. This dangerous wind is raised by the spirits of hunters who used to go hunting on Sunday in their earthly life, and, presumably, were turned into demons after death.

The souls of suicides (particularly those who had hanged themselves) are also connected with the airy regions of "otherworlds" (zaświaty). Owing to the location of their abode, they are called chmurnicy (from chmura 'cloud'), obłocznicy (from obłok 'cloud') or płanetnicy (from planeta 'planet') [KLS 1967: 482]. The latter were regarded as either demons or human beings credited with the supernatural ability to bring rain during periods of drought. In folk beliefs, the demonic inhabitants of the air cause precipitation, especially heavy rainfalls, storms and hail [Pełka 1987: 61, 66]:

- "clouds are transported on the shoulders of płanetnicy. These are black wizards who sprang from the spirits of the hanged" (chmury przenosza na swych ramionach płanetniki. Sa to czarnoksięznicy powstali $z$ duchów ludzi powieszonych);

- "it used to be said that clouds are driven by the souls of people who had committed suicide" (opowiadano, że chmury prowadza dusze ludzi, którzy popetnili samobójstwo);

- "it was said that the souls of unbelievers fly around with the clouds" (mówiono, że z chmurami latały dusze niewierzacych); 
- "clouds carried the souls of children who had died before they were baptised" (chmury nosity dusze dzieci zmarlych przed chrztem);

- "old people say that clouds carry on their backs the souls of dead people taken up by the air" (starzy ludzie opowiadaja, że chmury przenosza na plecach duchy zmarlych ludzi zabrane przez powietrze w górę).

Such beliefs build cognitive paths between the concepts of wind, soul, clouds and the demonic world, thus paving the way for numerous contexts which rely on these connections. This led to the development of further secondary meanings of the word $d u c h$, from an 'apparition, immaterial form of a dead person' to a 'damned soul', and finally zmora 'mare', upiór 'vampire/dangerous ghost', demon.

\subsubsection{Wind in the relations between the devil and man}

A belief that the devil lies in wait for sinful souls is apparent in numerous set phrases which make a comparison between man's greed or ruthless pursuit of his goals and the fiend's desire to gain a human soul: "tenacious as a devil bent on getting a soul" (zawziynty jak djaboł na dusze), "greedy as a devil for a soul" ( $\chi$ cəv'ic sa jak purtk ('diabel') na dəša), "lurking in wait for something like a devil for a sinful soul" (czyhnie na to, jak djaboł na grzysznóm dusze), "to sit like a devil on a sinful soul" (siedzieć jak djaboł na grzesznej duszy), "sits on a kreutzer like the devil on a soul" (siedzi na grejcarze, jak djabot na duszy, i.e. 'to be greedy, look after one's money carefully'), "guards something like the devil a sinful soul" (strzeże jak djabol grzysznej duszy), "to tremble [with greed] like a devil for a soul” (trzaśśc się jak djabet na duszę) [SGP 2004: 498-499].

The transformation of the meaning of $d u c h$, dusza to denote a damned soul influenced the development of the meaning of the lexeme wiatr 'wind', whose connotations allow for a direct link with infernal powers. A violent, gusty wind signifies a suicidal death and the fiend's joy at gaining a new soul: "the devil is happy because someone has hanged himself" (diabet się cieszy, bo się ktoś powiesit), "it's as windy as if a Jew had hanged himself" (wieje, jakby się Żyd powiesit), "it's windy, a woman must have hanged herself" (wieje, pewnie się baba powiesita) [Treder 1989: 39]. Wind may even be raised by the devil himself flying with a captured soul: "the devil is flying, he wants to catch a soul" (diobet loto,

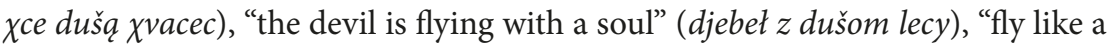
fiend to hell with a soul" (lecəc jak purtk $z$ dəša do p'ekła) [SGP 2004: 499, 500], "the evil one is riding with a damned soul to hell" (złi jadze z potępiona dëszq do pjekła), "the wind carried straw like a fiend a good soul" (wiater ze sloma lecôt jak purtka $z$ dobra dusza), "the fiend is riding a broom" (djôbet na mieteleku jedze) [Treder 1989: 40-41]. A demonic wind can also be caused by the souls of 
people who died a violent or sudden death (murder victims, persons engaged to be married who died before the wedding), or may become a tool in the hands of witches, who use its power to cast evil spells (rzucać uroki). It may even be seen as an embodiment of devilish beings themselves. Idiomatic Kashubian expressions provide lexical evidence of the belief that wind is produced by the devil. For instance, it is said that the devil "plays the ivy stick" or "plays a pipe" (grac na wierzbowym kiju, grac na gwizdówce), that is, whips up the wind from the sea; there are also comparisons such as "the wind/storm like an evil spirit" (wiater/sztormiszcze jak złi dëch) [Treder 1989: 40].

Whirlwinds are considered to be the devil's dance: e.g. "the devil's dance" (djôbli tuńc, diabli taniec), "the fiend's dance" (biésowi tuńc), "the dance of three devils" (trzech biésów tuńc), "the devil is dancing in the fields" (because of people's sins) (czort tańczy po polach), "the devil is dancing with his grandmother" (dôjbet tancuje ze swoja starka) [Treder 1989: 41]. The image of the devil whirling in a dance became the basis for the conceptualisation of wind as the devil's wedding: "the devil is going to the wedding" (diabet jedzie na wesele, czort jedzie $z$ wiesielom), "the devil is throwing a wedding party" (diabet wesele wiprawia), "the devil is getting married" (diabet się żeni), "the devil is revelling" (djôbet wëprawiô zapusty), "the fiend's wedding" (purtkové/djôblé godë) [Treder 1989: 41], "the devil is marrying his mother" (diabet się ze swoja matka żeni) [Bączkowska 1986: 57].

A whirlwind, especially when accompanied by a swirling column of dust, may resemble a human shape; hence in the folk imagination it becomes an embodiment of the devil himself, who can be seen in the vortex if one "looks through the sleeve" (wezrac przez nogawke) [Treder 1989: 41] (cf. 'dust devil' in English). In Kashubia, it is said in such cases "When the devil has nothing to do, he blows sand around" (kiej djôbet robotë ni mô, tej on piôskę kurzi) or "the devil hurls shit around" (djôbet motô gówno) [Treder 1989: 42-43]. The link between a whirlwind and evil powers is also evinced in its numerous names in dialectal Polish: Kashubian krack, Masovian kręcek, (from kręcić 'to swirl, whirl'), and Częstochovian wijc (from wić 'to wind'), all of which mean 'devil as a whirlwind'. The etymological connection between wind and blowing is clearly illustrated in the most common Slavic name for wind, vichrro, deriving from the verb vijo, viti 'to blow' [KLS 1967: 476]. Other verbal expressions that suggest a swirling movement and the violent power of wind include "whirls like pig shit" (krący sę jak swinie gówno) "a whirler/devil swirls" (kranci sia krańciek/jurk), "a whirler is flying" kręcëšnik lecy, "a shitter is flying" (srel lecy), "a madman is flying" (szelińc lecy). Common names for a whirlwind such as "pig shit" (swinié gówno, świńskie gówno), "pig air" (świńskie powietrze), "pig wind” (śfiński wichyr) 
[Treder 1989: 42-43] derive from the curse formula warding off devilish powers [Dźwigoł 2004: 114]. Northern peoples (Slavs, Finns and Teutons) regarded excrement as a magic weapon [Treder 1989: 43]. This belief can also be found in spells for undoing a disease, e.g. [Engelking 1991a: 162]:

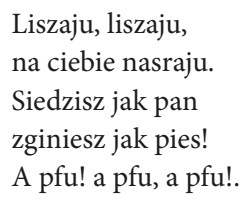

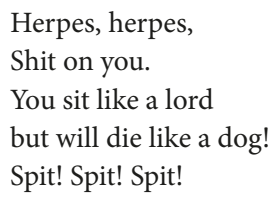

The image of the devil as a black pig [KLS 1967: 316, 471] or a black pig ridden by witches [Dźwigoł 2004: 102] throws more light on the name "pig shit" (świńskie gówno) applied to a whirlwind. In local dialects, the devil commonly assumes an animal form (a black dog, ram, horse, cat, goat) [Treder 1989: 120]. Hence it may be presumed that the Kashubian proverb "ride like a devil on a lame pig" (jachac jak djôbet na kulawi swini) [Treder 1989: 247] or the name "black pig" (czarna świnia) used when a fire goes out by itself (e.g. the saying "the black pig has got into the stove" (czarna swinia wlazła $w$ piec) meaning the devil has extinguished the fire) are directly related to the image of the whirlwind devil as a black pig. The Kashubian expression "the devil hurls shit around" (djobet motô gówno) to describe wind provides a semantic motivation for the protective cry "pig shit" (śwńskie gówno), which subsequently came to be used as the name of a whirlwind itself.

\subsubsection{Wind in the relations between man and demons}

The belief in the presence of the devil in a whirlwind and the danger involved in encountering this phenomenon led to the development of patterns of safeguards. These were regulated by a code of warnings and commands which advised falling face down on the ground, crouching or running away to get out of the demon's way and avoid getting dust in one's eyes or even being abducted by the devil in the process. Other commands, Christian in origin, prescribe the use of religious symbols and religious-magical (or purely magical) gestures [Pełka 1987: 55-56]:

- to protect oneself from the devil appearing in the form of a whirlwind, one should cross oneself, say a prayer (Hail Mary), or summon the help of the Holy Family, crying out “Jesus, Mary, St Joseph, save me!” (Jezus Maria, Józefie święty, ratuj!), and lie down on the ground, crouch, or run away home; 
- seeing an approaching column of dust raised by the wind, one should cross oneself with one's face towards the wind, or - with one's back towards the wind - one should cross oneself, recite the formula of a spell against the wind, cross oneself once again and spit behind one's back;

- to appease the wind, the man of the house should stand upon an axe; the woman of the house, having crossed herself, should pronounce the formula of the spell "O wind dear, go to the woods, go to the forests, where the sun doesn't reach, where nothing gets born, where winds don't blow, where birds don't sing" (Wiatreczku drogi, idź na bory, idź na lasy, gdzie słońce nie dochodzi, gdzie nic się nie rodzi, gdzie wiatry nie dowiewaja, gdzie ptaszki nie śpiewaja), and then say Hail Mary;

- one should get out of its way (crouch, lie face down), for the devil hidden in a whirlwind may even capture a man in order to kill or maim him by throwing him hard against the ground.

Shepherds in the Tatra Mountains, in turn, identified gusty winds with the souls of the hanged and the damned. To drive the wind away, one had to sprinkle flour and blessed salt onto the corners of the house so that "when it [the wind] blows and takes [flour and salt] away, it stops blowing and goes somewhere else" (jak on zdmuchnie i weźnie se, to przestaje wiać i idzie ku indziej). Such beliefs were accompanied by threats and warnings [Pełka 1987: 56]:

Who doesn't give anything to it [the wind] - it will blow out his fire, or flood [his property] with water. Or, out of disrespect, it will blow everything around. It's a bad thing to pick a fight with such a one. It will recognise the man on the road by his smell and won't let go.

Kto mu nie dać - ogień zduchnie, abo wodom zaleje. Abo na despekt zbyrta sytko naobkoło. Z takim to źle zacynać. Na drodze cłeka pozna i po zapachu i takiemu nie popuści.

Another method to ward off dark forces was to swear "pig shit" (świńskie gówno) three times. The efficacy of the words was believed to be reinforced by carrying dried pig excrement on oneself. Holding it in one's hand when uttering the curse deprived the demon of its power. It was also possible to destroy a devil dancing in a whirlwind by throwing a knife or another sharp object at him; in such cases traces of blood appeared on the knife [KLS 1967: 480]. The curse formula "pig shit" was commonly used, as is evidenced by the fact that it came to function as the name for the devil embodied in a whirlwind, generating also a range of semantically similar variant names such as srala, usraniec (from srać 'to shit'), gnojarz (from gnój 'dung') [Dźwigoł 2004: 114], purtk (from purtac 'to break 
wind', miec purta 'to have diarrhoea'). The euphemistic character of such names indicates a concern with protecting oneself in the face of hostile and dangerous dark forces [Masłowska 1987: 82, 85-89; Treder 1989: 120; Krawczyk-Tyrpa 2001b: 55].

Apart from names, which display the highest degree of entrenchment, scenes involving the devil embodied in a whirlwind also feature speech acts such as curses or commands urging people to protect themselves. The perlocutionary force of a curse, reinforced by a gesture (showing pig excrement to the wind) and the utterance of a magical formula "Spit, spit, pig shit is going mad" ( $T f$, $t f i$, świnie gówno se gzy) [Treder 1989: 43], destroys the devilish power through INTENSIFICATION OF COUNTERFORCE. The gesture of spitting is also frequently found in magical practices which are intended to reverse the effects of negative phenomena or undo evil spells (zamawianie, odczynianie). It has its prototype in the mythical scenes of creation when the devil, spitting out earth hidden in his mouth, made swamps and mountains (and polluted the earth with his spittle); the fiend also spat on the body of newly created Adam, for which he was cursed.

By contrast, incantations based on the structure "One should crouch/ fall face down/ run away" (Trzeba kucnaćc/ paść na twarz/ uciekać) function as warnings, whose perlocutionary force urges one to follow customary forms of protective behaviour in order to ward off evil spirits. In both cases the FORCE schema takes the form of INNER COMPULSION, a fully conscious adoption of a defensive attitude towards hostile supernatural forces. In the case of curses, the experience of FORCE involves COUNTERACTION, leading to the neutralisation of devilish powers, while warnings, which advise getting out of the demon's way, rely on the DIVERSION schema.

Magical practices combined with Christian-based religious ways of conduct were also employed to ward off hail and storm clouds, driven by air demons. The aim of such rituals was to invoke the help of supernatural powers in order to avert the storm, directing it away to remote, desolate wastelands, forests or waters. The rules of behaviour relied on the COUNTERFORCE schema, with the power of God opposing the demonic forces. God's aid was secured by the performance of strictly prescribed ritual sanctifying actions, additionally reinforced by the magical properties of the objects used for the purpose (usually a bread peel, a wooden poker, a rake, a garden fork, a harrow laid with its teeth upwards). The INTENSIFICATION OF FORCE was to be achieved thanks to consecrating the space above the house, tearing the cloud apart with sharp tools, or driving it away by other magical means. The measures to be taken were prescribed by the following commands [Pełka 1987: 62-65]: 
- to drive away a storm cloud, St Agatha's salt should be sprinkled towards it (St Agatha's salt was believed to have a purifying power against demons);

- church bells should be rung (the sound of sacred bells would reach the clouds, causing the demon to withdraw, taking the cloud with it);

- Loreto bells should be rung (owing to bans on ringing church bells to drive away storm clouds, small hand bells were used instead with the same intention and expected outcome);

- blessed bread should be burnt and taken outside the house during the storm (the smoke from blessed bread, like salt, purifies the air, making the space above the house/field sacred and impenetrable to evil forces);

- a garden fork, poker and harrow should be taken out in front of the house and laid with their spikes upwards; in addition, noise should be made by striking a hammer against steel sheets (to tear up and frighten away the cloud);

- a bread peel and bread oven brush (attributes of the holy domestic hearth, meant to protect against thunder) should be taken outside the house or into the field;

- a cross or holy pictures should be hung on the outer walls of the house, or taken around the yard and put in the windows (sanctification by creating a concentric space of power);

- a lit "thunder candle" (gromnica) ought to be put in the window, and it should be used to burn out the sign of the cross on the window pane (as above, the objective is to delineate a sacred space, protected by sacramentals and the purifying power of fire);

- biting stonecrop should be put around in the house, and the house should be fumigated (smoke from blessed herbs sanctifies and purifies the space around);

- a rosary should be worn around the neck and prayers should be said aloud (the power of active words reinforced by the power of the rosary is capable of summoning the aid of the Virgin Mary);

- an Easter palm should be put in the window (delineating the borders of a sacred space);

- garlands blessed on the day of Corpus Christi should be stuck behind the beams in the attic, hung in the windows and from the ceiling, and scattered around the house; they should also be burnt (as a symbol of the accumulation of power through the use of blessed herbs, sanctifying the domestic space, and smoke, purging the space above the house).

Even though the methods used to sanctify space in order to ward off the clouds brought by evil powers are analogous to those adopted to propitiate God's 
wrath, they rely on different patterns of the FORCE schema. When holy objects are used to sanctify space in order to deprive demonic forces of their powers and drive them away, the underlying schema is that of COUNTERACTION. The use of sacramentals makes it possible to enter the sphere of the sacred, thus gaining access to divine power, capable of destroying demonic forces (in accordance with the ATTRACTION schema). Practices aiming to avert punishment, in turn, involve directly addressing the SOURCE OF FORCE (employing the ATTRACTION and INTENSIFICATION schemas) with the hope that the clouds or epidemics would go away according to God's will. In acts of propitiation there is no room for COUNTERFORCES since clouds and winds are subject to God's will and act at His command. The actions of human beings and their intermediaries (saints, Jesus, the Virgin Mary) are only to gain favour with God, whose power may BLOCK the epidemic, hail or storm and direct them away from their course, in keeping with the DIVERSION schema.

Another set of rules prohibits certain activities during a storm [Pełka 1987: 62]:

- no household chores must be performed during a storm;

- lamps must not be lit at home during a storm.

Prohibitions against performing actions other than magical-religious ones could have been motivated by fear that any accumulated protective energy might be disturbed which, in turn, could weaken its power or cause an unexpected diversion of the path of force.

In folk interpretation, supernatural forces derive from God or Satan. Płanetnicy (from planeta 'planet', sing. płanetnik), beings in charge of clouds, were either believed to be demonic in origin (like the damned souls of suicides), or were regarded as human beings endowed by God with a special supernatural power to govern weather, especially winds, clouds and storms. While respected, they were also feared in interpersonal relations. Additionally, since they were considered to be chosen by God, people turned to them as mediators capable of driving away storms. Płanetnicy chosen by God used magical-religious protective techniques as described above, while those who derived their powers from demonic sources employed secret spells known only to themselves [Pełka 1987: 71]:

(1) To drive away clouds, płanetnicy used secret spells, which no one knew but they themselves. Each planetnik had his own spells.

(2) Some people, who were wizards by birth, received extraordinary power. This came from their birth. 
(1) Do odpędzania chmur płanetniki używali tajemnych zaklęć, których nie znał nikt poza nimi. Każdy płanetnik miał własne zaklęcia.

(2) Moc niespotykaną otrzymywali niektórzy ludzie, którzy byli czarownikami od urodzenia. To przychodziło razem z urodzeniem.

\subsubsection{Souls in the power of evil forces: ghosts, spectres, witches}

Belief in innate demonic powers is clearly displayed by the command to keep a close watch on newborn babies to ascertain which infant could become an upiór 'vampire/walking dead/spectre' in future, and thus become dangerous to the people around. It was the duty of the midwife delivering the baby to check whether it had the marks of a future upiór, such as the presence of a caul or teeth. In Kashubia it was said that a child was born "in a bonnet", "hat", "cap", "garland" (urodzël sa $v$ czôpku, w czôpeczce, czôpuszku, mucce, pajiczënie, plechu, wiônuszku, wieszbie) or that it "brought its own teeth" (przëniesc sobie zębë). (In other parts of Poland, being born with a caul signified good luck; such an interpretation also used to be the case in Kashubia, as indicated in records collected by earlier Kashubian lexicographers: Alexandr Hilferding and Gustaw Pobłocki [Treder 1989: 86].) The caul on the newborn's head meant the child was going to become a wieszczi, i.e. 'a wizard, diviner, prophesier' or 'a vampire sucking out the blood of the living family members in their sleep. Teeth, in turn, were a sign of an opi, a dangerous kind of vampire/walking dead who rose from the grave to cause the death of his family, neighbours or even the entire village (cf. the proverb "the opi hunts people down" (opi ludzi tropi)). If an opi managed to reach the church bell and set it tolling, it brought death upon all the living within earshot [Sychta 1969: 330-331]. Consequently, the examination of a newborn baby was treated with utmost seriousness. If potential danger was detected, a number of commands prescribed the appropriate behaviour in order to destroy any evil powers present:

- if a baby is born with a caul, it means that it is going to become a vampire (upiór) after death; to prevent it, the caul must be burnt immediately after the delivery, and the ash conserved until the seventh birthday, when it should be mixed with water blessed on Holy Saturday and given to the child to drink (the FORCE of such water would destroy any demonic powers, in keeping with the COUNTERACTION model);

- if a newborn child has two teeth, it is going to become a vampire/walking dead (opi); to prevent him from harming others after death, the teeth ought to be broken, and the body given special treatment after death (opatřec).

The preparation for burial (n. opatrzenie, v. opatrzeć) of the body of a person considered to have the markings of a future upiór (vampire/walking dead) 
involved creating obstacles to prevent it from escaping the grave, thus relying on the BLOCKAGE schema. Detailed instructions were passed on from generation to generation and were followed strictly in order to make it impossible (or at least more difficult) for a vampire/walking dead (opi, wieszczi) to leave the grave. According to a proverb, if "the dead has work to do, he will not rise [from the grave]" (umarli muši mec robotą, tej on ńe vstońe) [Sychta, 1969: 331]:

- the dead should be given a page from a prayer book with no amen on it (lack of the word endowed with causal power constituted BLOCKAGE);

- a coin, or lime, earth from his/her own grave or ground brick should be placed in the mouth of the dead so that he/she cannot leave the grave before he/she has chewed it up (BLOCKAGE);

- a fishing net should be put into the grave as undoing the knots would take him/her a long time and delay them (BLOCKAGE);

- poppy seeds should be scattered over his/her body or soil, dug from the place where two boundary ridges cross, should be sprinkled under his/her chin (the magical power of such soil provides a COUNTERFORCE, neutralising the power of the vampire);

- to "discourage him/her from walking after death" (odstrašc go od chodzenégo po smercë), the dead should have his/her heels cut off and be buried without shoes (BLOCKAGE);

- a cross made of aspen, or a "thunder candle" (gromnica), should be placed under his/her head. The symbol of the cross as such provides a COUNTERFORCE, while the use of aspen wood or a thunder candle acts as an INTENSIFIER;

- during the funeral procession, the coffin should be opened at the village border and the dead put face down so that "he/she cannot find the way home" (ne nalåz drogi dodom) (DIVERSION schema - a change of the path of the FORCE);

- mourners at the funeral (pogrebnicy) should cover their faces so that the deceased cannot recognise them and go back home with them (BLOCKAGE);

- if all the measures above fail to stop the vampire/walking dead (upiór), the grave should be dug up, and the head of the dead cut off with a scythe; the head should then be placed between the corpse's legs, so that the upiór cannot reach it and put it back on his/her neck; it was believed that the upiór would wait for this and say "Cut, if you want, but at once, or I'll do it to you" (K'iej chcesz, to tni, ale od razu, abo jå ceb'e). The head must then be cut off immediately, or the upiór will do the same to his executioner (BLOCKAGE).

In all scenes involving a dead body, the persuasive force of commands and warnings acquires causal power. The participants act motivated by INNER 
COMPULSION, with full awareness of, and conviction in, their beliefs. Fearing death at the hands of an upiór induces them to comply with all traditional prescriptions. If the upiór's executioner finds the grave deserted, he must wait for the dead's return; otherwise he would be torn to pieces should he meet the ghost on his way [Sychta 1969: 331].

The common belief that some people have innate demonic properties and rise from their graves after death to suck the blood of the living, especially their relatives, finds a lexical reflection in numerous names recorded in all Polish folk dialects and beyond (in both Slavic and other languages). The etymology of the most popular name, upiór, is unclear; ${ }^{5}$ the word reached Poland in the form wampir, probably from Germany (cf. German Vampir, as well as Polish folk names wampierz, wapirz, wapierz) after a long journey from other languages, during which it had undergone a range of phonetic changes [Dźwigoł 2004: 67].

Polish folk names for upiór ${ }^{6}$ have been recorded in numerous phonetic variants (often arising as a result of euphemism, a strategy applied to avoid summoning the demon by the utterance of its name): up'ur, upier, tupior, tupir, opi, tepi, łåp’i, tup'i, wupi, wupji, wypier, njełop, topyrnik ('a man with two hearts and feathers in his armpits'). The corresponding Kashubian names are up'ôr, up'ôn, op'ôl, op'i, uup'i, uep'i, håp'i, rop'i, nełåp, połap. ${ }^{7}$ Names such as niełap (njełop, ńełåp) have the semantic structure of a magic spell nie łap 'do not catch/grasp', based on naïve folk etymology. In this way, by their association with the verb łapać 'to catch, grasp', they are to protect the speaker from being caught by an upiór [Dźwigol 2004: 65; SEKasz 1994: 199-200]. ${ }^{8}$

5 For a survey of etymological research see Dźwigoł 2004: 66-67. Semantic interpretations suggest a connection with flying (as the upiór is believed to take the shape of a night bird) [Brückner 1957: 594]; Kazimierz Moszyński associates the name with blowing, or bloating, as in 'bloated with swallowed blood' [KLS 1967: 616], while Leszek Moszyński - with feathers, as in 'a bird-like figure of a feathered demon' [Moszyński 1991: 160]. Wanda Budziszewska bases her argument on an association with dust or ash, as 'one who has not turned to dust after death' [Budziszewska 1983-1985: 13-14]; for Wiesław Boryś, in turn, it is an agent noun derived from the Proto-Slavic verb $v$-prati, vo-prrati 'sink one's teeth into' ('one who sinks his teeth into a body to drink blood') [Boryś 1975: 159].

6 Names of the upiór from various dialectal sources quoted after Dźwigoł 2004: 64-65.

7 The view that the Kashubian opi and standard Polish upiór derive from the same source is shared by Hanna Popowska-Taborska [Popowska-Taborska 1995: 151].

8 According to the authors of that dictionary, the typically Kashubian names of the upiór with the $-i$ following the plosive consonant at the end (łåp' $i$, opi, łup'i) developed as a result of secondary associations with the sound of the vampire's footsteps: the 
Synonyms for the word upiór do not pose interpretative difficulties as they refer directly to the demonic figure of the dead who did not leave the earth after death: umarlak, umrzyk, (from umrzeć 'to die') or nieboszczyk 'the deceased'. Other recorded names include potepieniec 'the damned', dusza pokutujaca 'penitential soul', duch 'ghost', dusza 'soul', dusza zmartego 'soul of the dead', nocny duch pokutujacy 'nocturnal penitential spirit'. This indicates that apart from those who acquired demonic powers through fate, the upiór group also came to include the damned. In the folk dialects of Warmia and Masuria, such penitential souls were called szpuk or spuk, from the German Spuk 'evil spectre, phantom, apparition, bogey'. In ethnographic materials collected in Masovia, szpuk features as 'the ghost of the dead who came back home' and in the Augustów region it is 'a house ghost, a damned soul doing penance in the attic'. The verbs deriving from szpuk: szpuknać, szpukować 'to haunt' suggest a successful adaptation of the loan word in Polish folk culture, where analogical beliefs were current. Synonyms for upiór also include euphemisms such as straszydło, strach, straszek, straszysko, deriving from the noun strach 'fear', as well as złe, zły duch 'evil spirit', złośliwy duch 'malicious spirit', which identify an upiór with a demon [Dźwigoł 2004: 70].

Partial synonyms of upiór include names which may additionally refer to similar, but not identical phenomena. For example, two words for a witch, strzyga and wieszczyca, not only became the basis for the formation of male forms (standard and dialectal Polish strzygoń, Kashubian wieszczy), but merged semantically with the concept of 'a ghost of the dead walking the earth'. Strzyga - also recorded as stšiha, štšiha, szcziga, szczyga - refers to a type of upiór 'vampire/walking dead', while as a word with both male and female gender forms, strzyga/strzygoń serves to denote 'a human being with two souls' or 'the soul of a person who did not receive the sacrament of Confirmation'. Other related meanings include: strzygon 'an evil spirit that cuts (strzyże) a person's clothes', strzyga, strzygonia 'nocturnal bogey', strzyz 'a child born with teeth who takes away other children after death'.

The Kashubian name wiešči, in turn, deriving from the Proto-Slavic *věščjb 'a sorcerer/seer/diviner' has retained its original meaning only marginally. Although vjęšči, vješčc, vže ̌̌š may mean 'an all-knowing person', or 'a sleepwalker, in most cases they refer only to a vampire/evil spectre. The female forms wieszczyca, wiescyca deriving from the Slavic věščica, věščaja have completely

onomatopoeic łup, lup, łup (cf. Sychta 1969: 30: v'ešči šd i gådåt som do se: łup, łup, łup 'the phantom walked and talked to himself: stomp, stomp, stomp') - as well as typical intentional distortions prompted by the principles of the taboo [SEKasz 1994: 199-200]. 
lost their connection with divining (wieszczenie), and function solely as names for a female vampire.

More than phonetic, it is semantic discrepancies that reveal the multi-layered nature of beliefs in the afterlife of the human soul, its presence on earth after death and relations with the remaining, living members of the family and community. The connection with the demonic world determines the axiological charge of the concept and the polarity of its meaning, thus equating supernatural and demonic properties.

In folk belief, "innate" demonic qualities may manifest themselves during the lifetime of people who may not even be aware of their affliction. Evil supernatural forces rule their victims in their sleep. The soul of the afflicted leaves the body, turning into a mouse, cat, snake, moth or mosquito, to torment other people immersed in sleep, trouble farm animals, suck the sap out of plants or block sources of water. The traditional name for a night apparition is zmora, mora, mara 'mare,' although depending on the region, it is also known as gniotek, gnieciuch (from gnieść 'to crush') dusiołek (dusiołka, dusiciel) (from dusić 'to suffocate'), wietrznica (a female form deriving from wiatr 'wind'). The semantics of these names is related to the experience of the FORCE of the nocturnal apparition, whose presence is felt as an exhausting dream, a nightmare or a feeling of suffocation, causing fear and a sense of imminent danger. In the folk imagination, a mare sits on the chest of, or lies on, a sleeping person, crushing them under her weight and making it impossible to breathe freely. Sometimes mares even drink the blood of their victims [Czyżewski 1988: 133-134].

Less popular names include: ugardlëca (from gardto 'throat'), stodolanka (from stodoła 'barn'), koga (from 'a bed in the barn'), wodna zmora 'water mare', sotona, myrcha (from 'woman' (derogatory)), biża, bieża (from the sounds made to lull a child to sleep), bożek 'idol', koszmar 'nightmare', zky duch 'evil spirit' czort-diabet 'fiend-devil', nocny diabet 'night devil', upiór 'vampire/ghost', wiedźma 'witch' [Dźwigoł 2004: 57-62]. The various names indicate both the place and manner of such torture and the relationship with evil forces. Taking into account that women considered to be mares are not aware of this fact in their waking hours, the folk imagination allows for a far-reaching intervention of dark powers in human life. The actions of demonic forces may take the form of

9 Wanda Budziszewska considers the names mora, mara to be the oldest, deriving from the Indo-European ${ }^{\star}$ mer- 'squeeze, press' [Budziszewska 1991: 176-178], while Oleg Trubachëv [ESSJ vol. 19: 213-214] questions the connection of Proto-Slavic. ${ }^{*}$ mara with ${ }^{*}$ mora [after Dźwigoł 2004: 58]. 
OUTER COMPULSION, as when the eldest or youngest of the seven daughters of the house becomes a mare, or when such a transformation happens to a child during whose baptism the evil spirit has changed the words wiara 'faith' into mara 'mare' or Hail Mary into Hail Mare (zmoraś instead of zdrowaś). In such cases it is assumed that the agent must have been the evil spirit, who endowed the distorted words with causal power and thus took control of the woman's soul, forcing it to leave the body during sleep and harry other people. Mares (of all types indicated by their names) were believed to cause diseases affecting people, animals and plants. Regular nocturnal torture and sucking of blood rendered their victims powerless, weak and pale, which might even lead to death. Such beliefs are evidenced in lexicalised contexts, especially in comparisons of people who feel unwell or look unhealthy to a mare or to someone afflicted by a mare: "pale like a mare", i.e. sick (blady jak zmora), "pale as if all mares sucked out his blood at night" (blady, jakby go wszystki mory po nocach cyckały); Kashubian: "moans as if a mare was suffocating him" (jači jakbë go mora dësëła), "pale/ thin/ injured/ sleepless like a mare" (bladi/ chudi/ pokalečoni/ ńevësponi jak mora) [Dźwigoł 2004: 57]. Consequently, a number of measures were developed to get rid of the troublesome spectre. Their use demonstrates the perlocutionary force of speech acts, such as the following advice, commands and warnings [Czyżewski 1988: 136]:

- a mare can be rendered harmless by sleeping in a position opposite to the usual one so that she should mistake buttocks for the face and thus be shamed and outraged ("when she sees that it is not the face she kisses, she goes away, angry" (gdy spostrzega, że nie twarz caluje, rozgniewana odchodzi)); one can also eat one's own excrement so that "the mare will find such a person revolting" (zmora zbrzydzi sobie taka osobę) (REPULSION);

- a crossed axe and broom should be placed on the threshold, or an awl should be put in the door (BLOCKAGE);

- one should lie in bed with their wedding belt on or together with a goat (BLOCKAGE);

- one should cross oneself three times before going to sleep or repeat the words of a religious hymn (COUNTERACTION);

- a mare can be caught, but must be immediately released since she could bring about misfortune (BLOCKAGE).

In the case of visitations by a mare, the FORCE schema serves to conceptualise the actions of evil forces, capable of producing phenomena which cannot be explained in rational terms. Since the activities of demonic powers take place in particular circumstances, they are construed by means of the following 
schemas: LACK of CONTROL (night, sleep), COLOUR (lack of light) and DISINTEGRATION (the soul leaving the body). The FORCE experienced by both the victim and the agent is active at a particular time, in folk culture regarded as the time of the demonic (the visitation begins at night and finishes before the crowing of the cock), and in an appropriate place (usually a closed space, such as a house or a barn). It is also repeated at regular intervals (the mare haunts every night).

Synonyms for a mare such as czort-diabet 'fiend-devil', zły duch 'evil spirit', nocny diabet 'night devil' indicate that it was identified with evil spirits. In turn, names such as wiedżma 'witch', wieszczyca 'seer, diviner', bogina 'goddess' used to refer to a mare suggest a confusion with other representatives of the semidemonic world: vampires, walking dead, seers and genuine demons (bogina). Although the semantic structure of these designations clearly points to the type of relation with supernatural forces (wiedźma, literally 'a knowing woman', has access to secret knowledge, wieszczyca - the power of foretelling the future, and bogina belongs among the gods), their meanings have visibly extended and come to function as synonymous expressions referring to demonic and semi-demonic beings as well as persons possessing special prophetic powers. This is evidence of a gradual identification of spectres of penitential souls with demons or living people controlled in some way by dark forces.

People endowed with supernatural powers, in turn, can be divided into those who use their abilities to perform magical practices to benefit others (healing, undoing evil spells (zamawianie uroków)) and those who, in collusion with the devil, gain wealth at other people's expense and harm other people by casting evil spells which cause illness and misfortune. Thus the profiling of the linguistic image of wizards and witches takes place from the point of view of the manner and goal of the use of their supernatural powers.

Naturally, the axiological charge of all types of relations with evil forces is negative, especially that the price for the devil's services is the human soul (cf. the expressions "to give the soul to the devil" (oddać dusze diabłu), "he gave himself to the devil" (oddåt sa djåbłu), "to lose/ sell/ bequeath the soul to the devil" (duša zgub'ic/spredac/ zapisac diåbłu)) and the reward is hell: "be good to the devil and he will pay you back in hell" (zrób djåbłu dobře, a on ce p’ekłem odpłaci), "if you have a devil for your uncle, you will easily go to hell" (jak mász dziábła strykiem, to sie liko do piekła dostaniesz). Dealings with the devil are referred to by the following expressions: "to work with the devil" ( $z$ diabłem narabiać), "to work for the devil" (na diabła robić), "to make friends with the devil" (kumać się z diabłem), "to be in business with the devil" (mieć spótkę $z$ diabłem). Such dealings were believed to bring material profits, e.g. "he was said to be in business with the devil, 
and this devil provided him with money" (to podobno miot sputke $z$ diablym ji tyn djabot dostorcot mu p'ińinzy), "to keep in with the devil" ( $z$ djabłem dzierżyć), "he keeps in with the devil because he has a sack full of money" (in $z$ djoblym źeržy, bo p'ińnnzy mo dycki petno kapsa). By contrast, possession by the devil was construed as the evil spirit entering the body of a person, taking control of their mind and governing their actions: e.g. "the devil has entered someone" (diabet $w$ kogoś wstapil), "the devil has entered him" (d'iabył v ńo fstomp'ut), "to have a devil" (mieć diabła), "so they said he had a devil" (no ji gadal'i, žy djabła ma), "the devil has become attached to someone" (diabet się do kogoś przywiązat), "the devil has someone in his power" (diabeł kogoś pod moca ma), "the devil has him in his power" (Diabet go pod moca ma), "the devil stays in someone" (diabet w kimś siedzi), "to have a devil under one’s skin/ behind one’s ears" (mieć diabła za skóra/ za uszami), i.e. 'to listen to the devil's promptings', "ensnared/ possessed/ entangled by the devil" (omotany/ opętany/ oplatany diabtem), "leaning on the devil" (oparty o diabła) [SGP 1998: 512-520]. People who have dealings with the devil are believed to be able to see the future, as shown by the following comparisons [SGP 1998: 512-520]:

- "to know things in advance like the devil" (wiedzieć na przodek, jak diabet): "he knew everything in advance like the fiend, like the devil" ("on fsycko v́ezåt na

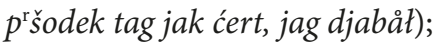

- "to know where the devil has kids" (v́ezec ze djåbet ma młode), "to know where the devil will breed" (v́ezec ze djåbet sq omłozit), meaning "to know about everything, be able to predict things'.

"A Freemason, doppelgänger, foreign nobleman (lit. 'noble devil') are all subject to the evil spirit" (Złému duchowi poddóny jest mason, farmazon, sobowtór, djôbet pański) [Treder 1989: 122], while converts to Lutheranism are said to "stink of the devil" (śmierdza diabłem) [SGP 1998: 515]. The devil's circle is naturally composed mainly of strangers (foreigners, people of a different faith) and people who are different, who possess special abilities (doppelgängers, wizards and witches). The circle can be extended, since a witch can "put/ feed/ whisper a devil/ Old Nick into someone" (zadac komu djôbła/kukę, wsadzëc komu jurka, wszepnać komus michôtka). The devil then "talks through a man": "a devil barks/ speaks through someone" (przez kogoś djôbeł szczekô, smętek gôdô bez kogoś), "an evil spirit talks through someone" (przez kogoś złi dëch gôdô); a person who is in the fiend's power is said "not to be oneself" (nie bëc soba) [Treder 1989: 71, 115]. Such expressions clearly indicate the operation of a FORCE that controls the actions of the devil's associates. Those who have sold their souls to the devil experience his power as INNER COMPULSION, consenting to the loss of their own 
personality and becoming alien to themselves (nie bëc soba). To enter the sphere of the devil means to become his "friend", "relative", hence witches are called "neighbours" (kumoszka) or "aunts" (ciotka, ciota) (cf. the Kashubian djåbla cotka 'the devil's aunt', djåbla starka 'the devil's grandmother'), ${ }^{10}$ and wizards "uncles" (wujek) (there are also male forms deriving from the female ciota 'aunt': ciot, ciót, pociot, pociót, as well as the adjectival form skumany 'friendly' (from kum 'godparent to one's child; a friend')) [Dźwigol 2004: 79]. The use of family relationships to denote links with evil forces involves a change of value on the axiological scale from positive to negative. Combined with the adjective diabli 'devil's/devilish', the vocabulary of family relations like ciotka 'aunt', starka 'grandmother', wuj 'uncle', pociot 'uncle/distant relative' becomes pejorative. In order to enter into a relationship with the devil and become apostołka wëznaniô djôbeskiégo 'an apostle of the devil's creed', divelka 'she-devil', nawiedzona 'possessed, i.e. a witch, one must not only renounce one's family, but also God, uttering a variant of the following formula [Treder 1989: 72]:

Jô wierzę w grónk, a sraję na Boga;

I believe in a pot, and shit on God;

Sraję w Boga, wierzę w grónk.

I shit on God, I believe in a pot.

By aligning themselves with the devil, witches are believed to gain a special power: urok (literally 'charm'), a harmful magical power contained in a look or word, thanks to which they can "cast an evil spell on someone" (zadać komu urok), "cast magic on someone" (zadac komu czarë), also euphemistically referred to as "do evil to someone" (zrobic komus zle), for fear of the active power of the word itself. The most dangerous is urzek (probably deriving from rzec 'say/ utter'), a type of evil charm produced by admiring or praising, since it can be reversed only by a stranger [Treder 1989: 68-69]. Such charms were believed to be particularly harmful, leading to the development of prohibitions against excessive praise and loud admiration, especially of newborn babies before baptism, as this could summon evil forces. There were also formulas counteracting the effects of praising [Treder 1989: 74]:

- it is forbidden to praise and admire a newborn child excessively;

- when someone offers excessive praise, one should say "kiss its arse" (kusznij to $w$ rzec) or "the charm on the dog" (to le je takié na psa urok), and then spit behind one's back three times.

10 For a full list of phonetic and derivational folk variants, see Dźwigoł 2004: 78-79. 
Magic spells and gestures allowed a witch, also called kåttunka, kåłtunica (from kottun 'Polish plait' (matted hair)) [Sychta 1976: 111], to cause someone's hair to mat (zasadzëc komu kôttón), prevent cows from producing milk ("dry out milk in cows" (zasëszëc mléko w krowach), "take away cows' milk" (odebrac mléko krowom)) or take away other people's crops: going out into the field, the witch would act out the motion of sowing, uttering the spell formula: "mine is all gain" (mój pożëtk je wszëtk), "I take benefit, but not all of it" (biere pożytek, ale nie wszytek), "gain for me, loss for thee" (mnie na użytek, tobie na ubytek) [Treder 1989: 70, 75].

In scenes of casting spells (zaklinanie, rzucanie uroku), the witch, as the agent, performs the role of a mediator since it is Satan, who remains in the background, who is the actual source of power. The conceptualiser - as a participant in the event - is drawn into the scene, where he/she plays an additional role of an observer. The FORCE at the witch's disposal - be it verbal or transmitted through a gesture or look - produces a particular change, accomplishing the intended goal. During the interaction, COUNTERFORCES (performative formulas and gestures of undoing the spell) are activated, thanks to which the devilish power is neutralised.

The most distinct and at the same time the most common profile of the witch focuses on her ability to perform magic (czarować). This includes names deriving from Proto-Slavic forms ${ }^{*}$ čarovbnica, ${ }^{*}$ čarovonikz, which have fully preserved the etymological root of the verb *čarovati, “čarovbnz 'do magic', such as čarovnica 'sorceress/witch', čarovník 'wizard/sorcerer', found in numerous phonetic and derivational variants in Polish dialects. ${ }^{11}$ This profile also includes compounds formed on the basis of ${ }^{*}$ čar 'magic/spell' and ${ }^{*}$ déjati 'do', yielding a meaning identical with the Proto-Slavic * čarovati, which serve as names for male associates of the devil: czarodziejnik, czarodejnik, czarodynik, czarodelnik, czarodzierz, caroz.yš. This group also includes names činkar, czynatań, czynatorki 'witches', deriving from the verb czynić 'do' employed in the context of magical practices, which in collocations with the word czary 'magic' acquires the meaning 'do magic': czynić czary > czarować. The prefixal form odczyniać 'undo' in collocation with the noun urok 'charm/spell' came to function as a phraseme odczyniać uroki 'undo charms/spells. ${ }^{12}$ An analogical semantic development can be observed in

11 I restrict my choice to those phonetic or derivational forms of the names in question which include additional semantic features relevant to the analysis (e.g. euphemisms, compounds).

12 The evolution of the meaning of the verbs czynić, robić 'to do' with respect to magic is consistent with the development of the Proto-Slavic * činiti, and can also be observed in 
names recorded in the Podhale region in southern Poland: porabjači 'wizards', porabjačky 'witches' (from porobić 'enchant', a prefixal form derived from robić 'to do') and in the Kashubian: kutin 'wizard', kutina 'witch' (from the Proto-Slavic ${ }^{*} k u t i t i$ 'do/make'). Similar names include the Kashubian tråpčik 'a man who can cast spells', paskudniik, paskudnica 'spellcaster' (from the adjective paskudny 'ugly/malicious'; cf. also the Kashubian opaskuzëc 'cast a spell', paskudne očë 'malicious eyes'), or paskudnica/paskudziarka 'bad witch', paskudziarz 'man who undoes spells' as well as zadåvajk, zadåvajka (from zadawać 'inflict') 'wizard, witch' recorded in other regions [Dźwigoł 2004: 72-76].

The way a witch looked at someone was also considered dangerous, hence she could be called "a woman with evil (lit. 'spellcasting') eyes" (baba o urocznych oczach) [Dźwigoł 2004: 78]; her eyes were also referred to as krzëwè lit. 'crooked', lëché 'bad', paskudne 'ugly/malicious', uroczné 'bewitching', zaczarowané 'enchanted', cëdowné 'wonderful'. It was enough for a witch to "look askance at someone" (spojrzeć na kogo krzywym okiem) and her very "sharp/evil look" (ostré/lëché wezdrzenié) could cast an evil spell. Methods of avoiding the effects of magic spells were passed on by means of communicative acts such as the following:

- if a witch wants to cast a spell on you, you should quickly utter the magic formula "salt into your eyes!" (sól tobie w oczy!) [Treder 1989: 80];

- "If you spit in the witch's eyes, she won't be able to cast a spell on you" (Kiéj plëniesz babie w oczë, to cę nie uroczi) [Treder 1989: 70].

It is said that a witch has "red eyes" (mô dzëwé (czerwioné) oczë) or that "she has a billy goat with horns on its head in her eyes" ("instead of maidens", i.e. pupils (zamiast panienków)) since they reflect the devil in the shape of a goat. This belief provided the basis for the now obsolete set phrase "a goat looks out of his eyes" (kozica mu patrzy z oczu), i.e. there is evil in the way he looks at one. Other lexicalised forms reflecting the belief in the evil power of "spellcasting" eyes are comparisons and phrasemes, or set phrases, such as "to have eyes like a witch" (mieć slépia jak czarownica), "evil eyes" (złé oczë), "to look askance at something" (krzëwo sę na co przëzdrzec), i.e. to cast an evil spell, "to look around" (zazdrzec

folk dialects: czynić 'to cast spells, to do magic' (lit. 'to do'), načinić 'to charm someone', čynić czary 'to do magic', czynić zaklęcia 'to cast (lit. do) spells', czynienie 'doing' (in the sense of 'doing magic'), uczynek 'casting a spell' (lit. 'a deed') [Popowska-Taborska 1987: 212; Dźwigoł 2004: 73]. 
$w$ koło), i.e. to enclose space with a magic circle, "to look into someone's arse" (zazdrzëc komu w rzëc), i.e. to cast an evil spell [Treder 1989: 70-71].

Belief that the devil passes on secret knowledge to witches on the Thursdays coinciding with the new moon (nowy czwartek) (cf. the invective ty czwartkowa cioto! 'you Thursday aunt!' (i.e. witch)) is evinced in such names as wiedźma 'witch', lit. 'a knowing woman', znachor 'healer', 'one who knows', mędrzyca 'witch', lit. 'a wise woman' [Dźwigoł 2004: 75]. The same words were applied to denote both people who engaged in reversing diseases and undoing evil spells, and demonic beings as such. Thus the practice of magic and the possession of secret knowledge were seen as evidence of access to dark forces, and the boundaries between black and white magic were often fluid. Nevertheless, the names jędza or babojędza 'witch' [SGP 1981:236] were reserved for those women who were "friends with the devil" (skumane $z$ diabłem), who used their knowledge "for their gain, and other people’s loss" (na swój pożytek, innym na ubytek), evil persons able to induce weakness or illness, and cast evil charms. Both jędza and babojędza derive from the Proto-Slavic ${ }^{*} j e g a>{ }^{*} j e d z a$, meaning 'nasty, evil' [SłSE 1956: 577-578], which gives them a definitely negative axiological charge.

The preservation of the etymological meaning in the semantics of the names of witches and magic spells points to both their ancient origin and the continuity of beliefs in the impact of the demonic world on earthly reality and the human condition.

The FORCE schema is also visible in the conceptualisation and grammaticalisation of phenomena connected with the experience of supernatural forces, especially evil ones. "The evil" (złe), the agent, is imagined as an immaterial spirit, an invisible causal force. This is reflected in the impersonal verbal forms employed to present its actions: pomieszało mu $w$ głowie '[it] got him confused in the head', łamało mu kości '[it] broke his bones' (i.e. 'his bones hurt'), odjęło mu mowe ' [it] took away his power of speech'. The amorphousness of the demon is also conveyed through the ostensible lack of subject in such sentences as nocami wyje/piszczy/straszy ' [something/it] howls/squeaks/haunts at night'. By contrast, God's power is never referred to in impersonal terms.

\subsection{Air symbolism}

By definition, symbol refers to the spiritual sphere; imaging the relations between the physical and metaphysical worlds, it reveals the mysteries of the invisible sacred. The non-material nature of air and its pre-existential character predispose it to become an image of what is both eternal and ethereal, what links, and 
at the same time divides, heaven and earth; everything that is invisible, spiritual, immaterial.

In its cosmic dimension, the element of air becomes a symbolic image of infinity. The mythical basis of air symbolism is provided by the biblical scene before the creation of the world, in which God, as a Spirit, "was hovering over the face of the waters" (ESV Genesis 1:2) in cosmic space. Thus the first religious aerial symbol represents God - as an invisible spirit - and the infinite space in which He moves. Consequently, the imagery connected with air is characterised by a lack of spatial limits, immateriality and capacity for flight.

It is a feature of symbol that it may combine ambivalent meanings; hence the aerial imagery of the sacred refers to both the immaterial and bodiless Spirit of God and the evil demon. As the element of air is dynamic, the presence of the sacred is represented by means of wind: the movement of air. A gust of wind in biblical scenes symbolises the Spirit of God, though it is not identified with Him [Forstner 1986: 74-75]. Although a strong wind accompanying God's presence appears several times in the Bible, ${ }^{13}$ it is the Pentecostal gust that is best established in the social consciousness since the descent of the Holy Spirit is an important feast celebrated by the Roman Catholic Church.

Owing to the ambivalent nature of the symbol, in folk culture a strong wind may be conceptualised as a sign of God's will (blessing or wrath), or it may indicate the presence of the devil.

Associating the wind with the devil stems from a belief that "the devil lost his old power over people, so he takes his revenge under the guise of wind, raising gales and causing damage" (diabeł stracił dawna władzę nad ludźmi, mści się tedy pod postacia wiatru, zrywajac wichury i wyrzadzajac szkody). Such a view complements a vision of the world which is based on the opposition between good and evil. The fight between God and Satan is exemplified by scenes in which Prophet Elijah, acting on the will of God, or God Himself strike the devil with thunderbolts, thus restoring divine order. Folk interpretations have the wind blowing before a storm as a sign of the devil running away from lightning [KLS 1967: 473].

13 The descent of the Spirit of God (the Holy Ghost) was accompanied by a strong gust of wind, whirlwind or gale: "the Lord passed by, and a great and strong wind rent the mountains, and brake in pieces the rocks before the Lord; but the Lord was not in the wind" (KJV 1 Kings 19:11); "At his sight shall the mountains be shaken, and at his will the south wind shall blow" (DRB Ecclesiasticus 43:17). See also Forstner 1986: 74. 
Images of wind and thunderbolt as attributes of divine justice (including the fight against evil demons) are also found in other European cultures [Eliade 1958: 82-83; KLS 1967: 473; Kowalski 1998: 586], which is evidence of their ancient character. Winds bringing thunderstorms were believed to converge on places where crimes had been committed or where impure souls had their dwelling.

Similarly, the image of a strong wind (usually combined with a storm and hail) may symbolically represent God's wrath directed against people. ${ }^{14}$ On the other hand, gusty wind may also symbolise the devil capturing a soul to carry it to hell, or the actions of demons stirring up gales. Ritual ways of protecting oneself against these powers (see Chapters 5.2.2 and 5.3.2 above) reactualise the symbolic meaning of transcendence as a manifestation of the will and power of the sacred. They also confirm the cultural message of human dependence on God's benevolence and of the constant threat posed by dark forces.

Traces of the ancient symbolic representation of wind as a bull can be found, according to Jerzy Treder, in Kashubian phrases such as "the wind (storm, frost) has broken its horns" (wiater (sztorëm, mróz) okidt sobie rogi), "the wind has been whipped on the horns" (wiater dostôt [batige] po rogach), "stiff breeze will soon break its neck" (sztywnô briza (...) wnet kark złómie) and "storms will soon wring their neck" (sztormë wnet skręca kark), signifying that the wind/ storm has abated [Treder 1989: 39]. The depiction of sky divinities who manifest their presence through storms and gales as roaring bulls is related to their atmospheric "specialisation" and fecundating powers. Bull-shaped gods of wind and rain are found in many cultures across Africa, Europe and Asia [Eliade 1958: 83, $87-88] .{ }^{15}$ Thus the bull is a very ancient symbol of supernatural powers associated with wind, and its preservation in Kashubia is consistent with the general tendency of archaisms to concentrate in peripheral areas.

As a symbol of God's creative power, the image of wind goes back to the myth of the creation of man. The life-giving breath of God is analogous to the propagating function of wind, pollinating plants, bringing rain and impregnating women. The fertility symbolism of wind is reactivated during wedding ceremonies (see Chapter 5.2.1 above) and in the custom of dunajowanie, the annual singing of love songs dedicated to young girls, practised around the town

14 In many cultures, principal sky divinities manifest their power and will by means of storm, wind and thunder [Eliade 1958: 42, 46, 49-50, 53-54, 66].

15 Owing to its connection with fecundity, the sky divinity in the form of a bull developed into a fertility god symbolised by the moon [Eliade 1958: 92]. 
of Biłgoraj in the Zamość region of eastern Poland [SSSL 1.2: 255]. In scenes from dunaj songs, "lush winds" (bujne wiatry) snatch the maiden garland (a symbol of virginity) from the girl's head and throw it into "deep water" (dunaj). The young man who will retrieve the garland will expect the girl to give herself to him: "What kind of reward will we get, what reward for diving underwater? (...) My own young self, me myself, young like a berry" (co nam będzie za nagroda, za nagroda spod niewoda? (...) ja sama młoda, ja sama młoda jako jagoda) [Szymańska 1992: 123; SSSL 1.2: 255, 256-257].

The wind which deprives a girl of her "maiden garland" (virginity) and gives rise to a new life has powers parallel to those of divine breath. Its opposite is "pestilential/death air" (morowe powietrze), which happens by God's leave, or is spread by demonic forces. In this way the symbol combines at once the image of creative power and destruction. The semantic memory of myth survives in ritual magical actions, such as the ceremonial walking around fields or protective practices against epidemics (see Chapters 5.2.2 and 5.3.2 above).

The function of a kiss, in turn, as a symbolic gesture imitating divine breath, is to bestow good health on the recipient: "originally, [a kiss] was probably an attempt to pass on the vital force through the soul hidden in breathing, blowing or puffing" [KopSS 1990: 327]. A greeting in the form of a kiss signifies the wish that the other person "be whole", based on the WHOLE and LINK schemas, which are grounded in the experience of the necessity to preserve the integrity of the human body. The archaic significance of a life-restoring kiss, imitating divine breath, was preserved in fairy tales (about the Sleeping Beauty, or a prince/princess turned into a frog). Conversely, the phrase "kiss of death" (pocalunek śmierci) functions as the opposite of the "kiss of life" (pocalunek $\dot{z} y c i a)$.

The meaning of wind as a symbol of the power of "otherworlds" (zaświaty) is re-activated in ritual behaviour prescribed for situations involving direct contact with a gale or whirlwind. Death symbolism appears in warnings against the effects of "being blown around" (owianie). Demonic forces may bring about possession, madness or even death; hence the command to avoid walking against the wind, and to run away, crouch or lie face-down on the ground should one encounter a demonic gust [KLS 1967: 471]. Protection from the effects of "a bad breeze" (zły powiew) was to be provided by apotropaic measures, especially when reinforced by multiplication: symbolic gestures (crossing oneself, sprinkling with holy water) accompanied by verbal acts (praying, crying out the curse "pig shit" (świńskie gówno), or scaring evil forces away with a formula "I eat garlic" (jem czosnek)), the use of sacred amulets (medals, rosaries) or magical objects (garlic, dry excrement). Arising as a result of the devil's presence, an otherworldly gust 
signifies the proximity of the sphere of death and the implied attendant danger [Kowalski 1998: 589].

The symbolic life-giving breath is also imbued with otherworldly power, be it the cosmic breath of the earth or the first cry of a newborn baby, announcing its arrival in this world and adaptation to a new life. Although birth always involves the first inhalation of air, which is related to divine breath, it is also accompanied by the danger of an otherworldly gust which may threaten the life and health of the infant. This is why a mother taking her baby outside puts a rosary on him/ her "so that the wind should not blow something" (żeby coś wiatr nie podmuchat) [Engelking 2002: 32]. A protective measure against the effects of an evil gust, the rosary engages divine power as a counterforce which obviates the danger.

Prohibitions against weaving and spinning at Christmastide so that the devil does not get entangled in the thread are also connected with the demonic symbolism of wind. Christmas is a period of particularly high activity among evil powers, and thus is conducive to the appearance of a devil dancing in a whirlwind [Kowalski 1998: 588]. The turning of a spinning wheel and the spooling of thread are analogous to the swirling movement of the air associated with the presence of the evil spirit. As such, they might cause the devil to become entangled in the thread, which could lead to sinister results (e.g. the matting of hair in a Polish plait (kottun)) [Szyfer 1969: 66]. The prohibition is also explained by the symbolism of woven cloth and thread, representing human life, and hence the consequences of the devil's entanglement in human fate.

The divine breath, the origin of all life, has also become a symbol of the soul. The presence of the soul in the body measures out the time of human life on earth. "To breathe out the spirit" (wyzionać ducha), "to give up the spirit to God" (oddać Bogu ducha) means to set the air in motion, to sever the invisible, immaterial part of the human essence from the body. The belief that purgatorial souls fly in the wind or that souls soar upwards on their way to "otherworlds" is also related to the image of the soul as a form of being connected with the element of air. Such beliefs are reflected in rituals preparing the dying for their passage to the metaphysical world. Making a hole in the ceiling in the case of prolonged agony constituted a symbolic opening of the way to "the other world" (tamten świat) [KLS 1967: 480]. Also, the ritual burning of the fingernails and hair of the deceased allowed the soul - heavily burdened with sins - to soar up to heaven carried by the smoke [SSSL 1.1:269]. At all the stages of the funeral rite, the symbolic severing of the link with the world of the living served to facilitate the soul's transition into eternal life. The parting with the successive borders of "own" space: the threshold of the family home, the limits of one's farm, field, village, prevented the return of the soul back home. It was only "the tolling of a 
knell", "ringing after a soul" (podzwonne, dzwonienie po duszy) that enabled the soul to break away from the earth and fly upwards [SGP 2004: 499]. The sound of church bells, reaching up to heaven, sanctified the airy space and repelled evil spirits lurking in wait for the soul. The very act of participation in the ritual (prayers during the vigil of the so-called "empty nights" (puste noce) after the death, hymns sung during the funeral procession and the whole religious rite) provided, for the mourners, a sacred experience of contact with infinity. The symbolic character of the rite of passage was increased by the suspension of earthly time, as all the clocks were stopped between the moment of death and the removal of the body.

The passage from earthly time to eternity is reflected in such phrases as "someone's time has come" (na kogoś przyszła godzina), the Kashubian "the clock has stopped" (zegar se powiesyt), "eternal clock" (wieczny zegar) [Treder 1989: 176]. The feast concluding the burial ritual (stypa) marked the final exclusion of the deceased from the land of the living. Kashubian expressions connected with the funeral meal: "to drink away the skin" (skórke przepic), "drink to the skin" (za skore pic), "drink away the skin of the dead" (przepic nieboszëka skórę), and a toast in honour of the dead "to this skin" (to za tę skórę) [Treder 1989: 178], vividly illustrate the idea of bidding farewell to the mortal shell of the body as well as to the released soul. For the mourners, participation in the funeral meal, often noisy and heavily laced with alcohol, meant a return to everyday reality, which had been interrupted by the intrusion of death into the land of the living.

The symbolic connection of wind with spirits and souls is also evident in scenes of inviting the wind to Christmas Eve supper (wieczerza wigilijna) recorded in the Żywiec region in the south of Poland [Gieysztor 1986: 142; KLS 1967: 485]. Christmas is a miraculous period when the mythical time of origins is re-created, connecting heaven and earth, hence the souls of the ancestors can visit their family homes. A special place was laid for them at the table, and the remains of the meal were left on the table for the souls to feed on when all the household was asleep. Inviting the wind (like inviting the wolf from the wood) ${ }^{16}$ is probably a euphemistic address to the souls of dead family members. The use of the euphemism prevented the arrival of unwelcome guests: the evil spirits who

16 Not only the souls of the ancestors, but also "all that is alive" (wszystko, co żyje) was invited to Christmas Eve supper: frost, wind, the sun, animals (wolves, foxes), birds, God, angels and saints. Such customs and beliefs have been recorded especially in the south of Poland [cf. KLS 1967: 741, map 25]. 
might have overheard the invitation [Krawczyk-Tyrpa 2001b: 100]. Although the origins of Christmas Eve supper go back to pre-Christian times, when it was a celebration of the dead, in folk culture the custom came to be subsumed by the Christian ritual. This adaptation was aided by the magical atmosphere of Christmas. The symbolism of wind as a representation of the soul and of the spiritual world as such reveals the mysteries of transcendence, making it possible for the participants in the ceremony to commune with the supernatural world. Spreading a white linen towel between the table and a window provided a symbolic link between this and the other world. ${ }^{17}$ On this occasion, as at the time of death, the souls were supposed to enter and exit the house through the window.

Wind's immaterial nature, as well as the constant movement of the air, led to the development of the symbolic meaning of transience, oblivion, impermanence. The standard Polish expression "to throw words to the wind", i.e. to say things without meaning them (rzucać słowa na wiatr) or the dialectal form of a magic spell "sickness to the wind" (ochwôt na wiater), i.e. may sickness perish with the wind, are a case in point. The magical undoing of a disease is also related to practices of sending the wind (especially one that brings rain or storm clouds) to remote and desolate places. In such cases, the healer, a person skilled in performing magical rites, plays the archetypal role of the agent, while the wind becomes the object of his/her actions [Pełka 1987: 56]:

wiatreczku drogi,

idź na bory, idź na lasy,

gdzie słońce nie dochodzi,

gdzie się nic nie rodzi,

gdzie wiatry nie dowiewają,

gdzie ptaszki nie śpiewają.
Wind dear,

Go to the woods, go to the forests,

Where the sun doesn't shine,

Where nothing is born,

Where winds don't blow,

Where birds don't sing.

In this case, the perlocutionary force of the magical verbal formula relies on the REPULSION OF FORCE schema.

17 White cloth (and sometimes hemp thread) featured in all rites of passage: it was put on the threshold before a child was taken out to church to be baptised; a white towel was used to tie the hands of people engaged to be married, and white linen was spread before the newly-weds after the marriage ceremony. During funerals, a white towel was placed in front of the cross standing at the fork in the road, and during feasts in memory of the dead (uczta zaduszna) a white cloth was spread between the window and the table as a path for the souls [Benedyktowicz D., Benedyktowicz Z. 1992: 63, 93, 123]. 
The symbolism of transience can also be seen in the ritual of burning the bodies of criminals and scattering their ashes to the four winds, so that their memory should perish for ever. In contrast to verbal rites of casting and undoing spells (zaklinanie, odklinanie), in the scene of scattering the ashes it is the wind that performs the archetypal role of the agent, blowing the ashes away, while the participants in the event play marginal roles. The ritual of exclusion from the community, sentencing the dead to oblivion, is structured by the DISINTEGRATION schema: PART-WHOLE, LINK-lack of LINK.

The transience of wind seems also to be evoked in such onomatopoeic compounds as szwistum-poszwistum, fistum-pofistum recorded in Kashubian in the meaning 'slowly, sluggishly/heavily' (dated) [Sychta 1972: 206]. Aleksander Brückner treats them as proverbs (by analogy with lelum polelum); Jan Bystron, in turn, regards them as personifications of wind [Brückner 1980: 229; Bystroń 1947: 142, after Treder 1989: 40]. Aleksander Gieysztor mentions "Pochwist" as an onomatopoeic name for 'bad weather' as well as a wind named poświściel or pochwiściel: "Every time people in Ukrainian Rus' clap their eyes on this wind [poświściel or pochwiściel], they always incline their heads in all manner of bows" (gruba Ruś Ukrainna ile razy ten wicher przed oczyma jej przypada, zawsze głowy swe nachylajac pokłon mu rozmaicie wyrzadza) [Gieysztor 1986: 150]. ${ }^{18}$

In light of these facts, Bystrońs interpretation seems well-grounded, and the Kashubian szwistum-poszwistum, fistum-pofistum would appear to be a remnant of the old Slavic cult of air, as preservation of archaisms in peripheral areas is a common phenomenon. The development of the secondary meaning 'slowly, sluggishly/heavily', completely detached from the original (perhaps under the influence of the proverbial lelum polelum $)^{19}$ is not without parallel, either, as such processes are known to occur, especially in the case of expressively charged lexical items.

18 Aleksander Gieysztor quotes Marcin Błażowski, the early seventeenth-century translator of Marcin Kromer's chronicle (written in the mid-sixteenth century), who elaborated on the question of spirits of a lower order than gods, associated with wind and weather. According to Gieysztor, the names of higher gods were completely lost, unlike the names of demons.

19 According to Aleksander Gieysztor [Gieysztor 1986: 151-153], there is a correspondence between Slavic folklore connected with Lelum Polelum, which points to surviving traces of ancient beliefs in twin deities, and the myth of the twin sons of the sky in Lithuanian and Latvian culture. The Slavic equivalents are associated with the astral sphere, and are identified with the sun and the moon, or possibly the morning star. 
The multilayered symbolism of air reveals not only the changeable nature and ambiguous functions of this element, but first and foremost represents its association with the invisible sacred: its mighty power, unpredictability and omnipresence. Hence air, in the cosmic dimension, symbolises infinity. The symbolic imagination, employing the element of air to convey the unfathomable mystery of transcendence, relies on various patterns of the FORCE schema. Ritual practices reactivate the meaning of mythical models, especially the creative power of the divine spirit calling the world into existence, as well as the animating force of divine breath, represented through the image of a life-giving gust of wind. Mythical symbolic images come to life in human interactions inspired by the experience of the power of the sacred, providing the ritual participants with a sense of identity (as sharers in a symbolic scene) and an occasion to commune with the spiritual world. Furthermore, the axiological polarity of the symbol not only evokes images of the competing powers of good and evil, but also provides the basis for ethical choices and precautionary steps (in the form of a system of commands, prohibitions, threats or rules for performing rites and rituals).

As far as the creation of ethical models is concerned, positive value is clearly ascribed to spiritual matters connected with a religious attitude and belief in eternal life after death. This is apparent in oath formulas, in which the soul - as the highest value - is the guarantee of the veracity of the speaker: "On my soul!" (Na moj dusu!), "As I desire my soul's salvation!" (Jako zbaviynio dusy pragnem!) [SGP 2004: 500].

A symbolic representation constitutes an element of the overall conception of the cosmos, hence aerial symbols are connected with other elements of the structure of the universe: fire (wind and lightning), water (wind and rain) and earth (wind, rain, soil). In addition, a symbolic image conveys the complex nature of human existence in both its physical and metaphysical dimensions. The first and last breath frame the limits of our earthly life, transcended by the soul leaving the body to unite with the divine or demonic sacred.

Symbolic images open the way for building cognitive paths which include the concept of air in a web of semantic interrelations. Connections with the Spirit of God, infinity, space, heaven/sky, freedom, flight, power and might build the image of the invisible sacred. Wind as a manifestation of God's wrath introduces into the system the concepts of destruction, storm, thunder, hail, clouds, diseases, epidemics, the plague, failure of crops and hunger. The network of such interrelations is superimposed on the experience of the destructive power of demonic wind, thus extending the structure by adding further connections with a whirlwind, frenzied dance, maelstrom, insanity, impetuousness, suicidal death, or danger in general. 
By contrast, the movement of air symbolising divine creative powers comes to be linked with such concepts as inspiration, fertility, bountiful crops, life, breath, change, but also spirit, spirituality, inner (spiritual) life and soul. The latter provides a path for further connections with the world of the spirits - demons, spectres, witches, charms, curses, penitential souls, and, by the same token, with eternal life.

The image of changeable wind, symbolising transience and impermanence, in turn, opens the way for semantic links with situations in which words lose their causal power ("to throw words to the wind"), undoing and reversing spells, the mutability of fate, good fortune and misfortune (favourable vs unfavourable winds), nothingness, void and change.

Some connections, especially ones that are most often repeated or used in highly conventional contexts, produce linguistic stereotypes of a greater or smaller degree of lexicalisation. Among the most stable forms are: fixed phrases such as "surrender the soul to God", i.e. to die (oddać Bogu ducha), "to lurk in wait like a devil for a soul" (czyhać jak diabet na dusze); processes of name formation with a distinct semantic structure (gniotek 'one who crushes', dusiołek 'one who suffocates'); as well as semantic links between words, visible in their etymology (dusza 'soul', wiać 'blow', oddech 'breath'). Stereotypical features are also rendered in commonly used comparisons "to follow (lit. 'to cling to') someone like a mare" (przyczepić się do kogo jak zmora), "to look like a vampire/mare", i.e. pale (wygladać jak strzyga/zmora). Cultural context, in turn, determining the semantic range of concepts based on common knowledge, is reflected in communicative acts and their illocutionary force (e.g. a vampire should have his head cut off with a scythe). Finally, conventional beliefs are also preserved in fixed formulas of casting and undoing spells (e.g. "salt into your eyes" (sól ci w oczy)) or oaths (e.g. "on my soul" (na-mu-duszu)), which function as texts of culture [Niebrzegowska-Bartmińska 2007: 194; Ożdżyński 1988: 130-131]. ${ }^{20}$

20 For a different understanding of the term "texts of culture", see Bartmiński, Niebrzegowska-Bartmińska 2009, 72-73. 


\section{Fire}

\subsection{Archetypal profiles of the cult of fire}

As in the case of water, the dynamic nature of the element of fire made it a particularly significant hierophany of supreme sky divinities. The names of such IndoAryan gods as the Indian Dyaus, the Roman Jupiter, the Greek Zeus and the Germanic Tyr-Zio derive from the original twofold meaning of 'light/day' and 'sacred' (the Sanskrit div 'shine', 'day'; dyaus 'sky', 'day'; dios, dies; deivos, divus). This indicates their connection with the shining sky and with ${ }^{\star}$ Dieus, the hypothetical sky divinity common to all Aryan tribes (with the thunderbolt as his attribute) [Eliade 1958: 66]. In the course of time, sky gods, who - owing to their fecundating powers - were believed to be the creators of the universe, became "specialised" rather than omnipotent: their interrelations with earth, water, the sun and the moon endowed these divine cosmic entities with the power to govern fertility and vegetation [Eliade 1958: 50-54, 67; Gieysztor 1986: 133].

The variety of the human experience and the attendant tendency towards "specialisation" of divinities led to the development of a complex and extended conception of fire. Myths and rituals associated with fire fall into three categories: the cult of earthly fire, the domain of the Indian Agni (the Roman Vulcan and Vesta), atmospheric fire or lightning, an attribute of the Indian Indra and Vayu (the Baltic Perkunas), and heavenly fire - the sun, represented by the Indian Surya (the Baltic Saule) [Gieysztor 1986: 132]. Slavic deities connected with fire included Svarog (most likely a personification of the sun understood as supreme fire) and his son Svarozhich (Swarożyc), the equivalent of Dazhbog (Dadźbog/ Dażbog). The latter, god of the hearth and sacrificial fire, was also ascribed the functions belonging to Perun, god of the sky and lightning. Such an overlap in the functions of different divinities is not unusual and is also observed in Indian mythology [Gieysztor 1986: 134-137].

While Polish folk culture preserved, to some extent, this threefold conceptualisation, the idea of the sacred nature of fire was subject to modifications resulting from the impact of Christian tradition, with its notion of purgatorial fire and the fire of hell. Hence the concept of heavenly fire (understood as the sun, the supreme divinity) was redefined, even if, at the symbolic level, the sun continued to function as an image of God and preserved a number of features associated with fire. The archaic image of the shining sky has also survived in the profile of heavenly fire as "the light filling the sky/heaven" (jasność wypetniajaca niebo). Atmospheric fire in the form of lightning, in turn, continued to be seen 
as an instrument in the hands of God. Finally, owing to its practical function and its significance in the spiritual sphere, the concept of the home fire also had an important place in folk culture.

\subsection{The profiles of otherworldly fires}

\subsubsection{The creation myth and heavenly fire}

The life-giving power of fire was prototypically manifested in scenes of the impregnation of mother-earth by a bolt of lightning. As described in Chapter 4 above, it is also evinced in the belief in the power of the first crash of thunder in spring (which restores earth's fertility) and in the procreative power of sunbeams (an equivalent of lightning), summoned in wedding rituals. All these elements make up the sacral profile of fire, based on the notion of the inexhaustible life-giving power of God embodied in a thunderbolt.

Traces of the creation myth according to which the world came into being through a flash of lightning suggest the otherworldly origin of the heavenly fire (ogien niebieski) that animated the world, manifesting the will and power of the Creator. In the process of profiling, the conceptualiser's religious-mythical perspective makes him/her perceive fire as an embodiment of God's power. This is apparent in the names - boży ogien' 'divine fire', ogien $z$ nieba 'fire from the sky/ heaven', ogień niebieski 'heavenly fire' [SSSL 1.1: 293; Szadura 1998: 333-337] and in a belief in the sanctity of fire: the dominant semantic feature of its sacral profile. Considering its divine origin, and even identification with God, heavenly fire is the archetype of the fire of "otherworlds" (ogien zaświatowy). In folk culture it is viewed as the primordial fire (symbolising the Creator), the force which brought the world into being and which will bring it to an end. This image is construed according to the SOURCE-PATH-GOAL pattern of the FORCE schema.

Prophecies telling of the rain of fire (deszcz ognisty) that will burn the earth are based on the Christian vision of the end of the world found in the Book of Revelation [20:7-10]. Stories about the ultimate destruction and the Last Judgment were popular in oral literature, particularly in funeral hymns and songs of wandering beggars (pieśni dziadowskie) [Grochowski 2003: 115; Michajłowa 2010: 168-178]:

Proszę ja was posłuchajcie o straszliwym sądzie, że Pan Jezus dobrym i złym razem płacić będzie.
I beg you, please hear the tale of the dreadful judgment, when Jesus the Lord will repay the good and the bad. 
Że przed skończonym światem wielgi cuda będą że wognisty deszczy z nieba na cały świat będą.

I pirony z nieba będą na cały świat bili, są miasteczka i klasztory, będą się palili.

I ta góra $\mathrm{z}$ górami rozbijać się będzie, i dolina $\mathrm{z}$ dolinami; wszędy równo będzie. Jak zatrąbi święty Michał w trąbę głosu swego:

A wstawajcie dusze zmarłe, przed sędzie swojego.
Before the end of the world great wonders will be, from heaven rains of fire will fall on the whole world. And thunderbolts from heaven will strike the world over and town and cloister will go up in flames. And mountain with mountain and valley with valley will shatter and crumble, and all be made low. And the trumpet will sound In Saint Michael's hand: Arise, dead souls, to stand before your judge.

[Michajłowa 2010: 172; cf. variant SSSL

1.1: 293; Lubelskie 3, 627-630]

The scene of the ultimate cataclysm is construed according to the FORCE schema in conjunction with the DESTRUCTION (PART-WHOLE) and CONTROL schemas. God performs the archetypal role of the agent: He is in full control of the event and wields His power using rains of fire as an instrument; the earthly world is the object of His action. The image follows the pattern of OUTER COMPULSION, with the conceptualiser drawn into the scene both as an observer and object exposed to the rain of fire.

The image of the power which will bring the world to an end is grounded in the conceptualiser's direct experience of the unharnessed, destructive power of lightning. The scene of utter destruction of the world by thunder, bolts of lightning and a column of fire invokes the concept of a punishing thunderbolt fire (ogien piorunowy), which, like heavenly fire, comes from "otherworlds" (zaświaty) and as an embodiment of God's power - acquires some of its properties.

Unlike thunderbolt fire, however, divine fire symbolises the Creator himself and is ascribed properties of the sacred. According to the archetypal pattern, heavenly fire - also known as heavenly light (światłość niebieska) - is conceptualised as the light filling the sky that shines but does not burn and that gives light to the sun and the stars [SSSL 1.1: 293] (which came into being by

1 The translators would like to thank Jean Ward for her help in translating this passage. 
God's looking [KLS 1967: 443; Tomicki 1978: 111]). A direct connection between heavenly light and celestial bodies - the sun, the moon and the stars - is evinced in a folk belief which views them as openings in the sky - windows, doors or holes through which the light of heaven penetrates [SSSL 1.1: 89]. This occurs through the intercession of the Holy Virgin: "By her will, the Lord's saints open little gates in heaven onto the moon and the sun [so that they shine]" (Za jej wola święci pańscy na księżyc, jak i na słońce otwieraja furtki z nieba [żeby świecity]) [Benedyktowicz D., Benedyktowicz Z. 1992: 42]. "The Mother of God decided that one gate of heaven should always be open; if the Lord God ordered that it be closed, the sun would go dark at once" (Matka Boska postanowiła, żeby $z$ nieba ku ziemi zawdy jedna furta otwarta była i gdyby Pan Bóg kazał te furte zawrzeć, to by wneteczki słońce ściemniało) [Benedyktowicz D., Benedyktowicz Z. 1992: 41]. This aspect of heavenly fire expands its profile to include the brightness of God's glory.

The identification of heavenly light with God is apparent in a belief that the moon is God's face and the sun is His eye. This is reflected in the prohibition against pointing one's finger at the sun for fear of plucking out God's eyes [SSSL 1.1: 127].

Heavenly fire is also a constitutive element of the folk image of heaven - the abode of God, angels and saints - as a palace filled with light. ${ }^{2}$ This brightness is visible from the earth when the sky/heaven opens up at twilight or during a storm [Niebrzegowska 1999e: 10]:

- "God lives somewhere in the blue sky beyond the clouds. Heaven is a place of extraordinary light: flashes of lightning, which come from the radiance of heaven when it opens up during a storm, are proof of that" ( $W$ btękitnym niebie, gdzieś za chmurami mieszka Bóg. W niebie panuje nadzwyczajna jasność: dowodem tego sa błyskawice, pochodzace od blasku, jaki rzuca niebo, otwierajace sie podczas burzy);

- "afterglow is a sign that the clouds are gone to have a rest, and the glowing purple radiance is the light of angelic choirs" (zorza, to znak, że chmury sie ściagnęty i odpoczywają, a widoczny kawałek światłości różowej, to światło $z$ chórów anielskich).

Mental and linguistic identification of heavenly fire (also known as Boże ognisko 'God's bonfire') with heaven and with God is a case of metonymic expansion

2 A parallel image is that of a palace at the bottom of the waters, the dwelling place of water demons. 
based on the COLOUR schema (light). Heavenly light is opposed to the darkness of before the creation. According to the biblical myth, the act of creation involved providing the world with light (the sun lit up from heavenly light) and hence with life. In direct experience, this opposition is embodied in the contrast between day (light) and night (darkness).

\subsubsection{Thunderbolt fire}

Thunderbolt fire (ogien piorunowy) - an embodiment of the power of heavenly fire (ogien niebieski) falling to earth in the form of thunder, bolts of lightning or a column of fire - displays features consistent with its function as an instrument in the hands of the Lord. Thunder and lightning are a manifestation of God's wrath, a portent or instrument of punishment aimed at ridding the world of evil - Satan, demons and sinners. Although lightning is a form of otherworldly fire (ogien zaświatowy) and is thus regarded as sacred, its semantic dominant is that of a purifying force. Belief that sinners are punished by fire from heaven is commonly found in prayers to Jesus, the Virgin Mary and saints asking for their protection and intercession and for the remission of punishment; such prayers were said particularly during the so-called fire processions. The motif was also popularised by "letters from heaven" (listy z nieba: warnings against God's wrath, believed to have been sent by Jesus himself; they were usually circulated in handwritten copies distributed by wandering beggars (dziad) or sold at village markets) [SSSL 1.1: 345]:

I, Jesus, the Son of the Living God, will punish you with famine, with the plague, with fire, with sword, with your enemy [and] with various diseases which by my leave will last until you become humble and stop sinning and being wicked (...).

Ja Jezus Syn Boga żywego bęndę Was karał głodem, powietrzem, ogniem, mieczem, nieprzyjacielem, chorobami różnemi, które z dopuszczenia mego długo trwać będą aż jeżeli się nie upokorzycie grzechów waszych i złości nie przestaniecie (...).

In the conceptualiser's experiential base, the experience of the unharnessed power of fire is structured by the FORCE and CONTROL schemas. These two schemas provide the basis for the mental imaging of divine intervention in earthly reality, realised as a thunderbolt which causes a fire or strikes the victims of God's wrath. Ways of behaving in the face of thunderbolt fire stem from a religious attitude characterised by fear of God. They are guided by such socially sanctioned directive/persuasive rules as [Bartmiński, Niebrzegowska 1998: 214; SSSL 1.1: 291, 342-343]: 
- it is forbidden to put out fires which have broken out as a result of a thunderbolt "because it's a grave sin"; "because those trying to put them out would be killed by lightning"; "because through defending [property] the fire may spread to even more buildings" (bo to cięzki grzech; bo by piorun samych gaszacych zabit; bo przez bronienie jeszcze więcej zabudowań zapalić się może);

- it is forbidden to rescue a person struck by lightning.

In the conceptualisation of fire scenes, the archetypal function of the agent is attributed to the bolt of lightning or to the fire that it causes (which is visible in the scene), although it is God (an invisible spirit) who is the actual agent present in the background. This metonymic identification of the instrument of punishment with the actual agent results from the animisation of fire, which is perceived as a living being endowed with feelings and emotions [Szadura 1998: 330]. The function of the object, in turn, is assigned to the person punished for his/her wicked deeds or to the devil hit by God's burning arrows.

Such manifestations of God's will are believed to proceed according to a range of various scenarios which are based on the experience of FORCE as a singular, rapid stroke that has an immediate result. The destructive power of a bolt of lightning may be directed against demons (cf. "scared like a devil of a thunderbolt" (boi się jak diabeł pioruna; Kashubian equivalent: bojec sę jak djôbet grzmotu); cf. also Kashubian djôbli pôlc 'the devil's finger', i.e. 'belemnite') [Treder 1989: 246]. Lightning strikes the haunts of the devil and other evil forces - trees, particularly oaks and willows [Marczewska 2002a: 124, 200]. In folk belief, trees are dwelling places of the souls of unbaptised infants and stillborn babies (which often take the form of birds); as damned souls, they are also pursued by divine fire [KLS 1967: 486]. Stones struck by lightning - known as kamienie piorunowe 'thunderstones' - are believed to have magical properties: they offer protection, particularly from lightning, fire and evil forces [Brzozowska 2009: 61]. ${ }^{3}$

The prohibition against rescuing a person struck by lightning stems from a belief that he/she had been used as a shield by an evil force, thus becoming a victim of the fight between God and Satan. Consequently, such a person was considered to have been chosen by God and his/her soul was believed to go straight to heaven [KLS 1967: 485]. Likewise, the prohibition against rescuing

3 Belief in the magical properties of thunderstones is a reflection of ancient beliefs according to which they were used as a weapon by the god of thunder and lightning (according to Ivanov and Toporov - Perun); a modified Christian version had St Elijah or Archangel Michael throw round-shaped thunderstones to kill Satan [Brzozowska 2009: 57, 59]. 
buildings set on fire by a stroke of lightning reflects a belief that they must be the place where the devil had hidden from God's punishing hand [KLS 1967: 466]. Material recorded in the late nineteenth century confirms that, according to traditional folk interpretations of justice, punishment by lightning was inflicted particularly on those who had refused to give bread to orphans, and on landowners who had set their own wealth before the needs of their peasants [SSSL 1.1: 291].

Scenes in which evil is annihilated by means of lightning also feature the wind as a key participant. Identified with demonic forces, it is seen as an instrument used against God's will: while God rids the world of evil using fire, the devil uses the wind in order to turn the results of God's action against innocent people "where there is a fire, there is wind"; "the wind turns fire towards full barns" ( $g d z i e$ pożar, tam wiatr wieje; na pełne stodoly wiatr ogień nawraca) [Kozioł 1986: 51], cf. also the proverb "A weak fire will be blown out by a small gust of wind, a huge one gets bigger when the wind blows" (Staby ogien lada wiatr zgasi, a wielki sie od wiatru mnoży) [SSSL 1.1:344]. Scenes in which the devil drives the wind are construed using a combination of image schemas. The dominant one is FORCE which comes from the source of power and fulfils the goal of punishment, i.e. destruction (the use of the PART-WHOLE schema); the punishment is intended for the culprit (the CENTRE schema). The ultimate goal of this destructive action, however, is to restore order and re-establish good relations between God and the earthly world; this is conceptualised by means of the LINK schema. The FORCE representing the devil's action, in turn, does not come from the source of power; its goal is to spread the fire beyond the centre so that other buildings are also affected (the use of the CENTRE-PERIPHERY schema). Given that such a fire is the devil's doing, one can and, indeed, should take action against it by appealing to God's power and by using various measures representing different models of the FORCE schema (REMOVAL OF OBSTACLE, BLOCKAGE, REPULSION). This aim is served by different patterns of protective behaviour which - as linguistic correlatives of the FORCE and CONTROL schemas - take the form of commands and warnings using such volitional verbs as należy/nie należy 'one should/shouldn't', trzeba 'one needs to', można 'one can'. They acquire a performative value if the principles they declare are followed by the participants in the event.

The fire scenario involves two different stages, the first of which is construed as a struggle between the punishing God and the hiding devil. The archetypal roles of the agent and the recipient of the action are performed by the two sacred powers. Since - being spirits - they are beyond the sensory perception of the observers, they remain in the background of the event and their roles are taken over by the instrument and the object of punishment (which are accessible to 
the senses). In a pattern consistent with the experience of FORCE as OUTER COMPULSION, the conceptualiser is drawn into the scene as a passive observer and experiences it regardless of his/her own will.

It is only during the second stage of the scenario that the conceptualiser takes over the archetypal role of the agent. In doing so, he/she acts according to socially accepted rules applicable on the occasion. On the one hand, he/ she observes the prohibition against rescuing buildings set on fire by a thunderbolt, since attempts to save them would amount to acting against God's will. On the other hand, he/she follows magical protective practices in order to save other buildings from destruction. Participants of the event surround the site of the fire so that the punishing force destroys only the object upon which it has been sent. They appeal to the fire as the executor of God's order and entreat it to spare other buildings. Aiming to limit the damage caused by the destructive force, their speech acts rely on the BLOCKAGE schema, with the words uttered in the name of divine or holy persons as a protective barrier. In this way, those who defend themselves against the blaze summon the power of the sacred (the ATTRACTION OF FORCE schema). They use magical formulas addressed to fire (called Zygmunt), ${ }^{4}$ which usually take the form of commands invoking the Holy Trinity, Jesus Christ or the Virgin Mary [SSSL 1.1: 343; Kozioł 1986: 50]:

- "In the name of the Father, the Son and the Holy Spirit. Zygmunt! I bless you with the sign of the Holy Cross, I cover you" (W imie Ojca $i$ Syna i Ducha Świętego Zygmuncie! Żegnam Cię krzyżem świętym, przykrywam Cię);

- "Fire, you burning flame, the Lord Jesus, a man of God, orders you, through me, His unworthy servant, not to spread any further but to remain in this place; keep what you have seized by God's power and with the help of the Holy Spirit"; the spellcaster ran around the fire three times saying "Our Father" each time (Ogniu, ty płomieniu gorejacy, rozkazuje tobie Chrystus Pan, mąz boży, przeze mnie, sługe niegodnego, abyś się dalej nie rozszerzat, lecz na tym miejscu został; coś ująt, to trzymaj przez Pana Boga moc, Ojca i Ducha Świętego pomoc).

4 In folk culture, fire is treated as a living being with feelings, emotions and the faculty of understanding. The anthropomorphisation of fire is evinced not only by speech acts addressed to it but also by calling it by the first name. The name Zygmunt also functions as a euphemism; taking the destructive power of fire into consideration, the use of a conventional euphemism was believed to be safer (as was the case of the use of such names as Jurek, Purtk and Czarny 'the black one' when talking about the devil). 
Uttered in the name of the sacred, such formulas are endowed with causal power: they prevent fire from veering away from the chosen path and the intended goal. The conceptualisation of the scene, which relies on the FORCE schema, also involves the CENTRE-PERIPHERY (attempts to focus the force of the blaze on the object struck by lightning) and CONTROL schemas (practices aiming to protect the neighbouring buildings and to draw fire away from inhabited areas). Charming the fire (zaklinanie ognia) using commands was possible thanks to adopting the role of a mediator speaking on behalf of the sacred. This role could only be performed by people versed in the use of magical practices since the enraged fire was believed to chase the spellcaster, who tried to use this as an opportunity to draw it away to the fields, uninhabited areas or a body of water [SSSL 1.1: 342]. Sometimes he used incantations aimed at placating the fire, and addressed it by its first name, like a fellow stranger addressing a guest [SSSL 1.1: 346]:

Ogieniaszku, Zygmuncie, Świętym krzyżem żegnam cię

Tyś gość i ja gość,

Nie pal się, bo już dość.
Fire Zygmunt, dear sir,

With the sign of the cross I thee bless

You're a guest and I'm a guest

Now, stop burning, have a rest.

The repertoire of incantations also included salutation and request formulas, albeit the illocutionary force of a request is far more limited than that of an order. By uttering a greeting, the spellcaster showed his respect to the fire and humbly accepted the blaze as an act of God; adding a request was an attempt to appease the fire in order to prevent further damage [SSSL 1.1: 346; Kozioł 1986: 50]:

- "Welcome, our guest in a red coat; go high up and don't spread around" (Witaj nam gościu w czerwonym płaszczyku, nie bierz się szyroko, a bierz się wysoko).

All the options and measures at the spellcaster's disposal rely on the LINK schema, which is a constitutive element of the concept of "one's own/familiar" (swój). On the one hand, the charmer introduces himself as a guest, which puts him, like the fire, in the position of a stranger among the participants of the event, and makes him a fellow representative of another world, subject to its rules. On the other hand, he speaks on behalf of the sacred, thus suggesting that both the fire and the spellcaster himself have to respect God's orders.

Protective practices against fires were characterised by an accumulation of different measures: magical formulas were combined with circular gestures and the use of sacramentals, such as holy pictures, holy water and St Agatha's salt. The 
principles of their application were subject to strict rules phrased as directive/ persuasive formulas, for example [SSSL 1.1: 341-342; Kozioł 1986: 50-51]:

- one needs to/should run around the fire with St Agatha's salt three times;

- one needs to/should walk around the buildings that are on fire (carrying pictures of saints, St Agatha's salt, holy water, the Holy Cross or a picture of Our Lady) three times, following the movement of the sun in the sky (from east to west);

- one needs to/should protect the buildings endangered by the fire by shielding them with a holy picture of St Agatha, St Lawrence or Our Lady of Częstochowa;

- one needs to/should throw St Agatha's salt in four directions so that the flames will go up, the wind will blow in a different direction and the fire will spread elsewhere.

In recommended magical practices for protection, the FORCE schema is evinced in several patterns of interaction. One of them involves REPULSION, observed in the practice of shielding endangered buildings with holy pictures or statues (particularly of St Barbara, St Lawrence and St Florian) in the belief that they had the power of sanctifying the protected area, thus making it inaccessible to evil forces which would want to spread the fire.

Recourse to God's power is also apparent in practices aimed at defending property using blessed objects: St Agatha's salt and bread, both of which are indirectly connected with fire - bread is baked in a stove (heated by fire), and salt has purifying properties similar to those of fire. Their power is intensified as they are blessed on St Agatha's feast (5 February). Applied as an additional measure, throwing St Agatha's salt in four directions is most likely supposed to purify the entire area surrounding the buildings which are on fire, so that demons trying to escape from the blaze would have no access to it. These forms of protection, based on the principle of ATTRACTING FORCE - the power of the sacred - achieve their aim thanks to the intercession of the saints. Relying on the COUNTERFORCE schema, such measures are supposed to result in the neutralisation of the punishing force of fire and its self-extinction. Indeed, as a conscious being with feelings, fire is believed to be able to recognise and read the signs that it receives.

Magical practices aimed at preventing fire from spreading beyond the area to which it has been sent rely on the BLOCKAGE model. They are undertaken according to rules prescribing that one should passively submit to the punishment but at the same time actively protect the neighbouring buildings: 
- fire caused by lightning can only be tackled using milk [KLS 1967: 466];

- in order to calm the fire, one needs to/should go around the burning buildings on horseback three times [SSSL 1.1: 432; Kozioł 1986: 50];

- in order to calm the fire, a naked man must run around the house [SSSL 1.1: 432; Kozioł 1986: 50];

- one needs to/should mark a circle with blessed chalk around the place which is ablaze and utter the following formula: "Fire, I order you/ In the name of God and His blood/ Not to go beyond this circle" (Nakazuje ci ogniu/ W imie Boga i krwi jego/ Byś nie przestapił koła tego) [SSSL 1.1:346].

This scenario is based on the FORCE and CENTRE schemas: marking a circular border around an area affected by a fire aims to focus the impact of God's power on the object for which it has been intended. It is not only the act of making a circle as such (walking or running around, riding on horseback), but also its threefold repetition (and the fact that, in one case, the person performing the ritual is naked) that activate the INTENSIFICATION OF FORCE schema. Although the scenario of God's punishment works on the assumption that FORCE acts regardless of the will of event participants (the OUTER COMPULSION schema), they actively interact in the event and take the central position in the scene. While the thunderbolt (which acts in the name of God) performs the role of the agent, those who witness the event are drawn into the scene, realise the expected course of action and, in this way, co-create the scenario. Their engagement in protective action is consistent with the pattern of INNER COMPULSION (conscious submission to prescribed rules of behaviour).

In turn, magical practices whose aim is to divert a fire towards open spaces where there are no buildings, or to placate it and lead it out of the village [SSSL 1.1: 291-292; Kozioł 1986: 50-51], rely on the BLOCKAGE, REPULSION or DIVERSION models.

Owing to their performative nature, directive/persuasive formulas are meant to bring about the expected change, in this case - determining the course of action of the FORCE: focusing the impact of the fire on the object for which it has been intended (SOURCE-PATH-GOAL), limiting the extent of its operation (BLOCKAGE) or leading it away from the village (DIVERSION).

Euphemistic forms of addressing fire used in salutation formulas (e.g. "Welcome, our guest in a red coat" (Witaj nam gościu w czerwonym płaszczyku)), as well as the practice of entreating and placating it, are grounded in an animist concept of fire. Addressing fire by its first name (Zygmunt) and asking it for consideration, in turn, are signs of personification. Fire is thus treated as a living being that exerts influence on the course of events and that should be shown 
respect, both because of its sacred nature and because (as an elemental force and an instrument in God's hands) it inspires human fear [Szadura 1998: 330-333].

The conceptualisation of fire as a conscious being endowed with feelings and emotions is also apparent in protective practices which involve communicating with fire using symbols. Shielding houses to prevent them from the blaze by means of a sieve, an apron or a kerchief is supposed to show the fire that people are defending their hearth:

- a fire can/needs to/should be calmed using a sieve which the woman of the house received as part of her dowry; the sieve should be turned in the direction opposite to that of the fire [SSSL 1.1: 344];

- a fire can be calmed using an apron or a kerchief, or any item of clothing worn by the bride at her wedding; one needs to/should throw St Agatha's salt into the fire from four sides with one hand, and wave such a garment towards the open space where there are no buildings with the other, uttering the following spell formula at the same time [SSSL 1.1:344]:

W imię Ojca i Syna i Ducha Świętego. In the name of the Father, the Son and the

Zygmuncie!

Żegnam cię krzyżem świętym,

Przykrywam cię.

Idź w przestrzeń!

Idź w słup!
Zygmunt!

Holy Spirit.

I bless you with the sign of the Holy Cross,

I cover you.

Go away!

Turn into a column!

The combined use of words, gestures and symbolic objects is an example of cumulative action aiming to achieve the expected result [NiebrzegowskaBartmińska 2007: 193]. The agent (a woman protecting her house) relies on several models of the FORCE schema: ATTRACTION (of divine power), INTENSIFICATION and REPULSION (the use of objects associated with the feminine).

Such practices are also possibly related to the concept of fire putting out fire a thunderbolt that strikes the same object again [SSSL 1.1:292] - or to the idea of communication and interaction between different kinds of fire. ${ }^{5}$ In the case of

5 The idea of contact and communication between different fires is found in a story with a dialogue between two fires, in which one of them complains to the other about being mistreated by members of the household; the two fires burn the house down to punish the wrongdoers [SSSL 1.1: 268; Szadura 1998: 331-332; 2000: 333-342]. 
protecting a house using objects associated with femininity (a sieve, an apron, a kerchief), it could be argued that the type of fire evoked - the equivalent of a thunderbolt striking again - is the home fire, and that its power prevents the blaze from spreading beyond the object of punishment for which it has been intended. This interpretation is supported by the fact that salutations addressed to a thunderbolt fire are modified versions of those used to welcome the home fire, e.g. "Welcome, our guest in a red coat" (Witaj nam gościu w czerwonym płaszczyku) is a variation on "Welcome, our expected guest" (Witaj nam gościu pożądany) [Bartmiński (ed.) 1989: 133]. This would constitute another example of the combined impact of two opposites: blessing and punishment. The punishing power of the thunderbolt fire would then be moderated by the protective power of the home fire, sent from heaven as a gift of God's grace.

The construal of fire scenes is characterised by an open scenario which relies on different patterns of FORCE in conjunction with the CONTROL and PARTWHOLE schemas. These are actualised in speech acts directed to a thunderbolt fire (salutations, entreaties, placating formulas, commands in the name of divine persons) and other participants of the event (commands, prohibitions, warnings and threats). In this context, threats evoke a dramatic version of the scenario: if the participants of the event do not follow prescribed rules, those who tackle the fire will be killed by lightning and even more buildings will be set ablaze [SSSL 1.1: 291]. According to folk beliefs, the ultimate result depends solely on the reaction of thunderbolt fire, a conscious living being representing God's will and power.

The belief that thunderbolt fire destroys evil, and thus protects divine order on earth, is a manifestation of trust in God's providence, power and justice. Prayers asking for the intercession of the Blessed Virgin and the saints who suffered martyrdom by fire, in turn, can be classified as protective practices; they confirm belief in God's mercy on the one hand, and the power of intercession on the other [SSSL 1.1: 345-347]:

- “O Mother! Soften your Son's heart with your entreaties for our sake. When He wants to punish us, save us from His wrath, protect us, shield us with your own breast. Mary, be like a dyke protecting us from the plague, famine, fire and war; when you see your Son's wrath, take the weapon out of His hand" ( $O$ Matko! za nami miękcz Syna prośbami. Gdy ma karać, broń - przed gniewem, chroń, zastaw piersiami. Stań się nam Maryja jako wał zbrojny, od powietrza, głodu, ognia i wojny, gdy Syna ujrzysz gniew, rozbrój jego dłoń);

- "Ask Him, Mother, unceasingly, not to let us perish from famine (...). You are a burning torch - always protect us from fire. So that we won't know what 
a blaze is and will always be grateful" (Proś Go, Matko, każdej chwili, byśmy z głodu nie zginęli (...) Tyś gorejąca pochodnia - broń nas zawsze od ognia. Byśmy pożaru nie znali i zawsze ci dziękowali);

- "O Saint Lawrence, may you always protect the whole world and our kingdom from thunderbolt and accidental fire (...). Win God's love for us, Patron, in all our needs and at the time of death. Ask God to spare us His punishment, flames and fires" (Ciebie Wawrzyńcze święty za Patrona niechaj cały świat $i$ nasza korona uznaje zawsze w ogniu piorunowym i przypadkowym (...). Nam zjednaj Boska miłość, Patronie w wszelkich potrzebach i ostatnim zgonie. Uproś, aby Bóg oddalit swe kary, ognie i pożary);

- "O Saint Florian, protect us from fire, the plague and sudden death" (Święty Florianie broń od ognia, powietrza i nagłej śmierci);

- "O Saint Christopher, glorious martyr, intercede on behalf of those who turn to you so that they are protected from the plague, earthquake, lightning, fire, flood; save them from God's rightful wrath here on earth" (Święty Krzysztofie, chwalebny męczenniku, uproś tym, którzy się do Ciebie uciekaja, ochronę od powietrza, moru, trzęsień ziemi, piorunów, ognia, wylewu, osłaniaj ich przed słusznym gniewem Bożym, tu na ziemi);

- "Dear Saint Barbara, God's sweet follower! (...) I also ask you, do not let me die a miserable death, burn in fire or drown in water" (Święta Barbareczko, zakonniczko Boża! (...) ja cię też proszę, bym marnie nie zginęła, w ogniu nie zgorzała, $w$ wodzie nie utonęła).

The texts of these entreaties reveal certain differences between the power attributed to the Virgin Mary on the one hand, and the saints on the other. While prayers to the saints are limited to requests for their intercession, those addressed to the Blessed Virgin express a belief that she can control fire. This is apparent in the requests asking her to shield the believers "with her own breast" (zastaw piersiami, as above), with her hair or her mantle (as in the following incantation addressed to fire: "Let you be covered with the Virgin Mary's hair [and] the Virgin Mary's mantle so that you won't do harm" (Niechaj cię ochyna Panny Maryjej włosy, Panny Maryjej płaszcz, abyś nie zaszkodził)), and in the belief that a fire can be stopped "by the Virgin Mary's power" (Panny Maryjej moca) [SSSL 1.1: 342]. In view of the analogical beliefs concerning Mary's power over other natural elements, and in her perpetual intercession and pity for sinners (whom she releases from purgatory or saves from the damnation of hell), there is no doubt that the Mother of God (Matka Boża) plays a particularly significant role in Polish folk culture. 
Apart from prayers, protective practices also included: keeping "letters from heaven", placing bunches or garlands of blessed herbs in different parts of the house, lighting a "thunder candle" (gromnica) during a storm, keeping bread and salt blessed on St Agatha's feast (5 February), sprinkling the house with blessed salt, carrying hawthorn embers from the bonfire lit in front of the church on Easter Saturday around the house; in another protective custom, firemen poured water over houses on Easter Monday "so that there won't be a fire" (żeby się nie paliło) [SSSL 1.1: 343]. Compliance with such instructions constitutes an example of the performative force of commands conveyed in communicative acts.

\subsubsection{Hell fire}

The fire of hell is the opposite of heavenly fire and belongs to the lower sphere of "otherworlds" (zaświaty), which is in the power of God's adversary, Satan. It is conceived as flames bursting out of an abyss, a fiery lake or a burning sea of fire [SSSL 1.1: 296]:

- "a great abyss which stank terribly and the fire of hell burst out" (celuść okropna iśniej śmierdziało okrutnie i ogień piekielny buchat);

- "a place filled with fire, a fiery lake" (miejsce wypetnione ogniem, ogniste jezioro);

- "where the sea is in flames" (tam, gdzie morze się pali).

Ogien piekielny 'the fire of hell' collocates with the verbs gorzeć, palić, piec 'to burn, scorch' (cf. piec się w piekle 'to burn in hell'; piekło gorejace 'burning hell'; zgorzeć $w$ piekle 'to burn in hell'). In collocations with piekło 'hell', the Old Polish gorze (< Old Church Slavonic gore 'suffering, sorrow, grief') meant the suffering of a dead person's soul burning in the fire of hell. The meaning of the Proto-Slavic *pečals 'hell' might have had a direct impact on the semantic evolution of the Old Church Slavonic gore 'suffering' towards 'suffering of hell' > 'suffering from the fire of hell', which in turn determined the meaning of palić, płonać, piec 'to burn/ blaze/ scorch' in collocations with ogien 'fire' (particularly the fire of hell) and in the context of the state of the soul (cf. palacy/piekacy wstyd, gniew 'burning/ scorching shame, anger') [Michajłowa 2010: 189]. This explains palenie 'burning' and pieczenie 'scorching' as the basic features of hell fire, which set it in opposition to heavenly fire, one that gives light but does not burn. The only element that these opposite fires share is their eternal nature, as they both belong to the sacred (divine or demonic). 
In contrast to life-giving divine fire, the fire of hell is associated with the world of death. Since the experience of the power of demonic fire (ogien demoniczny) is confined to "otherworlds" (zaświaty), it only affects the souls of wrongdoers who have made a conscious decision to follow the path of evil in their lifetime, e.g. by breaking the social order sanctioned by a system of commands, prohibitions, warnings and threats. Demonic fire is an instrument in the hands of Satan and has no power over the living. By contrast, God - the giver of life and lord of thunder and lightning - can intervene in man's earthly existence directly, regardless of human will: He can destroy evil with thunderbolt fire, provide people with life-giving earthly fire (ogien ziemski) and with the light and warmth of heavenly fire, transmitted by the sun, the moon and the stars. In this way, access to heavenly light (which, by means of metonymic extension, is identified with heaven) is not limited to the afterlife, but is also part of the experience of all living people (both good and wicked). As a result, the schemas underlying images of divine fire on the one hand, and demonic fire on the other, are based on different models of the experience of FORCE. In the case of divine fire, the source of FORCE is unlimited in terms of power and space, and its operation involves OUTER COMPULSION. The power of demonic fire, in turn, is limited as it can only operate in a particular space (hell) and in relation to a particular category - the souls of those who have been damned as a result of their conscious submission to evil forces. The underlying pattern here, then, is INNER COMPULSION.

Although both thunderbolt fire and hell fire play a similar function - that of an instrument in the hands of the divine or demonic sacred - it is only the former that the folk imagination perceives as a living being. Indeed, while both of them arouse fear, there are no examples of approaching hell fire as an animate object or a being endowed with feelings and emotions, as is the case with thunderbolt fire. The fire of hell, then, is seen as an object, an attribute of Satan, and personification is applied only to its master.

Scenes featuring exposure to the fire of hell are concerned with life after death. Since this unknown reality is inaccessible to the conceptualiser, he or she does not participate in the event and is situated outside the scene, assuming the role of an interpreter. Damned souls - the object of action - "fry in cauldrons under which burns the fire of hell" [SSSL 1.1: 296] and are tortured by devils - the agents - "with burning shackles, torches and tongs" [Szadura 1998: 336].

In scenes of the Last Judgment, particularly as presented in funeral hymns, both God the Judge (in the person of Jesus Christ) and Satan are the agents: Jesus takes good souls to heaven and sends wicked ones to hell, while Satan burns the damned in fire [Adamowski, Doda, Mickiewicz 1998: 301]: 
And when the Lord Jesus comes down from heaven to give judgement,

He will tell the good ones - go to heaven, and the bad ones - be damned.

A jak stąpi Pan Jezus z nieba do sądzenia,

Dobrym powie - do nieba, grzesznym - w potempienie.

In the background, there are sometimes other supernatural figures: angels, saints (particularly St Peter, who opens the gates of heaven) and the Virgin Mary, who takes pity on damned souls and asks Jesus to have mercy on them [Adamowski, Doda, Mickiewicz 1998: 299-300]:

Święty Piotr trzyma kluczy,

Grzeszna dusza w niebo stuczy.

Święty Michał w trąbę trąbi

Wszystkie dusze na sąd budzi

Na tym sądzie sam Bóg będzie,

Wszystkie dusze sądzić będzie.

Wstańcie dobre - po prawicy,

A grzesznicy - po lewicy.

Dobre stali - zaśpiewali,

A grzesznicy zapłakali,

Matka Boska usłyszała,

Do Jezusa zawołała.

O Jezusie, Synu Kochany,

Ulituj się nad duszami

Daruj dla nich wszystkie winy,

Wprowadź ich do rajskiej krainy.
Saint Peter keeps the keys,

A sinful soul knocks on heaven's door

Saint Michael blows his trumpet

And wakes all souls to rise for judgment.

God Himself will be there

To judge all souls fair and square

Good ones - on the right you stand

Sinners - stand you on the left hand.

The good ones - stood and sang

But the sinners burst out weeping.

The Holy Mother heard them all

And to Jesus she did call.

O Jesus, my dear Son,

Have mercy on these souls,

Forgive them all their sins,

And lead them to paradise land. ${ }^{6}$

In folk scenarios of the Last Judgment preserved in funeral hymns and prayers, dead souls are not passive, but take action by trying to save themselves from eternal damnation. In a typical pattern, they invoke the holy names of Jesus and Mary and their power [Szymańska 1998: 229]:

Jezu, Maryja, Jezu Maryja

Sprawcie święte Dwa Imiona,

Żeby dusza potępiona nie była.
Jesus and Mary, Jesus and Mary,

Two Holy Names,

Don't let this soul be damned.

6 The translators would like to thank Jean Ward for her help in translating this passage. 
Such types of texts as funeral hymns and speeches, songs of wandering beggars (pieśni dziadowskie), sermons, stories and prophecies often include the motif of warnings from the dead to the living about the inevitability of death; the dead also urge those who want to protect their immortal souls from eternal damnation and suffering in the fire of hell to live a good life while they still can [Adamowski, Doda, Mickiewicz 1998: 313]:

Jedna garstka ziemie dziedzictwo człowieka, Każdy w dół swój wpadnie, choć przed nim ucieka.

Niech nas nie zasmuca podziemne więzienie,

Frasuj się człowiecze o duszy zbawienie. Jedna garstka ziemi wszystkim jednakowa, Lecz nie jednakową tajemnicę chowa. Jedna garstka ziemi wiedzie do żywota, Jedna garstka ziemi pcha w piekielne wrota. Jedna garstka ziemi jest hasłem zbawienia, Jedna garstka ziemi hasłem potępienia.
A handful of dust is all man's inheritance, Each one will fall into his pit, escape though he may try.

Let us not grieve o'er the underground prison,

But let's take thought for the soul's salvation. A handful of dust is the same for all, Yet more than one secret it conceals within. One handful of dust leads to life eternal, One handful of dust drives to the gates of hell. One handful of dust is a sign of salvation, One handful of dust is a sign of damnation. ${ }^{7}$

Images of fire and hell and beliefs with which they are associated are well established in the social consciousness. This stems from the repetitive nature of the funeral rite, an event attended by all members of the community perceived as "one's own" (swó j). The ritual evocation of the scene of the Last Judgment is conducive to the emergence of presupposed threats, admonishments and warnings. They do not need to take the form of actual speech acts performed in direct communication, but are part of the habitus due to the repetitive nature of motifs present in ritual texts. Their perlocutionary force is apparent in the behaviour of mourners at the ceremony - their shared prayer and reflection on life, aiming to protect them from God's punishment.

In folk culture, a serious breach of social norms (such as children's disobedience to their parents, harm done to others, or a crime) deserves punishment in hell fire and entails exclusion from the community of the living and the dead. Since wicked deeds are perceived as a threat to the order of the world, those who commit them are cursed so as to protect the community. The curse is treated as a fulfilment of God's decree, and malediction formulas invoking punishment in hell fire are uttered in the name of the Creator. In this way,

7 The translators would like to thank Jean Ward for her help in translating this passage. 
the person who casts a curse only performs the role of a mediator executing God's will [Engelking 2017: 215]. Objects of the perlocutionary force of such speech acts (przeklętnicy 'the cursed ones') are not only excluded from the community, but also their souls are condemned to eternal damnation already in their lifetime, as they lose the right to the grace of salvation [Engelking 2017: 250, 301].

In general, curse formulas rely on the use of a direct invocation of God: Bodaj cię... lit. 'God grant that' (May you), e.g. "May you burn in the fires!" (Bodaj cię ognie spiekty!); "May you never leave hell!" (Bodajeś z piekła nie wyjrzał!); "May you burn!” (Bodajś zgorzał!, Bodajś się spalit) [Engelking 2017: 250]. Alternatively, they employ the same pattern without the direct invocation itself, e.g. "May you be swollen by fire!” (Żeby cię ogień pochłonąt!); "May you burn!" (A palita byś ty się!) [SSSL 1.1: 279]; "May you not be spared the eternal fire!” (Żeby cię wieczny ogień nie ominał!); "May you burn in hell!” (Żebyś się w piekle palit!); "May you burn (lit. fry) in hell!" (Żebyś się w piekle smażył!); "Let the devils take you" (Niech cię diabli wezma!!) [Engelking 2017: 250]. Although in some curse formulas the fire of hell is not explicitly present - it is substituted with hell or the devil (e.g. "May you be miserably killed by hell" (Bodaj cie marnie piekło zabiło!); "May you be tormented by devils in the other world" (Ażeby ciebie na tamtym świecie diabli ciagali!)) - it remains the implied means of punishment.

Curse and malediction formulas which invoke the fire of hell as the ultimate punishment for evil done to others establish a cognitive path between the concept of demonic fire and that of punishment. In this scenario, the divine sacred in the background of the scene is the agent, while the person casting a curse and the executor of punishment (Satan) - who are both in the centre perform God's will. Neither the person casting a curse, nor the devil invoked in the formula have the power to impose punishment in hell fire, as it is God who is the highest judge. In this way, the role of Satan is confined to the perlocutionary sphere of the curse, its effects, which makes him the executor of God's will. The object of punishment, in turn - as a result of his/her evil deeds and refusal to repent for sins - consciously condemns him/hersef to eternal suffering and damnation.

This kind of punishment, resulting from God's ultimate judgment, is characterised by a different pattern of the FORCE schema than in the case of thunderbolt fire, used as an instrument of God's wrath. Most importantly, in using thunder and lightning as a tool of destruction of evil forces (and in this way restoring divine order in the world), God performs the role of the agent; His power is manifested as a singular, rapid stroke with an immediate result. By contrast, in the case of punishment in hell fire, the impact of FORCE extends 
indefinitely in time and does not annihilate evil, but eternally separates the sphere of good (heaven/paradise) from the sphere of evil (hell). God's judgment maintains order in "otherworlds" (zaświaty): it prevents Satan from interfering with the domain of God and preserves God's power over hell. In folk belief, the blood of Christ has the power to put out the fire of hell, and Satan is only the executor of God's judgments [SSSL 1.1:298]:

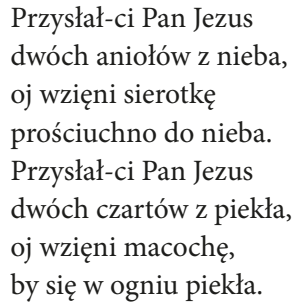

\author{
The Lord Jesus sent \\ two angels from heaven; \\ $\mathrm{O}$, they took the little orphan \\ straight to heaven. \\ The Lord Jesus sent \\ two devils from hell; \\ $\mathrm{O}$, they took the stepmother \\ to burn in hell.
}

The two spheres are associated with two different kinds of fire: the divine sphere - with heavenly fire, identified with divine light and life-giving power; the sphere of the devil - with hell fire, which burns but does not consume. In the folk imagination, "Hell is simply a place of terrible darkness and great heat. There's eternal fire there" (Piekło to jest po prostu ciemność tam straszna, i goraco bardzo. Tam jest ogien wieczysty) [SSSL 1.1: 299], which suggests that the fire of hell does not give light. Some synonyms of ogien piekielny 'the fire of hell' indicate its connection with this location or with the devil, who is in charge of it: ogień piekła 'hell's fire', ognie piekielne 'fires of hell', ogień czartowski/diabelski 'the devil's/fiend's fire' [SSSL 1.1:296]; the names ogień wieczny/wieczysty 'eternal fire', and the collocations with the verbs palić and piec 'to burn', and smażyć lit. 'to fry', in turn, describe its main characteristics.

The connection between fire and Satan, apparent in the lexicon, can also be noticed in the image of demonic beings who take the shape of animals breathing fire from their nostrils (e.g. a black horse, ram or dog). Folk tales and stories include a motif of mythical birds with fiery feathers or tails (a kłobuk or a raróg), which bring people money or golden seeds [SSSL 1.1: 300]. Eyes burning with the fire of hell, in turn, were supposed to be an important distinguishing feature of an upiór 'vampire', a boginka, a female demon (lit. 'goddess') or a wodnik 'a water demon'. Buried treasure was believed to glow with demonic fire, and lights (ogniki) burning on marshes and swamps were identified as evil spirits in disguise [SSSL 1.1:299-303]. 


\subsubsection{Purgatorial fire}

The concept of otherworldly fire purging souls of sins has a religious basis, and derives directly from Christian belief in divine justice, which rewards good and punishes evil. However, even the most wicked sinners are given a chance of redemption provided they willingly do penance for their sins. Although the profile of purgatorial fire shares some elements in common with hell fire, such as burning that causes pain, the main difference lies in its function, which is purging souls of their sins. The punishing and purifying function of purgatorial fire makes it similar to the profile of thunderbolt fire but relies on a different model of the FORCE schema. The main parameter of the action of such purifying fire is its duration, which is proportional to the weight of sins, and the source of FORCE is divine power: the power of God's mercy, leaving sinners the hope of entering paradise after their punishment has been served. The result of the FORCE's impact is not the annihilation of evil, as in the case of a thunderbolt, but the transformation of a sinful soul through the act of penance.

The profile of purgatorial fire is a complex structure, overlapping with some elements of hell fire (burning) and thunderbolt fire (a form of punishment). In common with hell fire, its FORCE can be experienced only after death, while its distinctive feature is its limited duration and purifying properties. This naturally has an impact on the approach to imaging purgatorial fire and its location: purgatory.

The hybrid nature of the profile of purgatorial fire, composed of qualities of other otherworldly fires, determines the situation of purgatory itself between heaven and hell. Heaven, hell and purgatory constitute the three fundamental elements of the spatial structure of "otherworlds" (zaświaty). Their respective location has been imagined in different ways, depending on the adopted principle of organising the space of "otherworlds" in relation to the earthly vantage point of the conceptualiser. In the vertical order, in which heaven is situated above and hell below the earth, purgatory could be placed either underground, close to hell, or up in the air, below the gates of heaven. The horizontal arrangement located purgatory between heaven and hell, somewhere at the end of the world, beyond the borders marked by "the great rivers which enclose the world" (rzeki wielkie, co zamykaja świat) [KLS 1967: 603]. In such a model, human souls had to cross a river in order to pass through the border between life and death [Niebrzegowska 1999d: 12; Michajłowa 2010: 96-97; Masłowska 2011: 125]. 
The motif of a border between this and the other world is grounded in the direct experience of an area bisected by a river into "this" side (close to the conceptualiser) and "the other side", beyond the opposite bank, unfamiliar to the conceptualiser. Hence the metaphor of a river separating the land of the living from the land of the dead is found in many cultures, ${ }^{8}$ as is the image of souls crossing a river to reach the other world [KopSS 1990: 367]. Slavic cosmic mythology shows souls making their way to the other world in a canoe or flying across as birds [SSSL 1.1: 440]. In religious tales and legends, a river of fire divided paradise from purgatory, with both spaces located in the other world [Niebrzegowska 1999d: 12]:

(...) there was still a long way ahead to the border of purgatory with the fields of paradise beyond it (...). Suddenly, on the border, he finds himself on the bank of a huge river; its waters, black as soot, burn with a fire of many colours. Above this wide river hangs a tiny bridge, as narrow as a baulk, so that it is difficult to stand firmly even on one foot. On both sides of the bridge, fiends stand in water up to their waist (...), they push down whoever dares step onto the bridge.

(...) jeszcze był kawał drogi do granicy czyśćcowej, poza którą następowały rajskie błonia (...). Wtem ni ztąd ni zowąd na granicy, napotyka ogromną rzekę: jej wody są jak sadza czarne, płoną ognisto w różnych kolorach. Na rzece tej szerokiej, zawieszony mosteczek tak wąski jak belka, że nawet jedną nogą nie stanie na nim dobrze. Z obu stron mostu diabli zamoczeni po pas w wodzie (...), spychają natychmiast, ktoby tylko na most wniść się odważył.

Other folk images present purgatory as a "desert of scorching heat" (pustynia petna spiekoty) [SSSL 1.1:294] or as "a large field or a house, in which every soul has its cell" [SSSL 1.1: 294]. In purgatorial scenes, penitential souls play the archetypal role of the object; the role of the agent proper is ascribed to a punishing God, though in some versions of the scenario it is performed by the devil, while purgatorial fire is the tool of punishment. The conceptualiser, as an observer, is located outside the scene where the action takes place. The central position is taken by the sinner and the devil as the torturer, with the actual agent and source of power (God) remaining in the background.

8 The motif of a fiery river and a narrow bridge crossed by souls on their journey to heaven after death derives from medieval literature. It was consolidated in the social imaginary by preachers, who were eager to use the image of God's punishment awaiting sinners in purgatory, in order to urge their listeners to repent and uphold moral values in their life [Sokolski 1990: 67, 248]. 
In this way, the purgatorial scenario gives the devil a subordinate role - that of the executor, who has access to purgatorial fire, but can neither use its power independently nor influence the manner and duration of the punishment [SSSL 1.1: 294]:

Each soul sits on a heap of burning ashes which grows colder and smaller as they get purified from sins. Devils mete out punishment while angels make a record of how long each has been suffering in purgatorial fire.

Każda dusza wysiaduje na popiele rozpalonym i coraz zmniejszającym się, gdy z grzechów się oczyszcza. Diabli wymierzają karę, a aniołowie zapisują, ile kto w ogniu czyśćcowym wybył i wytrzymał.

The Creator is the sole master of purgatorial fire and may - by the intercession of the Virgin Mary, Jesus Christ or St Lawrence - shorten the sinners' suffering. It is only thanks to prayers of the living (families, friends, neighbours) that souls may be delivered from the torment of purgatory.

Belief in the need for, and efficacy of, prayers for the dead, as well as the conviction of the inevitability of punishment for sins, is reflected in funeral rites. In scenes of parting with the world, the master of ceremonies plays the role of the deceased, asking the family and relatives to forgive their wrongdoings, to make an offering to the Church and to pray for their soul [Adamowski, Doda, Mickiewicz 1998: 306]:

Wszystko mi wybaczcie, za wszystko Forgive me all I've done wrong, pardon me darujcie, for all

A za moją duszę pacierz ofiarujcie, And offer up a prayer for my soul,

Choć jeden paciorek, dla duszy zbawienie,

„Ojcze nasz" i „Zdrowaś”, „Wieczne Just one bead for my soul's salvation, Our Father, Hail Mary, Rest Eternal. odpocznienie".

Belief in the active power of words is also evinced by the conventions of funeral hymns, which voice the laments, complaints, warnings and commands of the dead, addressed directly to the participants of the ceremony. The illocutionary force of the warning depends on the depiction of purgatorial fire, meant to arouse fear, while the complaint should stir pity in the listeners:

(1) Ogień w czyśćcu bardo ostry,

Otoczył mnie płomień bystry,

I zewsząd mnie ogień pali,

Nikt się nade mną nie użali.

[Szymańska 1998: 218]
(1) Searing fire in purgatory,

Quick flames have surrounded me,

Fire burns me all around

And none takes pity on me. 
(2) Zaczynam lament więźniów jęczących, W czyśćcowych mękach pokutujących, Słuchaj, żyjący człowiecze,

Co za ogień straszny piecze przewiniających. What terrible fire wrongdoers burns. ${ }^{9}$ [Adamowski, Doda, Mickiewicz 1998: 309] ${ }^{10}$
(2) I begin the lament of captives moaning, In purgatorial torment doing penance, Hear, all ye who are still alive,

The depiction of torment suffered by the purgatorial soul, coupled with the admonition that a similar fate awaits everyone, is not only meant to arouse sympathy, but also to strengthen the illocutionary force of the request and induce family members to pray for the dead and thus deliver them from purgatorial fire. Speech acts featuring in funeral hymns may take a complex form, combining admonition, request and command [Adamowski, Doda, Mickiewicz 1998: 308]:

(...)

Dusza w czyśćcu pokutuje,

Zmiłowania wyczekuje.

Wy nie wiecie dzieci o tem,

Co każdego czeka potem,

Czem możecie pomagajcie,

Duszę z czyśćca wybawiajcie.

(...)

Niech mszę świętą zakazuje

I ubogim ofiaruje,

Na tym ubytku nie będzie,

Duszę z czyśćca wydobędzie.
(...)

A soul does penance in purgatory,

It awaits God's clemency.

Children, you know not

What is in store for you,

Help in any way you can

To save a soul from purgatory.

(...)

Have a Holy Mass said,

And offer it for the poor,

There will be no loss in this,

It will deliver a soul from purgatory. ${ }^{11}$

The duty of godchildren to pray for the souls of their godparents is conveyed through imperative speech acts. Although the command is not expressed through modal verbs such as trzeba, powinno się, musieć (ought to, should, must), it is explicit in formulations of such beliefs: "a godchild has a duty to [= must, should] pray for the souls of his godparents. If he dies before them, he passes through the heat of purgatory once on their behalf" [SSSL 1.1: 294].

9 The translators would like to thank Jean Ward for her help in translating this passage.

10 This hymn - which survived in the oral tradition in a number of different variants originally comes from the narrative poem Przeraźliwe echo traby ostatecznej (The terrible echo of the final trumpet, Poznań, 1670) by the Baroque preacher Clemens Boleslavius (Klemens Bolesławiusz, died in Kalisz, 1689) [Adamowski, Doda, Mickiewicz 1998: 310].

11 The translators would like to thank Jean Ward for her help in translating this passage. 
The act of summoning divine power and delivering the soul from the torment of purgatorial fire relies on the FORCE schema, involving several phases and a number of other schemas such as LINK, CONTROL and CENTRE. In ritual scenes, the conceptualiser is also a participant in the event, identifying with the group in which he/she plays one of the roles according to a conventional scenario.

In the first phase, the FORCE schema operates according to the principle of OUTER COMPULSION. The participants of the scene comply with the accepted norms of behaviour, praying to the Virgin Mary or Jesus and asking for mercy for the soul of the dead. The efficacy of FORCE is additionally increased by the use of the LINK and CONTROL schemas. As fear of death and of the terrifying vision of purgatorial fire, which will engulf people after their own death, needs to be assuaged, the perlocutionary FORCE of commands is apparent in the conscious and voluntary compliance with norms of conduct (INNER COMPULSION schema). The FORCE of a prayer for the dead, in turn, relies on the ATTRACTION of supernatural power.

In the second phase, grounded in the belief in the active power of the words of prayer, holy persons intercede on behalf of the sinful soul, appealing to God's mercy to shorten the punishment and forgive trespasses. As in the first phase, the FORCE schema involves the ATTRACTION of power; however, the impact of the prayer is much stronger thanks to the status of the intercessors.

The third phase involves a manifestation of the power of God's mercy, thanks to which the term of punishment is shortened and the sinful soul is freed from the torment of purgatorial fire. The impact of the FORCE coming directly from the ultimate source is immediate, while the result of the appeal to God's power depends on a number of factors. The status of the mediator is the most important: the divine persons - the Son and the Holy Spirit - take the highest position, followed by the Virgin Mary and other saints, especially patrons of the dying: St Barbara, St Anne, St Joseph, St Lawrence, St Philomena. The cult of those saints, considered to be effective mediators between God and the dying, is well rooted in Polish culture. It goes back to the seventeenth-century tradition of the ars bene moriendi, as evidenced by titles of religious hymns such as Barbaro święta, perło Jezusowa (St Barbara, Jesus' Pearl), W ciemnościach niedowiarstwa Barbara zrodzona (St Barbara, Born in Heathen Darkness), Już przed Toba upadamy, Anno święta cudowna (We Fall on our Knees Before You, Wonderful St Anne), Szczęśliwy, kto sobie patrona Józefa ma za opiekuna (Happy Is He Who Has St Joseph for a Patron), Pieśn do świętej Filomeny (Hymn to St Philomena). They were sung in the moment of dying, during "empty nights" (puste noce), the period of vigil between the death and the funeral, and during 
the funeral ceremony. Some of them, circulating in the form of so-called "funeral notebooks" (zeszyty pogrzebowe) kept by the village community, still exist today [Szymańska 1998: 213].

Apart from divine and holy persons, to whom the dead were commended, folk culture ascribed particular powers to the prayers of wandering beggars ( $d z i a d)$ because of their poverty, similar to the example of Christ, and their blindness, which allowed them insight into otherworldly reality [Grochowski 2003: 114; Michajłowa 2010: 61; Niebrzegowska-Bartmińska 2011]. It was believed that death would be gentle for a dziad, since the sins he might have committed during his earthly wanderings would be forgiven on account of his beggarly life, and thus he would be spared the torment of purgatorial fire [Szymańska 1998: 217]:

Śmierć ci dziadowi wszystko podaruje,

Bo on chodzi od wsi do wsi,

A torby nosi,

I Boga prosi.
Death will forgive a wandering beggar everything

Because he goes from village to village Carrying his bags And praying to God.

In contrast to other Slavic countries, Polish folk culture is distinct in placing a special emphasis on the role of the Virgin Mary as an intercessor for sinners and a mediator between earth, heaven and purgatory. According to folk beliefs, twice a week, on Wednesdays and Saturdays, the Holy Mother holds out a rosary to sinful souls to help them out of purgatory [SSSL 1.1:295].

The Most Blessed Virgin descends from heaven down the road through paradise and walks together with the saints to purgatory every Saturday and Wednesday (...); she holds out a rosary to one soul that she sets free and takes from purgatory to paradise, leading it through the gates of stone.

Najświętsza Panienka zstępuje $\mathrm{z}$ nieba gościńcem przez raj i idzie ze świętymi $\mathrm{w}$ każdą sobotę i środę do czyśćca (...); podaje różaniec jednej duszyczce uwolnionej i tę przez różaniec z czyśćca do raju wprowadza kamienną bramą. [Benedyktowicz D., Benedyktowicz Z. 1992: 40]

Scenes from funeral hymns presenting the journey of souls after death (especially the sinful ones, deserving damnation) feature the figure of the Virgin Mary interceding with her Son to obtain mercy for the sinners [Szymańska 1998: 211]: 
Dusze rzewnie zapłakały, Zdrowaś Maryja, ${ }^{12}$ Souls burst into tears, Hail Mary, i do piekła zawołały, Zdrowaś Maryja: And called to hell, Hail Mary:

Piekło, piekło przyjmij nas, Hell, hell take us, bo Pan Jezus nie chce znać nas, Zdrowaś For the Lord Jesus doesn't want to know us, Maryja.

Witaj róża i lilija, Hail rose and lily, niech się serce w nas rozwija. Zdrowaś Maryja. Let our hearts bloom, Hail Mary.

(...) (...)

Gdy Matka Boska usłyszała, Zdrowaś

When the Mother of God heard them, Maryja,

i na świętego Piotra zawołała, Zdrowaś Maryja:

Piotrze, Piotrze weź swe klucze, Peter, Peter, take your keys, wpuść do raju grzeszne dusze, Zdrowaś Let sinful souls into heaven, Hail Mary. Hail Mary. Maryja.

Belief in the effectiveness of Our Lady's intercession is expressed in request speech acts, as can be seen in the opening lines of funeral hymns, for example: "O Sorrowful Mother, turn your eyes" (Matko Bolesna, swe oko zwróć); "O Sorrowful Mother, protect" (Matko Bolesna w opiece swej miej); "O blessed Mother, to you we run" (Matko Najświętsza do Ciebie biegniemy); "O Blessed Mother, to your heart" (Matko Najświętsza do serca Twego); "Our Lady of the Rosary, queen of heaven and earth" (Różańcowa Pani nieba, ziemi); "O loving Mother, protectress of people" (Serdeczna Matko, Opiekunko ludzi); "O our hope in our sorrow and suffering” (Nadziejo nas utrapionych, zewsząd w nieszczęściu ściśnionych); "Hail holy Queen of heaven, mother of mercy" (Witaj Królowo Nieba i Matko Litości); "Hail glorious Mother who suffered great sorrow" (Witaj Matko uwielbiona, żalem serdecznym zraniona); "From our hearts we call, O Mary" ( $Z$ głębi serc naszych wołanie, Maryjo); "O Mary, Mother of God, you are our dear hope" (O Maryja, Matko Boga, Tyś nadzieja droga). ${ }^{13}$

Prayers of propitiation addressed to the Virgin implicitly reveal the belief in the power of her intercession. Appealing to her maternal protection and mercy, such speech acts have a bipartite structure: illocutionary (arousing pity) and perlocutionary (interceding with God, usually the Son, and, in obtaining forgiveness for the sinner, freeing him/her from the fire of hell).

12 Jerzy Bartmiński analyses different variants of this hymn [Bartmiński 1998b: 149-168].

13 The titles quoted after Adamowski, Doda, Mickiewicz 1998: 316-318. 
The second factor that has an impact on the efficacy of the appeal to God's power is the time of the prayer. In folk culture, the time of death is seen as special, and the period between death and funeral is subject to strong supernatural influences, including the forces of evil, lurking for the soul of the deceased. Hence the command to keep vigil by the dying and pray for them during their final hours and throughout the period up to the burial. During the first stages of the ritual, at the moment of death and during "empty nights", prayers and hymns appeal for intercession to the Virgin Mary and holy patrons of good death; hymns and prayers accompanying the funeral ceremonies proper are addressed to Jesus, God the Father and the Holy Spirit.

The opening lines of funeral hymns often include words praising God's mercy, e.g. "O infinite, merciful God" (Ach nieskończony, litościwy Boże), "O infinite Grace, O Father, Son, Holy Spirit” (W łaskawości Niepojęty Ojcze, Synu, Duchu Święty); His power and glory, e.g. "O great God" (Ach wielki Boże), "O eternal, infinite God" (Boże przedwieczny, Boże niezmierzony), "We praise you, God" (Ciebie Boże chwalimy), "We worship You" (Ciebie uwielbiamy); or expressions of humble trust, e.g. "We humbly call to You, Lord" (Do Ciebie Panie pokornie wołamy), "He who commends himself to the protection of the Lord" (Kto sie w opieke podda Panu swemu), "Father, we pray to thee" (Ojcze, modlim się do Ciebie), "I trust God in my sorrow" (Ufam Bogu w mem nieszczęściu), "I believe in You, the living God" (Wierze w Ciebie, Boże żywy), "In the name of the Almighty Father, the Son and the Holy Spirit" (W Imię Ojca Wszechmogacego, Syna i Ducha Świętego).

The opening lines of hymns addressed to Jesus, in turn, introduce supplications that invoke His infinite mercy and often make reference to His pain, wounds and death on the cross that He suffered for people's sins [Adamowski, Doda, Mickiewicz 1998: 315-318]: "O good Jesus, our Lord” (Dobry Jezu, a nasz Panie); "O my merciful Jesus, I’m a miserable man” (Jezu mój litościwy, ja człowiek nieszczęśliwy); "O sweet Jesus, our love" (Jezu słodki, miłość nasza); "O Jesus fainting in Gethsemane" (Jezu w Ogrojcu mdlejacy); "O Jesus wounded for my sins" (Jezu zraniony, za me duszne rany); "O Jesus in bonds, break the shackles of my malice” (Jezu związany, rozkuj kajdany, w które mnie złość podała); "Kneeling in Gethsemane, praying to the Father" (Klęczac w Ogrojcu, modląc się Ojcu); "Who is worthy to cry over your death for us, sinners" (Któż opłakać godnie może za nas grzesznych śmierć Twa Panie); "O my dear Jesus, you are the source of grace” (O Jezu mój drogi, Tyś jest źródłem łask); “A poor captive soul in purgatory begs by the wounds of Christ" (Więzień w czyśćcu zatrzymany, prosi na Jezusa rany); "Hail Jesus Christ on the cross, by your wounds..." (Zawitaj ukrzyżowany Jezu Chryste, przez Twe rany); "O saviour of the world, Lord Jesus, by your blood 
that was shed" (Zbawco świata, Jezu Panie, przez drogiej krwi Twej wylanie); "O Lord Jesus Christ, let a drop [of blood] from your wounds fall" (Zrzuć z ran Twoich krople, Jezu Chryste Panie).

Appeals to the mercy of God the Father, the Son and the Holy Spirit directly invoke the source of infinite power ruling over purgatorial fire (which will die out only on the Day of the Last Judgement), and express a deep belief that a sinner may be spared the eternal torment of hell fire.

The principal factor affecting the perlocutionary power of a speech act of entreaty addressed to divine persons is belief in the efficacy of prayer. Great importance was attached to the presence of a wandering beggar (dziad) both during the vigil by the bedside of the dead and during the funeral ceremonies. The dziad - as a stranger amidst the village community, a newcomer from distant places - was considered to be a perfect mediator between this (familiar) and the other (alien) world. Consequently, he was asked to continue praying for the salvation of the soul after the funeral.

All Souls' Day (2 November) was seen as the best time to offer prayers for souls suffering in purgatorial fire, especially if the prayer was said by a $d z i a d$. Alms given to a wandering beggar in return for his prayers had to be generous and offered out of a sincere heart; in this way, the almsgivers could be assured they would be given credit for their actions in the other world [Michajłowa, 2010: 100-103].

Although wandering beggars were believed to be effective mediators, additional magical measures were taken to increase their power. In the Podhale region in southern Poland, beggars were given gifts of linen on All Souls' Day, so that their prayer, travelling on this symbolic path, should reach Jesus immediately [Michajłowa 2010: 98]. The concept of a linen bridge linking the physical and metaphysical worlds relies on the LINK schema, while the cumulative actions are meant to INTENSIFY FORCE.

Making an offering was also included among socially accepted commands, taking the form of presupposed speech acts such as:

- one should/it is right to make an offering for a Mass to be said for the soul of the deceased;

- one should/it is right to give alms to a wandering beggar so that he prays for the deceased.

The command to make an offering to the Church for a Mass to be said for a deceased family member is also included in funeral hymns [Adamowski, Doda, Mickiewicz 1998: 310]: 
Nie miej jałmużnę za szkodę sobie,

Będzie zasługa i tobie w grobie,

Co ty biednemu w kościół rzucisz,

$\mathrm{Z}$ tego pewnie nie zasmucisz duszę $\mathrm{w}$ tej dobie.

Czyli szelążkiem, czy skibką chleba,

$\mathrm{Z}$ rąk twych podana komu potrzeba,

Czy msza święta zakupiona,

Moją duszę udręczoną wkupi do nieba.
Don't think of alms as a loss to you,

When you're in the grave it will be to your

merit,

What you throw to the poor in church

Will not sadden your soul at that time.

Whether a penny or a crust of bread

Given by your hands to any in need

Or an offering made for a Mass to be said

It will buy into heaven my suffering soul. ${ }^{14}$

Place was the next factor affecting the efficacy of attracting supernatural powers. Liminal places were thought to be the most conducive to contact with the other world. It was not an accident that most cultures believed that the land of the dead was divided from the land of the living by a river. Consequently, the bridge which souls had to cross to go to the other side was regarded as a symbolic place connecting the two worlds [Michajłowa 2010: 98]. Such beliefs underlie the custom of building footbridges over rivers and streams to make it easier for souls to cross the border between life and death. If a cemetery was located on the other side of a river, neighbours taking part in the funeral procession did not cross it so as not to enter the sphere of death: it was only the priest and family who accompanied the dead to the grave [Niebrzegowska 1999d: 13]. The prohibition against crossing a river going after a coffin served as a protective measure. If a river bisected a village, graveyards were built on both sides, which again was a precaution motivated by fear of crossing the border of life ("If a river splits a village in half, there are cemeteries on both sides" (Jeśli rzeka rozdziela wioskę na dwoje, to i cmentarze sa po obu jej stronach)) [Niebrzegowska 1999d: 13; Masłowska 1999: 184; 2011: 122].

Belief in the "interspheric" character of a road [Adamowski 1999d: 15-18; 2011: 179] lies at the root of the ritual hanging of white linen towels on crosses standing at forks in the road, or tying them to the harness of the horses pulling the cart with the coffin to the cemetery. The cloth represented human earthly life, and constituted a border between "this" and "the other" world [Kozłowska-Doda 2011: 107]. Similarly, the cloth which was used to lower the coffin into the grave, and which later served as tablecloth during the funeral reception, also played the role of a bridge between the worlds [Adamowski 2011: 185]. White linen, used

14 The translators would like to thank Jean Ward for her help in translating this passage. 
as an attribute in all rites of passage from the cradle to the grave, symbolises the circular journey from eternity into earthly life and back into eternity.

Other symbolic places of passage include gates, doors, thresholds, fences and forks in the road, dividing "own/familiar" (swój) from "strange/alien" (obcy) space. Consequently, crossing the successive borders of the "own" world during the funeral ceremony marked the stages of the ritual exclusion of the deceased from the world of the living [Kozłowska-Doda 2011: 106]. The passage to heaven or hell also involved going through gates, with the gate of hell always held wide open, while the gates of heaven, guarded by St Peter, were only opened to let in pure souls. Souls who did not receive absolution on earth had to go first through purgatorial fire unless their family and friends delivered them from their punishment by offering prayers at the prescribed place and time.

Souls burdened by a curse or a crime could not find their place on earth, in water or in air [Engelking 2017:251]. Their passage to the other world could only be facilitated by purgatorial fire [SSSL 1.1: 279]:

Wysła dusycka z ciała

Nie widzą, gdzie się podziała.

(...)

A czemu ty duszyczko płaczesz?

Bom się na matkę zamierzyła.

Gorsze moje zamierzenie,

Niźli czyje uderzenie.

Wiedźcież mnie na ogień gorący,

Żeby ze mnie tak krew kapała,

Jak mojej matki łzy kapały.
A little soul has left the body,

No one can see where it's gone.

(...)

And why are you crying, little soul?

Because I aimed to strike my mother.

My intention was worse

Than another's deed.

Take me to the burning fire,

Make my blood drip

As my mother's tears did.

Belief in the purifying properties of fire and the possibility of passage into the other world in a dematerialised form induced the families of the damned (potepieńcy, sing. potepieniec; including suicides) to burn their dead bodies or to light a pyre in the place where they had died so that their soul might soar up with the smoke into the sphere it could not reach on its own, and there beg for purgatorial fire [Masłowska 2011: 123; SSSL 1.1: 275].

The relationships between different otherworldly fires and the earth are a complex matter. Heavenly fire is perceived as grace granted by heaven to the living and a reward for the soul after death. Thunderbolt fire performs a regulating function: it restores order on earth and is part of the continuing fight between God and Satan. Heavenly and purgatorial fires also have an impact on earthly life. On the one hand, fear of punishment impels people to live a better life; on the other, the image of purgatorial fire burning the souls of ones nearest 
and dearest and their pleas for prayer from beyond the grave induce the living not only to keep in contact with the world of the dead, but to commend them to God's mercy and ask saints to intercede on their behalf, as well as to visit graves and to give alms to the poor (especially to wandering beggars). Notably, belief in the intercession of particular saints, especially those who suffered martyrdom by fire for their faith, provides a link with the metaphysical world. The saints to whom prayers are addressed perform the role of "our own" representatives in "the other" world. They deliver those souls that are commended to them from the suffering of purgatorial fire, ensuring their gratitude to, and protection of, the living. Belief in the protective role of the ancestors, one of cultural archetypes, is also apparent in the significance attached to the figure of a wandering beggar (dziad), who is not only treated as a mediator between heaven and earth, but also identified with the ancestral spirit, a conveyor of human fate [Michajłowa 2010: 101]. Fortune-misfortune (dola-niedola) is understood here as an inevitable fate, inherited and passed on from generation to generation. Fortune (dola) is a state of grace (happiness) and magical protection enjoyed by the community thanks to adherence to rituals, norms and cultural models communicated by a system of commands and prohibitions [Engelking 2017: 252]. In folk culture, a breach of the cultural code, a breaking of the intergenerational links, is equated to the loss of one's heritage and the blessing of the ancestors and thus is tantamount to an act of inviting misfortune. The very name $d z i a d$ 'grandfather/the oldest man in the family/ancestor' applied to wandering singers-beggars, who passed on communal traditions and moral teaching, indicates the connection with kin, which in this case seems to encompass humankind in general. In this way, wandering beggars played a positive social role, maintaining contact with the ancestors, warning of the punishment in hell fire and praying for souls suffering the torments of the fire of purgatory.

\subsection{The profile of the home fire}

In folk culture, the fire "created by the Lord God for people's comfort" (stworzony przez Pana Boga dla wygody człowieka) [SSSL 1.1:284] is known as "a gift of God" (dar Boży), "a gift of heaven" (dar nieba) and "God's treasure" (skarbicek boży) [SSSL 1.1: 266]. In Christian conception, fire is a gift of grace, bestowed in the act of creation: "The Lord God created fire, water and earth" (Pan Bóg stworzył łogień, wode i ziemie) [SSSL 1.1: 284]. Divine origin endows fire with sacred properties and makes it an object of veneration (as a gift of God); it is also believed to have healing and purifying powers. Although ogien domowy 'home fire' (earthly fire, accessible to direct sensual cognition) is not a fire of 
"otherworlds", it provides a link between heaven and earth and thus displays a number of features that are common to the sacral profile [Szadura 1998: 333]. The presence of fire - the heavenly source of light and warmth - endows the household with a sacred status: ognisko domowe 'the hearth' (lit. 'home bonfire') and dom 'house/home' are treated as synonyms. The position and role of fire in the household is apparent in conventional forms of direct address and patterns of behaviour towards it, regulated by a system of commands, prohibitions and warnings.

The concept of the home fire is structured by the FORCE, LINK, CONTROL and CENTRE-PERIPHERY schemas. The experience of FORCE in relation to fire, the giver of light and warmth in the sacred sense, builds cognitive paths that link it with God's blessing and the attendant healing, protective and purging powers, which the home fire draws straight from its source - heavenly fire, identified with God Himself. The LINK, WHOLE and CENTRE schema, in turn, underlie the functions ascribed to the home fire and its equivalents: the stove and table, the focal points of family life providing the centre of the concentric "own" space. Unlike the unharnessed elemental force, the home fire is confined to the stove, "tamed" and controlled by people; hence it belongs to the "own/familiar" (swój) sphere [Maćkiewicz 1997: 72-74; Masłowska 2007b: 111]. However, since its power was believed to derive from its divine origin, it required special treatment, based on traditional rules, passed on orally from generation to generation. These included both speech acts addressed directly to fire (greetings, farewells, thanks and requests) and commands, prohibitions, warnings and threats addressed to people using it. Such treatment indicates that fire was considered to belong to the supernatural sphere, alien to the human being. Scenes featuring the home fire rely on source domains and include their basic parameters, thus building cognitive paths linking analogous models of conduct towards earth, wind, and, particularly, the sun, to which fire is related.

Human response to fire as a gift bestowed by the grace of God involved different forms of expressing gratitude and showing respect and veneration, in recognition of its sacred nature. Kindling a "living fire" ( $\dot{z} y w y$ ogień) by friction (an imitation of the sexual act) amounted to a symbolic act of conception [SSSL 1.1: 271, 289; Szadura 1998: 330], which could be regarded as a ritual re-enactment of the divine act of creation, bringing a new being to life.

Like a newborn child, fire was given a name, used when greeting it or addressing it with a request. The name of the home fire was also used when trying to calm down a fire of conflagration. Traditionally, fire was called Zygmunt, which reflected its lively nature. The name has semantic links with such dialectal forms as zygać/zyzać 'to make provocative gestures', żegi/zugi 'long sparks 
of a bonfire', $\dot{z} g a c$ ' to poke with a sharp object', podżegać 'to incite, stir up; to stir up fire' [DorSJP], zyga 'a spinning top (children's toy); a restless, fidgety person' [Vasmer 1986-1987]..$^{15}$

The ritual of lighting a fire was performed according to a few conventional scenarios, in which the conceptualiser played the role of the agent, and fire was the object or instrument of action. The place, time and purpose of starting a fire determined the setting of the event and the rules that were to be followed.

The most solemn occasion was that of kindling a ritual "new fire" (nowy ogień), which was considered pure and sacred, and hence also known as boży/ czysty/pierwszy ogien' 'God's/pure/the first fire'. As "new fire" was believed to have extraordinary protective and healing powers, the ritual (zywe rozpalenie) required observing the following principles [SSSL 1.1:290]:

- before lighting the fire one should cross oneself and do it again once the first spark has appeared ("as if blessing a special gift of heaven" jak gdyby dla pobłogosławienia szczególnego daru nieba) [SSSL 1.1: 285];

- a "new fire" should be started by rubbing together pieces of a particular type of wood: hazel, alder or aspen, ${ }^{16}$

- a "new fire" should be started under the open sky;

- "new fire" should be solemnly taken back home on the same evening;

- the "first fire" should be kept at home all the year round;

- in the event of an epidemic, all home fires should be extinguished; a "new fire" should be kindled again and taken back home.

A "new fire" was started at different times of the year and was associated with a number of rituals:

- on St Lawrence's day (10 August), the patron saint of fire, a "new fire" was lit as part of the ritual restoring the power of fire. On the eve of the feast, the "old fire", whose original power was believed to have weakened as a result of earthly impurity, was extinguished; this act was accompanied by the following formula: "In the name of the Father, the Son and the Holy Spirit, go with God, dear fire, and sleep" ( W imię Ojca i Syna i Ducha świętego, idź z Bogiem

15 Quoted after Szadura 1998: 330-331.

16 Depending on the region and the occasion, "new fire" was also started using stones, particularly thunderstones, a piece of metal, blessed touchwood (hubka święcona), beech touchwood (hubka $z$ buku), willow touchwood (hubka wierzbowa), an iron coin with a rough edge (żelazna moneta $z$ rabkami na obwodzi), a fire striker, flint and touchwood, a knife or an axe and touchwood [SSSL 1.1:270]. 
ogieniaszku, a śpij). The "new fire" was greeted with an analogical formula (the only difference being a welcome instead of a farewell): "In the name of the Father, the Son and the Holy Spirit, rise with God, dear fire, and burn" ( $W$ imię Ojca i Syna i Ducha świętego, wstań z Bogiem ogieniaszku, a gorzej) [SSSL 1.1: 278];

- on Easter Saturday a "living fire" ( $\dot{z} y w y$ ogień) was kindled (using stones) during the ceremony of blessing fire;

- on St John's Eve a "new fire" was started during rituals celebrating fire and water; it was used to light the so-called Saturday bonfires (ognie sobótkowe; bonfires lit on consecutive Saturdays between Easter and Whitsunday), which were believed to rid the area of evil forces and stimulate the life-giving power of the sun;

- on the Eve of Epiphany or Easter Saturday a "new fire" was started at home using a rope lit from the fire blessed in church; this fire was kept all year round.

Once started, this fire burning in the home was part of the rhythm of family life. The source of light and warmth, it was seen as a guarantee of life and prosperity in the household. Since it provided a link with the supernatural world, it was supposed to be kept burning all year round; it was also customary to use blessed herbs when lighting a fire for the first time in a new house, or starting a new fire in the stove at Easter [SSSL 1.1:290]:

- on Easter Saturday, the first fire in the stove should be started using thorn garlands from last year;

- blessed herbs should be thrown into the first fire lit in a new house.

Like other natural elements, fire was considered sacred and commanded respect. In a number of cases, norms of conduct concerning fire, earth and the sun display certain analogies:

- one should greet the fire when kindling it in the morning, using such formulas as: "Welcome, dear fire/ holy guest/ dear little Jesus/ God's dear treasure/ Zygmunt" (Witaj ogieńku/ święty gościu/ Jezusieńku/ skarbiczku boży/ Zygmuncie); variant: "Welcome, our expected guest, our dear little Jesus. We welcome our Lord and His light" (Witoj gościu pożądany, Jezusieńku nasz kochany. Witamy Pana naszego i światłość jego) [SSSL 1.1:278]; in some older records, such salutations also included a plea for protection from hunger: "O holy fire, God's treasure, don't let us suffer poverty" (Ogieńku święty, skarbicku boży, nie dejże nas też nigdy zubożyć) [SSSL 1.1: 278];

- one should put the fire to sleep in the evening: make the sign of the holy cross over it while saying "Dear fire, stay in the fireplace, don't go out to see our 
neighbour because I like you here" (Ogieńku kochany siedź w kominku, nie chodź do sasiada, bom ja tobie rada); other formulas used on the occasion invoked Jesus and all the saints: "Sleep here, dear fire, with the Lord Jesus and all the saints" (śpij tu ogieniaszku z Panem Jezusem i ze wszystkiemi Świętemi), St Lawrence: "O the most blessed Saint Lawrence, I give this dear fire to your most holy protection" (Święty Wawrzeńcze przebłogosławiony, tobie oddaje ogniaszek sławiony, pod najświętsza twoją opiekę), or the guardian angel: "O Holy Angel, sit on this stool by the fire" (Święty Janiołecku, siedze na stolecku, przi tem ogienecku) [SSSL 1.1: 279];

- it is forbidden to extinguish the home fire by pouring water over it; it should only be covered with ashes [SSSL 1.1:271];

- it is forbidden to pour dirty water in the fire [SSSL 1.1:273];

- it is forbidden to spit in the fire "because it's as if [you were spitting] on the Lord Jesus" (bo to tak, jakby w Pana Jezusa); "or else the fire will get offended and burn the one who's been spitting" (bo się ogień zagniewa i plującego spali); "or else you'll be made to lick a red-hot stone after death" (bo po śmierci każa lizać kamień rozpalony do czerwoności); "or else your tongue will come out in spots" (bo język spryszczy) [SSSL 1.1: 273];

- it is forbidden to urinate on the fire "or else you'll break out in spots all over" (bo caly sparszywiejesz) [SSSL 1.1: 273];

- it is forbidden to stand with your back to the fire or swear near it [SSSL 1.1:273];

- "It's forbidden to pour water over the fire because it's a sin; it should only be covered with ashes" (Ognia zalewać nie wolno, bo to grzech, należy go tylko przysypać popiołem) [SSSL 1.1: 285];

- it is forbidden to lend or borrow fire so that life and happiness are not taken out of the house; "Those who borrow fire in their lifetime have to return it in hell" (Kto za życia ognia pożycza, w piekle oddać musi) [SSSL 1.1: 272];

- it is forbidden to tease fire, use it as a toy or play with it: "Fire isn't your brother, you can’t play with it" (Ogień nie twój brat, żebyśsię z nim bawit) [SSSL 1.1: 274];

- it is forbidden to put sharp objects in the fire because it can get hurt; it is forbidden to trample on it "because it's a living creature" (bo to jest żywe) [SSSL 1.1: 273-274].

The fact that formulas for greeting fire and the sun were addressed to Jesus means they were considered divine (as hierophanies of God, by analogy to archetypal patterns of a religious cult). One example of identification of God with fire can be found in the lyrics of a folk Christmas carol: "Even stranger it was that 
God, who is fire, took shelter in hay without setting it aflame; O hay, hay, why don't you burn, why don't you at least give some warmth to the Lord" (Rzecz to dziwniejsza, że Bóg ogniem bywszy, w siano sie ukryt, siana nie spaliwszy. Oj siano, siano, czemu nie gorejesz, czemu przynajmniej Pana nie ugrzejesz) [SSSL 1.1: 279]. Burning thorny branches (symbolising Christ's crown of thorns) in bonfires lit on Easter Saturday is another example of a symbolic connection between fire and Jesus.

A direct connection between fire and the sun is apparent in the dates prescribed for kindling a "new fire" (coinciding with the summer and winter solstices, and the spring and autumn equinoxes), ritual dances around "Saturday bonfires" (a circular movement imitating the movement of the sun across the sky) and the ritual of carrying fire around fields in a clockwise direction. Also, it was forbidden to stand with one's back both to fire and the sun [Szadura 1998: 335; SSSL 1.1: 287].

Rules against defiling the sacredness of fire display certain analogies to those observed in the case of earth and water. This is particularly visible in the prohibition against spitting in the fire ("because it's as if [you were spitting] on the Lord Jesus" (bo to tak, jakby w Pana Jezusa)) and spitting into water ("because water is used for baptism"; "because it's spitting in the face of the Mother of God" (bo woda się chrzci; bo pluje się Matce Boskiej w twarz)). Such offences were believed to be punished according to the nature of the element - with fire or drowning. If someone accidentally offended the earth by spitting on the ground, they had to apologise immediately by saying "It's not upon you, mother-earth" (Nie na ciebie, matko-ziemio). Other examples include prohibitions against urinating and swearing.

The time for the ritual lighting of fire was determined not only by the Christian calendar, but also by special occasions in the life of the household and its members, such as birth, marriage and death.

Lighting a fire on the day a child was born was not only a symbol of a new life, but also of the infant's inclusion in the order of the earthly world, where it would be surrounded by both good and evil. The "living fire" kept burning by the newborn's cradle played mainly a protective function - it guarded the new life and scared away evil spirits that threatened the unbaptised soul [SSSL 1.1:274]. Since a newborn child came from the "alien" (obcy) world, it was believed that its arrival was accompanied by extraordinarily heightened interference from demonic forces. Under the circumstances, the fire was exposed to impurity and had to be provided with a bowl of water to clean itself. This belief is also apparent in the everyday custom of leaving a pot of water by it overnight so that fire, "which is purity itself and gets tainted through contact with the world" (ktorry 
jest sama czystościa i bruka się w zetknięciu ze światem), could cleanse itself [SSSL 1.1:266].

The use of fire as a symbol of life and happiness, hence also love, can be observed in the custom practised in the Polish mountains, in which a young man lights a bonfire for the girl he chooses; the bonfire is a sign of growing affection (cf. ogien miłości 'the fire of love', płomień miłości 'the flame of love') and of their future life together by the family hearth: "There's a fire burning in the mountain meadow, Johnny boy has lit it for his girl" (Na holi, na holi ogienek sie poli, nakłod go Jasinek ku dziewcyny woli) [SSSL 1.1:282]. By contrast, one way of refusing a marriage proposal was to extinguish the fire in the hearth on the arrival of the matchmakers: "O mother, pour water over the fire, the matchmakers are coming. O pour it, pour it, let them pass by" (Oj zaléj, matko ogień, bo w zaloty jada, Zaléj-ze go zaléj - niechaj jada dalej) [SSSL 1.1: 281]. Fire was also extinguished during the wedding ritual of putting on the wife's bonnet (oczepiny), thus signifying the end of parental control over the bride and marking her departure from the family hearth: "Put the fire out, put it out, don't let it burn; don't let the mother and the daughter boast" (Zagaś ogień zagaś, niechize się nie pali, niechize się matula $z$ córeczka nie chwali) [SSSL 1.1:281]. Such scenes rely on the LINK schema, which enables the building of cognitive paths between the act of extinguishing fire and a rejection of a marriage proposal or a ritual passage from maidenhood to married life

Fire also accompanied people at the time of their death. Placing a lit "thunder candle" (gromnica) in the hands of a dying person was supposed to light the path for the soul leaving the body and scare away evil forces lurking in wait for it. Fire was also kept burning for the dying to warm their souls and purify the space tainted by death. The presence of death opened the household up to contact with "otherworlds" (zaświaty). In order to protect it, and prevent interference from supernatural forces, members of the household performed practices following generally accepted principles [Diakowska 2011: 132-113]:

- all windows and doors should be closed;

- the chimney should be blocked;

- the fire should be extinguished;

- the clock should be stopped and the mirrors should be covered;

- water kept at home should be poured out.

In the death scenario, mourners experience the impact of supernatural forces beyond human control (OUTER COMPULSION). They are drawn into the scene and have to play the roles dictated by fear of alien forces on the one hand, and by socially determined protective practices on the other. Fear of the consequences 
of disobeying accepted norms of behaviour means that the commands are fulfilled according to the pattern of INNER COMPULSION; hence the communicative acts acquire a perlocutionary force. The concept of death as disintegration (breaking off LINKS) is reflected in the custom of extinguishing the fire as a sign of the extinguished life of a family member. Moreover, extinguishing the fire and pouring out water prevented them from being defiled by the presence of death. After the funeral, a return to normality required the lighting of a "new fire".

The divine origin of fire endows it with supernatural powers that could be put to use against evil forces and applied in healing practices: "Fire comes from God and that's why it has special powers; it has the power to heal and to help against evil" (Ogień pochodzi od Boga i temu ma takie przywileje, że ma moc $i$ leczy i przeciw złemu on pomaga) [SSSL 1.1: 274]. However, acquiring access to its sacred powers demanded either the ability to perform magical practices or the possession of secret knowledge about ways of annihilating demons and expelling diseases by means of fire. Instructions how to destroy evil include the following examples [SSSL 1.1:274]:

- you can destroy an evil spirit by throwing a piece of paper with its name in the fire;

- you can get rid of a mare (zmora) if you catch it in a bottle and throw it in the fire; the mare "goes out through the chimney as a long streak of black smoke" ([zmora] w dymie jako czarna dtuga prega wychodzi kominem);

- you can throw an ember into a child's bathwater to destroy demons hiding there; just in case, bathwater should then be poured out onto the fire;

- you can drive away evil forces by burning sticks arranged in the shape of the cross;

- you can summon and destroy witches if you make a fire on Christmas Eve using aspen twigs collected every day starting with the feast of St Lucy (13 December); next to it, you need to place a pot with a linen bag (powazka) spiked through with needles.

As usual, such magical practices relied on the principle of accumulation, based on the INTENSIFICATION OF FORCE schema: the power of fire was intensified thanks to the time (Christmas Eve, St Lucy's day) and manner of their performance (arranging burning sticks in the shape of the cross; using needles so that the witch could not escape from the fire). In such scenes, evil forces are construed as the object, while fire is the actual agent of destruction, even if the act of burning is performed by the conceptualiser. Magical practices, both healing ones and those aiming to destroy evil, involved uttering spells, for example [SSSL 1.1: 279]: 
- "Spells! Mighty spells! (...) I cast you! By hot fire, by hot stones, by people’s eyes!” (Uroki! Urocyska! (...) Zamowiom! Na ogień gorący, Na kamienie gorace, na ludzkie ślipie!);

- a weeper's spell: "Go away, fiend! Go into the eternal fire, out of this innocent body! Go beyond the forests, beyond the mountains, to the fork in the road! Never return here! Break your legs! Let this fumigation work so that there is no more crying. In the name of the Father, the Son and the Holy Spirit! Let the will of God be done!" (Idź czorcie! Idź w ogień wieczny Z tego niewinnego ciała! Idź za lasy, Za góry, Na rozstajne drogi! Nie wracaj tu nigdy, Połom sobie nogi! Niech to kadzenie wyjdzie na pożytek, Że ustanie ten płacz wszytek. W imie Ojca i Syna i Ducha Świętego! Niech sie stanie wolo Bożo!).

Belief in the causal power of spells is based on the INNER COMPULSION schema. The spell acquires a perlocutionary force when the word turns into action. In scenes of expelling a disease (identified with the devil or an evil spell), the healer performs the role of the agent. He/she appeals to the power of fire or the Holy Trinity, in the name of which he/she speaks. Although the healer is a mediator between heaven and earth and acquires access to the source of power, it is in fact the sacred, which remains in the background, that is the actual agent. The disease and the patient (drawn into the scene as a passive participant) are the objects of magical practices; the conceptualiser assumes the role of an observer. The disease is banished to burn in fire (in hell) or is chased away to an "interspheric" location (e.g. a fork in the road, swamps, "beyond the forests/mountains"), a desolate, uninhabited place regarded as "alien" $(o b c y)$. In this case, the spatial imagery is based on the opposition between the CENTRE (human body) and PERIPHERY (the realm of death).

Belief in the purifying power of fire, capable of overcoming demonic forces and diseases, is revealed in the annual magical protective practices performed at "Saturday bonfires" (ognie sobótkowe). Lighting ritual bonfires was believed to protect cattle and crops from diseases, ensure a better harvest and keep hail away from the fields. "Saturday bonfires" consecrated the space of human activity outside the farms, particularly in the fields, and purged it of witches and their spells: "the bonfires were lit so that evil spells and witches would burn in their flames" (ogniska palono, aby w ich ogniu spłonęty czary i czarownice) [SSSL 1.1: 288].

Similar rituals of protection involved keeping a bonfire (watra) burning in mountainside meadows (hala) throughout the grazing season. Analogically to the home fire, such a bonfire was believed to protect people and cattle, and thus commanded special respect. Since both the fields and mountain meadows were 
considered to belong to the "alien" ( $o b c y$ ) sphere (conceptualised in terms of the PERIPHERY schema), they were constantly under threat from demonic forces. This explains the practice of driving cattle through burning embers the day they arrived in the mountains [SSSL 1.1:289].

By contrast, a burning bonfire created a space perceived as "one's own/ familiar" (swój), equivalent to that of the home fire. The space lit by the flames was a safe and sacralised sphere where evil forces had no access (in keeping with the CENTRE schema). Putting out such a bonfire was subject to certain prescriptive rules, which endowed this action with ritual significance [SSSL 1.1:271]:

- a fire should be extinguished with respect; this should be done by pouring sheep cheese broth or holy water over it;

- one should make the sign of the cross over the fire before putting it out;

- the embers should be arranged in the shape of the cross and covered with ashes so that witches do not have access to it.

Ways of handling fire controlled by people indicate the complexity of its conceptual structure. As revealed by their profiles, both the home fire and fires of "otherworlds" are perceived as living beings endowed with feelings, emotions and the faculty of moral judgment. Most importantly, they are viewed as sacred, which means that they derive their power straight from the source and can pass it on to people on condition that it will be used according to God's will. Given its role in building links between God and people, the home fire is the basis for the conceptualisation of the "own/familiar" (swój) sphere. It is the focal point not only of human-divine relations (as a constant gift of grace), but also social ones (family, the community practising the same rituals). In spatial terms, a burning fire also functions as the centre of the household (hearth $>$ stove $>$ table), or as its equivalent in the "strange/alien" (obcy) sphere (a bonfire on a mountain meadow). In the context of the human body, fire is also associated with the centre, either of fiery emotions (serce ogarnięte żarem/ogniem miłości lub nienawiści 'heart consumed by the fire of love/hatred') or feverish thoughts (rozpalona głowa 'burning head'; płomień myśli 'flame of thought').

The home fire offers protection from the interference of evil forces, which keep trying to extinguish it. In the folk imagination, fire in the kitchen stove could be smothered by a mare (zmora) [SSSL 1.1:272], or - in Kashubia - by a devil in the guise of a black pig. This belief can be traced in the connotative layer of such Kashubian expressions and phrases as: czôrnô swinia wlazła $w$ piec 'the fire has gone out' (offensive), 'a place in the bread oven that is not hot enough', lit. 'a black pig has got into the stove'; arch. czôrnô swinia 'poverty', lit. 'a black pig. Some examples of analogous phrases meaning 'the fire has gone out' used in 
Kashubia and the region of Kociewie include: czôrny kot wlôzł w piec, lit. 'a black cat has got into the stove'; kot zaszczôł ogin, lit. 'a cat has pissed on the fire'; czôrny kot zazdrzoł do pieca, lit. 'a black cat has looked in the stove'; czôrnô swinia leżi w piecu, lit. 'a black pig is lying in the stove'; dzëko swinia wlazła w ogin, lit. 'a wild boar has got into the fire'; czôrny dziena wlôzł $w$ piéck, lit. 'a black boar has got into the stove'; w ogniszczu je czôrnô swinia, lit. 'there's a black pig in the fireplace'. The devil (Kashubian: purtk) appears in such phrases as: purtk wlôzł $w$ komin 'there's smoke coming from the stove', lit. 'the devil has got into the chimney'; purtk $w$ kominie sadzy, ogónem $w$ kominie wëmiôtô 'there's smoke coming from the stove', lit. 'the devil has got into the chimney and is sweeping it with its tail'; djôbet ogónę zamiótt w piécku 'the fire has gone out', lit. 'the devil has swept the stove with its tail'. Also witches, believed sometimes to appear in the guise of a black cat or a wolf, were held to blame for extinguishing the fire: czarownica wlazła w pieck, lit. 'a witch has got into the stove'; wilk ju ogin wëgast, lit. 'a wolf has put out the fire' [Treder 1989: 46].

Apart from smothering the home fire, evil forces were also believed to lurk in wait for travellers, to whom they appeared as błędne ogniki 'will-o'-the-wisps' (lit. 'wandering lights'), also known under a number of different names, particularly in Kashubia: purtka skôcze, lit. 'a devil is jumping'; purtka $z$ widą, djôbeł $z$ latarnia, lit. 'a devil with a lantern'; ognisti chłop, lit. 'a fiery man'; dzëwi latarnik, lit. 'a wild lamplighter'; zaczarzony widnik, neol. 'wireman'; djôblé slépia, lit. 'devil's eyes'; kurzé/wilcze slépię, lit. 'a hen's/wolf's eye'. Evil forces can be encountered particularly in the "strange/alien" (obcy) sphere, on marshes and in remote places, as apparent in such phrases as purtk ju bez błota jedze 'the devil is going across the marshes', smolinc se przesuszô 'the devil is drying [something]' (associated with a belief that smolinc, euphemistically 'the devil', dries money on marshes),${ }^{17}$ djôbet ognie puszczô 'the devil is blowing fires' [Treder $198947-48]$. Demonic fire is the opposite of both heavenly and the home fire. It is an attribute of the devil, who uses it to tempt people with the glow of hidden treasures and to lead them astray, particularly if they are drunk. "Wandering lights" were also believed to be penitential souls, e.g. the Kashubian: miérca $z$ wide "an unscrupulous farmer who sued his neighbour over the borders in his lifetime and is now doing his penance by wandering around fields after death" [Treder 1989: 48]. In this way, demonic fire serves to distinguish alien, usually "interspheric" space, and in its most extreme form - as the fire of hell - marks the domain of the devil.

17 For the motif of the devil drying gold, see Niebrzegowska 1999b: 293-303. 


\subsection{Fire symbolism}

The symbolism of fire derives from ancient cosmogonic myths, in which fire played an important role in the creation of the world. This element, whose force and dynamism was most visibly manifested in a bolt of lightning from the sky, became the basis for the conceptualisation of the divine might of the sky god. The life-giving properties of rain which accompanied thunderstorms most likely had a bearing on the development of a belief in the fertilising power of the divinity who manifested its presence as a fire from the sky. Fire - comprising fundamental qualities conditioning the development of life: light, warmth and energy - meets all the criteria to become a symbol of divine power.

Construed in terms of the FORCE schema, the link between God and fire depends on a multistage process of symbolisation, based on the structural metaphor GOD IS FIRE (fire is power $>$ power needs to have a source $>$ the source of power is God; the result of the action of force is change $>$ the power of God's fire calls to life the whole universe and causes specific changes). Such imaging corresponds to the cosmogonic myth in which the earth was brought into existence by a bolt of lightning, and the complementary myth of the sky impregnating the earth by means of life-giving rain [Tomicka, Tomicki 1975: 35], as is consistent with the human experience (the link between storm and rain). The currency of the symbol is validated in the ritual of the first ploughing of the year, which takes place after lightning has struck for the first time in spring, or, in the Christian version, after the feast of Our Lady of the Opening (Matka Boska Roztworna, 25 March), thus corresponding to the belief that a spring thunderbolt opens up and releases the vital powers of the sleeping earth.

In the Old and New Testament, fire is a symbolic manifestation of God's presence [KopSS 1990: 267]:

- "And mount Sinai was altogether on a smoke, because the Lord descended upon it in fire" (KJV Exodus 19:18);

- "And the angel of the Lord appeared unto him [Moses] in a flame of fire out of the midst of a bush: and he looked, and, behold, the bush burned with fire, and the bush was not consumed" (KJV Exodus 3:2);

- "For the Lord thy God is a consuming fire" (KJV Deuteronomy 4:24);

- "For, behold, the Lord will come with fire (...) to render (...) his rebuke with flames of fire" (KJV Isaiah 66:15).

The representation of almighty God as fire is thus deeply ingrained in Christian culture. This had a strong bearing on the folk image of Jesus as a living flame of 
the home fire, apparent in the ritual salutations addressed to it, welcoming divine light and Christ Himself. In this way, the symbol became part of a wider conceptual context. The network of cognitive paths for which fire provides a semantic node includes the concepts of divine love, holiness, light, warmth, home, family and life in general. It is also connected with the mystery of the Resurrected Christ's divinity, reflected in the ritual blessing of fire on Easter Saturday. A spark struck from a stone symbolises Christ risen from the tomb to a new, transformed life. The flame serves to light the paschal candle in church, the fire of which is then solemnly carried home (using a rope lit from the paschal candle). A consecrated fire - a symbol of Christ - brings blessing to the home, protecting it from misfortune [Forstner 1986: 78-79]. The command to keep the fire burning throughout the year makes direct contact with the sacred possible, as is conveyed in scenes of welcoming and bidding farewell to it. The very act of lighting a fire at home is a ritual symbolising the beginning of life, thus including the house as a microcosm in the order of the universe. While starting a fire meant the introduction of life - light and warmth - into the house, the extinguishing of fire was connected with death. The meanings ascribed to fire in rituals of birth and funeral confirm its symbolism as divine grace and protection.

The ambivalence of fire as a symbol of God's power is conveyed through images of the thunderbolt as a sign of divine wrath. In this case, the mythical model is provided by the scene in which the Archangel Michael throws Lucifer downward out of heaven at God's command, and pins him, with a thunderbolt, to the post standing in the middle of hell. Protective rituals warding off thunderstorm and appeasing thunderbolt fire are connected with the symbolism of lightning as a manifestation of God's punishment.

Images of a thunderbolt chasing demons, drawing on the biblical scene of St Michael's victorious battle against the rebel angels, are reflected in set phrases: e.g. the Kashubian "to tan someone's hide like St Michael the devil's", i.e. 'to beat someone’ (wëgarbowac komus skórę jak swęti Michôł djôbłu) [Treder 1989: 110] or the saying "to scold someone like St Michael the devil" (objechac kogoś jak św. Michat diabta). The model of the purgation of the world of evil forces by means of fire is re-enacted in rituals of symbolic annihilation by means of burning representations of: death (a figure representing winter in the rite of welcoming spring [SSSL 1.1:268]), poverty (by burning old spoons on New Year's Day [SSSL 1.1:268]), sin and evil (by burning a straw figure representing Judas on Maundy Thursday [SSSL 1.1:268]), witches (by burning brooms on St John's night so that witches cannot fly to hell [SSSL 1.1: 288]), disease (by burning objects identified with an illness, e.g. barley grains to cure a stye (jęczmien lit. 'barley') or the sick 
person's clothes [SSSL 1.1: 275]), vampires (by burning the bodies of suicides, suspected of walking on earth after death [SSSL 1.1:274]).

The symbolism of purgation through the power of sacred fire which drives away evil forces can be found in ritual practices: passing through fire (a mother carrying her child to be baptised passed over burning embers put on an axe at the threshold of the house) [SSSL 1.1: 274], carrying St John's fire in a procession around fields and gardens [SSSL 1.1: 288], lighting a cigarette or a pipe before setting out on a journey [SSSL 1.1:274], walking around a room or a house with blessed fire (or its equivalent - burning embers taken out of a blessed fire [SSSL 1.1: 274]). Such symbolic images of being purged of sin by sacred fire build cognitive paths linking particular personifications of evil and misfortune brought upon people by evil forces. Hence the concept of fire kindled with a stone is included in a network of interrelations with the demonic world, danger, magic, witches, vampires, ghosts, illnesses and poverty.

The symbolism of fire as God's punishment can be exemplified both by a thunderbolt that sets the house of a sinner on fire and by the image of the eternal fire of hell. Funeral rites, which include hymns and prayers that evoke the torments of hell to warn of the punishment by eternal fire, reactualise the symbolism of fire that burns but does not destroy. The curse ritual also features the symbolism of punishment by eternal fire. Malediction formulas bringing God's wrath upon the wrongdoer rely on the same images of burning fire and eternal damnation. The symbolism of punishment includes fire in a network of concepts connected with anger, punishment, damnation, death, hell, evil, impure forces, demons and devils, and hatred.

The opposite of hell fire, representing eternal punishment, is heavenly fire, symbolising the eternal existence of God. The basis of ritual imagery can be found in the biblical command to keep the sacred fire burning as a sign of the constant presence of God, and a symbol of the fervour of the Holy Spirit, in which the sacrifice of the New Testament was to find its fulfilment [Forstner 1986: 77]. This command is fulfilled by the ritual keeping of the fire burning all year round at home and in mountainside meadows during the pasturing season "for so the Holy Spirit commanded and so it has been repeated for years and years" (bo tak Duch Święty rozkazat i tak od lat kazuja) [SSSL 1.1: 271]. Belief in the eternity of heavenly fire is also visible in rituals of kindling a "new fire" to replace the "old fire", which has lost its original power as a result of being tainted by the impurity of the world. The annual ritual of lighting and extinguishing fire represents the eternal cycle of life and death. Kindling a fire under the open sky was supposed to enable access to inexhaustible divine energy, maintaining life on earth. 
Heavenly light also represents the radiance of divine majesty and glory. Such a concept of heavenly fire builds cognitive paths connecting its semantics with light, brightness, holiness and majesty, which are ascribed the highest value on the axiological scale, and thus are naturally linked with good, creativity (iskra boża, lit. 'God's spark', dar boży, lit. 'God's gift', meaning 'talent'), wisdom, knowledge (światty umyst 'enlightened mind', oświecenie 'enlightenment'), majesty (blask chwaty 'the radiance of glory') and the sun. In this way, the sun, the brightest light in the sky, together with heavenly fire comes to represent symbolically God's power. Observation of the sky suggested the periodical weakening and increasing of the sun's activity, which already in ancient cultures had led to the development of ritual practices of lighting fires in order to strengthen the sun's power [KopSS 1990: 268]. This custom may have provided the archetypal model for rituals renewing the power of fire as the earthly equivalent of the sun in the sky. In both cases the aim was to maintain contact with the sacred source of life-giving energy. The lighting of fires on earth in order to quicken the power of the sun was an example of imitative magic, manifesting cosmic interaction in the process of channelling energy deriving from the same sacred source. Thus the fertility symbolism of both the sun and fire is based on their common divine origin.

In Polish folk culture, the custom of lighting bonfires, in some areas still observed today, is practised following the spring equinox, on consecutive Saturdays between Easter and Whitsunday. Hence its name sobótek 'Saturday fire' in north-eastern Poland, ognie świętojańskie 'St John's fires' (in Masovia and Silesia), and, in eastern Poland, kupalnocka, kopalnocka, kupalonecka, kopielonecka, kapała 'Kupala's night' or, less frequently, ognie kupalne 'Kupala's fires', palinocka 'burning night', ognie czerwcowe 'June fires', ognie byliczne 'wormwood fires' (from the herb added to the flames) [SSSL 1.1: 286]. As the names suggest, the rituals were connected with the feast of St John the Baptist, called Janko Kupała in eastern Poland, under the influence of the Ruthenian form of the saint's name.

The ritual way of starting a fire na cztery rogi lit. 'from four corners', corresponding to the four corners of the world and the movement of the sun in the sky, was conducted according to the principles of kindling and handling "living fire". Bidding a ceremonial farewell to fire, as well as throwing medicinal herbs into the flame to intensify its magical properties and dancing in a sunwise movement, reactualised symbolic meanings ascribed to fire and the sun. The ceremonial procession carrying fire along field boundaries served to increase the fertility of the land, while lighting bonfires and driving farm animals through burning embers purged them of demons and protected from illness. The custom of young people jumping 
across bonfires also had a purifying function. "Saturday bonfires" consecrated the space around, freeing it from evil forces and witches [SSSL 1.1: 286-288]. The semantic dominant of ritual actions accompanying the lighting of "Saturday bonfires" is a purifying and life-giving power, which the sun and fire draw from the divine source. Hence their symbolic content relies mainly on concepts directly related to life (good crops, happiness, fertility, safety), even if, in keeping with the nature of symbol, fire also represents opposite meanings connected with the influence of the demonic world: evil, epidemics and black magic. 

Part 3 Imaging the relations between the physical and metaphysical worlds: the sun and the moon 



\section{The sun}

\subsection{The creation myth and the life-giving profile of the sun}

The nature of the relationship between the earth and the sun was determined in the scene of the creation of the world, in which God assigned the sun a subordinate function:

When the earth He created had grown so much that it reached the threshold of heaven, the God of light said unto her: "Thou earthly world, the souls' stairway to heaven thou shalt be; I will give thee light, I will give thee heat from the sun so that thou bearest life and thou nourishest what thou givest birth to".

Kiedy ziemia stworzona dorosła pod próg nieba, Bóg światła rzekł do niej: „Ziemio, świecie ziemski, ty będziesz dla duchów schodami do nieba, oświecę cię światłem, ogrzeję słońcem, żebyś rodziła i żywiła, co urodzisz". [Mit krakowski (The Cracow Myth), K vol. 7: 4; Benedyktowicz D., Benedyktowicz Z. 1992: 34]

The continuing existence of this myth in folk culture is evidenced by contemporary field work records in which the sun is described as bowing to the earth at sunset [SSSL 1.1: 124]. Confirmed by everyday experience, such convictions are the foundation of belief in the life-giving power of the sun, which was imbued with divine energy already in the act of creation [SSSL 1.1:143]:

- "The sun is a ray from heaven/the sky" (Słońce jest to promień od nieba);

- "It is well-known that the sun is a great light, given to us by God, that it warms us, and the earth yields crops under its rays, and it is well that way" (Stonce to wiadomo, że jest to świattość wielga, od Boga nam dana, że uona nas ugrzewa, ji ziemia rodzi pod słońcem ji dobrze jest).

Prayers asking for a propitious day were addressed to the rising sun, while the setting sun was invoked in prayers of thanks for its beneficial light and warmth [SSSL 1.1: 126]:

- "Dear sun, how you warm us and light us with your grace, how glad I am to see you again and get up this morning" (Stuneszko, jak ty nas ogrzewasz $i$ oświecasz twoją łaską, jakże sa cesza, żem sq cebie doczekała i dziś wstała);

- "Dear sun, thank you that this day has finished so happily" (Stuneško, ${ }_{3} q k u j q$ ce, žesmë tak ščąslëv'e skuńcëlë ten ${ }_{3}$ én).

In such prayers, God is worshipped through the mediation of the sun, the largest source of light in the sky. This is clearly visible in invocations such 
as "Hail, welcome, divine light which lights up the whole world and me, the sinful man" (Zawitaj, powitaj jasności boska, która cały świat oświecasz i mnie człowieka grzesznego) [SSSL 1.1: 127], in which the sun is a textual equivalent of God. Both the perception of the sun as an epiphany of the sacred as well as any gestures of worship related to it are universal, as demonstrated by the proliferation of solar deities and mythical tales associated with them in ancient cultures [MifyNM 1988: 461]. The metaphor GOD IS LIGHT is grounded in the COLOUR schema. The ability to see is fundamental to the development of the experiential base, hence many cultures feature parallel representations of the sun as a deity (Helios, Osiris, Odin) or the eye of heaven [Kowalski 1998: 516]. The same image can be found in Polish folk culture: "some say that the sun is the eye of God and this is why it sees everything" (jedni powiadaja, $\dot{z}$ e stonce to oko Boga i dlatego to ono widzi wszystko). This is connected to the belief that the function of the sun is to ensure that order is preserved on earth. Pointing a finger at the sun or throwing rubbish towards it was strictly forbidden since such actions were seen as offending God Himself; these prescribed restrictions confirm that the image is well grounded in folk culture [SSSL 1.1: 127]:

- one must not point one's finger at the sun (so as not to poke out the Lord God's eyes);

- one must not throw rubbish towards the sun (so that it does not get in His eyes).

A mythical point of view is also apparent in treating the sun (as well as the planets, the moon and stars) as a living and sentient being, represented by a figure of a man [Kowalski 1998: 517-518; Niebrzegowska 1986: 38]:

(1) [The sun is] a huge man, his face, eyes and mouth are clearly visible - he looks at the world from above. The sun - like a man - can be happy [or sad]: the sun leaps when it rises, for the Lamb of God is happy at Christ's Resurrection; on All Souls' Day, the sky weeps and the sun weeps;

(2) it is alive, like a man walking, with eyes and a gob on it; it even eats raw honey with a large wooden spoon, and it has its home and farm, brothers and sisters, [who are] holy, as it is holy.

(1) [Słońce to] wielki człowiek, widać dokładnie twarz jego, oczy, usta - patrzy na świat z wysoka. Słońce - jak człowiek - umie się cieszyć [i smucić]: słońce wschodzi podskakując, bo Baranek Boży cieszy się ze zmartwychwstania Chrystusa; na dzień zaduszny to niebo płacze ji słońce płacze;

(2) jest żywe, kieby człek chodzący z oczami i gębą, nawet miód przaśny jada kopyścią, ma przy sobie dom i gospodarstwo, ma braci i siostry, święte, bo ono jest święte. 
Modelled on the immediate world of the conceptualiser, the personification of the $\operatorname{sun}^{1}$ and the image of its abode as a farm are canonical examples of interpreting supernatural phenomena in familiar terms and images. In this way, the sacred is made to appear more approachable and the heavenly sphere comes to be included in the "own/familiar" (swój) category. In an analogical process, constellations are perceived in terms of agricultural scenes (raking and bringing hay home) or familiar Passion and Nativity scenes, in which particular stars represent either shepherds paying homage to the Child, the Virgin Mary and St Joseph, or the tools of Christ's Passion: hammers, ropes and nails [Niebrzegowska 1990: 146-149; SSSL 1.1: 205, 206].

Although such anthropomorphising of the heavenly sphere allows the conceptualiser to approach the sacred, he/she nevertheless remains outside the scene as an observer, thus preserving a God-fearing distance. Subjects become participants in the scene only when their conduct towards the sun follows socially accepted norms, forbidding standing with one's back to it; urinating in its direction; swearing; slaughtering animals or even looking straight at it [Kowalski 1998: 518; SSSL 1.1: 127]. Such scenarios of typically euphemistic behaviour, which demand that the sun should be venerated and treated as taboo, are a visible expression of a deeply religious attitude towards the Creator, who bestows life and grants power on earth.

Belief in the sun's life-giving power is apparent in speech acts, especially in oaths invoking the sun and in curses based on the opposition life vs death. Other maledictions and oaths feature the motif of the absence of the sun, or the inability to see its brightness, as the ultimate punishment, tantamount to wishing death on someone, in accordance with the belief that "there is no life without the sun" (bez słońca nie ma życia) [SSSL 1.1: 125]. Examples of such curses include the Kashubian "May you be on a mountain and may the sun not shine on you" (Żebys bét na górze i żebë na ce stince nie swiéciło) [Treder 1989: 18], and "May the sun not shine for you", "May you not see the sun",

1 Personification of the sun and heavenly bodies is a widespread phenomenon, known already in ancient times. In the mythologies of many cultures found around the world the sun was represented in a masculine or a feminine form (e.g. Siberian cultures picture the sun and the moon as female figures). Conventional images also feature the representation of the sun and the moon as two brothers, a brother and sister (as the Greek Helios and Semele), or a pair of twins. Tales about the daughter of the sun are also a common motif in solar mythology [MifyNM 1988: 461]. 
"May you not see a ray of the sun" (Żeby tobie Słońce nie świeciło, A bodajś już słońca nie ogladat, Żebyś nie ujrzat promienia od słońca) [SSSL 1.1: 124] recorded in other parts of the country. In turn, "May I never see the light of the sun" (Niech nigdy jasności nie ogladam słońca) [SSSL 1.1: 126] may serve as an example of an invocation to the sun emphasising the consequences of breaking an oath. Analogous curses invoking the earth, e.g. "May the earth not support you!" (Żeby cie ziemia nie nosita!) indicate that both the earth and the sun are assigned the status of the highest court of ethical judgment. Such a level of axiological value may only derive from the metonymic relationship of the earth and the sun with the Creator Himself. This is reflected in a belief that "the sun, like the whole world, comes from God" (słońce, podobnie jak caly świat, pochodzi od Boga) [SSSL 1.1: 121].

This image also features in magical healing practices invoking the curative power of the sun in order to overcome a disease (analogous to the healthrestoring powers ascribed to earth). Linguistic correlatives of the FORCE schema can be found in texts that implicitly rely on a belief that "the sun kills all diseases" (słonce zabija wszelkie choroby) as well as those in which analogical content is expressed explicitly, e.g. in proverbs ("Where the sun does not go, the doctor goes" (Gdzie słońce nie chodzi, tam chodzi dochtór) [SSSL 1.1: 125]), in magical formulas uttered while expelling a disease, and in commands prescribing the time regarded as the most conducive to spellcasting (dependent on the position of the sun).

In scenes of expelling disease from the body, the sun appears either in the background or as the agent, depending on the type of incantation. When the healer banishes a disease to a place where sunlight does not reach ("Go where the sun does not shine" (Idź, gdzie stonce nie doświeci)), it is the sun that is assigned the archetypal role of the agent, while the illness becomes the object of its action. Although the spellcaster assumes a central position in the scene and directly addresses the object, it is other factors that decide about the annihilation of the disease. Since the spellcaster does not have sufficient power to expel the illness, he or she relies on the ATTRACTION OF FORCE schema. The healer utters the words of a spell in the name of God (or holy persons), thus invoking the source of power. In this way, the objective is achieved and the disease, deprived of access to the energy of the sun (life), passes to the domain of death.

The formula of a protective spell against snake bite can serve as an example of magical action aimed at cutting a disease off from the source of energy [SSSL 1.1: 131]: 
W imię Ojca i Syna (...)

Wąż, wąż, wąż!

Szkaradne imię, Szkaradne plemię,

Któreś wypuścił!

Idź pod kamień,

Idź do wody,

Idź, gdzie słońce nie świeci

I miesiąc nie dochodzi.
In the name of the Father and the Son (...)

Snake, snake, snake!

Ugly name, ugly tribe,

Which sprang from you!

Go under a stone,

Go into water,

Go where the sun does not shine

And the moon does not reach.

In another scenario, the healer utters a spell on behalf of the sick person. In this case the roles of the agent and object overlap, and the incantation itself takes the form of a self-fulfilling wish addressed to the sun, which is the main actor, even if it remains in the background. The cure spell for epilepsy (choroba św Walentego 'St Valentine's disease') is a model example [SSSL 1.1: 133-134]:

Niech mie już nie szarpią wszelkie natury,

Niech mie nie ciskają z ziemie do góry.

Niech bedzie słońce świeciło my wesoło,

A niech księżyc mnie oświeca także.

Gwiazdy niech my pomagajo,

A ziemia święta niech mnie nie tyro.
May all natural powers no longer buffet me, May they not hurl me up from the ground. May the sun shine on me merrily, And may the moon shine on me, too. May the stars help me, And may the holy earth not knock me about.

The formula for curing St Anthony's fire (róża, lit. 'rose', erysipelas), in turn, assigns the role of a collective agent to the sky/heaven and all objects found in it: the sun, moon and stars, as well as the Holy Trinity and Our Lady, even though it is the sick person or the spellcaster on his/her behalf that utters the spell. Thus its illocutionary force is that of an urgent entreaty for help [SSSL 1.1: 134]:

Jasna nieba, jasna słońca

Jasień miesiąc i jasne gwiazdy

I Święta Trójca i Matka Boska,

Stań do pomocy,

Jak we dnie, tak i w nocy.
Bright sky, bright sun,

Bright moon and bright stars

And the Holy Trinity and Mother of God,

Come to help me,

Both day and night.

In the most prototypical cure spell formula, the archetypal role of the agent is taken by the healer, who invokes the power of the sun and the moon, as well as the Transfiguration and the Last Judgment to gain control over the disease [SSSL 1.1: 134]: "I cast a spell on you, guest, by [the power of] the sun and the moon, the Transfiguration and the Last Judgment" (Zaklinam cię gościu na słońce $i$ księżyc, na Przemienienie Pańskie, na Sąd Ostateczny). 
Despite the incantation being addressed directly to the disease, the spellcaster uses an euphemistic form of address, calling it a "guest". In addition, he or she invokes supernatural sources of power and deploys a speech act of the strongest illocutionary force, i.e. a binding spell (zaklinanie). By combining all related means of expression in one formula, the perlocutionary force of the utterance is released in order to deliver the body from pain.

Thus in most cases the role of the agent is played by the person performing the magical ceremony, with the disease, represented in a strongly personified form, as the object of action. However, the illness is "set in motion" - engaged in the process - thanks to supernatural powers. In this way, the energy coming from the source of power expels the disease from the body of the sick subject. The conceptualiser, who takes the role of an observer, is nevertheless drawn into the scene. Becoming its passive participant, he or she identifies with other participants of the event and accepts the scenario of the action.

The time when the scene takes place, or more precisely the image of time indicated by the presence or absence of the sun in the sky, also has a significant influence on the perlocutionary force of an incantation. Magical time, that most favourable to spell scenarios, begins at sunset and lasts until dawn. In folk belief, the setting sun passes to "the other world", and the moon takes over as the ruler of the sky. Depending on its phase, the moon may additionally intensify the efficacy of curative practices (see below). In binding and cure spells (zaklęcia, zamówienia) invoking the source of power, the sun is ranked at the same level as divine persons, and is often connected with the moon and stars, the only bright spots in the night sky. Their shared quality of light constitutes the semantic node binding the chain; and it is their capacity to produce light, combined with their location in the sky, which provides the metonymic point of contact with the sacred.

\subsection{Sunrise and sunset: the temporal and spatial boundaries}

For the conceptualiser, the position of the sun in the sky is the focal point of temporal and spatial orientation. Subject to cosmic rhythms, the movement of the sun divides day from night, determines the time of day and controls seasonal vegetation cycles. At the same time, it produces a polarity of space, thus providing the basis for the conceptualisation of the passage of time as a spatial

2 For more about the euphemistic expressions for disease in Polish dialects see KrawczykTyrpa 2001b: 87-92. 
movement. The connection between the places where the sun appears and disappears on the one hand, and the presence or absence of light making human activity possible on the other, is a factor determining their valuation and cultural function. Axiological values ascribed to light, life, activity and warmth, inextricably tied with the sun, display an isometric correspondence with sunrise in the east. By contrast, sunset in the west heralds the end of day, darkness, and is thus associated with life coming to a halt and becoming submerged in sleep.

In the experiential base, the inability to see is linked to the LACK OF CONTROL schema. Hence sunset, as a time of day, evokes negative associations with darkness, the blurring of shapes and a return to a state of chaos, which arouse anxiety and fear. In this way the movement of the sun in the sky came to be recorded in the human experiential base as a model determining the cycle of life and the order of the world. Re-enactment of the model was meant to ensure a correspondence between actions undertaken and the rhythm of nature, and thus have a bearing on their favourable course. A magical attitude to the world required that all everyday activities should be subordinated to the solar model so as not to bring misfortune by disrupting the established order [BrzozowskaKrajka 1994: 36-37].

Consequently, all actions performed during ceremonies and ritual practices were executed according to the direction of the movement of the sun in the sky: from the east to the west "so that everything fares well as the sun in the sky" (żeby się wszystko dobrze wiodło tak jak tymu słońcu na niebie) [SSSL 1.1: 123]. This was the direction in which the first ploughing of the year took place, the first fistful of grain was thrown into the ground when sowing, and the first handful of cut corn stalks at harvest was put on the ground. Similarly, at weddings the circle of dancers around the bride and groom moved sunwise, while at funerals the dead were buried towards the east (with their legs to the west) so that they could look at sunlight; meals were started facing east and finished with the sign of the cross [SSSL 1.1: 148]. The opposite direction - anti-sunwise - was reserved for magical practices aimed at undoing spells, or intended to cast evil charms (urok) [SSSL 1.1: 148].

Sunrise and sunset not only indicate liminal time (the beginning and end of day and night), but also determine the borders between this and the other worlds. The places on the horizon where the rising sun appears and the setting sun disappears are the limits of this world, which explains the concept of sunset as the passage to the other world. The image of the sun as the eye of God [KLS 1967: 443; Kupiszewski 1974: 21; SSSL 1.1: 127] gives rise to a belief that after sunset the earth passes into the power of impure forces. This produces an anxiety about performing certain activities after dark and generates a whole system 
of precautions, which must be obeyed strictly so as not to bring misfortune upon oneself and members of one's household.

Breaching such prohibitions against working in the field and doing farm chores in the absence of sunlight (after sunset) was believed to lead to plants and animals losing their vital power. For example [Bartmiński, Niebrzegowska 1994: 130-132; SSSL 1.1: 152]:

- after sunset one must not "work in the field, sow grain, carrots, peas and beans" (robić $w$ polu, siać zboża, marchwi, grochu i fasoli), for nothing will turn out well (as a result of the loss of life-giving power);

- after sunset one must not collect eggs, or the hens will stop laying; or set hens on eggs, or they will lose fertility.

The division into day and night gives rise to the opposition light vs darkness, beginning vs end, safety vs lack of safety ${ }^{3}$ (grounded in the CONTROL schema, relying directly on the direct experience of the ability or inability to see). Fear of the danger from demons lurking in wait for human beings finds expression in a system of prohibitions based on the oppositions mentioned above. Such prohibitions take a fixed linguistic form, employing phrases such as nie wolno 'it is forbidden', trzeba 'one should', należy 'one ought to', which function as the basic exponents of the illocutionary force.

The opposition between the beginning and end constitutes the semantic dominant in a series of prohibitions against starting any activities after dark. In turn, numerous rules limiting contact with the outside world - such as that against taking out or bringing anything into the house, or the command to close windows - are based on the opposition OPEN vs CLOSED (a specific variant of the CONTAINER schema, according to Lakoff and Johnson [Lakoff, Johnson 1980: 14-32], or the Alcmene syndrome, as suggested by Ludwik Stomma [Stomma 1976: 99-110]).

Since human beings have no influence over the fact that they cannot see properly in the dark, the model of behaviour subordinated to the solar movement imposed by nature relies on the FORCE schema construed as OUTER COMPULSION. On the other hand, however, belief in the danger threatened by, and dire consequences of, non-compliance with prohibitions means that the influence of INNER COMPULSION can also be perceived. It is reflected in the

3 For an extensive discussion on the symbolism of the dichotomy between the day and night in traditional Polish folklore, see Brzozowska-Krajka 1994. 
very form of such prohibitions, including elements of warning. Thus, after dark [SSSL 1.1: 152]:

- it is forbidden to sell milk and dairy products (cream, cheese, butter, whey) because the cows will lack milk, will have less milk, milk will go so sour or "the cow will run dry" (krowa sie zeschnie); or the buyer himself (or a witch taking the shape of a stranger) may deprive cows of milk;

- one should not lend fire ("or horses will not prosper" (bo konie nie będq się darzyć)), salt, bread or even sourdough because horses will go blind and the whole farm will suffer the awful consequences;

- it is forbidden to make pickled cabbage because it will not turn out well;

- one should not give back borrowed meat or pigs will die;

- it is forbidden to look inside beehives or even talk about bees because it is a sin;

- it is forbidden to look inside birds' nests when there are eggs or nestlings in them because they will be eaten by ants.

Special prohibitions pertained to the protection of children, believed to be especially prone to fall victim to the machinations of night demons: strzyga 'vampire', morzysko 'mare', nocnica 'night demon', who could change or snatch away the child or make it suffer weeping fits (płaczki) [SSSL 1.1: 153]:

- it is forbidden to take out nappies drying in the house after dark because the baby will not go to sleep and will keep crying all night;

- it is forbidden to carry out or pour away water used to bathe the baby "because something bad may stray its way" (bo może się coś przyplatać);

- it is forbidden to bathe a baby after dark or leave the room where it is sleeping for fear of vampires.

The system of directives also prescribes staying within the "own/familiar" safe space of the home as a precaution. The consequences of breaching this command may result in a loss of happiness and prosperity, or bringing poverty to the household [SSSL 1.1: 153]:

- rooms should not be swept and rubbish thrown away, or luck will be thrown out of the house;

- water should not be poured away outside of the house, or luck will be poured away;

- one must not bring anything into the house from the outside, or poverty will be brought in (the prohibition concerns linen drying out in the farmyard); 
- one should not open windows, set dogs on anyone, give alms or make a noise "or some evil spirit may be brought in" (bo może to sprowadzić jakieś licho).

\subsubsection{After sunset: the demonic time}

Lack of sunlight stirs forces connected with the demonic sacred. Darkness is conducive to magic and casting evil spells (zadawanie uroków). After sunset one may bring harm upon others: cause a loss of sight, deprive cows of milk, make animals fall ill, cause bad harvest [SSSL 1.1: 152; Kowalski 1998: 519]. However, although night is the time associated with an increase in the activity of witches and other evil forces in league with the devil, the magical properties of darkness may also be used for protection. Thus practices aimed at undoing evil spells and warding off the effects of any hostile actions of demons are thought to be most effective when they are held after sunset or immediately before dawn [Niebrzegowska-Bartmińska 2007: 179]. In such cases the COUNTERACTION variant of the FORCE schema is employed, causing the neutralisation of opposing powers. The COUNTERACTION schema is used in directive-persuasive speech acts which indicate the moment of sunset or the time right before sunrise as the most appropriate for performing healing practices [SSSL 1.1: 152]:

- the moment of sunset is the most efficacious for healing weeping fits (płacznice) in infants as well as inflammation of the eye;

- spells healing the following conditions should be cast after sunset: night blindness (kurza ślepota, lit. 'chicken blindness'), styes (jęczmień, lit. 'barley'), keratitis/trachoma (łuszczka, from łuszczyć się 'peel'), St Anthony’s fire (róża, lit. 'rose', erysipelas), atopic eczema (ogniopiór, from ogień 'fire' and pióro 'feather'), groin/armpit lumps (siekiernica, from siekiera 'axe'), herpes (liszaj), fear/stress (przestrach), consumption (suchoty), fever (febra), headache;

- precautions against sheep diseases, as well as practices for curing lumps/ulcers (źólw, lit. 'tortoise/turtle') and parasites in cattle, should also be performed after sunset;

- medicinal herbs should be collected after sunset, as this is when they have the greatest power;

- evil charms cast to frighten a child should be undone by pouring away his/ her bathwater at a fork in the road before sunrise (the sun could revive the disease, causing a relapse);

- erysipelas (róża, see above) should be burnt after sunset or before sunrise (burning imitates the purifying effect of the sun). 


\subsubsection{Before sunrise: the magical time}

The energy of the rising sun could be used to increase the efficacy of magical practices connected with fertility, abundant harvest and protection of crops. In speech acts prescribing the commencement of an activity before dawn, the FORCE schema functions according to the ATTRACTION and INTENSIFICATION patterns. The commands specify not only the time of day, but also particular dates on which such practices should be performed, thus illustrating a profound belief that all supernatural powers must be summoned in order to achieve the intended goal [SSSL 1.1: 147]:

- crops and harvest may be protected from destruction by sprinkling them with holy water before sunrise (on Easter Monday, the second day of Pentecost, on St Agatha's day);

- binding spells cast on birds and insects to prevent them from destroying crops should be performed before sunrise;

- crops may/should be protected from hail, heavy rain and disease before sunrise, a week after the feast of Corpus Christi, on Good Friday, on Friday of the Easter Octave and on St John's Day;

- crops may be protected from weeds, especially from thistle, before sunrise on Christmas Eve, St Stephen's Day, and the eve of the Passion of St John the Baptist (29 August);

- to protect horses from evil spirits (mares (zmora)), they should be bathed in running water before dawn.

Plentiful crops could be ensured by the performance of magical practices before dawn on festive days [SSSL 1.1: 147]:

- to ensure that winter rye grows tall and strong, a few grains should be thrown on the soil before dawn on the feast of the Passion of St John the Baptist;

- to ensure that wheat grows tall and strong, it should be sown before dawn on St Valentine's Day;

- to get a good crop of cabbage, it should be hilled on the eve of St John's Feast and touched with a broom before dawn to provide additional protection against pests;

- to get a good carrot harvest, one should roll around on the carrot patch at dawn at Pentecost;

- to ensure good crops, straw should be wrapped around the trunks of fruit trees on Christmas Eve. 
The material quoted above demonstrates that magical practices employed a wide range of actions in order to acquire causal power. The combination of the energy of the rising sun with "contrary" actions (such as the use of darkness to annihilate the effects of spells, evil charms or disease), the deployment of an attribute of a witch (e.g. touching a cabbage with a broom), enclosing actions (tying straw around tree trunks, closing windows after dark) or practices meant to transfer the fecundating powers of the human body to the earth (rolling about on the ground) - suggests their very ancient provenance. Rolling about on the ground at dawn was associated directly with a belief in the impregnating powers of sunbeams (also apparent in wedding rituals). In both cases the magical practice relied on direct contact with the life-giving powers of the earth and the sun.

Banishing disease to places deprived of sunlight was meant to kill it. Similar effects were supposed to be achieved through the use of soil, clay or stone "which have not seen the sun" (które nie widziały słońca) [SSSL 1.1: 125] in the treatment of a number of diseases. In such cases, magical practices re-enacted the most basic human experiences: the action of FORCE in all its variants: the use of BLOCKAGE (protective measures), COUNTERFORCES (annihilating the illness), ATTRACTION OF FORCE (invoking the mediation of divine and holy persons), INTENSIFICATION OF FORCE (the synergic effect of actions and their attendant circumstances, i.e. gestures and spells performed at an appropriate time and in an appropriate place). The conviction that the effect of human actions depended on supernatural, cosmic forces, and that it was possible to win their favour and thus gain access to their power, was deeply ingrained in folk culture. This is apparent where there are attempts to both use the vital energy of the rising sun and deploy the destructive properties resulting from lack of light (or even have recourse to the magical practices of witches). The same purpose was served by the invocation of the divine source of power through the use of sacramentals (holy water), the performance of magical practices on the feast days of the patron saints of bountiful harvest (especially St John the Baptist, St Agatha, St Vincent) or recourse to the miraculous powers ascribed to the days celebrating the return to the time of origins: Christmas Eve and the Resurrection Sunday.

In cosmogonic legends collected in the region of Dobrzyń, Satan's counteraction to the creation of the sun - the greatest light in the sky - was to steal a piece of it to make the moon [SSSL 1.1: 121]. Such beliefs, combined with a number of magical practices performed at night to annihilate disease, and with prohibitions against carrying out some activities after sunset, include the sun in the general dichotomy of life vs death, based on the COLOUR schema 
(light vs dark). The same opposition also involves the TEMPERATURE and FORCE schemas (warm vs cold, force vs lack of force); in this context the hot/ burning sun is seen to have a purifying, healing and life-giving (fecundating) function: e.g. "[It] burns out all evil that lurks in the roads" (Wypala wszystko, co złe siedzi na drogach) [SSSL 1.1: 125] - illustrating its purifying function; "The sun comes out from behind the hill, and you, consumption, leave the skin" (Wychodzi słoneczko zza góry, Wychodźcie suchoty ze skóry) [SSSL 1.1: 133] exemplifying its healing function; "Even a capon will crow when the sun burns hot" (I kapłon zapieje, kiedy słońce dogrzeje) [SSSL 1.1: 132] - demonstrating its fecundating function.

Preconceptual schemas which include the sun in a system of binary oppositions life vs death form the basis of solar symbolism, associating the sun with the sacred [Brzozowska-Krajka 1994: 33-38; SSSL 1.1: 128-129], and further, by analogy, with the sphere of human life. In its symbolic dimension, the sun is perceived either as an embodiment of a deity, or as a mediator connecting heaven and earth. As such, then, the relationship between the sun and the sacred mirrors the relationship between the sun and the earth.

\subsection{Sun symbolism}

The sun as a symbol of deity is deeply rooted in Christian culture as a result of a direct semantic link between divinity and light, which may be regarded as a universal cultural archetype found in the mythologies of various peoples. ${ }^{4}$ The early Christian Church, in adapting certain images and archetypes from the classical tradition, applied them primarily to Christ as "the sun of justice" or "the sun of salvation". The Old Testament, in turn, offers important parallels between the sun and God the Father. ${ }^{5}$ From the moment the Creator uttered the words "Let there be light", calling the light day and darkness night [KJV Genesis 1:3-5] and then established the sun in the sky to give warmth and light to the earth, light became permanently connected with the sun and the sacred. As a result of the belief in the divine origin of light, the sun came to be perceived as a theophany

4 Images of solar deities, albeit displaying significant differences, are found in many ancient religions [Kowalski 1998: 516; Lurker 1990: 113; MifyNM 1988: 461].

5 In Isaiah (60:20) the cosmic sun becomes a metaphor for God; also Psalm 104 features the image of the sun as a parallel demonstrating God's omnipotence [Lurker 1990: 115]. However, in the process of adopting ancient and oriental images, Christianity gave them a different character [Forstner 1986: 97-98]. 
of the sacred ("God is light, and in him is no darkness at all" [KJV 1 John 1:5]). Additionally, light itself - as an immaterial phenomenon by nature - seems to be the most appropriate image to render the spirituality of God [Forstner 1986: 95].

In the human experience, light makes it possible to see, hence it is regarded as the highest good and grace bestowed by God. Consequently, in Christian culture, the sun, created to shine on and warm the earth, is seen as God's gift [LéonDufour 1975: 499]. As an attribute of God, light naturally connects deity with the sun, and ascribes to sunbeams a life-giving power which they transmit to the earth.

In this way, light symbolism turns the sun into a theophany and endows it with a mediatory role. Worshipping God through salutations, gestures and magical practices directed to the sun is a typical example of analogical action, which reactualises the semantic unity of the world with the sacred sphere. The sun features as a symbol of God primarily in prayers addressed to the sun as an image of God the Father or Jesus Christ, e.g. "Welcome, welcome, rosy-hued sun, welcome, heavenly treasure that shines on us, poor people on earth. How beautiful and bright you are, sent straight from God. Praised be Jesus Christ for you" (Witåj nåm, witåj słonecko różane, witåj, skarbie niebieski, co przyświecås nåm, biednym ludziom na ziemi. Jakżeś ty piekne, błyscace, prosto od Boga posłane. Pokwålony niek bydzie za ciebie Jezus Chrystus) [Brzozowska-Krajka 1994: 35; SSSL 1.1: 126]. Religious gestures and ways of conduct were similarly motivated, e.g. "When the sun began to rise, they knelt towards the east and made the sign of the cross" (Gdy słońce zaczynało wychodzić, klękali na wschód słońca i robili znak krzyża świętego na sobie) [SSSL 1.1: 126].7 Analogical gestures were also performed during wedding rituals: "Fall to the ground [dear Mary], fall to the ground towards the sun, may you be blessed by your father and mum" (Upadaj [Marysiu], upadaj w strone za słońcem, niech cię błogosławi mamusia $z$ ojcem) [SSSL 1.1: 136]. In this blessing scene, while the parents play the role of the agent, it is God symbolised by the sun that actually performs the action.

6 Whereas in the Old Iranian religion the dualist view of the world relies on the antinomy of the equal powers of light and darkness, Christian teaching emphasises the sole primacy of God, who unites all oppositions (good and evil, life and death, beginning and end), while the forces of darkness, represented by Satan, are always inferior, even if they actively oppose God. Thus the Creator remains the only ruler of the world [Lurker 1990: 93-95].

7 The custom of facing the rising sun was already practised by the first Christians, who turned their faces towards the sun during prayer. Even in modern times, churches were still oriented towards the east [Lurker 1990: 116; Forstner 1986: 98]. 
In Christmas carols and Easter hymns, the sun symbolises Christ [SSSL 1.1: 134]:

Królowie biegną do ciemnej szopy,

(...)

czołem biją jasnemu,

pod ciała cieniem słońcu utajonemu.

Słońce przedwieczne, przez Twe zjawienie, które się żarzysz nam na zbawienie, zapal, zapal, zapal zmrożone

w cieniu zimnej nocy serca zgaszone.
To the dark shed, the Kings run,

(...)

they bow their heads to the bright sun, under the body's shadow concealed.

Through your appearance, eternal sun, which glows for our salvation, light, light, light frozen hearts, extinguished in the shadow of cold night.

Cf. also: "Sleep little star pleasant to the eye,/ Sleep the loveliest little sun in the sky" (Lulajże przyjemna oczom gwiazdeczko,/ Lulaj najśliczniejsze świata słoneczko) [SSSL 1.1: 212]. Analogical phrases are used in lullabies for children: "Sleep my little daughter,/ My little sun" (Uśnij mi córeczko,/ Ty moje słoneczko) [SSSL 1.1: 128].

The sun as a symbol of the Virgin Mary appears in the biblical image of a woman clothed with the sun, pregnant with Christ (it is also a symbol of the Church). Painted by manuscript illuminators, Mary's image from Revelations, with the moon under her feet and a crown of twelve stars on her head, became a cosmic emblem of the beauty of the Holy Virgin. From the fifteenth century onwards, this image, particularly popular with baroque and rococo painters, became so widespread that it filtered into folk culture, both in the form of pictures and sculptures [Forstner 1986: 102-103; Lurker 1990: 111]. It also became a frequent motif in Marian hymns: "A crown of twelve stars/ On her head,/ Clothed with the sun,/ With the moon under her feet"; "Here comes a maid adorned,/ $(\ldots) /$ with the moon and the sun clothed" ( $Z$ dwunastu gżozdów/ Koruna na głoże,/ Łodżano też $w$ słońce,/ Kszénżyc pod nogamy; Idzie panna ozdobiona,/ (...)/ W miesiąc, stońce ustrojona) [SSSL 1.1: 140, 212]. Subsequently, the image was adapted in carols expressing good wishes, sung for young girls [SSSL 1.1: 128]. The comparison of the Virgin Mary to the sun moving in the sky also appears in prayers: "On Sunday morning rises the dear sun, Our Lady by the hand leads her Son/She walks in the sky/heaven" (W niedziele rano słoneczko wschodzi, Najświętsza Panienka swego syna za raczkę wodzi/po niebie chodzi); the same formula is used as the incipit in wedding songs: "The sweet sun goes/ rises in a circle/around/up (...), [and the bride] drives to her wedding/goes to the table" (Kołem/kręgiem/górą słoneczko idzie/wschodzi (...), [panna młoda] do ślubu jedzie/za stót idzie). The association of Our Lady with the sun (motivated by her purity, beauty, the light of God's grace) influenced the development of 
analogical comparisons used to describe the bride - "a maid as beautiful/lovely as the sun" (panna piękna/śliczna jak słońce) [SSSL 1.1: 123].

Solar motifs of even more ancient provenance have an established place in wedding rituals. In wedding songs from the region of Podlasie in eastern Poland, the sun and the moon are a couple, the sun symbolising the bride, and the moon - the groom. ${ }^{8}$ The custom of forming a dancing circle moving sunwise is also associated with the sun: "[the wedding guests] follow the sun; they go around as the sun goes so that the young couple should prosper like the sun in the sky" ([wesele idzie] za słońcem w krąg, tak jak słońce chodzi, żeby młodym sie wszystko dobrze wiodło, tak jak tymu stuńcu na niebie) [SSSL 1.1: 123]. The meaning of such symbols relies on the COLOUR schema (light) as well as CENTRE (circle), VERTICAL (up), LINK (connection with the sacred) and FORCE (the life-giving power of the sun).

The symbolic identification of the Virgin Mary with the sun is also illustrated by a belief that on Saturday, which is the day of Our Lady, Guardian of Orphans (hence it is also known as sierocki dzien' 'the day of orphans'), the sun must appear, even if for a short while, to dry the shirts of orphans or Mary's coat, wet from the tears of souls weeping in purgatory; cf. the proverb "On Saturday there must always be even a short sunny spell" ( $W$ sobotę musi być zawsze choć troche stonca) [SSSL 1.1: 124]. Thus the appearance of the sun in the sky on that day was identified with the symbolic presence of the Virgin Mary.

The sun as a symbol of truth appears in such proverbs as "You will not cover the sun with a sack", "Don’t say anything against the sun" (Słońca workiem nie zasłonisz; Nie mów przeciw słońcu) as well as in oaths invoking the sun, uttered to confirm the truthfulness of the speaker's words "May I never see the light of the sun again" (Niech nigdy jasności nie ogladam słońca) [SSSL 1.1: 129]. Such symbolism also underlies the custom of turning towards the sun during business transactions to prove the validity of the deal [SSSL 1.1:126]. Linguistic habits invoking the sun as proof of veracity are synonymous with summoning the sacred as witness (cf. expressions such as "to swear by all that is sacred"

8 The common motifs of presenting the groom as the moon, his company as stars, and the bride as the sun, as well as sun and moon decorations on wedding bread, have prompted Viacheslav Ivanov and Vladimir Toporov to propose a hypothesis that the wedding scene re-enacts the mythical model of the wedding between two heavenly bodies [Ivanov, Toporov 1974: 245-246]. If this hypothesis is accepted, the connection between solar wedding motifs and the connotations linking the Virgin Mary with the sun will appear secondary. 
(zaklinać się na wszystkie świętości), święta prawda '[it is] absolutely true', lit. 'holy truth'), and as such they entail acceptance of divine punishment if these oaths are broken.

The sun also functions as a symbol of happiness and prosperity, as in the following examples: "life full of sunlight"; "For some the sun shines and sets behind mountains, for me, an unhappy one, it sets behind the clouds"; "The sun will shine in front of our gate, too", variant: "the sun will also rise behind my own barn" (życie pełne słońca; Jednym słońce świeci i zapada w góry, a mnie nieszczęśliwej zachodzi za chmury; Będzie i przed naszymi wrotami słońce; variant: Za mojo stodoło stońce wzejdzie) [SSSL 1.1: 137]. The association between the sun and happiness is based on a belief in the mediatory function of the sun, whose light transmits the power of God's grace to human beings, ensuring prosperity, welfare, affluence and fertility: all that is identified with happiness. The presence of the sun in the sky on the wedding day was regarded as a good omen, predicting marital happiness for the newly-weds. The symbolism of the kołacz/korowaj (traditional wedding bread, also called pieróg weselny) was similarly associated with the sun (for more on the solar symbolism of bread see below). The korowaj was decorated with circles echoing mythological symbols associated with the sun and the moon, and with green branches representing either a forest, thus making it possible to see it as a symbol of the tree of life, ${ }^{9}$ or an orchard, evoking associations with fertile soil and fecundity [Bączkowska 1988: 80; Kubiak I., Kubiak K. 1981: 74-75]. As such, the symbolism of the kołacz includes meanings connected with fertility, welfare and blessing, bestowed on the newly-weds by heaven: "Accept a piece of the korowaj, this gift from God" (Imajże się korowaja, tego Bożego dara). Ritual texts of dialogues directed to the korowaj as if it were a living being who had come from a different world and was endowed with a personality of its own, also point to a link with the sun [Bączkowska 1988: 80-82, 92-93]:

9 The parallel between wedding bread and a forest in songs from the region of Polesie points to identification with the tree of life, while the comparison to the orchard symbolises fertility and abundance [Ivanov, Toporov 1974: 244-245, 151, after Bączkowska 1988: 80]. 
O witajze nas kołacu rumiany, od pana Jezusa i Najświętszej Panny, od starszej swachny zesłany. A gdzieżeś to bywał święty korowaju? (...)

Oj bywał ci ja u kręgu miesiąca, oj bywał ci ja u jasnego słońca.

[SSSL 1.1: 137]
O welcome our blushing-red kołacz, sent by the Lord Jesus and the Virgin Mary, the queen of matchmakers.

And where have you been, holy korowaj?

(...)

Oh, I have visited the circle of the moon, I have visited the bright sun.

The sun as a symbol of perfection features in such phrases as "to look for spots on the sun", i.e. "look for a fault in something perfect" (plamy na słońcu szukać), "who hates his neighbour also sees spots on the sun" (kto bliźniego nienawidzi, ten $i$ w słońcu plamy widzi) [SSSL 1.1: 124]. In such phrases, contrast serves to strengthen the image of the sun as perfection, which acquires a deeper symbolic significance in view of the identification of the sun with deity. It is only the sacral dimension of perfection that reveals the real sense of the symbol, thus demonstrating it to be a living concept, generating chains of analogies that link seemingly distinct images into a coherent whole.

The sun is also symbolised by the egg and bread. In both cases symbolic meanings rely on the link between the sun and the sacred, thus including the symbolic object in the cosmic structure. The egg was metaphorically associated with the sun owing to its colour and shape, as well as its life-giving properties. As a germ of life, the egg contains powers within it that can be compared to the life-giving powers of sunbeams. Their symbolic identification is possible thanks to their ancient meanings derived from cosmogonic myths according to which the sun and the egg gave rise to life on earth (see Chapter 4.3 above). The currency of this meaning is reactualised in magical beliefs and practices analogical to those invoking the power of the sun and their connection between the sun and happiness (e.g. healing by rolling an egg over the body of a sick person, the belief in magical properties of painted Easter eggs). This connection can also be seen in analogical images in which the egg and the sun may symbolise the resurrected Christ. It is a vivid illustration of the equivalence between macro and microcosm. An extreme example of the use of such identification may be found in magical practices in which an offering of an egg placed on an oak tree (also associated with solar symbolism) is meant to summon the sun [SSSL 1.1: 133]:

(1) Pokaz-ze się słonecko,

Dám ci biáłe jajecko!

Połozę cie na dębie,
(1) Sweet sun, show thyself,

I will give thee a white egg!

I will lay thee on an oak tree, 
Roztocą cię gołębie.

Połozę cię na grusce,

Roztocą cię chrabąsce.

Położę cię na śliwie,

Roztocą cię scęśliwie.

(2) Świeć się świeć słoneczko!

Dam ci jajeczko,

Jak kureczka zniesie

$\mathrm{Na}$ dębowym lesie.

Weźmij jajo do raju,

Niech się dusze radują
Pigeons will roll thee.

I will lay thee on a pear tree,

Beetles will roll thee.

I will lay thee on a plum tree,

They will roll thee happily.

(2) Shine, sweet sun, shine!

I will give you an egg

When the hen lays it

In an oak forest.

Take the egg to paradise,

Let the souls rejoice.

The multilayered meanings activated in particular actualisations of the image reveal further semantic aspects of the symbolising and symbolised object. In the first instance, the function of the magical formula is to attract the sun by means of an offering, which is at the same time its equivalent. As pointed out above, the association between the egg and the sun is very ancient, as evidenced by one of the old Egyptian versions of the cosmogonic myth, according to which $\mathrm{Ra}$, the sun god, was born from an egg placed on top of a mound that emerged out of the dark depths of the primeval ocean [Lurker 1990: 89]. The magical action of placing an egg on an oak (high up) seems to be parallel to the mythical motif of the birth of the sun. Such analogies in the representation of the elementary components of the cosmos in distant cultures are not uncommon. This does not mean that they are interrelated, but rather suggests that they belong to the experiential base. ${ }^{10}$ In Polish culture, the sun, the egg and the oak form a chain of solar motifs connected by means of analogy and correlation. The oak and the sun are linked by their divine attributes ${ }^{11}$ while their association with the

10 The Old Indian account of the creation of the world quoted by Vladimir Toporov [Toporov 1967: 93] displays marked similarities: "He (...) first (...) created the waters, and placed his seed in them. That (seed) became a golden egg, in brilliancy equal to the sun", The Laws of Manu, I, 8-9, trans. George Bühler (The Laws of Manu: The Sacred Books of the East vol. 25, trans. George Bühler, ed. F. Max Müller, New Delhi: Atlantic, 2002 [1886], p. 5).

11 The link between the oak and the solar demiurge connected with vegetation is illustrated in a folk riddle in which the oak is an equivalent of the sun: "There is an oak in the village/ with no leaves, no branches and no flowers/ and it serves all the world" (Stoi dąb na wsi/ ni liści ni gałęzi, ni kwiatu/ i stuży całemu światu) [ZWAK 1, 133, 57, after Brzozowska-Krajka 1994: 35]. 
egg depends on the analogy of the cyclical process of death and regeneration, common to all the elements in the chain.

The second variant of the magical formula quoted above reveals the egg's wider significance and the role of its transformative capacities (hidden life) in attempts to establish contact with the supernatural world. An analogical attempt to keep in touch with the souls of the dead can be seen in the East Slavic custom of throwing Easter eggshells into a river (a border between worlds) as a sign of connection between the two spheres. The same meanings are actualised in the tradition of putting an egg into the coffin to facilitate the passage of the dead to the afterlife [Niewiadomski 1989: 69; 1999: 145; Kowalski 1998: 174].

According to Vladimir Toporov, the association of the egg both with the sun (life) and with the world of the dead is an archetypal motif found in folk tales about the world hatching from an egg. Stories from various parts of the world feature the opposition between a golden and silver egg (equivalents of the sun and the moon, both belonging to the heavenly sphere) and the underwater darkness corresponding to the underground space of the otherworld. In addition, Slavic folklore links the motif of the golden egg with water and a bird, thus making it an equivalent of the rising and setting sun, which also either emerges from or sinks into the waters [Toporov 1967: 94-96].

Such symbolic imaging opens the way for the forging of multidirectional connections, and hence the link between the sun, egg and earth through their shared demiurgic properties becomes fully justified. The egg - as a symbol of the sun - also becomes an attribute of fertility and wealth. This links it with the earth, as reflected in the ritual of feeding the earth with eggs (scattering Easter eggshells in the fields, throwing a fresh egg into a furrow, giving each other decorated Easter eggs). Due to the connection between fertility and the underground realm, as well as the cycle of death and rebirth common to the egg, sun and earth, the egg also comes to be a symbol of regeneration [Toporov 1967: 97-98; Niewiadomski 1999: 140].

Owing to its outward resemblance (colour, shape, temperature), bread also serves as a symbol of the sun. Its deeper symbolic significance is revealed through a network of semantic connections between the earth and the sun (as a metonym of heaven). The cosmogonic myth links bread with the earth (kneaded by God in the shape of a loaf of bread), while the role of "the souls' stairway to heaven" ascribed to it assumes its cosmic unity with the sacred sphere. The semantics of such unity can be seen in magical formulas uttered by women while baking bread: "Bread, come out high, like the sun in the sky" (Zdarzë se chleba, jak stunce $z$ nieba), "Bread, bake well and high, like the sun in the sky" (Upiecz się chlebie, jak słońce na niebie), "Bread, rise as high as the sun in the sky" (Rośnij ty chlebie, jak słońce na niebie), "May bread come out good and brown 
as if baked by the sun" (Niech się chléb darzy, jak słónuszko skwarzy) [Treder 1989: 17], "Bread, rise as high as the sun in the sky" (Rośnij chlebie jak słonko na niebie) [SSSL 1.1: 127]. Additionally, the efficacy of such formulas is intensified by gestures imitating growth (jumping). Shaping the amorphous mass of dough (an equivalent of chaos) into a fixed form while baking constitutes a clear parallel with the act of creation. The re-enactment of the divine gesture sanctifies not only the activity, but also its product. ${ }^{12}$ The semantic node linking the concepts of bread, the sun, earth and woman is fertility and, in a more general sense, life as such [Kubiak I., Kubiak K. 1981: 121]. Symbolic meanings reveal cognitive paths framing seemingly distinct concepts into a network of interrelations. The semantic chain linking bread and heaven (through the mediation of the sun) underlies the symbolism of rites of passage - wedding and death - where bread, like the egg, plays a transformative function. Wedding bread (kołacz), decorated with images of the sun and the moon, is treated as a gift from heaven (like the sun), bringing the newly-weds (who change their state) God's blessing in the form of fertility and prosperity. The analogy to the life-giving properties of the sun and the fecundating function of sunbeams determines this common semantic direction connected with life [Kubiak I., Kubiak K. 1981: 117-123].

By contrast, "funeral bread" (chleb żałosny, lit. 'mournful bread') eaten by mourners during the funeral ceremony, as well as the custom of putting a loaf of bread into the coffin (parallel to the custom of putting in an egg), represents the reverse direction of transition: from earth to eternity. As aids in the passage to the metaphysical world, intended to ensure immortality, bread and the egg act as an analogy of the setting sun, which dies, falling into the darkness, only to return to new life at dawn. In this way, by completing the cycle, the diametrically opposite meanings - life and death - are combined to symbolise unity [Kubiak I., Kubiak K. 1981: 102].

12 The symbolic meaning of the stove as an otherworldly cave (an equivalent of the woman's womb) from which bread is born, gives rise to the semantic chain breadstove-woman. In Silesia, it is said about a baby being born that "the stove has fallen apart" (piec się rozleciat). The symbolic meaning of bread as a gift from God, in turn, endows it with the quality of sacredness in all its ritual uses [Kowalski 2000: 75]. 



\section{The moon}

\subsection{The creation myth: the sacral profile of the moon}

According to the folk worldview, God made lights in the sky so as to illuminate the earth both day and night [SSSL 1.1: 143]:

When the Lord God made the earth, He said: Let us make light. The first light was the biggest, that was the sun. The second light was smaller, that was the moon. And the third light, said God, the stars.

Jak Pan Bóg stworzył ziemię i powiedział: Zróbmy światłość. Pierwsza światłość była największa, było słonko. Druga światłość była mniejsza, był księżyc. A trzecia światłość, powiedział Bóg, gwiazdy.

The creation of the sun and the moon introduced the division between day and night, based on the opposition: light vs darkness. Construed in terms of the CONTROL schema, lack of light (and the attendant inability to see) is associated with a sense of danger. Thus, like the sun, the brightness of the moon, which disperses the dark, was conceptualised as a sign of God's grace, constantly watching over the world. In this way, both lights came to be treated as hierophanies of God, as is apparent in the common practice of identifying the sun with the eye of God, and the Kashubian designation of the moon as bożi vid 'God's lantern' [Treder 1985: 18]. ${ }^{1}$

As the largest and brightest light in the night sky, the moon is the equivalent of the sun, which lends it some of its radiance: "The sun is like life, it shines with its own light, the moon is like art, it feeds on that which is borrowed" (Stoniszko je jak żëcè lsni blaskę włásnym, ksężéc zás jak kunszt: żéwi sę pózéczonym) [SSSL 1.1: 132]. According to Slavic folk beliefs, the moon was created by Jesus Christ. Having been blessed by God the Father, it became the night sun, as evidenced by its names: the Ukrainian nochnyk and Macedonian nočnik, lit. 'night light', and Polish nocne stońce 'the night sun' [SlavDrev 2004: 144].

Both in Slavic culture and other mythologies from around the world, the sun and the moon form an inseparable, mutually complementary pair [MifyNM 1988: 461], represented as a married couple, a father and son, or as siblings: two brothers or a brother and sister [SlavDrev 2004: 145; SSSL 1.1: 159]. However,

1 In Ukrainian, the moon is called Bozhe oko 'God's eye' or lytso Boha 'God's face' [SlavDrev 2004: 144-146]. 
their co-occurence in collections and parallels does not rule out the oppositional treatment of the sun and the moon. ${ }^{2}$

In their interaction with the Creator, both the sun and the moon (together with the stars) glorify God: they greet the newborn baby Jesus, serve the Holy Mother, cry at Christ's tomb and rejoice at His Resurrection [SSSL 1.1: 161]. In numerous cultures, the moon is associated with the death and resurrection of a deity [Eliade 1958: 157-158]. Christian culture adapted this tradition in order to build a symbolic image of the mystery of Christ's Resurrection, based on the analogy between the periodic three-day disappearance of the moon from the sky and its subsequent rebirth on the one hand, and the death of the God-man who rose from the dead in divine form after three days on the other. The multilayered meanings of the symbol also include parallels between the light of the sun, Jesus, and the reflected light, his Church, as well as analogies between the death and resurrection of God and the death and the eagerly anticipated resurrection of man [Forstner 1986: 101-102] which distinguishes Christianity from other systems of religious belief:

God having provided this, that thou also, the man who art formed of blood, mightest not refuse credence to the resurrection of the dead, but mightest believe concerning thyself also what thou seest in respect of the moon. ${ }^{3}$

A folk tale from Cracow in which the sun and the moon are created at the behest of the Virgin Mary corresponds with the image of the moon as a symbol of the resurrected Jesus [SSSL 1.1: 161; Benedyktowicz D., Benedyktowicz Z. 1992: 50]:

For the glory of the Lord Jesus, the Mother of God ordained the sun and the moon, for she is brighter than them, and shines on them from heaven. By her will, the Lord's saints open up little gates in heaven onto the moon and the sun [so that they shine].

Matka Boska dla chwały Pana Jezusa postanowiła słońce i księżyc, bo ona od nich jaśniejsza, świeci na nie z nieba. Za jej wolą święci Pańscy na księżyc, jak i na słońce otwierają furtki z nieba [żeby świeciły].

With its capacity for transformation, and its role as foil to the constant sun, the moon may be regarded as a source of dualism in religions other than Christianity

2 The elementary opposition in Slavic languages, built on the basis of the dichotomy bright vs dark, is the connection of the moon with the sphere of death, and the sun with the sphere of life [SlavDrev 2004: 144-146].

3 Cyril of Jerusalem, Catechetical Lectures, Lecture 18, section 10 (The Catechetical Lectures of St Cyril, Archbishop of Jerusalem, in Nicene and Post-Nicene Fathers: Second Series, Volume VII, Cyril of Jerusalem, Gregory Nazianzen, ed. Philip Schaff and Henry Wallace. New York: Cossimo Classics, 2007 [1893], p. 136); see Forstner 1986: 102. 
[Eliade 1958: 183-184]. It is also the most important medium between the divine and human spheres.

This perceived duality is already apparent in mythical stories relating to the moon's origin, in which the biblical scene of creation is disturbed by the devil's interference. As in other demiurgic acts, FORCE, operating in terms of the source (God) - path (God's word) - goal (the sun) schema, comes up against the COUNTERACTION of the antagonistic demonic sacred. According to a legend from the Dobrzyń region, the devil stole a piece of the sun from God in order to create his own source of light, but burnt himself in the process and so dropped it. The stolen piece became the moon, which is less perfect than the sun since it can neither produce warmth nor shine on its own [SSSL 1.1: 161].

The motif of the devil also appears in a Kashubian mythological legend, in which the origin of the moon is represented as the result of St Michael's chase of the devil during the war between the heavenly spirits and rebel angels [Sychta 1968: 181]:

The moon (ksažëc) is named such since it is a wheel from off the chariot in which the heavenly prince ( $k s \tilde{z} z \check{z} a$ ) Michael chased the devil across the sky during this great battle between angels. It was such a terrible battle that in the fury of the chase a wheel came off the chariot. The black spots on the moon are the marks left by the axle grease of the heavenly chariot.

(...) ksąžëc tèmu są nazèvå ksąžěc, bo to je koło od voza, na chtërnim ksõžą ńeb’eski Michål diabla po ńeb’e gonil, jak ta v’elgå bitva medze ańolami bëla. Ta bitva bëla strašnå, že od chutkego gońeńå kolo odpadlo od voza. Čårnè plamë na ksąžëcu to je ta smara od osë ńebeskèłe voza.

The mythical fight between good and evil, which accompanies each stage of the act of creation, is also apparent in the conceptualisation of the world and the actions of these cosmic forces. As a result of the presence of the demonic motif in the myth about its origin, the moon is ascribed ambivalent values associated with both divine and satanic power. The network of semantic connections between the moon and night, darkness, sleep and, consequently, death, is additionally conducive to the emergence of demonic lunar connotations [SlavDrev 2004: 144].

The balance between such meanings is maintained thanks to the constant cycle of lunar phases, which impose a cosmic rhythm, the alternating laws of life and death, on the world. The temporary and physical sphere of life is represented by the waxing of the moon, while its gradual waning anticipates the end of earthly existence, opening the way up to eternity. The three-day absence of the moon from the sky becomes an image of the transition into the land of the dead, while 
its rebirth into a changed form demonstrates the transformation and eternal triumph of regenerated life. Thus the moon may be termed the first dead, the one that sets out the path to "otherworlds" (zaświaty) and, through association with death, maps out the first stage in the journey of souls to heaven. Following the moon's example, after regeneration - purification from sins - they will be able to pass into the heavenly sphere [Eliade 1958: 171]. In Slavic culture, during its three-day disappearance the moon was believed to shine onto the land of the dead [SlavDrev 2004: 144].

Featured in folk tales, scenes in which purgatorial souls do their penance on the moon illustrate a belief in the inevitability of punishment for the breaching of divine laws. The conceptualiser, acting as an observer of the events taking place on the moon, ascribes the archetypal roles to those who disobeyed God's will: to Cain for killing Abel ${ }^{4}$ and to Twardowski, the Polish Faustus, for making a pact with the devil. The background occasionally includes the figures of the original parents and Judas [SSSL 1.1: 167]:

- "Kashubians believed the moon to be a shield (...), since the figure of Eve at the spinning wheel and Adam leaning on his pitchfork can be seen on it" (Księżyc Kaszubi brali za tarczę (...), widać bowiem na niej Ewę przy kołowrocie i Adama opartego na widtach) [Treder 1985: 18];

- "It can be seen on the moon how Cain holds Abel, the brother that he has killed, on a pitchfork, with his legs and arms outstretched" (Na księżycu widać, jak Kain trzyma na widłach Abla, brata swego którnego zabit, a nogi i ręce ma roztapyrzone) [SSSL 1.1: 184, see also similar records from around Poland];

- "Time was when my mum, well, my mother would tell me that Twardowski is on the moon, he does his penance there (...)" (Jeszcze kiedyś mi mama, matka opowiadała, że Twardowski na księżycu jest, bo pokutuje (...)) [Bartmiński (ed.) 1989: 115, see also other numerous variants].

Such scenes gave rise to analogous images of sinners doing penance on the moon for having worked on a feast day, for fratricide, theft, etc. The widespread use of the motif suggests that the image of the moon as a place where souls served their punishment for sins committed during their earthly life was well established in the folk imagination [SSSL 1.1: 183, 184, see also similar records]:

4 In a folk version from the Caucasus the moon represents Abel's decapitated head [SlavDrev 2004: 144]. 
(1) They stay there as punishment (...) for working on the feast of Our Lady of the Warming [the Annunciation, 25 March]; he spread manure in the fields, and she churned butter at home.

(2) There is a man on the moon who stole a bundle of pea-stalks when he was alive. Now in death, he carries this bundle on his back as punishment. If you have a good look at the moon, you can see him walking, bent over, carrying the bundle on his back.

(3) When they both came to pick up their sheaves, he struck his older brother with a pitchfork and killed him. God then destroyed the whole farm belonging to the murderer, and cast him alive into hell. So that this great crime should remain a fixed image before people's eyes to remind them of it, and keep them from committing a similar one, with His own hand God drew this picture on the moon. (...) The moon became a place of punishment and penance.

(1) Za karę tam siedzą (...) że pracowali w sam dzień Matki Boskiej Zagrzewnej. On w polu gnój rozrzucał, ona w chałupie masło robiła.

(2) Na miesiącku jest człowiek, chtóry za życio ukrod wiązke grochówki. Za kore dźwigo te wiązke po śmierci na plecach. Jak się dobrze na miesiącek przypatrzéć, to widać, jak idzie skrzywiony i wiązke niesie na plecach.

(3) Gdy obaj przyjechali po snopy, uderzył widłami starszego brata i zabił go. Bóg wnet zniweczył cale zbrodniarza gospodarstwo, a samego wtrącił żywcem do piekła. Aby zaś ludziom widok tej wielkiej zbrodni ciągle przypominał i odwodził ich od podobnej, sam swoją ręką na księżycu obraz pomieniony nakreślił. (...) Księżyc stał się miejscem kary i pokuty.

Interpretation of such scenes varies, depending on the point of view of the conceptualiser. The scenario which places Adam and Eve on the moon recalls original sin, the source of the human inclination to evil. Such a view focuses on the dangers of evil instincts latent in every human being, fratricide being a case in point. In the story of Twardowski, a Polish nobleman who signed a pact with the devil, the centre of interest is shifted to show the power of prayer and the possibility of escaping Satan's clutches even at the last hour:

In the Bochnia district, folk say that Twardowski the sorcerer lives on the moon. Satan is said to have abandoned him there, even though he was meant to have been captured and taken to hell. But Twardowski began to sing the Liturgy of Hours, and his singing weakened the power of the evil spirit. Twardowski will do his penance on the moon till Judgment Day.

W bocheńskim powiecie lud mieści na księżycu czarownika Twardowskiego. Szatan miał go tam porzucić, chociaż do piekła miał być porwany. Twardowski bowiem począł śpiewać godzinki, a śpiewaniem tem osłabił moc złego ducha. Na księżycu Twardowski pokutować będzie do sądnego dnia. [SSSL 1.1: 185]

The sheer number of stories repeating the prototypical scenario in which sinners serve time on the moon as punishment for evil deeds committed in earthly life 
is evidence of the vitality of the motif and its moralising power. In this way, the profile of the moon as "a place of penance for souls" comes to be included in a network of concepts connected with: a journey towards a goal, guilt, punishment, death, regeneration, redemption, evil, good and eternity. The following legend may illustrate the connotations connected with the symbolism of lunar transformation [SSSL 1.1: 162]:

The moon changes every month because, since the time Cain killed Abel, God has commanded the moon to go to hell every month and there to be remoulded anew, while the forces of hell try to tear the moon to pieces and bury it in the ground.

Księżyc zmienia się co miesiąc, bo od czasu zabicia Abla przez Kaina Bóg każe księżycowi co miesiąc iść do piekła i tam się przetapiać na nowo, a siły piekielne próbują rozdrapać księżyc i zagrzebać w ziemi.

This passage displays a marked similarity to ancient legends about lunar deities killed and hacked to pieces by evil forces, and their cyclic reincarnation during the phase of the moon's disappearance [Eliade 1958: 176]. Motifs linking the Polish folk tale quoted above and myths dating back to ancient times and distant cultures include: the killing of the moon (dividing the body of a lunar deity tearing the moon to pieces); the moon's supernatural power, which allows it to come back to life and last eternally; and the perennially active forces of evil, associated with darkness, which unsuccessfully try to fight with the sacred. The Polish tale additionally includes the motif of the "remoulding of the moon in hell fire" at God's behest, which is evidence of God's absolute power over the supernatural world. Subjecting the moon to the action of hell fire purges it from demonic influences, cleansing the souls of sinners who dwell on it in the process.

Both texts are structured by the same preconceptual image schemas: the FORCE schema, evident in the fight between divine and devilish powers, the former being indestructible; the DESTRUCTION schema (PART), represented by demonic forces and the moon itself during its waning phase; and the WHOLE schema, underlying the cycle of regeneration. The Polish tale additionally involves God's CONTROL over the forces of evil. Such correspondences evince the archaic roots of lunar beliefs and the vitality of the myth reinforced by the symbolic imagination, which links the image of the moon with supernatural reality.

In ancient cultures, the moon was also seen as the dwelling place of the souls of heroes [Eliade 1958: 171-172], and was thus associated with the concept of reward rather than punishment. Although the folk imagination peopled the moon mainly with the souls of sinners, mythical tales and legends also place 
worthy figures on the moon, such as St George, rewarded by the Virgin Mary for destroying the dragon [Benedyktowicz D., Benedyktowicz Z. 1992: 50]:

The Most Blessed Virgin said to St George: Since you have so gallantly defended this innocent creature, this pure virgin, you will, my knight, drive a starry chariot across the sky, and I will give you my dear moon to be your dwelling.

Najświętsza Panienka rzekła Jerzemu świętemu: Kiejśmi pięknie, ładnie obronił niewinne stworzenie, dziewicę czystą, to za to mój rycerzu, po niebie na gwieździstym wozie jeździć będziesz i mój miesiączek odstępuję ci na mieszkanie.

Looking at the moon (especially in its full phase), one can see the figure of St George, playing the lute or violin in praise of the Virgin Mary. However, it is forbidden to look at the musician for too long, for "if someone gazes at the moon, and the player's string breaks, one's eye will pop out, which is why one mustn't gaze at the moon" (gdyby się kto w miesiaczek wpatrzyt, a skrzypkowi wtenczas pękła struna, to człowiekowi oko wyskoczy, dlatego nie wolno wpatrywać się w miesiączek) [SSSL 1.1: 184]. This motif may be connected with the prohibition against pointing one's finger at the moon, since "whoever does that (...) [his] hand will wither" (bo temu, $k$ to to robi (...) ręka uschnie) [SSSL 1.1: 165]. An analogical rule concerns pointing one's finger at the sun, which would suggest that both the sun and the moon used to be treated as hierophanies of deity, and later became a taboo.

According to a tale from the region of Wielkopolska in western Poland, the soul of the Polish king Władysław Warneńczyk, the defender of Christianity who died fighting the Turks in the battle of Varna (1444), was also transferred to the moon [SSSL 1.1: 185]:

The Antichrist brought the bodies of the fallen Turks back to life by turning their faces to the moonlight; Polish diviners supposedly saw the face of the dead king, Władysław, whose body had disappeared during the carnage, on the disc of the moon, and the Polish knights, seeing that their king was looking down on them from above, wanted to avenge his death and performed great feats of prowess.

Antychryst ciała poległych Turków wskrzeszał, obracając ich twarz ku światłu księżyca, wróżbici polscy ujrzeć mieli oblicze poległego króla Władysława, którego ciało zniknęło w czasie rzezi, na tarczy księżyca, a rycerze polscy widząc, że król z góry na nich patrzy, odemścić go chcieli i cudów waleczności dokonywali.

The motif of bringing the dead Turks back to life by turning their faces toward the moonlight derives from a belief in the power of moon beams to resurrect the dead. ${ }^{5}$ The association of the moon with the souls' journey links it with the

5 The motif of the moon bringing the Turks back to life is connected with Bulgarian beliefs that the moon shines for the Turks (pagans). The mutability of the moon 
concept of the afterlife, while traces of the myth of the moon's origin are apparent in the influence it has over the demonic world. The periodical death and rebirth of the moon determine its supernatural powers and attendant magical properties, which increase as it waxes and culminate at full moon. The light of the moon was believed to be particularly powerful, capable of pulling the dead out of their graves. The power of the moon also animated damned and penitential souls which had already turned into demons, and stimulated the powers of wizards and witches [SSSL 1.1: 167].

The moon plays the archetypal role of the agent in scenes where, on moonlit nights, penitential spirits come back to haunt the earth. Although the moon is the source of power here, it remains in the background of the scene, which is occupied by ghosts of dead lovers, suicides and knights acting out their final moments. Scenes connected with the death of lovers (one or both) often feature in folk poetry, especially in ballads, where the souls of the dead frequently take the shape of doves [SSSL 1.1: 180]:

(1) Gdzie się ich [kochanków] wznosi mogiła, (1) At their [the lovers'] grave

Rosną dwie brzozy płaczące

(...)

Two weeping birches grow

Tam, przy księżycu poświacie

(...)

dwa gołąbków przylatywa,

There, by moonlight,

siada jako siostra przy bracie, two doves fly down,

dziobkami się pogłaskiwa.

Widziano także na jawie,

jak ten gołąb, gołębica,

w niebo wzlatują w postawie

mdławej jak promyk księżyca.

they sit like brother and sister,

they nuzzle each other's beaks.

It was also seen, as if in the daylight hour

how these two turtle doves

fly up into the sky,

their shapes as faint as a moon beam.

corresponds to the godlessness of the Turks, who do not accept the Christian faith. Moreover, the Belarusian expression referring to the moon as "gipsy sun" suggests its connection with strangers [SlavDrev 2004: 144].

6 Depictions of human souls as birds are widespread in folk culture, as illustrated in a variety of contexts. The Milky Way, regarded as the road along which souls travel to heaven, is also called the Bird Way [SSSL 1.1: 252]; the souls of unbaptised children are often presented as birds. The motif can also be found in a folk song, in which the spirit of a girl murdered by her lover appears as a dove sitting on an oak tree: "An oak tree has grown on that grave/ a sweet white dove sits on it" (Na tej mogile wyróst-ci dąbeczek/ na niej bieluchny siada gołąbeczek) [Marczewska 1998: 122]. 
(2) Usnął Jasiu na murawie, śniło mu się jak na jawie: przyleciała gołębica [zmarła narzeczona], znikła przy blasku księżyca.
(2) Johnny slept upon the grass, had a dream as if waking: a dove came [his dead fiancée], she vanished by the moonlight.

In the oral tradition, tales and legends often focus on battle scenes which claimed the lives of many knights, and show the figures of both well-known and anonymous souls consigned to purgatory. Processions of spirits can be seen in the moonlight up to midnight; the heroes of these recalled events disappear at dawn, at the first crowing of the cock [SSSL 1.1: 183]:

- "On the anniversary of that battle, whose precise day and month they do not know, both armies [Polish and Swedish] rise from their graves and fight until midnight. (...) On a moonlit night, knights can be seen in pursuit of one another. When the cock crows, everything disappears until the next year" (W każda rocznice bitwy, której dnia i miesiąca dobrze nie wiedza, wstaja oba wojska [polskie i szwedzkie] z grobów i walcza aż do pótnocy. (...) Nawet jeśli noc księżycowa, widać uganiających się za sobą rycerzy. Gdy kur zapieje, wszystko znika aż do przysztego roku);

- "[Persuaded by his wife, King Jan Sobieski sold people to the Tatar Khan. Regretting his deed, he jumped into a lake on his horse.] For this, every night, especially when the moon shines, he rides out on his horse, (...) and when the cock crows, returns to the bottom [of the lake] to do his penance" ([Król Sobieski za namowa królowej sprzedał ludzi chanowi tatarskiemu. Żałując swego uczynku, wskoczył na koniu w jezioro.] Za to co nocy, zwłaszcza kiedy księżyc świeci, wyjeżdża na koniu, (...) a kiedy kur zapieje, wraca na dno odbywać swoja pokute);

- "People say that this place [near a cross by the roadside] is haunted. Twice I have met there a human figure, kneeling in prayer. This was in the month of January. It was frosty, the moon was shining beautifully, it was twelve oclock. I passed by, I didn't turn back. Perhaps it was a spirit that needed something, a prayer to be released" (Ludzie mówia, ze tam [koło krzyża przy drodze] strasy. Dwa razy spotykałem tam postać ludzkum klęcaco, która się modliła. To było w miesiącu styczniu. Mroźno było, księżyc swieci ładnie, była godzina dwunasta. Przestem, ale nie oglądałem się. Może to był duch, który coś potrzebuje, modlitwę na wybawinia).

In legends, songs and ballads, the conceptualiser is located outside the scene, relating the events according to the adopted stereotype. Conversely, in witnesstype narration, he/she locates him/herself in the middle of the scene as the 
central character, presenting the event from the point of view of the subject who experiences an encounter with a ghost.

There is a wealth of folk material illustrating a belief that the power of the waxing moon is transferred to demonic beings who become increasingly more active between the new and full moon. At new moon devils and witches hold their midnight feasts on Łysa Góra (lit. 'Bald Mountain'), while vampires gather at a fork in the road, each time assuming a different shape (up to seven shapes during each new moon) [SSSL 1.1: 167, 191]. A belief that witches gathered together on barren mountain tops is preserved in names of peaks such as Łysa Góra lit. 'Bald Mountain', Babia Góra 'Womens' Mountain', which are endowed with fixed demonic connotations [Pełka 1987: 198]. On moonlit nights all kinds of evil spirits: zmory 'mares', dusiołki lit. 'chokers', strzygonie 'vampires', gnieciuchy lit. 'crushers' are particularly persistent in harrying their human victims, as evidenced by the semantic structure of their names, connected with choking at night as a way of tormenting people in their sleep.

A belief that the full and the new moon have a particularly strong influence on water demons may point to vestiges of the archaic connection between water and the moon. ${ }^{7}$ According to folk beliefs, topielniki, topielce, utopce 'drowning demons' (lit. 'drowners'), wodniki 'water demons', rusatki 'undines', boginki 'goddesses', dziwożony 'wild women' emerge from the waters to harm people in various ways. ${ }^{8}$ The ghosts of the drowned lie in wait for the living so as to drag them into water and drown them; boginki, rusałki and mamuny, malicious female demons, try to steal children left unattended by their mothers, leaving little vampires in their place; wodniki, in turn, destroy crops, flooding the fields with water [SSSL 1.1: 167; Dźwigoł 2004: 162-177; Pełka 1987: 88 ff].

Sorceresses and witches were also believed to expose themselves to the influence of the waxing moon, walking in the meadows and field boundaries at night, often naked, to become imbued with its supernatural power. "At midnight during new moon, to replenish her powers, a witch goes to the crossroads and throws rags behind her" (Na nowiu o pótnocy, aby nabrać mocy, czarownica chodzi na krzyżówki i rzuca szmaty za siebie) [SSSL 1.1: 190]. Witches would also gather herbs on such occasions, both healing and poisonous ones, to use in their magical practices. It was believed that herbs picked during the full moon were more efficacious thanks to the influence of the moonlight. The first phase of a

7 The moon was believed to rule the waters [Eliade 1958: 159-161].

8 A wealth of lexical material concerning the names of all manner of demonic beings can be found in a study by Renata Dźwigoł [Dźwigoł 2004]. 
new moon, in turn, was commonly regarded as witching time, since spells and evil charms performed in this period were believed to be the most potent [SSSL 1.1: 167].

\subsection{The influence of the moonlight on human beings}

The light of the moon, thought to be capable of raising the dead from the grave, re-awaking vampires and activating all evil forces, was seen as a danger to the living. It was children in particular that had to be protected from its harmful shine, as the moon could even pull them out through the window. It was believed that moon beams could "pull people up"; if they passed over a sleeping person, they could turn him/her into a sleepwalker, cause miesięcznik 'moon disease', the symptoms of which included a reluctance to eat and drink and sleeping with eyes open, or tunnik 'moonlight illness', characterised by weeping, convulsions and stomach problems. Practices followed in order to prevent such harmful effects include the following commands and prohibitions [SSSL 1.1: 165]:

- the window or bed should be curtained, the baby should be wrapped up in a kerchief so that the moon does not shine on his/her face;

- one should sleep in a place where moon beams do not reach;

- a vessel filled with water should be placed on the window sill so that the beams lose their powers;

- millet should be scattered about, and tracks made in it, which the moon will have to follow (losing its way in the process);

- bread crust should be placed on the window sill;

- if the moon beams have touched the baby, he/she should be passed across a well;

- drinking water should be covered, for if the moon shines on it, and then someone should drink it, they will become a sleepwalker;

- a person who is ill should avoid the moonlight so that the disease does not "take root";

- a pregnant woman should not walk in the moonlight with her head uncovered, for she will have a difficult delivery.

This system of precautions also included situations in which the individual was in a liminal state, subject to the influence of a number of supernatural powers of various kinds: he/she was asleep (a state of symbolic death) or experienced a transitional phase (a pregnant woman, a newborn child). The synchronic impact of such different powers from "the other world" was considered dangerous and 
harmful. ${ }^{9}$ Where there was no CONTROL, the INTENSIFICATION OF FORCE schema was negatively valued by the conceptualiser. This gave rise to directives prescribing precautions to be taken in order to deprive moon beams of their magic powers, which reached their climax at full moon.

The FORCE schemas underlying such commands involve OBSTACLE (water, millet, bread crust), BLOCKAGE (curtaining the windows), EVASION (choosing a place where the moonlight does not reach), aiming to counteract the power emanating from the moon. While such scenes involve OUTER COMPULSION (the conceptualiser has no control over the fact that the moon shines), he/she takes the role of the agent who may either avoid the effects of the moonlight, or consciously ignore them, exposing him/herself and his/her family to their harmful influence, thus putting their well-being at risk. In both cases, the agent will act according to INNER COMPULSION, prompting him/her to comply with the norms or reject them. In this way, although the moon appears in the scene only in the background, its presence and role determine the activity of the conceptualiser.

The religious-magical attitude towards supernatural powers provides the basis for scenarios which enable the individual to make use of the moon's power for his/her own good. However, access to the source of this power requires strict adherence to socially accepted norms and models of conduct, informed by a belief in the divine provenance of the power emanating from the moon and its influence on both human fate and the forces of nature.

Observation of the phases of the moon provided the basis of the conceptualisation of time, which is reflected in the name miesiac 'month/moon' used to designate both the thirty-day cycle and the moon itself. Modern language has also preserved the division of the month into four quarters corresponding to the length of the lunar cycle, i.e. a week (tydzień) [Kowalski 1998: 267]. The archaic method of measuring time "in moons" is still used in Kashubian dialects: "He lacks two moons [months] to a full year" (Le ješ dva ksažžéce do god), "This moon [month] she will be seventy years old" (V tim ksąžëcu ona mdze sètmedzesąt lat) [Sychta 1968: 281].

9 Such overlapping of magical powers was regarded as particularly dangerous in liminal places, on the border between worlds, since it could activate an unexpected transformation [Kowalski 1998: 641]. It can be assumed that liminal time can have a similar effect. In such special circumstances, powers usually regarded as benevolent or life-giving may reveal their ambivalent properties, which may turn out to be harmful or even fatal. 
The emotional attitude to this nocturnal clock is expressed by diminutive forms derived from the word miesiac 'moon/month': miesiączek, miesiaczeńko, miesiączyczek, and księżyc 'moon': księżyczek, księżyczeńko [SSSL 1.1: 159]. The derivational structure of the word księzyc is patronymic, as indicated by the dedicated suffix -ic. The word $k s i e ̨ z y c$, formed by adding the suffix -ic to the derivational base ksiadz 'prince', originally meant 'son of the prince', but already in Old Polish it also functioned as 'prince, ruler' as such. The same patronymic form and meaning are also found in other Slavic languages, but the meaning 'moon' developed only in Polish and originally referred exclusively to the new moon [SłSE 1968: 277; Budziszewska 1990: 224; SSSL 1.1: 187], which would indicate that this phase held a special significance.

A belief that the moon is the ruler of the night sky, influencing human fate, health and happiness, lies at the root of scenes welcoming its return. The salutation scenario involves direct address to the new moon, hence both the moon and the person greeting it take their places in the scene. Since the moon is the source of power, its ritual welcome relies on the ATTRACTION OF FORCE. The salutation displays the typical features of a homage due to a ruler, including the evocation of royal attributes such as the crown, sceptre and gold [SSSL 1.1: 191, 192]:

Welcome dear moon, new/heavenly prince/heir, yours be the heavenly crown/sceptre and crown/gold crown, and mine be health and good fortune/protection.

Witaj miesiączku/księżycu nowy/niebieski dziedzicu/królewiczu, tobie niebieska korona/berło i korona/ złota korona, a mnie zdrowie i fortuna/ochrona.

The salutation was accompanied by gestures of prayer: standing up, bowing three times, and then uttering a formula of a supplication for prosperity, health, happiness or wealth. The choice of specific time (the moment of the appearance of the new moon) was also significant, and served to ensure a prolonged action of grace during the waxing phase [SSSL 1.1: 188]. While such greetings were also addressed to the sun as a giver of life, identified with the sacred, the ritual accompanying the appearance of the moon reflects its special status, as the moon was believed to have a direct bearing on human fate [Niebrzegowska 1992: 76-77]. Human health and a general physical condition was linked with the lunar cycle, which provided a model for the three stages of life as such: childhood, maturity and old age [Kowalski 1998: 267]. Who was born during the new moon would never grow old, "is always young" (v'edno je młodi) [Sychta 1969: 162]; who was born during the waning moon (na wiotku lit. 'during the slack [phase]') would be weak [SSSL 1.1: 199]. Spellcasters/diviners (guślarze) advised asking the new moon for protection against headache, toothache and pains in the knees and 
bones. Incantations such as the following were supposed to ensure good health [SSSL 1.1: 191]:

- "welcome dear new moon, [protect me] from toothache, headache and hurting eyes" (witom cię miesiączku nowy, od bolenia zębów, ócz i głowy);

- "(...) from pain in the knees and bones, save us by God's love" ((..) od bolenia kolan i kości, Zachowaj nas w Bożej miłości);

- "happiness and health to me, bright shining to you, and the salvation of my soul for me" (me na ščéśće ji na zdroje, tobe na jasne śf'ecyńe, a me na dušne zbavjéńje);

- "Welcome (...) [may you bring] happiness, health [and] blessing" (Witojcie (...) Na szczęście, na zdrowie, Na błogosławieństwo).

Salutations wishing the moon a bright crown of stars, sceptre, praise and glory and, in return, asking for happiness and good fortune also often served as a good augury of wealth for the poor or a promise of a good spouse for a young man or woman [Biegeleisen 1929b: 505; Niebrzegowska 1992: 76; SSSL 1.1: 189, 192]:

- "A crown in the sky [for thee] and good fortune and happiness on earth [for me]!" (W niebie korona, a na ziemie fortóna i szczęście!);

- "Welcome, welcome, moon, (...) Bright crown of stars for thee, health and good fortune for me" (Witam cie witam miesiacu, (...) Tobie światło z gwiazd korona, a mnie zdrowie i fortuna).

The moon was also evoked in divination scenarios connected with magic, especially love magic. Unmarried girls addressed the new moon, asking it to show them their future fiancé in their dreams: "New moon, son of David, show me with whom I am to stand in front of the altar" (Księzycu nowy, Synu Dawida, daj mi znać, $z$ kim mam przed oltarzem stać). To win the love of the chosen young man, a girl was supposed to call his name for three days at new moon; she could also use herbs collected at new moon which "do harm to the male sex" [SSSL 1.1: 189; Niebrzegowska 1992: 77].

Divination practices also included forecasting the weather on the basis of the look and position of the moon: "If the new moon has its horns up, the weather will be good; if down - rain" (Jak miesiączek po nowiu ma rożki do góry-pogoda, a jak na dót - deszcz). A moon shrouded in haze augured bad weather, and "if New Year falls at new moon" (gdy gody przypadaja na nowiu), crops will not be good. Rain was also forecast by a foggy halo around the moon [SSSL 1.1: 191; Niebrzegowska 1992: 79- 80]. In Kashubia, the moon is said to "dry" during the

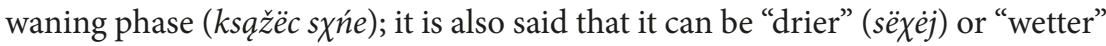
(muekrei) [Sychta 1968: 281]. 
The connection between rain and the moon is grounded in an ancient belief that the moon can release or withhold rain, since it rules over the waters on earth and in the sky [Eliade 1958: 159-161]. Consequently, the moon was also believed to exert power over the plant world. The waxing moon "pulls things up", thus making them grow. To make full use of its beneficial power, sowing and planting time should fall within the period from the new to full moon, while harvesting, scything or cutting trees should be performed at full moon or during the waning phase. Such recommendations are particularly associated with the oldest and most established of cultivated crops (cereals such as barley and millet, and vegetables like cabbage or cucumbers), thus indicating their ancient provenance [SSSL 1.1: 189]. The illocutionary force of commands regulating the time of sowing and planting is expressed through such correlatives as trzeba 'should/ ought to', należy 'should/ought to' and dobrze jest 'it is good to', as well as by the cause-result structure of persuasive phrases [SSSL 1.1: 188; Niebrzegowska 1992: 77]:

- barley/millet should be sown because it will grow big and pure;

- cucumbers should be sown because they will grow and turn out well;

- cabbage should be planted because it will grow well and will not rot in the barrel [during fermentation];

- it is good to plant or graft young trees because they will take root and grow high.

By analogy with the discernible growth of plants coinciding with the waxing of the moon, the same principle was extended to apply to farm work and the development of life in general. The scenario of invoking the power of the moon by synchronising human activities with the lunar cycle was regulated by rules specifying when such activities should begin and end [Kowalski 1998: 269, 270; Niebrzegowska 1992: 77-78].

For example, as far as typical farmyard chores were concerned, the waxing of the moon was the recommended time for sheep shearing so that wool should grow thick and strong more quickly, or for transferring the cattle to new barns so that the farm should be more prosperous. The beginning of the lunar cycle was favoured as a particularly effective time to begin all manner of new activities, including a new stage in one's life. It was thus an auspicious time for weddings, weaning babies, starting to build a new house, moving house. It was also thought advisable to perform magical activities aiming to increase wealth, such as shaking a pouch with money to make it multiply [Niebrzegowska 1992: 77; SSSL 1.1: 189]. 
The moon's notable influence on growth and development could also bring about negative effects - such as the growth of weeds or the hardening of grain. Scenarios aimed at preventing the impact of these unfavourable forces involved systems of prohibitions against making a start at sowing (especially of peas, buckwheat and potatoes) or ploughing during the first lunar phase since weeds, subject to the ever-renewing quality of the moon, would display similar properties, thus resulting in bad crops [Niebrzegowska 1992: 78; SSSL 1.1: 190].

The system of prohibitions also forbade beginning the treatment of diseases during the new moon, as it was believed that any side effects might risk aggravating the illness. It was thus the waning of the moon that was thought to be most conducive to fighting disease.

The system of both commands and prohibitions that aimed to make use of, or protect from, the influence of the moon, relied on imitative magic. The waxing of the moon was believed to cause development and growth of everything (bad and good) that was started at new moon. The full moon, in turn, guaranteed the highest degree of multiplication: abundant crops, fertility of people and animals, perfect happiness. Activities that should be performed at full moon included farmyard scenarios: planting potatoes (ensuring abundant crops), sowing peas, broad beans, cereals (the pods and ears would be full), setting hens on eggs, breeding animals, cutting grass (hay would dry well), cutting trees for timber (the wood would be healthy), laying the foundations of a new house. Since the full moon was believed to increase fertility and stimulate human sexual activity, it was also the most auspicious time to win the love of the chosen partner [SSSL 1.1: 195].

Conversely, scenarios of magical practices performed during the waning of the moon were oriented towards destruction, annihilation, disintegration. This was the time for: ploughing the stubble left after harvest to prevent weeds from growing, weaning heifers, building a house so that it would not be infested with bedbugs, casting cure spells so that diseases should disappear together with the old moon [SSSL 1.1: 199]. Scenes involving the last phase of the moon, referred to as wiotek, lit. 'the slack one' in dialects of southern Poland, relied on the weakening of FORCE, accompanied by schemas of disintegration: LACK of LINK and PART. In such scenes the moon appears in the background, while the role of the agent is assumed by the conceptualiser, who takes the central place in the scene, and identifies with other participants in the event, who either possess the same knowledge, or benefit from the experience of their elders. Although disintegration schemas are ascribed negative value, the aim of the action is positively charged as a result of contextual transvaluation. 
As far back as ancient times, the supernatural power ascribed to the moon by most cultures of the world had stemmed from a belief that the cyclicity of its transformations reflected the rhythm of the cosmos itself. Thus the moon was regarded as a great clock of nature, determining vegetation cycles of plants, ruling the waters, and thus governing the rhythm of life on earth. Taking into account its connections with night, the supernatural world and eternity, the function of the moon acquires all the greater significance in the cosmic dimension as it links the finite cycle of human life and infinity. Its capacity to provide a synthesis of polar opposites (life vs death, earthly existence vs eternity) and its connection with transcendence endow the moon with symbolic qualities. Hence in many ancient religions the moon, as a hierophany, has the markings of divinity [Eliade 1958: 161-163; Kowalski 1998: 269].

To a greater or lesser extent, all those properties are also ascribed to the moon in Polish culture. The very name księzyc 'moon' indicates its high status as a ruler, even though originally the word most likely referred only to the new moon [SłSE 1968: 277; Budziszewska 1990: 224; SSSL 1.1: 187]. In addition, the new moon was believed to have a supernatural magic power, and it was probably for this reason that this phase of the lunar cycle was distinguished by appellations evoking its divine majesty, used in prayer-like salutations. In the Lublin region of Poland, the new moon is called niebieski dziedzic 'heavenly heir', niebieski królewicz 'heavenly prince', syn Dawida 'son of David'. It occurs in collections with royal attributes: crown, sceptre and gold, e.g. "Welcome, welcome prince, heavenly heir, yours be the sceptre and crown, and mine be health and fortune"; "A gold crown for the moon, and happiness and fortune for me" (Witaj, witaj królewiczu, Niebieski dziedzicu, Tobie berło i korona, A mnie zdrowie i fortuna; Miesiącowi złota korona, a mnie szczęście i fortona) [Niebrzegowska 1992: 74; SSSL 1.1: 193].

Observation of the stages of lunar life - birth, growth, aging, death - makes it possible to see the moon as a living being, subject to the same biological processes as the humans. This brings the moon much closer to the human experience and enables the inclusion of "dear moon" (miesiaczek) in the "own/familiar" (swój) category. The moon is represented by means of everyday objects used in the farmyard whose look corresponds to the shape of the moon in its particular phases, and which consequently come to function as its names. Thus the new moon is called sierpik 'little sickle' in Małopolska, Mazovia, Warmia and Masuria; sierp (księżyca, miesiączka) 'sickle (of the moon)' across Poland, except Kashubia, where it is known as kosa 'scythe'. In Silesia it is kosak, kosaczek 'sickle'; in the Podegrodzie dialect - bicyk 'little whip'; okrażek 'little circle' in the region 
of Białystok; obraczka 'ring' in Sierpc; pałaczek 'bow' in Kozienice; róg 'horn' in Brzesko; rożek 'little horn' in Podhale; rogal 'croissant' in Piaseczno; rogalik 'little croissant' in Gostyń, Iłża and Mielec. The new moon is also often referred to as "a snippet" of the moon, as reflected in names from north-eastern Poland such as krajka, skrajka, skraweczka, krawka, skrawka deriving from the verb kroić 'cut', used alongside designations such as ćwierćlćwiartka księżyca/miesiączka 'a quarter of the moon' [SSSL 1.1: 188]. Such names are also used to refer to the last quarter of the lunar cycle.

The beginning and end of the lunar cycle are referred to as pierwsza/ostatnia ćwiartka/skrajka, kwadra, kwatera 'first/last quarter' or pierwszy sierp/ostatek $k s i e ̨ z y c a$ 'first crescent (lit. sickle)'/'the end of the moon' [SSSL 1.1: 187-188, 198]. The waning of the moon is referred to as $z$ petni, $z$ pełna lit. 'after fullness', pót 'half', połówka księżyca/miesiąca pótmiesiączka, półksiężyc, pótmiesiączek 'halfmoon', ostatnia połowa 'last half', półkole, 'semicircle' [Niebrzegowska 1992: 74; SSSL 1.1: 197].

In contrast to the new moon, the phase of the full moon is best conveyed by the name widek lit. 'the well-seen one' used in the Cracow region; in other parts of the country it is referred to as petnia, księżyc/miesiąc $w$ petni or na petni 'full moon', or in conjunction with an adjective: księżyc/miesiąc petny, okragly, caly 'full/round/whole moon' [SSSL 1.1: 193, 194].

The conceptualisation of the moon from the "own/familiar" (swój) point of view also takes into account its physical properties: young, new, old, leading to the creation of phrases such as młody/nowy miesiąc/miesiaczek/księżyc 'young/ new moon', stary miesiąc/miesiączek/księżyc 'old moon', młody/nowy pan 'young/ new lord', as well as księżyc/miesiąc na młodzie 'moon in its youth', księżyc na starze 'moon in its old age', księżyc/miesiąc $w$ nowiu, na nowie, nów, nowia 'new moon' [SSSL 1.1: 187]. Names for the waning moon are formed as opposites to the new moon: e.g. southern Polish wiotek, wietek (derived from wiotki 'weak, soft, old, slack', cf. wietrzeć 'to weather', zwietrzaly 'weathered') and starzyk, staryk 'old man/grandfather' recorded in Warmia and Masuria. The contrast between the old and new moon is also reflected in fixed phrases, for example in wishes and proverbs [SSSL 1.1: 198-199]:

- "God, give us health, both during the waning phase and the new moon" (Boże, dej zdrowie, jak na wietku, tak i na nowie);

- "New Year under a full moon, a year of good crops; under a waning moon, a year of hunger" (Jak Gody pod petnia, to rok urodny, a jak na wiotku, to rok głodny). 


\subsection{Moon symbolism}

The multilayered nature of the lunar symbol relies on a connection between the moon and the mystery of eternity on the one hand, and earthly life (including human fate) on the other. Rich in meanings, moon symbolism makes it possible to move freely between the supernatural and earthly spheres, or to speak about both of them at the same time. The multidimensional character of the symbol enables the formation of connections with concepts linked by cognitive paths established by experience and myth (associations with water, fertility, vegetation, the demonic world, death, etc.). The vitality of lunar symbolism, evinced especially in magical practices and their attendant system of commands, prohibitions and rituals, suggests the key role played by the moon in the interaction between the world and "otherworlds" (zaświaty). The connections between the moon and other components of the cosmos - the natural elements and planets - also assign it a special place in the universe, which is reflected in the symbolic images rendering such relationships. Mircea Eliade mentions four main spheres of lunar symbolism, found in many cultures at various stages of their development [Eliade 1958: 182-183]. Polish folk culture added its own meanings to the four universal symbolic profiles:

(1) fertility (further connected with water, woman, vegetation, mythical ancestor);

(2) cyclic regeneration (represented especially through the symbolism of lunar animals and related rituals and beliefs);

(3) time and fate (as an image of living time, determined by the cosmic rhythm, and of fate as a thread spun by the moon);

(4) transformation (related to the symbolic death and regeneration in a new form in rites of passage, or shape shifting of demonic beings).

In folk culture, the lunar symbolism of fertility links the moon and the woman. Her biological fertility cycle is correlated with the thirty-day cycle of the moon, as reflected in the word miesiaczka 'menses', derived from miesiac 'moon/month'. In Kashubia it is said of a woman in the last month of pregnancy "she is in the new moon" (ona je na młodzim, from młodz 'the last phase of the moon', lit. 'youth') [Sychta 1969: 91]. Belief in the influence of the moon on pregnant women is also demonstrated by the prohibition against walking in the moonlight with one's head uncovered (see above). Similarly, folk tradition interprets the appearance of the moon in a dream as predicting pregnancy [Niebrzegowska 1996: 179], while the full moon is thought to be conducive to love and impregnation, and the most favourable time for entering into marriage [SSSL 1.1: 195, 197]. This is apparent 
in the motif of the full moon featuring in many variants of wedding songs [SSSL 1.1: 197]:

Jak ja młodziuchny żenił się, wtenczas miesiączek spełnił się, a jasne zorze, najjaśniejsze przez całą nockę świeciły; variant:

Jakem się żenił młody, Miesiąc pełnił się wtedy: Gwiazdy niebo zasiały, Jasne zorze gorzały.
When I was young and getting married, the sweet moon was full, and a bright glow, the brightest, shone all night long in the sky; variant:

When I was getting married young, the moon was full: The sky was sprinkled with stars, Bright light was aflame.

Similarly, a belief that an image of the original married couple - Adam and Eve - is visible on the disc of the full moon adds to the moon's marital connotations. As in ancient cultures, this image, introduced to Christian tradition by the Book of Genesis, also links the moon with the figure of the mythical ancestor.

The fertility symbolism of the moon in folk culture also pertains to the plant and animal world. The system of commands which prescribe that sowing, setting hens on eggs and impregnating animals should be performed at full moon or new moon clearly relies on the perceived interdependence of growth, good harvest, animal fertility and lunar phases. The analogy between the image of the waxing moon, the growth of plants and the number of animal offspring, as well as the parallel between the full moon and full ears of corn or pods of beans, seems obvious.

Fertility symbolism, exemplified by an abundance of crops, is connected with the power of the moon over the plant world in general. According to folk beliefs, the magical properties of herbs used both to cast evil charms and for healing or protective purposes increase proportionally to the intensity of the moonlight [Kowalski 1998: 270]. In this way, cognitive paths linking the moon with herbs used by witches in their magical practices lead towards the demonic sphere (see below).

The next connection in the symbolic network linking the image of the moon with fertility and growth of plants is water, especially rain water. This association may be illustrated by weather forecasts (about rain or drought) made on the basis of what the moon looks like: "Trickle from the horn, scorching from the swell (i.e. the waxing moon with its semicircle turned towards the earth)" (Z roga cieče $z$ papa p'éce). The moon with its horns pointing down predicts rain, as does a 
halo enveloping the moon, or clouds covering it: "the moon is wading, it will be rainy” (ksamžëc brodzi, to mdze šlapa 'słota') [Sychta 1968: 281].

The symbolism of periodic regeneration is also connected with water. Belief that the moon rules the waters is among the prototypical meanings of moon symbolism in ancient cultures. The image of the moon disappearing into, and appearing out of, the darkness evokes analogical associations with a submerging in, and emerging from, water; the connection with this symbolic death and regeneration by submerging in water provides sufficient basis for the formation of a cognitive path linking water and the moon.

The Christian concept of resurrection also includes elements of the lunar symbolism of regeneration (see above), analogical to the aquatic image of regeneration by baptism.

The symbolic imagination represented the periodic disappearance and regeneration of the moon through the imagery of lunar animals, ${ }^{10}$ which in turn were used as symbols of ritual rites of passage. In Polish folk culture, the bear, which, like the moon, disappears periodically during the hibernation period only to reawaken in spring, serves to represent the succession of seasons - the return of spring after the barren winter. The folk custom of "going round with a bear" played by a man in disguise (chodzenie $z$ niedźwiedziem) was a ritual means of summoning spring, based on imitative magic. ${ }^{11}$ Parading through a village with a "bear" that had emerged from its winter hibernation was believed to restore the cycle of vegetation. The custom of "drowning the bear" (topienie niedźwiedzia), in turn, was a magical way of banishing death (winter) and summoning spring [SSSL 1.1: 181, 364]. As a symbol of death, the bear's winter hibernation (in a cave) sets out cognitive paths linking it with the underground world, and thus

10 Of lunar animals, Mircea Eliade lists the bear (because of its periodic disappearance) and the snake (cyclically changing skin) [Eliade 1958: 168-170, 175, 449].

11 The bear is an animal much associated with ritual in many cultures. The custom of dressing up as a bear during annual feasts or wearing a bear skin during initiation rituals is connected with magical properties ascribed to the animal [Krawczyk-Tyrpa 2003: 248]. This is also evinced by the Romanian practice of changing, in the case of sickly or weak children, the name given to a child during baptism to a name formed from the word bear (like Ursus, Ursina, Ursana, Ursula, Ursu) in the hope they would acquire the strength and vitality of the animal [Krawczyk-Tyrpa 2003: 249; Budziszewska 1989a: 238]. Although scholars do not see a relationship between the bear's magical properties and its symbolic function as a representation of the moon, it is nevertheless evident that the essence of the animal's extraordinary properties is related to transformation. This would point to traces of a nearly effaced cognitive path linking the bear and the moon, forming the basis of the symbolism of this lunar animal. 
with otherworldly reality, while the ritual drowning of the "bear" actualises lunar symbolism: the cyclic death and regeneration of the world.

"Going round with an aurochs" (chodzenie $z$ turem, or, in later times, $z$ turoniem) probably played a similar role, although, in this case, the symbolic image had a different structure. As an equivalent of an aurochs (tur) [Budziszewska 1995: 47-51], the turon (a wooden animal head with big horns and a snapping jaw) symbolised strength and sexuality, while its gilded horns must have evoked the image of the regenerated new moon, associated with fertility and wealth [Kapełuś 1991: 15-31]. Processions of carol singers and mummers (kolędnicy) accompanied by representations of aurochs or people disguised as an aurochs/turon usually took place during the carnival period (zapusty) between the Epiphany and Ash Wednesday, hence the ritual actualised the symbolism of fertility. However, Slavs also celebrated another festival connected with the cult of the aurochs, as indicated by its name turzyce, traces of which can be found in rituals performed around Pentecost, also called gaik and majówka [Budziszewska 1995: 48-49]. According to Wanda Budziszewska, such feasts dedicated to the aurochs, and practised in Poland as late as the times of the chronicler Jan Długosz (1415-1480), derived from the pagan ritual of Stado, extending beyond Slavic areas, since traces of the cult of the aurochs can also be found in Romania. ${ }^{12}$ Both the time of the celebrations and the name of the festival referring to the aurochs suggest a connection with spring rituals: "On this day and the three following days ancient Slavs celebrated the god Tur (Aurochs) (...), and they offered all their love acts in veneration to the demon Tur" [Budziszewska 1995: 50].

Traces of the cult of the aurochs, and the symbolically interconnected properties of fertility and vitality ascribed to both the animal and the moon, suggest that in Slavic culture the aurochs, like the bear, was also a lunar animal symbolising a moon deity. This is apparent in the identical symbolic representation of the aurochs and the moon - the gilded horns ${ }^{13}$ - especially that the

12 Names deriving from the word tur (aurochs) suggest vestiges of the Slavic festival of the aurochs, celebrated during the Pentecost period; cf. Slovak Turíce, Croatian turica. The root tur features also in the dialectal Romanian name of a demonic being turică [Budziszewska 1995: 50].

13 Wanda Budziszewska [Budziszewska 1995: 50] notes that the aurochs' horn featured in coats of arms, and that heroes in Russian epics (bylina) drank from enormous aurochs horns set in gold, while in Lithuanian noble families such horns were passed on from generation to generation. The cap-turon (goat-aurochs) from a Polish folk tale also had golden horns and hoofs. In folk Christmas plays, the so-called Herody, Herod's golden 
bull was a common symbol of the moon and fertility in ancient cultures [Eliade 1958: 92-93]. Cognitive paths linking brightness with divinity, royal power and gold lead to further connections with wealth and prosperity, also identified with fertility in rural culture.

As part of the annual celebrations welcoming the return of spring, the rituals of "going round with the aurochs" and "the bear" come to be included in a more general symbolic framework of the periodic regeneration of nature's power governed by supernatural cosmic forces. In a characteristic synthesis, such symbolism relies on images of those animals whose physical strength could represent both earthly vitality and divine majesty.

The symbolism of periodic regeneration is also visible in the scene of remoulding the moon in hell fire, repeated from the time of the first murder committed by Cain on his brother Abel, as recounted by a legend quoted in Chapter 8.1 above. The first sin of fratricide, the belief that purgatorial souls (including the souls of Cain and Abel) do their penance on the moon and the image of the purification of the moon in hell fire are mutually related. It is thus possible to interpret the cyclical remoulding of the moon as the purification of souls dwelling there, enabling their transformation and passage to heaven. The symbolism of purification builds cognitive paths between the moon and fire, sin and penance, guilt and redemption. The next scene, in which the devils tear the moon apart and attempt to bury its remains in the ground, relies on the opposition light vs darkness (based on the COLOUR schema). The symbolic imagination employs the cognitive paths linking darkness with demonic forces and light with divinity to create a profile of the moon as representing the duality of the concept of the sacred as the forces of both good (the divine sacred) and evil (the demonic sacred). The image of the regenerating moon represents the inexhaustible power of the divine sacred ruling over the physical and metaphysical worlds, irrespective of the actions of the forces of evil.

The image of the death and regeneration of the moon is grounded in myths and points to its symbolic association with eternity. Eternal life represented by the constantly regenerating moon does not stand in contradiction to the role performed by the lunar cycle as a measure of earthly life. The essence of this symbol is that it can combine different planes of existence, moving between one and the other or showing them to be mutually complementary. This feature is particularly visible in scenes of initiation, usually taking place in the presence

cloak, decorated with gold horns symbolising the moon, was supposed to protect him from danger [SSSL 1.1: 172]. 
of the moon. In wedding scenes, the moon appears in the background of ceremonies accompanying the rite of passage: the passing on of the maiden garland, slicing the wedding bread (korowaj), or putting on the wife's bonnet (oczepiny).

The lunar symbolism of time and fate illustrates most clearly the close relationship between the human being and the moon. The analogy between the phases of the moon and human life from the cradle to the grave becomes the basis for further comparisons, measuring out the rhythm of earthly life in correlation with the cosmos.

The connection between man's fate and the moon is rendered by the symbolic image of a spinner located on the moon who spins a thread of gossamer human life, thus incorporating it into the sphere of eternity. By contrast, the image of the Sibyl sewing a shirt on the moon symbolises earthly existence. When the Sibyl finishes her work, the world will end [SSSL 1.1: 167, 185]. Such images correspond with the ancient concept of the Moirai spinning the thread of human fate [KopSS 1990: 250]. In many cultures, thread is one of the archetypal symbols of life (fate), based on the LINK schema (the umbilical cord archetype), representing the connections between earthly existence and infinity [Eliade 1991: 117-118]. Polish folk culture actualises the symbolic image of thread-fate through a system of prohibitions against weaving, spinning and winding yarn at New Year and on All Souls' Day, i.e. at ritual times of passage: periods vulnerable to intervention from supernatural, including demonic, forces, which could tangle the thread of human life in the coming year [KLS 1967: 477]. The symbol of the thread of life is also present in family rituals, especially in rites of passage. White linen and thread were placed on the threshold before a newborn baby was taken to church to be baptised; a linen towel was also used to tie the hands of the betrothed. During feasts held in honour of the souls of the departed, a white towel placed between the table and an open window provided a symbolic path for the souls of the ancestors arriving from "otherworlds" (zaświaty) [Benedyktowicz D., Benedyktowicz Z. 1992: 63, 93, 123].

The LINK schema and the archetypal symbolism of thread set out cognitive paths connecting the complex that includes fate, thread, spinning, weaving, warp and cloth, leading to the development of fixed metaphors for life such as przerwać nić zycia 'break the thread of life', i.e. die, osnowa życia 'the warp of life', przędza życia 'the thread of life', tkać los 'to weave one's fate'.

This complex of concepts represents life as a network of interconnections and includes images of bonds and magical knots, which display an axiological ambivalence typical of symbolic representations [Eliade 1958: 181-182]. Prototypically, they are charged positively, in keeping with the value normally 
ascribed to the LINK and WHOLE schemas. However, depending on the context, their value may shift towards the negative pole when knots symbolise problems, restrictions, difficulties in achieving the aim, or a connection with demonic forces (e.g być opętanym przez diabła, lit. 'to be bound by the devil', i.e. possessed). Magical practices performed by witches included binding someone's happiness, life, memory, etc. [KLS 1967: 292], while spinning, winding and weaving during prohibited periods could bring about misfortune. The spinner might inadvertently "tangle wool" and thus "entangle a wolf/horse/stallion" (wilka/konia/ogiera umotać), bringing a wolf to the village, or her wool might tangle into a "devil's knot" (djôbli węzet), which could cause farm animals to go lame [Sychta 1968: 196; 1969: 117; Treder 1989: 73].

In turn, positive value is ascribed to commands to untie and prohibitions against tying knots, applied in imitative magic in liminal situations, especially during childbirth or death (gestures of untying combined with opening) [KLS 1967: 192; Treder 1989: 72]:

- when a woman is in labour, her hair should/needs to be untied,

- all knots in her clothes should/need to be untied,

- everything in a room in which there is a woman in labour should be opened up.

The multilayered symbolism of the link between the human being and the moon, as well as the link between the moon and heaven (the sacred) governing human fate, is enacted in dialogue where the moon "participates" as an interlocutor or witness:

- in salutations addressed to the new moon (see above), e.g. "Welcome, new moon, good fortune and a crown for you and good health for me" (Witaj księżycu w nowie, tobie kuruna fortuna, mie zdrowie) [SSSL 1.1: 188]; the moon's influence on human fate is also evinced by a Kashubian belief that bowing to the moon three times when making a wish will guarantee that that wish will come true [SSSL 1.1: 188];

- in supplications addressed to the moon during the wedding ritual, e.g. "O shine, dear moon, shine above the door, (...) Young Mary dear, sit here with us (Oj świć miesiaczku, świć nade drzwiami, (...) Młoda Marysiu, siadoj z nami); "Sweet moon, shine from paradise on our wedding bread (korowaj), so that it is bright [when we] slice it finely" (Swjeć miesiączku z raju, naszemu korowaju, żeb było widniusieńko, krajać go drobniusieńko); "Shine dear moon, with your horn towards my small bedroom, I will be counting money for my garland" (Świećże mi miesiączku, rożkiem do kumory, będe rachowała za wianek talary) [SSSL 1.1: 174]. 
- in cure incantations, when the spellcaster expels illness from the body of the sick invoking the power of divine persons, the sun and the moon, e.g. "I cast a spell on you, guest, by [the power of] the sun and the moon, the Transfiguration and the Last Judgment" (Zaklinam cię gościu na słońce $i$ księżyc, na Przemienienie Pańskie, na sąd ostateczny) [SSSL 1.1: 134];

- in oaths sworn upon the moon, e.g. "as I want to look at the moon" (jak pragne księżyc ogladać!) [SSSL 1.1: 166]; "Haven't you made vows to me upon the moon and stars? For anyone would have believed such vows" (A boś ty mi raz przysiegat Na księży na gwiazdy? Bo to na taka przysięge Uwierzyłby każdy); "I have the moon and stars as my witnesses" (Mam ja na świadectwo Miesiaczek $i$ gwiazdy) [SSSL 1.1: 178];

- in curses and maledictions, e.g. "may you not see the moon" (żebyś nie widziat księżyca!) [SSSL 1.1: 166].

The linguistic structure of speech acts addressed to the moon points to its symbolic function as a ruler (a hierophany of a deity). At the same time, such structure provides a cultural model for how the moon should be referred to and indicates its highest axiological value, connected with truth (oaths), happiness (maledictions), fate (summoning the moon to participate in wedding rituals). The more or less fixed forms of addressing the moon to a large extent repeat the model of formulas directed to the sun (greetings, oaths, maledictions) and to the earth (oaths, maledictions, curses). The conventional character of such texts reflects the manner of conceptualisation of the structure of the world as a network of hierarchical interconnections. The use of the LINK, FORCE and VERTICAL schemas underlying such phrases clearly indicates that the bond/knot linking the human being with the sun/ the moon is symbolically perceived as a relationship between subject and ruler (hierophany of a divinity).

By contrast, the symbolism of knots/bonds acquires a negative charge in magical practices associated with witches, who tie up knots in order to form an obstacle, or to enclose (e.g. "to tie up someone’s luck" (zawiązać komuśszczęście)).

The symbolism of transformation based on the opposition light vs darkness derives from the rhythm of lunar phases, and thus constitutes an elementary component of the experiential base as the COLOUR schema. The symbols of light and darkness complement each other, creating a complex image of the whole. The moon, emerging from darkness, is perceived as an omen of light and good, similar to the rising sun, as reflected by the customs of greeting both the sun and new moon, accompanied by gestures of prayer, supplications and practices of divination. Additionally, the light of the moon is regarded as a gift 
from God, the nocturnal substitute of the sun, warding off the demons of darkness [SSSL 1.1: 143]:

And moon, lovely moon, is the son of the sun. When the sun goes to sleep and has a rest after a day's hard work, it leaves the moon for us so that we are not harried by spirits of the night.

A księżyc, śliczny miesiączek, to syn słońca, które, gdy śpi i odpoczywa po ciężkiej pracy, zostawia go nam, aby człowiek nie był napastowanym od strachów nocnych.

On the other hand, the new moon also stimulates the activity of demons and lends its power to witches, whose harmful practices become more efficacious. The moonlight, then, symbolises a dual power, subject to the forces of good, representing life, and forces of evil, connected with death. At the same time, however, it does not give ultimate form to either of them. Mircea Eliade ascribes the emergence of all kinds of dualisms present in myths and symbols to lunar phases: "The phases of the moon give us, if not the historical origin, at least the mythological and symbolic illustration of all dualisms" [Eliade 1958: 183].

Symbolism connected with things hidden in darkness and not yet fully formed is also closely bound to the moon (fertility, divination, prophecies). Primal experience of the succession of these contrary states is stored in the experiential base as diametrically opposite ways of existing in the world. This makes it possible to use the changes of the moon as a symbolic representation of the dichotomy between hidden life (either not yet born, or the afterlife) and full life, which transforming from the invisible to the visible form - changes its shape.

Demons emerging as a result of the moon's influence may turn into animals (e.g. a black dog, ram, horse), a wandering flame, or may take the shape of a human figure (e.g. a drowned man will appear in the form of a child). Witches, conversely, may turn from human beings into animals, e.g. a mouse, dog or frog [Pełka 1987: 196].

Similarly, figures known from oral folk tales also undergo symbolic transformation. In a well-known story about a prince-snake, a girl has to marry the snake guarding the spring whose "living water" ( $\dot{z} y$ wa woda) she needs to cure her mother [Niebrzegowska-Bartmińska 2007: 135-149]. The morphological structure of this tale is clearly of lunar provenance. Its basic feature is obviously the transformation of the snake/monster into a prince, as well as the time (night) when the change occurs. The next clue is provided by the snake/monster as such, known as a lunar animal in many cultures. In addition, according to the tale, the snake is the guardian of "living water", which restores life, youth and health, and thus effects a transformation. This capacity for change (birth in a new form) links water with the moon. Another correspondence to be noted involves the 
relationship between the snake-prince and the woman. The powers of fertility ascribed to the moon naturally connect it with femininity, and the relationship between the woman and the snake (symbolising the moon) is a common motif in culture [Eliade 1958: 167-171].

Lunar metaphysics presents the world under the governance of the moon as a world of mutability: winter turns into spring, youth into old age, life into death, death into eternal life; the seed sprouts and turns into a plant, a witch assumes an animal shape, while a vampire transforms into a small child. The cycle of moon phases governs the rhythm of life on earth, subjecting it to the cosmic rhythm. Thanks to the synthesising process of the symbolic representation of change, the connection between these polar opposites is preserved. The continuing vitality of symbolic images is ensured by their ritual re-enactments, as well as by tales, beliefs and convictions, passed on through acts of communication and reflected in traditional patterns of behaviour towards the moon. Awareness of socially accepted norms, whether observed or not, includes the participants of communication within the framework of "one's own/ familiar" world.

The stereotype of interaction between the moon - a representative of the metaphysical world - and the physical world is built on the basis of conceptualisations which are ingrained in the consciousness of language users. These conceptualisations may be actualised in a more or less conventional linguistic shape, or in a non-verbal form of contextual realisations relying on stereotypical semantic content (magical practices, divination, beliefs, e.g. that those born during full moon are strong and healthy, or that souls of sinners do their penance on the moon), which then become the basis for symbolic representations of the moon's properties and functions (e.g. the absence of the moon in the sky symbolises death). The moon's connotations and symbolism, in turn, point to other concepts, thus linking the meanings ascribed to it with a network of other images representing the interaction between worlds (moon-regeneration-immortality-majesty-divinity). They also become the starting point for the formulation of reproducible directive texts (commands, prohibitions, threats, warnings, recommendations) as well as partly conventionalised forms of address directed to the moon. Incantations, oaths, maledictions, salutations and proverbs are among the most conventionalised textual forms. Processes of lexicalisation, in turn, involve: phrases whose semantic structure indicates the moon's direct influence on human beings (e.g. łucznica 'sleepwalking', miesięcznik 'sleepwalker', lit. 'mooner') or its functions (miesiaczek 'month', miesiączka 'mensis'); fixed phrases (na starze 'on the wane', na nowiu 'during the first phase of the moon'); 
numerous names for the phases of the moon (nów 'new moon', wiotek lit. 'slack/weak moon') and derivative forms (miesiączek 'little/dear moon', rożek 'little horn'). Such phrases and forms often demonstrate an emotional attitude to the various phases of the moon, since their invocation is believed to provide access to the powers that they represent. 



\section{Conclusion}

\section{Preconceptual schemas in stereotypical representations and interpretations of the interaction between the physical and metaphysical worlds}

Preconceptual schemas have served both as the basis for the interpretation of the supernatural phenomena examined in this study and provided the starting point for tracing cognitive paths linking complex experiences into a whole and for imaging forms of interaction between the physical and metaphysical worlds. Given the fact that in the oldest of cultures it was the natural elements that served as images of supernatural forces, the present analysis has treated them as the basis for an examination of the spiritual dimension of human existence and man's position in the cosmos.

In folk culture, the impact of the supernatural world on the human condition is perceived from a religious point of view, thus assuming that the entire cosmos is ruled by God. The concept of God's causal power, which not only brought the world into being, but also governs it (a belief that is displayed in cosmogonic myths and perpetuated through ceremonies and rituals), relies on a complex of preconceptual schemas, among which FORCE, CONTROL and LINK play the most important role. To the religious mind, the four natural elements appear as the primeval matter used during the creation, as manifestations of constant divine control over the world and as a connection between God and human beings. Hence it is God's power that is always perceived to initiate a chain of interactions between heaven and earth. This power is manifested in scenes in which the elements - as instruments of God's will - play the role of the agent (while the Creator Himself, as an invisible spirit, remains in the background). From the point of view of the conceptualiser, then, contact with "otherworlds" (zaświaty) involves receiving signals from the metaphysical sphere and responding to them appropriately. This entails taking precautions against intervention by supernatural forces on the one hand, and creating conditions conducive to the use of benevolent powers of Providence on the other. In such cases, the human being takes the role of the visible agent, while the sacred remains the actual agent, invisible in the scene. In all cases, the conceptualisation of the relations between the human and supernatural worlds requires recourse to the power of the sacred.

Consequently, different models of the FORCE schema are present in all magical and ritual practices. In a stereotypical approach, divine contact with 
the world always relies on the FORCE schema, in which God is the SOURCE OF FORCE, manifesting its presence through actions leading to an immediate result. Human response, on the other hand, is structured in terms of a combination of various patterns of FORCE. Communication with the sacred usually involves actions based on the ATTRACTION of divine FORCE, both in order to obtain graces and to reverse unfavourable circumstances. Propitiation of God's wrath or protection against evil forces additionally employ the BLOCKAGE, DIVERSION, or REMOVAL OF RESTRAINT schemas. The use of various magical means, relying on the properties of the particular natural elements, follows the INTENSIFICATION OF FORCE schema.

In all scenes involving counteraction to the sacred, demonic forces not only appear inferior to God's power as such, but also ineffectual against the forces of nature (fire, spring water and earth) that represent it. Nevertheless, the Godcreated world is tainted by the persistent intrusion of evil forces, hence belief in the threat of constant danger and the necessity of a cyclic renewal, reflected both in the rhythm of the cosmos and the corresponding magical-religious rituals.

\section{The sacral profiles of the four elements and the relations between the physical and metaphysical worlds from the perspective of "own/familiar" (swój) vs "strange/alien" (obcy)}

A comparison of the recurring combinations of preconceptual schemas structuring stereotypical ways of perceiving the sacral profiles of the four natural elements makes it possible to demonstrate their contribution to the shaping of the relations between the categories of "own/familiar" (swój) and "strange/alien" $(o b c y)$. Water, earth, air and fire, endowed with a divine life-giving power in the earthly world, serve to represent a providential type of link (blessing), which is based on the FORCE, LINK, CONTROL and BALANCE schemas. The highest axiological value ascribed to heavenly grace co-creates conditions conducive to the establishment of relations based on the "own" schema. Direct experience of the life-giving power of the elements and re-enactment of God's gestures in magical practices reduce the distance between the physical and metaphysical worlds. The purification and sacralisation of space by means of fire and water, the properties of earth used in healing practices, or the reviving power of a kiss may illustrate the point. Re-enacting the moment of creation, man establishes direct contact with the sacred. By invoking God's power, he/she gains authority to act on His behalf. On occasions such as these, relations between God and the individual become very close, and in extreme cases, when the act of creation is directly re-enacted 
(e.g. in the ritual of the first sowing in spring), the agent is identified with the Creator. Access to the magical power of the elements is conditioned by adherence to strictly prescribed norms of behaviour, which entails acting in accordance with the INNER COMPULSION schema. Reciprocal communication between man and the sacred through the medium of the elements proceeds according to the same pattern, which involves a combination of the FORCE, CONTROL and LINK schemas. Thus the power of grace is manifested in the form of the life-giving properties of the elements, which sustain life and maintain order on earth, while man gains access to the power of the sacred by acting in the name of God according to strictly prescribed rules.

Additionally, in the physical sense, water, fire, earth and air function as bridges linking the human and metaphysical worlds. As long as the relations between the two spheres are predominantly determined by the LINK schema, we may speak about the creation of "own/familiar" space. Even when employed to image the journey of souls to "otherworlds" (zaświaty), the natural elements constitute recognisable signs of "this" world, or they determine its borders. This, however, is where their role in creating the "own/familiar" sphere ends. Leaving the world of the living, souls come to bridges linking two banks of a river at the end of the world, they travel along a road leading to a fork, or come to gates behind which fire divides heaven from purgatory and hell. Souls which cannot detach themselves from the earth are consigned to the clouds. While these are still elements of the "familiar" world, at the same time they also co-create an otherworldly reality structured by means of the CENTRE-PERIPHERY schemas, which play a dominant role in the projection of alien space.

The FORCE schema underlying images of the destructive power of the elements serves to create stereotypical scenes of cataclysms caused by God's wrath. A conflagration, a flood, the earth opening up to swallow sinners, or pestilent air bringing death to all living creatures are instruments of punishment. God's intervention strikes at the very core of evil, annihilating it completely. The aim of this destructive act is to restore divine order, and thus re-establish the link with the sacred. Hence the destructive power of the elements serves as an image of the providential order of the world. Even though punishment relies on FORCE acting according to the model of OUTER COMPULSION, the sense of guilt nevertheless prompts the human being to accept the visitation as a just sentence. The interpretation of the punitive mission of the elements bringing death and destruction is construed in terms of the DESTRUCTION (PART-WHOLE) schema, as well as the CONTROL, LINK and BALANCE schemas. The experience of the power of the elements is thus perceived ambivalently: on the one hand it is an outside intervention which destroys the "own" world, and thus may 
be seen as alien; on the other hand, since it destroys evil (an alien force) and restores original purity to the contaminated sphere, thus connecting it again with the sacred, it must be accepted as "own". The possibility of resorting to God's mercy, whose power can appease the elements, or at least limit the extent of destruction (as in the case of a flood or a fire), also has a bearing on forging closer ties between an admonishing heaven and a sinful earth.

"Alien" scenery is well exemplified by images of the ultimate cataclysm at the end of the world. Even though in Christian tradition it heralds the beginning of eternal life, the prospect of the Last Judgment and final punishment arouses fear. Nonetheless, from a religious point of view, the destructive powers of the elements acquire a positive axiological value. Images of the annihilation of the world by iron fire, stone rain, earthquake and flood are structured by the CONTROL and LINK schemas, thus anticipating a vision of eternal happiness and unity with the Creator for those who will prove worthy. After the final cataclysm "the other world" will transform into the "own" world for the good souls, while the damned will remain in the alien sphere. The image of the "own" sphere of heaven is shaped by the profile of heavenly fire, and the "alien" sphere - by the profile of hell fire.

The FORCE schema also underlies the image of the perennial fight between God and Satan, as a result of which demonic forces are located at the bottom of the waters or underground, where God cast down Lucifer. Consequently, the underwater and underground worlds become images of the most alien vision of "otherworlds", i.e. hell. The landscape of hell also features the motif of fire. Likewise, air is not free from the presence of demonic forces, which can use the force of wind to man's disadvantage, hide in the clouds and control the movement of air.

The location of the devil's abode as underground or at the bottom of the waters is grounded in the CENTRE-PERIPHERY and UP-DOWN schemas, which are usually employed to image alien, unfamiliar spaces. Moving beyond this prototypical location, demonic forces come to spread across all peripheral areas of "this" world, as evinced by names of demons which are derived from their dwelling places: waters and littoral areas, fields, swamps, forests and air. The presence of demons on earth is seen as evidence of the constant intrusion of "otherworlds" into earthly reality. This has a bearing on the duality of the conceptualisation of space, perceived as "own/familiar" - inhabited and controlled by people on the one hand, and "strange/alien" - distant, uninhabited and open to impure forces on the other. The imaging of the alien world in this case relies on the presence of representatives of "the other world"; as such, it is construed by means of the spatial CENTRE-PERIPHERY schema, while the 
LINK and CONTROL schemas are engaged in delimiting the borders dividing "own/familiar" from "strange/alien" space (thresholds, gates, wayside crosses).

The same schemas underlie norms developed by the community to specify appropriate behaviour in both spheres. In the "own" sphere, such norms must be observed in keeping with the model of INNER COMPULSION; by contrast, alien space, which is subject to the power of demons, appears amorphous, devoid of rules and control. Victims of evil spirits may be captured by a whirlwind or dragged into the depths of the waters, lured into swamps or into the wilderness (subject to forces of EXTERNAL COMPULSION). As a result of the presence of impure forces, the natural elements reveal their other, destructive side. In this capacity, they serve to represent symbolically the unfamiliar, alien, dangerous sphere, the sphere subject to intrusion by "the other", demonic world. This is accompanied by a negative axiological value and lack of LINK. An alliance with demonic forces (signing a pact with the devil) entails not only exclusion from the community, but also the loss of one's soul, which means permanent expulsion from the familiar sphere in this and the other world.

\section{The shaping of relations with the sacred world through communicative acts}

The use of the natural elements as symbolic images of God's presence (a gust of wind, a burning cloud, a burning bush), as well as His infinity and boundless power (the expanse of the ocean or air) makes it possible to lift the veil on the mystery of transcendence. Recourse to familiar phenomena in order to facilitate comprehension of what is, by nature, unfathomable, is marked by ambivalence. On the one hand, it reduces the distance to the sacred, thus including it among the categories of the own, familiar, knowable world. On the other hand, however, symbolic representation presupposes the impossibility of getting to know the mystery of transcendence through the senses, and thus entails a feeling of remoteness and alienation. All the same, identification with the unfamiliar sphere of the sacred depends on constant attempts to discover and maintain a link through communication, which is only possible when one adopts a religious attitude.

A stereotypical representation of God's communication with the earthly world through the medium of the four elements serves as a model for interactions on the part of human beings, who use fire, water, air and earth to establish contact with the sacred through ritual actions of symbolic character. Baptism, the blessing of water and its use for protection, purification and sacralisation, lighting a sacrificial fire as a sign of maintaining contact with God, a ritual blessing of fire and its 
use to purge and sanctify space (making it sacred, and thus also "own"), giving back the body to the earth and the last breath to God, are all forms of communication with sacred reality, as well as a sign of identification with, and belonging to, the divine world, regarded as "own".

Non-verbal means of communication, involving mainly ritual actions, form the foundations of stereotypical semantic contents deriving from established beliefs and convictions and their situational repetition, which creates ideal conditions for the achievement of semantic stability. As such, they become part of the cultural code enabling communication between members of the same community. The knowledge of context, and the ability to predict dialogue sequences, make it possible for the interlocutors to adopt a predetermined communicative strategy. Such a capacity for communicating by means of a restricted code is an indicator of bonds connecting a given social group, and grants an individual the status of a member of the "own" category.

Socially generated knowledge about the interaction between the physical and metaphysical worlds is grounded in myth, which gives rise to symbolic representations re-enacted in ritual. Thus the triangle myth-symbol-ritual is the basis of a cultural code. Myth is connected with faith and provides models of behaviour; symbol feeds the imagination, while ritual brings both of them to life by a re-enactment of the model. Symbol juxtaposes the known with the unknown, thus opening the semantic system to the possibility of forming new links with concepts that come to build a network of connotational connections, creating a chain of associations (e.g. the symbolic representation of the divine life-giving breath provided a motivation for the creation of phrases connected with creativity - natchnać kogoś 'inspire someone'; with life - tchnać w coś życie 'to breathe life into something'; with death - wyzionać ducha 'breathe out one's spirit', paść bez ducha 'fall without spirit'; with feelings - upaść na duchu 'one's spirits sink'; and with immateriality - zniknać jak duch 'disappear like a ghost').

Through re-enactment of the model and the use of symbol, ritual creates a new situational context for old meanings. Participation in ritual actions and the manner of their performance require verbalisation: the establishment and transmission of rules of behaviour, organised into a system of norms and directives like należy 'one should', trzeba 'one ought to', nie wolno 'one must not/it is forbidden. The force of their impact also depends on the degree of identification of the individual with the group and on the internal need to comply with socially binding norms and values. A common system of values is one of the most important factors which determine one's sense of identity. The perlocutionary force of normative-persuasive communicative acts depends both on group pressure and on whether adherence to the norms is in the individual's interest. 
Ritual forms of behaviour - based on models - entail formalised utterances, addressed to supernatural powers in order to change an existing state of affairs. The act of creation by the divine word serves as an archetype of all verbal acts. Such verbal acts (usually reinforced by gestures and other magical practices) rely on belief in the power of the active word and implicitly or explicitly invoke the causal power of the sacred. The content of verbal formulas of this kind varies in terms of length, function and the circumstances when they are employed. What they have in common is a high degree of conventionalisation and the principle of inviolability of the content, even though they may also serve as the basis for the creation of new magical texts. Repetitiveness, and thus the possibility of re-enactment, is evidence of their stereotypical character. As a consequence of their conventional and ritual nature, as well as strictly prescribed circumstances of their use (including the place and time), such verbal formulas are classified as texts of culture (understood as a complex of verbal and non-verbal actions) [Eugowska 1990: 179; Niebrzegowska-Bartmińska 2001: 103; 2007: 194; Tsiv'ian 1993: 111].

An examination of the ways of communicating with supernatural forces in magical formulas reveals the conceptualiser's attitude towards the sacred from the "own/familiar" vs "strange/alien" perspective. Direct addresses to the sacred in dangerous situations, e.g. "God/Mother of God/St Joseph, save me!" (Boże/ Matko Boska/Józefie Święty ratuj!) (preceded by spitting in the direction of an oncoming whirlwind believed to be caused by the devil) introduce a clear polarity between the invoked causal power of the divine sacred, with which the subject identifies, and an alien and hostile satanic force.

In oaths and binding spells like "May I not see the sun" (Niech nie ujrze słonca), "May the earth swallow me if I don't speak the truth" (Niech mnie ziemia pochłonie, jeśli nie mówię prawdy), the invocation of God as a witness is implied by the linguistic correlative of FORCE niech 'may' (may God's power cause me to... if I don't speak the truth). By calling upon God's authority and justice, individuals swearing an oath create a bond linking them with the sacred, and they consent to punishment should they lie or not keep their word. Thus they declare their belief in divine justice, which entails acceptance of the divine scale of values and an identification with this system. This type of communication also presupposes the presence of God at the moment of making an oath and His active reaction in case it is breached.

A seemingly similar form of relationship (expecting God's active response and readiness to mete out punishment) is created by means of curses and maledictions, in which the person who utters them openly calls upon God to deliver justice: "May you become all twisted/ be struck by lightning/ not leave hell” (Bodaj cię pokręciło/ piorun trzasł/ żebyś z piekła nie wyszedł!; Bodaj i.e. Bóg 
daj, żeby, lit. 'God grant that'). Through God's power, maledictions are meant to bring illness, death or eternal damnation upon the cursed one. Considering that only God has the right to utter curses, the person who produces a malediction positions him/herself as a mediator acting in God's name [Engelking 2017: 139143]. The degree of identification with the sacred in curses is thus much higher than in oaths, even though they rely on the same belief in, and acceptance of, the justice of divine verdicts.

Binding spell formulas addressed to fire, hail, disease or "bad charm" (urok) involve speaking in the name of God (Jesus Christ, Holy Spirit, Holy Trinity) or the Virgin Mary. Invoking the power of the sacred and the right to act on its behalf, the spellcaster utters a command, a request or a threat demanding that an action cease, symptoms be reversed, or illness leave the body. The adoption of the role of God's representative/mediator presupposes a very close link between the spellcaster and the sacred, and may follow different patterns.

In incantations expelling disease from the human body, the healer may invoke Jesus or the Virgin Mary - the first doctors, who themselves banished illnesses during their stay on earth:

As the Most Blessed Virgin and the Lord Jesus were walking along a road, they met sciatica (strzelec-postrzelec, lit. 'hunter-shooter'). "Where are you going?" "I'm on my way to this (...) man (...); I'll give him aches and pains in his bones and suck his blood." "Don't go there. We've been there already and done a good thing."

Szła Najświętsza Panienka z Panem Jezusem drogą, napotkała strzelca-postrzelca. Kaj ty idziesz strzelcu-postrzelcu? Dy ja idę do tego człowieka [...] i będę mu kości łupać, krew ssać. Nie chodźże tam strzelcu-postrzelcu, bo my już tam byli i dobrze sprawili. [Niebrzegowska-Bartmińska 2001: 157]

In such cases, identification relies on a repetition of the model, and the Holy Virgin and Jesus Christ appear to belong to "this" world; hence the distance is greatly reduced, providing an opportunity to form a closer relationship with holy persons or acting in their name.

In binding spells addressed to fires started by lightning, the spellcasters' interactions with fire are based on the principle of similarity (both the spellcaster and fire are guests belonging to a different world), which entitles them to speak in the name of God [SSSL 1996: 346]:

Ogieniaszku, Zygmuncie,

Świętym krzyżem żegnam cię

Tyś gość i ja gość,

Nie pal się, bo już dość.
Fire Zygmunt, dear sir, With the sign of the cross I thee bless You're a guest and I'm a guest Now, stop burning, have a rest. 
Fire, you burning flame, the Lord Jesus, a man of God, orders you, through me, His unworthy servant, not to spread any further (...).

Ogniu, ty płomieniu gorejący, rozkazuje tobie Chrystus Pan, mąż boży, przeze mnie, sługę niegodnego, abyś się dalej nie rozszerzał (...).

Thus such mediators build their relations with the sacred by distancing themselves from "this world" and fully identifying themselves with the supernatural one, showing respect for, and compliance with, God's will.

A mediator may also be someone who imitates Christ by living a life of a wandering beggar (dziad), and thus is regarded as a man of God. The figure of God-beggar merges Christ with earthly reality, identifying Him fully with the "own/familiar" sphere. This, in turn, ennobles the wandering beggar and entitles him to play the role of Jesus. As a result, supplications made by a beggar - man of God - to heaven were believed to be much more efficacious, and his actions in the name of God (the issuing of warnings or commands) fully justified. The identification of a wandering beggar with Jesus relied not only on the acceptance of his divinity in the human dimension, but also on acknowledgement of his status as a representative of heaven in "this" world.

Supplication formulas in prayers function in a similar way. The conceptualiser appeals directly to God's mercy, often additionally invoking the intercession of the Virgin Mary or the saints. Consequently, it is not the conceptualiser, but figures belonging to the sacred sphere that play the role of mediators. The choice of heavenly intercessors is guided by their perception as representatives of "one's own/familiar" sphere in "the other" world, in the belief that their human origins will induce them to show more understanding and make them more inclined to help those who have not yet achieved unity with the sacred, but strive for it in their earthly existence.

For those adopting the attitude of worship, the sacred becomes the ideal to strive towards; they fully accept and believe in the power of God's mercy and the intercession of the saints. On the other hand, however, prayers also demonstrate a pragmatic approach. Rituals for welcoming the sun as an equivalent of the sacred, and prayers addressed to God at sunset, have purely practical intentions. The morning prayer is a form of casting a spell to ensure success, and the evening one is meant to provide protection from evil. Conventional prayer phrases such as "I lie down with God/ I get up with God/ I give my soul to God" (Z Bogiem ligam/ Z Bogiem wstaje/ Bogu dusze ma oddaję) have the markings of magical incantations [Krajka 1995: 190-192]. This is evidence of the fact that the folk worldview does not make a rigid distinction between magical and religious attitudes. In both cases verbal actions rely on the same preconceptual 
schemas: FORCE, LINK and CONTROL, and they have a corresponding goal: to shape reality by releasing the causal power of words thanks to the invocation of the original source of all power, i.e. God Himself.

The convention of the so-called "wish-making carol" (kolęda życzaca) is similar, the difference being that carol singers present themselves as mediators, bringing people the gift of a good word straight from heaven, thanks to which this projected reality has the force of a self-fulfilling prophecy [NiebrzegowskaBartmińska 2001: 206]:

Dobry wieczór, panie gospodarzu, do ciebie woła cię Pan Bóg na podareczek do siebie. Urodziło ci się sto kup żyta na polu, dajże ci, Boże, szczęścia i zdrowia $\mathrm{w}$ tym domu.
Good evening, master of the house, the Lord God calls you to give you a little gift. Your field has yielded a hundred stacks of rye, may God give you happiness and health in this house.

The festive spirit of Christmas with all its customs evokes the wonder of the Nativity, uniting the physical world with supernatural reality. Accordingly, God's blessing is bestowed on the earth, which comes to share in the properties of the heavenly sphere. Carol singers and mummers (kolęnicy), who re-enact the sacred time, perform the role of witnesses of the Nativity. In this way, they bring the gift of grace to the house, thanks to which all the participants experience communion with the sacred. Such attempts to establish and maintain a constant link manifest a need to be closer to heaven. The performance of rituals and celebration of holidays, especially Christmas and Easter, cyclically reactualise the time of origins - a return to the act of creation - when earthly and divine realities still constituted one whole, untainted by evil. While performing a ritual, the conceptualiser comes to play the archetypal role of the agent, re-enacting the divine creation of the world, which gives him/her the right to act in the name of God.

The distance separating both realities is determined by the point of view of the conceptualiser, which is not limited to the physically understood centre but also involves his/her spiritual attitude, deriving from a belief in the magical power of ritual, and so bringing him/her directly into contact with the supernatural world. Thanks to the presence of the LINK schema, interactions with the divine sacred are placed in the "own/familiar" category. In combination with the CENTRE schema, this may produce a prototypical effect, which in some cases comes to be the dominant element. Consequently, a sense of belonging to the "better world" is actualised in the course of a constant dialogue between "this" and "the other" world. 


\section{The physical and metaphysical worlds in a cosmic perspective}

The inclusion of the sun and the moon introduces a cosmic dimension to the present analysis of the relations between the world and "otherworlds" (zaświaty). This dimension is crucial in the very act of creation, which determines the role of the particular components of the cosmos vis-à-vis one another and the Creator. In the "own/familiar" perspective, relations between God, the four elements and the earth rely on the re-enactment of the model of human family (with either a caring or, conversely, severe God the Father looking after His human children). A change of perspective, preserving the dominant position of the Creator, obliterates the division into the earthly and metaphysical worlds, extending the concept of the "world" to encompass both spheres. In folk culture, the cosmic model is construed in terms of the metaphor THE WORLD IS A KINGDOM, whereby the interactions between God, the earth, the four elements and the heavenly bodies are presented as a relationship between the ruler and the subjects. The world - heaven and earth - created by God remain under His rule; they worship the Creator and the Holy Virgin Mary, paying them homage [SSSL 1996: 20]:

The only Ruler above all rulers, to whom the heavenly spheres with their circling, the sun, the moon, the stars always bow low as to their master.

Jedynowładny Rządco nad rządcami, którego niebo swemi obrotami, słońce, miesiąc, gwiazdy czynią pokłon zawżdy jako panu swojemu.

The "own/familiar" perspective in the conceptualisation of the world as a whole shapes the image of the sun, the moon, wind, water, fire and earth as living beings, represented in human form, and endowed with feelings, awareness and an ethical sense [Bartmiński 2009b: 135-137, 208]. For a devout Christian, their participation in the worship of God is a natural phenomenon. The unity of the natural and human worlds involves a shared experience of the events in which they participate on equal terms, either playing the archetypal roles, or appearing in the scene as witnesses or in the background. The role of the conceptualiser usually amounts to that of an observer who provides an account of events, even if in some cases he/she co-creates the scenario as an active participant.

Homage scenarios are part of the most important religious feasts, such as the Feast of the Holy Trinity, Christmas and Easter, celebrated at major turning points in the annual natural cycle, determined primarily by the look and activity of the sun. This happens, for example, in scenes connected with the Feast of the Holy Trinity, in which the sun is assigned the archetypal role of the agent, bowing 
to the Lord, while other participants in the scene, including the conceptualiser, remain in the background [Bartmiński (ed.) 1989: 107]:

- "All I know about the sun is that on the Feast of the Holy Trinity when the sun is about to have a rest, it sort of bends, it bows" (Ja to o stońcu jino tylo wiem, że same Święto Trójce to słońce jak ma spoczywać (...) to się tak kręży, kłanio się);

- "On the Day of the Holy Trinity, before sunset [the sun] trembles, the sun goes down and comes up, and this can be seen with the naked eye on Holy Trinity Day" (Na dzień Świętej Trójcy przed zachodem [słońce] drga, słońce odchodzi "od góry ji do góry podchodzi, ji to można zauważyć gołym okiem, na dzień Świętej Trójcy).

In scenes connected with the birth, death and resurrection of Christ, the sun together with heaven and earth participate in the events: they greet the Child, weep after the death of Jesus, or display special signs indicating His triumph over death.

The most extensively developed scenario seems to be that concerning Christmas Day, which is endowed with a special aura of wonder fitting the importance attached to the coming of the Messiah. In ritual Christmas carol singing and mumming (kolędowanie), preserved in both fixed patterns of conduct and texts of Christmas carols, the conceptualiser relates events from the point of view of a participant. In this way, he/she gives them an air of authenticity, abolishing the temporal and spatial distance and bringing holy persons the Virgin Mary, St Joseph and the newborn Child Jesus - into the scene. In keeping with the intention of the carol scenario, the action concentrates around the main figure: the newborn Christ, who unites heaven and earth through becoming incarnate by the Holy Virgin. The cosmos as a whole together with the Church creates the miraculous scenery of God's coming to the earth, as demonstrated by a series of extraordinary events accompanying His birth: signs in the sky, the behaviour of the natural elements serving the Mother of God, and the rejoicing of all the world [Niebrzegowska-Bartmińska 2007: 127-133].

The star heralding the birth of the Son of God and showing the way to Bethlehem plays the role of the agent. The role of an instrument is assigned to swaddling cloths made "from a little bright star" ( $z$ jasnej gwiazdeczki) and the moon, which served as Mary's headscarf (pogłówniczek Maryi) and was used to envelop the baby. Miraculous events forming part of the carol scenario also include the River Jordan, which flowed to Bethlehem of its own accord to help Mary wash the baby [Niebrzegowska-Bartmińska 2007: 124]: 
Jasna gwiazda nad Betlejem świeciła,

Kiej Maryja swego syna powiła

(...)

A w czymżeś go okąpała? - Maryja?

Sama rzeka Jordan przypłynęła - lilija
A star shone bright o'er Bethlehem,

When Mary did bring forth her son (...)

But where did'st thou bathe him, Mary, lily fair?

The very Jordan river flowed of itself to her. ${ }^{1}$

Churches also play the role of the agent, showing their happiness at Christ's birth through extraordinary events and actions performed by inanimate objects of their own accord [Niebrzegowska-Bartmińska 2007: 126]:

Same się kościoły pootwierały,

bo się Pana Boga uradowały

- Panna Maryja

Heh, hej lelija - Panna Maryja!

Same się dzwonki pozadzwaniały (...)

Same się świece pozapalały (...)

Sama się msza odprawiała (...)

Sama się monstrancja występowała, bo się Boga uradowała

- Panna Maryja.
The churches opened of their own accord, for they rejoiced in God the Lord

- O Mary Our Lady

Hey, hey, o lily - Mary Our Lady!

Bells rang of themselves (...)

Candles lit of themselves (...)

Mass said of itself (...)

The monstrance displayed itself

for it rejoiced in God

- O Mary Our Lady. ${ }^{2}$

The sun also plays an active part, leaping, dancing and crouching on Christmas Day [SSSL 1996: 124], thus sharing in the joy of the world. The cyclic invocation of this sacred time makes it possible to experience events directly and gives access to the source of power - God's grace, which restores the primal order and sacredness of the earth.

On Easter morning, the throne of Christ can be seen on the disc of the sun, a lamb can be seen leaping in the sunlight, while the sun itself "rises and sets three times, and every time it shows itself, it dances merrily" (trzy razy wschodzi i zachodzi, a co raz się pokaże, to tańcuje wesoło i tak za każdym razem); "At Easter a lamb leaps in the rising sun, or the sun itself leaps" (Na jastrë baranek skôcze we wschôdającym słońcu, abo słonce samo skôcze) [Treder 1989: 16].

By contrast, Christ's death causes cosmic weeping: the whole world cries at the Lord's tomb on Good Friday: "dwellers of heaven", "exiles on the earth", "angels", "holy spirits", "heavenly rooms", "the bright sun", "the disc of the moon", "stars", "clouds", "thunderbolts", "lightning", “winds", "showers", "hail”, "frost", "snow", "streams", "rivers and springs", "floods", "sea dykes", "islands", "sea rocks", “fish",

1 Translated by Jean Ward.

2 Translated by Jean Ward. 
"underwater unfathomed wonders" (nieba mieszkańcy, ziemi wygnańcy, anieli, duchy święte, niebieskie pokoje, jasne słonce, koło miesięczne, gwiazdy, obłoki, chmury, pioruny, blyskawice, wiatry, dżdze, grady, mrozy, śniegi, potoki, rzeki $i$ źródła, zatopy, morskie waty, wyspy, morskie skaty, ryby, podwodne niepojęte dziwy) [Majer-Baranowska 1988: 109-110]. ${ }^{3}$ The lament scenario also includes examples of unprecedented acts by the sky, earth and sun: "all creation wept, the sun was eclipsed, the earth shook greatly, rocks fell, tombs opened wide" (stworzenie płakało, słońce się zaćmiło, ziemia barzo drżała, opoki się padały, groby się otwierały) [Majer-Baranowska 1988: 121].

The lament of heaven can also be heard on All Souls' Day and provides a warning against the evil which has overwhelmed God's own world [MajerBaranowska 1988: 121]:

Posłuchajcie proszę pilnie, jak niebo płacze usilnie; miesiąc, słońce i z gwiazdami płacze, lituje się nad nami. Bo za wieku teraźniejszego nie usłyszy nic dobrego.
Please listen carefully how heaven weeps wretchedly; the moon, the sun and the stars weep, they take pity on us. For in the present age and year no good tidings will they hear.

The words of the above song from the repertoire of wandering beggars (pieśn dziadowska) suggest the division of the cosmos into the sacred sphere (heaven with all the planets and stars in the firmament) and the earthly world, prone to sin. However, the upper part of the cosmos shows pity towards the earth and, together, both heaven and earth rejoice at the birth and weep at the death of the Lord. Such motifs demonstrate the existence of close bonds and constant communication between the two spheres, as well as a cosmic solidarity of feelings, reactions and ways of worshipping God. In linguistic terms, this attitude is expressed through the treatment of heaven and earth as a whole, as evinced by the interchangeable use of the word ziemia 'earth' to mean świat 'world', and conversely, the world to mean the earth. In a similar vein, the horizon is perceived as the end of the world, beyond which the heavenly sphere begins. The imaging of heaven and earth as a whole constituting the world relies on the LINK, WHOLE, BALANCE, and VERTICAL AXIS schemas, preserving the hierarchy inherent in the UP-DOWN structure.

3 Urszula Majer-Baranowska quotes the lyrics of a religious hymn assimilated by folk culture as the source. 


\section{Summary}

This study presents a model of the interaction between the physical and the metaphysical worlds based on an analysis of the role of the four natural elements (water, earth, air, fire) and two celestial bodies (the sun and the moon) in the imagery of the micro- and macrocosms in Polish folk culture. Focusing on cognitive processes, it seeks to identify the preconceptual image schemas underlying the folk conceptualisation of the world. The first chapter introduces principal assumptions of cognitive semantics and describes the image schemas which structure perceptions of physical and metaphysical reality. Their presence and function in the interpretation of those two distinct spheres makes it possible to discover cognitive paths linking entire complexes of knowledge stored in the experiential base and employed to conceptualise man's place in the universe.

The CENTRE-PERIPHERY and UP-DOWN schemas introduce a hierarchy of values in a horizontal and vertical dimension, thus playing an important role in the valuation of relations between the physical and metaphysical worlds. The UP-DOWN hierarchy plays the primary role: it emerges as the basic model of perception and organisation of the world, called the Great Chain of Being. In this unconscious cultural model, all the material and spiritual beings occupy their appropriate positions in a hierarchical arrangement.

As the sun and the moon belong to the upper spheres of the cosmos, they are associated with the sacred (the UP-DOWN schema). Their presence and movement in the sky are the prototype for the abstract concepts of time and space. The experience of light or its absence, in turn, introduces the division into day and night (the COLOUR schema, based on the ability to see) giving rise, in abstract terms, to the concepts of life and death, God and Satan, good and evil.

From the human point of view, the earth is situated in the centre of the universe. This motivates a bipolar conceptualisation of the world, based on the opposition between what is "own/familiar" (swój) and "strange/alien" (obcy), and makes it possible to distinguish different rules governing those spheres. This is why the perceptual space available to the individual's senses is considered "one's own" world, while lower spheres, situated underground or underwater, come to constitute the underworld. It is a space belonging to alien and malicious forces, a demonic world of death (structured by the CENTRE-PERIPHERY schema). Such a perception of the universe gives rise to stereotypical patterns based on mental models combined into a network of semantic interrelations. 
The model of interaction with an otherworldly reality proposed in the present study is based on the FORCE schema and its various patterns (i.e. COMPULSION, BLOCKAGE or ATTRACTION). A system of rituals, commands, prohibitions and magic formulas creates a framework which makes it possible to establish relations with the sacred. The prime intention of rituals is to gain access to the power of the sacred in order to cause a desired change, be it annihilation of evil, a blessing or a successful initiation into a new stage of life. The axiological charge of those magical practices relies on the belief that they serve to protect the harmony between human life and divine order.

Analysis of ritual behaviours from the perspective of the creation myth facilitates a grasp of their symbolic importance and the way they function as universal cultural patterns. Characteristic of folk culture, a religious attitude towards the universe makes it possible to conceive of language as a tool capable of creating reality. This belief in the causal power of words becomes the basis for magical practices as well as ethical and moral rules, which make up a system of commands and prohibitions. Magical formulas, oaths or commands constitute texts of culture that are reproduced in specific situational contexts. In this way, stereotype, understood as common knowledge shared by the addresser and the addressee, lies at the heart of communication and provides a sense of cultural identity.

Presented in the context of Polish folk culture and traditions, such linguistic behaviour demonstrates how language processes the experience of the senses in order to create an abstract conceptual system, which in turn provides symbolic meanings forming a network of related images. The study also shows how the conceptualiser's point of view influences the interpretation of the world, and how the memory of the creation myth shapes Polish folk culture. 


\section{Bibliography}

Adamowski Jan, 1986, O semantyce góry, Akcent, no. 4, pp. 40-47.

Adamowski Jan, 1989, Gościniec 'droga' w wierszowanym folklorze polskim, Etnolingwistyka, vol. 2, pp. 73-81.

Adamowski Jan, 1992, Językowy portret 'lądu’ polskiej kulturze ludowej, Etnolingwistyka, vol. 5, pp. 83-94.

Adamowski Jan, 1996, Współczesne opowieści i pieśni Maryjne z Mazowsza i Podlasia, Etnolingwistyka, vol. 8, pp. 235-262.

Adamowski Jan, 1999a, entries in: Słownik stereotypów i symboli ludowych, ed. Jerzy Bartmiński, vol. 1, Kosmos, part 2, Lublin: Wydawnictwo Uniwersytetu Marii Curie-Skłodowskiej: Dolina, pp. 68-85; Góra, pp. 86-122; Grota, pp. 133-135; Jar, pp. 147-149; Jaskinia, pp. 140-147; Ląd, pp. 57-61; Pieczara, pp. 136-139; Wąwóz, pp. 150-152.

Adamowski Jan, 1999b, Dolina jako przestrzeń miłości, in: Folklorystyczne $i$ antropologiczne opisanie świata. Ksiegga ofiarowana Profesor Dorocie Simonides, ed. Teresa Smolińska, Opole: Wydawnictwo Uniwersytetu Opolskiego, pp. 283-292.

Adamowski Jan, 1999c, Dół w ludowym obrazie świata (pochodzenie i lokatywność), in: Językowy obraz świata, ed. Jerzy Bartmiński, Lublin: Wydawnictwo Uniwersytetu Marii Curie-Skłodowskiej, pp. 155-182.

Adamowski Jan, 1999d, Kategoria przestrzeni w folklorze. Studium etnolingwistyczne, Lublin: Wydawnictwo Uniwersytetu Marii Curie-Skłodowskiej.

Adamowski Jan, 2008, Postać obcego w polskich obrzędach dorocznych. Od obcości do wspólnoty, Etnolingwistyka. Problemy języka i kultury, vol. 20, pp. 191-200.

Adamowski Jan, 2011, Na rozstaju dróg, czyli o semantyce skrzyżowania w polskiej kulturze tradycyjnej, in: Droga w języku i w kulturze, ed. Jan Adamowski, Katarzyna Smyk, Lublin: Wydawnictwo Uniwersytetu Marii Curie-Skłodowskiej, pp. 179-188.

Adamowski Jan, Doda Jadwiga, Mickiewicz Halina, 1998, Śmierć i pogrzeb w relacjach Polaków zamieszkałych na Białorusi, Etnolingwistyka. Problemy języka i kultury, vol. 9/10, pp. 253-318.

Adamowski Jan, Niebrzegowska Stanisława (eds.), 1999, W zwierciadle języka $i$ kultury, Lublin: Wydawnictwo Uniwersytetu Marii Curie-Skłodowskiej.

Andrae Walter, 2007, The life of symbols, trans. Ananda K. Coomaraswamy, in: Ananda K. Coomaraswamy, Figures of Speech or Figures of Thought?: The 
Traditional View of Art, ed. William Wroth, rev. ed., Bloomington: World Vision, pp. 227-230; (translation of the conclusion to Walter Andrae, Die ionische Saule, Bauform oder Symbol?, Berlin, 1933).

Antropov Nikolaĭ, 2004, Kodovaia struktura belorusskikh obriadov i ritualov sviazannykh s vyzyvaniem dozhdia, Etnolingwistyka. Problemy języka $i$ kultury, vol. 16, pp. 241-255; (Антропов Николай, Кодовая структура белорусских обрядов и ритуалов, связанных с вызыванием дождя).

Antropov Nikolă̆, Boganeva Elena, Volodina Tat'iana, 2008, Ėtnokul'turnye stereotipy v mezhkonfessional'nykh otnosheniiakh v Belorussii: opyt ètnolingvisticheskogo kommentirovaniia, Etnolingwistyka. Problemy języka i kultury, vol. 20, pp. 269-280; (Антропов Николай, Боганева Елена, Володина Татьяана, Этнокультурные стереотипы в межконфессиональных отношениях в Белоруссии: опыт этнолингвистического комментирования).

Anusiewicz Janusz, 1995, Lingwistyka kulturowa. Zarys problematyki, Wrocław: Wydawnictwo Uniwersytetu Wrocławskiego.

Anusiewicz Janusz, Bartmiński Jerzy (eds.), 1998, Język a kultura, vol. 12, Stereotyp jako przedmiot lingwistyki. Teoria, metodologia, analizy empiryczne, Wrocław: Towarzystwo Przyjaciół Polonistyki Wrocławskiej.

Apresjan Jurij D. (Apresian Iuriǐ D.), 1992, Systemic lexicography, in: EURALEX '92, Proceedings I-II: Papers submitted to the 5th EURALEX International Congress on Lexicography in Tampere, Finland, part 1, (Studia Translatologica, ser. A, vol. 2), ed. Hannu Tommola et al., Tampere: University of Tampere, pp. 3-16.

Arkhipenko Natal'ia, 2000, Otbiranie moloka u korov ( $\mathrm{k}$ issledovaniiu odnogo mifologicheskogo motiva), Etnolingwistyka. Problemy języka i kultury, vol. 12, pp. 167-179; (Архипенко Наталья, Отбирание молока у коров (к исследованию одного мифологического мотива)).

Avalon Annwyn, 2019, Water Witchcraft: Magic and Lore from the Celtic Tradition, Newburyport: Weiser Books.

Awdiejew Aleksy, 1992, Składnik wyjściowy w gramatyce kognitywnej, in: Język a kultura, vol. 8, Podstawy metodologiczne semantyki współczesnej, ed. Iwona Nowakowska-Kempna, Wrocław: Wydawnictwo Uniwersytetu Wrocławskiego, pp. 57-71.

Bakhtin Mikhail, 1984, Rabelais and His World, trans. Helene Iswolsky, Bloomington: Indiana University Press.

Bakhtin Mikhail, 1986, The problem of speech genres, in: Mikhail Bakhtin, Speech Genres and Other Late Essays, trans. Vern W. McGee, ed. Caryl Emerson, Michael Holquist, Austin: University of Texas Press, pp. 60-102. 
Bane Theresa, 2012, Encyclopedia of Demons in World Religions and Cultures, Jefferson: McFarland \& Company.

Bane Theresa, 2014, Encyclopedia of Beasts and Monsters in Myth, Legend and Folklore, Jefferson: McFarland \& Company.

Baranowski Bohdan, 1969, Życie codzienne wsi między Warta a Pilica w XIX w., Warszawa: Państwowy Instytut Wydawniczy.

Baranowski Bohdan, 1986, Ludzie gościńca w XVII-XVIII w., Łódź:

Wydawnictwo Łódzkie.

Barthes Roland, 1964, On Racine, trans. Richard Howard, New York: Hill and Wang.

Barthes Roland, 1972a, Critical Essays, trans. Richard Howard, Evanston: Northwestern University Press.

Barthes Roland, 1972b, Mythologies, trans. Annette Lavers, London: Cape.

Bartmiński Jerzy, 1980a, Słońce, in: Słownik ludowych stereotypów językowych, ed. Jerzy Bartmiński, Wrocław: Wydawnictwo Uniwersytetu Wrocławskiego, pp. 205-230.

Bartmiński Jerzy, 1980b, Założenia teoretyczne słownika, in: Słownik ludowych stereotypów językowych, Wrocław: Wydawnictwo Uniwersytetu Wrocławskiego, pp. 7-36.

Bartmiński Jerzy, 1985, Stereotyp jako i przedmiot lingwistyki (cz. 1), in: $Z$ problemów frazeologii polskiej i słowiańskiej III, ed. Mieczysław Basaj, Danuta Rytel, Wrocław: Zakład Narodowy im. Ossolińskich, pp. 25-53.

Bartmiński Jerzy, 1986a, „Bóg się szerzy”. Przykład chrystianizacji noworocznej kolędy ludowej, in: Biblia a literatura, ed. Stefan Sawicki, Jan Gotfryd, Lublin: Towarzystwo Naukowe Katolickiego Uniwersytetu Lubelskiego, pp. 479-497.

Bartmiński Jerzy, 1986b, Kolęda i jej odmiany gatunkowe, in: Kolędowanie na Lubelszczyźnie, ed. Jerzy Bartmiński, Czesław Hernas, Wrocław: Polskie Towarzystwo Ludoznawcze, pp. 78-184.

Bartmiński Jerzy, 1986c, Wszystko się zmieniło, jak nigdy nie było, in: Kolędowanie na Lubelszczyźnie, ed. Jerzy Bartmiński, Czesław Hernas, Wrocław: Polskie Towarzystwo Ludoznawcze, pp. 5-10.

Bartmiński Jerzy, 1988a, Definicja kognitywna jako narzędzie opisu konotacji, in: Konotacja, ed. Jerzy Bartmiński, Lublin: Wydawnictwo Uniwersytetu Marii Curie-Skłodowskiej, pp. 169-183.

Bartmiński Jerzy, 1988b, Niebo się wstydzi. Wokół ludowego pojmowania ładu świata, in: Kultura, literatura, folklor. Prace ofiarowane Czesławowi Hernasowi, ed. Marek Graszewicz, Jacek Kolbuszewski, Warszawa: Ludowa Spółdzielnia Wydawnicza, pp. 96-106. 
Bartmiński Jerzy, 1988c, Słownik ludowych stereotypów językowych. Założenia ogólne, Etnolingwistyka, vol. 1, pp. 11-34.

Bartmiński Jerzy, 1989, Językowe sposoby porządkowania świata. Uwagi na marginesie biłgorajskich relacji o kosmosie, Etnolingwistyka, vol. 2, pp. 49-58.

Bartmiński Jerzy, 1990, Punkt widzenia, perspektywa, językowy obraz świata, in: Językowy obraz świata, ed. Jerzy Bartmiński, Lublin: Wydawnictwo Uniwersytetu Marii Curie-Skłodowskiej, pp. 109-127.

Bartmiński Jerzy, 1993a, O profilowaniu pojęć w słowniku etnolingwistycznym, in: Profilowanie pojęć. Wybór prac, Lublin: Wydawnictwo Uniwersytetu Marii Curie-Skłodowskiej, pp. 7-17.

Bartmiński Jerzy, 1993b, O profilowaniu i profilach raz jeszcze, in: O definicjach i definiowaniu, ed. Jerzy Bartmiński, Ryszard Tokarski, Lublin: Wydawnictwo Uniwersytetu Marii Curie-Skłodowskiej, pp. 269-275.

Bartmiński Jerzy, 1994a, Język naturalny. O przedmiocie badań etnolingwistycznych, Przegląd Akademicki, no. 13/14, pp. 12-13.

Bartmiński Jerzy, 1994b, Obraz w głowie. Co znajduje się w „Słowniku stereotypów językowych"?, Przegląd Akademicki, no. 11, pp. 12-13.

Bartmiński Jerzy, 1995, Formy obecności sacrum w folklorze, in: Folklor sacrum - religia, ed. Jerzy Bartmiński, Maria Jasińska-Wojtkowska, Lublin: Instytut Europy Środkowo-Wschodniej, pp. 9-19.

Bartmiński Jerzy, 1997, Dom - Świat - opozycja czy współdziałanie?, in: Dom w języku i w kulturze, ed. Grażyna Sawicka, Szczecin: Wydawnictwo JotA, pp. $11-24$.

Bartmiński Jerzy, 1998a, Czy „językowy” jest tylko stereotyp „formalny”?, in: Jezzyk a kultura, vol. 12, Stereotyp jako przedmiot lingwistyki. Teoria metodologia, analizy empiryczne, ed. Janusz Anusiewicz, Jerzy Bartmiński, Wrocław: Towarzystwo Przyjaciół Polonistyki Wrocławskiej, pp. 105-108.

Bartmiński Jerzy, 1998b, Dusze rzewnie zapłakały. Odmiany gatunkowe pieśni o wędrówce dusz szukających miejsca wiecznego spoczynku, Etnolingwistyka. Problemy języka i kultury, vol. 9/10, pp. 149-168.

Bartmiński Jerzy, 1998c, Podstawy lingwistycznych badań nad stereotypem na przykładzie stereotypu matki, in: Język a kultura, vol. 12, Stereotyp jako przedmiot lingwistyki. Teoria, metodologia, analizy empiryczne, ed. Janusz Anusiewicz, Jerzy Bartmiński, Wrocław: Towarzystwo Przyjaciół Polonistyki Wrocławskiej, s. 63-83.

Bartmiński Jerzy, 2001, Między systemem a tekstem. Standardy semantyczne i standardowe motywy, in: Język w komunikacji, ed. Grażyna Habrajska, Łódź: Wydawnictwo Wyższej Szkoły Humanistyczno-Ekonomicznej w Łodzi, pp. 59-69. 
Bartmiński Jerzy, 2005, Iazykovoŭ obraz mira: ocherki po ètnolingvistike, ed. Svetlana M. Tolstaia, Moskva: Indrik; (Бартминьский Ежи, Языковой образ мира: очерки по этнолингвистике, ред. Светлана М. Толстая, Москва: Индрик, 2005).

Bartmiński Jerzy, 2006a, Językowe podstawy obrazu świata, Lublin: Wydawnictwo Uniwersytetu Marii Curie-Skłodowskiej.

Bartmiński Jerzy, 2006b, Niektóre pojęcia i problemy lingwistyki lubelskiej, Etnolingwistyka. Problemy języka i kultury, vol. 18, pp. 77-90.

Bartmiński Jerzy, 2007, Opozycja „swój/obcy” a problem językowego obrazu świata, Etnolingwistyka. Problemy języka i kultury, vol. 19, pp. 35-59.

Bartmiński Jerzy, 2009a, Aspects of Cognitive Ethnolinguistics, trans. Adam Głaz, ed. Jörg Zinken, London: Equinox.

Bartmiński Jerzy, 2009b, Stereotypy mieszkaja w języku. Studia etnolingwistyczne, Lublin: Wydawnictwo Uniwersytetu Marii Curie-Skłodowskiej.

Bartmiński Jerzy (ed.), 1989, Relacje o kosmosie. Teksty gwarowe z okolic Biłgoraja, Etnolingwistyka, vol. 2, pp. 95-149.

Bartmiński Jerzy (ed.), 1990, Językowy obraz świata, Lublin: Wydawnictwo Uniwersytetu Marii Curie-Skłodowskiej.

Bartmiński Jerzy (ed.), 1993, Profilowanie pojęć. Wybór prac, Lublin: Wydawnictwo Uniwersytetu Marii Curie-Skłodowskiej.

Bartmiński Jerzy, Majer-Baranowska Urszula, 1996, 'Dunaj' w polskim folklorze, Etnolingwistyka. Problemy języka i kultury, vol. 8, pp. 167-184.

Bartmiński Jerzy, Mazurkiewicz-Brzozowska Małgorzata, 1993a, Lud. Profile pojęcia i ich konteksty kulturowe, in: Nazwy wartości. Studia leksykalnosemantyczne, vol. 1, ed. Jerzy Bartmiński, Małgorzata MazurkiewiczBrzozowska, Lublin, Wydawnictwo Uniwersytetu Marii Curie-Skłodowskiej, pp. 213-231.

Bartmiński Jerzy, Mazurkiewicz-Brzozowska Małgorzata (eds.), 1993b, Nazwy wartości. Studia leksykalno-semantyczne, vol. 1, Lublin: Wydawnictwo Uniwersytetu Marii Curie-Skłodowskiej.

Bartmiński Jerzy, Niebrzegowska Stanisława, 1994, Stereotyp słońca w polszczyźnie ludowej, Etnolingwistyka, vol. 6, pp. 95-143.

Bartmiński Jerzy, Niebrzegowska Stanisława, 1996, entries in: Słownik stereotypów i symboli ludowych, ed. Jerzy Bartmiński, vol. 1, Kosmos, part 1, Lublin: Wydawnictwo Uniwersytetu Marii Curie-Skłodowskiej: Księżyc, pp. 158-202; Niebo, pp. 85-118; Słońce, pp. 119-157.

Bartmiński Jerzy, Niebrzegowska Stanisława, 1998, Profilowanie a podmiotowa interpretacja świata, in: Profilowanie w języku i w tekście, ed. Jerzy Bartmiński, 
Ryszard Tokarski, Lublin: Wydawnictwo Uniwersytetu Marii CurieSkłodowskiej, pp. 211-224.

Bartmiński Jerzy, Niebrzegowska Stanisława, 1999, Językowy obraz polskiego nieba i piekła, in: Tysiąc lat polskiego słownictwa religijnego, ed. Bogusław Kreja, Gdańsk: Wydawnictwo Uniwersytetu Gdańskiego, pp. 195-203.

Bartmiński Jerzy, Niebrzegowska-Bartmińska Stanisława, 2004a, Dynamika kategorii punktu widzenia w języku, tekście i dyskursie, in: Punkt widzenia w języku i w kulturze, ed. Jerzy Bartmiński, Stanisława NiebrzegowskaBartmińska, Ryszard Nycz, Lublin: Wydawnictwo Uniwersytetu Marii CurieSkłodowskiej, pp. 321-358.

Bartmiński Jerzy, Niebrzegowska-Bartmińska Stanisława (eds.), 2004b, Punkt widzenia $w$ tekście $i w$ dyskursie, Lublin: Wydawnictwo Uniwersytetu Marii Curie-Skłodowskiej.

Bartmiński Jerzy, Niebrzegowska-Bartmińska Stanisława, 2009, Tekstologia, Warszawa: Wydawnictwo Naukowe PWN.

Bartmiński Jerzy, Niebrzegowska-Bartmińska Stanisława, Nycz Ryszard (eds.), 2004, Punkt widzenia w języku i w kulturze, Lublin: Wydawnictwo Uniwersytetu Marii Curie-Skłodowskiej.

Bartmiński Jerzy, Niewiadomski Donat, 1999, entries in: Słownik stereotypów i symboli ludowych, ed. Jerzy Bartmiński, vol. 1, Kosmos, part 2, Lublin: Wydawnictwo Uniwersytetu Marii Curie-Skłodowskiej: Podziemie, pp. 465481; Ziemia, pp. 17-56.

Bartmiński Jerzy, Panasiuk Jolanta, 1993, Stereotypy językowe in: Encyklopedia kultury polskiej XX wieku, vol. 2, Współczesny język polski, ed. Jerzy Bartmiński, Wrocław: Wiedza o Kulturze, pp. 363-387.

Bartmiński Jerzy, Puzynina Jadwiga, 2001, Językowy obraz Chrystusa we współczesnej kulturze polskiej, in: U progu trzeciego tysiąclecia. Człowiek nauka - wiara. Księga pamiątkowa Sympozjum Naukowego zorganizowanego w Uniwersytecie Warszawskim z okazji 2000-lecia chrześcijaństwa w dniach 19-21 listopada 1999, ed. Aleksandra Białecka, Jacek Jadacki, Warszawa: Semper, pp. 457-484.

Bartmiński Jerzy, Tokarski Ryszard, 1993, Definicja semantyczna: czego i dla kogo?, in: O definicji i definiowaniu, ed. Jerzy Bartmiński, Ryszard Tokarski, Lublin: Wydawnictwo Uniwersytetu Marii Curie-Skłodowskiej, pp. 47-62.

Bartmiński Jerzy, Tokarski Ryszard (eds.), 1993, O definicjach i definiowaniu, Lublin, Wydawnictwo Uniwersytetu Marii Curie-Skłodowskiej.

Bartmiński Jerzy, Tokarski Ryszard (eds.), 1998, Profilowanie w języku i w tekście, Lublin: Wydawnictwo Uniwersytetu Marii Curie-Skłodowskiej.

Bączkowska Grażyna, 1986, Ludowy duch wiatru, Akcent, no. 4, pp. 56-58. 
Bączkowska Grażyna, 1988, Korowaj, Etnolingwistyka, vol. 1, pp. 79-99. Belova Ol'ga V. (ed.), 2004, "Narodnaia Bibliia": Vostochnoslavianskie étiologicheskie legendy, Moskva: Indrik; (“Народная Библия”: Восточнославянские этиологические легенды, сост. и комент. Ольга В. Белова, Москва: Индрик, 2004).

Belova Ol'ga V., Petrukhin Vladimir Ia., 2004, Genezis „chuzhikh” v svete fol'klornoù ètiologii, Etnolingwistyka. Problemy języka i kultury, vol. 16, pp. 257-268; (Белова, Ольга В., Петрухин Владимир Я., Генезис 'чужих' в свете фольклорной этиологии).

Benedyktowicz Danuta, Benedyktowicz Zbigniew, 1992, Dom w tradycji ludowej, in: Encyklopedia Kultury Polskiej XX wieku. Studia i materiały, Wrocław: Wiedza o Kulturze.

Benedyktowicz Zbigniew, 2000, Portrety „obcego”. Od stereotypu do symbolu, Kraków: Wydawnictwo Uniwersytetu Jagiellońskiego.

Benedyktowicz Zbigniew, 1980, O niektórych zastosowaniach metody fenomenologicznej w studiach nad religią, symbolem i kulturą, part 1, Etnografia Polska, vol. 24, no. 2, pp. 9-45.

Berezovich Elena L., 2004, Obraz prostranstva v zerkale iazykovoĭ traditsii: metodika opisaniia i nekotorye rezul'taty, Etnolingwistyka. Problemy języka $i$ kultury, vol. 16, pp. 111-127; (Березович Елена Л., Образ пространства в зеркале языковой традиции: методика описания и некоторые результаты).

Berezovich Elena L., 2008, Ėtnicheskie stereotipy i problema lingvokul'turnykh sviazel, Etnolingwistyka. Problemy języka i kultury, vol. 20, pp. 6376; (Березович Елена Л., Этнические стереотипы и проблема лингвокультурных связей).

Berger Peter L., Luckmann Thomas, 1991, The Social Construction of Reality: A Treatise of the Sociology of Knowledge, London: Penguin.

Bernstein Basil, 1965, A sociolinguistic approach to social learning, in: Penguin Survey of the Social Sciences, ed. Julius Gould, Harmondsworth: Penguin, pp. 144-168.

Biegeleisen Henryk, 1928, Wesele, Lwów: Instytut Stauropigijski.

Biegeleisen Henryk, 1929a, Lecznictwo ludu polskiego, Kraków: Polska Akademia Umiejętności.

Biegeleisen Henryk, 1929b, U kolebki, przed ołtarzem, nad mogiła, Lwów: Instytut Stauropigijski.

Biegeleisen Henryk, 1930, Śmierć w obrzędach, zwyczajach i wierzeniach ludu polskiego, Warszawa: Dom Książki Polskiej.

Birket-Smith Kaj, 1965, The Paths of Culture: A General Ethnology, trans. Karin Fennow, Madison: University of Wisconsin Press. 
Black Ronald (ed.), 2005, The Gaelic Otherworld: John Gregorson Campbell's Superstitions of the Highlands and the Islands of Scotland and Witchcraft and Second Sight in the Highlands and Islands, Edinburgh: Birlinn.

Bohdanowicz Janusz (ed.), 1999, Komentarze do Polskiego Atlasu

Etnograficznego, vol. 5, Zwyczaje. Obrzędy i wierzenia pogrzebowe, Wrocław: Polskie Towarzystwo Ludoznawcze.

Boryś Wiesław, 1975, Prefiksacja imienna w językach słowiańskich, Wrocław: Zakład Narodowy im. Ossolińskich.

Boryś Wiesław, Popowska-Taborska Hanna, 1994-2010, Słownik etymologiczny kaszubszczyzny, vol. 1-6, Warszawa: Instytut Slawistyki Polskiej Akademii Nauk, Slawistyczny Ośrodek Wydawniczy.

Bourdieu Pierre, 1977, Outline of a Theory of Practice, trans. Richard Nice, Cambridge: Cambridge University Press.

Bowman Marion, Valk Üli (eds.), 2012, Vernacular Religion in Everyday life: Expressions of Belief, London, Oakville: Equinox.

Brückner Aleksander, 1939, Dziad, in: Aleksander Brückner, Karol Estreicher, Encyklopedia staropolska, vol. 1, Warszawa: Księgarnia Trzaski, Everta i Michalskiego.

Brückner Aleksander, 1957, Słownik etymologiczny języka polskiego, Warszawa: Wiedza Powszechna.

Brückner Aleksander, 1980, Mitologia słowiańska i polska, Warszawa: Państwowe Wydawnictwo Naukowe.

Brzozowska Małgorzata, 1996, entries in: Słownik stereotypów i symboli ludowych, ed. Jerzy Bartmiński, vol. 1, Kosmos, part 2, Lublin: Wydawnictwo Uniwersytetu Marii Curie-Skłodowskiej: Drogie kamienie, pp. 421-439: Kamień, pp. 349-404; Skała, pp. 124-133.

Brzozowska Małgorzata, 2000, Etymologia a konotacja wybranych nazw kamieni, Etnolingwistyka. Problemy języka i kultury, vol. 12, pp. 265-278.

Brzozowska Małgorzata, 2009, Etymologia a konotacja słowa. Studia semantyczne, Lublin: Wydawnictwo Uniwersytetu Marii Curie-Skłodowskiej.

Brzozowska-Krajka Anna, 1994, Symbolika dobowego cyklu powszedniego w polskim folklorze tradycyjnym, Lublin: Wydawnictwo Uniwersytetu Marii Curie-Skłodowskiej.

Brzozowska-Krajka Anna, 1995, Między magią a religią. O modlitewkach ludowych, in: Folklor sacrum, religia, ed. Jerzy Bartmiński, Maria JasińskaWojtkowska, Lublin: Instytut Europy Środkowo-Wschodniej, pp. 183-200.

Buchowski Michał J., 1993, Magia i rytuał, Warszawa: Wydawnictwo Instytutu Kultury. 
Budziszewska Wanda 1983-1985, Z nazw motyla w językach słowiańskich na tle porównawczym, Rocznik Slawistyczny, vol. 43, no. 1, pp. 13-19.

Budziszewska Wanda, 1989a, Imiona ochronne Słowian bałkańskich, Onomastica, vol. 34, pp. 237-244.

Budziszewska Wanda, 1989b, O niektórych nazwach chorób i związanych z nimi demonów w językach słowiańskich, in: Paralele w rozwoju słownictwa języków słowiańskich, ed. Hanna Popowska-Taborska, Wrocław: Zakład Narodowy im. Ossolińskich, pp. 153-160.

Budziszewska Wanda, 1990, Z semantyki magii, Etnolingwistyka, vol. 3, pp. 7-19.

Budziszewska Wanda, 1991, Z problematyki obcości w języku magii, in: Język a kultura, vol. 4, Funkcje języka i wypowiedzi, ed. Jerzy Bartmiński, Renata Grzegorczykowa, Wrocław: Wiedza o Kulturze, pp. 87-92.

Budziszewska Wanda, 1995, Śladami tura, Etnolingwistyka, vol. 7, pp. 47-51.

Budziszewska Wanda, 1999, Dwie kultowe nazwy księżyca u Słowian, in: Językowy Obraz Świata, ed. Jerzy Bartmiński, Lublin: Wydawnictwo Uniwersytetu Marii Curie-Skłodowskiej, pp. 207-214.

Budziszewska Wanda, 2001, Z „diabelskiego” słownictwa, Etnolingwistyka. Problemy języka i kultury, vol. 13, pp. 227-230.

Bukraba-Rylska Izabella, 2008, Socjologia wsi polskiej, Warszawa: Wydawnictwo Naukowe PWN.

Bukraba-Rylska Izabella, 2016, Religijność ludowa oczami socjologa. Zjawisko krytyka - obrona, Twórczość Ludowa, no. 3-4, pp. 17-20.

Burszta Józef, 1974, Kultura ludowa - kultura narodowa, Warszawa: Ludowa Spółdzielnia Wydawnicza.

Burszta Wojciech, 1994, W obliczu współczesności, in: Pożegnania paradygmatu? Etnologia w obliczu współczesności, ed. Wojciech Burszta, Warszawa: Instytut Kultury, pp. 102-110.

Burszta Wojciech, 1998, Antropologia kultury. Tematy, teorie, interpretacje, Poznań: Zysk i S-ka.

Burzyńska Anna, Kamienicki Jan, 1998, Wpływ przeszłości na językowy obraz śmierci i zwierząt w polszczyźnie, Etnolingwistyka. Problemy języka i kultury, vol. 9/10, pp. 81-92.

Bystroń Jan S., 1947, Etnografia Polski, Warszawa: Spółdzielnia Wydawnicza "Czytelnik".

Bystroń Jan S., 1960, Dzieje obyczajów w dawnej Polsce, vol. 1, Warszawa: Państwowy Instytut Wydawniczy.

Bystroń Jan S., 1980, Tematy, które mi odradzano, Warszawa: Państwowy Instytut Wydawniczy. 
Caillois Roger, 1959, Man and the Sacred, trans. Meyer Barash, Glencoe: Free Press.

Campbell Joseph, Moyers Bill, 1988, The Power of Myth, New York: Doubleday.

Cassirer Ernst, 1953, An Essay on Man: An Introduction to a Philosophy of Human Culture, New York: Doubleday.

Cassirer Ernst, 2013, Language and the construction of the world of objects, in Ernst Cassirer, The Warburg Years (1919-1933): Essays on Language, Art, Myth, and Technology, ed. and trans. Steve G. Lofts, Antonio Calcagno, New Haven, London: Yale University Press, pp. 334-362.

Celary Ireneusz, 2004, Tradycje i zwyczaje pogrzebowe na Górnym Śląsku, in: Pobożność ludowa w życiu liturgiczno-religijnym i w kulturze, ed. Rudolf Pierskała, Teresa Smolińska, Opole: Redakcja Wydawnictw Wydziału Teologicznego Uniwersytetu Opolskiego, pp. 295-305.

Chlebda Wojciech, 1991, Elementy frazematyki. Wprowadzenie do frazeologii nadawcy, Opole: Oficyna Wydawnicza Leksem.

Chlebda Wojciech, 1993, Frazematyka, in: Encyklopedia kultury polskiej XX w., vol. 2, Współczesny język polski, ed. Jerzy Bartmiński, Lublin: Wydawnictwo Uniwersytetu Marii Curie-Skłodowskiej, pp. 327-337.

Chlebda Wojciech, 1998, Stereotyp jako jedność języka, myślenia i działania, in: Język a kultura, vol. 12, Stereotyp jako przedmiot lingwistyki. Teoria metodologia, analizy empiryczne, ed. Janusz Anusiewicz, Jerzy Bartmiński, Wrocław: Towarzystwo Przyjaciół Polonistyki Wrocławskiej, pp. 31-41.

Chlebda Wojciech, 2007, Kiedy swój staje się obcym, Etnolingwistyka. Problemy języka i kultury, vol. 19, pp. 89-98.

Chlebda Wojciech, Kochman Stanisław (eds.), 1996, Frazeologia a religia. Tezy referatów międzynarodowego sympozjum naukowego. Opole 4-6 września 1996, Opole: Komisja Frazeologii Słowiańskiej Międzynarodowego Komitetu Slawistów.

Chwalba Andrzej (ed.), 2006, Obyczaje w Polsce. Od średniowiecza do czasów współczesnych, Warszawa: Wydawnictwo Naukowe PWN.

Cirlot Juan E., 1971, A Dictionary of Symbols, 2nd ed., trans. Jack Sage, New York: Philosophical Library.

Ciupak Franciszek, 1973, Katolicyzm ludowy w Polsce, Warszawa: Wiedza Powszechna.

Cooper Jean C., 1992, Symbolic and Mythological Animals, London: Aquarian/ Thorsons.

Czarnowski Stefan, 1956, Kultura religijna wiejskiego ludu polskiego, in: Stefan Czarnowski, Dzieła, vol. 1, Studia z historii kultury, ed. Nina Assorodobraj, 
Stanisław Ossowski, Warszawa: Państwowe Wydawnictwo Naukowe, pp. 88-107.

Czyżewski Feliks, 1988, Zmora. Hasło do „Słownika stereotypów i symboli ludowych", Etnolingwistyka, vol. 1, pp. 133-143.

Czyżewski Feliks, 1994, Burza w wierzeniach ludowych, Etnolingwistyka, vol. 6, pp. 169-175.

Diakowska Edyta, 2011, Ostatnia droga duszy - między obrzędem wyłączenia ze społeczności żyjących a włączeniem do społeczności umarłych, in: Droga w języku i w kulturze. Analizy antropologiczne, ed. Jan Adamowski, Katarzyna Smyk, Lublin: Wydawnictwo Uniwersytetu Marii Curie-Skłodowskiej, pp. 129-140.

Dobrowolski Kazimierz, 1961, Studia nad teorią kultury ludowej. Zagadnienia reliktu kulturowego w świetle materiałów źródłowych z południowej Małopolski, in: Etnografia Polski, vol. 4, pp. 15-92.

Durand Gilbert, 1964, L'imagination symbolique, Paris: Presses universitaires de France.

Dźwigoł Renata, 2004, Polskie ludowe słownictwo mitologiczne, Kraków: Wydawnictwo Naukowe Akademii Pedagogicznej.

Eliade Mircea, 1958, Patterns in Comparative Religion, trans. Rosemary Sheed, New York: Sheed \& Ward.

Eliade Mircea, 1959a, Archetypes and repetition, in: Mircea Eliade, Cosmos and History: The Myth of the Eternal Return, trans. Willard R. Trask, New York: Harper, pp. 1-48.

Eliade Mircea, 1959b, The Sacred and the Profane: The Nature of Religion, trans. Willard R. Trask, New York: Harcourt.

Eliade Mircea, 1991, Images and Symbols: Studies in Religious Symbolism, trans. Philip Mairet, Princeton: Princeton University Press.

Engelking Anna, 1984, Istota i ewolucja eufenizmów (na przykładzie zastępczych określeń śmierci), Przegląd Humanistyczny, no. 4, pp. 115-129.

Engelking Anna, 1988, Z pogranicza etnografii i językoznawstwa. Analiza rytuału błogosławieństwa przedślubnego, in: Polono-Slavica Varsoviensia. Studia nad językiem polskim, ed. Renata Grzegorczykowa, Barbara Klebanowska, Warszawa: Wydawnictwa Uniwersytetu Warszawskiego, pp. 181-192.

Engelking Anna, 1990, Klątwa rodzicielska w kulturze ludowej, Etnolingwistyka, vol. 3, pp. 21-37.

Engelking Anna, 1991a, Magiczna moc słowa w polskiej kulturze ludowej, in: Jezzka a kultura, vol. 1, Podstawowe pojęcia i problemy, ed. Janusz Anusiewicz, Jerzy Bartmiński, Wrocław: Wiedza o Kulturze, pp. 157-166. 
Engelking Anna, 1991b, Rytuały słowne w kulturze ludowej. Próba klasyfikacji, in: Język a kultura, vol. 4: Funkcje języka i wypowiedzi, ed. Jerzy Bartmiński, Renata Grzegorczykowa, Wrocław: Wiedza o Kulturze, pp. 75-85.

Engelking Anna, 2002, Udzielanie dóbr za pomocą słowa, czyli o rytuale błogosławieństwa w kulturze ludowej, w: Fascynacje folklorystyczne. Księga poświęcona pamięci Heleny Kapełuś, ed. Magdalena Kapełuś, Anna Engelking, Warszawa: Agade, pp. 31-40.

Engelking Anna, 2007, Uwagi o mało znanych aspektach kategorii swój/obcy w ujęciu Józefa Obrębskiego, Etnolingwistyka. Problemy języka i kultury, vol. 19, pp. 61-74.

Engelking Anna, 2017, The Curse: On Folk Magic of the Word, trans. Anna Gutowska, Warsaw: Institute of Slavic Studies, Polish Academy of Sciences.

Ėtimologicheskiŭ slovar' slavianskikh iazykov. Praslavianskiu leksicheskiu fond, 1974-2014, vol. 1-39, ed. Oleg N. Trubachëv, Moskva: Nauka, 1974; (Этимологический словарь славянских языков. Праславианский лексический фонд, вып. 1-39, ред. Олег Н. Трубачёв, Москва: Наука, 1974).

Fasmer Max (Vasmer Max), 1986-1987, Etimologicheskiu slovar' russkogo iazyka, vol. 1-4, trans. and suppl. Oleg N. Trubachëv, Moskva: Progress; (Макс Фасмер, Этимологический словарь русского языка, т. 1-4, пер. и доп. Олег Н. Трубачёв, Москва: Прогресс, 1986-1987).

Ferenc-Szydełkowa Ewa, 1988, Rok kościelny a polskie tradycje, Poznań: Księgarnia Świętego Wojciecha.

Fife James, 1994, Wykłady z gramatyki kognitywnej, in: Podstawy gramatyki kognitywnej, ed. Henryk Kardela, Warszawa: Polskie Towarzystwo Semiotyczne, pp. 9-64.

Filipiak Marian, Rajewski Maciej (eds.), 2006, Rytuał. Przeszłość i teraźniejszość, Lublin: Wydawnictwo Uniwersytetu Marii Curie-Skłodowskiej.

Fischer Adam, 1921, Zwyczaje pogrzebowe ludu polskiego, Lwów: Zakład Narodowy im. Ossolińskich.

Forstner Dorothea, 1986, Die Welt der christlichen Symbole, 5th ed., Innsbruck, Wien: Tyrolia-Verlag.

Frazer James G. 1996, The Golden Bough: A Study in Magic and Religion, abridged 1 vol. edition, Harmondsworth: Penguin.

Fromm Erich, 1951, The Forgotten Language: An Introduction to the Understanding of Dreams, Fairy Tales and Myths, New York: Holt, Rinehart and Winston.

Gadamer Hans-Georg. 2004, The limits of Erlebniskunst and the rehabilitation of allegory, in: Hans-Georg Gadamer, Truth and Method, trans. William 
Glen-Doepel, Joel Weinsheimer, Donald G. Marshall, revised 2nd ed., London, New York: Continuum, pp. 61-70.

Galasińska Aleksandra, 1989, Pole leksykalno-znaczeniowe OBCY na podstawie powieści Edwarda Redlińskiego „Konopielka”. Analiza etnolingwistyczna, Polonica, vol. 14, pp. 121-141.

Genette Gerard, 1966, Espace et langage, in: Figures, Paris: Editions du Seuil, pp. 101-108.

Gennep Arnold, van, 1960, The Rites of Passage, trans. Monika B. Vizedom, Gabrielle L. Caffee, London: Routledge and Kegan Paul.

Gerlich Halina, 1998, Cykle ludzkiego życia, Katowice: Muzeum Historii Katowic.

Gieysztor Aleksander, 1986, Mitologia Słowian, Warszawa, Wydawnictwa Artystyczne i Filmowe.

Gloger Zygmunt, 1978, Encyklopedia staropolska ilustrowana, vol. 1-4, Warszawa: Wiedza Powszechna.

Godlewski Grzegorz (ed.), 2003, Antropologia słowa. Zagadnienia i wybór tekstów, Warszawa: Wydawnictwa Uniwersytetu Warszawskiego.

Godyń Jan, 1995, Od Adama i Ewy zaczynać. Mały słownik biblizmów języka polskiego, Warszawa: Towarzystwo Miłośników Języka Polskiego.

Golachowska Ewa, Zielińska Anna (eds.), 2011, Wokół języka religii. Konstrukcje i destrukcje tożsamości, Warszawa: Slawistyczny Ośrodek Wydawniczy.

Gołębiowska Teresa, 1974, Nazwy rodziców chrzestnych w gwarach polskich, Zeszyty naukowe Uniwersytetu Jagiellońskiego, issue 340, pp. 95-115.

Gomme George L., 1892, Ethnology in Folkore, London: Kegan Paul, Trench Trübner \& Co.

Góra Aleksandr (Gura Aleksandr), 2000, O zasadach opisu zwierząt w słowiańskiej kulturze ludowej, Etnolingwistyka. Problemy języka $i$ kultury, vol. 12, pp. 251-263.

Grabka Barbara, 2005, Święta religijne w języku zapisane, Język Polski, vol. 85, no. 1, pp. 51-55.

Grand Elena N., 2017, Tales from Poland: Collection of Ancient Tales, CreateSpace Independent Publishing Platform.

Grochowski Piotr, 2003, Dopusty Boże. Kilka uwag na temat motywów religijnych w pieśniach z repertuaru dziadowskiego, in: Nie złota legenda. Kanoniczność a apokryficzność w kulturze, ed. Jarosław Eichstaedt, Krzysztof Piątkowski, Ożarów: Towarzystwo Przyjaciół Muzeum Wnętrz Dworskich, pp. 113-126.

Grochowski Piotr, 2009, Dziady. Rzecz o wędrownych żebrakach i ich pieśniach, Toruń: Wydawnictwo Naukowe Uniwersytetu Mikołaja Kopernika. 
Grodziński Eugeniusz, 1979, Wypowiedzi performatywne. Z aktualnych zagadnień filozofii języka, Wrocław: Zakład Narodowy im. Ossolińskich.

Grzegorczykowa Renata, 1992, Kognitywne ujęcie znaczenia a problem realizmu filozoficznego, in: Jezzy a kultura, vol. 8, Podstawy metodologiczne semantyki współczesnej, ed. Iwona Nowakowska-Kempna, Wrocław: Wydawnictwo Uniwersytetu Wrocławskiego, pp. 37-42.

Grzegorczykowa Renata, 1998, O rozumieniu prototypu i stereotypu w współczesnych teoriach semantycznych, in: Język a kultura, vol. 12, Stereotyp jako przedmiot lingwistyki. Teoria metodologia, analizy empiryczne, ed. Janusz Anusiewicz, Jerzy Bartmiński, Wrocław: Towarzystwo Przyjaciół Polonistyki Wrocławskiej, pp. 109-115.

Grzegorczykowa Renata, 1999, Pojęcie językowego obrazu świata, in: Językowy obraz świata, ed. Jerzy Bartmiński, Lublin: Wydawnictwo Uniwersytetu Marii Curie-Skłodowskiej, pp. 39-46.

Grzegorczykowa Renata, 2001, O specyficznych funkcjach wypowiedzi religijnych, Etnolingwistyka. Problemy języka i kultury, vol. 13, pp. 77-84.

Grzegorczykowa Renata, 2004, Idee kognitywizmu jako podstawa badań porównawczych w zakresie semantyki, Etnolingwistyka. Problemy języka $i$ kultury, vol. 16, pp. 75-84.

Grzegorczykowa Renata, 2008, Od wspólnoty do obcości. Rozwój znaczeniowy polskiego przymiotnika „obcy”, Etnolingwistyka. Problemy języka i kultury, vol. 20, pp. 39-50.

Grzegorczykowa Renata, Pajdzińska Anna (eds.), 1996, Językowa kategoryzacja świata, Lublin: Wydawnictwo Uniwersytetu Marii Curie-Skłodowskiej.

Habrajska Grażyna, 1998, Prototyp - stereotyp - metafora, in: Język a kultura, vol. 12, Stereotyp jako przedmiot lingwistyki. Teoria metodologia, analizy empiryczne, ed. Janusz Anusiewicz, Jerzy Bartmiński, Wrocław: Towarzystwo Przyjaciół Polonistyki Wrocławskiej, pp. 116-123.

Heiner Heidi Anne (ed.), 2011, Mermaid and Other Water Spirit Tales from Around the World, SurLaLune Press.

Hochleitner Janusz, 2006, Obrzędy doroczne w kulturze chłopskiej Warmii południowej w XVI-XVIII wieku, Białystok: Wydawnictwo Uniwersytetu Warmińsko-Mazurskiego.

Hryń-Kuśmierek Renata, Śliwa Zuzanna, 2000, Encyklopedia tradycji polskich, Poznań: Wydawnictwo Podsiedlik-Raniowski i Spółka.

Humboldt Wilhelm, von, 1999, On Language, On the Diversity of Human Language Construction and its Influence on the Mental Development of the Human Species, trans. Peter Heath, ed. Michael Losonsky, Cambridge: Cambridge University Press; chapter 2: General considerations of the course 
of man's development, pp. 23-24; chapter 6: The same [conjoint action of individuals and nations] continued, pp. 41-55; chapter 7: Transition to closer consideration of language, pp. 46-47; chapter 8: Form of languages, pp. 48-53.

Iudin Alekseǐ V., 1998, Vostochnoslavianskiĭ zagavor: struktura, semantyka i pragmatyka teksta, in: Tekst, analizy, interpretacje, ed. Jerzy Bartmiński, Barbara Boniecka, Lublin: Wydawnictwo Uniwersytetu Marii CurieSkłodowskiej, pp. 169-183; (Юдин Алексей В., Восточнославянский заговор: структура, семантика и прагматика текста).

Iudin Alekse ̌ V., 1999, Mifotoponimiia russkikh zagovorov, Etnolingwistyka. Problemy języka i kultury, vol. 11, pp. 177-196; (Юдин Алексей В., Мифотопонимия русских заговоров).

Iudin Alekseĭ V., 2001a, Magicheskie performativy v zagovorakh i kalendarnykh pesniakh Vostochnykh Slavian, Etnolingwistyka. Problemy języka i kultury, vol. 13, pp. 139-148; (Юдин Алексей В., Магические перформативы в заговорах и календарных песнях Восточных Славиан).

Iudin Alekseř V., 2001b, Personifitsirovannye likhoradki v vostochnoslavianskikh narodnykh predstavleniiakh (na materiale zagovorov), Etnolingwistyka. Problemy języka i kultury, vol. 13, pp. 169-178; (Юдин Алексей В., Персонифицированные лихорадки в восточнославянских народных представлениях (на материале заговоров)).

Iudin Alekseǐ V., 2003, Poniatie kartiny/modeli mira v pol'skom i russkom iazykoznanii, in: For East is East, Liber amicorum Wojciech Skalmowski, ed. Tatjana Soldatjenkova, Emmanuel Vaegmans, Leuven, Paris, Dudley: Peeters, pp. 267-275; (Юдин Алексей В., Понятие картины/модели мира в польском и русском языкознании).

Ivanov Viacheslav V., Toporov Vladimir N., 1965, Slavianskie iazykovye modeliruiushchie semioticheskie sistemy, Moskva: Nauka; (Иванов Вячеслав В., Топоров Владимир Н., Славянские языковые моделирующие семиотические системы, Москва: Наука, 1965).

Ivanov Viacheslav V., Toporov Vladimir N., 1974, Issledovaniia v oblasti slavianskikh drevnosteŭ: Leksicheskie i frazeologicheskie voprosy rekonstruktsii tekstov, Moskva: Nauka; (Иванов Вячеслав В., Топоров Владимир Н., Исследования в области славянских древностей: Лексические и фразеологические вопросы реконструкции текстов, Москва: Наука, 1964). Jakitowicz Maria, Wróblewska Violetta (eds.), 2003, W kręgu folkloru, literatury i jezzyka. Prace ofiarowane prof. Janowi Mirosławowi Kasjanowi w 70. rocznice urodzin, Toruń: Wydawnictwo Uniwersytetu Mikołaja Kopernika.

Janicka-Krzywda Urszula, 1993, Patron, atrybut, symbol, Poznań: Pallottinum. 
Janus Elżbieta, Mayenowa Maria R. (eds.), 1977, Semiotyka kultury, Warszawa: Państwowy Instytut Wydawniczy.

Jasiewicz Zbigniew, 1991, Kultura ludowa a ludowość kultury, Lud, vol. 74: 191-196.

Johnson Mark, 1990, The Body in the Mind: The Bodily Basis of Meaning, Imagination and Reason, Chicago, London: University of Chicago Press.

Józefów-Czerwińska Bożena, 2017, Zabobonem nazwano... O wierzeniach, wartościach $i$ dawnych przekonaniach mieszkańców pogranicza polskobiałoruskiego w ich zwiazzkach z przeszłością, Milanówek: Wydawnictwo Trzecia Strona.

Kajfosz Jan, 2001, Językowy obraz świata w etnokulturze Śląska Cieszyńskiego, Czeski Cieszyn: PROprint.

Kalisz Roman, 1993, Pragmatyka językowa, Gdańsk: Uniwersytet Gdański.

Kalisz Roman, 1994a, Kognitywna analiza aktów mowy, in: Podstawy gramatyki kognitywnej, ed. Henryk Kardela, Warszawa: Polskie Towarzystwo Semiotyczne, pp. 109-116.

Kalisz Roman, 1994b, Teoretyczne podstawy językoznawstwa kognitywnego, in: Podstawy gramatyki kognitywnej, ed. Henryk Kardela, Warszawa: Polskie Towarzystwo Semiotyczne, pp. 65-76.

Kamiński Maciej, 1988, O lokalistycznej interpretacji świata w magii, in: Język a kultura, vol. 1, Podstawowe pojęcia i problemy, ed. Janusz Anusiewicz, Jerzy Bartmiński Wrocław: Wiedza i Kultura, pp. 167-172.

Kapełuś Helena, 1991, O turze złotorogim. Szkice kolędowe, Warszawa: Instytut Badań Literackich PAN.

Kardela Henryk, 1988, Tak zwana gramatyka kognitywna a problem stereotypu, Etnolingwistyka, vol. 1, pp. 35-46.

Kardela Henryk, 1990, Ogdena i Richardsa trójkąt uzupełniony, czyli co bada gramatyka kognitywna, in: Językowy obraz świata, ed. Jerzy Bartmiński, Lublin: Wydawnictwo Uniwersytetu Marii Curie-Skłodowskiej, pp. 15-38.

Kardela Henryk, 1992a, Gramatyka kognitywna jako globalna teoria języka, in: Język a kultura, vol. 8, Podstawy metodologiczne semantyki wspótczesnej, ed. Iwona Nowakowska-Kempna, Wrocław: Wydawnictwo Uniwersytetu Wrocławskiego, pp. 9-22.

Kardela Henryk, 1992b, Onomazjologiczny aspekt semantyki kognitywnej, in: Język a kultura, vol. 8, Podstawy metodologiczne semantyki współczesnej, ed. Iwona Nowakowska-Kempna, Wrocław: Wydawnictwo Uniwersytetu Wrocławskiego, pp. 43-56.

Kardela Henryk, 1994, Metaforyczne rozszerzenie kategorii a onomazjologiczna perspektywa znaczenia wyrażeń, in: Podstawy gramatyki kognitywnej, ed. Henryk Kardela, Warszawa: Polskie Towarzystwo Semiotyczne, pp. 77-85. 
Kardela Henryk, 1998, Profilowanie a kategorie podmiotu i dopełnienia w gramatyce R. Langackera, in: Profilowanie w języku i w tekście, ed. Jerzy Bartmiński, Ryszard Tokarski, Lublin: Wydawnictwo Uniwersytetu Marii Curie-Skłodowskiej, pp. 79-90.

Kardela Henryk (ed.), 1994, Podstawy gramatyki kognitywnej, Warszawa: Polskie Towarzystwo Semiotyczne.

Karłowicz Jan, 1900-1911, Słownik gwar polskich, vol. 1- 6, Kraków: Akademia Umiejętności.

Kazancewa Helena (Kazantseva Elena), 2006, Człowiek w zagadkach: archetyp i jego struktura, Etnolingwistyka. Problemy języka i kultury, vol. 18, pp. 187-198.

Kąś Józef, 2002, Wizerunek mężczyzny i kobiety w tradycyjnej społeczności wiejskiej (na materiale gwar orawskich), in: Rozmaitości językowe ofiarowane prof. dr hab. Januszowi Strutyńskiemu z okazji Jego jubileuszu, ed. Mirosław Skarżyński, Monika Szpiczakowska, Kraków: Księgarnia Akademicka, pp. 101-109.

Kiersnowski Ryszard, 1990, Niedźwiedzie i ludzie w dawnych i w nowszych czasach. Fakty i mity, Warszawa: Państwowy Instytut Wydawniczy.

Klimka Libertas, Straižys Vytautas, 1997, The cosmology of the ancient Balts, Journal for the History of Astronomy, vol. 28, Archaeoastronomy supplement, issue 22, pp. S57-S81.

Kobylińska Józefa, 2004, Stereotyp księżyca w utworach prozatorskich Władysława Orkana, in: Język polski $w$ perspektywie diachronicznej $i$ synchronicznej. Księga poświęcona Profesorowi Jerzemu Brzezińskiemu w siedemdziesiąta rocznice urodzin, ed. Krzysztof Maćkowiak, Cezary Piątkowski, Zielona Góra: Uniwersytet Zielonogórski, pp. 143-154.

Kolberg Oskar, Dzieła wszystkie, 1961-, vol. 1-, Warszawa, Kraków (ongoing).

Kolbuszewski Jacek, 1996, Cmentarze, Wrocław: Wydawnictwo Dolnośląskie.

Kołakowski Leszek, 1982, To speak of the unspeakable: Language and the Holy. The need for taboos, in: Leszek Kołakowski, Religion. If There is no God... On God, the Devil, Sin and other Worries of the so-called Philosophy of Religion, New York and Oxford: Oxford University Press, pp. 161-206.

Koniushkevich Mariia, 2001, Prokliatiia v rechevom povedenii Belorusov, Etnolingwistyka. Problemy języka i kultury, vol. 13, pp. 155-168;

(Конюшкевич Мария, Проклятия в речевом поведении Белорусов).

Kopaliński Władysław, 1990, Słownik symboli, Warszawa: Wiedza Powszechna. Kopaliński Władysław, 2006, Słownik mitów i tradycji kultury, Warszawa: Dom Wydawniczy Bellona. 
Kopeć Józef J., 1983, Uwarunkowania historyczno-kulturowe czci Bogarodzicy w polskiej religijności, in: Religijność ludowa. Ciagłość i zmiana, ed. Władysław Piwowarski, Wrocław: Wydawnictwo Wrocławskiej Księgarni Archidiecezjalnej, pp. 21-63.

Kopeć Józef J., 1996, Formy kultu maryjnego w polskiej religijności XIX wieku, Roczniki Teologiczne, vol. 43, no. 4, pp. 165-187.

Kopeć Józef J., 1997, Bogarodzica w kulturze polskiej XVI wieku, Lublin: Redakcja Wydawnictw Katolickiego Uniwersytetu Lubelskiego.

Koper Anna, 1993, Typy informacji i ich układ fasetowy w definicjach haseł z pola „meteorologia” w „Słowniku ludowych stereotypów językowych”, in: $O$ definicjach i definiowaniu, ed. Jerzy Bartmiński, Ryszard Tokarski, Lublin, Wydawnictwo Uniwersytetu Marii Curie-Skłodowskiej, pp. 293-303.

Koper Anna, 2000, Empiryczne i mitologiczne podstawy przepowiedni meteorologicznych. Czas w przepowiedniach, Etnolingwistyka. Problemy języka i kultury, vol. 12, pp. 233-249.

Korżyk Krzysztof, 1992, Semantyka kognitywna - problemy i metody (Kilka uwag natury filozoficznej), in: Język a kultura, vol. 8, Podstawy metodologiczne semantyki współczesnej, ed. Iwona Nowakowska-Kempna, Wrocław: Wydawnictwo Uniwersytetu Wrocławskiego, pp. 57-70.

Kostyro Teresa (ed.), 1987, Symbol i poznanie. W poszukiwaniu koncepcji integrującej, Warszawa: Państwowe Wydawnictwo Naukowe.

Kotula Franciszek, 1970, Hej, leluja!, Warszawa: Ludowa Spółdzielnia Wydawnicza.

Kotula Franciszek, 1974, Po rzeszowskim Podgórzu błądząc, Kraków: Wydawnictwo Literackie.

Kowalik Artur, 2004, Kosmologia dawnych Słowian. Prolegomena do teologii politycznej dawnych Słowian, Kraków: Nomos.

Kowalski Piotr, 1998, Leksykon. Znaki świata. Omen, przesąd, znaczenie, Warszawa: Wydawnictwo Naukowe PWN.

Kowalski Piotr, 2000, Chleb nasz powszedni. O pieczywie w obrzędach, magii, literackich obrazach i opiniach dietetyków, Wrocław: Towarzystwo Przyjaciół Ossolineum.

Kowalski Piotr, 2002, Woda żywa: opowieść o wodzie, zdrowiu, higienie i dietetyce, Wrocław: Towarzystwo Przyjaciół Ossolineum.

Kowalski Piotr, 2007a, Kultura magiczna. Omen, przesąd, znaczenie, Warszawa: Wydawnictwo Naukowe PWN.

Kowalski Piotr, 2007b, Opowieść o chlebie, czyli nasz powszedni, Kraków: Ikon.

Koziara Stanisław, 2001, Frazeologia biblijna w języku polskim, Kraków: Wydawnictwo Naukowe Akademii Pedagogicznej. 
Kozioł Maria, 1986, „Gość w czerwonym płaszczu...”. Pogańskie i chrześcijańskie elementy w ludowym stereotypie ognia, Akcent, no. 4, pp. 48-51.

Kozioł Maria, 1989, Strzygoń, Etnolingwistyka, vol. 2, pp. 85-92.

Kozioł Maria, Szadura Joanna, 1996, entries in: Słownik stereotypów i symboli ludowych, ed. Jerzy Bartmiński, vol. 1, Kosmos, part 1, Lublin: Wydawnictwo Uniwersytetu Marii Curie-Skłodowskiej: Ogień czyśćcowy, pp. 294-295; Ogień piekielny, pp. 296-299.

Kozłowska-Doda Jadwiga, 2011, Symbolika drogi w obrzędowości pogrzebowej (na materiale białoruskim i polskim), in: Droga w jezzyku $i$ w kulturze, ed. Jan Adamowski, Katarzyna Smyk, Lublin: Wydawnictwo Uniwersytetu Marii Curie-Skłodowskiej, pp. 103-117.

Krănbrok-Dukova Ute, 1988, 'Desen' i 'liav' v bŭlgarskite govori, in: Vtori mezhdunaroden kongres po bŭlgaristika: Dokladi, ed. Panteleĭ Zarev et al., vol. 5, Dialektologiia i onomastika, ed. Dora Ivanova-Mircheva et al., Sofiia: Bŭlgarskata akademiia na naukite, pp. 56-65; (Уте КрайнброкДукова, 'Десен' и 'ляв’ в българските говори, в: Втори международен конгрес по българистика: Доклади, глав. ред. Пантелей Зарев и др., т. 5, Диалектология и ономастика, ред. Дора Иванова-Мирчева и др., София, Българската академия на науките, 1988, с. 56-65).

Krawczyk Anna, 1982, Cechy części ciała jako tworzywo semantycznej struktury związków frazeologicznych (na materiale gwarowym), in: $Z$ problemów frazeologii polskiej i słowiańskiej, vol. 1, ed. Mieczysław Basaj, Danuta Rytel-Kuc, Wrocław: Zakład Narodowy im. Ossolińskich, Wydawnictwo PAN, pp. 135-143.

Krawczyk Anna, 1989, Język źródłem wiedzy o człowieku, Etnolingwistyka, vol. 2, pp. 29-38.

Krawczyk-Tyrpa Anna, 1996, Akt mowy a ludowe zakazy językowe, in: Studia dialektologiczne, vol. 1, ed. Bogusław Dunaj, Jerzy Reichan, Kraków: Instytut Języka Polskiego PAN, pp. 359-364.

Krawczyk-Tyrpa Anna, 1998, Gwary a religia, in: Varia Linguistica, ed. Łucja M. Szewczyk, Bydgoszcz: Wyższa Szkoła Pedagogiczna, pp. 127-130.

Krawczyk-Tyrpa Anna, 2001a, Niedźwiedź - małpa Północy?, Twórczość Ludowa, no. 2, pp. 13-16.

Krawczyk-Tyrpa Anna, 2001b, Tabu w dialektach polskich, Bydgoszcz: Wydawnictwo Akademii Bydgoskiej im. Kazimierza Wielkiego.

Krawczyk-Tyrpa Anna, 2001c, Uniewinniająca zwyczajność. O „wiejskich” eufemizmach w dialektach polskich, Etnolingwistyka. Problemy języka $i$ kultury, vol. 13, pp. 63-75.

Krawczyk-Tyrpa Anna, 2003, Niedźwiedzie i ludzie - opozycja rozmyta, in: Język a kultura, vol. 15, Opozycja homo - animal w języku i kulturze, ed. 
Anna Dąbrowska, Wrocław: Wydawnictwo Uniwersytetu Wrocławskiego, pp. 243-250.

Krawczyk-Tyrpa Anna, 2005, Frazeologia somatyczna. Związi frazeologiczne o znaczeniach motywowanych cechami części ciała w gwarach polskich, Wrocław: Oficyna Wydawnicza Leksem.

Krupp Edwin C., 1991, Beyond the Blue Horizon: Myths and Legends of the Sun, Moon, Stars, and Planets, New York and Oxford: Oxford University Press.

Krzeszowski Tomasz P., 1994, Parametr aksjologiczny w przedpojęciowych schematach wyobrażeniowych, Etnolingwistyka, vol. 6, pp. 29-51.

Krzeszowski Tomasz P., 1995, Connotation and denotation, in: Reference in Multidisciplinary Perspective: Philosophical Object, Cognitive Subject, Intersubjective Process, ed. Richard A. Geiger, Hildensheim: Georg Olms, pp. 363-373.

Krzeszowski Tomasz P., 1997, Angels and Devils in Hell: Elements of Axiology in Semantics, Warszawa: Energeia.

Krzeszowski Tomasz P., 1999, Aksjologiczne aspekty semantyki językowej, Toruń: Wydawnictwo Uniwersytetu Mikołaja Kopernika.

Krzyżanowski Julian, 1962-1963, Polska bajka ludowa w układzie systematycznym, vol. 1-2, Wrocław, Warszawa, Kraków: Towarzystwo Naukowe Warszawskie.

Krzyżanowski Julian (ed.), 1965, Słownik folkloru polskiego, Warszawa: Wiedza Powszechna.

Krzyżanowski Julian (ed.), 1969-1978, Nowa księga przysłów i wyrażeń przysłowiowych polskich, vol. 1-4, Warszawa: Państwowy Instytut Wydawniczy.

Kubiak Irena, Kubiak Krzysztof, 1981, Chleb $w$ tradycji ludowej, Warszawa: Ludowa Spółdzielnia Wydawnicza.

Kupiszewski Władysław, 1974, Polskie słownictwo z zakresu astronomii i miar czasu, Warszawa: Państwowe Wydawnictwo Naukowe.

Kupsiński Z., 1988, Obrzędy i wierzenia ludowe Wielkiego Tygodnia w Opoczyńskiem, in: $Z$ badań nad religią i religijnością ludową, ed. Henryk Zimoń, Warszawa: Verbinum, pp. 116-131.

Kurcz Ida, 1987, Język a reprezentacja świata w umyśle, Warszawa: Państwowe Wydawnictwo Naukowe.

Kurek Czesław, 1978, Tradycja i wspótczesność opolskich starostów weselnych, Opole: Instytut Śląski.

Kurek Halina, 2004a, Językowo-kulturowy obraz wsi podkarpackiej wpisany w nazwy roślin, in: Studia linguistica Danutae Wesołowska oblata, ed. Halina Kurek, Janina Labocha, Kraków: Universitas, pp. 129-156. 
Kurek Halina, 2004b, Punkt widzenia w językowym obrazie świata społeczności wiejskiej, in: Punkt widzenia w języku i w kulturze, ed. Jerzy Bartmiński, Stanisława Niebrzegowska-Bartmińska, Ryszard Nycz, Lublin: Wydawnictwo Uniwersytetu Marii Curie-Skłodowskiej, pp. 209-223.

Kurkowska Halina, Skorupka Stanisław, 1959, Stylistyka polska, Warszawa: Państwowe Wydawnictwo Naukowe.

Lakoff George, Johnson Mark, 1980, Metaphors We Live By, Chicago, London: University of Chicago Press.

Langacker Ronald W., 1987, Foundations of Cognitive Grammar, vol. 1, Theoretical Prerequisites, Stanford: Stanford University Press.

Langacker Ronald W., 1988, A view of linguistic semantics, in: Topics in Cognitive Linguistics, ed. Brygida Rudzka-Ostyn, Amsterdam, Philadelphia: John Benjamins, pp. 49-90.

Langacker Ronald W., 1991, Foundations of Cognitive Grammar, vol. 2, Descriptive Application, Stanford: Stanford University Press.

Langacker Ronald W., 1995, Wykłady z gramatyki kognitywnej. Kazimierz nad Wisła, grudzień 1993, trans. Joanna Berej et al., ed. Henryk Kardela, Lublin: Wydawnictwo Uniwersytetu Marii Curie-Skłodowskiej.

Langacker Ronald W., 2008, Cognitive Grammar: A Basic Introduction, Oxford: Oxford University Press.

Laskowska Elżbieta, 1993, Wartościowanie w języku potocznym, Bydgoszcz: Wydawnictwo Wyższej Szkoły Pedagogicznej.

Lecouteux Claude, 2016, Encyclopedia of Norse and Germanic Folklore, Mythology, and Magic, Rochester: Inner Traditions.

Léon-Dufour Xavier, 1975, Dictionnaire du Nouveau Testament, 2nd ed., Paris: Éditions du Seuil.

Léon-Dufour Xavier, 1995, Dictionary of Biblical Theology, 2nd ed., trans. ed. P. Joseph Cahill, Boston: St. Paul Books and Media.

Leszczyński Zenon, 1988, Szkice o tabu językowym, Lublin: Wydawnictwo Katolickiego Uniwersytetu Lubelskiego.

Lévi-Strauss Claude, 1966, The Savage Mind, London: Weidenfeld and Nicolson.

Lévi-Strauss Claude, 1985, The View from Afar, trans. Joachim Neugroschel, Phoebe Hoss, Oxford: Blackwell.

Lewandowski Andrzej, Radkiewicz Józef, 1991, Bocian w mowie i folklorze, Zielona Góra: Wyższa Szkoła Pedagogiczna im. Tadeusza Kotarbińskiego.

Lewicki Andrzej M., 1976, Wprowadzenie do frazeologii syntaktycznej. Teoria zwrotu frazeologicznego, Katowice: Wydawnictwo Uniwersytetu Śląskiego. 
Lewicki Andrzej M., 1993, Językoznawstwo polskie XX wieku, in: Encyklopedia kultury polskiej XX w., vol. 2, Wspótczesny język polski, ed. Jerzy Bartmiński, Lublin: Wydawnictwo Uniwersytetu Marii Curie-Skłodowskiej, pp. 589-624.

Lewicki Andrzej M., Pajdzińska Anna, 1993, Świat przez pryzmat frazeologizmów, in: Encyklopedia kultury polskiej XX w., vol. 2, Współczesny język polski, ed. Jerzy Bartmiński, Lublin: Wydawnictwo Uniwersytetu Marii Curie-Skłodowskiej, pp. 321-325.

Lewkijewska Elena E. (Levkievskaia Elena E.), 2004, Semantyka okna w tradycyjnej kulturze Słowian wschodnich, trans. Irina Lappo, Etnolingwistyka. Problemy języka i kultury, vol. 16, pp. 173-177.

Libera Zbigniew, 1995, Medycyna ludowa. Chłopski rozsadek czy gminna fantazja, Wrocław: Wydawnictwo Uniwersytetu Wrocławskiego.

Libura Agnieszka, 1995, Metaforyka potoczna w przestrzeni semantycznej światło - ciemność, Rozprawy Komisji Językowej (Wrocław), vol. 21, pp. 25-58.

Libura Agnieszka, 2000, Wyobraźnia w języku. Leksykalne korelaty schematów wyobrażeniowych Centrum - Peryferie i Sity, Wrocław: Wydawnictwo Uniwersytetu Wrocławskiego.

Lippmann Walter, 1922, Public Opinion, New York: Macmillan.

Lurker Manfred, 1987, Wörterbuch biblischer Bilder und Symbole, 3rd ed., München: Kösel.

Lurker Manfred, 1990, Die Botschaft der Symbole: in Mythen, Kulturen und Religionen, München: Kösel.

Łeńska-Bąk Katarzyna, 1999, Performatywność rytuału i ceremonii, in: Folklorystyczne i antropologiczne opisanie świata. Ksiegga ofiarowana Profesor Dorocie Simonides, ed. Teresa Smolińska, Opole: Wydawnictwo Uniwersytetu Opolskiego, pp. 113-121.

Łeńska-Bąk Katarzyna, 2002, Sól ziemi, Wrocław: Towarzystwo Przyjaciół Ossolineum.

Łowmiański Henryk, 1986, Religia Słowian i jej upadek (w. VI-XII), Warszawa: Państwowe Wydawnictwo Naukowe.

Ługowska Jolanta, 1990, Rola kontekstu w procesie kształtowania się kulturowych znaczeń tekstów folkloru, in: Tekst w kontekście. Zbiór studiów, ed. Teresa Dobrzyńska, Wrocław: Zakład Narodowy im. Ossolińskich, pp. 175-186.

MacLeod Sharon Paice, 2018, Celtic Cosmology and the Otherworld: Mythic Origins, Sovereignty and Liminality, Jefferson: McFarland \& Company. Maćkiewicz Jolanta, 1990, Morze, Etnolingwistyka, vol. 3, pp. 77-94. 
Maćkiewicz Jolanta, 1997, Wszędzie dobrze, ale w DOMU najlepiej (There is no place like home) czyli DOM we frazeologii polskiej i angielskiej, in: Dom w języku i w kulturze, ed. Grażyna Sawicka, Szczecin: Wydawnictwo JotA, pp. 69-76.

Maćkiewicz Jolanta, 1999, Co to jest „językowy obraz świata”, Etnolingwistyka. Problemy języka i kultury, vol. 11, pp. 7-24.

Maćkiewicz Jolanta, Majer-Baranowska Urszula, 1999, Morze, in: Stownik stereotypów i symboli ludowych, ed. Jerzy Bartmiński, vol. 1, Lublin: Wydawnictwo Uniwersytetu Marii Curie-Skłodowskiej, pp. 381-417.

Madejowa Maria, Kudyba Wojciech, Mlekodaj Anna (eds.), 2003, Orkan czytany dzisiaj, Nowy Targ: Zakład Poligraficzny "MK".

Maisonneuve Jean, 1988, Les rituels, Paris: Presses universitaires de France.

Majer-Baranowska Urszula, 1986, Deszcz i jego zapładniająca funkcja, Akcent, no. 4, pp. 30-36.

Majer-Baranowska Urszula, 1988, Stereotyp językowy 'płaczu' w polszczyźnie ludowej, Etnolingwistyka, vol. 1, pp. 101-131.

Majer-Baranowska Urszula, 1991, Świętość źródła w polskiej kulturze ludowej, part 1, Twórczość Ludowa, no. 2, pp. 17-20; part 2, Twórczość Ludowa, no. 3-4, pp. 73-75.

Majer-Baranowska Urszula, 1993, „Woda” - profile pojęcia w polszczyźnie ludowej, in: O definicjach i definiowaniu, ed. Jerzy Bartmiński, Ryszard Tokarski, Lublin: Wydawnictwo Uniwersytetu Marii Curie-Skłodowskiej, pp. 227-291.

Majer-Baranowska Urszula, 1995, Dualizm religijny w ludowych wierzeniach o pochodzeniu wody, in: Folklor - sacrum - religia, ed. Jerzy Bartmiński, Maria Jasińska-Wojtkowska, Lublin: Instytut Europy Środkowo-Wschodniej, pp. $115-128$.

Majer-Baranowska Urszula, 1999a, entries in: Słownik stereotypów i symboli ludowych, ed. Jerzy Bartmiński, vol. 1, Kosmos, part 2, Lublin: Wydawnictwo Uniwersytetu Marii Curie-Skłodowskiej: Jezioro, pp. 355-379; Krynica, pp. 279-283; Potop, pp. 419-422; Powódź, pp. 422-426; Stok, pp. 284-287; Woda, pp. 153-235; Woda kryniczna, pp. 283-284; Woda z jeziora, pp. 379-380; Woda ze stoku, pp. 287-288; Woda źródlana, pp. 275-278; Woda żywa, pp. 235-246; Zdrój, pp. 288-293; Źródło, pp. 265-275.

Majer-Baranowska Urszula, 1999b, Stereotyp językowy ‘żywej wody’ w polskim folklorze, in: W zwierciadle języka i kultury, ed. Jan Adamowski, Stanisława Niebrzegowska, Lublin: Wydawnictwo Uniwersytetu Marii CurieSkłodowskiej, pp. 416-426.

Majer-Baranowska Urszula, 2001, Woda jako lek w polskiej kulturze ludowej, in: Studia Literaria Polono-Slavica, vol. 6, Morbus, Medicamentum et 
sanus. Choroba, lek i zdrowie, ed. Roman Bobryk, Jerzy Faryno, Warszawa: Slawistyczny Ośrodek Wydawniczy, pp. 127-137.

Majer-Baranowska Urszula, 2003, Podmiot jako wartość, in: Język w kręgu wartości. Studia semiotyczne, ed. Jerzy Bartmiński, Lublin: Wydawnictwo Uniwersytetu Marii Curie-Skłodowskiej, pp. 243-259.

Majer-Baranowska Urszula, 2004, Dwie koncepcje profilowania w lingwistyce, Etnolingwistyka. Problemy języka i kultury, vol. 16, pp. 85-109.

Makuchowska Marzena, 1995, Styl religijny, in: Przewodnik po stylistyce polskiej, ed. Stanisław Gajda, Opole: Uniwersytet Opolski, pp. 449-473.

Malinowski Bronisław, 1935, Coral Gardens and their Magic: A Study of the Methods of Tilling the Soil and Agricultural Rites in the Trobriand Islands, vol. 2, The Language of Magic and Gardening, London: George Allen \& Unwin; part 4, chapter 1: Language as tool, document and cultural reality, pp. 4-10; part 4, chapter 5: Meaning as function of words, pp. 52-62.

Malinowski Bronisław, 1948, Magic, Science and Religion and Other Essays, ed. Robert Redfield, Glencoe: The Free Press.

Malinowski Bronisław, 1962, Sex, Culture and Myth, New York: Harcourt, Brace and World.

Mandler Jean M., 1984, Stories, Scripts, and Scenes: Aspects of Schema Theory, Hillsdale: L. Erlbaum Associates, Publishers.

Marczewska Marzena, 1998, Dąb - drzewo zmarłych. Z rozważań nad językowo-kulturowym obrazem dębu, Etnolingwistyka. Problemy języka $i$ kultury, vol. 9/10, pp. 121-134.

Marczewska Marzena, 1999, Wierzba - drzewo diabelskie (z rozważań nad ludowym językowym obrazem drzewa), Kieleckie Studia Filologiczne, vol. 13, pp. 65-79.

Marczewska Marzena, 2001, Aspekty wierzeniowe w rekonstrukcji językowego obrazu drzew, in: Język a kultura, vol. 16, Świat roślin w języku i w kulturze, ed. Anna Dąbrowska, Irena Kamińska-Szumaj, Wrocław: Wydawnictwo Uniwersytetu Wrocławskiego, pp. 83-98.

Marczewska Marzena, 2002a, Drzewa w języku i w kulturze, Kielce: Wydawnictwo Akademii Świętokrzyskiej.

Marczewska Marzena, 2002b, Miejsce symboliki w ludowym językowym obrazie drzew, Studia Filologiczne Akademii Świętokrzyskiej, vol. 16, Kielce, pp. 121-136.

Markowska Danuta, 1972, Małżeństwo w tradycyjnej i współczesnej kulturze wiejskiej, in: Studia z zakresu socjologii etnografii i historii ofiarowane Kazimierzowi Dobrowolskiemu, Kraków: Wydawnictwo Literackie, pp. 169-171. 
Masłowska Ewa, 1987, Przeobrażenia semantyczne polskich gwarowych nazw diabła, Studia z Filologii Polskiej i Słowiańskiej, vol. 24, pp. 77-90.

Masłowska Ewa, 1999, Ludowy stereotyp rzeki - zarys struktury, in: Językowy obraz świata, ed. Jerzy Bartmiński, Lublin: Wydawnictwo Uniwersytetu Marii Curie-Skłodowskiej, pp. 183-191.

Masłowska Ewa, 2004, Kognitywne ścieżki zdrowia, in: Życie i zdrowie człowieka $w$ tradycji i kulturze polskiej, Materialy konferencji „Problematyka życia i zdrowia w tradycji i kulturze polskiej", Warszawa 16 października 2003, ed. Wojciech Bołoza, Ewa Wolnicz-Pawłowska, Warszawa: Wydawnictwo Uniwersytetu Kardynała Stefana Wyszyńskiego, pp. 179-192.

Masłowska Ewa, 2007a, Językowe i kulturowe konteksty towarzyszące wyznaczaniu granic tożsamości rodzinnej i grupowej w kaszubszczyźnie, Studia z Filologii Polskiej i Słowiańskiej, vol. 42, pp. 91-103.

Masłowska Ewa, 2007b, Swoi i obcy przy wspólnym stole, Etnolingwistyka. Problemy jezzka i kultury, vol. 19, pp. 109-132.

Masłowska Ewa, 2011, Wędrówka dusz w zaświaty - szerokim gościńcem i po bezdrożach (schematy wyobrażeń w kulturze ludowej), in: Droga w języku $i$ w kulturze. Analizy antropologiczne, ed. Jan Adamowski, Katarzyna Smyk, Lublin: Wydawnictwo Uniwersytetu Marii Curie-Skłodowskiej, pp. 117-128.

Masłowska Ewa, 2012a, Fantomy pamięci. Pamięć semantyczna pocałunku, in: Tradycja dla wspótczesności. Ciagłość i zmiana, vol. 6, Pamięć jako kategoria rzeczywistości kulturowej, ed. Jan Adamowski, Marta Wójcicka, Lublin: Wydawnictwo Uniwersytetu Marii Curie-Skłodowskiej, pp. 129-141.

Masłowska Ewa, 2012b, Pozytywne schematy destrukcji w relacjach z zaświatami, in: Wartości w językowo-kulturowym obrazie świata Słowian $i$ ich sasiadów, ed. Maciej Abramowicz, Jerzy Bartmiński, Iwona BielińskaGardziel, Lublin: Wydawnictwo Uniwersytetu Marii Curie-Skłodowskiej, pp. 289-304.

Masłowska Ewa, 2014, Działania w imię Boże - wyzwalanie sprawczej mocy słowa, in: Znaczenie - tekst - kultura. Prace ofiarowane Profesor Elżbiecie Janus, ed. Anna Kozłowska, Agnieszka Świątek, Warszawa: Wydawnictwo Uniwersytetu Kardynała Stefana Wyszyńskiego, pp. 385-398.

Masłowska Ewa, 2015, Kultura ludowa czy tradycyjna? Problemy z terminologią, in: „Ja daję właśnie materiał...” O dziele Oskara Kolberga w dwusetna rocznice Jego urodzin, ed. Ewa Antyborzec, Poznań: Instytut im. Oskara Kolberga, pp. 425-440.

Masłowska Ewa, 2016a, Dziad i baba - strażnicy duszy w języku i polskiej kulturze tradycyjnej, in: Antropologiczno-językowe wizerunki duszy w perspektywie międzykulturowej, vol. 1. Dusza w oczach świata, ed. Ewa 
Masłowska, Dorota Pazio-Wlazłowska, Warszawa: Instytut Slawistyki PAN, Wydział Orientalistyczny Uniwersytetu Warszawskiego, pp. 467-486.

Masłowska Ewa, 2016b, „Dobre słowo” jako tekst magiczny, Acta Universitatis Vratislaviensis, no. 3721, Język a Kultura, vol. 26, pp. 231-243.

Masłowska Ewa, 2017, Kamienne Serce - drewniana dusza. Kamień i drzewo jako archetypowe wzorce kreowania wizerunku psychofizycznej kondycji człowieka w języku i w kulturze tradycyjnej, in: Tekst v iazyke, rechi, kul'ture. Sbornik nauchnykh stateŭ, Minsk: Respublikanskii instytut vyssheŭ shkoly, pp. 200-214; (Текст в языке, речи, культуре. Сборник научных статей, Минск: Республиканский институт высшей школы).

Masłowska Ewa, Niebrzegowska Stanisława, 1999, entries in: Słownik stereotypów i symboli ludowych, ed. Jerzy Bartmiński, vol. 1, Kosmos, part 2, Lublin: Wydawnictwo Uniwersytetu Marii Curie-Skłodowskiej: Błoto, pp. 446-456; Rzeka, pp. 324-350; Woda rzeczna, pp. 350-355.

Mazur Józef, 1902, O miłości u ludu w życiu i pieśni, Lud, vol. 8, pp. 225-244.

Mazurek Robert, 2009, Jezus nie był wywrotowcem (wywiad Roberta Mazurka z Ryszardem Montusiewiczem), Magazyn Dziennika, 4-5 April.

Mazurkiewicz Małgorzata, 1986, Kamień: dzieło Boga czy diabelska sprawka?, Akcent, no. 4, pp. 52-55.

Mazurkiewicz Małgorzata, 1987, Kamień człekokształtny, czyli życie ukarane, Polska Sztuka Ludowa, vol. 41, no. 1-4, pp. 74-77.

Mazurkiewicz Małgorzata, 1988, Kamień piorunowy w polszczyźnie i kulturze ludowej (Szkic hasła do Słownika ludowych stereotypów językowych), in: Język a kultura, vol. 1, Podstawowe pojęcia i problemy, ed. Janusz Anusiewicz, Jerzy Bartmiński, Wrocław: Wiedza i Kultura, pp. 251-262.

Mazurkiewicz Małgorzata, 1989, Praca i sacrum w polszczyźnie ludowej, Etnolingwistyka, vol. 2, pp. 7-28.

Mazurkiewicz Małgorzata, 1990, Marmur. Dwie wersje artykułu hasłowego do „Słownika ludowych stereotypów językowych”, Etnolingwistyka, vol. 3, pp. 71-75.

Mazurkiewicz Małgorzata, 1991, Drogie kamienie w ludowym językowym obrazie świata, in: Język a kultura, vol. 2, Zagadnienia leksykalne $i$ aksjologiczne, ed. Jadwiga Puzynina, Jerzy Bartmiński, Wrocław: Wiedza o Kulturze, pp. 115-126.

Mazurkiewicz Małgorzata, 2009, Etymologia a konotacja słowa. Studia semantyczne, Lublin: Wydawnictwo Uniwersytetu Marii Curie-Skłodowskiej.

Mianecki Adrian, 2010, Stworzenie świata w folklorze polskim XIX i początku XX wieku, Toruń: Wydawnictwo Naukowe Uniwersytetu Mikołaja Kopernika. 
Michajłowa Katia (Mikhaĭlova Katia), 2002, Dziad wędrowny jako postać mediacyjna w kulturze ludowej Słowian, in: Fascynacje folklorystyczne. Ksiega poświęcona pamięci Heleny Kapełuś, ed. Magdalena Kapełuś, Anna Engelking, Warszawa: Agade, pp. 101-108.

Michajłowa Katia (Mikhaullova Katia), 2010, Dziad wędrowny w kulturze ludowej Słowian, trans. Hanna Karpińska, Warszawa: Oficyna Naukowa; original work: Mikhaullova Katia, Stranstvashtiiat sliap pevets prosiak vŭv folklornata kultura na slavianite, Sofiia: Izdatelsko Atelie 'Ab', 2006; (Михайлова Катя, Странстващият сляп певец просяк във фолклорната култура на славяните, София: Издателско ателие Аб, 2006).

Miczka Ewa, 2000, Prototyp w lingwistyce tekstu, in: Gatunki mowy i ich ewolucja, vol. 1: Mowy piękno wielorakie, ed. Danuta Ostaszewska, Katowice: Wydawnictwo Uniwersytetu Śląskiego, pp. 20-31.

Miczka Ewa, 2002, Kognitywne struktury sytuacyjne w interpretacji dyskursu, Katowice: Wydawnictwo Uniwersytetu Śląskiego.

Mify narodov mira. Éntsiklopediia, 1987-1988, vol. 1-2, ed. Serger A. Tokarev, Moskva: Sovetskaia Entsiklopediia; (Мифы народов мира. Энциклопедия, т. 1-2, гл. ред. Сергей А. Токарев, Москва: Советская Энциклопедия, 1987-1988).

Młynarczyk Ewa, 2003, Językowe wykładniki opozycji „swoi - obcy” w utworach Władysława Orkana, in: Orkan czytany dzisiaj, ed. Maria Madejowa, Wojciech Kudyba, Anna Mlekodaj, Nowy Targ: Zakład Poligraficzny "MK”, pp. 49-62.

Moroz Andreŭ B., 2007, Fol'klornyı̌ kontsept sviatosti: svoi ili chuzhie?, Etnolingwistyka. Problemy języka i kultury, vol. 19, pp. 143-153; (Мороз Андрей Б., Фольклорный концепт святости: свои или чужие?).

Moszyński Kazimierz, 1967-1968, Kultura ludowa Słowian, vol. 2, Kultura duchowa, parts 1 and 2, Warszawa: Książka i Wiedza.

Moszyński Leszek, 1991, Prasłowiańskie duchy w oczach slawisty-filologa, Acta Universitatis Nicolai Copernici, Filologia Polska, vol. 36, Nauki Humanistyczno-Społeczne, issue 230, pp. 149-170.

Moszyński Leszek, 1999, Początki słowiańskiego słownictwa religijnego, in: Tysiąc lat polskiego słownictwa religijnego, ed. Bogusław Kreja, Gdańsk: Wydawnictwo Uniwersytetu Gdańskiego, pp. 7-12.

Mróz Lech, 1976, Mit i myślenie mityczne, Etnografia Polska, vol. 20, no. 1, pp. $25-44$.

Muszyński Zbysław, 1988, Problem wiedzy pozajęzykowej w badaniach lingwistycznych, in: Konotacja, ed. Jerzy Bartmiński, Lublin: Wydawnictwo Uniwersytetu Marii Curie-Skłodowskiej, pp. 126-153. 
Muszyński Zbysław, 1992, Odnoszenie się wyrażeń w świetle procesu porozumiewania się, in: Język a kultura, vol. 8, Podstawy metodologiczne semantyki współczesnej, ed. Iwona Nowakowska-Kempna, Wrocław: Wydawnictwo Uniwersytetu Wrocławskiego, pp. 23-36.

Muszyński Zbysław, 2004, Punkt widzenia a relatywizm, in: Punkt widzenia w języku i w kulturze, ed. Jerzy Bartmiński, Stanisława NiebrzegowskaBartmińska, Ryszard Nycz, Lublin: Wydawnictwo Uniwersytetu Marii CurieSkłodowskiej, pp. 33-47.

Naaké John T., 2016, Slavonic Fairy Tales, Rawtenstall: Owlfoot Press.

Niebrzegowska Stanisława, 1986, Słońce raduje się - metafora czy mit?, Akcent, no. 4, pp. 37-39.

Niebrzegowska Stanisława, 1990, Gwiazdy w ludowym językowym obrazie świata, in: Językowy obraz świata, ed. Jerzy Bartmiński, Lublin: Wydawnictwo Uniwersytetu Marii Curie-Skłodowskiej, pp. 147-166.

Niebrzegowska Stanisława, 1992, Nów w polskiej kulturze ludowej i gwarach, Etnolingwistyka, vol. 5, pp. 73-82.

Niebrzegowska Stanisława, 1996, entries in: Słownik stereotypów i symboli ludowych, ed. Jerzy Bartmiński, vol. 1, Kosmos, part 1, Lublin: Wydawnictwo Uniwersytetu Marii Curie-Skłodowskiej: Droga Mleczna, pp. 252-257; Gwiazdy, pp. 203-221; Krzyż święty, pp. 150.

Niebrzegowska Stanisława, 1998, 'Dusze na pokucie'. Lubelskie opowieści wierzeniowe, Etnolingwistyka. Problemy języka i kultury, vol. 9/10, pp. 319-328.

Niebrzegowska Stanisława, 1999a, entries in: Stownik stereotypów i symboli ludowych, ed. Jerzy Bartmiński, vol. 1, Kosmos, part 2, Lublin: Wydawnictwo Uniwersytetu Marii Curie-Skłodowskiej: Potok, pp. 312-322; Ruczaj, pp. 295-296; Struga, pp. 296-303; Strumień, pp. 303-311; Woda ze strugi, p. 303; Woda ze strumienia, pp. 311-312; Woda z potoku, pp. 322-324.

Niebrzegowska Stanisława, 1999b, Czart złoto na bagnach suszy. Konceptualizacja bagna w polskiej tradycji ludowej, in: Folklorystyczne $i$ antropologiczne opisanie świata. Księga ofiarowana Profesor Dorocie Simonides, ed. Teresa Smolińska, Opole: Wydawnictwo Uniwersytetu Opolskiego, pp. 293-304.

Niebrzegowska Stanisława, 1999c, Gwiazdy w ludowym językowym obrazie świata, in: Językowy Obraz Świata, ed. Jerzy Bartmiński, 2nd ed., Lublin: Wydawnictwo Uniwersytetu Marii Curie-Skłodowskiej, pp. 137-154.

Niebrzegowska Stanisława, 1999d, Na krawędziach Ziemi są rzeki wielkie, co zamykają świat. O funkcjach rzeki jako granicy, Twórczość Ludowa, no. 1, pp. $12-15$. 
Niebrzegowska Stanisława, 1999e, Pośrodku nieba jest droga, czyli obraz Drogi Mlecznej w polskiej kulturze ludowej, Twórczość Ludowa, no. 2, pp. 9-11.

Niebrzegowska Stanisława, 2000, Przestrach od przestrachu. Rośliny w ludowych przekazach ustnych, Lublin: Wydawnictwo Uniwersytetu Marii Curie-Skłodowskiej.

Niebrzegowska Stanisława, Bartmiński Jerzy, 1996, entries in: Słownik stereotypów i symboli ludowych, ed. Jerzy Bartmiński, vol. 1, Kosmos, part 1, Lublin: Wydawnictwo Uniwersytetu Marii Curie-Skłodowskiej: Księżyc, pp. 158-186; Księżyc po pełni, pp. 197-198; Niebo, pp. 85-118; Nów, pp. 187192; Pełnia, pp. 193-197; Półpełnia, pp. 193; Puste dni, pp. 200-201; Słońce, pp. 119-144; Wiotek, pp. 198-199; Wschód słońca, pp. 144-155; Zachód słońca, pp. 151-156; Zaćmienie księżyca, pp. 201-202; Zaćmienie słońca, pp. 201-202.

Niebrzegowska Stanisława, Masłowska Ewa, 1999, entries in: Słownik stereotypów i symboli ludowych, ed. Jerzy Bartmiński, vol. 1, Kosmos, part 2, Lublin: Wydawnictwo Uniwersytetu Marii Curie-Skłodowskiej: Błoto, pp. 446-456; Rzeka, pp. 324-350; Woda rzeczna, pp. 350-355.

Niebrzegowska-Bartmińska Stanisława, 2001, Idea działającego słowa w tekstach polskich zamówień, Etnolingwistyka. Problemy języka i kultury, vol. 13, pp. 101-115.

Niebrzegowska-Bartmińska Stanisława, 2006, Konceptualizacja choroby w polszczyźnie potocznej i w polskich zamówieniach ludowych, in: Literatura ludowa i medycyna, part 3, Sposoby leczenia dawniej i dziś w świetle literatury i medycyny, ed. Eugenia Łoch, Grzegorz Wallner, Lublin: Wydawnictwo Lubelskiego Towarzystwa Naukowego, pp. 33-48.

Niebrzegowska-Bartmińska Stanisława, 2007, Wzorce tekstów ustnych w perspektywie antropologicznej, Lublin: Wydawnictwo Uniwersytetu Marii Curie-Skłodowskiej.

Niebrzegowska-Bartmińska Stanisława, 2010, Sakronimy w polskim ludowym obrazie ziól, in: Świecie nasz. Księga jubileuszowa dedykowana Profesorowi Czesławowi Kosylowi, ed. Halina Pelcowa, Lublin: Wydawnictwo Uniwersytetu Marii Curie-Skłodowskiej, pp. 277-289.

Niebrzegowska-Barmińska Stanisława, 2011, Posłuchajcie, grzesznicy, o straszliwym sądzie... Wykonawca, narrator i bohater ludowych pieśni dziadowskich, in: Slavianskiu i balkanskiu fol'klor, vol. 11, Vinograd'e. K iubileiu Liudmily Nikolaevny Vinogradovol̆, ed. Aleksandr V. Gura, Moskva: Indrik, pp. 181-194; (Славянский и балканский фольклор, вып. 11, Виноградье. К юбилею Людмилы Николаевны Виноградовой, отв. ред. Алексаднр В. Гура, Москва: Индрик, 2011). 
Niewiadomski Donat, 1986, Ziemia - materia aktów stwarzania, Akcent, no. 4, pp. 59-63.

Niewiadomski Donat, 1987, Orka złotym pługiem, Twórczość Ludowa, no. 4, pp. 21-23.

Niewiadomski Donat, 1988, Więź rozrodcza ziemi i człowieka. W kręgu symboliki fallicznej, Twórczość Ludowa, no. 1, pp. 33-34.

Niewiadomski Donat, 1989, Semantyka jajka w rytach orki i siewu, Etnolingwistyka, vol. 2, pp. 61-72.

Niewiadomski Donat, 1991, Semantyka ziarna w inicjalnych rytach siewnych, Etnolingwistyka, vol. 4, pp. 83-103.

Niewiadomski Donat, 1992, Motyw orki złotym pługiem. Semantyka noworocznej kolędy gospodarskiej, Etnolingwistyka, vol. 5, pp. 59-70.

Niewiadomski Donat, 1999, Orka i siew. O ludowych wyobrażeniach agrarnych, Lublin: Polihymnia.

Nikitina Serafima J. (Nikitina Serafima E.), 1998, Stereotypy jako bariery kulturowe, trans. Danuta Misiąg, in: Język a kultura, vol. 12, Stereotyp jako przedmiot lingwistyki. Teoria metodologia, analizy empiryczne, ed. Janusz Anusiewicz, Jerzy Bartmiński, Wrocław: Towarzystwo Przyjaciół Polonistyki Wrocławskiej, pp. 155-159.

Nowakowska-Kempna Iwona, 1992a, Aproksymacja semantycznego continuum, in: Język a kultura, vol. 8, Podstawy metodologiczne semantyki współczesnej, ed. Iwona Nowakowska-Kempna, Wrocław: Wydawnictwo Uniwersytetu Wrocławskiego, pp. 125-156.

Nowakowska-Kempna Iwona (ed.), 1992b, Język a kultura, vol. 8, Podstawy metodologiczne semantyki współczesnej, Wrocław: Wydawnictwo Uniwersytetu Wrocławskiego.

Nowosad-Bakalarczyk Marta, 2009, Płeć a rodzaj gramatyczny we współczesnej polszczyźnie, Lublin: Wydawnictwo Uniwersytetu Marii Curie-Skłodowskiej.

Ogrodowska Barbara, 2000, Boże Narodzenie w tradycji polskiej, Warszawa: Centrum Animacji Kultury.

Ogrodowska Barbara, 2001, Zwyczaje, obrzędy i tradycje w Polsce, 2nd ed., Warszawa: Verbinum.

Olszewski Daniel, 1996, Polska kultura religijna na przełomie XIX i XX w., Warszawa: PAX.

Ortega y Gasset José, 1963, Man and People, trans. Willard R. Trask, New York: Norton 1963; chapter 11: What people say: language. Toward a new linguistics, pp. 222-257; chapter 12: What people say: 'public opinion', social 'observances'. Public power, pp. 258-272. 
Ożdżyński Jan, 1988, Kontekst kulturowy w opisie leksykograficznym (w poszukiwaniu wspólnego kodu), Przegląd Humanistyczny, no. 7, pp. 115-133.

Pajdzińska Anna, 1990, Antropocentryzm frazeologii potocznej, Etnolingwistyka, vol. 3, pp. 59-68.

Pajdzińska Anna, 1995, Motywacja semantyczna przymiotników wartościujących, Etnolingwistyka, vol. 7, pp. 5-20; a modified version of original work in German: Semantische Motiviertheit polnischer Wertadjektive, in: Wartościowanie w języku i tekście, na materiale polskim i niemieckim, ed. Gabriel Falkenberg, Norbert Fries, Jadwiga Puzynina, Warszawa: Wydawnictwa Uniwersytetu Warszawskiego 1992, pp. 135-159.

Pajdzińska Anna, 1996, Wrażenia zmysłowe jako podstawa metafor językowych, Etnolingwistyka. Problemy jezzyka i kultury, vol. 8, pp. 113-130.

Panasiuk Jolanta, 1998, O zmienności stereotypów, in: Język a kultura, vol. 12, Stereotyp jako przedmiot lingwistyki. Teoria metodologia, analizy empiryczne, ed. Janusz Anusiewicz, Jerzy Bartmiński, Wrocław: Towarzystwo Przyjaciół Polonistyki Wrocławskiej, pp. 84-98.

Pawluczuk Włodzimierz, 1978, Żywioł i forma: wstęp do badań empirycznych nad kultura wspótczesną, Warszawa: Państwowy Instytut Wydawniczy.

Pelcowa Halina, 1999, Przeszłość w językowym obrazie świata współczesnej wsi, in: Przeszłość w językowym obrazie świata, ed. Anna Pajdzińska, Piotr Krzyżanowski, Lublin: Wydawnictwo Uniwersytetu Marii CurieSkłodowskiej, pp. 253-267.

Pelcowa Halina, 2006, Dialektologia a etnolingwistyka, Etnolingwistyka. Problemy języka i kultury, vol. 18, pp. 91-103.

Pelcowa Halina, 2007, Swój/obcy w świadomości mieszkańców lubelskich wsi, Etnolingwistyka. Problemy języka i kultury, vol. 19, pp. 75-87.

Pełka Leonard, 1987, Polska demonologia ludowa, Warszawa: Wydawnictwo Iskry.

Perszon Jan, 1999, Na brzegu życia i śmierci. Zwyczaje, obrzędy oraz wierzenia pogrzebowe i zaduszkowe na Kaszubach, Lublin: Towarzystwo Naukowe Katolickiego Uniwersytetu Lubelskiego.

Piątkowski Krzysztof, 1994, Badacz wobec tradycji, in: Pożegnanie paradygmatu? Etnologia wobec współczesności, ed. Wojciech Burszta, Warszawa: Instytut Kultury, pp. 117-129.

Pisarek Walery, 1975, Wyobrażenia o polskich stereotypach regionalnych, Zeszyty Prasoznawcze, no. 1, pp. 73-78.

Pisarkowa Krystyna, 1976, Konotacja semantyczna nazw narodowości, Zeszyty Prasoznawcze, no. 1, pp. 5-26.

Pisarkowa Krystyna, 1984, Historia składni języka polskiego, Wrocław: Ossolineum. 
Pisarkowa Krystyna, 1998, Zaklęcie magiczne a korespondencja tekstu z faktem, w: Tekst. Analizy i interpretacje, ed. Jerzy Bartmiński, Barbara Boniecka, Lublin: Wydawnictwo Uniwersytetu Marii Curie-Skłodowskiej, pp. 151-167.

Piwowarczyk Dariusz, 1988, Święto Matki Boskiej Zielnej w obrzędach i wierzeniach ludowych, in: $Z$ badań nad religia i religijnością ludowa, ed. Henryk Zimoń, Warszawa: Verbinum, pp. 132-148.

Pollington Stephen, 2017, The Elder Gods: The Otherworld of Early England, Anglo-Saxon Books.

Polska pieśń i muzyka ludowa. Lubelskie, 2011, vol. 4, parts 1-4, ed. Jerzy Bartmiński, Lublin: Instytut Sztuki Polskiej Akademii Nauk, Uniwersytet Marii Curie-Skłodowskiej, Wydawnictwo Muzyczne Polihymnia.

Popowska-Taborska Hanna, 1987, Kaszubski kutin 'czarownik'. Przyczynek do paralelizmów procesów nazwotwórczych, Studia Polonistyczne vol. 14/15, pp. 211-214.

Popowska-Taborska Hanna, 1989, Ślady kultury dawnych Słowian utrwalone w poszczególnych wyrazach słowiańskich, Studia z Filologii Polskiej $i$ Słowiańskiej, vol. 25, pp. 167-174.

Popowska-Taborska Hanna, 1990, Językowe wykładniki opozycji swój - obcy w procesie tworzenia etnicznej tożsamości, in: Językowy obraz świata, ed. Jerzy Bartmiński, Lublin: Wydawnictwo Uniwersytetu Marii Curie-Skłodowskiej, pp. 61-68.

Popowska-Taborska Hanna, 1991, Wczesne dzieje Słowian w świetle ich języka, Wrocław: Zakład Narodowy im. Ossolińskich.

Popowska-Taborska Hanna, 1993, Zanikające kaszubskie verba nocëc 'czarować, kunocëc 'guzdrać, Zeszyty Naukowe Uniwersytetu Gdańskiego. Prace Jezzkoznawcze, no. 17-18, pp. 191-192.

Popowska-Taborska Hanna, 1995, Ślady danych wierzeń słowiańskich utrwalonych w kaszubskiej leksyce, Światowit, vol. 40, pp. 144-157.

Popowska-Taborska Hanna, 1999, Od frazeologizmu do słowa jest tylko jeden krok (kasz. pošedlo - sch. pöšast 'zaraza'), in: W zwierciadle języka i kultury, ed. Jan Adamowski, Stanisława Niebrzegowska, Lublin: Wydawnictwo Uniwersytetu Marii Curie-Skłodowskiej, pp. 351-355.

Popowska-Taborska Hanna, 2006, Inaczej niż dotąd o kaszubskim kudiable, in: Hanna Popowska-Taborska, Szkice z kaszubszczyzny: dzieje badan - dzieje języka - zabytki - etymologie, Gdańsk: Instytut Kaszubski, pp. 325-328.

Popowska-Taborska Hanna, 2008, Opozycja swoi/obcy w języku ginących społeczności Drzewian połabskich i pomorskich Słowińców, Etnolingwistyka. Problemy jezzyka i kultury, vol. 20, pp. 215-222. 
Pośpiech Jerzy, 1987, Zwyczaje i obrzędy doroczne na Śląsu, Opole: Instytut Śląski w Opolu.

Primiano Leonard Norman, 1995, Vernacular religion and the search for method in religious folklife, Western Folklore, vol. 54, no. 1, pp. 37-56.

Przybylska Renata, 2004, Schematy wyobrażeniowe jako narzędzie analizy semantycznej, in: Studia Linguistica Danutae Wesołowska oblata, ed. Halina Kurek, Janina Latocha, Kraków: Universitas, pp. 195-205.

Putnam Hilary, 1975, Philosophical Papers, vol. 2, Mind, Language and Reality, Cambridge: Cambridge University Press.

Puzynina Jadwiga, 1988, Konotacje leksykalne w interpretacji tekstu literackiego, in: Konotacja, ed. Jerzy Bartmiński, Lublin: Wydawnictwo Uniwersytetu Marii Curie-Skłodowskiej, pp. 83-97.

Puzynina Jadwiga, 1989, Jak pracować nad językiem wartości?, in: Język a kultura, vol. 2, Zagadnienia leksykalne i aksjologiczne, ed. Jadwiga Puzynina, Jerzy Bartmiński, Wrocław: Wiedza o Kulturze, pp. 185-198.

Puzynina Jadwiga, 1992, Język wartości, Warszawa: Państwowe Wydawnictwo Naukowe.

Puzynina Jadwiga, 1993, O znaczeniu wartości, in: Nazwy wartości. Studia leksykalno-semantyczne, vol. 1, ed. Jerzy Bartmiński, Małgorzata Mazurkiewicz-Brzozowska, Lublin: Wydawnictwo Uniwersytetu Marii CurieSkłodowskiej, pp. 9-21.

Quasthoff Uta, 1989, Ethnozentrische Verarbeitung von Informationen: Zur Ambivalenz der Funktion von Stereotypen in der interkulturellen Komunikation, in: Wie verstehen wir Fremdes? Aspekte zur Klärung von Verstehensprozessen, ed. Petra Matusche, München: Goethe Institut, pp. 37- 62.

Rappaport Roy, 1999, Ritual and Religion in the Making of Humanity, Cambridge: Cambridge University Press.

Ratzinger Joseph, Pope Benedict XVI, 2007, Jesus of Nazareth: From the Baptism in the Jordan to the Transfiguration, trans. Adrian J. Walker, New York: Doubleday.

Robotycki Czesław, 1998, Nie wszystko jest oczywiste, Kraków: Wydawnictwo Uniwersytetu Jagiellońskiego.

Rosch Eleanor, 1978, Principles of categorization, in: Cognition and Categorization, ed. Eleanor Rosch, Barbara B. Lloyd, Hillsdale: Lawrence Erlbaum, pp. 27-48.

Roux Jean-Paul, 1988, Le sang: mythes, symboles et réalités, Paris: Fayard.

Rożek Michał, 1993, Diabeł w kulturze polskiej. Szkice z dziejów motywu i postaci, Warszawa, Kraków: Wydawnictwo Naukowe PWN. 
Rudenko Elena, 2007, Rol' oppozitsii 'svoǔ/chuzhoù' v organizatsii kontseptosfery 'kognitivnaia deiatel'nost", Etnolingwistyka. Problemy języka i kultury, vol. 19, pp. 203-210; (Руденко Елена, Роль оппозиции 'свой/чужой' в организации концептосферы 'когнитивнаиа деиательность').

Ryszkiewicz Marcin, 1994, Matka Ziemia w przyjaznym Kosmosie. Gaja $i$ zasada antropiczna $w$ dziejach myśli przyrodniczej, Warszawa: Wydawnictwo Naukowe PWN.

Rytel-Kuc Danuta, 1982, Leksykalne środki wyrażania modalności w języku czeskim i polskim, Wrocław: Zakład Narodowy im. Ossolińskich.

Sambor Jadwiga, 1998, Magiczne i religijne (chrześcijańskie) akty mowy, in: Człowiek - dzieło - sacrum, ed. Stanisław Gajda, Helmut Sobeczko, Opole: Opolski Instytut Filologii Polskiej, pp. 103-112.

Sapir Edward, 1949, Culture, Language and Personality: Selected Essays, ed. David G. Mandelbaum, Los Angeles: University of California Press.

Sawicka Grażyna, 1998, Funkcje stereotypu w nominacji językowej, in: Język a kultura, vol. 12, Stereotyp jako przedmiot lingwistyki. Teoria metodologia, analizy empiryczne, ed. Janusz Anusiewicz, Jerzy Bartmiński, Wrocław: Towarzystwo Przyjaciół Polonistyki Wrocławskiej, pp. 146-154.

Sawicka Grażyna (ed.), 1997, Dom w jezzyku i w kulturze, Szczecin: Wydawnictwo Uniwersytetu Szczecińskiego.

Schaff Adam, 1981, Stereotypy a działanie ludzkie, Warszawa: Książka i Wiedza. Simonides Dorota, 1988, Od kolebki do grobu: śląskie wierzenia, zwyczaje i obrzędy rodzinne w XIX wieku, Opole: Instytut Śląski w Opolu.

Simonides Dorota, Kowalski Piotr (eds.), 1991, Kultura ludowa ślaskiej ludności rodzimej, Wrocław: Volumen.

Sirhan Nadia F., 2014, Folk Stories and Personal Narratives in Palestinian Spoken Arabic: A Cultural and Linguistic Study, Basingstoke: Palgrave Macmillan.

Sławski Franciszek, 1952-1982, Słownik etymologiczny języka polskiego, vol. 1-5, Kraków: Towarzystwo Miłośników Języka Polskiego.

Słownik etnologiczny. Terminy ogólne, 1987, ed. Zofia Staszczak, Warszawa, Poznań: Państwowe Wydawnictwo Naukowe.

Słownik gwar polskich, 1977-2018, vol. 1-10; Źródła and vol. 1, ed. Mieczysław Karaś, Jerzy Reichan; vol. 2-5, ed. Jerzy Reichan, Stanisław Urbańczyk; vol. 6, ed. Joanna Okoniowa, Jerzy Reichan; vol. 7-9, ed. Joanna Okoniowa, Jerzy Reichan, Barbara Grabka, Renata Kucharzyk; vol. 10, part 1, ed. Barbara Grabka, Renata Kucharzyk; Wrocław, Kraków.

Słownik języka polskiego, 1996, ed. Witold Doroszewski, Warszawa: Wydawnictwo Naukowe PWN. 
Stownik ludowych stereotypów językowych. Zeszyt próbny, 1980, ed. Jerzy Bartmiński, Wrocław: Wydawnictwo Uniwersytetu Wrocławskiego.

Słownik prasłowiański, 1974-2001, vol. 1-8, ed. Franciszek Sławski, Wrocław: Zakład Narodowy im. Ossolińskich.

Słownik starożytności słowiańskich, 1961-1996, vol. 1-8; vol. 1-2, ed. Władysław Kowalenko, Gerard Labuda, Tadeusz Lehr-Spławiński; vol. 3, ed. Władysław Kowalenko, Gerard Labuda, Zdzisław Stieber; vol. 4-7, ed. Gerard Labuda, Zdzisław Stieber; vol. 8, ed. Antoni Gąsiorowski, Gerard Labuda, Andrzej Wędzki; Wrocław: Zakład Narodowy im. Ossolińskich.

Słownik stereotypów i symboli ludowych, 1996-2017, ed. Jerzy Bartmiński, vol. 1, Kosmos, part 1, Niebo, światła niebieskie, ogień, kamienie, 1996; part 2, Ziemia, woda, podziemie, 1999; part 3, Meteorologia, 2012; part 4, Świat, światło, metale, 2012; vol. 2, Rośliny, part 1, Zboża, 2017, Lublin: Wydawnictwo Uniwersytetu Marii Curie-Skłodowskiej.

Smolińska Teresa (ed.), 1999, Folklorystyczne i antropologiczne opisanie świata. Księga ofiarowana Profesor Dorocie Simonides, Opole: Wydawnictwo Uniwersytetu Śląskiego.

Smith Richard Gordon, 2019 [1908], Ancient Tales and Folklore of Japan, London: A. \& C. Black.

Sokolski Jacek, 1990, Staropolskie zaświaty, Wrocław: Wydawnictwo Uniwersytetu Wrocławskiego.

Stomma Ludwik, 1976, Mit Alkmeny, Etnografia Polska, vol. 20, no. 1, pp. 99-110.

Stomma Ludwik, 1981, Słońce rodzi się 13 grudnia, Warszawa: Ludowa Spółdzielnia Wydawnicza.

Stomma Ludwik, 1986, Antropologia kultury wsi polskiej XIX wieku, Warszawa: Instytut Wydawniczy PAX; French edition: Campagnes insolites: paysannerie polonaise et mythes européens, trans. Jacek Gąsiorowski, Philippe Sagant, Lagrasse: Verdier, 1986.

Sulikowski Andrzej, 1980, Chata i cztery żywioły, Znak, vol. 32, no. 10, pp. 1339-1349.

Sulima Roch, 1977, Współczesne przekazy ustne, in: Literatura ludowa i literatura chłopska, ed. Alina Aleksandrowicz, Czesław Hernas, Lublin: Uniwersytet Marii Curie-Skłodowskiej, Instytut Filologii Polskiej, pp. 111-128.

Sulima Roch, 2006, Folklorystyka i etnolingwistyka a horyzont poznawczy antropologii kultury, Etnolingwistyka. Problemy języka i kultury, vol. 18, pp. $121-128$.

Swienko Henryk, 1983, Magia w życiu człowieka, Warszawa: Młodzieżowa Agencja Wydawnicza. 
Sychta Bernard, 1967-1976, Stownik gwar kaszubskich na tle kultury ludowej, vol. 1-7, Wrocław: Zakład Narodowy im. Ossolińskich.

Sychta Bernard, 1957, Kaszubskie nazwy diabła, Jezzyk Polski, vol. 37, no. 1, pp. $28-44$.

Symotiuk Stefan, 1996, Język losu, Etnolingwistyka. Problemy języka i kultury, vol. 8, pp. 314-316.

Szadura Joanna, 1995, Popiół. Hasło do „Słownika stereotypów i symboli ludowych", Etnolingwistyka, vol. 7, pp. 81-96.

Szadura Joanna, 1996, entries in: Słownik stereotypów i symboli ludowych, ed. Jerzy Bartmiński, vol. 1, Kosmos, part 1, Lublin: Wydawnictwo Uniwersytetu Marii Curie-Skłodowskiej: Dym, pp. 314-321; Iskra, pp. 310-314; Nowy ogień, pp. 289-292; Ogień, pp. 264-285; Ogień czyśćcowy, pp. 294- 295 (co-author: Maria Kozioł); Ogień demoniczny, pp. 299-303; Ogień niebieski, pp. 292-294; Ogień piekielny, pp. 296-299 (co-author: Maria Kozioł); Ogień piorunowy, pp. 291-292; Ogień sobótkowy, pp. 286-289; Piasek, pp. 405-415; Piaski, pp. 416-417; Płomień, pp. 304-308; Płomień demoniczny, pp. 309310; Popiół, pp. 329-338; Pożar, pp. 339-348; Węgiel kamienny, pp. 418-420; Węgle, pp. 324-329; Żar, pp. 321-323.

Szadura Joanna, 1998, Profile ognia w polszczyźnie ludowej i potocznej, in: Profilowanie w języku i w tekście, ed. Jerzy Bartmiński, Ryszard Tokarski, Lublin: Wydawnictwo Uniwersytetu Marii Curie-Skłodowskiej, pp. 321-341.

Szadura Joanna, 2000, Ludowe formuły powitania i pożegnania ognia jako akty komunikacyjno-kulturowe, in: Język a kultura, vol. 13, Językowy obraz świata a kultura, ed. Anna Dąbrowska, Janusz Anusiewicz, Wrocław: Wydawnictwo Uniwersytetu Wrocławskiego, pp. 333-342.

Szafraniec Jan, 1994, Magia, ryty i terapia, Warszawa: Alfa.

Szczypka Józef, 1980, Kalendarz Polski, Warszawa: Instytut Wydawniczy PAX.

Szechlińska Dorota, 2005, Język, świat i jego obraz, Etnolingwistyka. Problemy języka i kultury, vol. 17, pp. 37-53.

Szober Stanisław, 1937, Na straży języka. Szkice z zakresu poprawności i kultury języka polskiego, Warszawa: Nasza Księgarnia.

Szpociński Andrzej, 1987, Procesy symbolizacji w badaniach społecznohistorycznych, in: Symbol i poznanie. W poszukiwaniu koncepcji integrujacej, ed. Teresa Kostyrko, Warszawa: Państwowe Wydawnictwo Naukowe, pp. 13-32.

Szyfer Anna, 1968, Zwyczaje, obrzędy i wierzenia Mazurów i Warmiaków, Olsztyn: Pojezierze. 
Szyfer Anna, 1969, Tradycyjna astronomia i meteorologia ludowa na Mazurach, Warmii i Kurpiach i jej współczesne przeobrażenia, Olsztyn: Pojezierze.

Szyjewski Andrzej, 2003, Religia Słowian, Kraków: Wydawnictwo WAM.

Szyjewski Andrzej, 2018, Etnologia Religii, Kraków: Nomos.

Szymańska Janina, 1992, Podlaskie pieśni włóczebne, Etnolingwistyka, vol. 5, pp. 97-134.

Szymańska Janina, 1998, Pieśni pustych nocy, Etnolingwistyka. Problemy języka i kultury, vol. 9/10, pp. 211-252.

Ślósarska Joanna, 1994, W świetle symboli, Łódź: Wydawnictwo Samira.

Tabakowska Elżbieta, 1995, Gramatyka i obrazowanie. Wprowadzenie do językoznawstwa kognitywnego, Kraków: Wydawnictwo Oddziału Polskiej Akademii Nauk.

Tabakowska Elżbieta, 1998, Profilowanie w języku i w tekście - perspektywa językoznawcy, tłumacza i poety, in: Profilowanie w języku i w tekście, ed. Jerzy Bartmiński, Ryszard Tokarski, Lublin: Wydawnictwo Uniwersytetu Marii Curie-Skłodowskiej, pp. 167-184.

Tabakowska Elżbieta, 2004, O językowych wyznacznikach punktu widzenia, in: Punkt widzenia w języku i w kulturze, ed. Jerzy Bartmiński, Stanisława Niebrzegowska-Bartmińska, Ryszard Nycz, Lublin: Wydawnictwo Uniwersytetu Marii Curie-Skłodowskiej, pp. 47-64.

Telija Weronika N. (Teliia Veronika N.), 1998, Frazeologizmy-idiomy jako stereotypy kultury, trans. Danuta Misiąg, in: Język a kultura, vol. 12, Stereotyp jako przedmiot lingwistyki. Teoria metodologia, analizy empiryczne, ed. Janusz Anusiewicz, Jerzy Bartmiński, Wrocław: Towarzystwo Przyjaciół Polonistyki Wrocławskiej, pp. 160-168.

Telus Małgorzata, 1998, Stereotyp grupowy a predykacja, in: Język a kultura, vol. 12, Stereotyp jako przedmiot lingwistyki. Teoria metodologia, analizy empiryczne, ed. Janusz Anusiewicz, Jerzy Bartmiński, Wrocław: Towarzystwo Przyjaciół Polonistyki Wrocławskiej, pp. 135-145.

Thomas William I., Znaniecki Florian, 1918, The Polish Peasant in Europe and America: Monograph of an Immigrant Group, vol. 1, Primary Group Organization, Boston: Richard G. Badger.

Tibbits Charles John, 2018, Folklore and Legends of the Russians and Polish, London: Abela Publishing.

Tillich Paul, 1960, The religious symbol, in: Symbolism in Religion and Literature, ed. Rollo May, New York: George Braziller, pp. 75-98.

Tokarski Ryszard, 1983, Uwagi o semantycznych mechanizmach zmian metaforycznych, in: Studia o metaforze, vol. 2, ed. Michał Głowiński, 
Aleksandra Okopień-Sławińska, Wrocław, Zakład Narodowy im. Ossolińskich, pp. 11-61.

Tokarski Ryszard, 1988, Konotacje jako składnik treści słowa, in: Konotacja, ed. Jerzy Bartmiński, Lublin: Wydawnictwo Uniwersytetu Marii CurieSkłodowskiej, pp. 35-53.

Tokarski Ryszard, 1990, Językowy obraz świata w metaforach potocznych, in: Językowy obraz świata, ed. Jerzy Bartmiński, Lublin: Wydawnictwo Uniwersytetu Marii Curie-Skłodowskiej, pp. 69-86.

Tokarski Ryszard, 1991, Człowiek w definicji znaczeniowej słowa, Przegląd Humanistyczny, no. 35, pp. 131-140.

Tokarski Ryszard, 1995, Semantyka barw we współczesnej polszczyźnie, Lublin: Wydawnictwo Uniwersytetu Marii Curie-Skłodowskiej.

Tokarski Ryszard, 1998a, Biała brzoza, czarna ziemia, czyli o miejscu stereotypu w opisie języka, in: Język a kultura, vol. 12, Stereotyp jako przedmiot lingwistyki. Teoria metodologia, analizy empiryczne, ed. Janusz Anusiewicz, Jerzy Bartmiński, Wrocław: Towarzystwo Przyjaciół Polonistyki Wrocławskiej, pp. 124-134.

Tokarski Ryszard, 1998b, Językowy obraz świata a niektóre założenia kognitywizmu, Etnolingwistyka. Problemy języka i kultury, vol. 9/10, pp. 7-24.

Tokarski Ryszard, 1998c, Kulturowe i tekstotwórcze aspekty profilowania, in: Profilowanie w języku i w tekście, ed. Jerzy Bartmiński, Ryszard Tokarski, Lublin: Wydawnictwo Uniwersytetu Marii Curie-Skłodowskiej, pp. 35-52.

Tolstaia Svetlana M., 1989, Ustnyı̆ tekst v iazyke i kul'ture, in: Tekst ustny. Struktura i pragmatyka, problemy systematyki, ustność w literaturze, ed. Maciej Abramowicz, Jerzy Bartmiński, Wrocław: Wiedza o Kulturze, pp. 9-14; (Толстая Светлана М., Устный текст в языке и культуре).

Tolstaia Svetlana M., 1995, Sakral'noe i magicheskoe v narodnom kul'te sviatykh, in: Folklor, sacrum, religia, ed. Jerzy Bartmiński, Maria JasińskaWojtkowska, Lublin: Instytut Europy Środkowo-Wschodniej, pp. 38-46; (Толстая Светлана М., Сакральное и магическое в народном культе святых).

Tolstaia Svetlana M., 1996, Magicheskie funktsii otritsaniia v sakral'nykh tekstach, Slavianovedenie, no. 1, pp. 39-43; (Толстая Светлана М., Магические функции отрицания в сакральных текстах // Славяноведение, 1996, № 1, c. 39-43).

Tolstaia Svetlana M., 2008, Slav. ${ }^{\star}$ svojb: semantika i aksiologiia, Etnolingwistyka. Problemy języka i kultury, vol. 20, pp. 29-38; (Толстая Светлана М., Слав. *svojb: семантика и аксиология). 
Tolstoĭ Nikita I., 1990, Iazyk i kul'tura (niekotorye problemy slawianskoŭ ètnolingvistiki), Zeitschrift für Slavische Philologie, Bd. L, Heft 2, Heidelberg, pp. 238-253; (Толстой Никита И., Язык и культура (некоторые проблемы славянской этнолингвистики)).

Tolstoĭ Nikita I., 1995, Iazyk i narodnaia kul'tura. Ocherki po slavianskoŭ mifologii i ètnolingvistike, Moskva: Indrik; (Толстой Никита И., Язык и народная культура. Очерки по славянской мифологии и этнолингвистике, Москва: Индрик, 1995).

Tolstoĭ Nikita I. (ed.), 1995-2009, Slavianskie drevnosti. Ėtnolingvisticheskiu slovar', vol. 1-4, Moskva: Mezhdunarodnye Otnosheniia; (Славянские древности. Этнолингвистический словарь, т. 1-4, ред. Никита И. Толстой, Москва: Международные отношения, 1995-2009).

Tołstaja Swietłana M. (Tolstaia Svetlana M.), 1998, Stereotyp w „języku kultury", trans. Danuta Misiąg, in: Język a kultura, vol. 12, Stereotyp jako przedmiot lingwistyki. Teoria, metodologia, analizy empiryczne, ed. Janusz Anusiewicz, Jerzy Bartmiński, Wrocław: Towarzystwo Przyjaciół Polonistyki Wrocławskiej, pp. 99-105.

Tołstaja Swietłana M. (Tolstaia Svetlana M.), 2004, Znaczenie symboliczne a punkt widzenia: motywacja znaczeń symbolicznych (kulturowych), in: Punkt widzenia w języku i w kulturze, ed. Jerzy Bartmiński, Stanisława Niebrzegowska-Bartmińska, Ryszard Nycz, Lublin: Wydawnictwo Uniwersytetu Marii Curie-Skłodowskiej, pp. 177-184.

Tomicka Joanna, Tomicki Ryszard, 1975, Drzewo życia. Ludowa wizja świata i człowieka, Warszawa: Ludowa Spółdzielnia Wydawnicza.

Tomicki Ryszard, 1976, Słowiański mit kosmogoniczny, Etnografia Polska, vol. 20, no. 1, pp. 47-99.

Tomicki Ryszard, 1978, Kosmogonia dualistyczna w Europie i Azji w XIX-XX wieku. Studium etnolingwistyczne, typescript held in the library of the Institute of Polish Philology at the Maria Curie-Skłodowska University in Lublin, made available by Prof. Jerzy Bartmiński.

Tomicki Ryszard, 1980, Ludowe mity o stworzeniu człowieka. Z badań nad synkretyzmem mitologicznym w Europie Wschodniej, Etnografia Polska, vol. 24, no. 2, pp. 49-117.

Tomicki Ryszard, 1981, Religijność ludowa, in: Etnografia Polski. Przemiany kultury ludowej, vol. 2, ed. Maria Biernacka, Maria Frankowska, Wanda Paprocka, Wrocław: Zakład Narodowy im. Ossolińskich, pp. 29-70.

Toporov Vladimir N., 1967, K rekonstruktsii mifa o mirovom iaitse (na materiale russkikh skazok), Trudy po znakowym sistemam, vol. 3 (Uchenye zapiski Tartuskogo gosudarstvennogo universiteta/ Tartu Riikliku Ülikooli 
Toimetised, issue 198), ed. Iuriĭ Lotman, Tartu, pp. 81-99; (Топоров Владимир Н., К реконструкции мифа о мировом яйце (на материале русских сказок) // Труды по знаковым системам, т. 3 (Ученые записки Тартуского гос. унивеситета, вып. 198), ред. Юрий. Лотман, Тарту, 1967, c. 81-99).

Toporov Vladimir N., 1973, O kosmologicheskikh istochnikakh ranneistoricheskikh opisaniŭ, Trudy po znakowym sistemam, vol. 6 (Uchenye zapiski Tartuskogo gosudarstvennogo universiteta/ Tartu Riikliku Ülikooli Toimetised, issue 308), ed. Iuriǐ Lotman, Tartu, pp. 106-150; (Топоров Владимир Н., 1973, О космологических источниках раннеисторических описаний // Труды по знаковым системам, т. 6, (Ученые записки Тартуского государственного унивеситета, вып. 308), ред. Юрий. Лотман, Тарту, 1973, с. 106-150).

Toporov Vladimir N., 2010, Mirovoe derevo. Univeslal'nye znakovye kompleksy, vol. 2, Moskva: Rukopisnye pamiatniki Drevneı̆ Rusi; (Топоров Владимир Н., Мировое дерево: Универсальные знаковые комплексы, т. 2, Москва: Рукописные памятники Древней Руси, 2010).

Treder Jerzy, 1985, Nazwy biblijne w polskiej frazeologii, Zeszyty Naukowe Wydziału Humanistycznego Uniwersytetu Gdańskiego. Prace językoznawcze, no. 11, pp. 87-97.

Treder Jerzy, 1989, Frazeologia kaszubska a wierzenia i zwyczaje (na tle porównawczym), Wejherowo: Muzeum Piśmiennictwa i Muzyki KaszubskoPomorskiej w Wejherowie.

Treder Jerzy, 2000, Kaszubi - wierzenia i twórczość. Ze Słownika Sychty, Gdańsk: Oficyna Czec.

Tsiv'ian Tat'iana V., 1993, O roli slova v tekste magicheskogo deřstviia, in: Slavianskoe i balkanskoe iazykoznanie. Struktura malykh fol'klornykh tekstov, ed. Svetlana M. Tolstaia, Tat'iana V. Tsiv'ian, Moskva: Nauka, pp. 111-121; (Цивьян Татьяна В., О роли слова в тексте магического действия // Толстая Светлана М., Цивьян Татьяна В. (отв. ред.), Славянское и балканское языкознание: Структура малых фольклорных текстов, Москва: Наука, 1993, с. 111-121).

Tsykhun Henadz', 2000, Iz bloknota uchastnika polesskikh ekspeditsiĭ, Etnolingwistyka. Problemy języka i kultury, vol. 12, pp. 181-187; (Цыхун Генадзь, Из блокнота участника полесских экспедиций).

Tuan Yi-Fu, 1977, Space and Place: The Perspective of Experience, London: Edward Arnold.

Turek Krystyna, 1993, Ludowe zwyczaje obrzędy i pieśni pogrzebowe na Górnym Ślasku, Katowice: Uniwersytet Śląski. 
Turek Krystyna, 1999, Religijność ludowa czasu śmierci (na przykładzie społeczności lokalnych Górnego Śląska), in: Folklorystyczne i antropologiczne opisanie świata. Księga ofiarowana Profesor Dorocie Simonides, ed. Teresa Smolińska, Opole: Wydawnictwo Uniwersytetu Opolskiego, pp. 135-142.

Turner Alice K., 1993, The History of Hell, New York: Harcourt Brace.

Tyrpa Anna, 2006, Etnolingwistyka „ludowa”, narodowa, porównawcza koncepcje neofilologów i polonistów, Etnolingwistyka. Problemy języka i kultury, vol. 18, pp. 105-116.

Urbańczyk Stanisław, 1991, Dawni Słowianie. Wiara i kult, Wrocław: Zakład Narodowy im. Ossolińskich.

Uspenskiı Boris A., 1982, Filologicheskie razyskaniia v oblasti slavianskikh drevnosteŭ. Relikty iazychestva v vostochnoslavianskom kul'te Nikolaia Mirlikiǔskogo, Moskva: Izdatel'stvo Moskovskogo universiteta; (Успенский Борис А., Филологические разыскания в области славянских древностей. Реликты язычества в восточнославянском культе Николая Мирликийского, Москва: Издательство Московского университета, 1982).

Vel'mezova Ekaterina V., 2001, Zametka o performativakh so znacheniem nachala deisstviia $\mathrm{v}$ cheshskikh zagovorakh, Etnolingwistyka. Problemy języka $i$ kultury, vol. 13, pp. 149-154; (Вельмезова Екатерина В., Заметка о перформативах со значением начала действия в чешскикх заговорах).

Vinogradova Liudmila N., 1995, Motivirovki obriadovykh deĭstviü: stereotipy religioznogo magicheskogo myshleniia, in: Folklor, sacrum, religia, ed. Jerzy Bartmiński, Maria Jasińska-Wojtkowska: Lublin: Instytut Europy Środkowo-Wschodniej, pp. 52-58; (Виноградова Людмила Н., Мотивировки обрядовых действий: стереотипы религиозного и магического мышления).

Vulcănescu Romulus, 1979, Kolumna niebios, trans. Danuta Bieńkowska, Zbigniew Stolarek, Warszawa: Ludowa Spółdzielnia Wydawnicza; original work: Coloana cerului, București: Editura Academiei Republicii Socialiste România, 1972.

Wańczowski Marian, 1993, Księga żałoby i śmierci, Opole: Marian Wańczowski.

Wasilewski Jerzy S., 1980, Podarować - znaleźć - zgubić - zabłądzić. Niektóre kategorie języka symbolicznego związane z opozycją życie - śmierć, Etnografia Polska, vol. 24, no. 1, pp. 283-298.

Wasilewski Jerzy S., 1989, Tabu a paradygmaty etnologii, Warszawa: Uniwersytet Warszawski, Wydział Historyczny.

Wężowicz-Ziółkowska Dobrosława, 1983, Świat wartości kolędy życzącej, Literatura Ludowa, no. 6, pp. 31-41. 
Wężowicz-Ziółkowska Dobrosława, 1986, Kochankowie z kalinowego lasu, Akcent, no. 4, pp. 23-29.

Wężowicz-Ziółkowska Dobrosława, 1991, Miłość ludowa. Wzory miłości wieśniaczej w polskiej pieśni ludowej XVIII-XX wieku, Wrocław: Polskie Towarzystwo Ludoznawcze.

Wierzbicka Anna, 1986, Analiza lingwistyczna aktów mowy jako potencjalny klucz do kultury, in: Problemy wiedzy o kulturze. Prace dedykowane S. Żółkiewskiemu, ed. Alina Brodzka, Maryla Hopfinger, Janusz Lalewicz, Wrocław: Zakład Narodowy im. Ossolińskich.

Wierzbicka Anna, 1996, Semantics: Primes and Universals, Oxford: Oxford University Press.

Wierzbicka Anna, 1999, Język - Umyst - Kultura. Wybór prac, Warszawa: Wydawnictwo Naukowe PWN.

Yoder Don, 1974, Toward a definition of folk religion, Western Folklore, vol. 33, no. 1, pp. 2-15; (reprinted, 1990, in: Don Yoder, Discovering American Folklife: Studies in Ethnic, Religious and Regional Culture, Ann Arbor: UMI Research Press, pp. 67-84).

Zadrożyńska Anna, 1988, Powtarzać czas początku, Warszawa: Wydawnictwo Spółdzielcze.

Zając Paweł, 2004, O zaświatach niedalekich $i$ cudach nienadzwyczajnych. Nadprzyrodzone w kulturze ludowej na przykładzie Huculszczyzny, Kraków: Nomos.

Zaleski Wincenty, 1989, Święci na każdy dzień, Warszawa: Wydawnictwo Salezjańskie.

Zankroff Laura Tempest, 2019, Weave the Liminal: Living Modern Traditional Witchcraft, Woodbury: Llewellyn Publications.

Zbiór Wiadomości do Antropologii Krajowej, 1877-1895, vol. 1-18, Kraków: Akademia Umiejętności.

Zhuĭkova Margarita V., 1988, Nominatsiia smerti i arkhaicheskoe myshlenie, Etnolingwistyka, vol. 9/10, pp. 67-80; (Жуйкова Маргарита, Номинация смерти и архаическое мышление).

Zimoń Henryk (ed.), 1988, Z badań nad religią i religijnością ludowa, Warszawa: Verbinum.

Zowczak Magdalena, 2000, Biblia ludowa. Interpretacje wątków biblijnych w kulturze ludowej, Wrocław: Fundacja na Rzecz Nauki Polskiej.

Zowczak Magdalena, 2015, Religijność na pograniczach. Eseje apokryficzne, Warszawa: Wydawnictwo DiG. 


\section{Index}

A

ablutions 98, 119, 124, 129, 132, 136

abundance 118, 136, 137, 145, 299, 324

access

- to dark forces 218, 223

- to divine power 211, 277

- to God's power 122, 196

- to grace 183

- to water's life-giving power 122

- to the sacred 156, 271, 337

- to secret knowledge 218, 223, 271

- to destructive power 131, 145, 337

- to creative power 77,177

- to the ultimate source of power 197, 272

act

- of creation $33,49,75,77,81-90$, $93,115,138,141,147,148,151$, $152,164,166,170-173,175-177$, $179,187,237,264,265,283,303$, $307,336,341,344,345$

- of reverence for the earth 152 , 153,183

acting in the name of God 124, 344 agricultural

- myth of creation 147, 163, 168

- profile of Our Lady 154, 183

- rites 170, 187, 374

air

- demons 203, 209

- symbolism 223-227, 229, 231

- pestilential 76, 195, 226

"alien" (obcy)

- scenery 338

- space $51,90,133,263,272$, 337,339
- sphere $39,265,273,274,338$, 339, 349

amorphous areas 63

ancient

- beliefs 59, 116, 230, 238

- symbols of fate 128,328

- symbolic representation of wind as a bull 225

angel $62,68,84,86,89,90,92,98$, $99,111,160,178,180,189,190$, $191,202,228,236,249,252,255$, $268,275,276,307,347,370$

archaic

- connection between water and the moon 106, 140, 314

- lunar symbols 106, 140

- roots of lunar beliefs 310

archetypal

- beliefs 59

- roles 33, 35, 56, 169, 239, 308, 345

- relations between God and man 86, 147

- symbols 328

axiological

- ambivalence 41, 44

- scale $31,35,53,89,104,162$, 220, 278

B

barrier

- between the physical and metaphysical reality 196 bath

- in scalding water 120

- ritual 121, 124, 129, 135, 136

bathwater 107, 125, 127, 132, 133, 271, 292 
belief

- in divine justice $111,253,341$

- in eternal life 187, 231

- in the life-giving power of the sun $267,278,279,283,285$, 287,300

- in the power of moon beams to resurrect the dead 311

- in the power of the first thunderclap of spring 150

- in the presence of demonic forces in water 116

- in the presence of the devil in a whirlwind 207

- in the purifying power of fire 210,272

- in the sacredness of water 114

- in supernatural phenomena 42 , $61,74,285,335$

- in the power of the sacred 20,23, $32,37,56,76,151,178,342,350$

- that the full and new moon has a particularly strong influence on water demons 314

- that the moon is the ruler of the night sky 288, 317

- that the moon rules the waters 325

- that the function of the sun is to ensure that order is preserved on earth 284

- that sinners are punished by fire from heaven 237

- that wind has a reviving power 192

blessing

- God's blessing 33, 103, 124, 137, $145,186,198,265,303,344$

- fire 76, 77, 267, 339

- of water, with holy water 77,114 , 116,123 border

- between day and night 72, 289

- between life and death 71, 72, 91, $188,253,262$

- between this and the other world $40,63,64,72,91,229,254$, 289,345

- between the physical and metaphysical world $13,23,25,30$, $31,36,56,61,74,125,182,188$, $223,335,345,349$

- of the village 197, 201

- crossing of the physical and symbolic border 72

bread

- and candles thrown down the well 112

- as a symbol of earth joins the upper and lower sphere of the cosmos 185

breath

- as a creative, life-giving and generative force 191

C

calling God's name 77

categorisation $30,31,55,60,61,65$

category

- “own/familiar" 20, 22, 24, 39, $60,62-69,71,72,75,90,119$, $124,153,201,241,263,265,273$, 285, 291, 321, 322, 336-339, 341, 343-345, 349

- "strange/alien" 22, 38, 63-69, 71, $124,159,161,162,201,263,273$, $274,336,338,339,341,349$ celebrations $46,51,94,97,116$, $135,136,140,165,185,199$, 326,327 ceremonies $40,114,128,140$, $185,188,225,255,260,261$, 289,335 
chain

- of symbolic associations 57, 73, 137,340

- of notions 137

Christian

- concept of resurrection 325

- practices 17, 209

Christianity 17, 82, 101, 105, 112, 295, 306, 311

Christmas

- as a miraculous period 228

- carol 51, 52, 96, 98, 135, 268, 297, 346

- celebrations 135, 185

circle

- magic 187, 197, 198, 223

cognitive

- analysis 29,73

- links 44

- paths 29, 41, 42, 57, 136, 139, 154, $163,168,173,190,205,231,265$, $270,276,278,323,324,325,327$, 335,349

- process 20, 22, 29, 30, 32, 34, 36, $38-42,44,46,48,50,52,56,57$, $59,60,68,168,190,278,349,370$

collective

- worldview 17

- identity 66

- imagination 62

common

- cultural code 67

- imagination 16

communicative acts $37,122,137$, $158,192,222,247,339,340$

communion between the physical and metaphysical worlds 182 conceptual system $22,29,41$, 47,350

conceptualiser $19,29,32,34-37,39$, $43,48,56,59,60,62-69,73-77$, $84,86,94,97,101,104,106-108$,
$111,113,115,119,127,147,148$, $151,162,163,169,171,181,221$, $234,235,237,240,248,253,254$, $257,266,271,272,285,288,308$, $309,313,316,320,335,341$, 343-346, 350

conceptualiser's bodily

perspective $65,66,69$

consciousness of language users 43, 44,332

construction of the scene $37,74,75$ contact

- between the lands of the living and the dead 187

- with the other world 187, 262, 264, 269, 270, 335

- with the sacred 15-17, 22, 38, 74, $95,108,137,170,276,278,288$, 336,339

conventionalised routines 20,30 cosmic

- centre 106

- egg 81, 82, 147, 163-168, 186

- dimension 47, 145, 224, 231, 321,345

- mountain 38, 48-50, 52

- order 19, 48, 49, 52, 83, 84, 89, 94, 184

- rhythm 46, 48, 140, 184, 188, 288, $307,321,323,332$

- tree 49-51

- vision of the universe 18,19

cosmos

- emerges from the primal ocean 133

- as a MOUNTAIN 52

- as a TREE 19, 52

- as a FAMILY 163

- as a living organism 48

- is ruled by God 335

- appearance of the 48, 81

- coherent image of the 18 
cosmos (continued)

- family as a model of the 153

- rhythmical renewal of the 48

- upper spheres of the 349

- lower spheres of the 349

creative power $39,77,134,137,142$, $170,177,225,226,232$

cult

- of air 202, 230

- of fire 233, 234

- of water 105, 108, 109, 111, 113,114

- of the earth 158,183

- of the aurochs 326,327

cultural

- context 17, 20, 22, 55, 60, 232

- continuum 15, 18

- code $16,18,58,67,74$, 264,340

- identity 46, 67, 350

- model of behaviour 17, 22, 58,340

- stereotypes 56

- unconscious model 31,52, 349 curative practices $120,166,288$ cure spells $91,96,155,156,161$, 288,320

curse formula 111, 158, 207, 208, 251

custom

- of greeting the sun 330

- of greeting the new moon 330

- of making a gift of bread (or sharing it) in rites of passage 185

- of offering sacramentals 112

- of pouring water in the newlyweds' room 128

- of sending Easter eggshells to "the other world" 187

- of sharing bread (opłatek 'wafer') at Christmas Eve supper 187 cyclic

- reincarnation during the phase of the moon's disappearance 310

- death and regeneration of the world 188, 302, 326, 327

cyclical remoulding of the moon 327

D

death

- air 76, 195, 196

- water 111

- as a woman 195

- marzanna as a personification of 195

demonic

- forces 19, 32, 75, 76, 85, 87, 116, $122,133,141,145,175,179,191$, 195, 209, 211, 216, 226, 239, 269, $272,273,310,327-329,336,338$, 339,349

- lunar connotations 307

- wind 202-205, 209, 211, 213, 215-217, 221, 231

- world 31, 50, 64, 67, 68, 71, 76, $89,205,216,218,223,277,279$, $312,323,339,349$

- image of water 89 demons $24,29,32,58,63,70-73$, $76,84,85,88,90,94,116,118$, $125,127,129,130,132,140-142$, $145,153,158,160,165,187,197$, 199, 202-204, 207, 209, 210, 217, $218,225,230,232,236-238,242$, 271, 276-278, 284, 290-292, 294, $295,308,312,314,323,331,333$, $336,338,339,348,350,353$

demiurgic

- act 83,118, 307

- powers of water 83, 115

destructive

- forces 33, 39 
- power 44, 76, 100, 101, 112, $130,131,132,142,145,231,235$, 238-240, 337-339

devil

- devil's doings 19, 58, 179

- interfering in the act of creation 87,307

- thrown into the depths of the waters 176

- pact with the 308,339

directive speech acts 112, 113, 161, 167,292

divine

- actions 32, 75, 147

- act of "breathing" 192

- energy symbolically enclosed in an egg 167

- forces 19

- intervention in earthly reality 237

- origin of fire 234, 264, 271

- punishment 85, 111, 196, 299

- power 32, 48, 76, 88, 170, 193, $211,244,253,257,275$

- world 187

- wrath 103, 190, 276

dousing people with water 117,119 dualist conception of the world 68 , 83,134

dualist cosmogony 82

duality of the conceptualisation of space 338

\section{E}

earth

- and bread as its symbol, are mediators between man and the sacred 184,185

- as an ethical authority 159

- as life-bearing mother 163, 169

- as the executor of God's judgment 252

- as a symbol of fertility 51,181
- demiurgic powers of 163

- emergence of the earth 81 earth's

- interior seen as "otherworlds" 160

- life-giving power 162

earthly

- life 89, 115, 129, 186, 204, 231, 262, 263, 308, 309, 323, 327, 328

- reality 44, 50, 129, 141, 223, 237, 338,343

- spheres 323

- worlds 33, 52, 65, 90, 91, 168, 235, $239,269,283,336,339,348$

Easter

- customs 165, 344

- dyngus 119

- egg (decorating, exchanging) 165, $166,170,187,300,302$

- eggshells 165, 170, 187, 188, 302

egg

- and cosmogonic energy 166

- an archaic solar symbol 166

- buried in the graves 187

- contains a seed of life 186

- rolling an egg over the sick person's body 166, 167

- transformative properties 187

elemental forces 25,76

eternal

- damnation 70, 249-251, 277, 342

- life 19, 89, 95, 142, 186-188, 227, $231,232,250,327,332,338$

F

fertility

- of the earth $76,147,150,164,182$, 183,188

- symbolism of wind 225

- symbolism of fire 278

- symbolism of the moon 323, 324

- symbolism of the sun 278 
fight between God and Satan 91, 93, $178,224,238,263,307,338$

final cataclysm 338

fire

- as a symbol of divine power 275

- as executor of God's order 240,252

- of hell 233, 247, 248, 251-253, 259, 261, 263, 264, 274, 277, 310,327

- earthly 233, 248, 264

- heavenly $76,233-237,247,248$, $252,263,265,277,278,338$

- home 234, 245, 264-266, 268, $269,272-274,276$

- otherworldly $234,235,237,239$, 241, 243, 245, 247, 249, 251, 253, $255,257-259,261,263$

- purgatorial 233, 253-258, 261, 263,264

- thunderbolt 235, 237, 245, 248, $251,253,263,276$

- magical formulas addressed to 240

- protective practices against 241

- conceptualisation of 76, 238, 244

- bonfire 236, 247, 265-267, 269, $270,272,273,278,279$

flood scenes 104

folk

- carols 147

- conceptualisation of the world 190, 349

- culture 13-15, 17, 18, 23, 45, 57-59, 63, 71, 105, 107, 116, 134, $135,151,154,164,180,195,202$, $215,218,224,229,233,234,240$, $246,258,260,264,278,283,284$, 294, 297, 312, 323-325, 328, 335, $345,348-350$

- beliefs 72, 88, 90, 101, 106, 141, 142, $159,204,245,258,305,314,324$
- genres 113, 122

- morality 45, 111

- religion 15, 16, 392

- religious practices $13,15,17,82$

- religiosity $13,15,16$

- stereotypes 13, 19, 22, 23, 56-59

- studies 15

- type culture $15,17,18$

forces

- of fertility 44

- of evil 33-35, 37, 49, 71, 118, 122, 124, 128-130, 139, 160, 210, 212, 216-218, 220, 226, 238, 251, 260, $267,270,271,274,276,279,310$, $315,327,331,336$

- of good 19,69, 81

formulas

- for undoing spells 200, 232

- counteracting the effects of praising 220

- for greeting fire and the sun 268

- spell 71,200, 342

- supplication 343 funeral

- bread 173, 186, 303

- ceremonies 260,261

- rites 81, 129, 255, 277

G

God

- allows an unfavourable wind to arise 196

- and Satan 93, 134, 139, 176-178, $224,238,263,338,349$

- bids Satan to bring a lump of earth from the bottom of the sea 201

- created the earth and made it the bearer of all life 184

- is worshipped through the mediation of the sun 283 
- is the just ruler of the world, rewarding good and punishing evil 193

- sends to the earth gold tools so that people can cultivate it and make it fertile 183

- sows the earth $177,180,183$

God's

- actions 33, 75, 137, 145

- blessing 33, 103, 124, 137, 145, 186, 198, 265, 303, 344

- grace 19, 107, 124, 245, 297, 299, 305, 347

- mercy 104, 245, 253, 257, 260, $264,338,343$

- life-giving breath 76,191

- punishment 33, 158, 159, 201, 243, 250, 251, 254, 257, 276, 277

- will 19, 308, 335, 343

- world 19, 133, 160, 179

golden plough 147, 182, 183

Great Chain of Being 31, 44, 49, $50-52,349$

group membership 35, 64, 66

$\mathbf{H}$

habitus 16, 250

hailstorm

- as a punishment for sins and unworthy conduct 194

harmful magical practices 20,131 harvest $118,136,142,154,183$, 197, 200, 272, 289, 292-294, 319, 320,324

heaven

- enable passage to 187

hell $49,57,64,68-71,76,91,93$, 109-111, 139, 141, 145, 152, 160, $165,167,170,179,187,188,203$, $205,218,225,228,233,246-248$, 250-253, 259, 261, 263, 264, 268, $272,274,276,277,302,309,310$, $327,337,338,341,370,391$ hierarchy of values 31,349

hierophanies of God 268, 305

holy

- figures 65, 94, 97, 100, 105, 109, $114,148,158,162$

- pictures as sacrifices 112

- pictures thrown into water 112

- springs $105,106,142$

human

- cognitive abilities 36

- fate $18,62,145,227,264,316$, $317,323,328,329$

I

identity $13,14,17,19,38,39,46,61$, $64-68,231,340,350$

image

- of the cosmos $18,19,23,52$, 147,153

- of the invisible sacred 189, 223, 231

imitative magic 112, 202, 278, 320, 325,329

instruments

- of punishment 337

- of the sacred power 23

L

land of the dead 70

language

- of commands 116

- of prohibitions 116

lexical chain 186

light $23,24,35,45,63,69,71-74$, $76,77,82,89,98,139,142,143$, $155,160,167,169,176,180,181$, 190, 191, 207, 218, 224, 230, 231, 233-237, 248, 252, 263, 265, 267, 270, 274-276, 278, 283, 284, 286, 288-290, 294-299, 305-307, 312, $315,324,327,330,349$

liminal places $161,262,316$ 
link

- between the human being and the moon 328,329

linguistic

- code 20,21, 56

- correlative of the FORCE schema 112, 160, 197, 239, 286

- image of the cosmos 19

- image of water 94

- stereotypes 23,56

- worldview 48, 60, 61, 63, 68

location of "otherworlds" 71

lunar

- animals 323, 325

- influence 310

- symbol 106, 140, 323, 331

- symbolism of time and fate 328

\section{M}

magical

- formulas 20, 171, 240, 241, 302, 341,350

- healing practices $37,76,84,138$, $158,166,167,187,192,218,271$, $286,300,314,324,336$

- practices 15, 20, 34, 39, 46, 60, 62, $67,76,77,98,113,117,119,123$, $126,130,131,133,134,136-139$, $141,147,155-158,161,167,168$, $187,192,209,218,221,242,243$, 271, 272, 286, 289, 293, 294, 300, $314,320,323,329,330,332,335$, $336,341,350$

- practices associated with witches 294

- practices performed at the first ploughing of the year 168

- protective practices performed at "Saturday bonfires" 272

- properties of herbs 324

- properties of the egg 164

- thinking 19
- time 39, 288, 293

- way of banishing death 325

marriage between heaven and earth $148,149,151,152,181$

mediating

- function of the earth 50

- and purifying properties of water 128

- mediation of the Virgin Mary or saints 107

mediator

- the spell caster plays the role of 200

- the witch performs the role of 221

mental stereotypes 55,56

metaphor 22, 29, 30, 36-38, 40, 44, $58,83,142,145,162,163,186$, $254,275,284,295,328,345,371$

metaphysical

- forces of good 19

- forces of evil 19, 327

- reality $21,23,25,196,349$

- worlds 13, 19, 20, 23-25, 27, 30, $31,35,36,40,42,56,61,63,64$, $79,125,182,188,223,261,281$, 327, 335-337, 340, 345, 349

miraculous

- healing 95, 99, 106, 155

- spring 106, 113

modal verbs $36,112,118,125,256$

moon

- as a place where souls served their punishment for sins 308

- as a symbol of the resurrected Jesus 306

- as a source of dualism in religions other than Christianity 306

- beams 311, 315, 316

- night-time counterpart of the sun 73

- identified as God's face 23 
- symbolism 140, 323-325, 327, 329, 331-333

- full $314,316,319,320$, $322-324,332$

- new 223, 314, 315, 317-322, 326, $329,330,331,333$

- waxing 307, 314, 319, 324

moon's

- influence on growth and development 320

- supernatural power 310,321

moonlight 314-317, 321, 323, 324,331

mother-earth 131, 136, 137, 147-149, 151, 153-159, 161-164, $172-174,183,184,234,269$

mystery

- of eternity 47, 323

- of transcendence 19, 231, 339

myth

- in which the earth was brought into existence by a bolt of lightning 275

- of periodic creation 188

- of the sky impregnating the earth by means of life-giving rain 275

- cosmogonic 45, 81, 83, 114, 137, $141,147,148,154,163,166,180$, $181,275,300-302,335$

- creation 22, 23, 45, 48, 77, 81, 83, $86,90,133,147,148,153,163$, $165,167,168,171,189,190,234$, 283, 285, 287, 305, 307, 309, 311, 313,350

mythical

- origins of the world 134

- pattern of thought 18

- spring water 95

- primeval mythical symbols 135

- time 46, 49, 94, 135, 158, 228

- thinking 17, 46, 61

mythologisation 14,18
$\mathbf{N}$

names of demons 24, 141, 338

natural

- disaster 34, 76, 101

- elements 23, 79, 162, 177, 246, $267,323,335-337,339,346,349$

- forces 23, 77, 216

- world 22, 32, 38, 40, 42, 43, 64, $73,74,76,126,148,162,188$ negative value $31,34,35,69,91$, $104,131,176,316,320$

- numerical concept strengthening the magical formula 156

O

oaths

- featuring the motif of the absence of the sun 285

- invoking the sun 285, 298

- sworn on water 114

- sworn on earth 114

object of magical practices 62,77 , 113,272

opposition

- between eternity and temporality 73

- bright vs dark 69

- heavenly fire vs the fire of hell 76

- good vs evil 176, 124, 296, 349

- light vs dark 71, 160, 181, 290, 305, 330

- day vs night 19

- near vs far 24, 71, 90, 201

- own/familiar vs strange/alien 24, 63-66, 159, 201, 349

- up vs down 71, 160, 181

oral

- communication 20,75

- folk culture 14 order of the human community 125 ordered cosmos 48 organiser of the scene 74,97 
otherworlds $40,50,51,63,64,70-73$, $88-91,105,130,135,142,145,160$, $173,174,187,204,226,227,234$, $235,247,248,252,253,265,270$, $273,308,323,328,345$

"own" space 127-130, 132, 199, 200, 227, 265

$\mathbf{P}$

pagan

- ritual 17,326

parallel $38,41,43-45,50,139,141$, $179,183,226,230,236,284,295$, 299, 301, 303, 306, 324

physical

- reality $21,23,196,349$

- world 18, 23-25, 27, 30, 31, 33, $36,43,56,61,125,182,188,223$, $281,327,332,335,336,340$, 345,349

point of view $16,19,29,33,35,37$, $39,43,59,61-63,66,74,75,77$, $89,94,97,107,113,114,119,134$, $142,144,145,151,162,169,193$, $218,284,309,314,322,335,338$, $344,346,349,350$

power

- of air 231, 232

- of divine blessing 95

- of fire 34, 128, 234, 237, 240, 266, $271,272,278$

- of earth 166, 167

- of hell 70

- of grace 337

- of the moon 311

- of the names of holy persons 201

- of the sacred 20,32, 37, 44, 56, $137,156,167,178,185,190,231$, $240,337,341,342,350$

- of water $76,94,100,101,105,107$, $109,111-115,117-136$
- of words 21, 158, 197, 257, 334,350

- the source of $20,75-77,83,139$, $275,286,288,294,312,344$

practices

- aiming to avert punishment 211

- of expelling the evil spirit from the body 191

- of burying passages from the gospel 199

- preventing the spread of an epidemic 201

- of sending the wind to remote and desolate places 229

- protective against the effects of hail, storms and torrential rains 197

prayers asking for the intercession

- of the Blessed Virgin 245, 246

- of patron saints of the dying: St Barbara, St Anne, St Joseph, St Lawrence, St Philomena 257 preconceptual image schemas

- BALANCE 30, 31, 35, 36, 40, 41, 77, 148

- BLOCKAGE 35, 37

- CENTRE-PERIPHERY 30, 31, 37, 40, 349

- COMPULSION 36,77

- COLOUR 23, 349

- CONTROL 23, 35, 40, 77, 335

- FORCE 77, 134, 295, 310, 335

- OUTER COMPULSION 77

- REMOVAL OF RESTRAINT 35

- REPULSION 35

- SCALE 30

- VERTICAL 30, 349

primordial

- ocean 85, 141, 176

- water $81,90,139$

profiling $29,42,43,57,73-77,234$ 
prohibition

- against burying suicides, villains in a consecrated ground 160

- against excessive praise and loud admiration, especially of newborn babies before baptism 220

- against pointing one's finger at the sun 236,311

- against pointing one's finger at the moon 236, 311

- against walking in the moonlight 323

- against weaving, spinning and winding yarn 328

prosperity $94,97,117-119$, 121-124, 126-128, 132, 136, 137, $142,145,186,267,291,299,303$, 317,327

prototype $18,30,48,49,51,53,57$,

$69,75,77,183,191,192,209,349$

purification

- of the moon in hell fire 327

- of space 336

$\mathbf{R}$

rainstone $150,151,181,338$

rainwater 126,137

real

- time 46, 135

- world 126, 130

reawakening the fertility of the earth 76

regeneration

- of the moon 327

relations between heaven and earth 147, 148, 153, 335

relations with the sphere of the sacred 20, 196

relationship with the sacred 47

religious

- dualism 82

- life 15
- rite $17,94,126,228$

- sensitivity 15,17

renewing the power of fire 278

restoration to the former state 138

restore

- the divine order 76,337

- original purity 116,338

- sanctity to water 109

restricted code 75,240

restrictions 59, 67, 284, 329

reviving

- power of a kiss 336

rite

- of inclusion 185

- of passage $40,47,71,108,122$, $125,128,129,151,185,228,229$, $263,303,323,325,328,363$

ritual

- actions of symbolic character 339

- baths 121

- circle 67

- cleansing 108, 130, 136

- context 134

- drinking of water 117

- Easter "kiss of the dead" game 187

- first bathing of the child 124

- magical action 147, 226, 335

- of baking bread 170

- of birth 47, 276

- of blessing fire on Easter Saturday 276

- of the blessing of water 34,114 , 116,139

- of burning the bodies of criminals and scattering their ashes to the four winds 230

- of kindling "new fire" 269, 277

- of lighting the fire 77, 269, 276

- sacrificial offerings 111-113

- scenarios 22, 170

- use of the egg 187 
ritual (continued)

- use of earth 23,336

- use of fire 23

- use of water 23,117

rituals

- of death 47

- of delineating concentric sacred space 210

- of exclusion 65

- of marriage 47

- of propitiation 112, 113

- of sharing an egg during Easter breakfast 187

- practised for protection against storm 201

- related to fertility, birth and death 168

- of the first ploughing of the year $118,142,164,168,170$, 275,289

- of the first sowing of the year 147 , 170,172

role in the scene

- of the agent $33,75,77,83,86$, $113,115,124,130,131,148,164$, $167,239,240,243,251,296,312$, $316,335,346$

- of an instrument 33,131, 346

- of an object 126

- of an observer 75, 77, 101, 272

rural

- culture 15, 17, 194, 327

- worldview 61, 193

S

sacramentals $33,77,109,112,115$, $126,210,211,241,294$

sacred

- marriage between heaven and earth 152,181

- nature of the symbol 182

- status of the earth 154,162
- union of the sky/heaven and earth 181

- contact with the 15-17, 19, 38, $74,95,108,137,276,278,288$, 336,339

- enter into the sphere of the 188 , 192, 197

sacrificial practices 111

sanctity of water 93-95, 97, 99, 101, $103,108,111,139$

Satan $68,70,86,87,91,93,134,138$, 139, 145, 147, 175-180, 201, 211, 211, 224, 237, 238, 247, 248, 251, 252, 263, 294, 296, 307, 309, 338, 341,349

scale of values $39,40,52,68$

scene

- of creation $23,77,83,88,145$, $148,168,169,179,187,201,209$, 283,307

- of death 193

- of God's revelation 95

- of casting spells 221

- of the Last Judgment 248, 250

semantic

- associations 44

- ambivalence 44, 140

- connotations 118

- link 18, 134, 143, 144, 155, 232, 265, 295

- memory of symbols 144

series of images 134

silver coin

- thrown into a well 112

- thrown into the bath of a newborn or sickly child 112

$\sin$

- original 115, 124, 139, 309

sinners

- doing penance on the moon 308 solar model of activity 289 solar motifs 298,301 
soul, souls

- of the damned 70,71, 76, 181, 205, 208, 211, 215, 238, 248, 249

- of the unbaptised $71,115,127$, 202, 203, 269

- purgatorial 37, 227, 256, 308, 327

- sinful 107, 111, 205, 257-259

- suffering 203, 261, 262

space

- method of sanctifying 198

- "own" space 127-130, 132, 199, 200, 227, 265

sphere

- of eternity 46,328

- of death 51, 91, 129, 227, 262, 306

- of life 51, 73, 306, 307

- of the afterlife 70

- of the sacred 20, 22, 65, 67, 138, $151,188,192,196,197,199,211$ strange/alien 22, 24, 38, 62-69, 71, $124,159,161,162,201,263,273$, $274,336,338,339,341,349$

stranger $38,65-67,75,124,131$, $185,193,219,220,241,261,268$, 291, 312

St Agatha's salt

- thrown into a well 37,112

stereotypes $13,18,19,22,23,30,31$, $38,46,55-59,67,232$

stereotypical

- models 20, 349

- motifs 113

- patterns 20, 68, 349

- scenes 337

sun

- curative power 288

- rays 283

- sunrise 90, 121, 122, 132, 176, 288-293, 296, 297, 299

- sunset 90, 141, 176, 283, 288-294, 343,346
- and moon 23, 134, 162, 230, 233, 236, 248, 281, 285, 287, 297-300, 302, 303, 305-307, 311, 312, 317, 330, 331, 345, 349

- as an epiphany of the sacred 284

- as a living and sentient being 284

- as a mediator connecting heaven and earth 295

- is the eye of God 236, 284, 289,305

- as a symbol of the Virgin Mary 297

- as a symbol of truth 298

- as a symbol of happiness and prosperity 299

- personification of the 74 , 233, 285

- symbolised by an egg 300

- symbolised by bread 300

sunlight 286, 289, 290, 292, 294, 299,347

sunwise direction (of actions) 289 supernatural

- phenomena 42, 61, 74, 285, 335

- forces $20,25,32,33,36,56,62$, $72,148,190,209,211,218,223$, $270,335,341$

- reality $19,23,41,46,63,76$, 185,344

symbolic

- connection between fire and Jesus 252, 269

- function 44, 57, 149, 184, 325, 330

- gestures 136, 226, 244

- imagination 19, 43, 44, 134, 231, 310,325

- images 19, 23, 42, 44, 134, 137, $144,183,188,231,277,323$, 332, 339

- life-giving breath 227, 340

- meanings $42,57,73,91,144,166$, $168,278,300,303$ 
symbolic (continued)

- network linking the image of the moon with fertility 324

- places of passage 263

- representations of air 23

- representations of earth 23

- representations of fire 23

- representations of water 23

- representations of the four natural elements 23

- scenery 188

- sphere of culture 18, 22

- thinking 19, 41-47, 49, 51, 53

symbolic complex 134, 183, 188

symbolism

- of fertility $136,137,145,182,225$, $278,323,324,326$

- of grace 142, 143, 145

- of lunar transformation 310, 323,330

- of regeneration and fertility 142

- of sprinkling with water 142

- of transformation 310, 330

- of the cross 201

- Christian 138, 142

system

- of commands 16, 20,119, 160, $231,248,264,265,320,323$, 324,350

- of prohibitions 16, 20, 126, 160, $231,248,264,290,320,320,323$, 328,350

$\mathrm{T}$

the term lud (folk) 13, 15, 58

thunderbolt

- as a sign of divine wrath 276

- chasing demons 276

- that sets the house of a sinner on fire 277

thunderstones 238, 266 time

- of demons 73

- of Christ's Passion 199

- for weddings, weaning babies, starting to build a new house 319

- of origins $34,46,49,94,97,125$, $126,135,158,182,228,294,344$

- of ritual practices 112

- of sowing and planting 319

- to begin all manner of new activities 319

- safe 72

- holiday 199

- contemporary 46

traditional

- culture 15

- rural communities 14,61

- wedding bread 186, 299

transcendence $19,46,225,229,231$, 321, 339

transcendent reality 45

transition from one reality to another 73

tree

- of life 48-52, 128, 135, 163, 299

- of the cross 51

threshold of death 71

U

unconscious cultural model 31 , 52,349

underground

- evil spirits 69, 160

- world 43, 50, 72, 76, 106, 325, 338

underwater world 90

underworld 71, 349

undoing evil charms 88, 289

undoing of the bride's plait 137,150 , 151, 181, 192

unearthly sphere 68

uninhabited area 241 
universe $15,18,19,42,43,49,52$, $70,81,135,145,162,176,231$, $233,275,276,323,349,350$

V

value

- system $18,45,60,61,73,74,77$, $152,172,231,340,341$

- positive $31,35,39,40,49,91,104$, $131,136,162,169,176,181,184$, $220,231,329,338$

- negative $31,34,35,69,91,93$, $104,131,176,316,320,339$

- the highest axiological 93, 231, $278,330,336$

vernacular perspective 16

Virgin Mary

- expelling disease 155

- healing a sick person 156

- interceding with her Son to obtain mercy for the sinners 258

- as a mediator between earth, heaven and purgatory 258, 264

- performs healing practices 37,157

- takes pity on damned souls 249

W

wandering beggar

- maintaining contact with the ancestors 264

- mediator between this (familiar) and other (alien) world 261

- presence during funeral ceremonies 261

- praying for the salvation of the soul 261

- warning of the punishment in hell fire 264

water

- as a tool of justice 111
- as a tool of punishment 101

- demons 24, 85, 314

- devils 90

- capacity to destroy evil 104

- cleansing properties 104

- pouring over people 118, 273

- pouring with $118,119,127,128$, $136,137,139,268,271$

- spring 95, 100, 105-108, 113, 117, $122,135,143,336$

- symbolism 104, 133, 135, 137, 139, 141-145

- sick water 132

- turned into wine 96

- used as protection against demons 127

- ambivalent properties of 138

- miraculous power 94

- murky 76

- destructive powers 44,131, 132, 142

- cleansing powers of spring 95

- dangerous 76

- dead man's 129, 130, 132

- life-giving power of 94, 104, 114, $115,117,119,122,124$

- living 95, 106-108, 114, 117, 142,331

- wondrous acts of 96

wealth $13,14,51,58,117,118$, $124,136,143,218,239,302,314$, $317-319,326,327$

wedding

- custom 136, 181

- ceremony 117, 122, 129, 192, 193

- ritual 118, 119, 128, 130, 150, 193, 234, 270, 294, 296, 298, 329

welcoming with bread and salt 184,185

whirlwind

- as the devil 76, 207

- as the devil's dance 206 
wind

- as God's life-giving spirit 191

- as a symbol of the power of "otherworlds" 226

- as a witness of events 193

- as a protective spirit accompanying human beings 191

- as an instrument of blessing, fertilising fields, bringing lifegiving rain to farmers and aiding sailors and fishermen 193

- as a symbol of God's creative power 225

- as an instrument in the hand of God 194

- gale-force 76, 200

- demonic symbolism of 231

- function of: pollinating plants, bringing rain and impregnating women 225

- names of 194 world

- annihilation of the 89,338

- axis of the 43, 48

- external 29, 42

- demonic 31, 50, 64, 67, 68, 71, 76, $89,205,216,218,223,277,279$, $312,323,339,349$

- divine 187

- God's 160, 179

- metaphysical 13, 19, 20, 23, 24, $30,31,35,36,42,48,49,56,61$, $63,64,79,125,182,188,223$, 227, 261, 264, 281, 303, 327, 332, $335-337,340,345,349$

- this and the other 40

- beginning of the 64, 135

- centre of the 135

- end of the 110,133,141, 145, 156 worlds

- metaphysical 13, 19, 20, 23-25, $27,30,31,35,36,42,56,61,63$, $79,125,182,188,223,261,281$, $327,335-337,340,345,349$ 


\title{
Polish Studies - Transdisciplinary Perspectives
}

\author{
Edited by Krzysztof Zajas and Jarosław Fazan
}

Vol. 1 Artur Płaczkiewicz: Miron Białoszewski: Radical Quest beyond Dualisms. 2012.

Vol. 2 Kinga Kosmala: Ryszard Kapuściński: Reportage and Ethics or Fading Tyranny of the Narrative. 2012.

Vol. 3 Michał Nowosielski: Polish Organisations in Germany. Their Present Status and Needs. 2012.

Vol. 4 Krzysztof Zajas: Absent Culture. The Case of Polish Livonia. 2013.

Vol. 5 Magdalena Sitarz: Literature as a Medium for Memory. The Universe of Sholem Asch's Novels. 2013.

Vol. 6 Barbara Przybyszewska-Jarmińska / Lech Sokół (eds.): Poland and Artistic Culture of Western Europe. 14th-20th Century. 2014.

Vol. 7 Katarzyna Fazan / Anna Róża Burzyńska / Marta Bryś (eds.): Tadeusz Kantor Today. Meta-morphoses of Death, Memory and Presence. Translated by Anda MacBride. 2014.

Vol. 8 Andrzej Hejmej: Music in Literature. Perspectives of Interdisciplinary Comparative Literature. Translated by Lindsay Davidson. 2014.

Vol. 9 Grzegorz Niziołek: Warlikowski: Extra Ecclesiam. Translated by Soren Gauger. 2015.

Vol. 10 Ryszard Koziołek: Sienkiewicz's Bodies. Studies of Gender and Violence. Translated by David Malcolm. 2015.

Vol. 11 Wojciech Tygielski: Italians in Early Modern Poland. The Lost Opportunity for Modernization? Translated by Katarzyna Popowicz. 2015.

Vol. 12 Dariusz Jarosz / Maria Pasztor: Polish-French Relations, 1944-1989. Translated by Alex Shannon. 2015.

Vol. 13 Urszula Augustyniak: History of the Polish -Lithuanian Commonwealth. State - Society Culture. 2015.

Vol. 14 Piotr Sobolczyk: Polish Queer Modernism. 2015.

Vol. 15 Jacek Soszyński / Agnieszka Chamera-Nowak (eds.): Book versus Power. Studies in the Relations between Politics and Culture in Polish History. Editorial assistance by Dan Embree. Translated by Jacek Soszyński 2015.

Vol. 16 Wojciech Kriegseisen: Between State and Church. Confessional Relations from Reformation to Enlightenment: Poland - Lithuania - Germany - Netherlands. Translated by Bartosz Wójcik and copy-edited by Alex Shannon. 2016.

Vol. 17 Urszula Sowina: Water, Towns and People. Polish Lands against a European Background until the Mid-16 $6^{\text {th }}$ Century. Translated by Justyna Woldańska. 2016.

Vol. 18 Grzegorz Krzywiec: Chauvinism, Polish Style. The Case of Roman Dmowski (Beginnings: 1886-1905). Translated by Jarosław Garliński. 2016.

Vol. 19 Andrzej Sakson: Von Memel bis Allenstein. Die heutigen Bewohner des ehemaligen Ostpreußens: Memelland, Kaliningrader Gebiet, Ermland und Masuren. Übersetzt von Marek Drewnowski. 2016.

Vol. 20 Antoni Mączak: Unequal Friendship. The Patron-Client Relationship in Historical Perspective. Translated by Alex Shannon. 2017.

Vol. 21 Olga Szmidt / Katarzyna Trzeciak (eds.): Face in Trouble - From Physiognomics to Facebook. Copy-edited by Soren Gauger. 2017. 
Vol. 22 Alina Cala: Jew. The Eternal Enemy? The History of Antisemitism in Poland. 2019.

Vol. 23 Agata Brajerska-Mazur / Edyta Chlebowska (eds.): Jew. On Cyprian Norwid. Studies and Essays. Vol. 1: Syntheses. 2019.

Vol. 24 Beata Nowacka / Zygmunt Ziątek: Ryszard Kapuściński. Biographie d’un écrivain. 2019.

Vol. 25 Stanisław Bylina: Religiousness in the Late Middle Ages. Christianity and Traditional Culture in Central and Eastern Europe in the Fourteenth and Fifteenth Centuries. 2019.

Vol. 26 Igor Kąkolewski / Christian Lübke / Przemysław Urbańczyk (eds.): The Dawning of Christianity in Poland and across Central and Eastern Europe. History and the Politics of Memory. 2020.

Vol. 27 Bogumił Szady: The Geography of Religious and Confessional Structures in the Crown of the Polish Kingdom in the Second Half of the Eighteenth Century. 2019.

Vol. 28 Ewa Masłowska: Mediating the Otherworld in Polish Folklore. A Cognitive Linguistic Perspective. Translated by Maria Fengler and Piotr Styk. 2020.

Vol. 29 Aleksandra Konarzewska: Der Ausgang aus der Unmündigkeit. Sexualität, Kultivierung und Entzauberung der Welt in der Prosa von Stanisław Brzozowski und Witold Gombrowicz. 2020.

www.peterlang.com 